\title{
FINAL REPORT ON DECOMMISSIONING OF WELLS, BOREHOLES, AND TILTMETER SITES GULF COAST INTERIOR SALT DOMES OF LOUISIANA
}

\author{
REVISION 0
}

JULY 1989

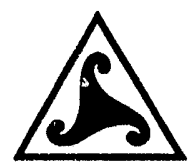

Prepared by: Stone \& Webster Engineering Corporation

Prepared for: U.S. Department of Energy Salt Repository Project Office 
1.0 INTRODUCTION

1.1 Participants

1.2 Scope of Work

2.0 PREREQUISITES 3

3.0 FIELD ACTIVITIES $\quad 8$

3.1 Site Reconnaissance

3.2 Plugging

3.2.1 Plugging Sequence

3.2.2 Variations from Typical Plugging Procedures

3.2.3 Squeeze Cementing

3.3 Removal of Wellhead Assemblies

3.4 Tiltmeter Site Removal

3.5 Site Restoration

3.6 Shallow Borehole Search

3.7 Geotechnical Boreholes

3.8 Surveying

4.0 DOCUMENTATION

4.1 State Documentation

4.2 SWEC Documentation

4.2.1 Administrative Documentation

4.2.2 Technical Documentation

4.2.3 Photo Documentation

5.0 LANDOWNER RELEASES

$\begin{array}{lll}6.0 & \text { SUMMARY } & 24\end{array}$

$\begin{array}{lll}7.0 & \text { REFERENCES } & 25\end{array}$

$\begin{array}{lll}8.0 & \text { APPENDICES } & 27\end{array}$

A. SWEC Project Documentation

$\begin{array}{ll}\text { Attachment-1 } & \text { : Weekly Reports } \\ \text { Attachment-2 } & \text { Site Reconnaissance } \\ \text { Attachment-3 } & \text { : Schematic of Preabandonment Site Status } \\ \text { Attachment-4 } & \text { Borehole Completion Sketch } \\ \text { Attachment-5 : Plugging Report } \\ \text { Attachment-6 }: \text { Perforation and Squeeze Cementing Report } \\ \text { Attachment-7 : Site Restoration Form }\end{array}$

DISCLAIMER

This report was prepared as an account of work sponsored by an agency of the United States Government. Neither the United States Government nor any agency thereof, nor any of their employees, makes any warranty, express or implied, or assumes any legal liability or responsibility for the accuracy, completeness, or usefulness of any information, apparatus, product, or process disclosed, or represents that its use would not infringe privately owned rights. Reference herein to any specific commercial product, process, or service by trade name, trademark, manufacturer, or otherwise does not necessarily constitute or imply its endorsement, recommendation, or favoring by th : United States Government or any agency thereof. The views and opinions of authors expressed herein do not necessarily state or reflect those of the United States Government or any agency thereof. 
B. State Documentation

Office of Conservation (OC):

Amended Permit to Drill for Minerals

Form

Work: Permit

Injection Well Work Permit

Plug and Abandon Report

Well History and Work Resume

Brine Manifest

Department of Transportation and Development

(DOTD): Water Well and Abandonment Form

$(M D-15-R)$

(DM-4R-Rev)

(UIC-17)

$(P \& A)$

(WH-1)

(DOTD-GW-2)

C. Additional Documentation

Variance Requests and Approvals

Site Location Plats

Landowner Releases

D. List of Personal Comrnunication References 


\section{LIST OF TABLES}

Table

$2-1$

$2-2$

$2-3$

Figure

1
Title

Well Status Summary

Summary Table of Plugging Data

SWEC Subcontractors

LIST OF FIGURES

Title

Site Location Map
Page

5

9

10

Page

4 


\subsection{INTRODUCTION}

In the late 1970s, test holes were drilled in northern Louisiana in the vicinity of Vacherie and Rayburn's Salt Domes as part of the Department of Energy's (DOE) National Waste Terminal Storage (NWTS) (renamed the Civilian Radioactive Waste Management (CRWM)) program. The purpose of the program was to evaluate the suitability of salt domes for long term storage or disposal of high ? avel nuclear waste. The Institute for Environmental Studies at Louisiana State University (IES/LSU) and Law Engineering Testing Company (LETCO) of Marietta, Georgia performed the initial field studies. In 1982, DOE awarded a contract to the Earth Technology Corporation (TETC) of Long Beach, California to continue the Gulf Coast Salt Dome studies. In 1986, DOE deferred salt domes from further consideration as repository sites. In 1987, Stone \& Webster Engineering Corporation (SWEC) was awarded a contract for the Technical and Field Services for the Salt Repository Project Office of DOE. Under this contract, SWEC was assigned responsibility for the decommissioning of test sites in Louisiana, Mississippi, Utah, and Texas.

This report describes test well plugging and site abandonment activities performed by SWEC in accordance with Activity Plan (AP) 1-3, Well Plugging and Site Restoration of Work Sites in Louisiana. The objective of the work outlined in this AP was to return test sites to as near original condition as possible by plugging boreholes, removing equipment, regrading, and seeding. Appendices to this report contain forms required by state of Louisiana, used by SWEC to document decommissioning activities, and pertinent documentation related to lease/access agreements.

\subsection{PARTICIPANTS}

The organizations involved in decommissioning activities in Louisiana and their role/responsibilities are summarized below:

1. Department of Energy/Salt Repository Project Office (DOE/SRPO) The branch of DCE responsible for overseeing studies related to siting a high level nuclear waste repository in salt. Salt sites were deferred from further consideration as a result of the December 1987 amendment to the Nuclear Waste Policy Act. Since that time, SPRO activities have focused on the closeout and restoration of sites in Texas, Mississippi, Louisiana, and Utah.

2. Battelle Memorial Institute - Office of Nuclear Waste Isolation (ONWI) The Battelle Memorial Institute, under contract to DOE, managed the geologic studies performed in Louisiana by other subcontractors (IES/LSU, LETCo, and TETC) through October 1986. ONWI was responsible for maintaining the final Records Turnover Packages (RTPs) provided by the subcontractors. Battelle/ONWI provided microfilm of applicable drilling/completion records for SWEC's review.

3. Institute for Environmental Studies/Louisiana State University (IES/LSU) IES/LSU worked closely with Law Engineering Testing Co. in performing early drilling and testing programs in Louisiana. In preparing for field activities, SWEC used many of the reports prepared by IES/LSU. 
4. Law Engineering Testing Company (LETCo)

Inder contract to Battelle, LETCo worked closely with IES/LSU in performing early (1975-1980) field studies in Louisiana. During this time, LETCo drilled and installed a majority of the test holes and tiltmeters located in northern Louisiana.

5. The Earth Technology Corporation (TETC)

Under contract to Battelle, TETC was the Southern Region Geologic Program Manager (GPM) for the Gulf Coast Salt Domes from 1982 to 1987. Field work performed by TETC consisted primarily of monitoring existing test wells. In 198E, TETC plugged and abandoned all but two wells (LSU-RIA, and DOE - Continental No. 1) at Rayburns Dome. Before SWEr. started decommissioning activities, it was necessary to transfer test well operatorship, lease agreements, government property, and related records from TETC to SWEC.

6. Stone \& Webster Engineering Corporation (SWEC)

In 1987, DOE awarded the Technical and Field Services Contract (TFSC) to SWEC for continuing studies related to siting a high level nuclear waste repository in salt. The contract's scope included the decommissioning of deferred salt sites in Utah, Mississippi, Louisiana and Texas. Early in 1988, DOE directed SWEC to proceed with decommissioning and restoration of these sites.

7. Louisiana Department of Transportation and Development (DOTD)

DOTD regulations, as set forth in Chapter III, Rules, Regulations and Standards for Plugging Abandoned Water Wells and Holes, govern plugging and abandonment activities for all DOE test wells dri.led in Louisiana.

8. Louisiana Department of Natural Resources, Office of Conservation (OC) The OC Amendment to Statewide Order No. 29-B contains regulations regarding plugging and abandonment of oil, gas, and deep disposal wells. The DOTD and OC have concurrent jurisdiction over DOE boreholes drilled deeper than freshwater sands. During plugging operations it was necessary for SWEC to contact OC and/or DOTD for clarification of regulations, or to request a variance.

9. Louisiana Department of Environmental Quality (DEQ)

DEQ normally regulates the plugging of boreholes associated with landfill sites and does not have direct jurisdiction over the deeper DOE test holes drilled in Louisiana. At their request SWEC maintained contact with the DEQ to keep them informed about shallow borehole activities.

10. Department of the Army, St. Louis Distric Corps of Engineers (COE) The majority of the access/lease agreements in Louisiana are between private landowners and the COE. SWEC worked closely with the COE to establish the status of existing leases, to reestablish expired agreements, and to obtain damage releases from landowners.

\subsection{SCOPE OF WORK}

As Technical and Field Services Contractor (TFSC) for the Salt Repository Project, SWEC was responsible for decommissioning observation wells, 
geotechnical boreholes, shallow borings, and tiltmeter pits. Initial records search identified 20 wells of varying depth at 10 different sites (Figure 1), 5 geotechnical boreholes, 118 shallow borings, and $1 \hat{\imath}$ tiltmeter pits. Subsequent research and site reconnaissance reve led that not all wells, borings, and pits listed above required decommissioning work. Details of the work accomplished are found in section 3.0 of this report.

SWEC's Activity Plan (AP) 1-3, "Well Plugging and Site Restoration of Work Sites in Louisiana," outlines the general scope of work, and a planned sequence of activities for the preparation, plugging, and restoration of the various types of test sites. The AP incorporates, by reference, Louisiana State regulations that apply to plugging and abandonment of specific types of test holes, and state forms to be filed by the operator (SWEC) and the state licensed subcontractor (Southwestern Laboratories) who actually performed the work in the field.

SWEC's Project Technical Procedure (PTP) 1-18, "Plugging and Abandonment of Boreholes and Restoration of Work Sites" outlines the steps and documentation required by the project for decommissioning of the sites. This PTP contains attachments that were used for documenting site reconnaissance, borehole plugging, perforating and squeeze cementing, site restoration, as well as daily and weekly progress.

\subsection{PREREQUISITES}

State records (DOTD, OC, and Geologic Survey), Project Records Turnover Packages (provided by Battelle Memorial Institute), Project Topical Reports (prepared by IES/LSU, LETCo, and TETC), and access/lease agreement information were reviewed by SWEC to determine whether all data relating to decommissioning was accurate and up to date. The review identified 11 additional shallow boreholes and one deep well not included in SWEC's original Activity Plan. DOE directed SWEC to include these sites in the scope of decommissioning activities in Louisiana. The records search also revealed that well V- 6 had been included on an incorrect landowner's lease agreement. This error required entering into a new access agreement with the correct landowner. Table 2-1 provides a complete list of wells included in the scope of plugging and restoration activities in Louisiana.

Regulations issued by State agencies were thoroughly reviewed and were considered at all steps of the decommissioning process. Observation wells drilled below fresh water sands, are jointly regulated by the $O C$ and DOTD and are supposed to be permitted by the state and receive a serial number from the OC. Five of the DOE wells (the four $V$-series wells, and the LSU-R1A well) were not permitted at the time of drilling. To facilitate filing of plugging and abandonment records, the $O C$ assigned these wells permit numbers (see telecon memo of $8 / 31 / 88$, Appendix D) and requested that SWEC use Injection Well Work Permits (UIC-17) rather than the normal DM-4R, and that all documentation be submitted directly to the OC Injection Mining Division in Baton Rouge, rather than to the district office.

DOTD regulations are set forth in Chapter III, Rules, Regulations, and Standards for Plugging Abandoned Water Wells and Holes. Section 3.2.0.0 of this document establishes the licensing and documentation requirements of the well owner and plugging contractor. This section states that plugging 


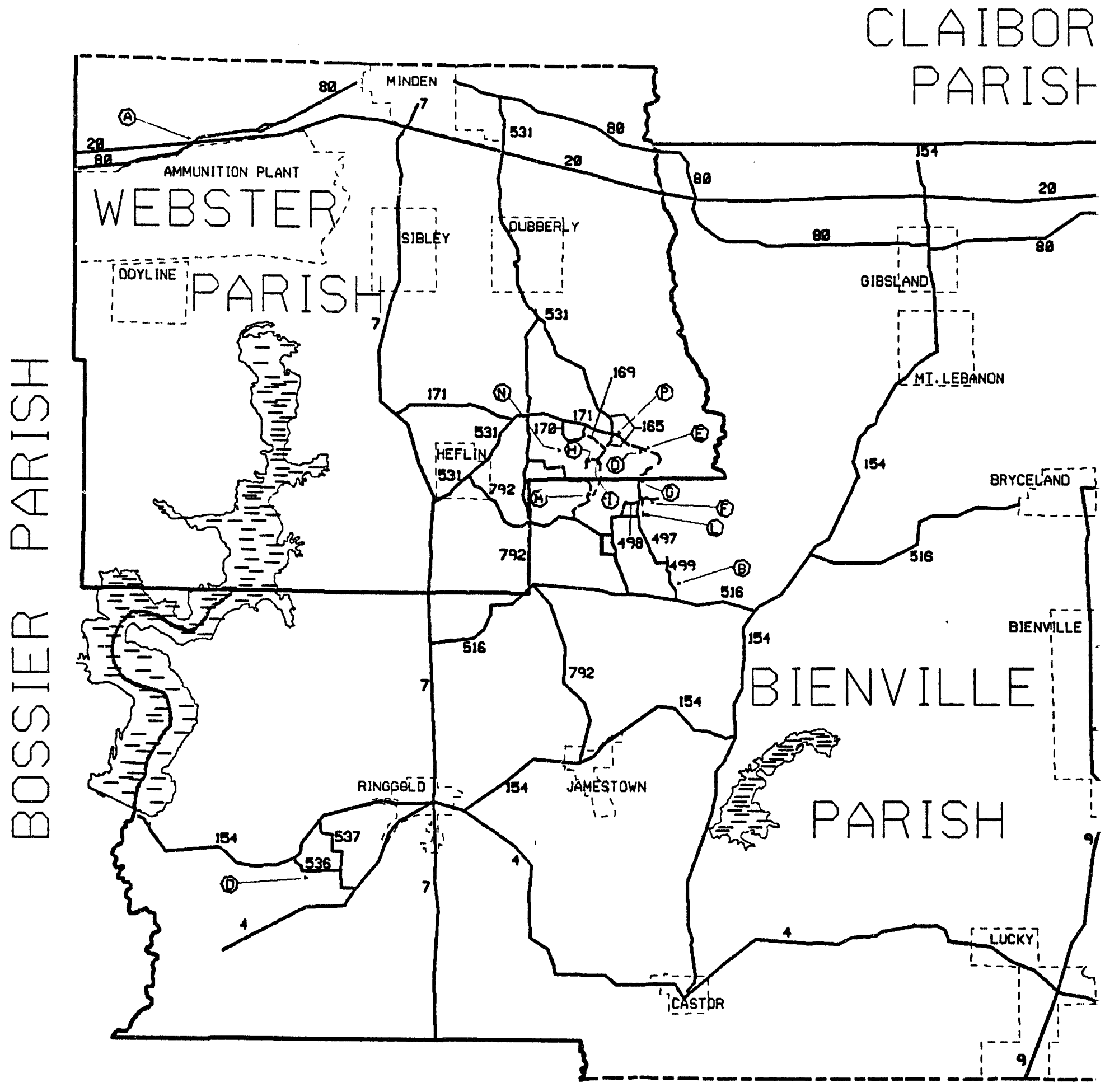

NOTE: NOT ALL ROADS SHOWN OR COMPLETED. 
WLL STATUS SUEMPI

\begin{tabular}{|c|c|c|c|c|c|c|c|c|c|c|}
\hline $\begin{array}{l}\text { BOLE/TILTETER } \\
\text { WhE }\end{array}$ & LOCATION & LAROOWER & OPBRATOR & $\begin{array}{l}\text { OC } \\
\text { PERAIT } \\
\text { SERIAL } \text { No. }\end{array}$ & 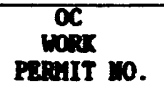 & MITI & $\begin{array}{l}\text { is AGREI } \\
\text { TMPE }\end{array}$ & EXPIRES & $\begin{array}{l}\text { MDOWTTR } \\
\text { RELEASE } \\
\text { (DATE) }\end{array}$ & STATUS \\
\hline LPEI - LH2A & $\begin{array}{l}\text { 1233.6'BNL \& } 360.4^{\prime *} \\
\text { SII, SBC.3, TiBH, R10w, } \\
\text { Webster Parish }\end{array}$ & $\begin{array}{l}\text { Louisinas } \\
\text { Power \& } \\
\text { Light (LPSL) }\end{array}$ & Stre & 165976 & $1050-88-1$ & $\operatorname{sinc}$ & LEASE & $10 / 1 / 88$ & $\begin{array}{l}\text { Mot } \\
\text { Obtnined } \\
\text { See Note } 1\end{array}$ & PLUGESD \\
\hline LPEL - LWE & 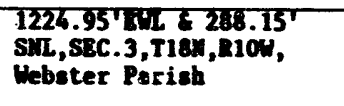 & $\begin{array}{l}\text { Louigians } \\
\text { Power \& } \\
\text { Light (LPEL) }\end{array}$ & sine & 165975 & $1049-8.1$ & STIC & TENSE & $10 / 1 / 86$ & $\begin{array}{l}\text { Mot } \\
\text { Obtained } \\
\text { See Note } 1\end{array}$ & PLUEED \\
\hline LFA - Li2WS & 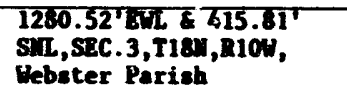 & $\begin{array}{l}\text { Louisians } \\
\text { Power \& } \\
\text { Light (LPEL) }\end{array}$ & STEC & 165973 & $1048-88-1$ & Sinic & LESE & $10 / 1 / 88$ & $\begin{array}{l}\text { lot } \\
\text { Obtained } \\
\text { See Note } 1\end{array}$ & PLUGESD \\
\hline $\begin{array}{l}\text { ICI Hodge Holdings } \\
\text { LVi6h }\end{array}$ & $\begin{array}{l}\text { 1862.3TSL } 178.4 \mathrm{Ki} \text {, } \\
\text { s8c.35,T17, paw, } \\
\text { Bienvilie Parish }\end{array}$ & $\begin{array}{l}\text { RCI Hodge, } \\
\text { Moldings, Inc. } \\
\text { (Wote 3) }\end{array}$ & STIBC & 168160 & $1054-86-1$ & $\infty 2$ & LESE & $9 / 30 / 88$ & $6 / 5 / 89$ & PLUGGD \\
\hline $\begin{array}{l}\text { ECI Hodge Holdings } \\
\text { LVI6B }\end{array}$ & 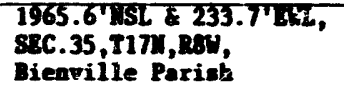 & $\begin{array}{l}\text { KCT Hodge } \\
\text { Eoldinge, Inc. } \\
\text { (llote 3) }\end{array}$ & $s^{2}: C$ & 168161 & $1053-86-1$ & Cot & DESE & $9 / 30 / 85$ & $6 / 5 / 89$ & PLUCESD \\
\hline $\begin{array}{l}\text { TCI Hodge Holdings } \\
\text { LUH6C }\end{array}$ & 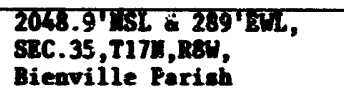 & $\begin{array}{l}\text { RCI lodge } \\
\text { Foldinge, Inc. } \\
\text { (Note 3) }\end{array}$ & 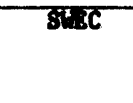 & 168162 & $1052-8.1$ & $\cos$ & LESTE & $9 / 30 / 88$ & $6 / 5 / 89$ & PLDECD \\
\hline $\begin{array}{l}\text { ICI Hodge Holdings } \\
\text { LVH6us }\end{array}$ & 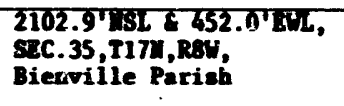 & $\begin{array}{l}\text { ICT lodge } \\
\text { Foldinge, Inc. } \\
\text { (Hote 3) }\end{array}$ & SISC & 166668 & $1051-83-1$ & co: & Trase & $9 / 30 / 88$ & $6 / 5 / 89$ & PLUEEDD \\
\hline $\begin{array}{l}\text { ICI Hodge Holdiage } \\
\text { LH7A }\end{array}$ & 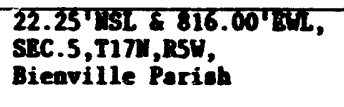 & $\begin{array}{l}\text { TCl Hodge } \\
\text { Holdinge, Inc. } \\
\text { (Hote 3) }\end{array}$ & Sac & 166669 & $1056-8.1$ & $\cos$ & Lens: & $9 / 30 / 68$ & $6 / 5 / 89$ & FLDEEED \\
\hline $\begin{array}{l}\text { KCI Hodge Holdings: } \\
\text { LH78 }\end{array}$ & 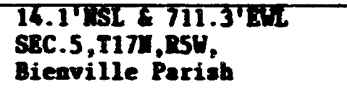 & $\begin{array}{l}\text { FCI Hodge } \\
\text { Foldings, Inc. } \\
\text { (Hote 3) }\end{array}$ & $S^{2}{ }^{2}$ & 166667 & $1055-88-1$ & Ca: & LAS: & $9 / 30 / 88$ & $6 / 5 / 69$ & PLIEEX \\
\hline $\begin{array}{l}\text { ICI Hodge Holdings } \\
\text { Linus }\end{array}$ & 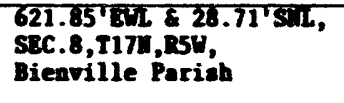 & $\begin{array}{l}\text { ICI lodge } \\
\text { Moldings, Inc. } \\
\text { (lote 3) }\end{array}$ & SthC & 166670 & $1058-68-1$ & $\cos$ & TWSE & $9 / 30 / 68$ & $6 / 5 / 89$ & PLUEE.T \\
\hline $\begin{array}{l}\text { KCI Hodge Holdings } \\
\text { L17A }\end{array}$ & 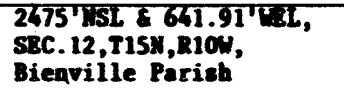 & $\begin{array}{l}\text { ICI Hodge } \\
\text { Moldinge, Inc. } \\
\text { (llote 3) }\end{array}$ & STEC & 16.158 & $1067-68-1$ & $c \alpha$ & LESE: & $9 / 30 / 88$ & $6 / 5 / 89$ & PLDEED \\
\hline $\begin{array}{l}\text { KCI Hodge Holdings } \\
\text { unin }\end{array}$ & 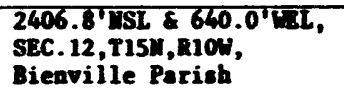 & $\begin{array}{l}\text { ICI Hodge } \\
\text { Holdinga, Inc. } \\
\text { (Hote 3) }\end{array}$ & SWEC & 168159 & $1046-88-1$ & $\cos$ & LEASE & $9 / 30 / 38$ & $6 / 5 / 89$ & PLUEEX \\
\hline
\end{tabular}


TAure 2-1

VIL STATUS sumary

\begin{tabular}{|c|c|c|c|c|c|c|c|c|c|c|}
\hline $\begin{array}{l}\text { BOLS/TILTESTRR } \\
\text { MANE } \\
\end{array}$ & LOCATION & LADOWIER & OPERATCR & $\begin{array}{c}\text { OC } \\
\text { PERMIT } \\
\text { SERIAL Wo. }\end{array}$ & $\underset{\substack{\text { OCRK } \\
\text { PERMIT }}}{.0 .}$ & $\operatorname{vITH}^{\text {ACC }}$ & $\begin{array}{l}S \text { AGREBHERT } \\
\text { TYPE }\end{array}$ & $r_{\text {EXPIRES }}$ & $\begin{array}{l}\text { PNDOWISR } \\
\text { BELEASE } \\
\text { (DATE) }\end{array}$ & STATUS \\
\hline $\begin{array}{l}\text { ICI Hodge Holdings } \\
\text { Lilins }\end{array}$ & 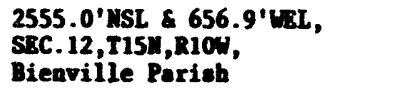 & $\begin{array}{l}\text { XCI Hodge } \\
\text { Holdinge, Inc. } \\
\text { (Note 3) }\end{array}$ & SwEC & 166673 & $1057-88-1$ & $\cos$ & LBASE & $9 / 30 / 88$ & 6/5/89 & PLUGGED \\
\hline A.X.C. Kayford - Vh & 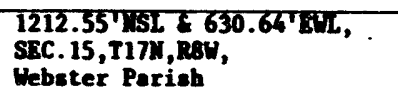 & A.X.C.Rayford & $\begin{array}{c}\text { DOF } \\
\text { REQUIRED }\end{array}$ & 971960 & 007356 & $\mathrm{Cos}$ & LESE & $9 / 30 / 88$ & $6 / 19 / 89$ & PLUGCED \\
\hline E.S. Connell - V5 & 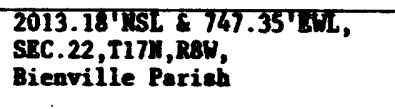 & E.S.Connell & $\begin{array}{c}\text { DOT } \\
\text { REQUIRED }\end{array}$ & 971961 & 007357 & COE & ExASE & $9 / 30 / 90$ & $6 / 10 / 89$ & PLUGGED \\
\hline G.P. Theus - 76 & 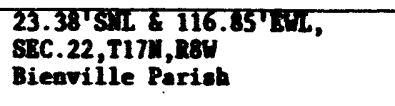 & G.P.Theus: & PEQUI & 971962 & 007358 & SWC $^{2}$ & TESAS: & $7 / 28 / 89$ & $11 / 28 / 88$ & PLUGESD \\
\hline E.S. Connell - V7 & 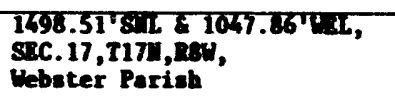 & T.S.conenII & pagirere & 971963 & 006703 & $\cos$ & WWE: & $9 / 30 / 90$ & $6 / 10 / 89$ & PLDGED \\
\hline |SU - RII & 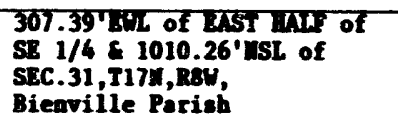 & D.D.llines & $\begin{array}{l}\text { Wor } \\
\text { REquiren }\end{array}$ & 971964 & 007359 & Sisc & TBSE: & $8 / 5 / 69$ & $3 / 16 / 89$ & PLUEES \\
\hline $\begin{array}{l}\text { Continental F.T. } \\
\text { No. } 1\end{array}$ & 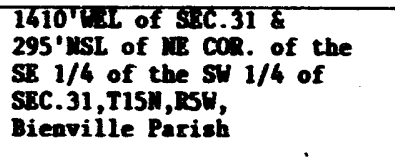 & $\begin{array}{l}\text { Continente1 } \\
\text { Hodge } \\
\text { Woodlends } \\
\text { Inc. } \\
\text { (lote 3) }\end{array}$ & DOE & 157686 & $2118-88-1$ & $\begin{array}{l}\text { m. h. } \\
\text { mans }\end{array}$ & TRASE & $9 / 30 / 88$ & $5 / 17 / 89$ & PLOFEDD \\
\hline Snith, et al - Mo. 1 & 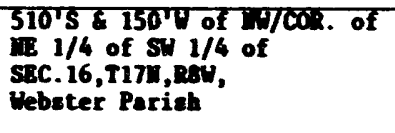 & E.S.Connell & DOE & 157091 & $2117-68-1$ & $\cos$ & TERE & $9 / 30 / 69$ & $\begin{array}{l}\text { See } \\
\text { Note } 2\end{array}$ & PLEE \\
\hline Filteter $-\mathrm{T1}$ & 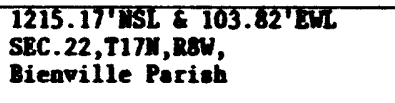 & B.S.Connell & $\begin{array}{c}\text { MOT } \\
\text { REQUIRED }\end{array}$ & $\begin{array}{c}\text { MOT } \\
\text { REQUIRED }\end{array}$ & $\begin{array}{l}\text { MOT } \\
\text { REQUIRED }\end{array}$ & $\mathrm{Cot}$ & IEASE & $9 / 30 / 90$ & $6 / 10 / 89$ & $\begin{array}{l}\text { BACTILLED } \\
\text { \& RESTORED }\end{array}$ \\
\hline Filtweter - T2 & $\begin{array}{l}2278.85 \text { WSL \& } 4065.20 \text { SWL } \\
\text { SEC.20,TIIT, RBW, } \\
\text { Bieaville Parish }\end{array}$ & E.S.Connell & $\begin{array}{l}\text { TOI } \\
\text { REQUIRED }\end{array}$ & $\begin{array}{l}\text { Rof } \\
\text { REQUIRED }\end{array}$ & $\begin{array}{c}\text { Mor } \\
\text { REQUIRED }\end{array}$ & $\cos$ & HESE & $9 / 30 / 90$ & $6 / 10 / 89$ & $\begin{array}{l}\text { BACTILLLD } \\
\text { \& RESTORED }\end{array}$ \\
\hline Tilteter - T3 & $\begin{array}{l}784.34 \text { 'SI \& } 113.08 \text { 'WII } \\
\text { SEC.18, TI7w, RaW, } \\
\text { Webater Parish }\end{array}$ & P.D.Holley & $\begin{array}{c}\text { NOT } \\
\text { REQUIRED }\end{array}$ & $\begin{array}{c}\text { HOT } \\
\text { REQUIRED }\end{array}$ & $\begin{array}{c}\text { MOT } \\
\text { REQUIRED }\end{array}$ & $\cos$ & LEASE & $9 / 30 / 89$ & $6 / 5 / 89$ & $\begin{array}{l}\text { BACTRILLWD } \\
\text { \& RESTORED }\end{array}$ \\
\hline
\end{tabular}


TABLE 2-1

WELL STATUS SUEuRY

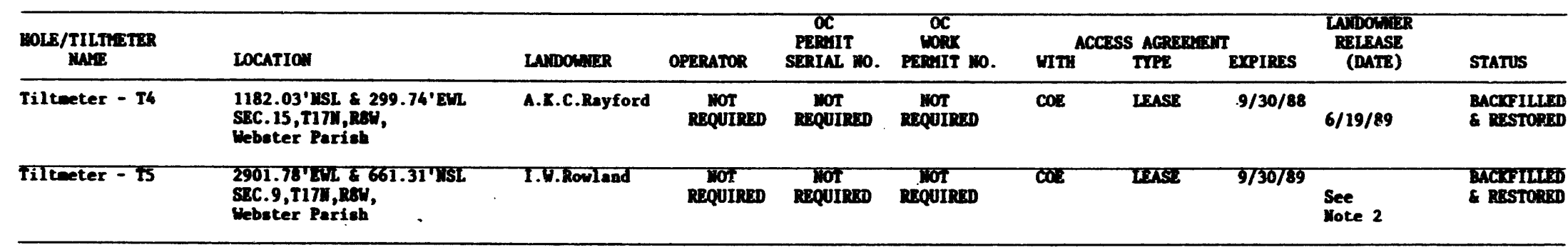

MOTES:

1. Ref. Appendix $D$ for applicable correspondence.

2. Ho written release required. Release is an sutonatic part of the lease if there is no landowner contact vith the coe at least twenty (20) days before the expiration or teraination of the lease.

3. Current landomer is Louisisan Minerals, Ltd.

*lief. Appeadir $\mathrm{C}$ for landonner releases. 
of abandoned wells must be done by a qualified DOTD licensed contractor and that variance requests (Appendix $C$ ) and documentation (Form DOTD-GW-2 in Appendix $B$ ) be submitted by the contractor.

The OC Statewide Order No. 29-B contains the rules and regulations that govern the plugging and abandonment of the deeper DOE wells, i.e., those drilled deeper than the base of the fresh water aquifers. Section XIX, part $F$ of this document addresses documentation and plugging requirements. These regulations require the well operator (SWEC) to file a Work Permit, Form DM-4R (see Appendix B); notify the OC District Manager 12 hours prior to and at the completion of plugging operations; submit a Plug and Abandon Report, Form P\&A (see Appendix B); and a Well History and Work Resume Report, Form WH-1 (see Append $: x$ B). Table 2-2 summarizes all data which was necessary to document field activities for both state and project requirements.

Meetings were held with the OC and DOTD in Baton Rouge to identify and resolve all differences between SWEC procedures, as outlined in AP 1-3, and state regulations. Both agencies agreed that SWEC's plugging procedures satisfied their respective regulations. Additionally, it was requested (ref. telephone memorandum 7/8/88, Appendix D) that SWEC direct a copy of all correspondence regarding the shallow and geotechnical boreholes (<200 ft) to the Department of Environmental Quality (DEQ).

SWEC then prepared contract documents to procure the services and equipment to complete well plugging and site restoration work. A description of the services and the contractors is listed in Table 2-3.

It was also necessary to transfer lease agreements, including leased storage facilities in Louisiana and well operatorship permits, from The Earth Technology Corporation (TETC) to SWEC. This transfer was accomplished via an Assignnent and Assumption Agreement between the two parties. At completion of the transfer, SWEC submitted Form MD-10-RA, Application to Amend Permit to Drill for Minerals (see Appendix B), to the OC to change the well operator from TETC to SWEC for 13 wells (see Table 2-1). Several of the lease agreements were renegotiated to extend through the scheduled completion of decommissioning activities.

\subsection{FIELD ACTIVITIES}

Field activities began on June 24, 1988 with the initiation of site reconnaissance and ended with well plugging and restoration at the $V-5$ site on January 11, 1989. There were six general types of Field Activities: (1) Reconnaissance, (2) Site preparation, (3) Plugging, (4) Removal of wellhead assemblies, (5) Removal and backfilling of tiltometer pits and (6) Site restoration.

\subsection{SITE RECONNAISSANCE}

Reconnaissance included the following activities: 1) locating wells, 2) visually inspecting sites and wells, 3) investigating borehole conditions, and 4) investigating annulus conditions. The initial step of reconnaissance was to plot reported site locations on USGS quadrangles and 
STONE \& WEBSTEF

DOE/SRI

SUMMARY TA

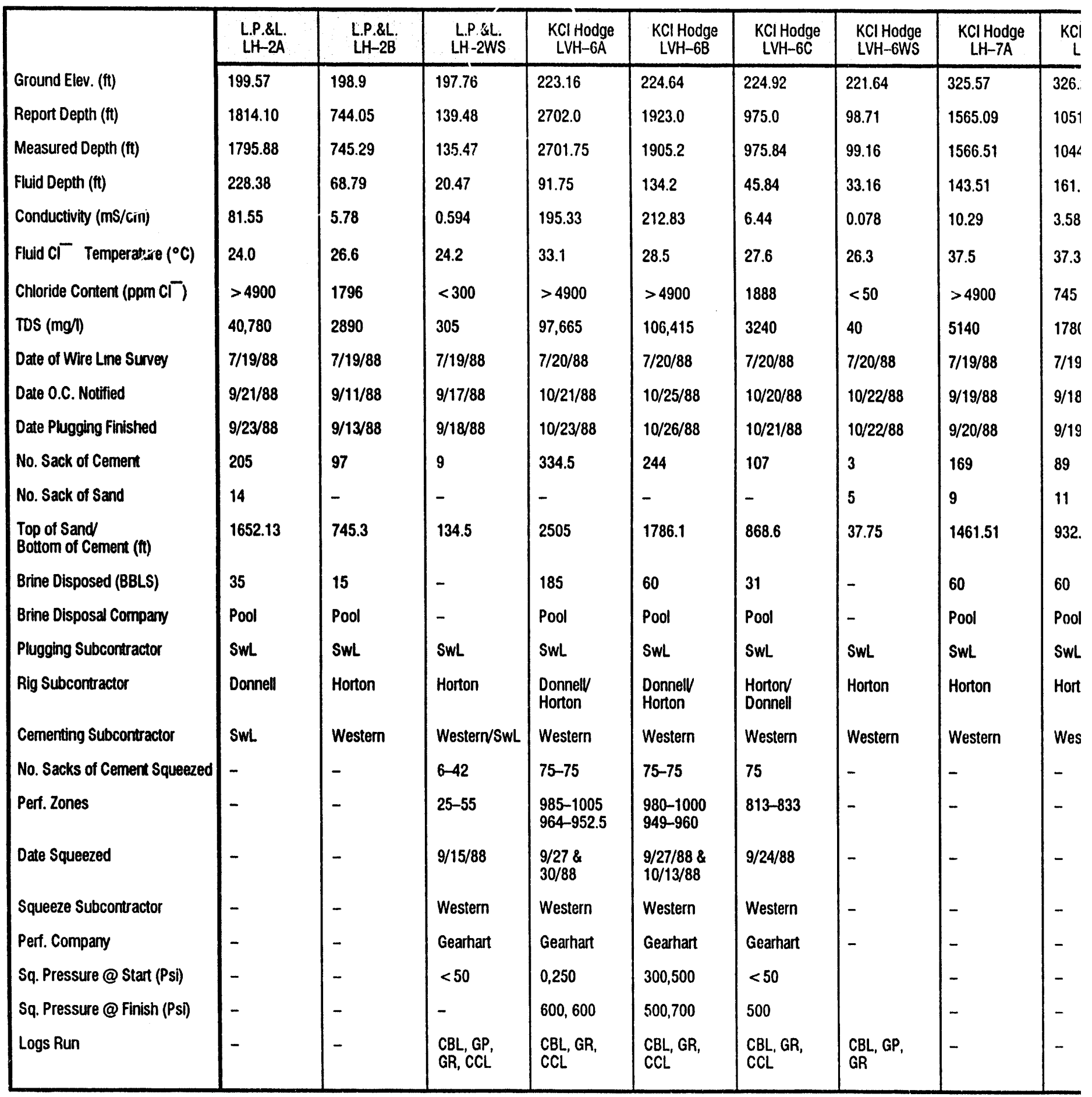

NOTES:

**Well V-7 was obstructed

Depth from ground level

0.C. $=$ Office of Conservation 


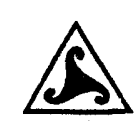

ENGINEERING CORPORATION

O TFSC LOUISIANA

3LE OF PLUGGING DATA

\begin{tabular}{|c|c|c|c|c|c|c|c|c|c|c|c|}
\hline $\begin{array}{l}\text { lodge } \\
-7 B\end{array}$ & $\begin{array}{l}\text { KCI Hodge } \\
\text { LH-7WS }\end{array}$ & $\begin{array}{c}\mathrm{KCl} \text { Hodge } \\
\mathrm{LH}-17 \mathrm{~A}\end{array}$ & $\begin{array}{c}\mathrm{KCl} \mathrm{Hodge} \\
\mathrm{LH}-17 \mathrm{~B}\end{array}$ & $\begin{array}{l}\text { KCl Hodge } \\
\text { LH-17WS }\end{array}$ & $\begin{array}{c}\text { N.C. Rayford } \\
\text { V-4 }\end{array}$ & $\begin{array}{c}\text { E.H.S. Connell } \\
\text { V-5 }\end{array}$ & $\begin{array}{l}\text { G.P. Theus } \\
\text { V }-6\end{array}$ & $\begin{array}{c}\text { E.H.S. Connell } \\
V-7\end{array}$ & LSU-RIA & $\begin{array}{c}\text { DOE } \\
\text { Cont.F.I\#1 }\end{array}$ & $\begin{array}{l}\text { DOE SMITH } \\
\text { et al } \# 1\end{array}$ \\
\hline 7 & 332.79 & 270.00 & 269.72 & 270.38 & 280.84 & 239.52 & 219.29 & 225.89 & 227.64 & 214.6 & 227.7 \\
\hline 0 & 595.0 & 2027.00 & 1377.94 & 433.53 & 488.0 & 387.0 & 618.0 & 806 & 488 & 424 & 972.0 \\
\hline 79 & 588.68 & 2012.91 & 1376.49 & 432.82 & 481.0 & 403.5 & 608 & $124.1^{\star \star}$ & 483.0 & $>500$ & 1075 \\
\hline \multirow[t]{5}{*}{ כ } & 195.18 & 301.91 & 13.99 & 79.29 & 58.0 & 54.2 & 20.5 & ** & 63.0 & Surface & Surface \\
\hline & 0.248 & 67.13 & 55.43 & 0.474 & 1.88 & 3.78 & 23.43 & 472.53 & 0.32 & 523.72 & 520.53 \\
\hline & 30.0 & Not taken & 30.5 & 29.1 & 27.7 & Not taken & 39.5 & Not taken & 37.7 & 28.5 & 24.0 \\
\hline & $<300$ & $>5000$ & $>5000$ & $<300$ & 595 & 1133 & $>4900$ & $>4900$ & $<50$ & $>3600$ & $>4900$ \\
\hline & 124 & 33,565 & 27,715 & 237 & 940 & 1850 & 11,715 & 236,265 & 160 & 261,860 & 260,270 \\
\hline 38 & $7 / 19 / 88$ & $7 / 20 / 88$ & $7 / 20 / 88$ & $7 / 20 / 88$ & $7 / 20 / 88$ & $1 / 04 / 89$ & $7 / 19 / 88$ & $9 / 01 / 88$ & $8 / 21 / 88$ & $8 / 21 / 88$ & $9 / 04 / 88$ \\
\hline 38 & $9 / 20 / 88$ & $10 / 27 / 88$ & $9 / 26 / 88$ & $9 / 22 / 88$ & - & - & $10 / 25 / 88$ & - & 10/28/88 & $11 / 01 / 88$ & $11 / 06 / 88$ \\
\hline \multirow[t]{7}{*}{98} & $10 / 31 / 88$ & $10 / 28 / 88$ & $11 / 04 / 88$ & $10 / 01 / 88$ & $10 / 27 / 88$ & $1 / 09 / 89$ & $10 / 25 / 88$ & $9 / 09 / 88$ & $10 / 31 / 88$ & $11 / 03 / 88$ & $11 / 07 / 88$ \\
\hline & 47 & 204 & 277.8 & 15 & 45 & 33 & 46 & 77 & 24 & 157 & 312 \\
\hline & 12 & 3 & 7 & 15 & 2 & 11 & - & - & 2 & - & - \\
\hline & 460.24 & 1959.65 & 1298.35 & 282.3 & Unknown & 367.36 & 603.0 & 742.0 & 454.0 & 478.4 & 1028 \\
\hline & - & 60 & 50 & - & 11.9 & 6 & 15 & 14 & 5.74 & 47 & 125 \\
\hline & - & Pool & Pool & - & Pool & Pool & Pool & Pool & Pool & Pool & Pool \\
\hline & SWL & SWL & SWL & SWL & SWL & SWL & SWL & SWL & SWL & SWL & SWL \\
\hline .7 & Horton & Donnell & Horton & Horton & Horton & SWL & Horton & Horton & Horton & Horton & Horton \\
\hline \multirow[t]{9}{*}{$=n$} & Western & Western & Western & Western & Western & SWL & Western & Western & Western & Western & Western \\
\hline & - & - & - & - & - & - & - & - & - & - & $75-75$ \\
\hline & - & - & - & - & - & - & - & - & - & - & $\begin{array}{l}535-555 \\
485-465\end{array}$ \\
\hline & - & - & - & - & - & - & - & - & - & - & $\begin{array}{l}11 / 09 \& \\
14 / 88\end{array}$ \\
\hline & - & - & - & - & - & - & - & - & - & - & Western \\
\hline & - & - & - & - & - & - & - & - & - & - & Gearhart \\
\hline & - & - & - & - & - & - & - & - & - & - & 0,0 \\
\hline & - & - & - & - & - & - & - & - & - & - & 250,800 \\
\hline & $\begin{array}{l}\text { CBL, GP, } \\
\text { GR, CCL }\end{array}$ & $\mathrm{CBL}, \mathrm{GP}$ & CBL, GP & $\begin{array}{l}\text { GP, CBL, } \\
\text { CCL, GR }\end{array}$ & CBL, GP & $\begin{array}{l}\mathrm{CBL}, \mathrm{GR}, \\
\mathrm{CCL}\end{array}$ & $\begin{array}{l}\mathrm{CBL}, \mathrm{GR}, \\
\mathrm{CCL}\end{array}$ & $\begin{array}{l}\mathrm{CBL}, \mathrm{GR}, \\
\mathrm{CCL}\end{array}$ & $\begin{array}{l}\text { CBL, GR, } \\
C B L\end{array}$ & $\begin{array}{l}\text { CBL, GR, } \\
\text { CCL }\end{array}$ & $\begin{array}{l}\text { CBL, GR, } \\
\text { CCL }\end{array}$ \\
\hline
\end{tabular}


TABLE 2-3

TABLE 2-3

SWEC SUBCONTRACTORS

\section{Description of Contract}

Land Agent

Plugging \& Cementing of Deen Wells and

Shallow Boreholes

Wireline Services

Squeeze Cementing

Geophysical Logging

and Perforating

Access Road

Reconditioning

Surveying
Purchase Order

Number

\section{.0035}

.0036

$\&$

.0030

.0061

.0063

.0062

.0060

.0066
Contractor's Name \& Address

David Miller

974 E. Fortification St.

Jackson, MS 39202

Southwestern Laboratories

P.0. Box 37571

Shreveport, LA 71105

Otis Engineering Corporation

P.0. Box 5335

Bossier City, LA 71171

Western Company

4920 Shed Road

Bossier City, LA 71111

Gearhart Industries, Inc.

P.0. Box 7717

Shreveport, LA 71137

Roy Edwards Construction

Rt. 1, Box 89B

Benton, LA 71106

Atchley \& Atchley, Inc.

412 La Salle St.

Shreveport, LA 71107
Comments

Assisted SWEC in title searches and lease negotiations

Western Company did

cementing. No shallow borehole plugging work was performed

Included depth measurements and fluid sampling 
TABLE 2-3 (Cont.)

Description of Contract

Site Restoration

Joseph C. Holmes, Jr.

Professional Services

Digital Conductivity

\& TDS Meter

Office Space
Purchase Order Number

.0045

.0040

.0059

.0076
Contractor's Name \& Address

Newt Brown Contractor, Inc.

Route 3, Box 1245

Minden, LA 71055

Joseph C. Holmes, Jr.

5515 S. Afton Pkwy.

Baton Rouge, LA 70806

Hach Co.

P.0. Box 389

Loveland, Colorado 80539

Sheraton Pierremont

1419 East 79th Street

Shreveport, LA 71105
Assisted SWEC in shallow

borehole search 
confirm the location by field inspection. The second phase was to evaluate and describe the condition of access roads, site pads, and wellheads. The as-found condition of the roads, pads and wellheads was documented with written descriptions, plan and profile sketches, and photographs according to PTP 1-18 (see Appendix A).

Information obtained during phase two of site reconnaissance identified where earthwork was necessary to accommodate the equipment involved in the plugging and abandonment operations. Well sites $\mathrm{LH}-7, \mathrm{LH}-17, \mathrm{~V}-4, \mathrm{~V}-5, \mathrm{~V}-7$, LSU R1A, and tiltmeter sites $\mathrm{T} 1$ and $\mathrm{T} 2$ required minor work. Sites $\mathrm{V}-7$ and $V-5$, however, required extensive earthwork to enable equipment to gain access to the site.

Phases one and two of site reconnaissance at well sites LH-2, LVH-6, LH-7, $\mathrm{LH}-17, \mathrm{~V}-4, \mathrm{~V}-6, \mathrm{~V}-7$ and tiltmeter sites T1, T2, T3, T4, and T5 were performed in June 1988. Three sites (Tiltmeter T5, DOE Smith et al. No. 1, and LSU-R1A) required lease renegotiations and one site (DOE Continental FI et al. No. 1) wis added to the scope of work at a later date. Therefore, reconnaissance on these sites could not be completed until August 1988.

Reconnaissance of site V-5 was delayed until January, 1989 because it could not be located based on existing well information.

Phase three of the reconnaissance process began in mid-July at sites where preliminary reconnaissance and earthwork had been completed and continued as sites became available. Otis Engineering was contracted by SWEC to perform downhole wireline surveys in each well. The purpose of the survey was to:

- Check for and attempt to clear borehole obstructions.

- Measure fluid level.

- Measure total depth of the well.

- Collect a water sample for salinity determination from approximately $10 \mathrm{ft}$ above the total depth.

- "Feel" for the riser pipe (where the well narrows to screen diameter - see Appendix A, Attachment 6).

Information collected during the wireline survey and testing was used to determine which wells would require disposal of saline borehole fluid, the quantity of fluid to be disposed of, and the quantity of cement needed to plug each well.

The OC Statewide Order 29-B, Section XV, paragraph 13.1 - Pollution Control, requires that all "produced" water with chloride concentrations $>500 \mathrm{ppm}$ be collected, removed from site, and disposed of at a state licensed disposal facility.

A Hach met, was used to measure the conductivity, total dissolved solids (TDS), and temperature of the downhole water samples. Quantabs were used to measure chloride ion $\left(\mathrm{Cl}^{-}\right)$concentration. Measurements showed that all 
wells except the four water supply wells (LH-2WS, LVH-6WS, LH-7WS, LH-17WS) and the LSU-R1A well had water with high TDS and $\left(\mathrm{Cl}^{-}\right)$ion concentration. Test data for each well can be found on Site Reconnaissance Forms (Appendix A).

The wireline contractor (Otis Engineering) encountered obstructions in two wells, V-7 and LSU-RIA. A wireline bailer successfully removed four minor sediment bridges from LSU-R1A. An obstruction in V-7 at $124.1 \mathrm{ft}$ required drilling and details on the removal of this obstruction are discussed in Section 3.2.2. A majority of the wells were constructed with tailpipes extending below the screen section. The tailpipes commonly were filled with deposits of pipe scale, which at times extended up into the well screen. Neither SWEC nor the state agencies (DOTD and OC) considered this material harmful and it was not removed before plugging (Notes of Conference; 8/15/8?, Appendix D).

The last phase of site reconnaissance was to evaluate the casing-to-borehole annular seal at the interface between the freshwater zone and the saltwater zone using Cement Bond Logs (CBLs). Stone and Webster obtained CBLs previously run by LETCo in the following wells: LH-2A \& B; LVH-6A, B, \& C; LH-7A \& B; and LH-17A. CBLs were run in the remaining eleven wells by Gearhart Industries.

The downhole geophysical survey produced four types of logs; a Cement Bond Log (CBL), Gamma Ray (GR), Casing Collar Locator (CCL), and Gravel Pack log (GP). The CBL evaluated the cement in the annulus, whereas the GR and CCL provided depth control. The GP evaluated the quality and quantity of gravel pack surrounding the screen section of the well as this could affect cement plug quantities. An evaluation of the geophysical logs indicated that five wells (LVH-6A,B and C, DOE Smith, and LH-2WS) had inadequate annular seals, as defined by the $O C$, and required perforating and squeeze cementing (see Section 3.3).

Geophysical logging of water supply wells (LH-2WS, LVH-6WS, LH-7WS, and LH-17WS) was not possible as the cemented portion of each well was above water level and the CBL tool needs a fluid medium to transmit the acoustic signal. An attempt was made to measure the cement bonding using a Gravel Pack Tool but did not provide any useful information.

\subsection{PLUGGING}

\subsubsection{Plugging Sequence}

SWEC subcontracted the plugging and abandonment work to Southwestern Laboratories Inc. (SWL). Appendix A contains SWEC's plugging reports and borehole completion sketches for each observation well that was plugged and abandoned. Plugging followed a typical procedure for most of the DOE wells (LH-2A, LH-7A, LH-7B, LH7-WS, LH-6WS, LH-17A, LH-17B, LH-17WS, V-4, V-5, $\mathrm{V}-6$, and LSU $\mathrm{R} 1 \mathrm{~A}$ ) in Louisiana. The typical plugging procedure is summarized as follows:

1. 20-40 mesh sand was tremied from TD to approximately $10 \mathrm{ft}$ above the screen. 
2. A cement-bentonite slurry $(13.2 \mathrm{lb} / \mathrm{gal})$ was placed by continuous pump-down from the top of the sand to ground surface.

3. Displaced brine was collected and removed to a disposal well.

4. Casing annuluses, open at ground surface, were filled with cement at the time of plugging.

\subsubsection{Variations from Typical Plugging Procedures}

Deviations from the typical sequence are described below:

- Well LH-2B: During placement of cement, the screen collapsed, allowing the gravel pack and formation to seize the tubing resulting in abandonment of $724 \mathrm{ft}$ of $2-3 / 8$ in. diameter tubing in the well. Cement was subsequently pumped into the tubing, from bottom to top, and into the casing-tubing annulus from $74 \mathrm{ft}$ (top of initial plug) to ground surface.

- Well LH-2WS: A cement retainer was set at $58.33 \mathrm{ft}$. Tubing was inserted through the retainer and cement was pumped into the lower screened section of the well. The tubing was pulled back through the retainer and the annulus was then squeeze cemented using the retainer as lower bridge plug (Section 3.3). After the squeeze operation, the well was plugged from the top of the retainer to ground surface.

- Well V-6: Because of a partial obstruction in the well, tubing could not be placed in the screen section to install the sand plug. Therefore, cement was pumped into the screen as well as the casing.

- Well V-7: This well was obstructed at $124.1 \mathrm{ft}$ below ground level. A drill rig was mobilized on September 1, 1988 to drill out the obstruction and probe the well to its completion depth $(806 \mathrm{ft})$. Drilling the obstruction initially produced large amounts of wood fiber, plastic, and aluminum. After two days of drilling and circulating the well was cleared to $740 \mathrm{ft}$. An additional day of drilling advanced the hole only $4 \mathrm{ft}$. At this time, various fishing operations were attempted to clear the well; the only significant result was the retrieval of an $18 \mathrm{in.}$ long piece of 2-1/2 in. diameter pipe. An additional day of drilling advanced the hole less than $1 \mathrm{ft}$.

On September 9, the plugging subcontractor (SWL) applied for, and received, a variance (see Appendix C - letter of $9 / 9 / 88$ ) from the Louisiana Department of Transportation and Development (DOTD) to plug the well from the top of the obstruction $(742.79 \mathrm{ft})$ to ground surface. Cement pumped for the plug was in excess of the volume required to fill the casing (See Appendix A). It is assumed that a portion of this cement bypassed the obstruction and filled the lower section of the well. 
- Wells LVH-6A, $B$, and C: These wells required squeeze cementing because of poor casing-borehole annular seals (Section 3.3). In each well, a drillable bridge plug was set, the casing was perforated, and cement was squeezed into the annulus. After squeezing and relogging the wells, the bridge plugs were drilled out and fell and became lodged where the wells narrow from 6-5/8 in. casing to $4-1 / 2$ in. riser pipe.

Various methods were tried to remove the bridge plug debris including conventional drilling (with and without extra weight), milling (using various types of diamond mill bits), spearing, and magnetic retrieval. The most successful method was magnetic retrieval. No method was able to completely clear bridge plug debris from the top of the riser pipe.

Southwestern Laboratories requested, and was granted, a variance by the DOTD to plug the three wells (LVH-6A, B, and C) from the obstructions to ground surface (see Appendix C - letter of 10/21/88). All three wells required cement in excess of that required to fill the casing. It is presumed that the extra cement bypassed the obstructions to fill the screen and the riser pipe.

- DOE Smith No. 1 and DOE Continental No. 1

Both of these wells were drilled to approximately 5,000 ft, but were cased to only 424 (DOE Continental) and $972 \mathrm{ft}$ (DOE Smith); neither was screened. In accordance with OC regulations, a balanced cement plug was placed at the bottom of the casing extending $50 \mathrm{ft}$ into the open borehole and $50 \mathrm{ft}$ up into the casing. This initial plug was allowed to cure for 24 hours before continuing plugging activities.

The DOE Continental No. 1 well was then cemented from the top of the balance plug to ground surface without any intervening work. The DOE Smith No. 1 well required squeeze cementing and is discussed in Section 3.2.3.

\subsubsection{SQUEEZE CEMENTING}

Remedial cementing (squeezing) in the borehole-casing annulus is required by the $O C$ in all wells where primary cementing does not effectively protect the freshwater aquifers from underlying saltwater zones. Meetings were held August 15, and September 8, 1988 between Stone \& Webster, the DOTD and the $O C$ to evaluate the need for cement squeezing. The results of these meetings indicated that only wells LVH-6A, B, and C and the DOE Smith well would require squeeze cementing. Attachment 1 of Appendix A contains squeeze cementing reports for the above four wells.

The DOTD and OC recommended that 50 cumulative feet of good annular seal exist at the fresh water - salt water interface. In most cases, a well required two squeeze operations to get the recoinmended length of seal.

Although site water supply (WS) wells did not penetrate the base of the freshwater, the casings were not cemented to total depth as is presently 
required by the DOTD. SWEC attempted to improve this seal in well LH-2WS by perforating and squeezing. No pressure buildup was established, indicating that cement flowed into the surrounding formation rather than into the annulus. Subsequent logging (CBL) revealed no improvement in the borehole seal and, with the concurrence of the OC, SWEC made no further attempts at squeezing the other water supply wells.

The typical sequence for squeezing a well is described as follows:

1. Set a bridge plug to isolate the bottom of the zone to be squeezed.

2. Perforate the casing ( 4 shots/ft for $20 \mathrm{ft}$ ).

3. Set a squeeze packer above the uppermost perforations.

4. Squeeze approximately 75 sacks (as recommended by the OC - see notes of meeting August 15) of Class A neat cement behind the casing.

5. Run CBL and evaluate results.

6. Proceed with plugging or resqueeze and $\log$, as necessary.

Squeezing in the DOE Smith well differed from the typical method as follows: (1) the top of the initial cement plug (see Section 3.2.2) was used as the bottom of the squeeze zone instead of a bridge plug and (2) an upper squeeze packer could not be set. In lieu of this, the well head was pressurized and shut-in during cementing. The well required two squeeze operations.

\subsection{REMOVAL OF WELLHEAD ASSEMBLIES}

After the wells were plugged, SWEC was responsible for removing the wellhead and cutting the casing to a minimum depth of $3 \mathrm{ft}$. below ground level, in accordance with DOTD and OC rules. The typical procedure was as follows:

- Excavate around the wellhead to a minimum depth of $4 \mathrm{ft}$.

- Inspect the area surrounding the outermost casing for visible annular space and grout.

- Cut off casing a minimum of $3 \mathrm{ft}$ below the ground surface.

- Weld a steel cap to the top of the outermost sasing of the well.

- Backfill the excavation with native soil and compact.

\subsection{TILTMETER SITE REMOVAL}

Five tiltmeter sites were located around the flanks of Vacherie Dome. Each site consisted of two pits lined with 42 in. diameter, corrugated steel pipes, with the exception of $T-1$ which had three pits. Pit depths varied from 2.5 to $5.5 \mathrm{ft}$ and were connected by one inch diameter, PVC conduit. One pit at each site had an 8 in. diameter, Schedule 80 PVC or corrugated 
steel pipe, filled with coarse blasting sand, extending down 4 to $8 \mathrm{ft}$ from the center of the pit floor. Appendix A, Attachments 3, 5, and 9 describe site conditions before decommissioning.

The pits penetrated no aquifer and, therefore, no state documentation was required. However, SWEC documentation was completed and the landowners were contacted for concurrence with the decommissioning/restoration work.

All material removed from the tiltmeter pits was inventoried, and disposed of at an offsite location. The pits were filled with 18 in. of clay, followed by layers of compacted native soil to ground surface and graded to the surrounding contours.

\subsection{SITE RESTORATION}

Site Restoration activities commenced in November 1988 after the majority of the well plugging and abandonment was completed. Newt Brown Construction Company was subcontracted to perform restoration. Typical site restoration included removal of all debris such as stumps, brush, and waste cement; regrading, and discing the topsoil; and seeding and fertilizing.

Tiltmeter $\mathrm{T}-4$ site required only minor grading and, at the owner's request, pine saplings were planted. At the $V-6$, DOE Continental No. 1, Tiltmeter $T-3$, and $T-5$ sites, no site restoration was required (see Appendix $D$ for landowner documentation). However, the landowner at site $V-6$ did request and receive compensation in lieu of restoration. In addition to the normal restoration at LSU-R1A, the landowner requested that pine seedlings be planted and a small pit be backfilled. The landowner of sites $V-5, T-1$ and $\mathrm{T}-2$, Willamette Industries (a paper company), received a cash settlement for tree damage.

\subsection{SHALLOW BOREHOLE SEARCH}

SWEC conducted a thorough records search to establish the locations and abandonment status of the shallow boreholes drilled in the vicinity of Vacherie Dome. The work involved examining state and project records, interviewing personnel involved with the shallow borehole program (i.e. drilling contractors, LSU/IES personnel, and landowners), and field surveys.

\section{Records Search}

a. State Records - SWEC contacted the various state agencies (Department of Transportation and Development, Department of Conservation, State Geologic Survey, and Department of Environmental Quality) presently involved in maintaining drilling, completion, production, and plugging records for oil and gas, water wells, and exploratory test holes. However, in 1977-79, the state agencies did not require submittal of plugging records for shallow boreholes and none were found.

b. Project Records - Battelle provided a complete list of IES/LSU and LETCo Records Turnover Packages (RTPS). SWEC selected applicable microfilm rolls for detailed review. A search of these records provided the following information: 
- Field plugging records for the $R(V R), T$, and $D$ series of shallow boreholes.

- Specifications for the drilling, sampling, and plugging of all shallow boreholes and the names of the drilling contractors who performed the work.

- IES/LSU field survey notes for the locations and elevations of the $B, S$, and $M$ series of shallow boreholes.

- Maps showing the locations of all shallow boreholes. However, the scale of the maps did not allow for accurate location in the field.

- Geologic cross sections showing the depths and elevations of all shallow borings.

- Numerous project reports, prepared primarily by IES/LSU, which presented and discussed the data obtained from drilling and testing in shallow boreholes. However, none of the reports contained plugging records or addressed plugging procedures or methods.

SWEC questioned present and former Battelle employees involved in the Gulf Coast Dome studies about the existence of plugging records. No additional information was obtained.

c. Drilling Contractors - SWEC contacted the two firms that drilled the shallow boreholes, McClelland Engineers and Fowler Drilling Co. Both firms performed a records search, but neither could provide any written documentation related to borehole plugging. McClelland Engineers (presently Grubbs, Garner and Hoskyn, Inc.) stated (telephone memorandum $10 / 11 / 88$ ) that the $B, S$, and $M$ series of holes were backfilled with drill cuttings and/or drilling mud. Fowler Drilling Co. said (telephone memorandum 10/29/88) it was standard practice to backfill borings with cuttings and mud, and according to their recollection this had been done for the shallow boreholes.

d. Louisiana State University - IES/LSU personnel stated that all field records had been turned over to Project (see "b " above). Dr. Joseph Holmes of LSU, who had direct involvement with the shallow borehole work, provided the following information:

- Dr. Holmes was present for the plugging of the "VR" ( $R$ ) and "T" series of boreholes. Plugging consisted of backfilling the holes with drill cuttings and topping off with cement.

- To his knowledge all the shallow boreholes where backfilled with drill cuttings or cuttings topped off with cement. The backfilling of borings was expected and stressed to all IES/LSU faculty and students involved in the field work. 
- Professional surveyors or LSU graduate students surveyed all the hole locations.

- Returning to the field 2-3 years after drilling the shallow boreholes, Mr. Holmes could locate only a few holes.

- Not all the boreholes, particularly the "B" series, are located on or adjacent to existing Parish or logging roads.

Dr. Holmes made a visit to the field with SWEC personnel in October, 1988. The results of this reconnaissance survey are discussed below under "Field Surveys".

e. Law Engineering Testing Company (LETCo) - Mr. John R. Diehl (presently employed by Marathon Oil Co.) was the LETCo on-site representative responsible for Quality Assurance during the drilling of approximately 50 shallow boreholes at Vacherie Dome. In conversations with SWEC, Mr. Diehl (telephone memorandum, $12 / 12 / 88$; Appendix $C$ ) stated that the shallow boreholes drilled under his supervision were backfilled with bentonite pellets, drilling mud, and/or cuttings.

SWEC could not locate other LETCo staff directly involved in the shallow borehole program. LETCo stated that all records had been turned over to Project (see "b" above).

f. The Earth Technology Corporation (TETC) - TETC encountered similar problems locating plugging records for the shallow boreholes at Rayburns Dome. A search of TETC files failed to provide any plugging information that was not contained in the Project RTP's (see "b" above).

g. Landowners - SWEC contacted landowners, to obtain permission to perform a land survey and visual search. The landowners comments varied from; "no comment," "what holes?," "there are no holes," to "there are holes." Permission was obtained from all but two landowners on whose land 9 holes $(M-1,-2$ and $-3, S-9,-10,-11$, -12 , and -13 , and $B-39)$ were drilled. The survey and visual search performed by SWEC is discussed below.

\section{Field Surveys}

a. SWEC and professional surveyors attempted to locate the $B, S$, and $M$ series (a total of 95 holes) of holes in the field using IES/LSU survey notes obtained from the Project Records. The survey notes were difficult to decipher, however, many of the holes are located along existing roadways and approximate distances could be determined with some confidence. SWEC staked and inspected the surveyed locations.

Shallow depressions (less than $1 \mathrm{ft}$ deep) and holes 6 in. to 8 in. in diameter, extending to depths of approximately $3 \mathrm{ft}$ were found within the vicinity of several staked locations. It is SWEC's opinion that these are animal burrows or old stump holes as 
similar open holes can be found throughout the study area. No significant depressions, deep vertical holes, collapsed features, drill cuttings, or remains of cement grout could be identified at any of the surveyed hole locations.

b. Site Reconnaissance by Dr. Holmes of LSU - A site visit was made by $\mathrm{Dr}$. Holmes in October, 1988 to assist SWEC in establishing the location of survey lines and, if possible, to locate individual boreholes. Dr. Holmes confirmed or corrected the surveyed lines established by SWEC for those holes located along existing roadways. However, exact hole locations still could not be established.

One shallow borehole (S-22), approximately $4 \mathrm{in.}$ in diameter and about $1.5 \mathrm{ft}$ deep, was tentatively found by $\mathrm{Dr}$. Holmes. Six adjacent holes, located along the same abandoned Parish road (S14A, 16, 17, 19, 20, and 21), could not be located by $\mathrm{Dr}$. Holmes or SWEC.

It is SWEC's opinion that the shallow boreholes were probably plugged immediately after completion of drilling, sampling, and logging. The plugging methods and materials most likely varied (cuttings, mud, cement) depending on the depth of the hole. The lack of surficial evidence of collapse at suspected locations suggests the holes were backfilled and/or have filled naturally with little or no detrimental effect. Our conclusion, based on existing information, is the shallow boreholes are adequately plugged and do not present a hazard.

Further searching (through records or in the field) for the shallow boreholes would consume many man-hours and produce minimal results. SWEC has spent extensive time searching through project, state, and subcontractors' drilling records to obtain the information, summarized above in section 3.6 .

An in-depth reexamination of these records will produce, at best, only a small amount of additionai information for the following reasons:

a. No state records exist for the drilling or plugging of the shallow boreholes because: 1) The drilling of the shallow boreholes preceded DOTD Chapter III regulations (1985) requiring submittal of plugging records to the state, and 2) OC Statewide order 29-B only regulates wells drilled below the freshwater sands.

b. On-site personnel such as drillers and project Q.A. representatives have already been contacted without producing anything more than the recollection that the standard procedure at the end of drilling was to either backfill with cuttings and mud, add bentonite pellets, or grout the holes (ref. telephone memorandum 6/17/88, Appendix D).

Any further attempt to relocate the shallow boreholes in the field would, in our opinion, also meet with minimal success. 
Records indicate that the shallow boreholes were surveyed in by LSU/IES project personnel and not by a professional subcontractor. Relocation of the boreholes in the field would be very difficult because they are lacking in the following ways:

a. There is no reference point indicated from which the survey started.

b. There is no indication whether true or magnetic north was used for the survey.

c. There is no indication whether angles were turned to the right or left.

d. Survey angles do not appear to have been doubled as a check for accuracy.

e. Angles were only recorded to the nearest degree, not to 10 seconds which is the normal practice.

f. In many cases, the backsight is very short, making the survey less accurate.

g. There is no closure or any tie points.

The notes were reviewed by a project engineer and a surveying subcontractor and the resulting reconstruction was laid out for the $B, S$, and $M$ lines. Surveyed locations were searched to a radius of 20 feet without any success. In some areas, the survey crews spent more time cutting and clearing brush and trees than laying out lines.

It is SWEC's opinion that further attempts to reconstruct survey notes and resurvey the lines will consume many man-hours but produce few, if any, results given the limitations (items a through $g$ above) of the original survey notes.

\subsection{GEOTECHNICAL BOREHOLES}

Five geotechnical boreholes were drilled in proximity to four of the Tiltmeter locations ( $\mathrm{T}-1$ through $\mathrm{T}-4)$. The borehole locations were obtained from a map published in an IES/LSU report The map provided approximate bearings and distances from the Tiltmeter locations to the geotechnical boreholes. Using this information, four of the five boring locations were found staked. Borehole TB-2C3 was not found.

The locations were probed with a $6 \mathrm{ft}$ length of rebar. Except for TB-2, the rebar penetrated the ground surface only about 4 to 6 inches. At the TB-2 location, the surface depression was easily penetrated about four feet. Further investigation showed a sizeable vertical opening that might indicate an "open hole" condition to a significant depth. A backhoe excavated a $10 \mathrm{ft}$ deep pit at the borehole location. A small diameter open hole at the bottom of the excavation was probed an additional $15 \mathrm{ft}$, before encountering solid material. The open hole was backfilled with sand, bentonite (dry) and cement (dry), and the excavation was backfilled with soil and compacted. 


\subsection{SURVEYING}

SWEC's review of project records failed to provide survey data for the $V-4$, $V-5, V-6, V-7$ wells, the LSU-R1A well, and the tiltmeter sites. SWEC had these sites and wells resurveyed and tied into both the USGS grid and the state Township and Range grid. Survey plats for all test sites can be found in Appendix $\mathrm{C}$.

The surveying contractor also assisted SWEC in the shallow borehole search (See Section 3.7). SWEC's records search produced an inadequate set of shallow borehole survey notes. From these notes the surveying contractor attempted to reconstruct a set of usable survey notes. Numerous assumptions (use of true or magnetic north, right or left turned angles, etc.) were required, thus, the resulting field locations were surveyed in without a high level of confidence.

\subsection{DOCUMENTATION}

Documentation of decommissioning activities was required by SWEC and the State of Louisiana.

\subsection{STATE DOCUMENTATION}

Plugging and abandonment forms were required by two state agencies; the Office of Conservation (OC) and the Department of Transportation and Development (DOTD). For the decommissioning work performed in Louisiana, the OC required that the operator (SWEC) submit the following:

Form MD-15-R - Amended Permit to Drill for Minerals - This form was required to change the operatorship of DOE wells from The Earth Technology Corporation (TETC) to Stone \& Webster Engineering Corporation (SWEC). Copies of these forms are contained in Appendix B.

Form DM-4R - Work Permit - This form was submitted to the District OC Office and approved prior to performing abandonment work at any $O C$ permitted well. Copies of the form are contained in Appendix B.

Form UIC-17 - Injection Well Work Permit - The V-series of wells (V-4, $5,6 \& 7)$ and the LSU-R1A well were not previously permitted with either the OC or DOTD. The State Department of Natural Resources (DNR), Office of Injection Mining, instructed SWEC to utilize Form UIC-17 for these five wells rather than DM-4R. Copies of these forms are contained in Appendix B.

Form WH-1 - Well History and Work Resume Report - The operator of a well must file this report when a new well is drilled or when work is performed on an existing well. SWEC submitted a report (see Appendix B) on each well that it plugged and abandoned in Louisiana.

Form P\&A - Plug and Abandon Report - The P\&A form summarizes the plugging and abandonment activities performed at a well. A copy of this form is in Appendix $B$. 
The OC also requires that a "Nonhazardous Oil Field Waste Shipping Control Ticket" (Appendix B) be completed by the hauling contractor when brine is removed from a well for disposal. This form identifies the well, operator, the type and quantity of waste, the transporter, and the commercial facility at which the waste is to be disposed.

The DOTD requires that the plugging contractor (Southwestern Laboratories) submit the following:

Form DOTD-GW-2 - Water Well Plugging and Abandonment - This form provides well owner and location information, a description of the well design, and details on how the hole was plugged. Copies of these forms are provided in Appendix B.

\subsection{SWEC DOCUMENTATION}

Documentation required by SWEC's Field Representatives is identified in the TFSC/SPRO Project Manual, AP-1-3 "Well Plugging and Site Restoration of Work Sites in Louisiana", and PTP 1-18, Documentation of Plugging and Abandonment of Boreholes and Restoration of Work Sites".

\subsubsection{Administrative Documentation}

Daily and Weekly Progress Reports were prepared and distributed by the Field Representatives. Originals of these reports were returned to the Project Headquarters Files at completion of field work, and have been turned over to DOE/SPRO as part of final Records Turnover Packages (RTPs). Copies of the Weekly Progress Reports are contained in Appendix B.

\subsubsection{Technical Documentation}

Documentation requirements for recording technical information related to plugging and restoration work are set forth in PTP 1-18 "Documentation of Plugging and Abandonment of Holes and Restoration of Work Sites." Final versions of all applicable SWEC forms are included in Appendix $A$ of this report as follows:

- Attachment 1: Weekly Progress Reports

- Attachment 2: Site Reconnaissance

- Attachment 3: Schematic of Pre-Abandonment Site Status

- Attachment 4: Borehole Completion Sketch

- Attachment 5: Plugging Report

- Attachment 6: Perforating and Squeeze Cementing Report

- Attachment 7: Site Restoration

\subsubsection{Photo Documentation}

Before and after photographs were taken of each site during reconnaissance and restoration and are included in Appendix $A$. 


\subsection{LANDOWNER RELEASES}

At the completion of field operations it was necessary to obtain releases from landowners on whose property test sites were located (Ref. Table 2-1). The primary purpose of the release is to document that surface site restoration (i.e., final grading, seeding, tree planting, access road upgrading or removal) was completed according to the requirements contained in the lease (access) agreements and that this work has been performed to the satisfaction of the landowner. SWEC was responsible for obtaining releases for the three (3) wells covered in agreements entered into between the landowner(s) and SWEC. The release for the DOE - Continental No. 1 well was obtained by the current lease holder, Dr. R. L. Thoms. Obtaining releases for the remaining wells and Tiltmeter sites was the responsibility of the Corps of Engineers. Releases were obtained from all but one landowner on whose land wells and tiltmeters were located (see Appendix C). Louisiana Power and Light (wells LP\&L LH2A, B, and WS) would not sign a landowner's release in spite of repeated attempts. Correspondence applying to this effort is located in Appendix C.

\subsection{SUMMARY}

In 1988, the Department of Energy authorized SWEC to decommission test well and tiltmeter sites at Vacherie and Rayburns Domes. During May and June, SWEC prepared required documents (Activity Plans, Project Procedures, and Scopes of Work), searched records for needed data, and completed the initial phases of site reconnaissance. During July and August, SWEC awarded contracts for site work, transferred and acquired necessary leases, obtained state permits, repaired access roads and site pads, and completed downhole reconnaissance activities. SWEC subcontractors decommissioned four of the five tiltmeter sites and surveyed the locations of the $V-4, V-6, V-7$ wells, the LSU-R1A well, and the five tiltmeter sites.

Well plugging began on September 1 and required, with the exception of the V-5 well, 11 weeks to complete. Plugging was completed on November 18 and restoration was completed on December 1 . Well V-5 was not located until December 14, and scheduling problems prevented its plugging until January 11, 1989.

An extensive effort was made between June and November to locate the 118 shallow borings, which resulted in one tentative location being found. Stone \& Webster has concluded from this search and other evidence (Section 3.7) that the shallow borings were sufficiently backfilled to eliminate any possible safety hazard. All field-related close-out activities for the salt dome sites in Louisiana have been completed. 


\subsection{REEERENCES}

Kolb, C.R., J.C. Holmes, and J.J. Alford, 1983. The Quaternary Geology of Vacherie Salt Dome, North Louisiana Salt Dome Basin, Volume 1, Louisiana State University - Institute of Environmental Studies, ONWI-467, prepared for Office of Nuclear Waste Isolation, Battelle Memorial Institute, Columbus, $\mathrm{OH}$.

Law Engineering Testing Company, 1982a. Gulf Coast Domes Geologic Area Characterization Report, North Louisiana Study Area, Vols. IV and V, ONWI-119, prepared for Office of Nuclear Waste Isolation, Battelle Memorial Institute, Columbus, $\mathrm{OH}$.

Law Engineering Testing Company, 1982b. Gulf Coast Salt Domes Well Completion Report: Site LVH-6, ONWI-182, prepared for Office of Nuclear Waste Isolation, Battelle Memorial Institute, Columbus, $\mathrm{OH}$.

Law Engineering Testing Company, 1982c. Gulf Coast Salt Domes Well Completion Report: Site LH-2, ONWI-181, prepared for Office of Nuclear Waste Iso ution, Battelle Memorial Institute, Columbus, $\mathrm{OH}$.

Law Engineering Testing Company, 1982d. Gulf Coast Salt Domes Well Completion Report: Site LH-7, ONWI-183, prepared for Office of Nuclear Waste Isolation, Battelle Menorial Institute, Columbus, $\mathrm{OH}$.

Law Engineering Testing Company, 1982e. Gulf Coast Salt Domes Well Completion Report: Site LH-17, ONWI-185, prepared for Office of Nuclear Waste Isolation, Battelle Memorial Institute, Columbus, $\mathrm{OH}$.

LETCo, see Law Engineering Testing Company .

Louisiana Department of Public Works, 1975. Chapter III, Rules, Regulations, Standards, and Methods of the Plugging and Sealing of Abandoned Water Wells and Holes, per State Act 535, Sections 5.A and 5.A.6, April.

Martinez, J.D., R.L. Thoms, D.H. Kupfer, C.R. Kolb, M.B. Kumar, R.E. Wilcox, and E.J. Newchurch, 1977. An Investigation of the Utility of Gulf Coast Salt Domes for the Storage or Disposal of Radioactive Wastes, prepared for Office of Nuclear Waste Isolation, Battelle Memorial Institute, Columbus, $\mathrm{OH}$.

Martinez, J.D., R.L. Thoms, C.R. Kolb, M.B. Kumar, R.E. Wilcox, and E.J. Newchurch, 1978. An Investigation of the Utility of Gulf Coast Salt Domes for the Storage or Disposal of Radioactive Wastes, prepared for U.S. Department of Energy.

State of Louisiana, 1974. Department of Conservation Statewide Order Governing the Drilling for and Producing of $0 i 1$ and Gas in the State of Louisiana, Order Number 29-B, Section XIX, August.

TETC - See The Earth Technology Corporation. 
The Earth Technology Corporation, 1987. Activity Plan for Louisiana Decommissioning of Vacherie Dome and Regional Boreholes, Rev. 1, prepared for Office of Nuclear Waste Isolation, Battelle Memorial Institute, Columbus, $\mathrm{OH}$. 


\section{APPENDIX A}

\section{SWEC PROJECT DOCUMENTATION}

- Attachment - 1: Weekly Reports

- Attachment - 2: Site Reconnaissance

- Attachment - 3: Schematic of Preabandonment Site Status

- Attachment - 4: Borehole Completion Sketch

- Attachment - 5: Plugging Report

- Attachment - 6: Perforation and Squeeze Cementing Report

- Attachment - 7: Site Restoration 
WEEKLY PROGRESS REPORT

ATTACHMENT 1

STONE \& WEBSTER ENGINEERING CORP.

\begin{tabular}{|c|c|c|}
\hline DOE / SRPO & J.O. No. 17500.26 & $\begin{array}{l}\text { PERIOD } \\
06 / 23 / 88 \text { TO } 06 / 30 / 88\end{array}$ \\
\hline $\begin{array}{l}\text { STATE AND SITE } \\
\text { LOUISIANA }\end{array}$ & \multicolumn{2}{|c|}{$\begin{array}{l}\text { SITE REPRESENTATIVE } \\
\text { R.T.DECONTO }\end{array}$} \\
\hline $\begin{array}{l}\text { SUMMARY OF ACTIVITIES } \\
\text { PLUGGING } \\
\text { SWEC CONDUCTED RECONNAISSA }\end{array}$ & $S$ AT THE DEEP BOR & HYDROLOGIC \\
\hline \multicolumn{3}{|c|}{ BOREHOLE AND TILTMETER SITES TO PLAN THE SEQUENCE OF FUTURE WORK AND UPDATE } \\
\hline \multicolumn{3}{|c|}{ EXISTING RECORDS. THE' SURVEY INCLUDED WRITTEN DESCRIPTIONS, SKETCHES AND PHOTO } \\
\hline \multicolumn{3}{|c|}{ WERE SUCCESSFULLY LOCATED AND DESCRIBED EXCEPT FOR THE DEEP BORHOLE V-5. } \\
\hline \multicolumn{3}{|l|}{ RESTORATION } \\
\hline NONE & & \\
\hline
\end{tabular}

\section{PROBLEMS}

PROGRAM LITERATURE INDICATES THAT THE DEEP BOREHOLE V-5 WAS BURIED DURING

FORESTING OPERATIONS. THERE IS NO SURVEY INFORMATION AVAILABLE FOR THIS

BOREHOLE. EFFORTS TO FIND INFORMATION THAT BETTER DEFINE THE LOCATION OF V-5

CONTINUE. .

CHANGES TO ACTIVITY PLAN

NONE

SITE VISITORS

NONE

WORK PLANNED FOR NEXT WEEK

WIRELINE SURVEYS BEGIN THE WEEK OF $7 / 11 / 88$ IN THE DEEP \& REGI NAL HYDROLOGIC

BOREHOLES TO LOCATE OBSTRUCTIONS AND TO SAMPLE BOREHOLE FLUIDS FOR SALINTY. 
WEEKLY PROGRESS REPORT

ATTACHMENT 1

STONE \& WEBSTER ENGINEERING CORP.

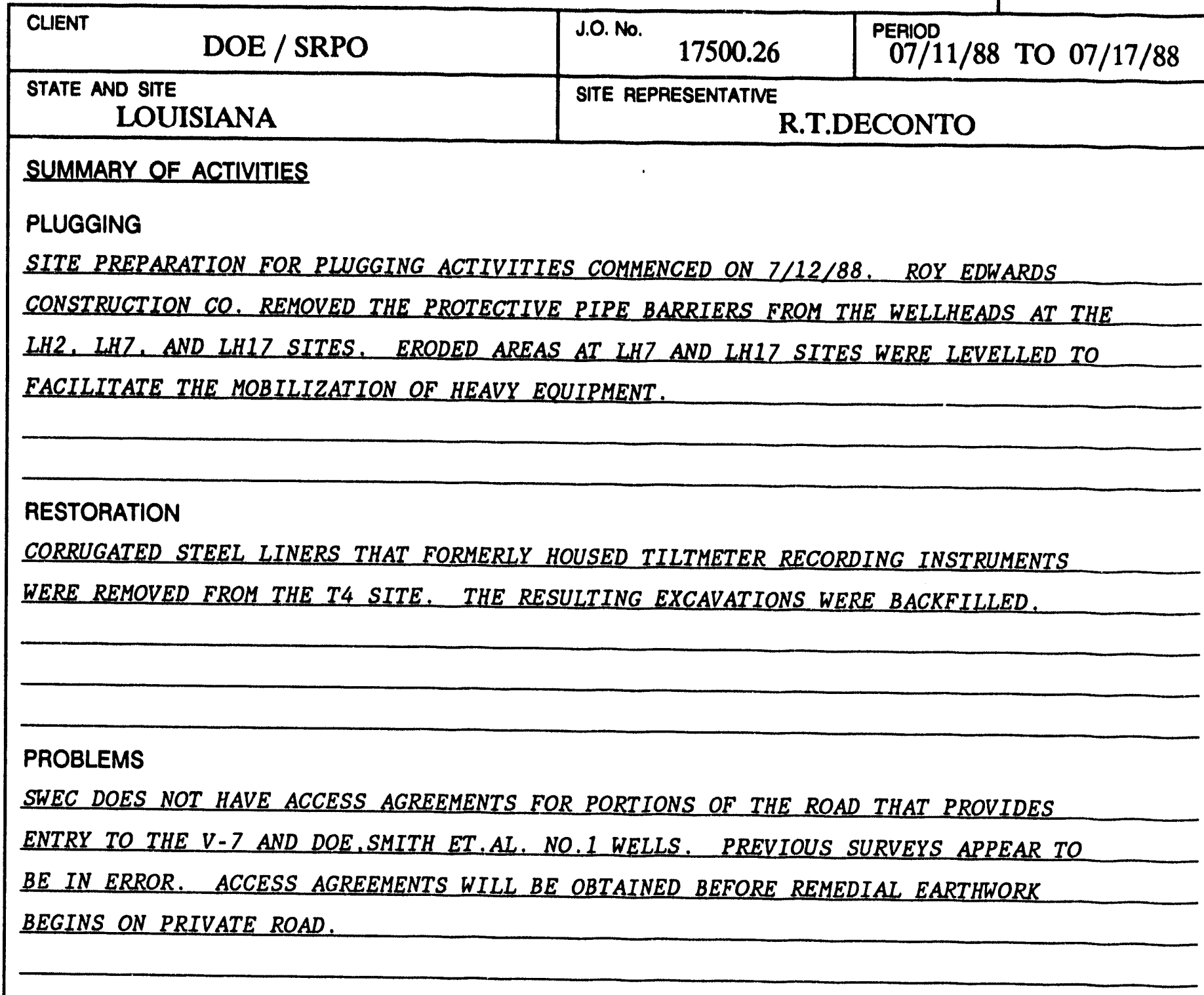

CHANGES TO ACTIVITY PLAN

NONE

SITE VISITORS

JIM HART, WEBSTER PARISH ROAD SUPERINTENDENT

WORK PLANNED FOR NEXT WEEK

SECURE DOE SMITH \& V-7 ACCESS ROAD AGREEMENT \& COMPLETE THE REQUIRED EARTHWORK. PERFORM WIRELINE SURVEYS AND GEOPHYSICAL WELL LOGGING AT DEEP BOREHOLE SITES. 
WEEKLY PROGRESS REPORT

ATTACHMENT 1

STONE \& WEBSTER ENGINEERING CORP.

\begin{tabular}{|c|c|c|}
\hline DOE / SRPO & 17500.26 & $\begin{array}{l}\text { PERIOD } \\
07 / 18 / 88 \text { TO } 07 / 22 / 88\end{array}$ \\
\hline $\begin{array}{l}\text { STATE AND SITE } \\
\text { LOUISIANA }\end{array}$ & \multicolumn{2}{|c|}{$\begin{array}{l}\text { SITE REPRESENTATIVE } \\
\text { R.T.DECONTO }\end{array}$} \\
\hline $\begin{array}{l}\text { SUMMARY OF ACTIVITIES } \\
\text { PLUGGING } \\
\text { ATCHLEY \& ATCHLEY (SURVEYC }\end{array}$ & EEP BOREHOLES V4 & $V T \&$ TILTMETERS \\
\hline \multicolumn{3}{|c|}{ I1.T2.T4.\& T5. OTIS ENG. PERFORMED WIRELINE SURVEYS IN WELLS AT } \\
\hline \multicolumn{3}{|c|}{ LH2, LH7,LH17,LVH6.V4,\& V6 SITES. SURVEYS INDI IATE WELLS UNOBSTRUCTED AND } \\
\hline \multicolumn{3}{|c|}{ DEPTHS IN ACCORDANCE WITH RECORDS. BOREHOLE FLUID SAMPLES TAKEN NEAR TOTAL } \\
\hline \multicolumn{3}{|c|}{ DEPTH WERE TESTED FOR TDS W/A CONDUCTIVITY METER. CBL LOGS WERE RUN IN THE } \\
\hline \multicolumn{3}{|c|}{ LH-17A,B.\&WS \& V4 WELLS. A RIGHT OF WAY AGREEMENT FOR V7\& THE LVH6 } \\
\hline \multicolumn{3}{|c|}{ SITE ACCESS WAS SECURED BY DAVID MILLER (LANDMAN). } \\
\hline \multicolumn{3}{|l|}{ RESTORATION } \\
\hline NONE & & \\
\hline
\end{tabular}

NONE

PROBLEMS

SITE RECONNASSAINCE AND TITLE RESEARCH ACTIVITIES REVEALED THAT DEEP BOREHOLE

V-6 IS LOCATED ON PROPERTY THAT IS NOT UNDER AN ACCESS AGREEMENT.

RECONNASSAINCE ACTIVITIES AT THIS LOCATION WERE SUSPENDED.

CHANGES TO ACTIVITY PLAN

NONE

SITE VISITORS

NONE

WORK PLANNED FOR NEXT WEEK

REPAIR TO THE VI ACCESS ROAD WILL BEGIN SO THAT WIRELINE AND LOGGING ACTIVITIES CAN BE COMPLETED. ACCESS TO SITE V-6 WILL BE SECURED IF POSSIBLE. 
WEEKLY PROGRESS REPORT

ATTACHMENT 1

STONE \& WEBSTER ENGINEERING CORP.

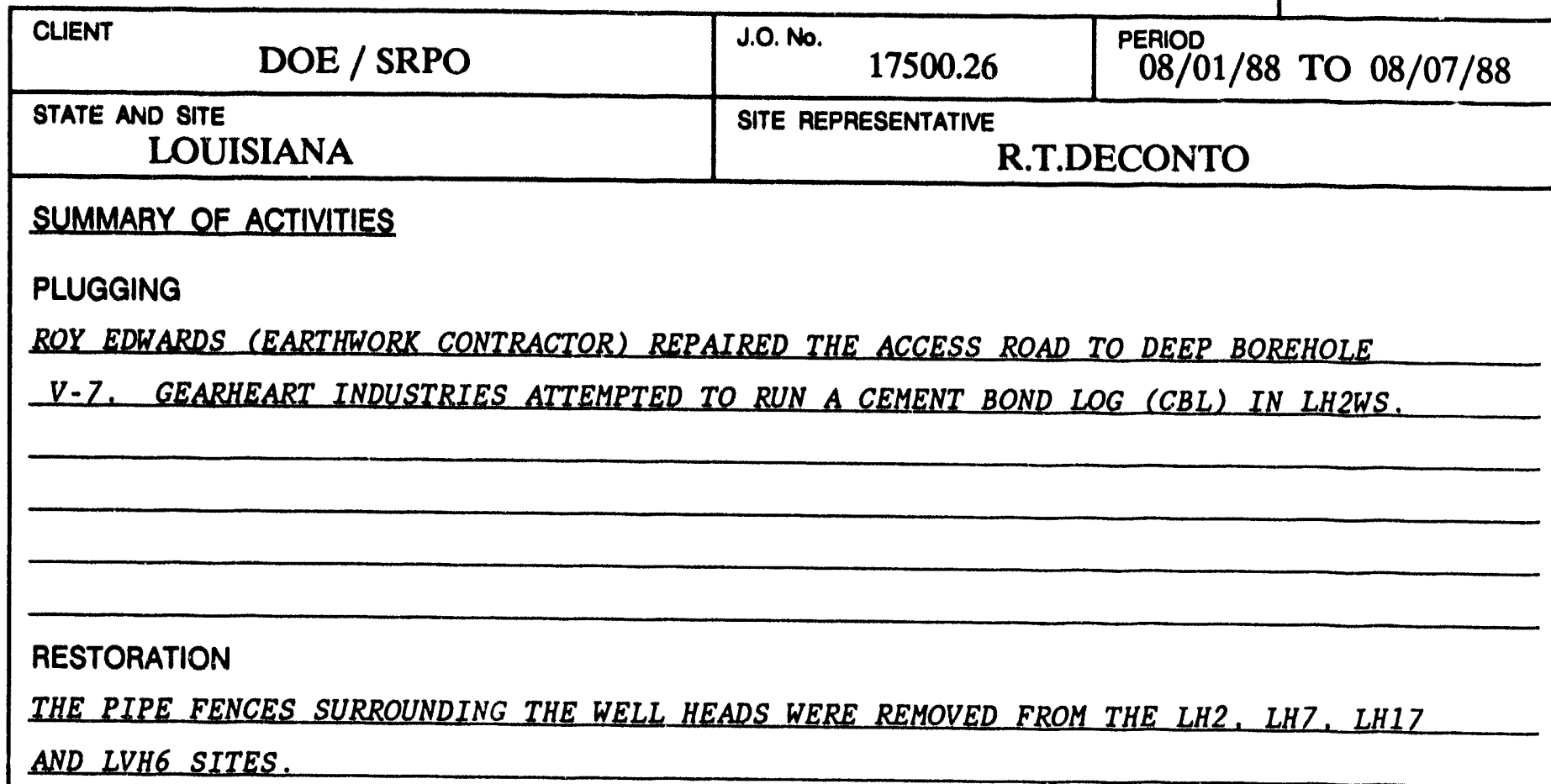

AND LVH6 SITES.

\section{PROBLEMS}

THE WIRELINE SURVEY IN BOREHOLE $V-7$ REVEALED AN OBSTRUCTION AT 121 FT. ATTEMPTS

TO CLEAN THE BOREHOLE WITH THE WIRELINE WERE UNSUCCESSFUL. LOGGING

DIFFICULTIES WERE ENCOUNTERED AT THE LH2WS BOREHOLE. A DEVIATION IN THE

CASING STRING PREVENTED USE OF THE CBL TOOL.

CHANGES TO ACTIVITY PLAN

NONE

SITE VISITORS

NONE

WORK PLANNED FOR NEXT WEEK

REMEDIAL WORK ON TILTMETER ACCESS ROADS. SECURE ACCESS AGREEMENTS TO LSU-RIA, V6. AND DOE-CONT. \#1 SITES. RUN WELL LOGS IN LHTWS, LH1TWS, LVH6WS, \& LSU-R1A. 
WEEKLY PROGRESS REPORT

ATTACHMENT 1

STONE \& WEBSTER ENGINEERING CORP.

\begin{tabular}{|l|l|l|l|}
\hline \multicolumn{1}{|c|}{ CLIENT DOE / SRPO } & J.0. No. 17500.26 & PERIOD \\
\hline $\begin{array}{c}\text { STATE AND SITE } \\
\text { LOUISIANA }\end{array}$ & \multicolumn{3}{|c|}{ SITE REPRESENTATINE } \\
\hline
\end{tabular}

SUMMARY OF ACTIVITIES

PLUGGING

THE EARTHWORK CONTRACTOR IMPROVED ACCESS ROADS TO TILTMETER SITES T1 AND T2 AND DEEP BOREHOLE PADS V7 \& LSU-RIA. GEOPHYSICAL WELL LOGS (CBL/GRAVEL PACK)

WERE RUN AT THE LH2WS, LHTWS, LH1TWS, LVH6WS, AND V-6 BOREHOLES. ACCESS

AGREEMENTS WERE OBTAINED FOR THE V-6, LSU-RIA, AND DOE-CONT, F.I. SITES. A

SITE RECONNAISSANCE SURVEY WAS PERFORMED AT THE LSU-R1A SITE.

\section{RESTORATION}

SOUTHWESTERN LABS (SWL) BEGAN RESTORATION ACTIVITIES AT TILTMETER SITES T1,T2, AND T3. CORRUGATED STEEL LINERS AND PVC PIPES WERE REMOVED FROM THE PITS. THE EXCAVATIONS WERE BACKEILLED WITH NATIVE SOIL AND CLAY.

\section{PROBLEMS}

LOW FLUID LEVELS IN THE WATER SUPPLY (WS) WELLS PROHIBIT COMPLETE COVERAGE OF THE CEMENT BOND LOG. ATTEMPTS TO FILL THE WELLBORES WITH FRESH WATER WERE UNSUCCESSFUL DUE TO HIGHLY PERMEABLE NATURE OF SCREENED INTERVAL.

\section{CHANGES TO ACTIVITY PLAN}

THE DOE-CONT. F.I. WEIL AT RAYBURN'S DOME WAS ADDED TO THE SCOPE OF WORK.

\section{SITE VISITORS}

PAUL MCMAHEN (WILAMETTE INDUSTRIES) VISITED TI SITE TO EXAMINE WORX RELATED DAMAGE :O SAPLINGS.

WORK PLANNED FOR NEXT WEEK

SITE RECONNAISSANCE ACTIVITIES WILL CONTINUE AT THE LSU-RIA AND DOE-CONT.F.I. SITES. PLUGGING/ABANDONMENT ACTIVITIES WILL BEGIN AT THE LH-2 DEEP BOREHOLE SITE 
WEEKLY PROGRESS REPORT

ATTACHMENT 1

STONE \& WEBSTER ENGINEERING CORP.

\begin{tabular}{|c|c|c|}
\hline DOE / SRPO & J.O. No. 17500.26 & $\begin{array}{l}\text { PERIOD } \\
08 / 15 / 88 \text { TO } 08 / 21 / 88\end{array}$ \\
\hline $\begin{array}{l}\text { STATE AND SITE } \\
\text { LOUISIANA }\end{array}$ & \multicolumn{2}{|c|}{$\begin{array}{l}\text { SITE REPRESENTATME } \\
\text { R.T.DECONTO }\end{array}$} \\
\hline $\begin{array}{l}\text { SUMMARY OF ACTIVITIES } \\
\text { PLUGGING } \\
\text { CONTINUED SEARCH FOR GEOTH }\end{array}$ & OLES USING RECENT & QUIRED \\
\hline \multicolumn{3}{|c|}{ INFORMATION, CIRCULAR, 6IN DIAMETER SURFACE DEPRESSIONS WERE LOCATED IN CLOSE } \\
\hline \multicolumn{3}{|c|}{ PROXIMITY TO PUBLISHED BORELHOLE LOCATIONS. DEPRESSIONS MAY REPRESENT CAVED } \\
\hline \multicolumn{3}{|c|}{ BOREHOLES TB-1. TB-2, AND TB-4. STEEL PROBES INSERTED INTO THE DEPRESSIONS } \\
\hline \multicolumn{3}{|c|}{ REVEALED THAT BACKFILL IN THREE WAS LOOSELY CONSOLIDATED NEAR THE SURFACE. } \\
\hline \multicolumn{3}{|c|}{ RECONNAISSANCE CONTINUE AT RAYBURN'S DOME DEEP BOREHOLES. THE LSU-RIA \& DOE- } \\
\hline \multicolumn{3}{|c|}{ CONT. F.I. NO. 1 WELLS WERE SURVEYED BY OTIS ENGINEERING. THE WELLS WERE DEPTH } \\
\hline \multicolumn{3}{|c|}{ SOUNDED AND FLUIDS WERE SAMPLED. } \\
\hline \multicolumn{3}{|l|}{ RESTORATION } \\
\hline
\end{tabular}

\section{PROBLEMS}

LOGGING OPERATIONS PLANNED AT THE LSU-R1A WELL AND DOE-CONT F.I. NO. 1 WELL ON 8/21/88 WILL BE DELAYED ONE DAY DUE TO EOUIPMENT FAILURE.

CHANGES TO ACTIVITY PLAN

NONE

SITE VISITORS

NONE

WORK PLANNED FOR NEXT WEEK

THE DEEP BOREHOLE PLUGGING CONTRACTOR WILL BEGIN REMOVING THE OBSTRUCTIONS FROM THE V-7 WELL AND PLUGGING AT THE LH-2 SITE. 
WEEKLY PROGRESS REPORT

ATTACHMENT 1

STONE \& WEBSTER ENGINEERING CORP.

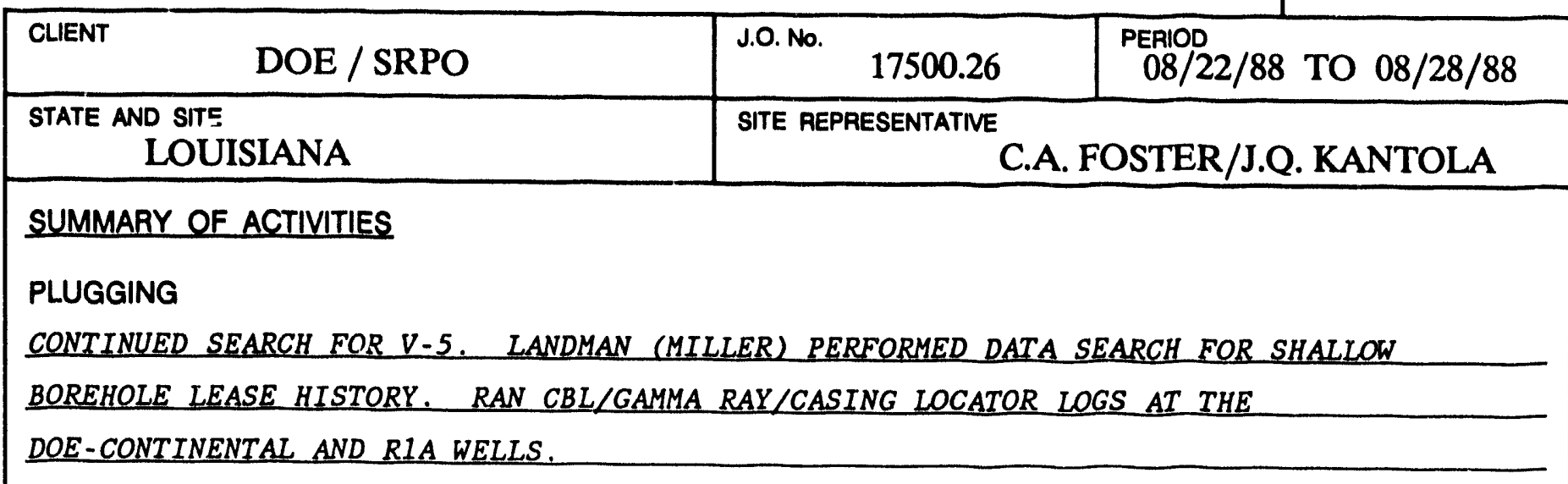

\section{RESTORATION}

NONE

\section{PROBLEMS}

CANNOT FIND WELL V-5. WILL CONTINUE SEARCH. START OF DEEP PLUGGING DELAYED UNTIL WEEK OF 8/29. WITH LATE START CONTRACTOR MAY HAVE TO MOBILIZE MORE THAN ONE RIG TO COMPLETE WORK BEFORE LEASES EXPIRE AT THE END OF SEPTEMBER.

CHANGES TO ACTIVITY PLAN

NONE

\section{SITE VISITORS}

AL FOSTER ARRIVED LATE $8 / 23 / 88$ AND REMAINED THROUGH $8 / 28 / 88$.

WORK PLANNED FOR NEXT WEEK

PERFORM SITE RECON. AT COE LEASE SITES T-5 AND DOE-SMITH. 
WEEKLY PROGRESS REPORT

ATTACHMENT 1

STONE \& WEBSTER ENGINEERING CORP.

\begin{tabular}{|l|l|l|l|}
\hline \multicolumn{1}{|c|}{ CLIENT DOE / SRPO } & J.O. No. 17500.26 & PERIOO & $08 / 29 / 88$ TO 09/04/88 \\
\hline $\begin{array}{c}\text { STATE AND SITE } \\
\text { LOUISIANA }\end{array}$ & \multicolumn{3}{|c|}{ SITE REPRESENTATINE } \\
\hline
\end{tabular}

SUMMARY OF ACTIVITIES

PLUGGING

SOUTHWESTERN LABORATORIES MOBILIZED DRILL RIG TO THE V-7 SITE TO CLEAR THE

OBSTRUCTION LOCATED AT $122 \mathrm{FT}$. DRILLING RETURNS INDICATED THE WELL IS PLUGGED

WITH WOOD. METAL CANS, AND ROCKS. THE OBSTRUCTION WAS CLEANED FROM 122 FT.

TO 750 FT. BY MILLING AND WASHING. OTIS ENG. OBTAINED FLUID SAMPLES AND

GEARHEART RAN CEMENT BOND LOGS IN THE V-T AND DOE-SMITH ET. AL. NO. 1 WELLS.

\section{RESTORATION}

NONE

PROBLEMS

OBSTRUCTION IN V-7 BOREHOLE DELAYED PLUGGING AND ABANDONMENT.

CHANGES TO ACTIVITY PLAN

NONE

SITE VISITORS

D. LOGAN FROM SWEC-OA AUDITED RECONNAISSANCE \& CONTRACTOR ACTIVITIES.

WORK PLANNED FOR NEXT WEEK

COMPLETE OBSTRUCTION REMOVAL AT V-7 AND PLUG AND ABANDON. MOVE TO LH2 SITE.

SURVEY LSU-RIA WELL LOCATION. 
WEEKLY PROGRESS REPORT

ATTACHMENT 1

STONE \& WEBSTER ENGINEERING CORP.

\begin{tabular}{|c|c|c|}
\hline DOE / SRPO & J.O. No. 17500.26 & $\begin{array}{l}\text { PERIOD } \\
09 / 05 / 88 \text { TO } 09 / 11 / 88\end{array}$ \\
\hline $\begin{array}{l}\text { STATE AND SITE } \\
\text { LOUISIANA }\end{array}$ & SITE REPRESENTATIVE & CONTO \\
\hline
\end{tabular}

\section{SUMMARY OF ACTIVITIES}

PLUGGING

SOUTHWESTERN LABORATORIES DRILLED THE OBSTRUCTION IN THE V-7 BOREHOLE TO

742.79 FT. THE WELL WAS PLUGGED FROM THE TOP OF THE OBSTRUCTION TO 3 FT. BELOW GROUND LEVEL. SW. LAB MOBILIZED TO THE LH-2B WELL AND PLUGGED THE WELL TO

73 FT BELOW GROUND LEVEL.

\section{RESTORATION}

NONE

\section{PROBLEMS}

OBSTRUCTION IN DEEP BOREHOLE V-7 PROHIBITED PLUGGING TO PLANNED DEPTH. THE DOTD AUTHORIZED PLUGGING FROM TOP OF OBSTRUCTION. DURING PLUGGING ACTIVITIES AT THE LH-2B WELL FORMATION CAVE IN THE SCREEN SECTION PREVENTED REMOVAL OF TUBING. TUBING STRING WILL REMAIN IN CASING AND THE REMAINING 73 FT. OF TUBING-CASING ANNULUS FILLED W/CEMENT.

CHANGES TO ACTIVITY PLAN

OFFICE OF CONSERVATION (BATON ROUGE) SAID IT WOULD NOT BE NECESSARY TO INFORM SHREVEPORT DIST. MAN. OF INTENT TO PLUG NON-PERMITTED WELLS: V4,V5,V6,V7,

\& LSU-RIA.

SITE VISITORS

PETE COLVIN (OFFICE OF CONSERVATION) INSPECTED P\&A OPERATION AT LH-2B ON $9 / 11 / 88$

WORK PLANNED FOR NEXT WEEK

COMPLETE CEMENTING TO 3 FT. BELOW GROUNDLEVEL IN LH2B. MOBILIZE TO LH2WS WELL AND LHT SITE TO CONTINUE P\&A. 
WEEKLY PROGRESS REPORT

ATTACHMENT 1

STONE \& WEBSTER ENGINEERING CORP.

\begin{tabular}{|c|c|c|}
\hline DOE / SRPO & 17500.26 & $\begin{array}{l}\text { PERIOD } \\
09 / 12 / 88 \text { TO } 09 / 18 / 88\end{array}$ \\
\hline $\begin{array}{l}\text { STATE AND SITE } \\
\text { LOUISIANA }\end{array}$ & \multicolumn{2}{|c|}{$\begin{array}{r}\text { SITE REPRESENTATNE } \\
\text { R.T }\end{array}$} \\
\hline \multicolumn{3}{|l|}{ SUMMARY OF ACTIVITIES } \\
\hline \multicolumn{3}{|l|}{ PLUGGING } \\
\hline \multicolumn{3}{|c|}{ SOUTHWESTERN LABS COMPLETED PLUGGING LH-2B, MOVED RIG TO LH-2WS TO SQUEEZE } \\
\hline \multicolumn{3}{|c|}{ AND PLUG LH-2WS. RIG AND EOUIPMENT THEN MOVED TO LH-7 SITE AND SET UP ON } \\
\hline \multicolumn{3}{|c|}{ LH-7B WELL, A SAND PLUG WAS PLACED FROM TD(1052) TO 11.3 FT. ABOVE THE SCREEN } \\
\hline SECTION OF $7 B(953$ FT. $)$ & & \\
\hline
\end{tabular}

\section{RESTORATION}

NONE

\section{PROBLEMS}

NONE

\section{CHANGES TO ACTIVITY PLAN}

WELL SCREENS WILL BE PLUGGED BACK WITH SAND RATHER THAN CEMENT. CHANGE HAS BEEN APPROVED BY STATE AGENCIES.

SITE VISITORS

PETE COLVIN (OC) VISITED LH-2 SITE ON 9/14. HE WAS INFORMED OF PLUGGING PLAN FOR LH-2WS.

WORK PLANNED FOR NEXT WEEK

FINISH PLUGGING LH-7B. SAND SCREENS AND PLUG REMAINING WELLS IN THE LH-7 NEST. MOVE RIG TO LH-17 SITE AND BEGIN PLUGGING ACTIVITIES AT THAT SITE. 
WEEKLY PROGRESS REPORT

ATTACHMENT 1

STONE \& WEBSTER ENGINEERING CORP.

\begin{tabular}{|c|c|c|c|}
\hline \multicolumn{1}{|c|}{ DLOENT / SRPO } & J.O. No. 17500.26 & PERIOD & $09 / 19 / 88$ TO 09/25/88 \\
\hline $\begin{array}{c}\text { STATE AND SITE } \\
\text { LOUISIANA }\end{array}$ & \multicolumn{3}{|c|}{ SITE REPRESENTATIVE } \\
\hline
\end{tabular}

\section{SUMMARY OF ACTIVITIES}

PLUGGING

PLUG LH-7B FROM TOP OF SAND PLUG (953) TO 3 FT. BELOW GROUND SURFACE. SAND

PLUGS PLACED IN SCREENS OF: LH-7A(1565-1469). TWS(595-460), 1TWS(433-280) AND

2A(1814-1652). WELLS THEN CEMENTED FROM THE TOP OF THE SAND PLUG TO THREE

FT. BELOW GROUND LEVEL. CASING ANNULUSES WERE FILLED WITH CEMENT TO

GROUNDLEVEL. SCREENED SECTION OF 17B(1378-1298) WAS SANDED. WELL LVH-6C WAS

PREPARED FOR SQUEEZING BY SETTING A DRILLABLE BRIDGE PLUG AT 850 FT. AND

PERFORATING. SECOND RIG (WORKOVER) MOBILIZED AND PLUGGED LH-2A. W.O. RIG

MOVED TO LVH-6C, SQUEEZE WELL W/75 SACKS OF CEMENT.

RESTORATION

NONE

\section{PROBLEMS}

MINOR EQUIPMENT PROBLEMS OCCURRED WHILE THE WORKOVER/PULLING RIG MIXED

CEMENT TO PLUG LH-2A. THIS HAS DELAYED THEIR PROGRESS BY 1-1/2 TO 2 DAYS.

CHANGES TO ACTIVITY PLAN

NONE

SITE VISITORS

A.L.THORTON (OFFICE OF CONSERVATION) VISITED LH-7 SITE ON $9 / 22$ TO INSPECT

PLUGGING OPERATION.

WORK PLANNED FOR NEXT WEEK

COMPLETE WORK ON LH-17B. BOTH RIGS (DRILL \& WORKOVER) TO WORK AT LVH-6 SITE.

SQUEEZE ANNULUS LVH-6A\&B.SAND SCREENS \& PLUG BACK LVH-6A,B,C, \&WS. EXCAVATE \&

CUTOFF WELLHEADS AT LH-2 SITE. 
WEEKLY PROGRESS REPORT

ATTACHMENT 1

STONE \& WEBSTER ENGINEERING CORP.

\begin{tabular}{|c|c|c|}
\hline DOE / SRPO & J.O. No. $\quad 17500.26$ & $\begin{array}{l}\text { PERIOD } \\
09 / 26 / 88 \text { TO } 10 / 02 / 88\end{array}$ \\
\hline $\begin{array}{l}\text { STATE AND SITE } \\
\text { LOUISIANA }\end{array}$ & \multicolumn{2}{|c|}{$\begin{array}{l}\text { SITE REPRESENTATIVE } \\
\text { R.T.DECONTO }\end{array}$} \\
\hline $\begin{array}{l}\text { SUMMARY OF ACTIVITIES } \\
\text { PLUGGING } \\
\text { GEARHEART INDUSTRIES SET W }\end{array}$ & E PLUGS AND PEROR & WELLS LVH6A \& $6 B$. \\
\hline \multicolumn{3}{|c|}{ WESTERN CO. SQUEEZED LHV6A FROM 985-1005FT \& 952.5-964 FT. IN ORDER TO SEAL } \\
\hline \multicolumn{3}{|c|}{ THE ANNULUS. SOUTHWESTERN LABORATORIES DRILLED OUT SQUEEZE ZONES IN LVH6A \& } \\
\hline \multicolumn{3}{|c|}{ ZONES. ALL SOUEEZE OPERATIONS WERE SUCCESSFUL. } \\
\hline \multicolumn{3}{|l|}{ RESTORATION } \\
\hline BELOW GROUND LEVEL AND WEL & TES OVER THE CUT & G TOPS. THE \\
\hline
\end{tabular}

\section{PROBLEMS}

DRILLING THE CEMENT RETAINER USED FOR SOUEEZING THE LVH6C WELL IS SLOWER THAN ANTICIPATED. A MILLING TOOL WILL BE PROCURED TO ACCELERATE RETAINER REMOVAL.

\section{CHANGES TO ACTIVITY PLAN}

NONE

\section{SITE VISITORS}

NONE

WORK PLANNED FOR NEXT WEEK

DRILL OUT THE CEMENT RETAINERS IN THE LVH6A \& LVH6C WELLS AND PLUG FROM TOTAL DEPTH TO SURFACE. SQUEEZE THE LVH6 WELL. 
WEEKLY PROGRESS REPORT

ATTACHMENT 1

STONE \& WEBSTER ENGINEERING CORP.

\begin{tabular}{|c|c|c|}
\hline DOE / SRPO & $\begin{array}{ll}\text { J.O. No. } & 17500.26\end{array}$ & $\begin{array}{l}\text { PERIOD } \\
10 / 03 / 88 \text { TO } 10 / 09 / 88\end{array}$ \\
\hline $\begin{array}{l}\text { STATE AND SITE } \\
\text { LOUISIANA }\end{array}$ & \multicolumn{2}{|c|}{$\begin{array}{l}\text { SITE REPRESENTATIVE } \\
\text { R.T.DECONTO }\end{array}$} \\
\hline
\end{tabular}

\section{SUMMARY OF ACTIVITIES}

PLUGGING

SOUTHWESTERN LABORATORIES CONTINUED PLUGGING AND ABANDONMENT ACTIVITIES AT THE LVH6 SITE. DRILLED OUT THE SECOND SQUEEZE ZONE IN THE LVH-6A WELL TO THE TOP OF THE BRIDGE PLUG \& $1020 \mathrm{FT}$. GEARHEART INDUSTRIES RAN CEMENT BOND LOG. THE BRIDGE PLUG WAS DRILLED OUT AND PUSHED TO THE TOP OF THE RISER PIPE AT APPROX. $2500 \mathrm{FT}$. THE WORKOVER RIG DRILLED OUT THE BRIDGE PLUG IN THE LVH6C WELL AND PUSHED THE REMAINING JUNK TO THE TOP OF THE RISER PIPE a 866 FT. RESTORATION NONE

\section{PROBLEMS}

REMAINING PIECES OF BRIDGE PLUGS FELL TO THE TOP OF RISER PIPES IN BOTH LVH6A \& LVH6C WELLS. ADDITIONAL TIME IS REQUIRED TO MILL THROUGH THE JUNK BRIDGED OVER THE RISER PIPES. MILLING TOOLS WERE PROCURED TO PERFORM THIS ACTIVITY.

\section{CHANGES TO ACTIVITY PLAN}

NONE

SITE VISITORS

NONE

WORK PLANNED FOR NEXT WEEK

MILL THROUGH JUNK AT THE TOP OF RISERS IN LVH6A\&C AND PLUG WELL. PERFORATE \& SQUEEZE THE LVH6B WELL WITH 75 SKS. AT APPROX. $1000 \mathrm{FT}$. 
WEEKLY PROGRESS REPORT

ATTACHMENT 1

STONE \& WEBSTER ENGINEERING CORP.

\begin{tabular}{|c|c|c|}
\hline DOE / SRPO & 17500.26 & $\begin{array}{l}\text { PERIOD } \\
10 / 10 / 88 \text { TO } 10 / 16 / 88\end{array}$ \\
\hline $\begin{array}{l}\text { STATE AND SITE } \\
\text { LOUISIANA }\end{array}$ & \multicolumn{2}{|c|}{$\begin{array}{l}\text { SITE REPRESENTATIVE } \\
\text { R.T.DECONTO }\end{array}$} \\
\hline \multicolumn{3}{|l|}{ SUMMARY OF ACTIVITIES } \\
\hline PLUGGING & \multicolumn{2}{|c|}{ SW LABS MOVED THE W.O. RIG FROM LVH6C TO LVH6A TO REMOVE THE BRIDGE PLUG JUNK } \\
\hline \multicolumn{3}{|c|}{ FROM THE TOP OF THE RISER PIPE (2494 FT.). OBSTRUCTION WAS ADVANCED TO 2505} \\
\hline \multicolumn{3}{|c|}{ FT. USING A TAPER TAP. TAPERED MILLING TOOL AND FLAT MILLING TOOL. THE DRILL } \\
\hline \multicolumn{3}{|c|}{ RIG MOVED OFF LVH6A TO LVH6B. SQUEEZED TWO ZONES $(949-960 \& 980-1000$ FT) EACH } \\
\hline \multicolumn{3}{|c|}{ W/ 75 SKS. OF CLASS H CEMENT. SQUEEZE ZONES WERE DRILLED OUT AND RAN CBL } \\
\hline \multicolumn{3}{|c|}{ INDICATED SQUEEZE WAS SUCCESSFUL. } \\
\hline \multicolumn{3}{|l|}{ RESTORATION } \\
\hline NONE & & \\
\hline
\end{tabular}

PROBLEMS

THE VARIOUS ACTIVITIES USED TO CLEAR THE RISER PIPE AT THE LVH6A WELL ARE

PROCEEDING SLOWLY. IN THE EVENT THAT FURTHER ACTIVITIES ARE UNSUCCESSFUL SWEC

WILL PLUG THE WELL FROM THE OBSTRUCTION TO GROUND LEVEL PENDING DOTD APPROVAL.

CHANGES TO ACTIVITY PLAN

NONE

SITE VISITORS

NONE

WORK PLANNED FOR NEXT WEEK

CONTINUE PLIIGGING AND ABANDONMENT ACTIVITIES AT LVH6 SITE. BEGIN SHALLOW

BOREHOLE SEARCH IN WEBSTER \& BIENVILLE PARISH. 
WEEKLY PROGRESS REPORT

ATTACHMENT 1

STONE \& WEBSTER ENGINEERING CORP.

\begin{tabular}{|c|c|c|c|}
\hline \multicolumn{1}{|c|}{ CLOENT } & J.C. No. & 17500.26 & PERIOD \\
\hline $\begin{array}{c}\text { STATE AND SITE } \\
\text { LOUISIANA }\end{array}$ & \multicolumn{3}{|c|}{ SITE REPRESENTATIVE } \\
\hline
\end{tabular}

\section{SUMMARY OF ACTIVITIES}

PLUGGING

DRILLED OUT BRIDGE PLUGS AND PERFORMED FISHING OPERATIONS TO REMOVE PLUG DEBRIS

FROM WELLS LVH6A, $B$, \& C. PLUGGED LVH-6C FROM 868.6' TO GROUNDLEVEL AND LVH-6WS

FROM 37.86' TO GL. SHALLOW BOREHC ' SEARCH - PREPAUED SURVEY NOTES TO LOCATE

SHALLOW BOREHOLES. SURVEY CREW STARTED WORK ON 10/20/88 AND LAYOUT WILL

CONTINUE THROUGH NEXT WEEK.

\section{RESTORATION}

NONE

\section{PROBLEMS}

EXTREME PROBLEMS IN DRILLING OUT \& REMOVAL OF BRIDGE PLUGS AT BOTTOM OF SQUEEZE ZONE IN WELLS LVH6A, $B$, \& $C$. OBTAINED VARIANCE FROM STATE (DOTD) TO CEMENT ABOVE RISER PIPES IN THESE WELLS.

\section{CHANGES TO ACTIVITY PLAN}

NONE

\section{SITE VISITORS}

JOE HOLMES FROM LSU IN FIELD ON 10/22/88 TO ASSIST IN SHALLOW BOREHOLE SEARCH.

WORK PLANNED FOR NEXT WEEK

COMPLETE PLUGGING REMAINING WELLS AT SITE LVH6 (6A\& $\&$ B). START PLUGGING

$\checkmark$ SERIES WELLS. CONTINUE SHALLOW BOREHOLE SEARCH. 
WEEKLY PROGRESS REPORT

ATTACHMENT 1

STONE \& WEBSTER ENGINEERING CORP.

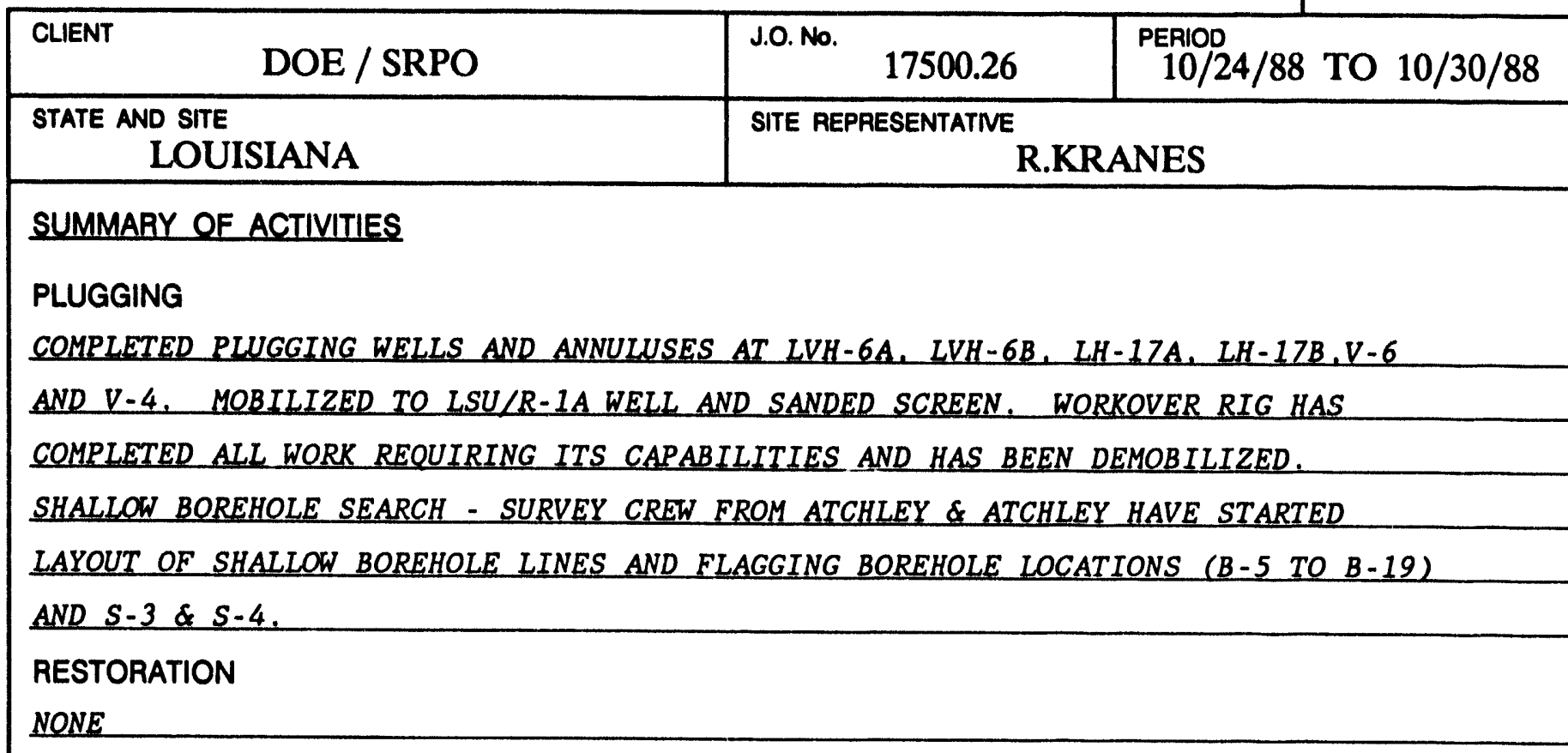

PROBLEMS

RAINY WEATHER HAS MADE IT DIFFICULT TO MOVE RIGS FROM STIE TO SITE. THIS

FACTOR MAY DELAY THE COMPLETION OF WORK BY 3 TO 4 DAYS.

CHANGES TO ACTIVITY PLAN

NONE

SITE VISITORS

A.L. "BAY" THORNTON (OFFICE OF CONSERVATION) FIELD INSPECTOR.

WORK PLANNED FOR NEXT WEEK

PLUGGING LSU/R-1A. FLOAT CEMENT PLUG 50 FT. IN/OUT OF CASING AT DOE-CONT. F.I.

\& PLUG CASING, CUT CASING \& -3FT. WELD PLATE, \& BACKFILL AT LH-7,LH-17,

\& LVH-6 SITES. CONTINUE SURVEYING SHALLOW BOREHOLE LOCATIONS. 
WEEKLY PROGRESS REPORT

ATTACHMENT 1

STONE \& WEBSTER ENGINEERING CORP.

\begin{tabular}{|c|c|c|}
\hline DOE / SRPO & 17500.26 & $\begin{array}{l}\text { PERIOD } \\
10 / 31 / 88 \text { TO } 11 / 06 / 88\end{array}$ \\
\hline $\begin{array}{l}\text { STATE AND SITE } \\
\text { LOUISIANA }\end{array}$ & \multicolumn{2}{|c|}{$\begin{array}{l}\text { SITE REPRESENTATIVE } \\
\text { R.KRANES }\end{array}$} \\
\hline $\begin{array}{l}\text { SUMMARY OF ACTIVITIES } \\
\text { PLUGGING } \\
\text { PLACED CEMENT PLUG IN THE }\end{array}$ & ED TO THE DOE-CON & TAL WELL, PLACED \\
\hline \multicolumn{3}{|c|}{100 FT. FLOAT PLUG AT THE BASE OF THE 9-5/8" CASING (50 FT. IN THE CASING AND } \\
\hline \multicolumn{3}{|c|}{ WELL. SURVEYED IN POSSIBLE LOCATION OF V-5 WELL AND PERFORMED SEARCH WITH } \\
\hline \multicolumn{3}{|c|}{ METAL DETECTOR. SHALLOW BOREHOLE SEARCH - INSPECTED POSITIONS LOCATED BY A\&A } \\
\hline \multicolumn{3}{|c|}{ SURVEYORS, NO EVIDENCE TO INDICATE PRESENCE OF THESE BORINGS. FOWLER } \\
\hline \multicolumn{3}{|c|}{ DRILLING CO. WAS CONTACTED. NO RECORDS EXIST INDICATING FINAL DISPOSITION. } \\
\hline \multicolumn{3}{|c|}{ DRILLER INDICATES BOREHOLES BACKFILLED WITH CUTTINGS \& MUD. } \\
\hline \multicolumn{3}{|l|}{$\begin{array}{l}\text { RESTORATION } \\
\text { NONE }\end{array}$} \\
\hline
\end{tabular}

\section{PROBLEMS}

NONE

\section{CHANGES TO ACTIVITY PLAN}

NONE

\section{SITE VISITORS}

NONE

\section{WORK PLANNED FOR NEXT WEEK}

CONTINUE SQUEEZE AND PLUG BACK WORK ON DOE-SMITH WELL. MAKE FULL AREA SEARCH WITH METAL DETECTOR FOR V-5. CONTINUE SHALLOW BOREHOLE SEARCH FOR B-40 THRU B-53 LINE. 
WEEKLY PROGRESS REPORT

ATTACHMENT 1

STONE \& WEBSTER ENGINEERING CORP.

\begin{tabular}{|c|c|c|}
\hline DOE / SRPO & $\begin{array}{ll}\text { J.O. No. } \quad 17500.26 \\
\end{array}$ & $\begin{array}{l}\text { PERIOD } \\
11 / 07 / 88 \text { TO } 11 / 13 / 88\end{array}$ \\
\hline $\begin{array}{l}\text { STATE AND SITE } \\
\text { LOUISIANA }\end{array}$ & \multicolumn{2}{|c|}{$\begin{array}{l}\text { SITE REPRESENTATNE } \\
\text { R.KRANES }\end{array}$} \\
\hline
\end{tabular}

SUMMARY OF ACTIVITIES

PLUGGING

AT DOE SMITH \#1 A FLOAT PLUG WAS PLACED AT THE BASE OF 9-5/8" CASING. WELL WAS PLUGGED BACK TO $40 \mathrm{FT}$. BELOW SOUEEZE ZONE (535-555). ZONE PERFORATED AND SQUEEZED WITH 75 SACKS OF CLASS H CEMENT. SQUEEZED ZONE WAS DRILLED OUT AND A CEMENT BOND LOG RUN. LOG INDICATES THE SQUEEZE WAS SUCCESSFUL. THE SEARCH FOR V-5 WELL WITH A METAL DETECTOR PROVED UNSUCCESSFUL. SHALLOW BOREHOLE SEARCH - CONTRACTOR WAS UNABLE TO PROVIDE PERSONNEL TO CONTINUE RECONSTRUCTION OF BOREHOLE LINE B-40 THRU B-53.

RESTORATION

NONE

PROBLEMS

METAL DETECTOR PROVIDED BY SURVEYOR HAS PROVED INADEQUATE. DETECTOR WILL NOT READ METAL OBJECTS AT DEPTHS GREATER THAN 18 INCHES, NOR WILL DETECTOR DISCRIMINATE BETWEEN LARGE METAL OBJECTS AND SMALL SCRAP PIECES FOUND IN V-5 STAKED AREA.

CHANGES TO ACTIVITY PLAN

NONE

SITE VISITORS

NONE

WORK PLANNED FOR NEXT WEEK

COMPLETE DOE-SMITH\#1 WELL. CUTTING/CAPPING OF REMAINING WELLS. ATTEMPT TO

LOCATE V-5 WELL WITH BETTER METAL DETECTOR. MEET WITH SITE RESTORATION CONTRACTOR. SURVEY SHALLOW BOREHOLE B40-B53 LINE. 
WEEKLY PROGRESS REPORT

STONE \& WEBSTER ENGINEERING CORP.

\begin{tabular}{|c|c|c|}
\hline DOE / SRPO & $\begin{array}{ll}\text { J.O. No. } \quad 17500.26\end{array}$ & $\begin{array}{l}\text { PERIOD } \\
11 / 14 / 88 \text { TO } 11 / 20 / 88\end{array}$ \\
\hline $\begin{array}{l}\text { STATE AND SITE } \\
\text { LOUISIANA } \\
\end{array}$ & \multicolumn{2}{|c|}{$\begin{array}{l}\text { SITE REPRESENTATIVE } \\
\text { R.KRANES }\end{array}$} \\
\hline \multicolumn{3}{|l|}{ SUMMARY OF ACTIVITIES } \\
\hline \multicolumn{3}{|l|}{ PLUGGING } \\
\hline \multicolumn{3}{|c|}{ DOE SMITH-\#1 WELL WAS PERFORATED AND SQUEEZED (465-485). THE CBL LOG INDICATES } \\
\hline \multicolumn{3}{|c|}{ AN ACCEPTABLE SQUEEZE. THE WELL WAS PLUGGED TO SURFACE. AN EXTENSIVE METAL } \\
\hline \multicolumn{3}{|c|}{ DETECTOR SURVEY WAS CONDUCTED TO SEARCH FOR V-5, RESULTS PROVIDED NO NEW } \\
\hline \multicolumn{3}{|c|}{ INFORMATION. CASINGS WERE CUT, PLATES WELDED ON CASINGS, AND EXCAVATIONS } \\
\hline \multicolumn{3}{|c|}{ BACKFILLED AT LVH-6A,B,C,WS : LH-17A,B,WS; V-4; V-6:DOE-SMITH, \& RIA. } \\
\hline \multicolumn{3}{|c|}{ SHALLOW BOREHOLE SEARCH - FINAL SURVEY B-40 TO B-53 STAKED. NO EVIDENCE } \\
\hline \multicolumn{3}{|c|}{ FOUND. } \\
\hline \multicolumn{3}{|l|}{ RESTORATION } \\
\hline \multicolumn{3}{|c|}{ RESTORATION WORK HAS STARTED WITH WORK BEING DONE ON THE LVH-6 SITE. THE V-4 } \\
\hline SITE AND THE DOE SMITH SII & & \\
\hline
\end{tabular}

PROBLEMS

NONE

CHANGES TO ACTIVITY PLAN

NONE

SITE VISITORS

NONE

WORK PLANNED FOR NEXT WEEK

ONLY MINOR RESTORATION WORK WILL BE DONE DUE TO THANKSGIVING HOLIDAY. 


\section{WEEKLY PROGRESS REPORT}

ATTACHMENT 1

STONE \& WEBSTER ENGINEERING CORP.

\begin{tabular}{|c|c|c|}
\hline DOE / SRPO & J.O. No. 17500.26 & $\begin{array}{l}\text { PERIOD } \\
11 / 21 / 88 \text { TO } 11 / 27 / 88\end{array}$ \\
\hline $\begin{array}{l}\text { STATE AND SITE } \\
\text { LOUISIANA }\end{array}$ & \multicolumn{2}{|c|}{$\begin{array}{l}\text { SITE REPRESENTATIVE } \\
\text { R.KRANES }\end{array}$} \\
\hline \multicolumn{3}{|l|}{ SUMMARY OF ACTIVITIES } \\
\hline PLUGGING & & \\
\hline
\end{tabular}

RESTORATION

NONE

\section{PROBLEMS}

NONE

\section{CHANGES TO ACTIVITY PLAN}

\section{SITE VISITORS}

NONE

WORK PLANNED FOR NEXT WEEK

FINISH ALL REMAINING LOUISIANA FIELD WORK - CUT \& CAP REMAINING WELLS

(LH-7A,B,WS \& DOE CONTINENTAL) 
WEEKLY PROGRESS REPORT

ATTACHMENT 1

STONE \& WEBSTER ENGINEERING CORP.

\begin{tabular}{|c|c|c|}
\hline DOE / SRPO & $\begin{array}{ll}\text { J.O. No. } \quad 17500.26 \\
\end{array}$ & $\begin{array}{l}\text { PERIOD } \\
11 / 28 / 88 \text { TO } 12 / 04 / 88\end{array}$ \\
\hline $\begin{array}{l}\text { STATE AND SITE } \\
\text { LOUISIANA }\end{array}$ & SITE REPRESENTATNE & INES \\
\hline
\end{tabular}

\section{SUMMARY OF ACTIVITIES}

PLUGGING

ALL WELL PLUGGING WAS COMPLETED AS OF 11/18/88. CASINGS FOR THE REAMAINING LOUISIANA WELLS (LH-7A,B,WS AND DOE-CONT. F.I.) WERE EXCAVATED, CUT OFF AND CAPPED AT OR BELOW THE MINIMUM 3 FT. DEPTH BELOW GROUND LEVEL AND THEN BACKFILLED AND GRADED.

\section{RESTORATION}

RESTORATION HAS BEEN COMPLETED AT ALL SITES.

\section{PROBLEMS}

NONE

CHANGES TO ACTIVITY PLAN

NONE

SITE VISITORS

NONE

WORK PLANNED FOR NEXT WEEK

CLOSE OUT LOUISIANA FIELD OPERATIONS. 
WEEKLY PROGRESS REPORT

STONE \& WEBSTER ENGINEERING CORP.

\begin{tabular}{|c|c|c|c|}
\hline \multicolumn{1}{|c|}{ CLIENT } & J.0. No. & 17500.26 & PERIOD \\
\hline $\begin{array}{c}\text { STATE AND SITE } \\
\text { LOUISIANA }\end{array}$ & \multicolumn{3}{|c|}{$\begin{array}{l}\text { SITE REPRESENTATME } \\
\text { R. KRANES }\end{array}$} \\
\hline
\end{tabular}

\section{SUMMARY OF ACTIVITIES}

PLUGGING

LAYNE CENTRAL, ORIGINAL DRILLERS OF V-5 WELL, WAS CONTACTED REGARDING LOCATION

OF THAT WELL. R. KRANES MET WITH ORIGINAL DRILLER OF V-5. DRILLER WAS ABLE

TO LOCATE WELL.

\section{RESTORATION}

COMPLETED

\section{PROBLEMS}

NONE

\section{CHANGES TO ACTIVITY PLAN}

NONE

SITE VISITORS

NONE

WORK PLANNED FOR NEXT WEEK

PLUG AND ABANDONMENT OF V-5 WELL TO BE DONE EARLY IN JANUARY 1989. EXACT DATE TO BE SET UP. 
WEEKLY PROGRESS REPORT

ATTACHMENT 1

STONE \& WEBSTER ENGINEERING CORP.

\begin{tabular}{|l|l|l|}
\hline \multicolumn{1}{|c|}{ DOLENT / SRPO } & J.O. No. 17500.26 & PERIOD $01 / 04 / 89$ TO 01/06/89 \\
\hline $\begin{array}{c}\text { STATE AND SITE } \\
\text { LOUISIANA }\end{array}$ & \multicolumn{3}{|c|}{ SITE REPRESENTATIE J.Q. KANTOLA } \\
\hline
\end{tabular}

\section{SUMMARY OF ACTIVITIES}

PLUGGING

SWEC CONDUCTED SITE RECCONNAISSANCE OF DEEP BOREHOLE V-5. SOUTHWESTERN LABS

SUBCONTRACTED DOZER TO PREPARE SITE ACCESS AND PLACED SAND PLUG IN

WELL V-5 (DEPTH 403.5 TO 367.36 FT). GEARHART INLUSTRIES PERFORMED A CEMENT

BOND LOG AND GAMMA RAY LOG ON V-5.

\section{RESTORATION}

NONE

\section{PROBLEMS}

LOST 3 JOINTS OF 2.3/8" DRILL PIPE IN V-5 RISER PIPE AREA.

\section{CHANGES TO ACTIVITY PLAN}

SITE VISITORS

NONE

WORK PLANNED FOR NEXT WEEK

FISH FOR 3 JOINTS OF DRILL PIPE, PLUG AND ABANDON V-5, SITE RESTORATION, AND PLUG GEOTECHNICAL BOREHOLE TB-2. 
WEEKLY PROGRESS REPORT

ATTACHMENT 1

STONE \& WEBSTER ENGINEERING CORP.

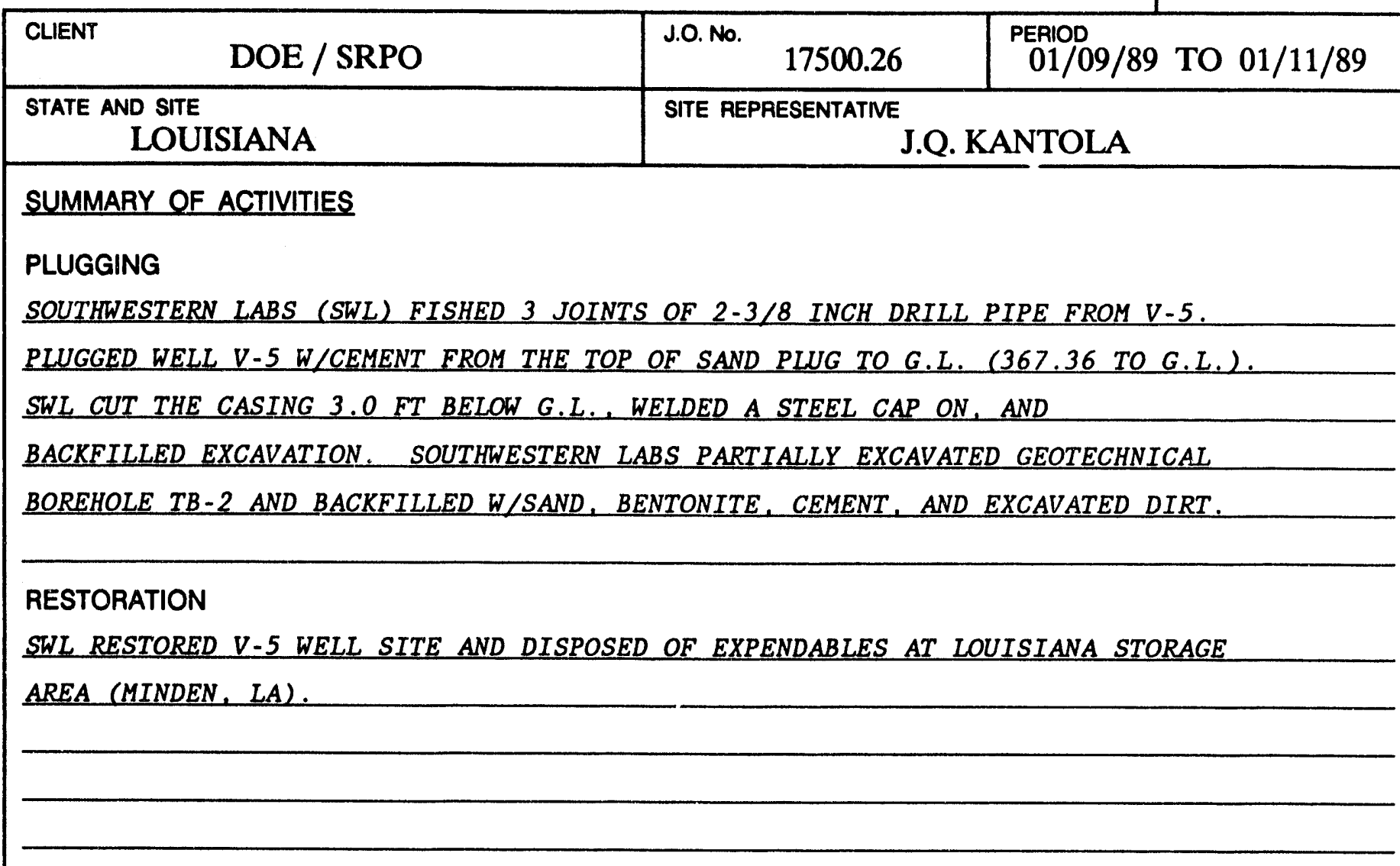

PROBLEMS

NONE

CHANGES TO ACTIVITY PLAN

NONE

SITE VISITORS

NONE

WORK PLANNED FOR NEXT WEEK

FIELD WORK COMPLETE. 
SITE RECONNAISSANCE FORM

\begin{tabular}{|l|l|}
\hline CLIENT & \multicolumn{2}{c}{ DOE / SRPO } \\
\hline $\begin{array}{l}\text { STATE } \\
\text { LOUISIANA }\end{array}$ & $\begin{array}{c}\text { WELL NAME \& NUMBER } \\
\text { L.P. \& L. LH-2A }\end{array}$ \\
\hline
\end{tabular}

LOCATION

1233.4 EWL \& 360.44 SNL* IN

SEC. 3, T18N, R10W - W WEBSTER PARISH

J.O. No.

17500.26

DATE

$06 / 24 / 88$

TFSC FIELD REPRESENTATIVE

JOAN L. WELC-LEPAIN

\section{DESCRIPTION OF SITE ACCESS}

ACCESS TO SITE IS ON N. SIDE OF HWY 79/80, TWO MILES W. OF INTERSECTION OF HWY 79/80 AND 7(N). GRAVEL ACCESS ROAD IS ABOUT 180 FT LONG. ACCESS TO WELLHEAD IS

ACROSS FLAT GRASSY AREA.

DESCRIPTION OF SITE PAD AREA

AREA SURROUNDING WELLHEAD IS FLAT AND GRASSY.

DESCRIPTION OF WELL HEAD

20 IN. CONDUCTOR PIPE $0.5^{\prime}$ HIGH, 13 3/8 CASING 0.6' HIGH, AND 6 IN PIPE 0.65'

HIGH WITH LOCKING, HINGED CAP. WELLHEAD PROTECTED BY METAL PIPE CAGE.

\section{DESCRIPTION OF PITS}

NA

DEPTH AND BOREHOLE - FLUID SURVEY: BY OTIS (07/19/88)

GROUND ELEVATION 199.57 FT (DATUM)

REPORTED DEPTH 1814.10 FT (SEE BOREHOLE COMPLETION SKETCH)

MEASURED DEPTH 1795.88 FT OBSTRUCTION NONE

FLUID DEPTH 228.38 FT CHLORIDE CONTENT $>4900$ ppm Cl-

CONDUCTMTY $81.55 \mathrm{~ms} / \mathrm{cm} \quad \mathrm{mgS} 40.780 \mathrm{mg} / \mathrm{L}$

TEMPERATURE 24.0

REMARKS

THE WELL COMPLETION REPORT FOR LH-2B HAS THE BOTTOM OF THE TAILPIPE 18.22 FT. LOWER THAN THE TOTAL DEPTH OF 1795.88 RECORDED. PIPE SCALE HAS PROBABLY FILLED THE TAIL PIPE. 


\section{SITE RECONNAISSANCE FORM}

\begin{tabular}{|l|l|}
\hline CLENT & DOE / SRPO \\
\hline $\begin{array}{l}\text { STATE } \\
\text { LOUISIANA }\end{array}$ & $\begin{array}{l}\text { WELL NAME \& NUMBER } \\
\text { L.P. \& L. LH-2B }\end{array}$ \\
\hline
\end{tabular}

LOCATION

1224.95' EHL \& 288.15' SNL* IN

SEC 3 , T18N, R1OH -. WEBSTER PARISH

J.O. No.

17500.26

DATE

TFSC FIELD REPRESENTATIVE

JOAN L. WELC-LEPAIN

\section{DESCRIPTION OF SITE ACCESS}

ACCESS TO SITE IS ON $N$. SIDE OF HWY 79/80. TWO MILES $W$. OF INTERSECTION OF HWY

$79 / 80$ AND $7(N)$. GRAVEL ACCESS ROAD IS ABOUT 180 FT LONG. ACCESS TO WELLHEAD IS

ACROSS FLAT GRASSY AREA.

DESCRIPTION OF SITE PAD AREA

PAD AREA IS FLAT AND GRASSY.

\section{DESCRIPTION OF WELL HEAD}

20 IN. CONDUCTOR PIPE 0.2' HIGH. 6.0 IN. CASING 0.65 FT. HIGH WITH HINGED, LOCK-

ING CAP. WELLHEAD PROTECTED BY STEEL PIPE CAGE.

\section{DESCRIPTION OF PITS}

NA

DEPTH AND BOREHOLE - FLUID SURVEY: BY OTIS $(07 / 19 / 88)$

GROUND ELEVATION 198.9 FT (DATUM)

REPORTED DEPTH 744.05 FT (SEE BOREHOLE COMPLETION SKETCH)

MEASURED DEPTH 745.29 FT OBSTRUCTION NONE FT

FLUID DEPTH $68.79 \quad$ FT CHLORIDE CONTENT 1796 pPm Cl-

CONDUCTMITY $5.78 \quad \mathrm{mS} / \mathrm{cm} \quad \mathrm{mg} / \mathrm{L}$

TEMPERATURE $26.6{ }^{\circ} \mathrm{C}$

REMARKS

NONE 


\section{SITE RECONNAISSANCE FORM}

\begin{tabular}{|l|l|}
\hline CLIENT & DOE / SRPO \\
\hline $\begin{array}{l}\text { STATE } \\
\text { LOUISIANA }\end{array}$ & $\begin{array}{l}\text { WELL NAME \& NUMBER } \\
\text { L.P. \& L. LH-2WS }\end{array}$ \\
\hline
\end{tabular}

LOCATION

1280.521 EWL \& 415.81 'SNL* IN

SEC 3, T18N, R1OW -. WEBSTER PARISH

J.O. No.

17500.26

DATE

$06 / 24 / 88$

TFSC FIELD REPRESENTATIVE

JOAN L. WELC-LEPAIN

DESCRIPTION OF SITE ACCESS

ACCESS TO SITE IS ON N. SIDE OF HWY 79/80. TWO MI. W. OF INTERSECTION OF HWY

79/80 AND $7(N)$. GRAVEL ACCESS ROAD IS ABOUT 180 FT LONG. ACCESS TO WELLHEAD IS

ACROSS FLAT GRASSY AREA.

DESCRIPTION OF SITE PAD AREA

PAD AREA IS FLAT AND GRASSY. WELLHEAD IS IN SMALL CEMENT PAD AT SURFACE.

DESCRIPTION OF WELL HEAD

4.0 IN. STEEL PIPE, 1.6 FT HIGH WITH HINGED, LOCKING CAP. WELLHEAD IS PROTECTED BY STEEL PIPE CAGE.

\section{DESCRIPTION OF PITS}

$\underline{N A}$

DEPTH AND BOREHOLE - FLUID SURVEY: BY OTIS (7/19/88)

GROUND ELEVATION 197.76 FT (DATUM)

REPORTED DEPTH 139.48 FT (SEE BOREHOLE COMPLETION SKETCH)

MEASURED DEPTH 135.47 FT OBSTRUCTION NONE

FLUID DEPTH $20.47 \quad$ FT CHLORIDE CONTENT $<300 \quad$ ppm CI-

CONDUCTMTY $0.594 \quad \mathrm{~ms} / \mathrm{cm} \quad \mathrm{TDS} \quad 305 \quad \mathrm{mg} / \mathrm{L}$

TEMPERATURE 24.2

REMARKS

BOTTOM OF THE WELL IS 4.01 FT SHALLOWER THAN WHAT IS REPORTED IN THE WELL COM-

PLETION REPORT. PIPE SCALE HAS PROBABLY FILLED IN THE TAIL PIPE. 


\section{SITE RECONNAISSANCE FORM}

\begin{tabular}{|l|l|}
\hline \multicolumn{2}{|c|}{ CLIENT } \\
\end{tabular}

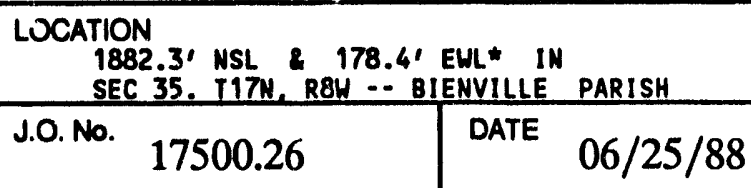

TFSC FIELD REPRESENTATIVE

R.T. DECONTO

DESCRIPTION OF SITE ACCESS

ACCESS ROAD IS ON E. SIDE OF PR 499, $0.6 \mathrm{MI}$. N. OF INTERSECTION WITH HWY 516. ENTRANCE SECURED BY LOCKED METAL GATE. ROAD IS APPROX. 1600 FT. LONG, LEVEL. GRAVEL.

DESCRIPTION OF SITE PAD AREA

PAD CONSISTS OF 6 INCH THICK, BLOCKY GRAVEL. PAD IS LEVEL \& CLEAR OF VEGETATION AND ENDS 2 FT. BEYOND WELL HEAD.

DESCRIPTION OF WELL HEAD

CONSISTS OF 20" DIA. CONDUCTOR PIPE W/WELDED STEEL COVER PLATE, 10 3/4" DIA SURFACE CASING EXTENDS THRU COVER PLATE. 6 IN. INNER CASING EXTENDS THROUGH SURFACE CASING COVER PLATE. INNER CASING LOCKED WITH HINGED STEEL CAP. WELLHEAD PROTECTED BY STEEL PIPE CAGE.

DESCRIPTION OF PITS

$\underline{N A}$

DEPTH AND BOREHOLE - FLUID SURVEY: $7 / 20 / 88$

GROUND ELEVATION 223.16 FT (DATUM)

REPORTED DEPTH 2.702 .0 FT (SEE BOREHOLE COMPLETION SKETCH)

MEASURED DEPTH 2701.75 FT OBSTRUCTION NONE FT

FLUID DEPTH 91.75 FT CHLORIDE CONTENT $\longrightarrow 4900$ PPm Cl-

CONDUCTNTY $195.33 \mathrm{mS} / \mathrm{cm}$ TDS $97.665 \mathrm{mg} / \mathrm{L}$

TEMPERATURE 33.1

REMARKS

SECURITY GATE CONTROLLED BY WILLAMETTE CORP. (PAUL MCMAHEN 318-377-4465) AND

LANDOWNER (MR. STEWART, FIRST HOUSE NORTH OF SITE ON PARISH RD. 499). 
SITE RECONNAISSANCE FORM

\begin{tabular}{|l|c|}
\hline CLENT & DOE / SRPO \\
\hline $\begin{array}{c}\text { STATE } \\
\text { LOUISIANA }\end{array}$ & $\begin{array}{c}\text { WELL NAME \& NUMBER } \\
\text { KCI HODGE LVH-6B }\end{array}$ \\
\hline
\end{tabular}

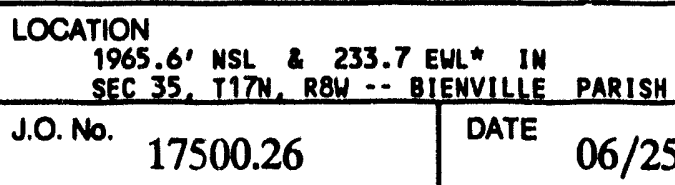

DESCRIPTION OF SITE ACCESS

ACCESS ROAD IS ON E. SIDE OF PR 499, 0.6 MI. N. OF INTERSECTION WITH HWY 516. ENTRANCE SECURED BY LOCKED METAL GATE. ROAD IS APPROX, 1600 FT LONG. LEVEL. GRAVEL.

DESCRIPTION OF SITE PAD AREA

PAD CONSISTS OF LARGE BLOCKY GRAVEL \& COBBLES. PAD IS LEVEL \& ABOUT I FT. THICK \& CLEAR OF VEGETATION. PAD EXTENDS 2 FT. BEYOND WELL HEAD \& IS 39 FT. WESTERLY EXTENSION OF ACCESS ROAD.

DESCRIPTION OF WELL HEAD

WELL HEAD CONSISTS OF 20" DIA. CONDUCTOR PIPE WITH 6" I.D. CASING STRING THROUGH WELDED STEEL PLATE COVERING CONDUCTOR PIPE. INNER CASING IS COVERED \& LOCKED WITH HINGED CAP. NO EVIDENCE OF CEMENT AROUND PIPE. PROTECTIVE STEEL PIPE CAGE SURROUNDS WELLHEAD.

DESCRIPTION OF PIIS NA

DEPTH AND BOREHOLE - FLUID SURVEY: BY OTIS $(7 / 20 / 88)$

GROUND ELEVATION 224.64 FT (DATUM)

REPORTED DEPTH 1923.0 FT (SEE BOREHOLE COMPLETION SKETCH)

MEASURED DEPTH 1905.2 FT OBSTRUCTION NONE FT

FLUID DEPTH 134.2 FT CHLORIDE CONTENT $\longrightarrow 4900$ ppm C1-

CONDUCTMTY $212.83 \mathrm{~ms} / \mathrm{cm}$ TDS $106.415 \mathrm{mg} / \mathrm{L}$

TEMPERATURE $28.5{ }^{\circ} \mathrm{C}$

REMARKS

SECURITY GATE ACCESS CONTROLLED BY LANDOWNER (MR. STEWART) LOCATED IN FIRST HOUSE NORTH OF SITE ON PARISH RD 499. WILLAMETTE CORP. ALSO HAS KEY (PAUL MCMAHEN 318-377-4465). THE TAILPIPE AND PART OF THE SCREEN HAVE BEEN FILLED WITH PIPE SCALE. THE TOTAL DEPTH MEASURED IS 17.08 FT. SHALLOWER THAN WHAT IS REPORTED IN THE WELL COMPLETION REPORT. 


\section{SITE RECONNAISSANCE FORM}

\begin{tabular}{|l|l|}
\hline CLENT & DOE / SRPO \\
\hline $\begin{array}{c}\text { STATE } \\
\text { LOUISIANA }\end{array}$ & $\begin{array}{c}\text { WELL NAME \& NUMBER } \\
\text { KCI HODGE LVH-6C }\end{array}$ \\
\hline
\end{tabular}

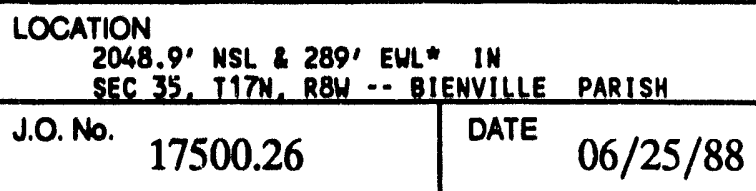

DATE

$06 / 25 / 88$

TFSC FIELD REPRESENTATINE

R.T. DECONTO

\section{DESCRIPTION OF SITE ACCESS}

ACCESS ROAD IS ON E. SIDE OF PR 499, 0.6 MI. N. OF INTERSECTION WITH HWY 516. ENTRANCE SECURED BY LOCKED METAL GATE. ROAD IS APPROX, 1600 FT LONG. LEVEL, GRAVEL.

DESCRIPTION OF SITE PAD AREA

LEVEL GRAVEL PAD WITH NO VEGETATION OFF ACCESS ROAD. PAD IS 42 FT LONG.

\section{DESCRIPTION OF WELL HEAD}

WELLHEAD CONSISTS OF 20 IN. DIA. CONDUCTOR COVERED WITH STEEL PLATE. 6.0 IN. CASING STICKS UP THROUGH PLATE AND LOCKED WITH A HINGED COVER PLATE. STEEL PIPE CAGE PROTECTS WELLHEAD.

DESCRIPTION OF PITS

NA

DEPTH AND BOREHOLE - FLUID SURVEY: $07 / 20 / 88$

GROUND ELEVATION 224.92 FT (DATUM)

REPORTED DEPTH 975.0 FT (SEE BOREHOLE COMPLETION SKETCH)

MEASURED DEPTH 975.84 FT OBSTRUCTION NONE

FLUID DEPTH 45.84 FT CHLORIDE CONTENT 1888 PPm Cl-

CONDUCTMTY $6.44 \quad \mathrm{~ms} / \mathrm{cm}$ TDS $3240 \mathrm{mg} / \mathrm{L}$

TEMPERATURE 27.6

REMARKS

ACCESS GATE CONTROLLED BY LANDOWNER (MR. STEWART) IN FIRST HOUSE NORTH OF SITE. WILLAMETTE CORP. ALSO HAS ACCESS CONTROL (PAUL MCMAHEN, 318 377-4465). 
SITE RECONNAISSANCE FORM

\begin{tabular}{|c|c|c|c|}
\hline CLIENT & DOE / SRPO & J.O. No. 17500.26 & DATE $06 / 25 / 88$ \\
\hline $\begin{array}{l}\text { STATE } \\
\text { LOUISIANA }\end{array}$ & $\begin{array}{l}\text { WELL NAME \& NUMBER } \\
\text { KCI HODGE LVH-6WS }\end{array}$ & \multicolumn{2}{|c|}{$\begin{array}{c}\text { TFSC FIELD REPRESENTATME } \\
\text { R.T. DECONTO }\end{array}$} \\
\hline \multicolumn{4}{|c|}{$\begin{array}{l}\text { DESCRIPTION OF SITE ACCESS } \\
\text { ACCESS ROAD IS ON E. SIDE OF PR 499.0.6 MI N. OF INTERSECTION WITH HWY } 516 .\end{array}$} \\
\hline \multicolumn{4}{|c|}{ ENTRANCE SECURED BY LOCKED METAL GATE, ROAD IS APPROX, 1600 FT LONG. LEVEL. } \\
\hline \multicolumn{4}{|c|}{ GRAVEL. } \\
\hline \multicolumn{4}{|c|}{$\begin{array}{l}\text { DESCRIPTION OF SITE PAD AREA } \\
\text { QNE FT THICK GRAVEL PAD IS A }\end{array}$} \\
\hline
\end{tabular}

DESCRIPTION OF WELL HEAD

WELLHEAD IS A 4 IN. DIA. STEEL CASING W/ HINGED LOCKING CAP, WELLHEAD PROTECTED BY STEEL PIPE CAGE.

DESCRIPTION OF PITS

NA

DEPTH AND BOREHOLE - FLUID SURVEY: $07 / 20 / 88$

GROUND ELEVATION 221.64 FT (DATUM)

REPORTED DEPTH 98.71 FT (SEE BOREHOLE COMPLETION SKETCH)

MEASURED DEPTH 99.16 FT OBSTRUCTION NONE

FLUID DEPTH $33.16 \quad$ CT CHLORIDE CONTENT $<50 \quad$ PPm C1-

CONDUCTMTY $0.078 \quad \mathrm{~ms} / \mathrm{cm}$ TDS $40 \quad \mathrm{mg} / \mathrm{L}$

TEMPERATURE 26.3

REMARKS

ACCESS GATE CONTROLLED BY LANDOWNER (MR. STEWART) IN FIRST HOUSE NORTH OF SITE. WILLAMETTE CORP. ALSO HAS ACCESS CONTROL. 


\section{SITE RECONNAISSANCE FORM}

\begin{tabular}{|c|c|c|c|}
\hline CLIENT & DOE / SRPO & J.O. No. 17500.26 & DATE \\
\hline $\begin{array}{l}\text { STATE } \\
\text { LOUISIANA }\end{array}$ & $\begin{array}{l}\text { WELL NAME \& NUMBER } \\
\text { KCI HODGE LH-7A }\end{array}$ & \multicolumn{2}{|c|}{$\begin{array}{l}\text { TFSC FIELD REPRESENTATIVE } \\
\text { J.L. WELC-LEPAI }\end{array}$} \\
\hline
\end{tabular}

DESCRIPTION OF SITE ACCESS

SITE IS ON EAST SIDE OF PARISH ROAD 173, $3.9 \mathrm{MI}$, SOUTH OF INTERSECTION WITH

PR 147. ACCESS ROAD IS STEEP. GRAVEL FOR 200 FT AND THEN BECOMES SOIL IITH MORE

GENTLE GRADE.

DESCRIPTION OF SITE PAD AREA

PAD AREA OVERGROWN WITH GRASS AND SMALL TREES.

DESCRIPTION OF WELL HEAD

6.0 IN. CASING INSIDE 12.0 IN. BOTH INSIDE 20 IN. CONDUCTOR PIPE. LOCKING.

HINGED CAP ON 6.0 IN. PIPE. WELLHEAD PROTECTED BY STEEL PIPE CAGE.

\section{DESCRIPTION OF PITS}

NA

DEPTH AND BOREHOLE - FLUID SURVEY: 07/19/88

GROUND ELEVATION 325.57 FT (DATUM)

REPORTED DEPTH 1565.09 FT (SEE BOREHOLE COMPLETION SKETCH)

MEASURED DEPTH 1566.51 FT OBSTRUCTION NONE FT

FLUID DEPTH 143.51 FT CHLORIDE CONTENT $>4900$ pPm C1-

CONDUCTMTY $10.29 \mathrm{mS} / \mathrm{cm} \mathrm{TDS} 5140 \mathrm{mg} / \mathrm{L}$

TEMPERATURE 37.5

REMARKS

NONE 
SITE RECONNAISSANCE FORM

\begin{tabular}{|l|l}
\hline CLIENT & DOE / SRPO \\
\hline $\begin{array}{c}\text { STATE } \\
\text { LOUISIANA }\end{array}$ & $\begin{array}{l}\text { WELL NAME \& NUMBER } \\
\text { KCI HODGE LH-7B }\end{array}$ \\
\hline
\end{tabular}

LOCATION

14.1 FT NSL \& 711.3 FT EHL* IN

SEC 5, IITM, R5H -.. BIENVILLE PARISH

J.O. No.

17500.26

DATE

$06 / 24 / 88$

TFSC FIELD REPRESENTATME

DESCRIPTION OF SITE ACCESS

SITE IS ON EAST SIDE OF PARISH ROAD 173, 3.9 MI, SOUTH OF INTERSECTION WITH

PR 147. ACCESS ROAD IS STEEP GRAVEL FOR 200 FT AND THEN BECOMES SOIL WITH MORE

GENTLE GRADE.

DESCRIPTION OF SITE PAD AREA

PAD AREA IS OVERGROWN WITH GRASS AND SMALL TREES. DRAINAGE CHANNEL RUNS THROUGH

PAD. SIX FOOT DEEP RAT HOLE REMAINING NEAR WELLHEAD FROM ORIGINAL DRILLING.

DESCRIPTION OF WELL HEAD

20 IN. CONDUCTOR PIPE WITH STEEL PLATE ON TOP. 6.0 IN. CASING STICKS UP THROUGH PLATE ABOUT 1 FT AND HAS LOCKING. HINGED CAP.

DESCRIPTION OF PITS

NA

DEPTH AND BOREHOLE - FLUID SURVEY: $07 / 19 / 88$

GROUND ELEVATION 326.27 FT (DATUM)

REPORTED DEPTH 1051.0 FT (SEE BOREHOLE COMPLETION SKETCH)

MEASURED DEPTH 1044.79 FT OBSTRUCTION NONE FT

FLUID DEPTH 161.29 FT CHLORIDE CONTENT 745 PPm C.

CONDUCTMTY $3.58 \mathrm{~ms} / \mathrm{cm} \mathrm{mg} / \mathrm{L}$

TEMPERATURE 37.3

REMARKS

THE TOTAL DEPTH IS 6.21 FT LESS THAN THE DEPTH REPORTED IN THE WELL COMPLETION REPORT, PIPE SCALE IN THE TAIL PIPE MAY BE THE CAUSE. 
SITE RECONNAISSANCE FORM

\begin{tabular}{|l|l|}
\hline CLIENT & DOE / SRPO \\
\hline $\begin{array}{l}\text { STATE } \\
\text { LOUISIANA }\end{array}$ & $\begin{array}{l}\text { WELL NAME \& NUMBER } \\
\text { KCI HODGE LH-7WS }\end{array}$ \\
\hline
\end{tabular}

LOCATION

621.85 FT EWL \& 28.71 FT SNL* IN

SEC 8, TITW. R5W - BIENVILLE PARISH

J.O. No.

17500.26

DATE

$06 / 24 / 88$

TFSC FIELD REPRESENTATIVE

J.L. WELC-LEPAIN

DESCRIPTION OF SITE ACCESS

SITE IS ON EAST SIDE OF PARISH ROAD 173, 3.9 MI, SOUTH OF INTERSECTION WITH

PR 147. ACCESS ROAD IS STEEP. GRAVEL FOR 200 FT AND THEN BECOMES SOIL WITH MORE

GENTLE SLOPE.

DESCRIPTION OF SITE PAD AREA

PAD AREA IS OVERGROWN WITH GRASS AND SMALL TREES.

DESCRIPTION OF WELL HEAD

6.0 IN. STEEL CASING STICKS UP 2.5 FT, WITH LOCKING HINGED CAP. WELLHEAD

PROTECTED BY STEEL PIPE CAGE.

DESCRIPTION OF PITS

NA

DEPTH AND BOREHOLE - FLUID SURVEY: $07 / 19 / 88$

GROUND ELEVATION 332.79 FT (DATUM)

REPORTED DEPTH 595.0 FT (SEE BOREHOLE COMPLETION SKETCH)

MEASURED DEPTH 588.68 FT OBSTRUCTION NONE

FLUID DEPTH 195.18 FT CHLORIDE CONTENT $<300 \quad$ pPm CI-

CONDUCTMTY $0.248 \quad \mathrm{mS} / \mathrm{cm}$ TDS $124 \quad \mathrm{mg} / \mathrm{L}$

TEMPERATURE 30.0

REMARKS

PIPE SCALE IN TAIL PIPE BELIEVED TO BE CAUSE OF 6.33 FT DIFFERENCE IN DEPTH RE-

PORTED IN WELL COMPLETION REPORT AND THIS SURVEY. 


\section{SITE RECONNAISSANCE FORM}

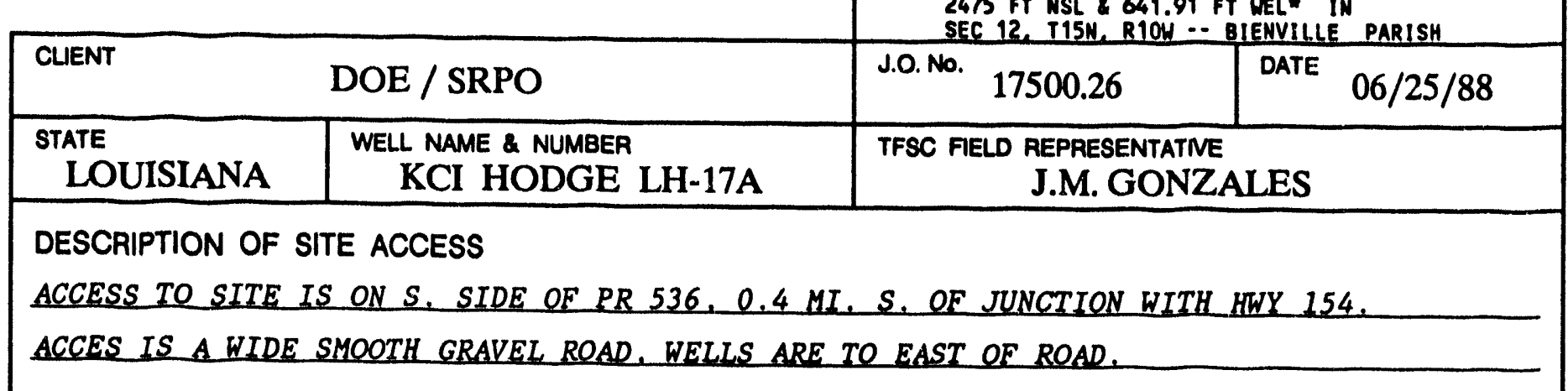

DESCRIPTION OF SITE PAD AREA

ROAD IS LEVEL TO WELLHEAD AND ABOUT 170 FT FROM ENTRANCE TO SITE. PAD IS LEVEL WITH SOME EROSION ON EAST SIDE. SEVERAL PILES OF TRASH ON SIDES OF ROAD.

\section{DESCRIPTION OF WELL HEAD}

20 IN CONDUCTOR PIPE AT SURFACE WITH COVER PLATE, 10.75 IN. CASING STICKS UP THROUGH PLATE, 6.0 IN. CASING STICKS OUT OF 10.75 IN. CASING 1.5 FT ABOVE G.L. HINGED. LOCKING CAP ON 6.0 IN. CASING. STEEL PIPE CAGE PROTECTS THE WELL HEAD.

\section{DESCRIPTION OF PITS \\ $\underline{N A}$}

DEPTH AND BOREHOLE - FLUID SURVEY: $07 / 20 / 88$

GROUND ELEVATION 270.00 FT (DATUM)

REPORTED DEPTH 2027.0 FT (SEE BOREHOLE COMPLETION SKETCH)

MEASURED DEPTH 2012.91 FT OBSTRUCTION NONE TT

FLUID DEPTH 301.91 FT CHLORIDE CONTENT $>5000$ ppm Cl.

CONDUCTMTY $67.13 \mathrm{~ms} / \mathrm{cm}$ TDS $33.565 \mathrm{mg} / \mathrm{L}$

TEMPERATURE NOT TAKEN ${ }^{\circ} \mathrm{C}$

REMARKS

PIPE SCALE IN TAIL PIPE IS BELIEVED TO BE CAUSE OF 14.1 FT DIFFERENCE IN DEPTH BETWEEN THE WELL COMPLETION REPORT AND THIS SURVEY. WIRELINE HAD TROUBLE ENTERING THE 4.0 IN. RISER PIPE BELOW THE 6.0 IN. PIPE. 
SITE RECONNAISSANCE FORM

LOCATION

640.0 FT WEL 2406.8 FII MSL II

SEC 12, IISN, RIOW -- BIENVILLE PARISH

\begin{tabular}{|l|l|l|l|}
\hline CLIENT & J.0. No. 17500.26 & DATE \\
\hline $\begin{array}{l}\text { STATE } \\
\text { LOUISIANA }\end{array}$ & $\begin{array}{c}\text { WELL NAME \& NUMBER } \\
\text { KCI HODGE LH-17B }\end{array}$ & TFSC FIELD REPRESENTATIVE \\
\hline
\end{tabular}

DESCRIPTION OF SITE ACCESS

ACCESS TO SITE IS ON $S$ SIDE OF PR 536, $0.4 \mathrm{MI}, S$. OF JUNCTION WITH HWY 154. ACCESS IS WIDE SMOOTH GRAVEL ROAD, WELLS ARE TO THE EAST. SEVERAL PILES OF

TRASH ALONG ROAD.

DESCRIPTION OF SITE PAD AREA

PAD IS OVERGROWN WITH BRUSH, WITH SOME EROSION ON EAST SIDE.

DESCRIPTION OF WELL HEAD

20.0 IN. CONDUCTOR PIPE STICKS UP 1.4 FT WITH STEEL PLATE ON TOP. 6.0 IN. CASING STICKS THROUGH THE COVER PLATE 0.8 FT. WITH HINGED IOCKING CAP. STEEL PIPE CAGE PROTECTS WELL HEAD.

DESCRIPTION OF PITS

NA

DEPTH AND BOREHOLE - FLUID SURVEY: $07 / 20 / 88$

GROUND ELEVATION 269.72 FT (DATUM)

REPORTED DEPTH 1377.94 FT (SEE BOREHOLE COMPLETION SKETCH)

MEASURED DEPTH 1376.49 FT OBSTRUCTION NONE FT

FLUID DEPTH $13.99 \quad$ FT CHLORIDE CONTENT $>5000$ PPm Cl-

CONDUCTMTY $55.43 \mathrm{~ms} / \mathrm{cm} \quad$ TDS $27.715 \mathrm{mg} / \mathrm{L}$

TEMPERATURE 30.5

REMARKS

NONE 


\section{SITE RECONNAISSANCE FORM}

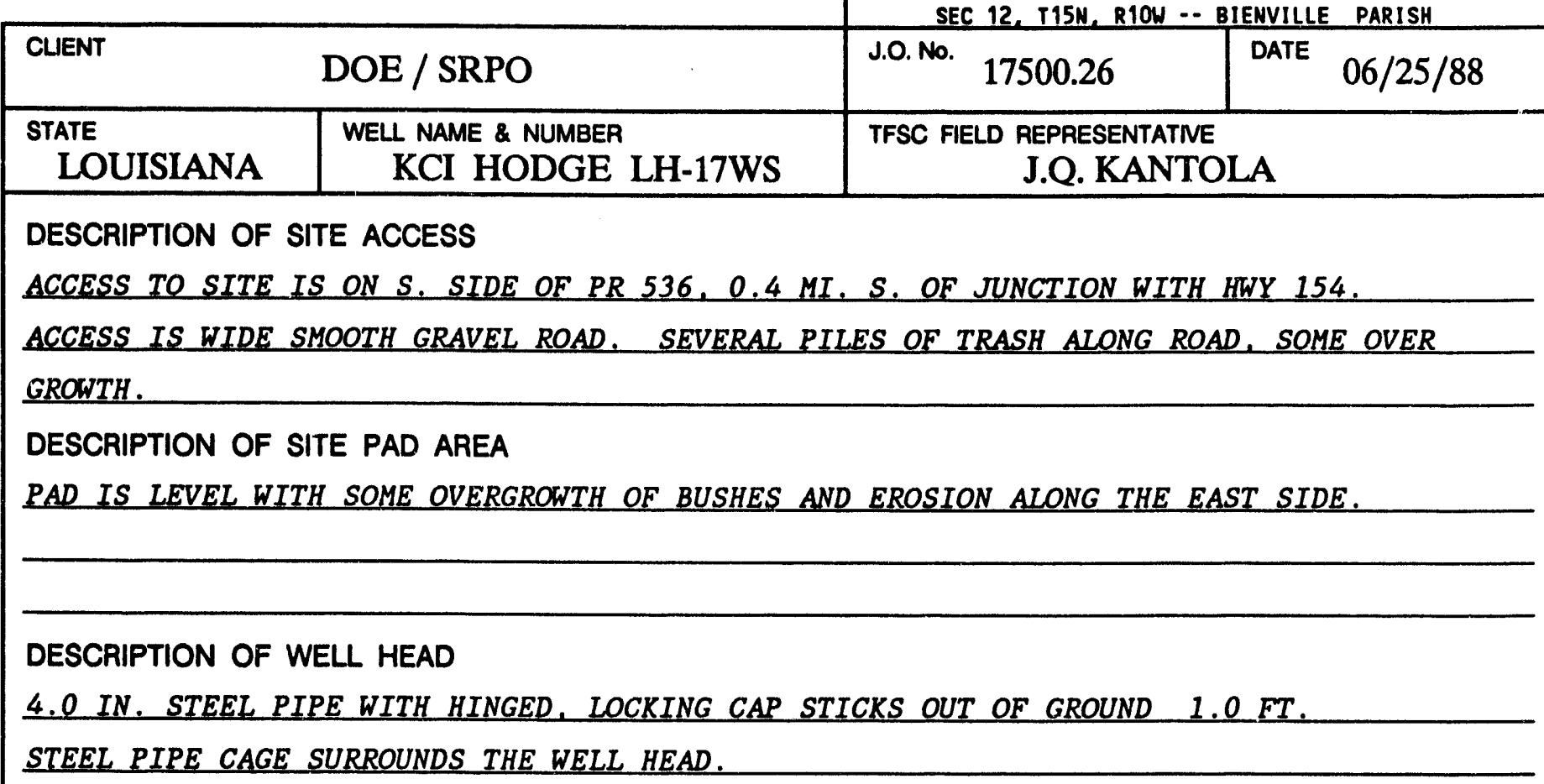

\section{DESCRIPTION OF PITS \\ NA}

DEPTH AND BOREHOLE - FLUID SURVEY: 07/20/88

GROUND ELEVATION 270.38 FT (DATUM)

REPORTED DEPTH 433.53 FT (SEE BOREHOLE COMPLETION SKETCH)

MEASURED DEPTH 432.82 FT OBSTRUCTION NONE FT

FLUID DEPTH $79.29 \quad$ FT CHLORIDE CONTENT $-<300 \quad$ PPm CI-

CONDUCTMTY $0.474 \quad \mathrm{~ms} / \mathrm{cm} \quad \mathrm{TDS} 237 \mathrm{mg} / \mathrm{L}$

TEMPERATURE $29.1 \quad{ }^{\circ} \mathrm{C}$

REMARKS

NONE 
SITE RECONNAISSANCE FORM

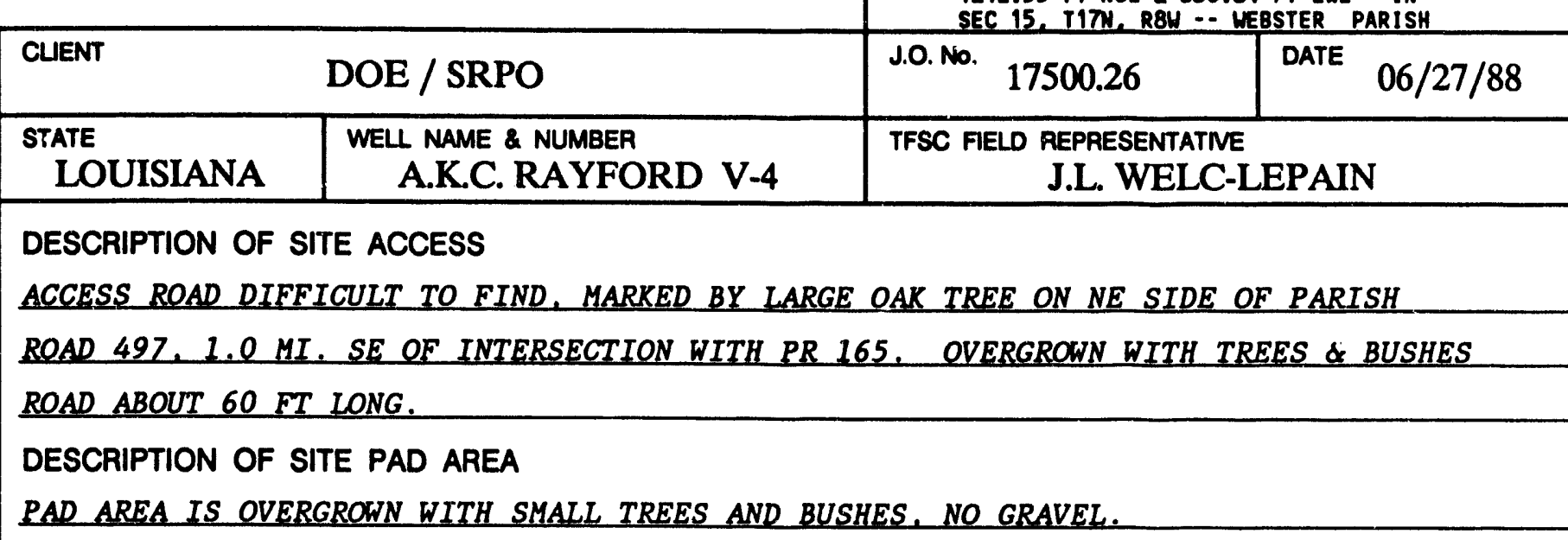

DESCRIPTION OF WELL HEAD

5.5 IN. STEEL CASING STICKING UP 7.0 IN. WITH 10.0 IN. FLANGE AND COVER

THREADED ON THE 5.5 IN. 3' $3^{\prime} 3^{\circ}$ CEMENT PAD AROUND WELL.

DESCRIPTION OF PITS

NA

DEPTH AND BOREHOLE - FLUID SURVEY: $07 / 20 / 88$

GROUND ELEVATION 280.84 FT (DATUM)

REPORTED DEPTH 488.0 FT (SEE BOREHOLE COMPLETION SKETCH)

MEASURED DEPTH 401.0 FT OBSTRUCTION NONE FT

FLUID DEPTH $58.0 \quad$ FT CHLORIDE CONTENT 595 ppm Cl-

CONDUCTMTY $1.88 \quad \mathrm{~ms} / \mathrm{cm} \quad \mathrm{TDS} .940 \quad \mathrm{mg} / \mathrm{L}$

TEMPERATURE 27.7

REMARKS

NONE 


\section{SITE RECONNAISSANCE FORM}

\begin{tabular}{|l|l|}
\hline \multicolumn{2}{|c}{ CLIENT } \\
\hline $\begin{array}{l}\text { STATE } \\
\text { LOUISIANA }\end{array}$ & $\begin{array}{l}\text { WELL NAME \& NUMBER } \\
\text { E.H.S. CONNELL V-5 }\end{array}$ \\
\hline
\end{tabular}

LOCATION

$2013.18 \mathrm{FT}$ NSL \& 747.35 FT EWL* IN

SEC 22, T17N, RBW - BIENVILLE PARISH

J.O. No.

17500.26

DATE

$01 / 04 / 89$

\section{DESCRIPTION OF SITE ACCESS}

ACCESS ROAD IS ON E. SIDE OF PR 497, 100 FT N. OF INTERSECTION WITH PR 498.

ACCESS INITIALLY BEARS NE. FOR 100 FT. WELL IS ABOUT 25 FT OFF THE S. SIDE OF

ROAD AT. 16 MI FROM PR 497.

DESCRIPTION OF SITE PAD AREA

PAD AREA IS LEVEL AND OVERGROWN WITH SMALL TREES AND GRASS.

\section{DESCRIPTION OF WELL HEAD}

5.0 IN. CASING STICKS UP 1.6 FT, 10.0 IN. FLANGE AND COVER PLATE THREADED

TO TOP OF 5.0 IN. CASING.

DESCRIPTION OF PITS

NA

DEPTH AND BOREHOLE - FLUID SURVEY: 01/04/89

GROUND ELEVATION 239.52 FT (DATUM)

REPORTED DEPTH 387.0 FT (SEE BOREHOLE COMPLETION SKETCH)

MEASURED DEPTH $403.5 *$ FT OBSTRUCTION NONE FT

FLUID DEPTH 54.2 FT CHLORIDE CONTENT 1133 PPM Cl-

CONDUCTMTY $3.78 \mathrm{~ms} / \mathrm{cm}$ TDS $1850 \mathrm{mg} / \mathrm{L}$

TEMPERATURE — NOT TAKEN ${ }^{\circ} \mathrm{C}$

REMARKS

* WIRELINE DEPTH IS TO TOP OF PLUGBACK IN OPEN HOLE BELOW TAIL PIPE. 
SITE RECONNAISSANCE FORM

\begin{tabular}{|l|c|}
\hline CLIENT & DOE / SRPO \\
\hline $\begin{array}{l}\text { STATE } \\
\text { LOUISIANA }\end{array}$ & $\begin{array}{c}\text { WELL NAME \& NUMBER } \\
\text { G.P. THEUS V-6 }\end{array}$ \\
\hline
\end{tabular}

DESCRIPTION OF SITE ACCESS

ACCESS IS ON E. SIDE OF PARISH RD 497 AT PARISH LINE. ACCESS IS A 260 FT SANDY DRIVEWAY ON LEFT OF RESIDENCE. ACCESS TO WELLHEAD IS ACROSS FLAT GRASSY AREA.

DESCRIPTION OF SITE PAD AREA

PAD AREA IS FLAT GRASSY AREA IN BACKYARD OF RESIDENCE, 3'X3' CEMENT PAD AROUND WELLHEAD.

DESCRIPTION OF WELL HEAD

5.5 IN. STEEL CASING STICKING UP 7 IN. WITH 10.0 IN. FLANGE AND COVER WELDED TO TOP. A 1.25 IN. PIPE WITH THREADED PLUG EXTENDS THROUGH COVER PLATE.

DESCRIPTION OF PITS

NA

DEPTH AND BOREHOLE - FLUID SURVEY: $07 / 19 / 88$

GROUND ELEVATION 219.29 FT (DATUM)

REPORTED DEPTH $618.0 *$ FT (SEE BOREHOLE COMPLETION SKETCH)

MEASURED DEPTH 608.0 FT OBSTRUCTION NONE

FLUID DEPTH 20.5 FT CHLORIDE CONTENT $>4900$

CONDUCTMTY $23.43-\mathrm{mS} / \mathrm{cm} \quad$ TDS $11.715-\mathrm{mg} / \mathrm{L}$

TEMPERATURE 39.5

REMARKS

* ACTUAL DEPTH OF TAILPIPE IS UNKNOWN. MAXIMUM REPORTED DEPTH IS 618 FT.

*NOTE: SNL $=$ South of North Line WSL $=$ North of South Line 
SITE RECONNAISSANCE FORM

\begin{tabular}{|l|l}
\hline CLIENT & DOE / SRPO \\
\hline STATE & WELL NAME \& NUMBER \\
LOUISIANA & E.H.S. CONNELL V-7
\end{tabular}

LOCATION

1498.51 FT SNL \& 1047.86 FT WEL* IN

SEC 17, TITN, RBU - - MEBSTER PARISH

J.O. No.

17500.26

DATE

$06 / 28 / 88$

TFSC FIELD REPRESENTATIVE

J.Q. KANTOLA

\section{DESCRIPTION OF SITE ACCESS}

ACCESS ROAD HEADS SW FROM INTERSECTION OF PR 165 AND PR 169, PARALLEL TO POWER-

LINE FOR .54 MI. TO A FORK IN ROAD. TAKE RIGHT FORK FOR. 25 MI. TO LEFTHAND

BEND IN ROAD. SITE IS ON INSIDE OF BEND.

DESCRIPTION OF SITE PAD AREA

PAD IS ABOUT $40 \times 30$ FT, GRASS COVERED WITH SMALL MOUND OF SOIL NEAR CENTER. NO GRAVEL ON PAD.

\section{DESCRIPTION OF WELL HEAD}

5.5 IN. STEEL PIPE PROJECTS OUT OF $3 \times 3$ FT CEMENT PAD. 6.0 IN. PIPE WITH 10.0 IN. FLANGE AND COVER PLATE ON TOP IS THREADED ONTO 5.5 IN. PIPE. TOTAL HEIGHT IS 0.9 FT.

\section{DESCRIPTION OF PITS}

$\underline{N A}$

DEPTH AND BOREHOLE - FLUID SURVEY: 09/01/88

GROUND ELEVATION 225.89 FT (DATUM)

REPORTED DEPTH $806 *$ FT (SEE BOREHOLE COMPLETION SKETCH)

MEASURED DEPTH 124.1 FT OBSTRUCTION 124.1 FT

FLUID DEPTH

CONDUCTMITY $472.53 \mathrm{mS} / \mathrm{cm}$ TDS $236.265 \mathrm{mg} / \mathrm{L}$

TEMPERATURE NOT TAKEN ${ }^{\circ} \mathrm{C}$

\section{REMARKS}

* THIS IS THE MAXIMUM REPORTED DEPTH OF THE TAILPIPE. ACTUAL DEPTH IS UNKNOWN DUE TO OBSTRUCTION AT 124.1 FT.

** FLUID LEVEL IS BELOW OBSTRUCTION. 
SITE RECONNAISSANCE FORM

\begin{tabular}{|l|c|}
\hline CLIENT & DOE / SRPO \\
\hline $\begin{array}{l}\text { STATE } \\
\text { LOUISIANA }\end{array}$ & $\begin{array}{c}\text { WELL NAME \& NUMBER } \\
\text { LSU R1-A }\end{array}$ \\
\hline
\end{tabular}

LOCATION

307.39' EWL OF EAST 1/2 SE1/4, 1010.261 NSL* IN J.O. No. SEC 31. T17N, R8W -- BIENVILLE PARISH 17500.26 DATE $08 / 13 / 88$

TFSC FIELD REPRESENTATIVE

R.T. DECONTO

\section{DESCRIPTION OF SITE ACCESS}

ACCESS IS OFF RT $40.45 \mathrm{MI}$. WEST OF THE INTERSECT/RT 4 \& RT 155. ACCESS HEADS SW OFF RT 4 NEAR 3 CLOSELY SPACED UTILITTY POLES ROAD IS OVER GROWN WITH GRASS SMALL TREES AND ENDS AT WELL HEAD IN CLEARING OF WOODS ABOUT 180 FT FROM RT 4. DESCRIPTION OF SITE PAD AREA

PAD IS CIRCULAR CLEARING AT END OF ROAD OVERGROWN WITH SMALL TREES. THERE IS A 12 FT DIA. 3 FT DEEP DRY PIT ABOUT 15 FT FROM WELLHEAD.

DESCRIPTION OF WELL HEAD

WELLHEAD IS A 4.0 IN. PIPE STICKING UP OUT OF A $3 \times 3$ FT CEMENT PAD 1.5 FT PIPE IS CAPPED WITH A LOCKED. THREADED PLUG.

\section{DESCRIPTION OF PITS}

NA

DEPTH AND BOREHOLE - FLUID SURVEY: $08 / 21 / 88$

GROUND ELEVATION 227.64 FT (DATUM)

REPORTED DEPTH $488 *$ FT (SEE BOREHOLE COMPLETION SKETCH)

MEASURED DEPTH 483.0 FT OBSTRUCTION NONE FT

FLUID DEPTH $\quad 63.0 \quad$ FT CHLORIDE CONTENT $<50 \quad$ PPm Cl-

CONDUCTMTY $0.32 \quad \mathrm{mS} / \mathrm{cm}$ TDS $160 \mathrm{mg} / \mathrm{L}$

TEMPERATURE $37.7{ }^{\circ} \mathrm{C}$

REMARKS

* BASE OF SCREEN

WELL OBSTRUCTED AT VARIOUS DEPTHS BETWEEN 80 AND 444 FT (MOSTLY AGGREGATES). OBSTRUCTIONS CLEARED BY WIRELINE BAILER. 


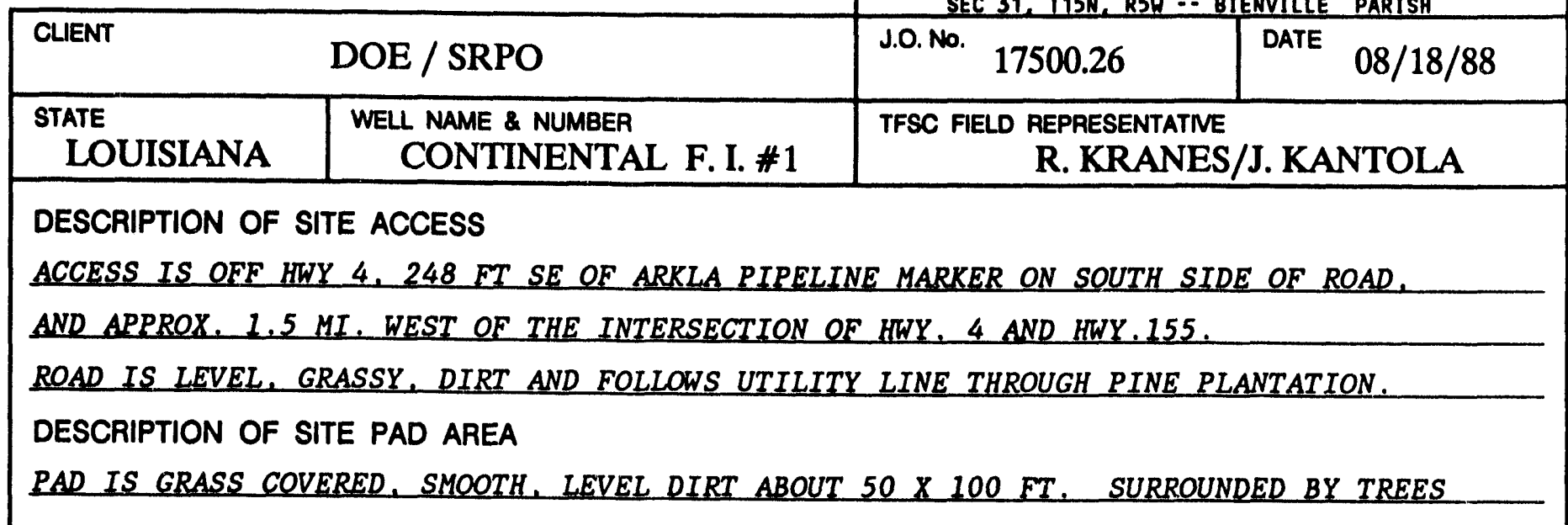

\section{DESCRIPTION OF WELL HEAD}

WELLHEAD STICKS UP FROM 2 FT DEEP WOODEN CELLAR. $95 / 8$ CASING IS CAPPED WITH TWO VALVE PRESSURE HEAD, EXTENDS 3.3 FT ABOVE G.L.

\section{DESCRIPTION OF PITS}

NA

DEPTH AND BOREHOLE - FLUID SURVEY: 08/21/88

GROUND ELEVATION $214.6 *$ FT (DATUM)

REPORTED DEPTH $424 * \star \quad$ FT (SEE BOREHOLE COMPLETION SKETCH)

MEASURED DEPTH $>500 \quad$ FT OBSTRUCTION NONE FT

FLUID DEPTH SURF, FT CHLORIDE CONTENT $>3600$ Ppm Cl.

CONDUCTMTY $523.72 \mathrm{mS} / \mathrm{cm} \quad$ TDS $261.860 \mathrm{mg} / \mathrm{L}$

TEMPERATURE 28.5

\section{REMARKS}

** BASE OF 9 5/8 CASING IS AT 424 FT. OPEN HOLE EXTENDS TO 5013 FT.

* TOP OF BRADEN HEAD FLANGE.

WELL UNDER SLIGHT PRESSURE, FLOWED DIESEL OIL WHEN VALVE REMOVED. 
SITE RECONNAISSANCE FORM

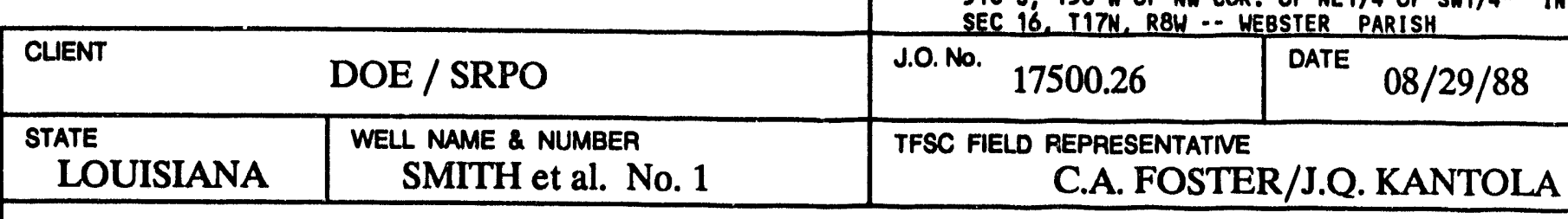

DESCRIPTION OF SITE ACCESS

ACCESS ROAD HEADS SW FROM INTERSECTION OF PR 165 AND PR 169 FOR ABOUT 54 MI. TO

A FORK. TAKE LEFT FORK FOR 2 MI. THEN TAKE RIGHT FORK FOR I MI. TO PAD AREA.

DESCRIPTION OF SITE PAD AREA

LARGE, LEVEL GRAVEL PAD (-1 ACRE) WITH WELLHEAD IN CENTER.

DESCRIPTION OF WELL HEAD

WELL HEAD IS $24 \times 36$ IN. SPOOL FLANGED TO SURFACE CASING WITH TWO 5000\# BRAYDEN

HEAD VALVES: ONE EXTENDING FROM SIDE OF SPOOL, ONE ATTACHED BY 2-3/4 IN. DIAM.

NIPPLE TO A COMPANION FLANGE BOLTED TO THE TOP OF THE SPOOL. WELLHEAD STICKS UP

FROM 4 FT. DEEP WOODEN CELLAR. TOP OF UPPER FLANGE IS AT GROUND LEVEL.

DESCRIPTION OF PITS

NA

DEPTH AND BOREHOLE - FLUID SURVEY: 09/04/88

GROUND ELEVATION 227.7 FT (DATUM)

REPORTED DEPTH $972.0 * \quad$ FT (SEE BOREHOLE COMPLETION SKETCH)

MEASURED DEPTH 1075 FT OBSTRUCTION NONE FT

FLUID DEPTH SURF. FT CHLORIDE CONTENT $>24900$ pPm CI-

CONDUCTIMTY $520.53 \mathrm{~ms} / \mathrm{cm}$ TDS $260.270 \mathrm{mg} / \mathrm{L}$

TEMPERATURE $24.0 \quad{ }^{\circ} \mathrm{C}$

REMARKS

* BOTTOM OF 9 5/8 CASING, OPEN HOLE TO 5043 FT.

WELLHEAD STICKS UP OUT OF LARGE WOODEN CELLAR WITH DRY GRAVEL BOTTOM. 
SITE RECONNAISSANCE FORM

\begin{tabular}{|l|l|}
\hline CLIENT & DOE / SRPO \\
\hline $\begin{array}{c}\text { STATE } \\
\text { LOUISIANA }\end{array}$ & $\begin{array}{c}\text { WELL NAME \& NUMBER } \\
\text { TILTMETER T-1 }\end{array}$ \\
\hline
\end{tabular}

LOCATION

1215.17 FT NSL \& 103.82 FT EHL* IN

SEC 22. T17N, RBH -.. BIENVILLE PARISH

J.O. No.

17500.26

DATE

$06 / 27 / 88$

TFSC FIELD REPRESENTATIVE

J.M. GONZALES

\section{DESCRIPTION OF SITE ACCESS}

ACCESS ROAD IS ON EAST SIDE OF PARISH ROAD 497. ABOUT 100 FT N OF INTERSECTION

WITH PR 498. ROAD DOUBLES BACK TO SOUTH UP STEEP, SANDY SLOPE FOR 1100 FT.

SITE IS ABOUT 100 FT EAST OF ACCESS ROAD AT TOP OF HILL. ROAD IN POOR CONDITION

DESCRIPTION OF SITE PAD AREA

PAD IS ABOUT $25 \times 30$ FT SANDY, GRASS COVERED AREA WITH SOME BUSHES AND PILES OF

DIRT. SOME EROSION ON EAST SIDE OF PAD. BENCHMARK LOCATED 18 FT NE OF TILT-

METER PIT.

DESCRIPTION OF WELL HEAD

TILTMETER SETUP CONSISTS OF 3 CORRUGATED STEEL PIPES, 3 1/2 FT IN DIA. AND

5 FT LONG. PLACED VERTICALLY IN THE GROUND. TWO PIPES ARE AT GROUND LEVEL WHILE

THE THIRD STICKS UP ABOUT 2 FT. INSIDE THE PITS ARE VARIOUS DIA. PVC AND STEEL

PIPES AND AN INSTRUMENT STAND. BOTTOMS OF ALL PITS ARE SOIL. ALL PITS HAD

HINGED, LOCKED COVERS WHICH HAVE BEEN RIPPED OFF.

DESCRIPTION OF PITS

NA

DEPTH AND BOREHOLE - FLUID SURVEY: NA

GROUND ELEVATION NA FT (DATUM)

REPORTED DEPTH NA TT (SEE BOREHOLE COMPLETION SKETCH)

MEASURED DEPTH NA OBSTRUCTION NA FT FT

FLUID DEPTH NA FT

CHLORIDE CONTENT NA PPM Cl-

CONDUCTMIY NA $\mathrm{NS} / \mathrm{cm}$ TDS NA $\mathrm{mg} / \mathrm{L}$

TEMPERATURE NA ${ }^{\circ} \mathrm{C}$

REMARKS

NONE 
SITE RECONNAISSANCE FORM

\begin{tabular}{|l|l|l|}
\hline CLIENT & DOE / SRPO \\
\hline $\begin{array}{c}\text { STATE } \\
\text { LOUISIANA }\end{array}$ & $\begin{array}{c}\text { WELL NAME \& NUMBER } \\
\text { GEOTECH. BORING TB-1 }\end{array}$ & TSO \\
\hline
\end{tabular}

DESCRIPTION OF SITE ACCESS

ACCESS ROAD IS ON EAST SIDE OF PARISH ROAD 497. ABOUT 100 FT $N$ OF INTERSECTION

WITH PR 498. ROAD DOUBLES BACK TO SOUTH UP STEEP. SANDY SLOPE FOR 21100 FT,

SITE IS ABOUT 100 FT EAST OF ACCESS ROAD AT TOP OF HILL. ROAD IN POOR CONDITION

DESCRIPTION OF SITE PAD AREA

TB-1 IS REPORTED TO BE LOCATED RELATIVE TO TILTMETER T-1 AT 122.5 FTON A BEARING

OF N63W. A SOFT DEPRESSION IN GROUND WAS LOCATED 135 FT FROM T-1 ON

THIS BEARING.

DESCRIPTION OF WELL HEAD

NA

DESCRIPTION OF PITS

NA

DEPTH AND BOREHOLE - FLUID SURVEY: NA

GROUND ELEVATION NA FT (DATUM)

REPORTED DEPTH NA N T (SEE BOREHOLE COMPLETION SKETCH)

MEASURED DEPTH NA FT OBSTRUCTION NA FT

FLUID DEPTH NA TH CHLORIDE CONTENT NA NPM Cl-

CONDUCTMTY NA $\mathrm{NS} / \mathrm{cm}$ TDS NA $\mathrm{mg} / \mathrm{L}$

TEMPERATURE NA ${ }^{\circ} \mathrm{C}$

REMARKS

THE APPROXIMATE LOCATION WAS PROBED WITH A STEEL ROD. NOTHING WAS FOUND OTHER

THAN AN AREA OF SOFT SOIL IN A DEPRESSION.

*NOTE: SNL = South of North Line

NSL $=$ North of South Line

EWL = East of West Line

WEL $=$ West of East Line

$P R=$ Parish Road 
SITE RECONNAISSANCE FORM

\begin{tabular}{|c|c|c|c|}
\hline & \multirow[b]{2}{*}{ DOE / SRPO } & \multicolumn{2}{|c|}{ SEC 20, UIM, REH “ BIEHVILLE PARISH } \\
\hline CLENT & & J.O. No. 17500.26 & DATE $06 / 28 / 88$ \\
\hline $\begin{array}{l}\text { STATE } \\
\text { LOUISIANA }\end{array}$ & $\begin{array}{l}\text { WELL NAME \& NUMBER } \\
\text { TILTMETER T-2 }\end{array}$ & $\begin{array}{l}\text { TFSC FIELD REPRES } \\
\text { J.L. } \mathrm{Y}\end{array}$ & EPAIN \\
\hline
\end{tabular}

\section{DESCRIPTION OF SITE ACCESS}

ACCESS ROAD ON N SIDE OF PARISH ROAD 494. ABOUT 1.3 MI. EROM INTERSECTION WITH PR 173. ACCESS IS GENERALLY LEVEL AND SANDY. AT 0.8 MI. FROM PR 494 GO LEFT ON POOR CONDITION ROAD. AT $0.3 \mathrm{MI}$. GO RIGHT FOR 400 ET TO SITE AT TOP OF HILL. DESCRIPTION OF SITE PAD AREA

SITE IS LEVEL, SANDY, WITH GRASS, BENCHMARK LOCATED 45 FT N OF TILTMETER PIT.

DESCRIPTION OF WELL HEAD

TILTMETER PITS CONSIST OF $2,31 / 2$ FT DIA. CORRUGATED PIPES 5 FT LONG PLACED VERTICALLY IN THE GROUND. STICKING UP 0.5 FT. PIPES ARE 7 FT APART WITH HINGED LOCKING COVERS. INSIDE THE PITS ARE VARIOUS DIA. PVC \& METAL PIPES PROTRUDING FROM THE BOTTOM AND SIDES OF THE LARGER CORRUGATED PIPES. BOTTOM OF PIT IS SOIL.

DESCRIPTION OF PITS

$\underline{N A}$

DEPTH AND BOREHOLE - FLUID SURVEY: NA

GROUND ELEVATION NA FT (DATUM)

REPORTED DEPTH NA F T (SEE BOREHOLE COMPLETION SKETCH)

MEASURED DEPTH NA OBSTRUCTION NA FT

FLUID DEPTH NA FT CHLORIDE CONTENT NA PPM C.

CONDUCTMTY NA $\mathrm{NA} / \mathrm{cm}$ TDS NA $\mathrm{mg} / \mathrm{L}$

TEMPERATURE NA

REMARKS

NONE 
SITE RECONNAISSANCE FORM

\begin{tabular}{|c|c|c|c|}
\hline CLIENT & DOE / SRPO & J.O. No. 17500.26 & $\begin{array}{ll}\text { DATE } & 06 / 27 / 88\end{array}$ \\
\hline $\begin{array}{l}\text { STATE } \\
\text { LOUISIANA }\end{array}$ & $\begin{array}{l}\text { WELL NAME \& NUMBER } \\
\text { TILTMETER T-3 }\end{array}$ & \multicolumn{2}{|c|}{$\begin{array}{l}\text { TFSC FIELD REPRESENTATIE } \\
\text { J.Q. KANTOLA }\end{array}$} \\
\hline \multicolumn{4}{|c|}{$\begin{array}{l}\text { DESCRIPTION OF SITE ACCESS } \\
\text { ACCESS ROAD IS ON RIGHT SIDE OF PARISH ROAD } 170 . .38 \mathrm{MI} \text {. FROM INTERSECTION WITH }\end{array}$} \\
\hline \multicolumn{4}{|c|}{ PR 171. ROAD IS NARROW AND SANDY WITH GATE AT. 15 MI. GO TO SECOND UTILITY } \\
\hline \multicolumn{4}{|c|}{ POLE PAST GATE, T-3 IS 75 FT S OF POLE ON TOP OF GRASSY KNOLL. } \\
\hline \multicolumn{4}{|c|}{ DESCRIPTION OF SITE PAD AREA } \\
\hline
\end{tabular}

\section{DESCRIPTION OF WELL HEAD}

TILTMETER PITS CONSIST OF $2.31 / 2$ FT DIA. CORRUGATED PIPES PLACED VERTICALLY IN THE GROUND. THE PIPES STICK UP LESS THAN 1 FT AND HAVE LOCKED, HINGED COVERS FOR WHICH WE HAVE NO KEYS.

\section{DESCRIPTION OF PITS}

NA

DEPTH AND BOREHOLE - FLUID SURVEY: NA

GROUND ELEVATION NA FT (DATUM)

REPORTED DEPTH N N F (SEE BOREHOLE COMPLETION SKETCH)

MEASURED DEPTH NA OBSTRUCTION NA NT

FLUID DEPTH NA FT CHLORIDE CONTENT NA NPM Cl-

CONDUCTNITY NA TDS $\mathrm{NA} / \mathrm{cm} \mathrm{mg} / \mathrm{L}$

TEMPERATURE

REMARKS

FOR ACCESS THROUGH GATES, CONTACT LANDOWNER (P.D. HOLLEY, $318 \quad 377-4812)$. 
SITE RECONNAISSANCE FORM

\begin{tabular}{|l|l|}
\hline CLIENT & DOE / SRPO \\
\hline $\begin{array}{c}\text { STATE } \\
\text { LOUISIANA }\end{array}$ & $\begin{array}{c}\text { WELL NAME \& NUMBER } \\
\text { GEOTECH. BORING TB-3 }\end{array}$ \\
\hline
\end{tabular}

LOCATION

$784.34 \mathrm{FT}$ SNL \& 113.08 FT WEL* IN

SEC 18, T1TN, R8W - . MEBSTER PARISH

J.O. No.

17500.26

DATE

$06 / 27 / 88$

TFSC FIELD REPRESENTATIVE

J.Q. KANTOLA

\section{DESCRIPTION OF SITE ACCESS}

ACCESS ROAD IS ON RIGHT SIDE OF PARISH ROAD 170, 38 MI. FROM INTERSECTION WITH

PR 171. ROAD IS NARROW AND SANDY WITH LOCKED GATE AT. $15 \mathrm{MI}$. GO TO SECOND

UTILITY POLE PAST GATE. SITE IS 75 FT S OF POLE.

DESCRIPTION OF SITE PAD AREA

TB-3 IS REPORTED TO BE ON A BEARING OF N60.05W FROM T-3 ABOUT 204 FT. VISUAL SEARCH AND PROBING WITH ROD WAS UNSUCCESSFUL IN LOCATING THE FORMER LOCATION OF THE BOREHOLE. SHALLOW DEPRESSION NEAR THE LOCATION WAS STAKED AND PHOTOGRAPHED. DESCRIPTION OF WELL HEAD

DESCRIPTION OF PITS

NA

DEPTH AND BOREHOLE - FLUID SURVEY: NA

GROUND ELEVATION NA FT (DATUM)

REPORTED DEPTH NA — FT (SEE BOREHOLE COMPLETION SKETCH)

MEASURED DEPTH NA FT OBSTRUCTION NA FT

FLUID DEPTH NA TT CHLORIDE CONTENT NA PPM Cl.

CONDUCTMTY NA $\mathrm{NA} \mathrm{ms} / \mathrm{cm} \quad$ TDS NA $\mathrm{mg} / \mathrm{L}$

TEMPERATURE NA ${ }^{\circ} \mathrm{C}$

REMARKS

NONE 
SITE RECONNAISSANCE FORM

\begin{tabular}{|l|l|}
\hline CLIENT & DOE / SRPO \\
\hline $\begin{array}{l}\text { STATE } \\
\text { LOUISIANA }\end{array}$ & $\begin{array}{l}\text { WELL NAME \& NUMBER } \\
\text { TILTMETER T-4 }\end{array}$ \\
\hline
\end{tabular}

LOCATION

1182.03 FT NSL \& 299.74 FT EWL * IN SEC 15, T17N, R8H - - MEBSTER PARISH J.O. No. 17500.26 DATE $06 / 27 / 88$

TFSC FIELD REPRESENTATINE

R.T. DECONTO

DESCRIPTION OF SITE ACCESS

ACCESS ROAD IS ON THE RIGHT SIDE OF PARISH ROAD $497,0.95 \mathrm{MI}$. SE FROM INTERSEC-

TION WITH PR 165. ROAD IS LEVEL BUT OVERGROWN WITH BRUSH.

DESCRIPTION OF SITE PAD AREA

TILTMETER PITS ARE LOCATED AT END OF ACCESS ROAD IN CLEARING ABOUT 18 FT IN DIA. CLEARING IS OVERGROWN WITH SMALL TREES AND BRUSH.

DESCRIPTION OF WELL HEAD

TILTMETER SETUP CONSISTS OF $2,31 / 2$ FT DIA. CORRUGATED PIPES ABOUT 5 FT LONG. PLACED VERTICALLY IN THE GROUND ABOUT 11 FT APART. PIPES STICK UP ABOUT.5 FT ABOVE GROUND AND HAVE HINGED, LOCKING COVERS, ONE OF WHICH IS RIPPED OFF. PVC PIPES OF VARIOUS DIA. PROTRUDE INTO THE PITS FROM SIDES AND BOTTOM. BOTTOM OF PITS IS SOIL.

DESCRIPTION OF PITS

NA

DEPTH AND BOREHOLE - FLUID SURVEY: NA

GROUND ELEVATION NA FT (DATUM)

REPORTED DEPTH NA_ F _ (SEE BOREHOLE COMPLETION SKETCH)

MEASURED DEPTH NA FT OBSTRUCTION NA FT

FLUID DEPTH NA FT CHLORIDE CONTENT NA N PPM CI-

CONDUCTNIT NA $\mathrm{NS} / \mathrm{cm} \mathrm{mg} / \mathrm{hA}$

TEMPERATURE

REMARKS

BENCHMARK NEAR ENTRANCE TO SITE. 
SITE RECONNAISSANCE FORM

\begin{tabular}{|c|c|c|c|}
\hline CLIENT & DOE / SRPO & J.O. No. 17500.26 & DATE $06 / 27 / 88$ \\
\hline $\begin{array}{l}\text { STATE } \\
\text { LOUISIANA }\end{array}$ & $\begin{array}{l}\text { WELL NAME \& NUMBER } \\
\text { GEOTECH. BORING TB-4 }\end{array}$ & \multicolumn{2}{|c|}{$\begin{array}{l}\text { TFSC FIELD REPRESENTATME } \\
\text { R.T. DECONTO }\end{array}$} \\
\hline \multicolumn{4}{|c|}{$\begin{array}{l}\text { DESCRIPTION OF SITE ACCESS } \\
\text { ACCESS ROAD IS ON RIGHT SIDE OF PARISH ROAD } 497 . .95 \mathrm{MI.SE} \text { OF INTERSECTION WITH }\end{array}$} \\
\hline
\end{tabular}

\section{DESCRIPTION OF SITE PAD AREA}

TB-4 IS REPORTED TO BE ON A BEARING N44W FROM T-4. ABOUT 134 FT. A HOLE ABOUT 6 IN. IN DIA. AND 4 FT DEEP WAS FOUND ON THIS BEARING 110 FT FROM T-4. THE HOLE WAS STAKED AND PHOTOGRAPHED. DESCRIPTION OF WELL HEAD

DESCRIPTION OF PITS

NA

DEPTH AND BOREHOLE - FLUID SURVEY: NA

GROUND ELEVATION NA FT (DATUM)

REPORTED DEPTH - NA FT (SEE BOREHOLE COMPLETION SKETCH)

MEASURED DEPTH NA FT OBSTRUCTION NA FT

FLUID DEPTH NA CHLORIDE CONTENT NA NA PPM C1-

CONDUCTMTY NA $\mathrm{NS} / \mathrm{cm}$ TDS NA $\mathrm{mg} / \mathrm{L}$

TEMPERATURE NA ${ }^{\circ} \mathrm{C}$

REMARKS

NONE

"NOTE: SNL = South of North Line 
SITE RECONNAISSANCE FORM

\begin{tabular}{|l|l|l|l|}
\hline CLIENT & J.0. No. 17500.26 & DATE $08 / 29 / 88$ \\
\hline $\begin{array}{c}\text { STATE } \\
\text { LOUISIANA }\end{array}$ & $\begin{array}{l}\text { WELL NAME \& NUMBER } \\
\text { TILTMETER T-5 }\end{array}$ & $\begin{array}{l}\text { TFSC FIELD REPRESENTATIE } \\
\text { C.A. FOSTER/J.Q. KANTOLA }\end{array}$ \\
\hline
\end{tabular}

\section{DESCRIPTION OF SITE ACCESS}

ACCESS IS THROUGH GATE ON LEFT SIDE OF LANDOWNER'S* ROAD (LEFT FORK OF PARISH RD 497) 0.5 MI. FROM INTERSECTION WITH PR 165.

\section{DESCRIPTION OF SITE PAD AREA}

SITE AREA IS 0.3 MI WNW OF ACCESS GATE IN SW RNER OF GRASSY FIELD/PASTURE ( 100 FT FROM N. SIDE OF PR 497).

DESCRIPTION OF WELL HEAD

TILTMETER PITS CONSIST OF TWO CORRUGATED PIPES, ABOUT 5 FT AND $31 / 2$ FT IN DIA., PLACED VERTICALLY IN THE GROUND ABOUT $101 / 2$ FT APART. LARGER ONE STICKS UP 1.0 FT. SMALLER ONE ABOUT $1.5 \mathrm{FT}$. BOTH PIPES HAVE HINGED. LOCKING COVERS. CONTENTS OF PIT UNKNOWN AS NO KEYS AVAILABLE AT THIS TIME.

\section{DESCRIPTION OF PITS}

NA

DEPTH AND BOREHOLE - FLUID SURVEY: NA

GROUND ELEVATION NA F _ F (DATUM)

REPORTED DEPTH NA N N (SEE BOREHOLE COMPLETION SKETCH)

MEASURED DEPTH NA FT OBSTRUCTION NA

FLUID DEPTH NA CHL CHIDE CONTENT NA NPM CI-

CONDUCTMTY NA TDS $\mathrm{NS} / \mathrm{cm} \mathrm{Ng} / \mathrm{L}$

TEMPERATURE NA

REMARKS

EASY ACCESS, OPEN WORK AREA.

* LANDOWNER IS I.W. ROWLAND (318) $377-5289$ 
SITE RECONNAISSANCE FORM

CLIENT

DOE / SRPO

WELL NAME \& NUMBER

STATE
LOUISIANA

GEOTECH. TB-2 \& TB-2C3

LOCATION

2278.85 FT NSL \& 4065.2 FT EWL* IN

SEC 20, IITN, REW -- BIENVILLE PARISH

J.O. No.

17500.26

DATE

TFSC FIELD REPRESENTATIVE

R. KRANES

DESCRIPTION OF SITE ACCESS

ACCESS ROAD ON N. SIDE OF PARISH ROAD 494. ABOUT 1.3 MI. FROM INTERSECTION WITH

PR 173. ACCESS IS GENERALLY LEVEL AND SANDY. AT $0.8 \mathrm{MI}$. FROM PR 494 GO LEFT ON

POOR CONDITION ROAD. AT $0.3 \mathrm{MI}$. GO RIGHT FOR 400 FT TO SITE AT TOP OF HILL.

DESCRIPTION OF SITE PAD AREA

TB-2 IS REPORTED TO BE ON A BEARING OF SO3E FROM T-2 AT 84 FT. A 2 FT DIA.

HOLE WAS LOCATED IN THIS GENERAL LOCATION. THE HOLE NARROWS TO 8 TO 10 IN. BE-

LOW SURFACE AND IS DEEPER THAN 4-FT PROBE.

DESCRIPTION OF WELL HEAD

TB-2C3 IS REPORTED TO BE ON A BEARING OF N105.8W EROM T-2 ABOUT 192.5 FT. NO INDICATION OF A BOREHOLE WAS FOUND IN THE GENERAL VICINITY.

DESCRIPTION OF PITS

NA

DEPTH AND BOREHOLE - FLUID SURVEY: NA

GROUND ELEVATION NA FT (DATUM)

REPORTED DEPTH NA N _ F (SEE BOREHOLE COMPLETION SKETCH)

MEASURED DEPTH NA FT OBSTRUCTION NA FT

FLUID DEPTH NA FT CHLORIDE CONTENT NA NPM CI-

CONDUCTMTY NA $\mathrm{NS} / \mathrm{cm} \mathrm{mg} / \mathrm{L}$

TEMPERATURE NA

REMARKS

NONE 


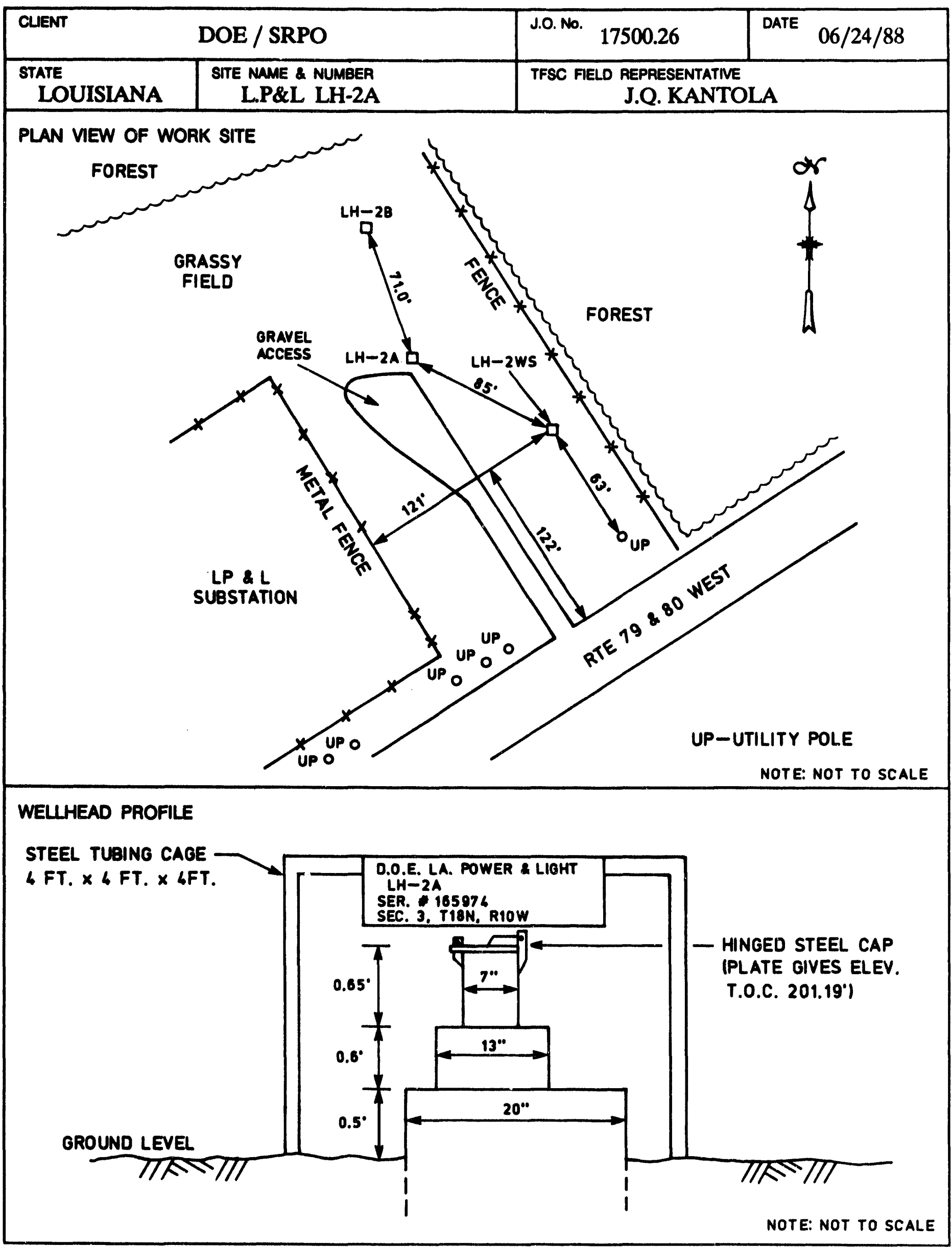




\begin{tabular}{|l|c|l|c|}
\hline CLIENT & J.0. No. 17500.26 & DATE $06 / 24 / 88$ \\
\hline $\begin{array}{c}\text { STATE } \\
\text { LOUISIANA }\end{array}$ & $\begin{array}{c}\text { SITE NAME \& NUMBER } \\
\text { L.P\&L LH-2B }\end{array}$ & \multicolumn{2}{|c|}{ TFSC FIELD REPRESENTATIVE } \\
\hline
\end{tabular}

PLAN VIEW OF WORK SITE FOREST
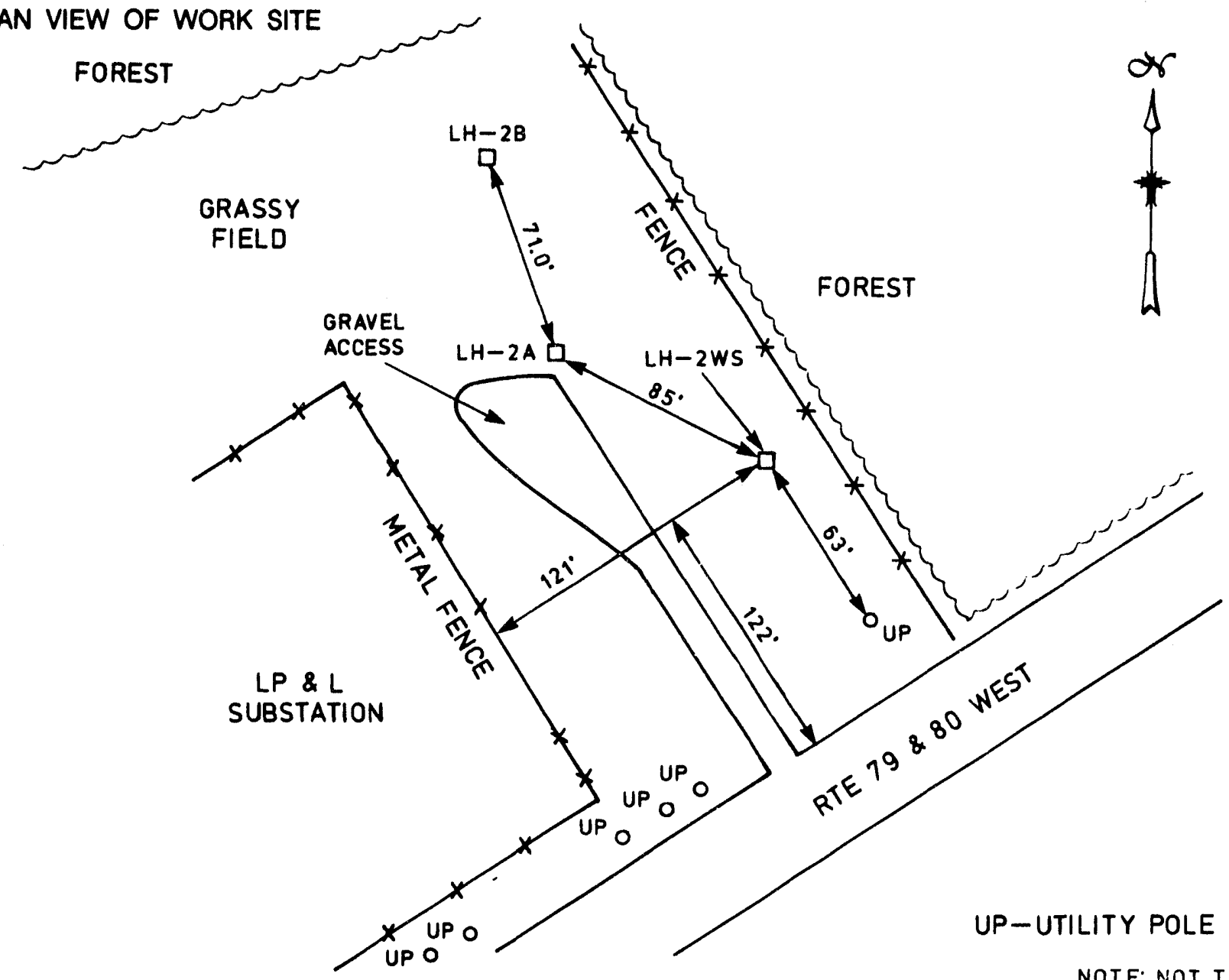

NOTE: NOT TO SCALE

\section{WELLHEAD PROFILE}

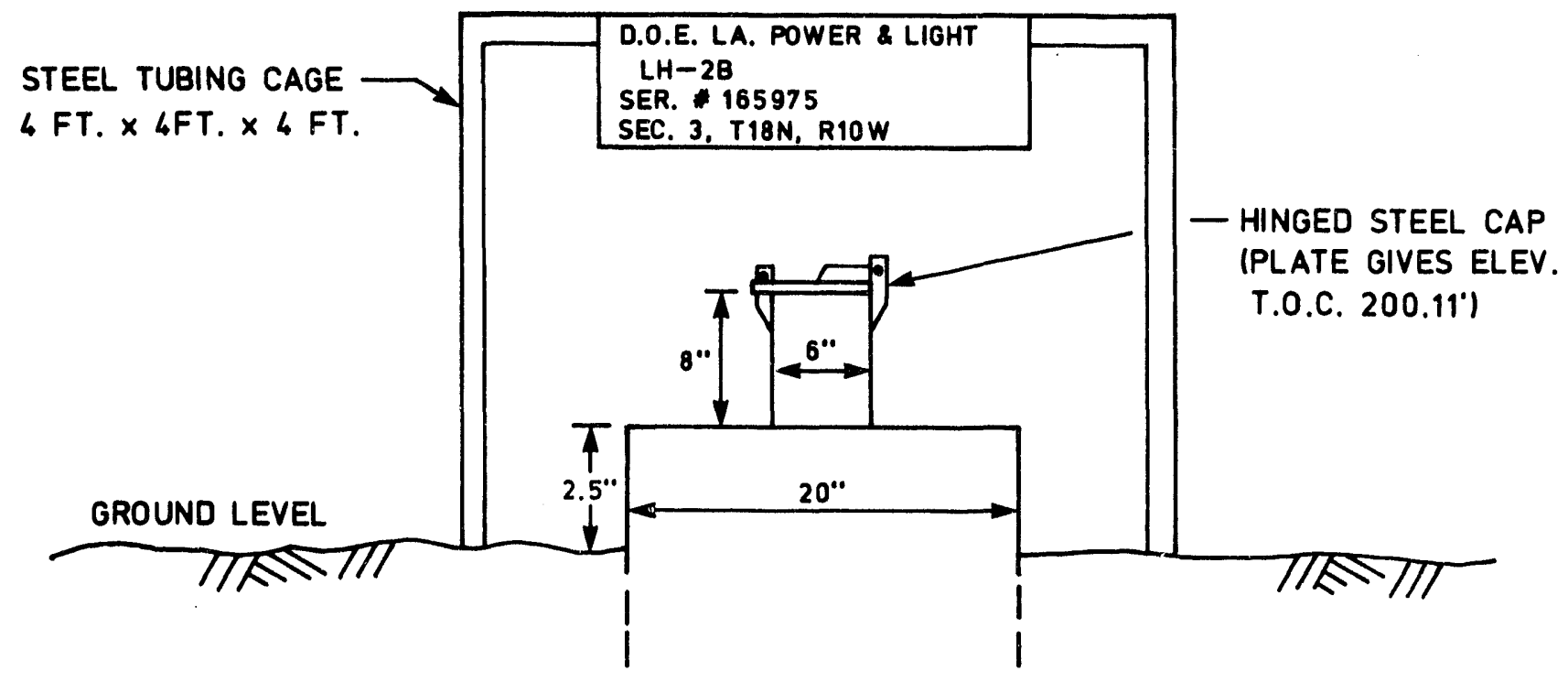




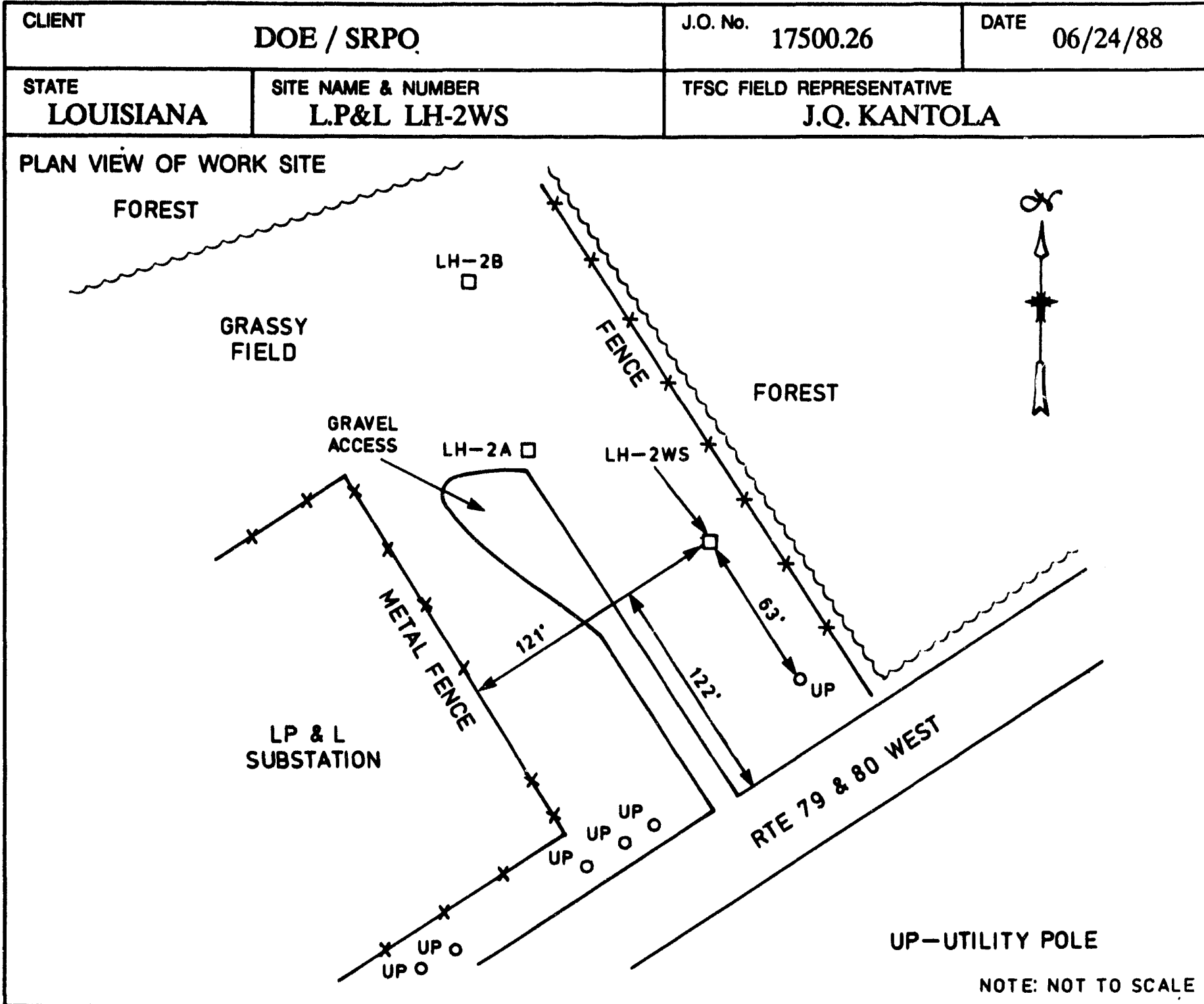

WELLLHEAD PROFILE

STEEL TUBING CAGE

4 FT. $\times 4$ FT. $\times 4$ FT.

GROUND LEVEL

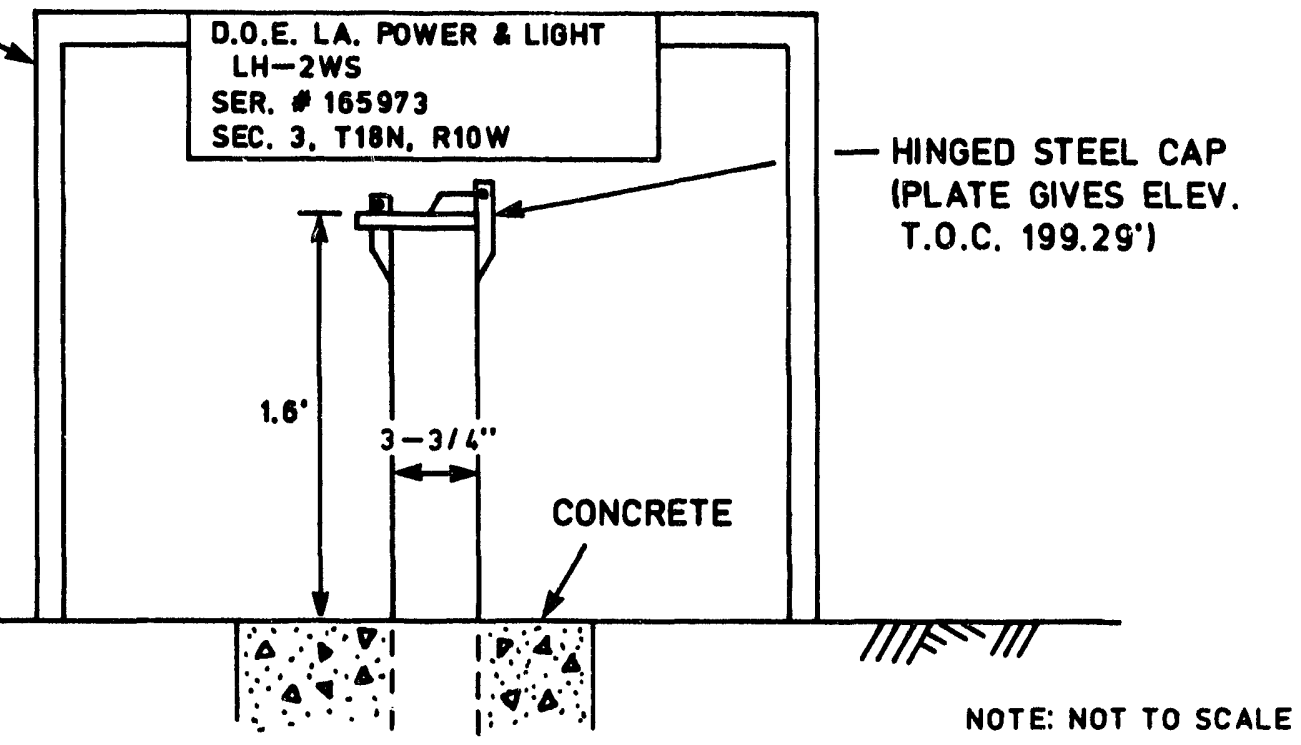




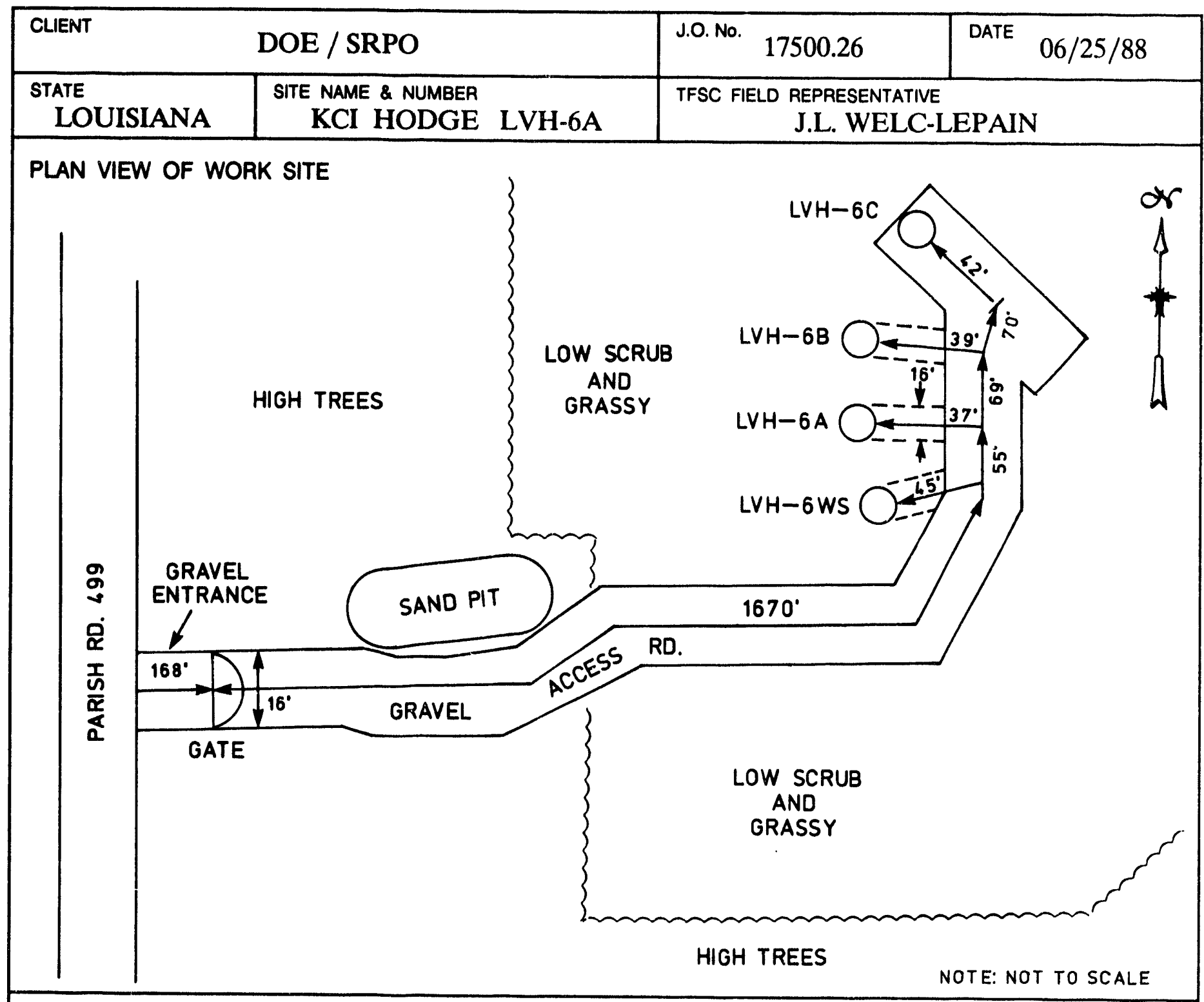

WELLHEAD PROFILE

HINGED STEEL CAP CONT. FOREST IND. LVH-6A SERIAL 168160 SEC. 35, T17N, R8W BIENVILLE PARISH, LA. (PLATE GIVES ELEV. T.0.C. $\left.224.41^{\circ}\right)$

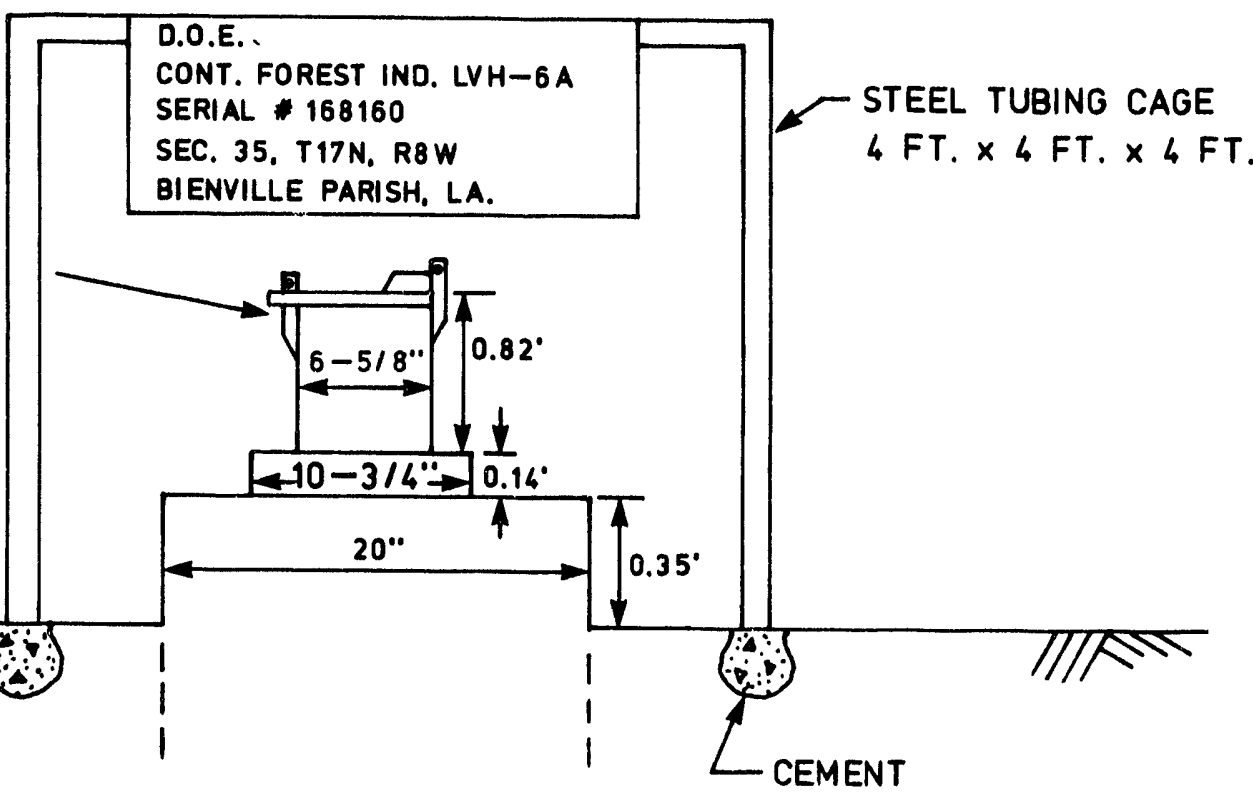




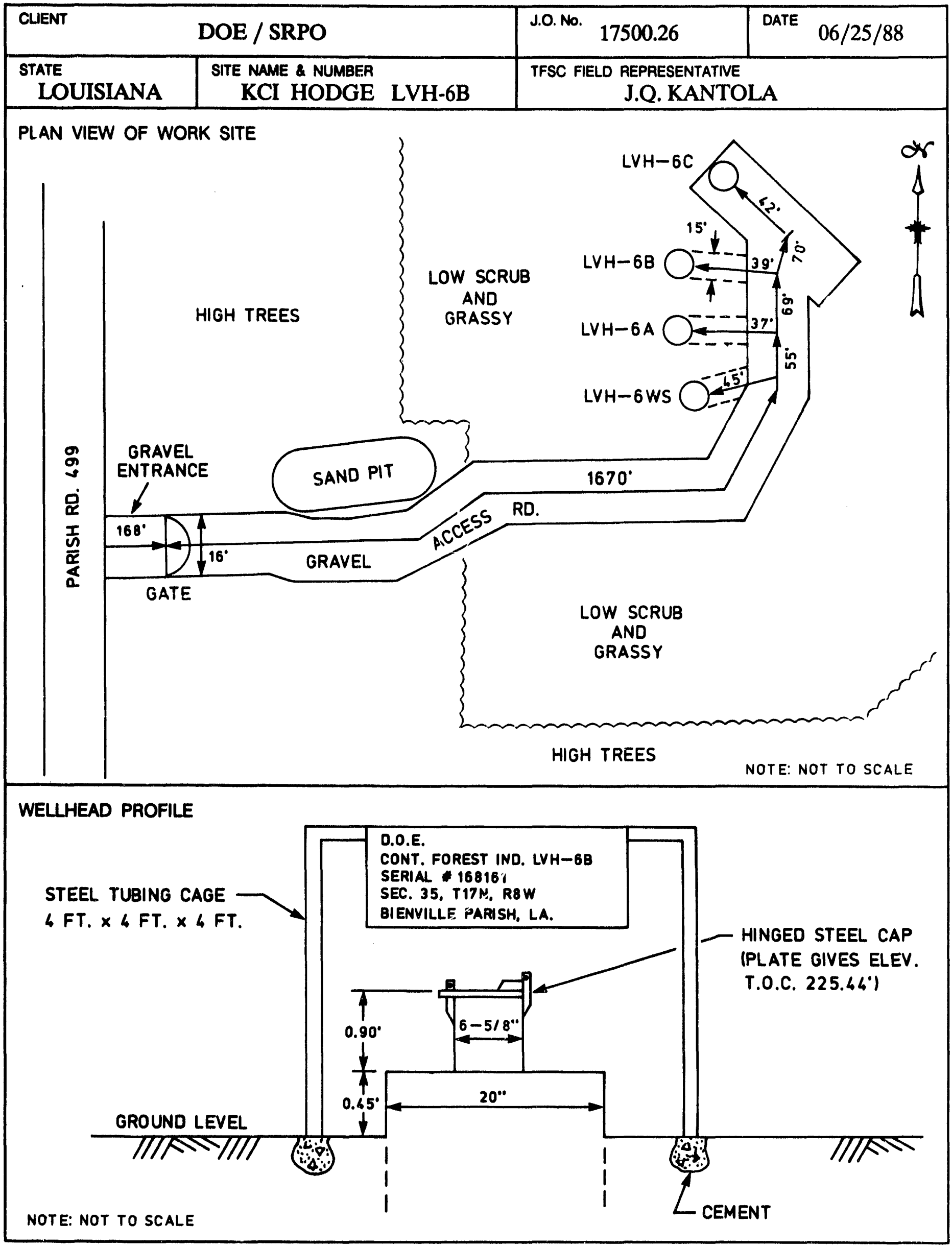




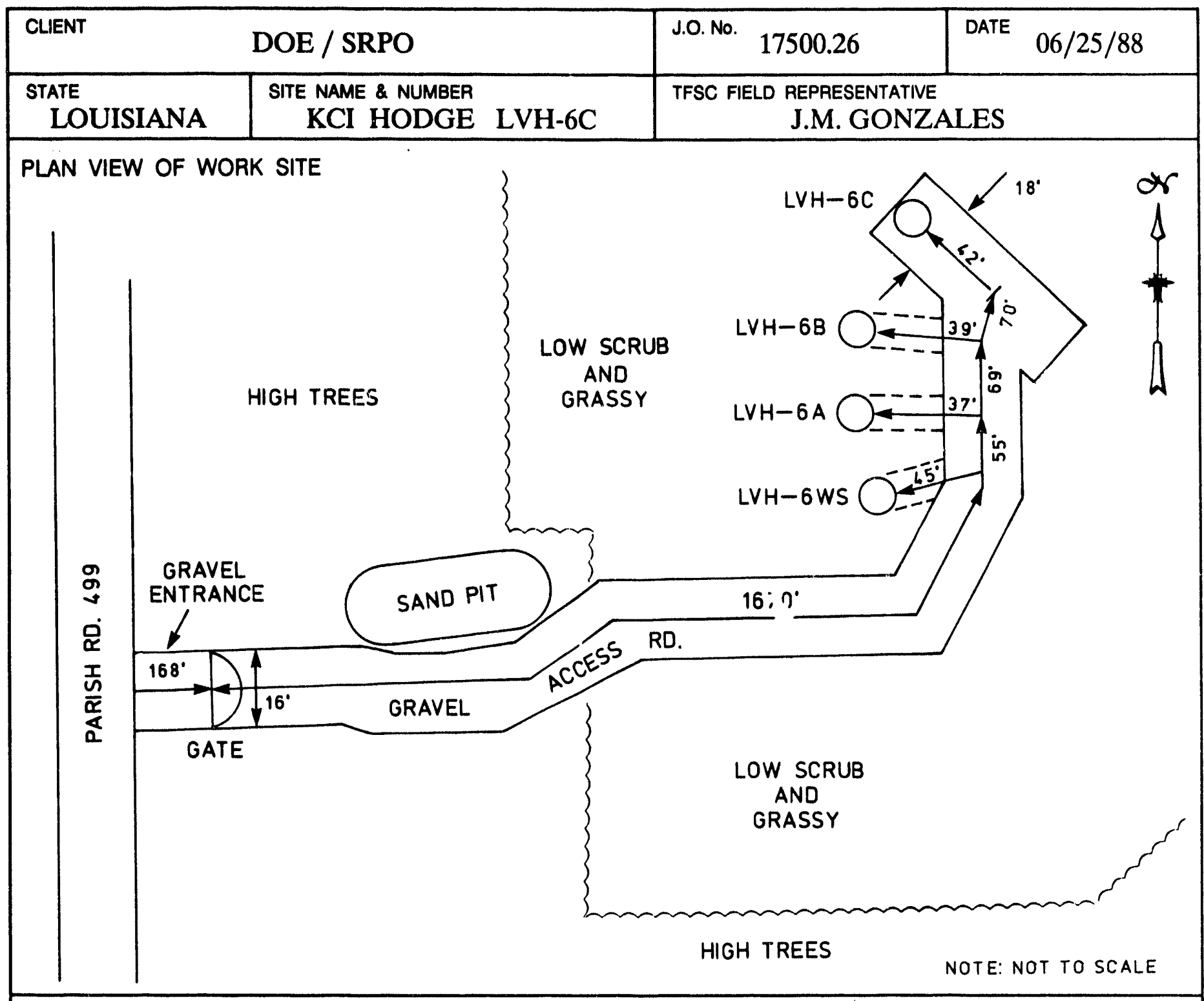

\section{WELLHEAD PROFILE}

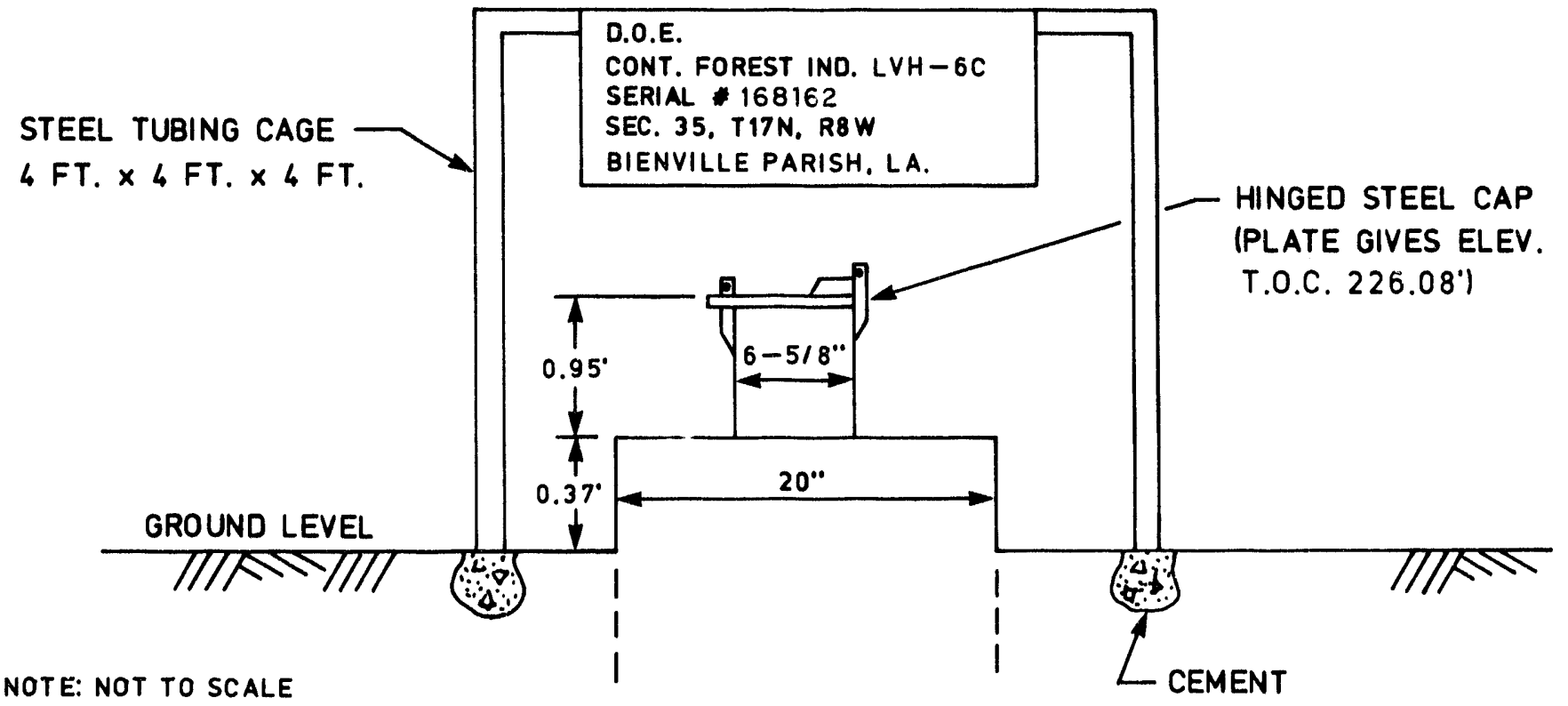




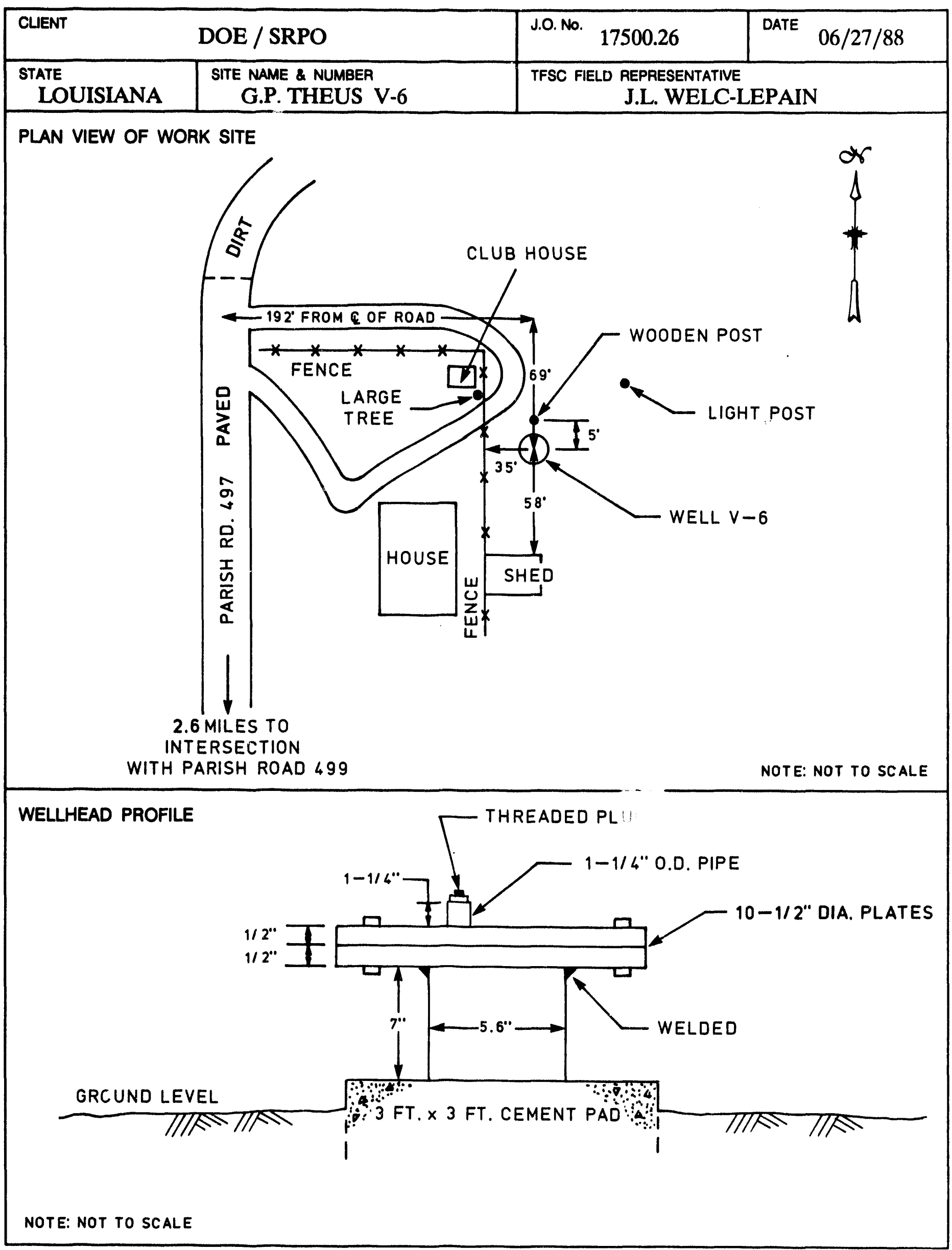




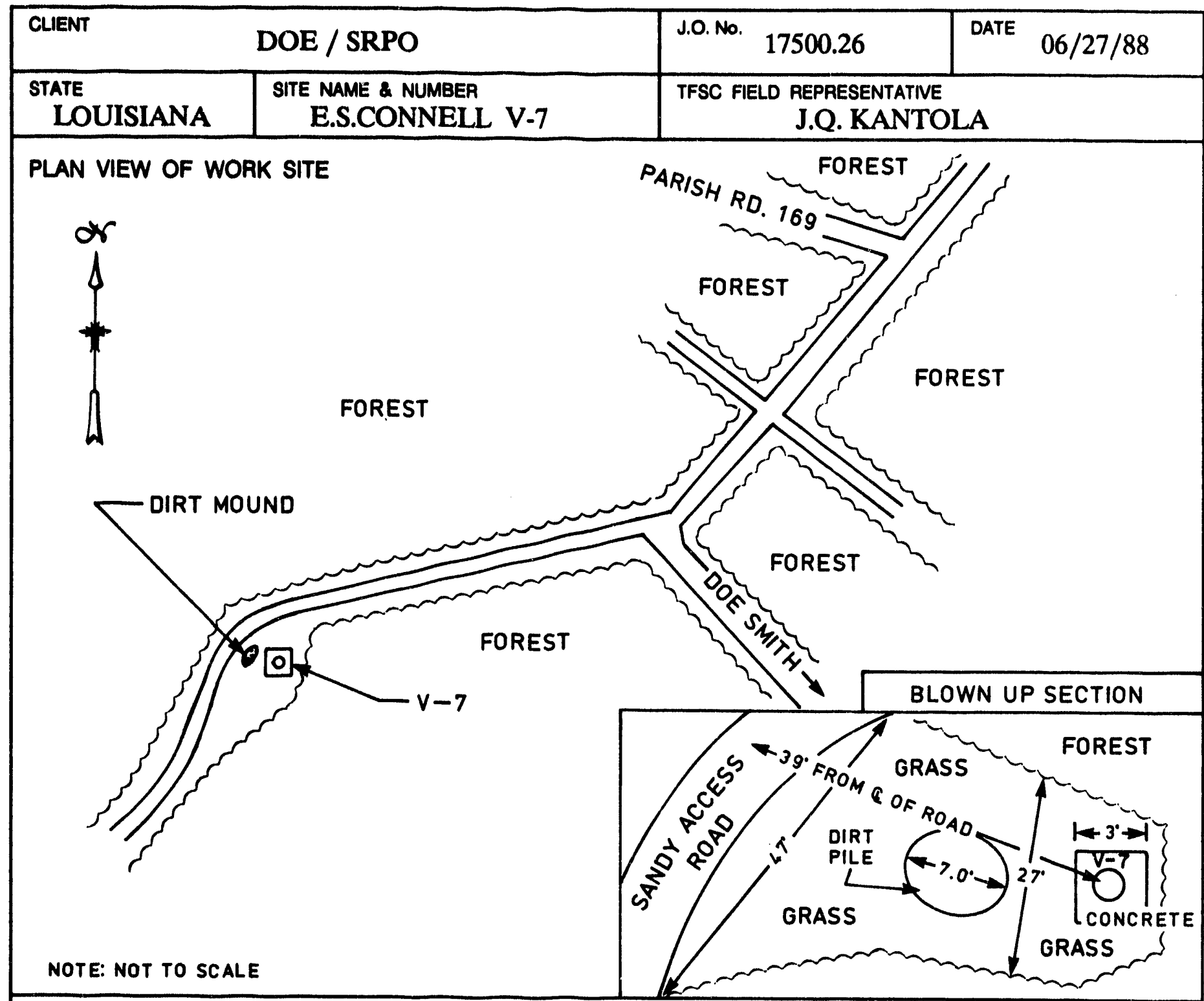

WELLHEAD PROFILE

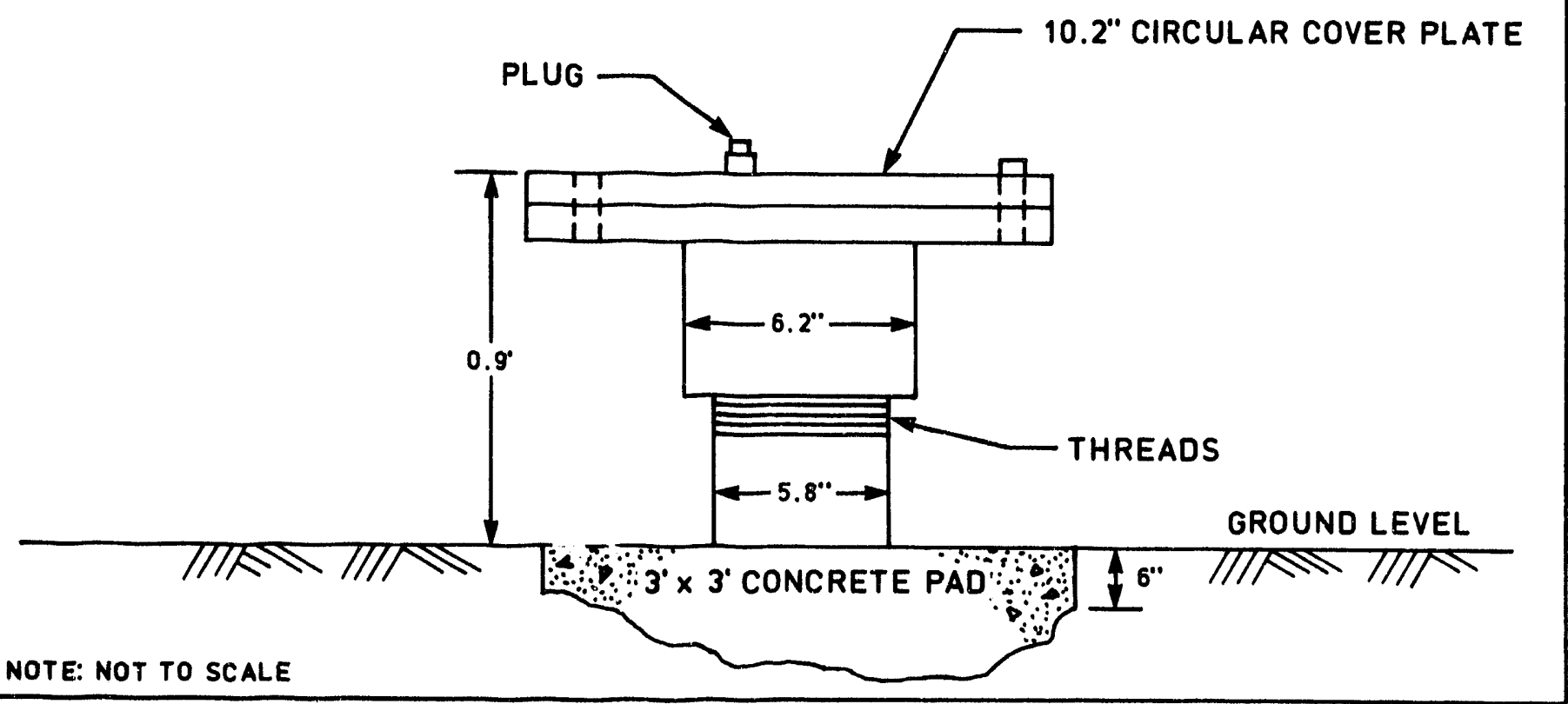




SLIENT




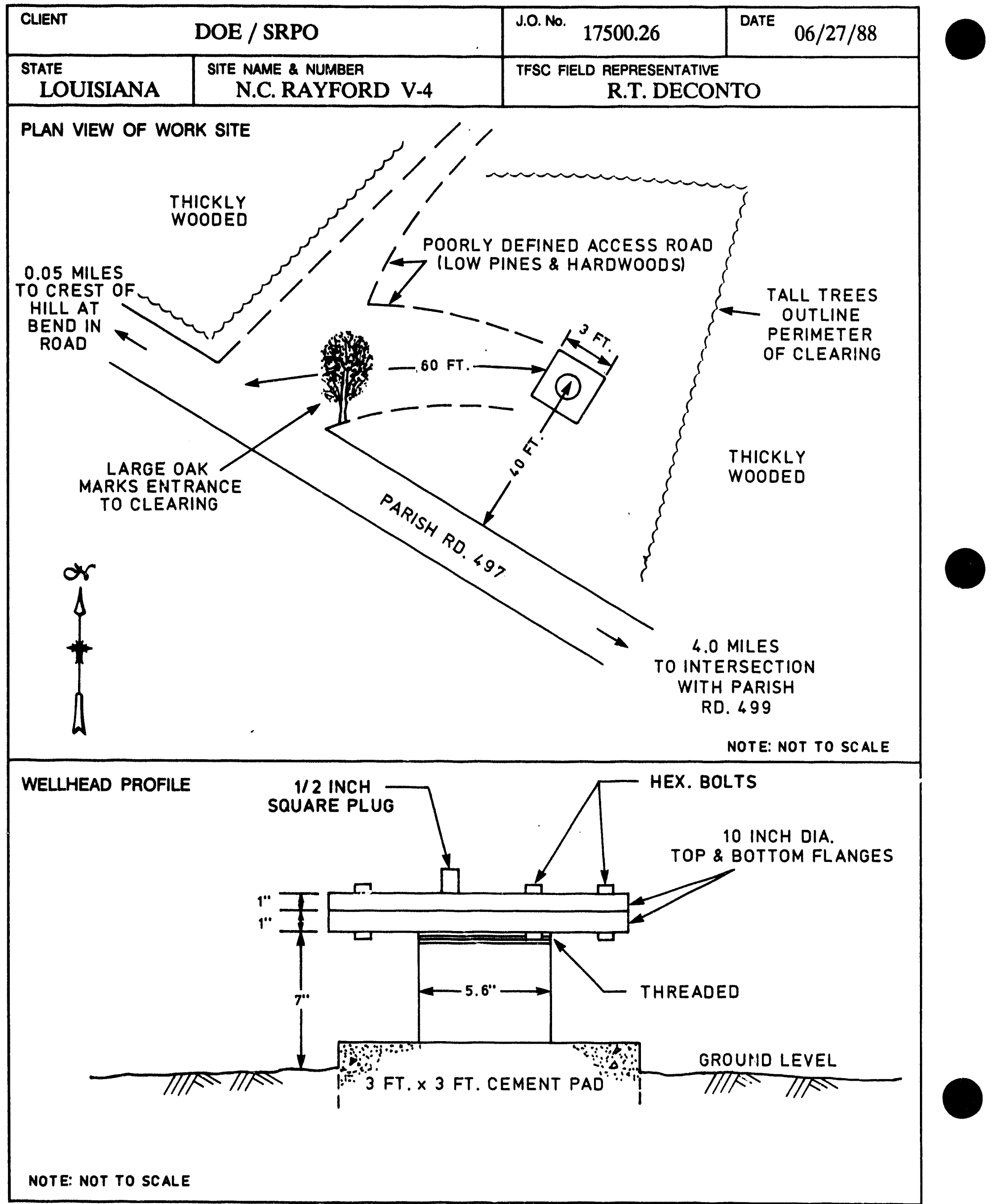




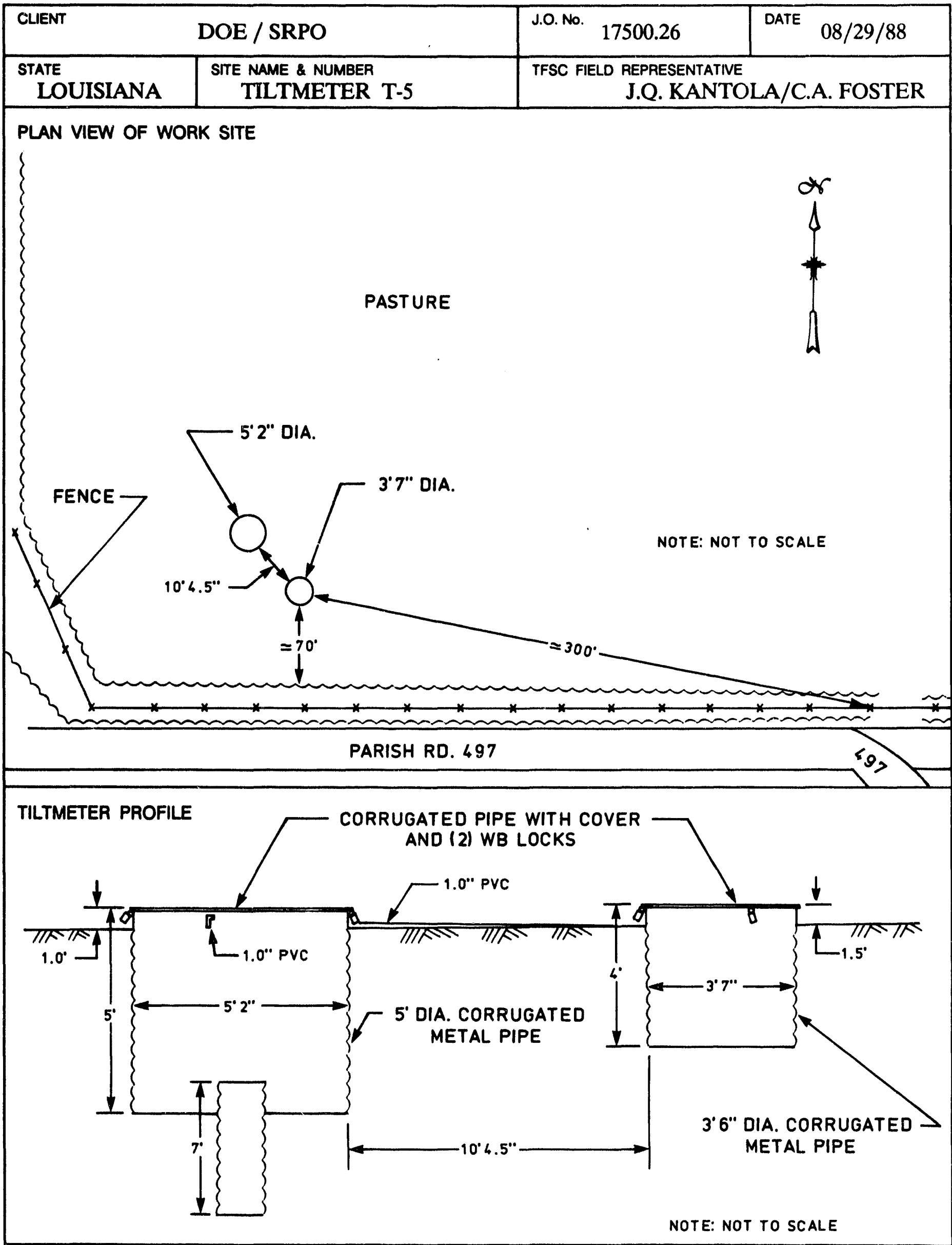




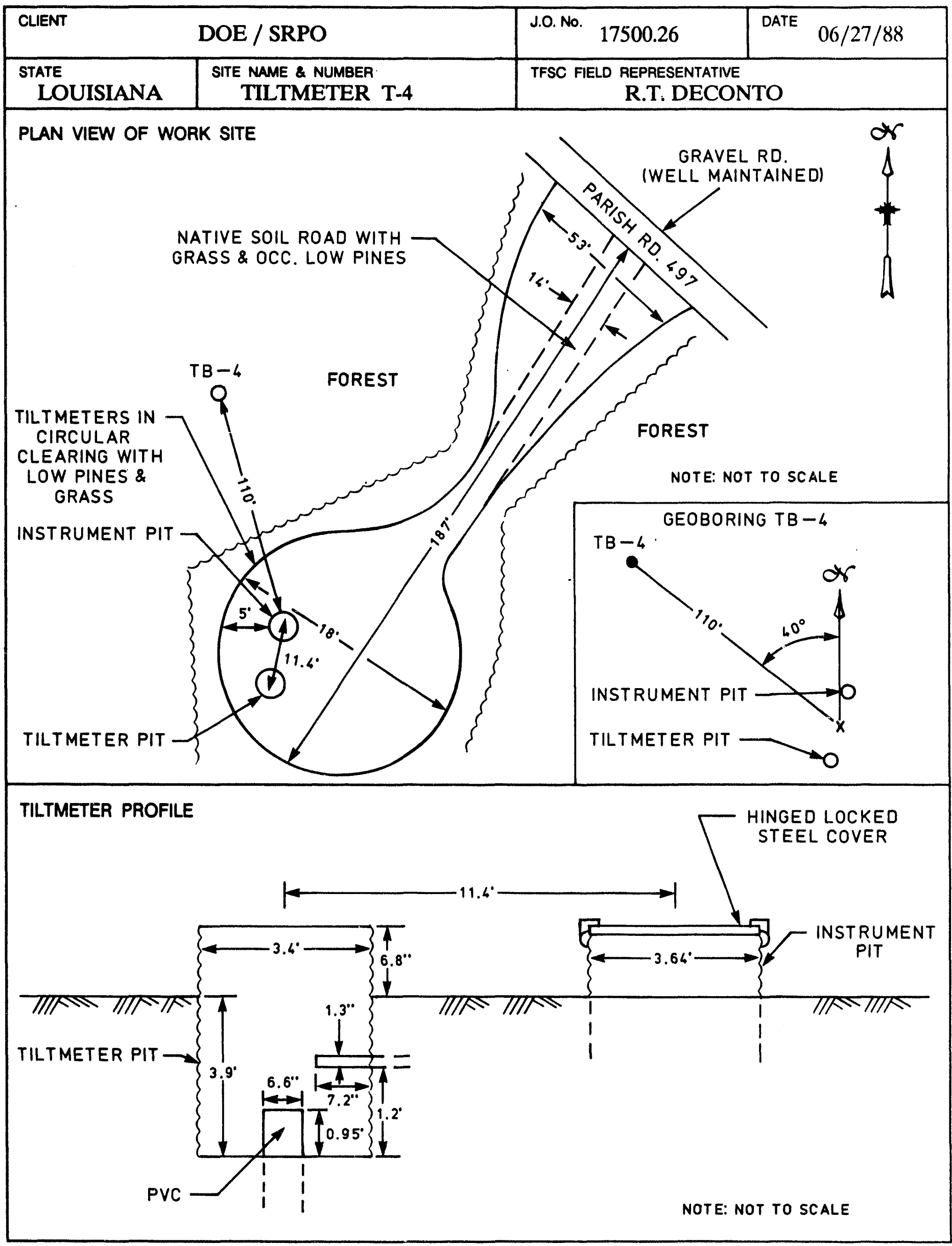




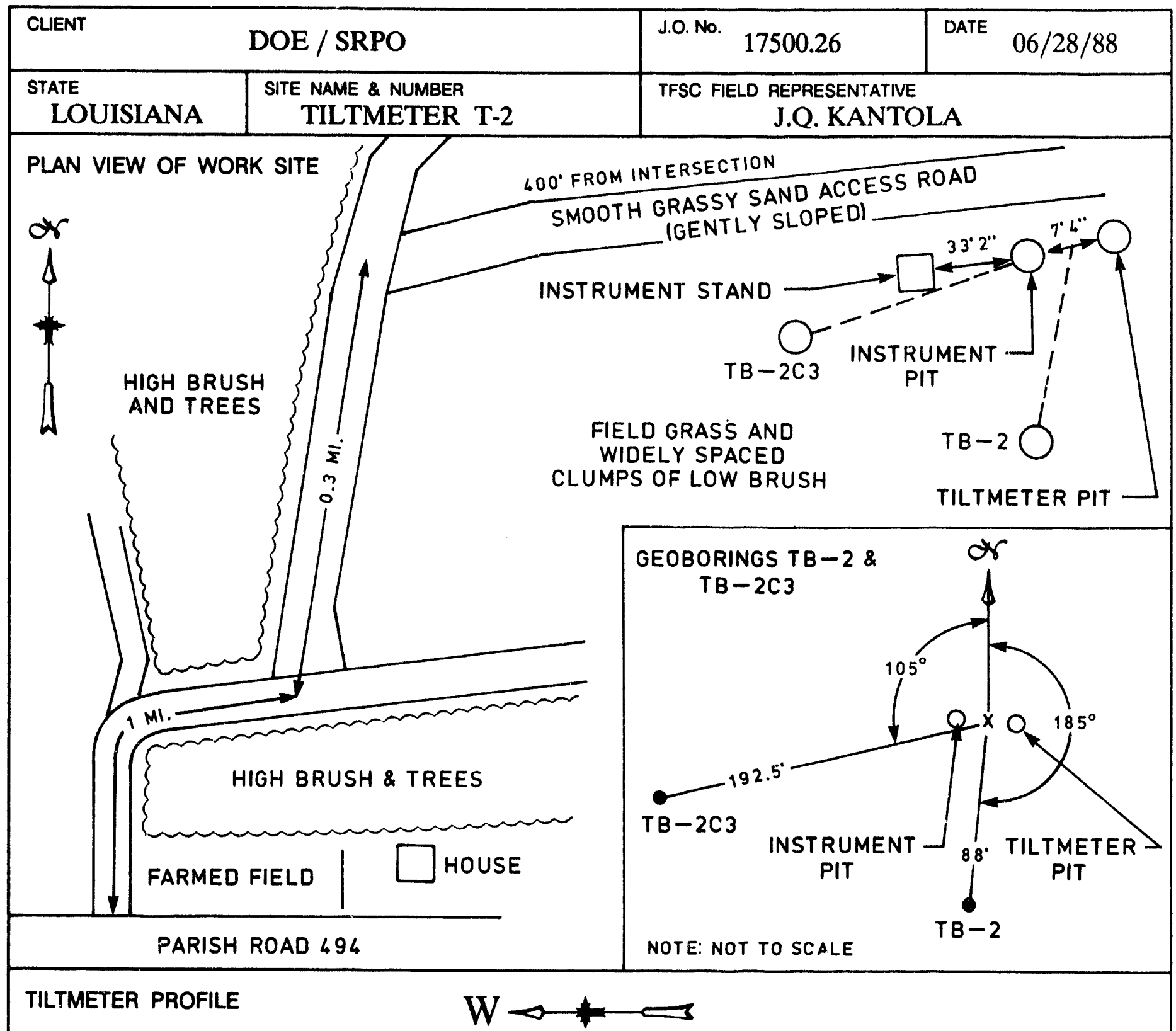

TILTMETERS WITH COVERS (BROKEN LOCKS)

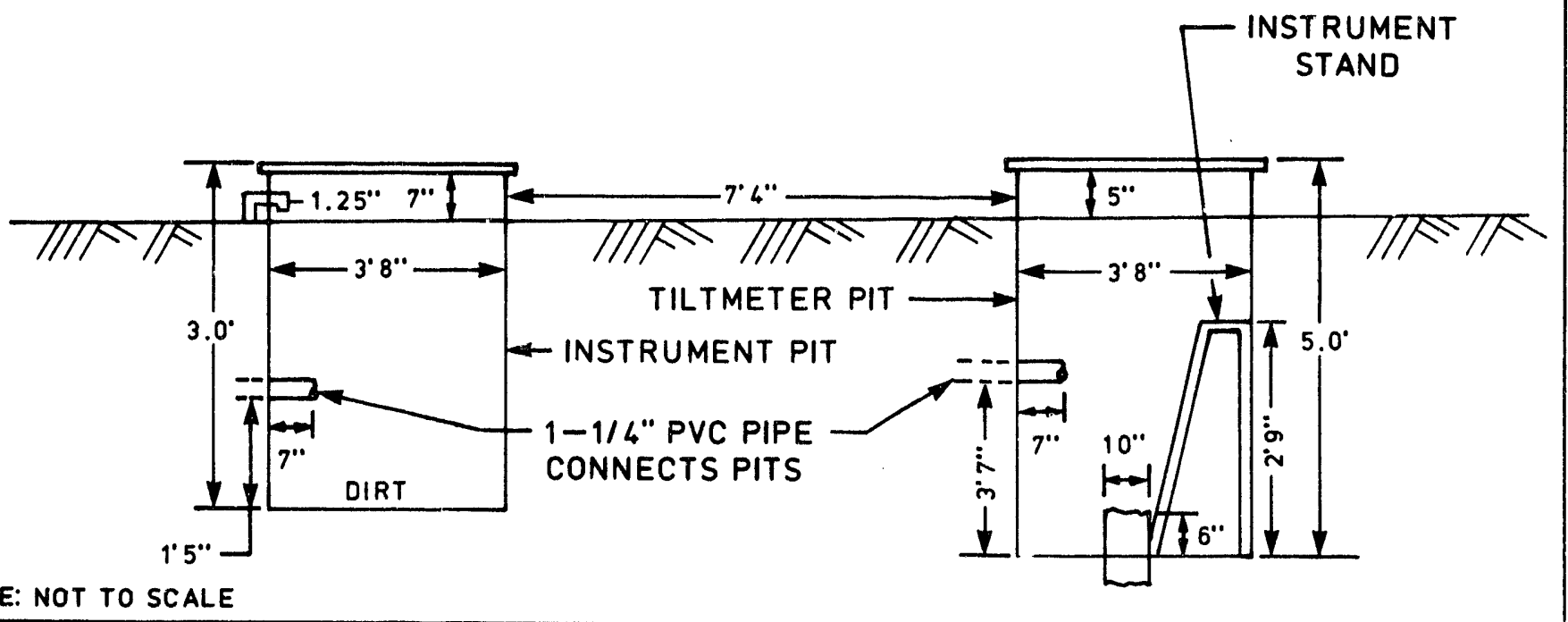




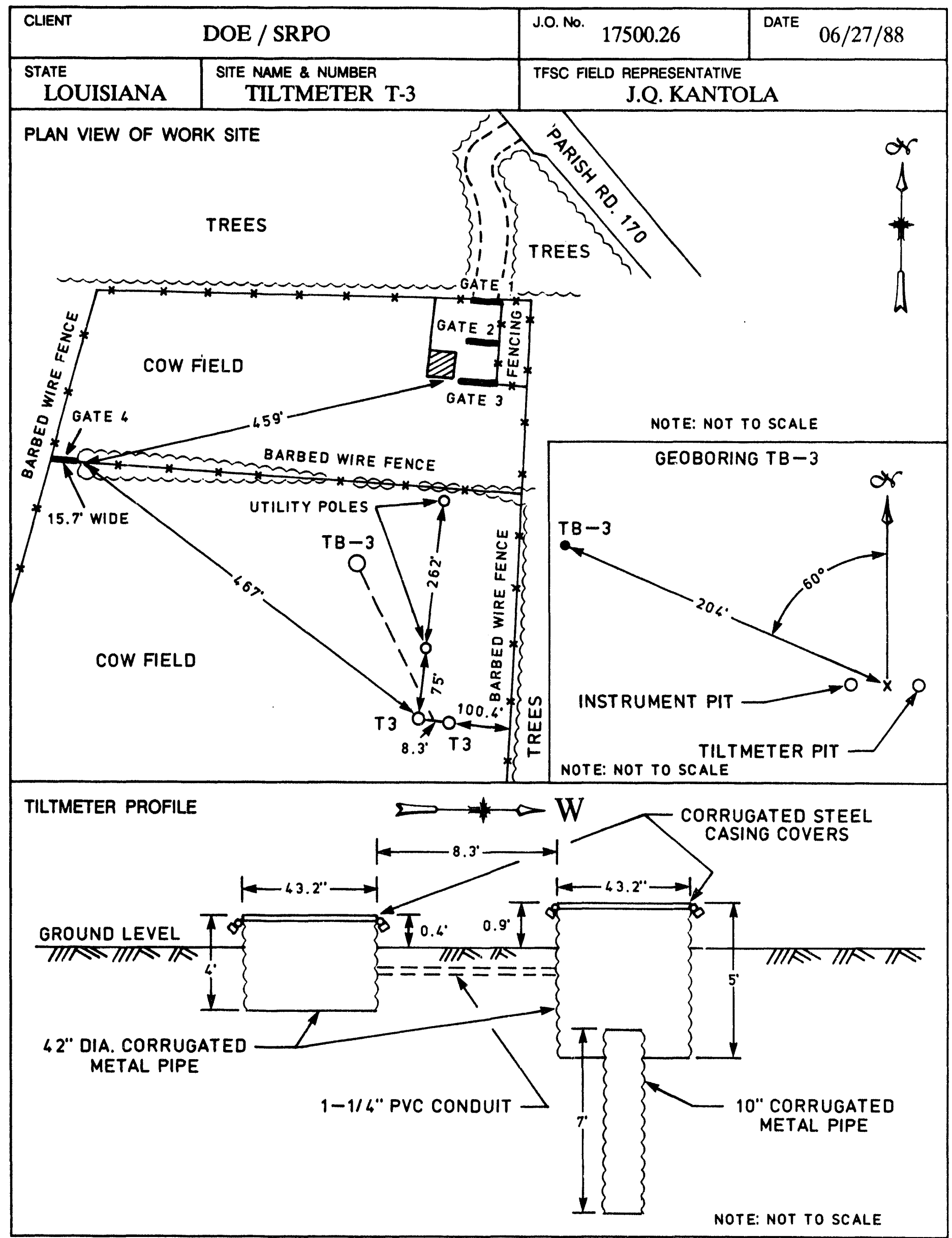




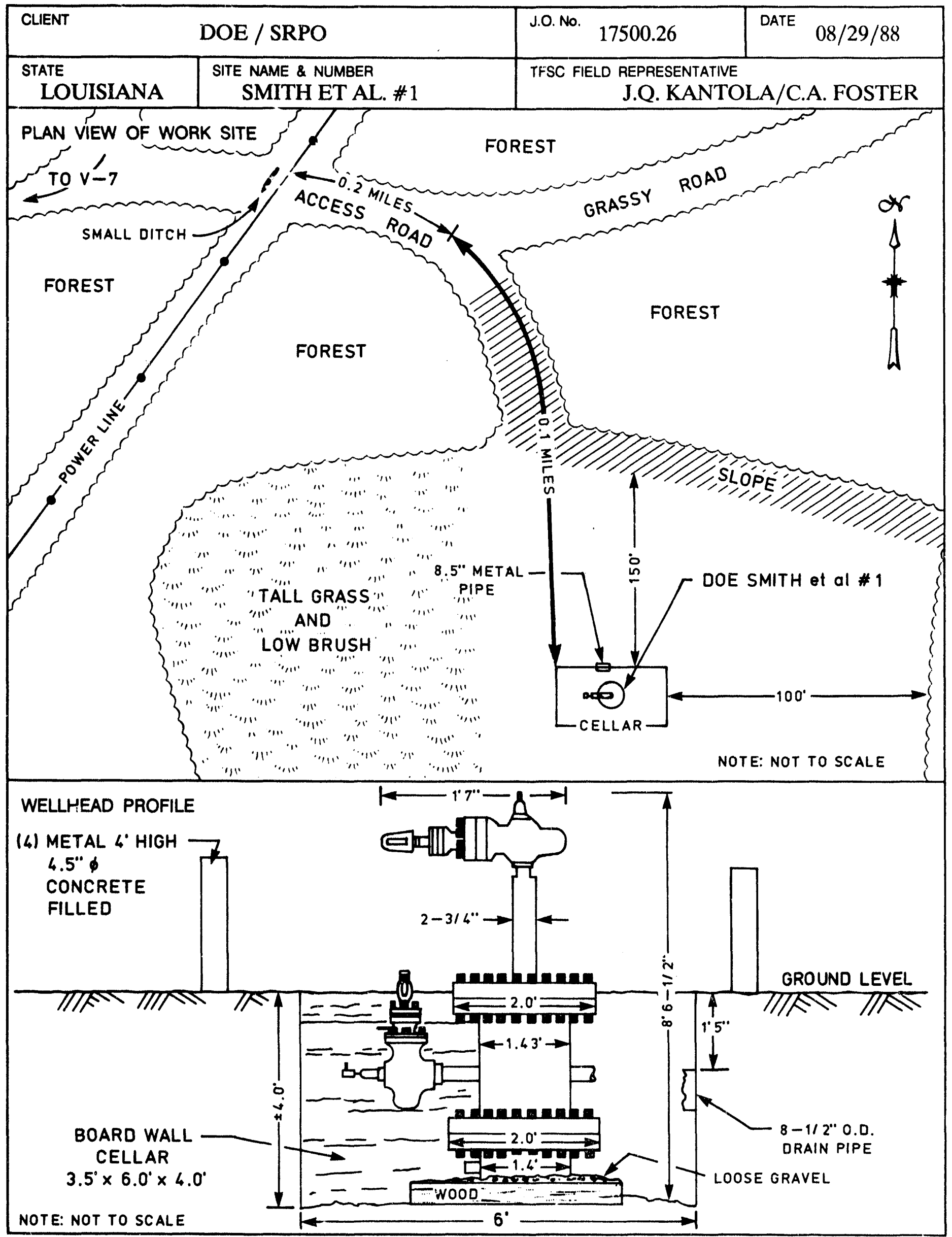




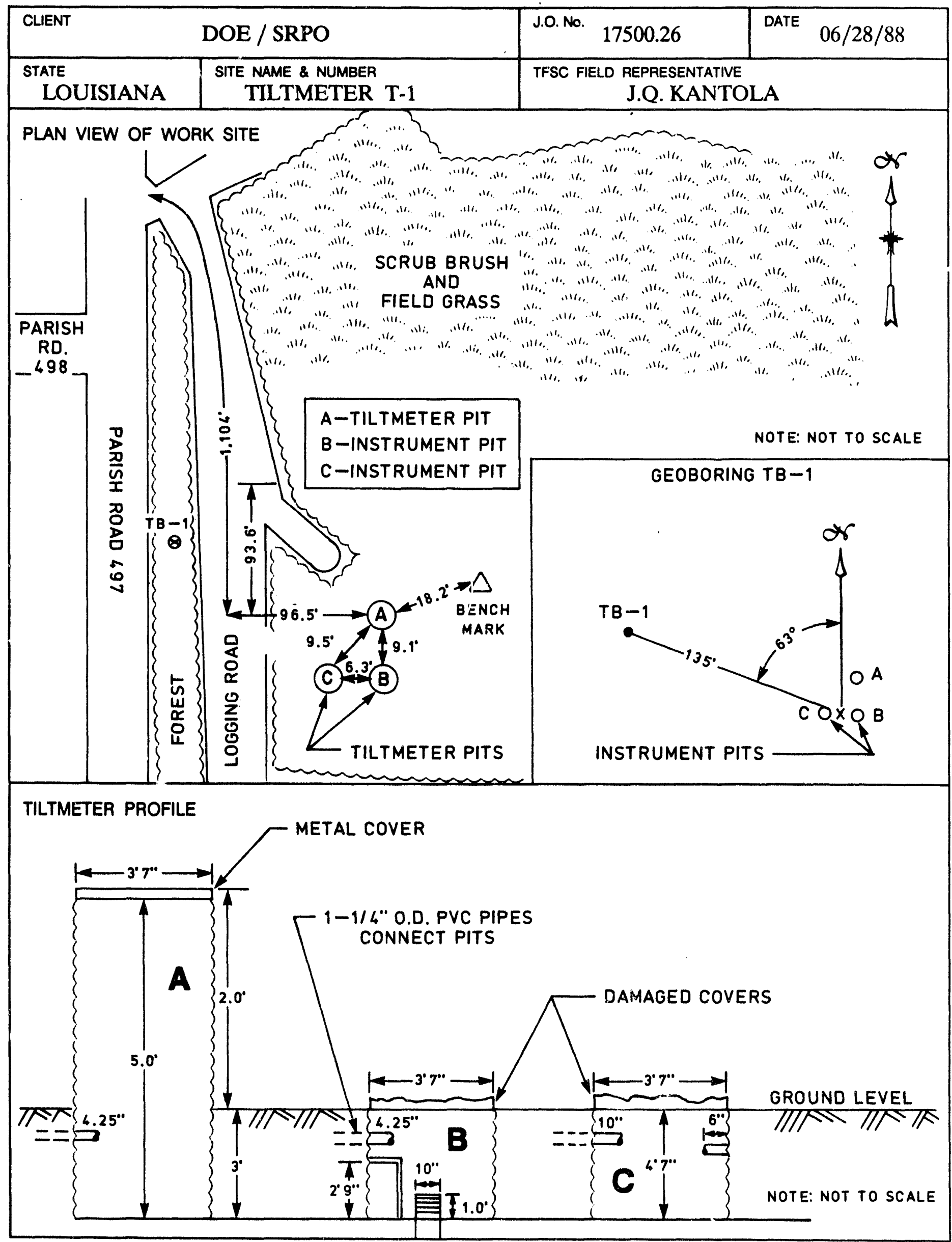




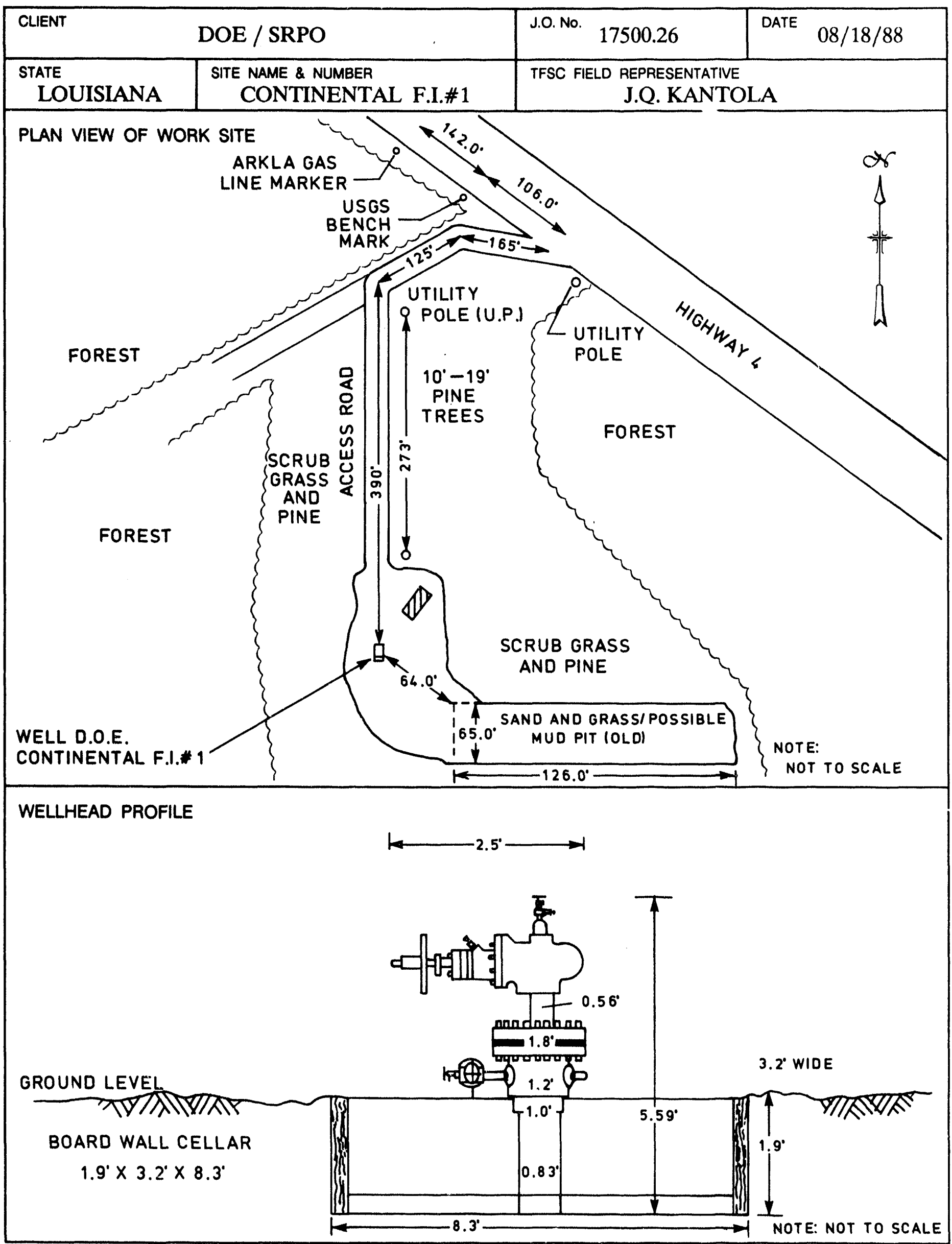




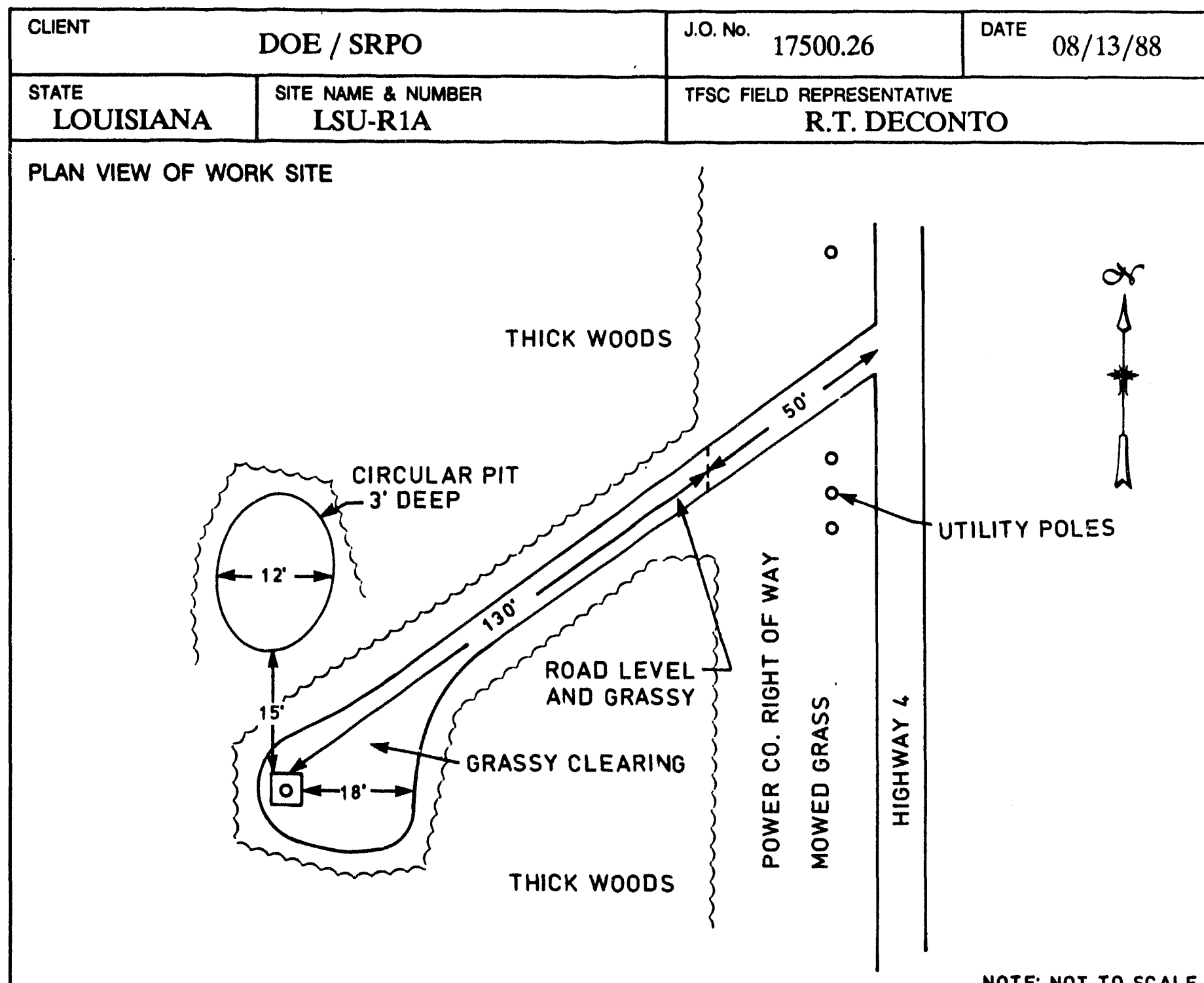

WELLLHEAD PROFILE

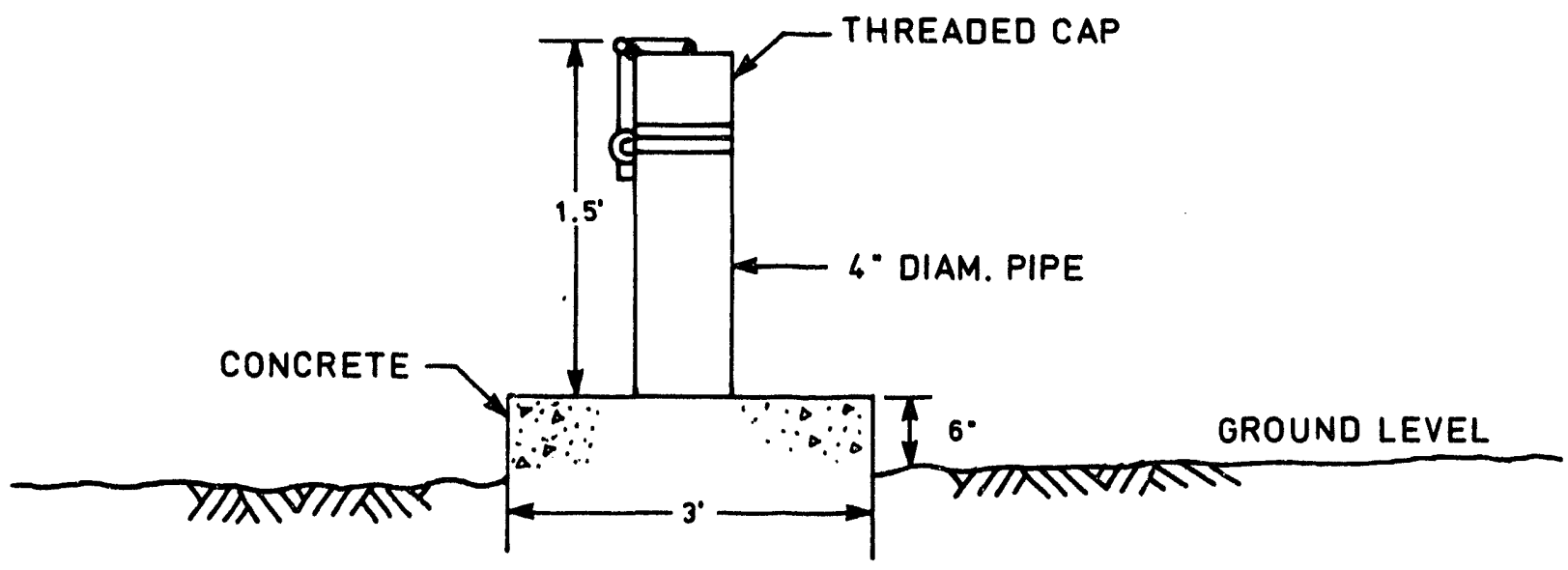




\begin{tabular}{|l|r|l|l|}
\hline CLIENT & J.0. No. 17500.26 & DATE $06 / 25 / 88$ \\
\hline $\begin{array}{c}\text { STATE } \\
\text { LOUISIANA }\end{array}$ & $\begin{array}{r}\text { SITE NAME \& NUMBER } \\
\text { KCI HODGE LH-17WS }\end{array}$ & \multicolumn{2}{|c|}{$\begin{array}{c}\text { TFSC FIELD REPRESENTATIVE } \\
\text { J.L. WELC-LEPAIN }\end{array}$} \\
\hline
\end{tabular}

PLAN VIEW OF WORK SITE

PARISH RD. 536

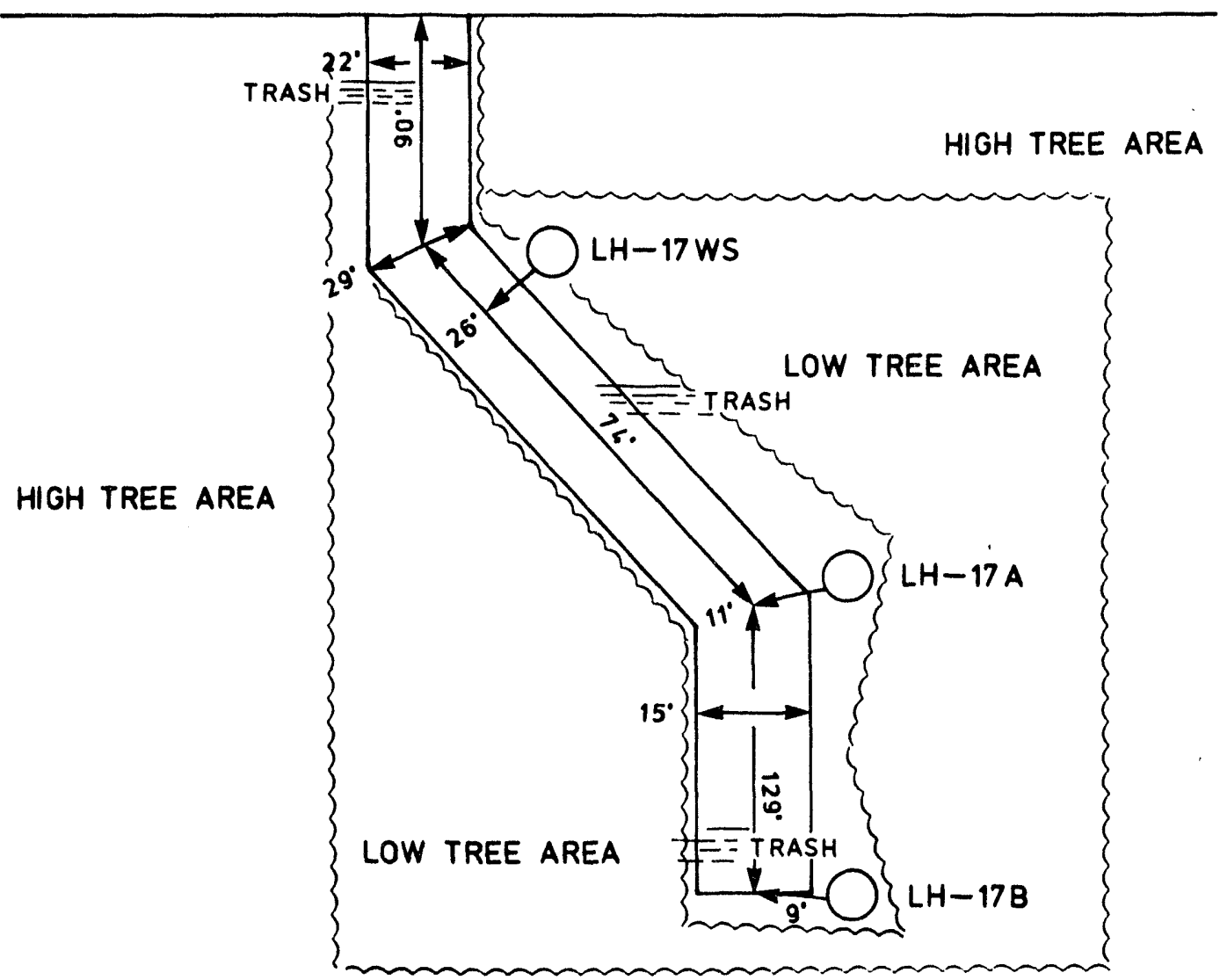

NOTE: NOT TO SCALE

WELLHEAD PROFILE

4 FT. $\times 4$ FT. $\times 4$ FT.

GROUND LEVEL

NOTE: NOT TO SCALE
D.O.E.

CONT. FOREST IND. LH-17WS

SERIAL * 166673

SEC.12, T15N, R10W

HINGED STEEL CAP

(PLATE GIVES ELEV.

T.O.C. 271.09')

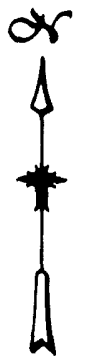




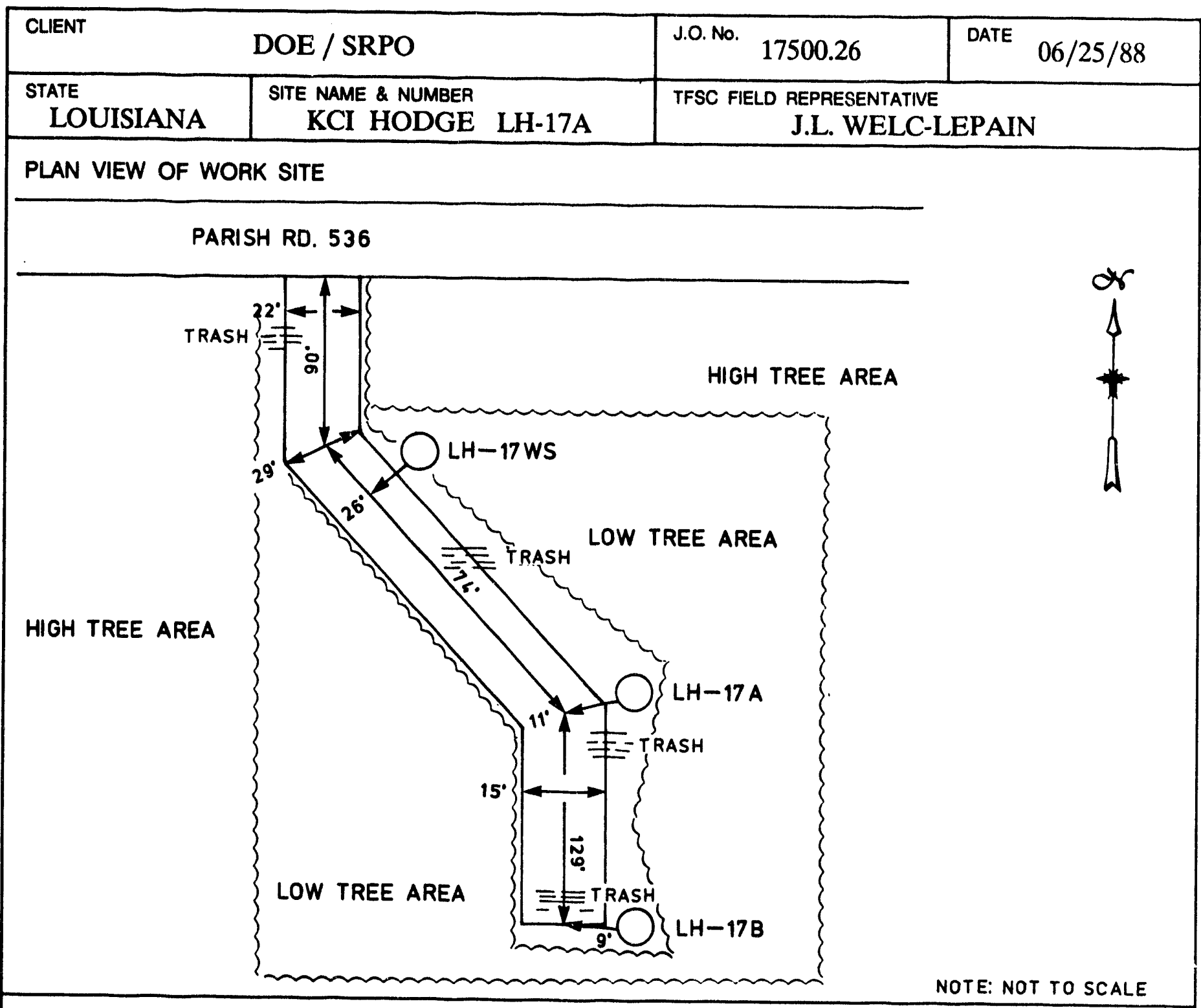

WELLHEAD PROFILE

HINGED STEEL CAP IPLATE GIVES ELEV. T.O.C. $271.09^{\prime}$ )

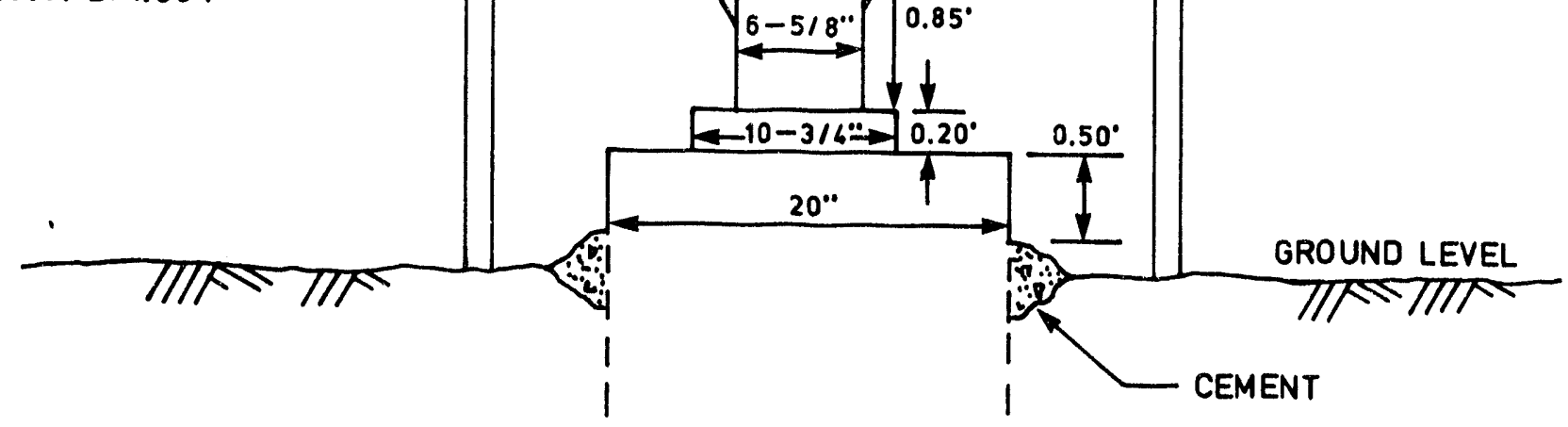




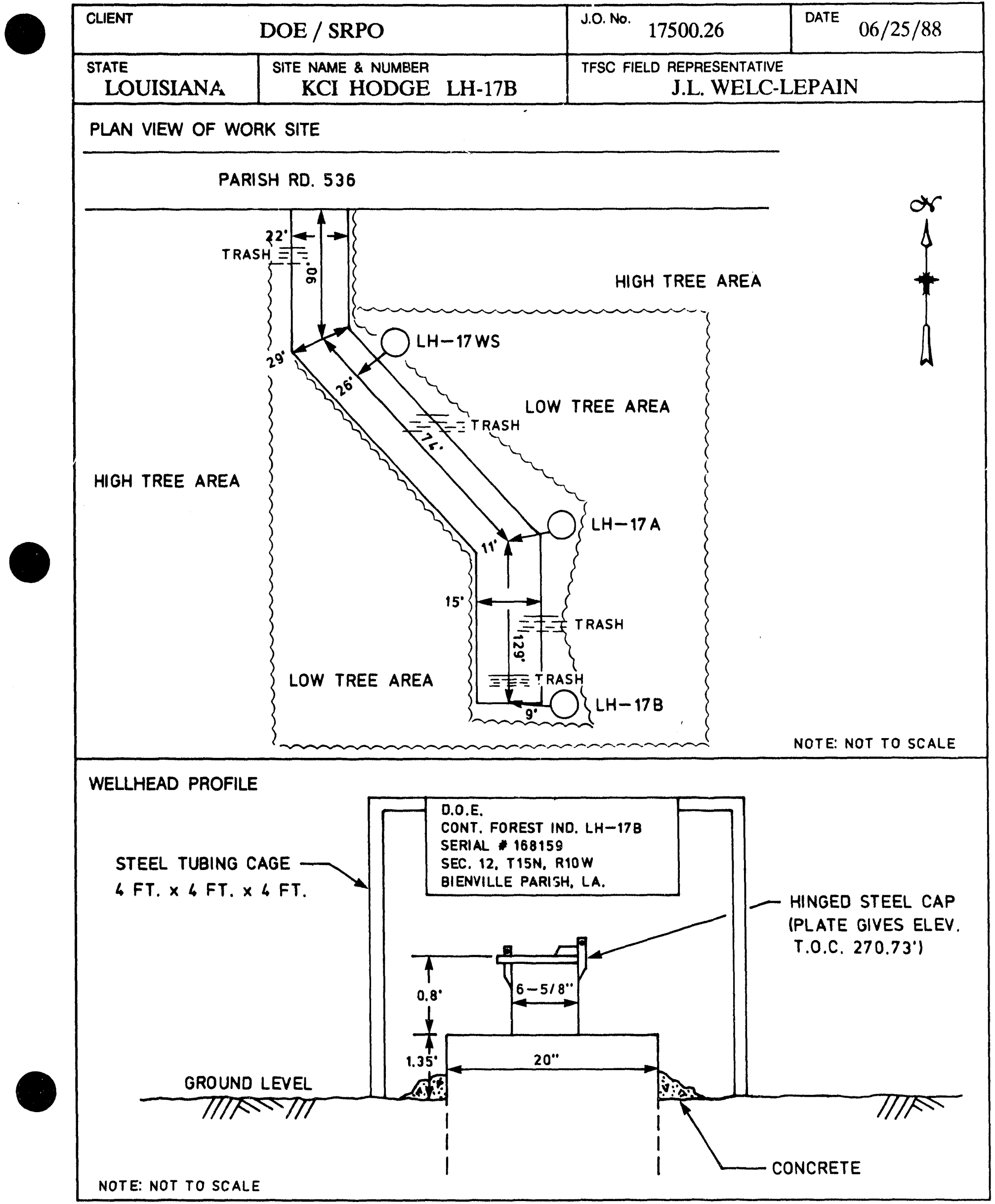




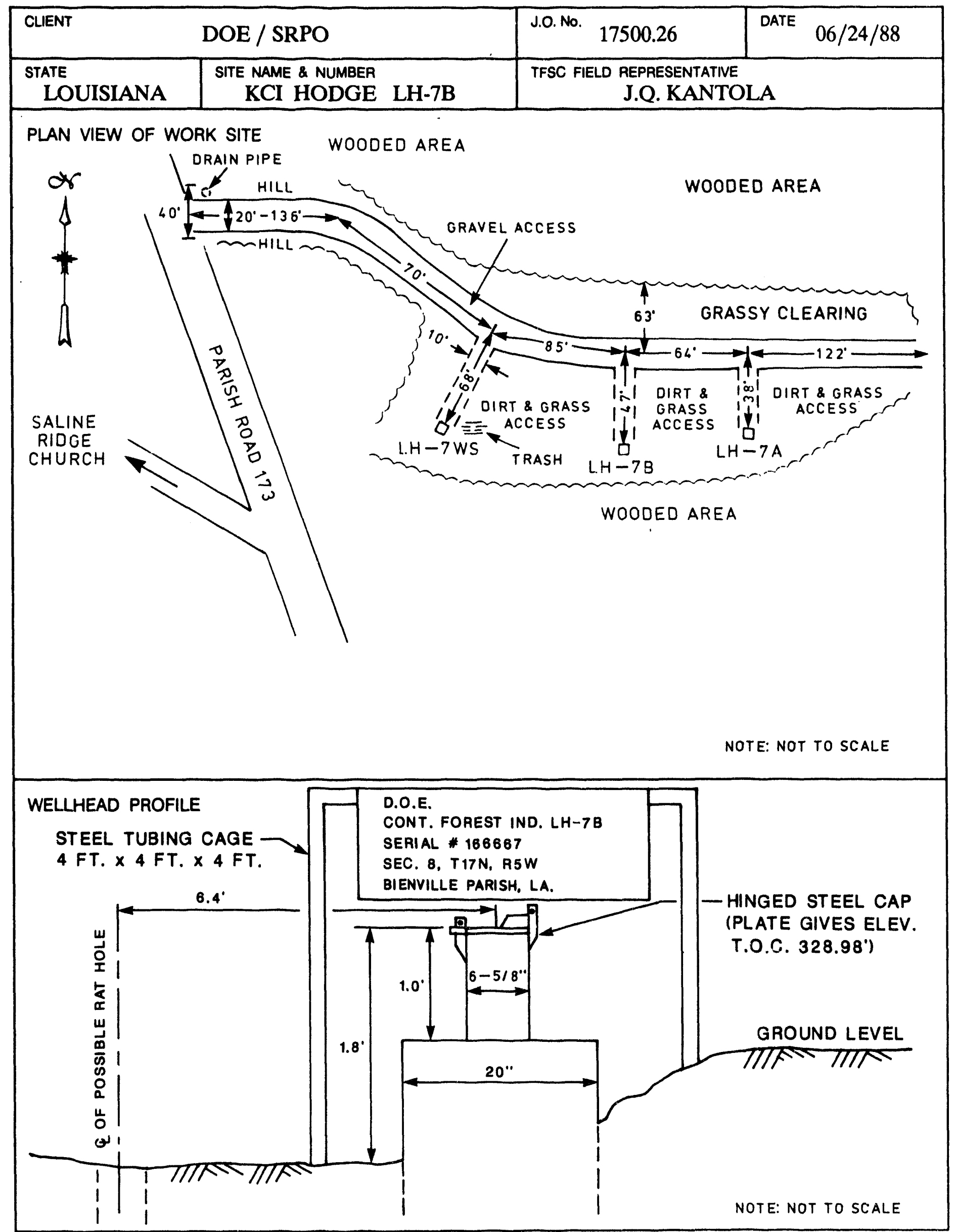




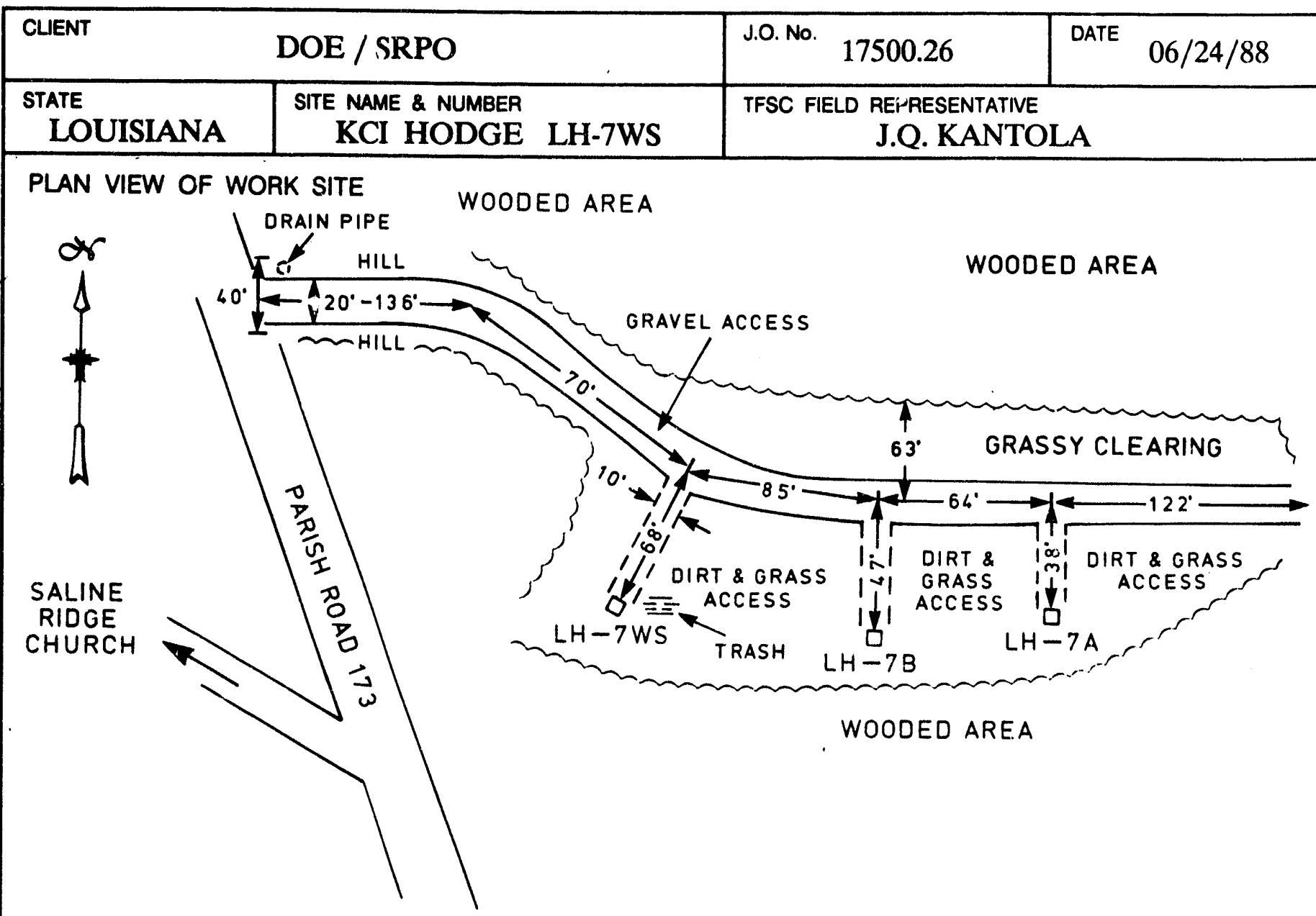

NOTE: NOT TO SCALE

WELLHEAD PROFILE

STEEL TUBING CAGE

4 FT. $\times 4$ FT. $\times 4$ FT.

D.O.E.

CONT. FOREST IND. LH-TWS

SERIAL * 166670

SEC. 8, T17N, R5W

BIENVILLE PARISH, LA.

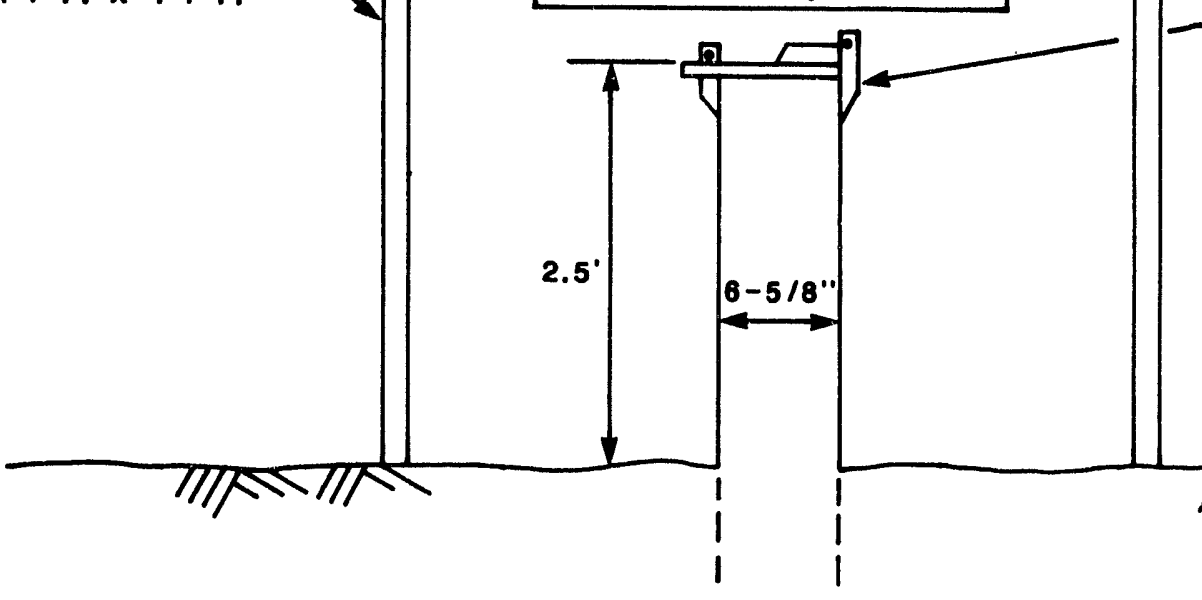

HINGED STEEL CAP (PLATE GIVES ELEV.

T.O.C. $335.29^{\prime}$ ) 


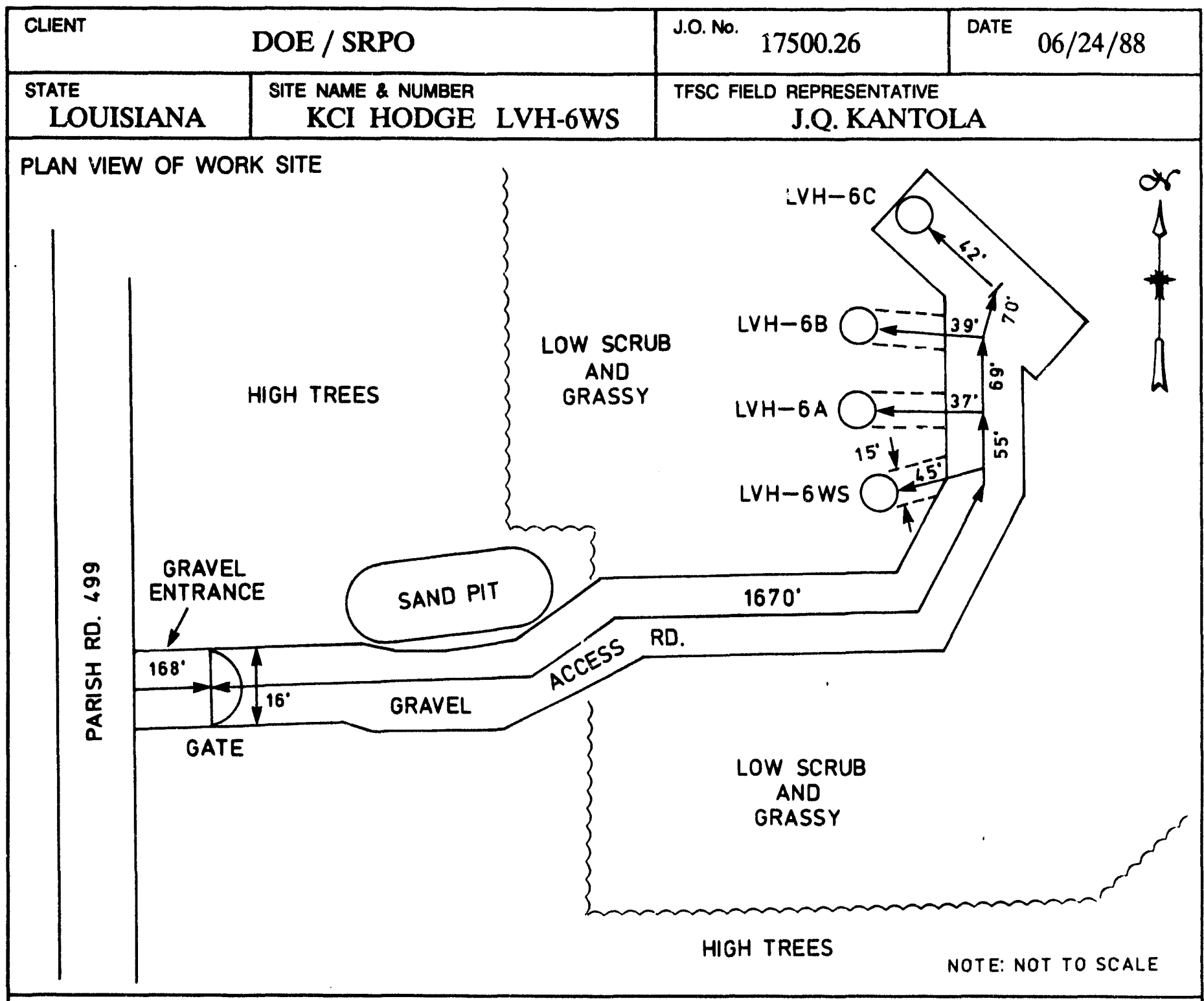

WELLHEAD PROFILE

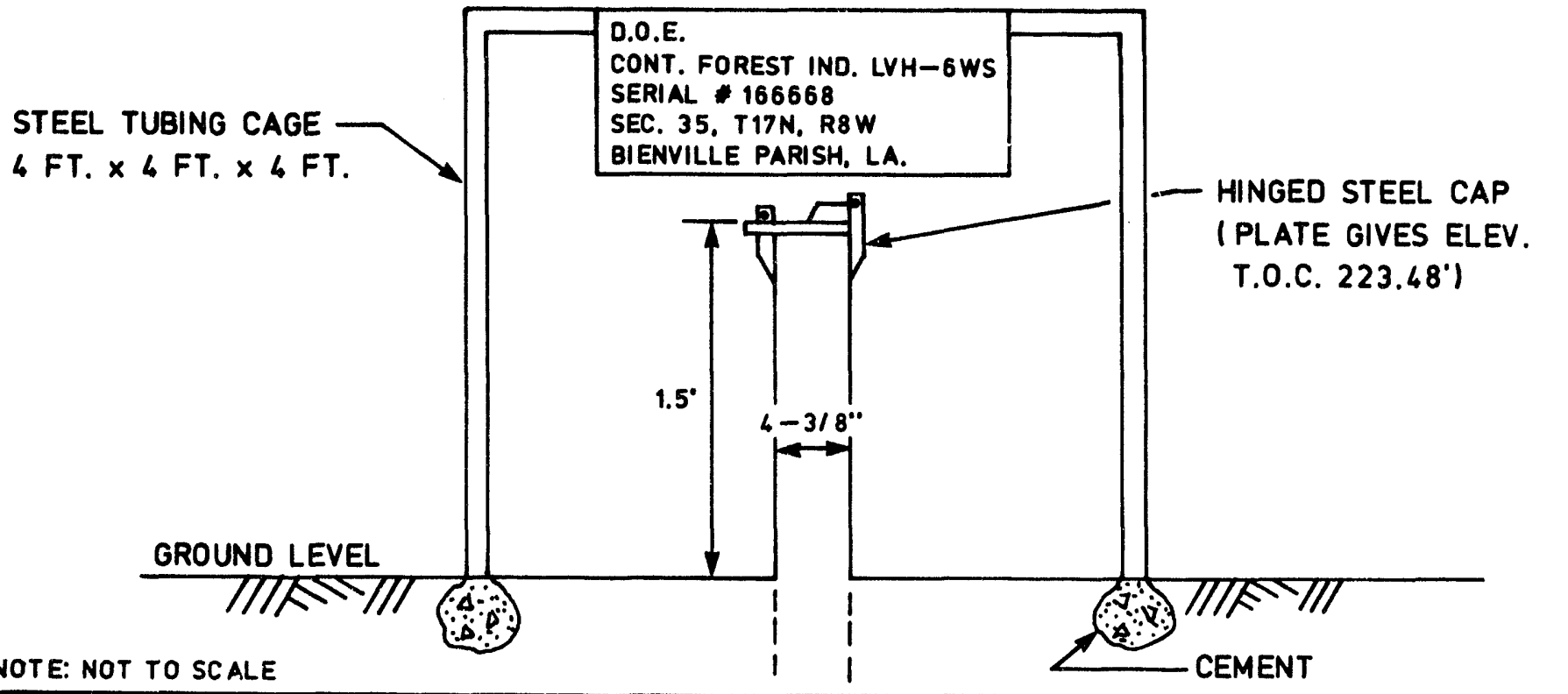




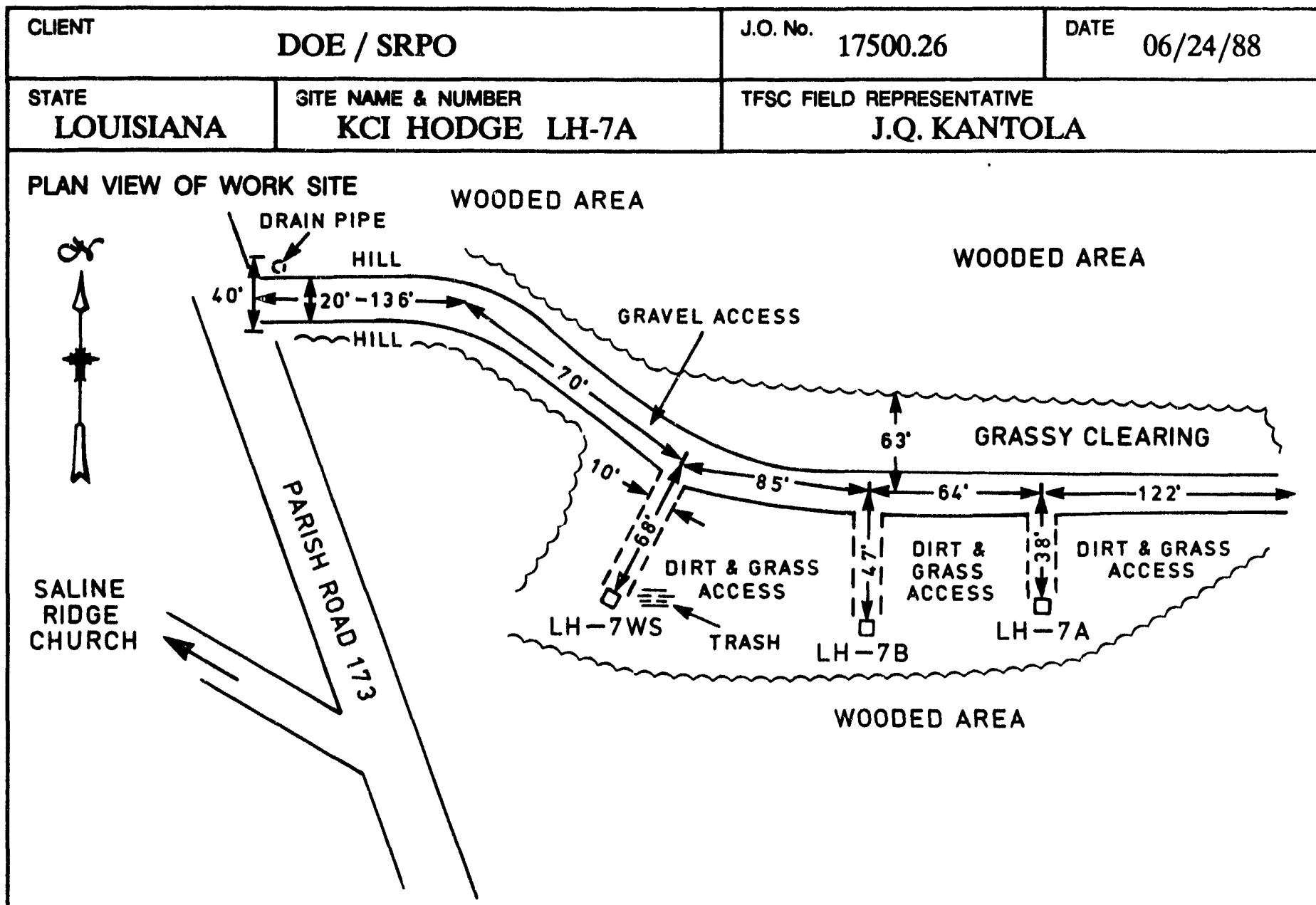

NOTE: NOT TO SCALE

WELHEAD PROFILE

HINGED STEEL CAP (PLATE GIVES ELEV. T.O.C. 327.06')

D.O.E.

CONT. FOREST IND. LH-7A

SERIAL 166669

SEC. 5, T17N, R5W

BIENVILLE PARISH, LA.

STEEL TUBING CAGE 4 FT. $\times 4$ FT. $\times 4$ FT.

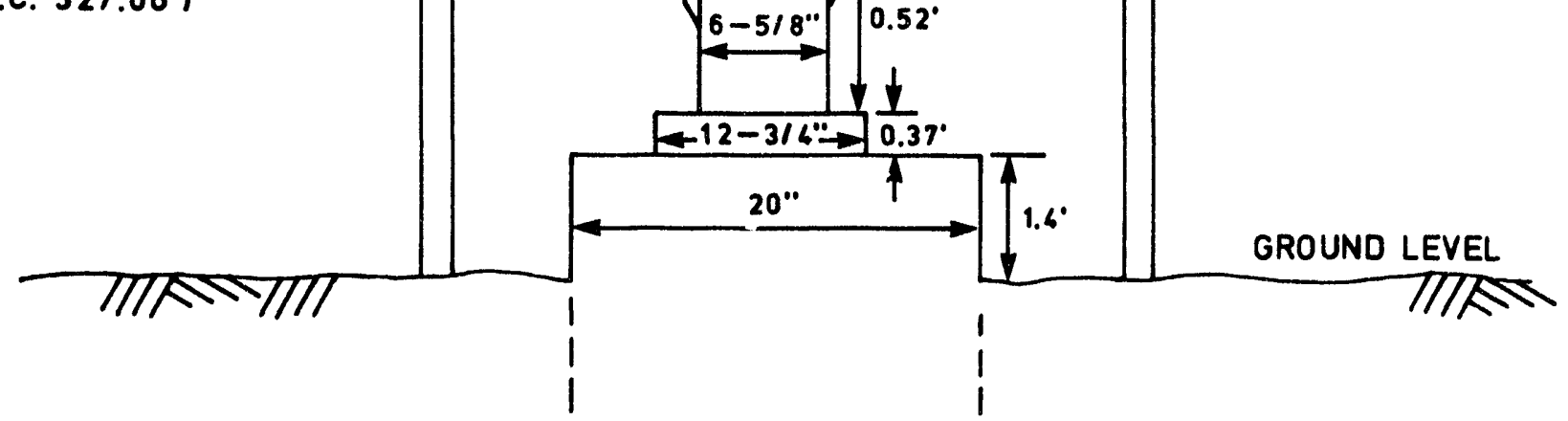




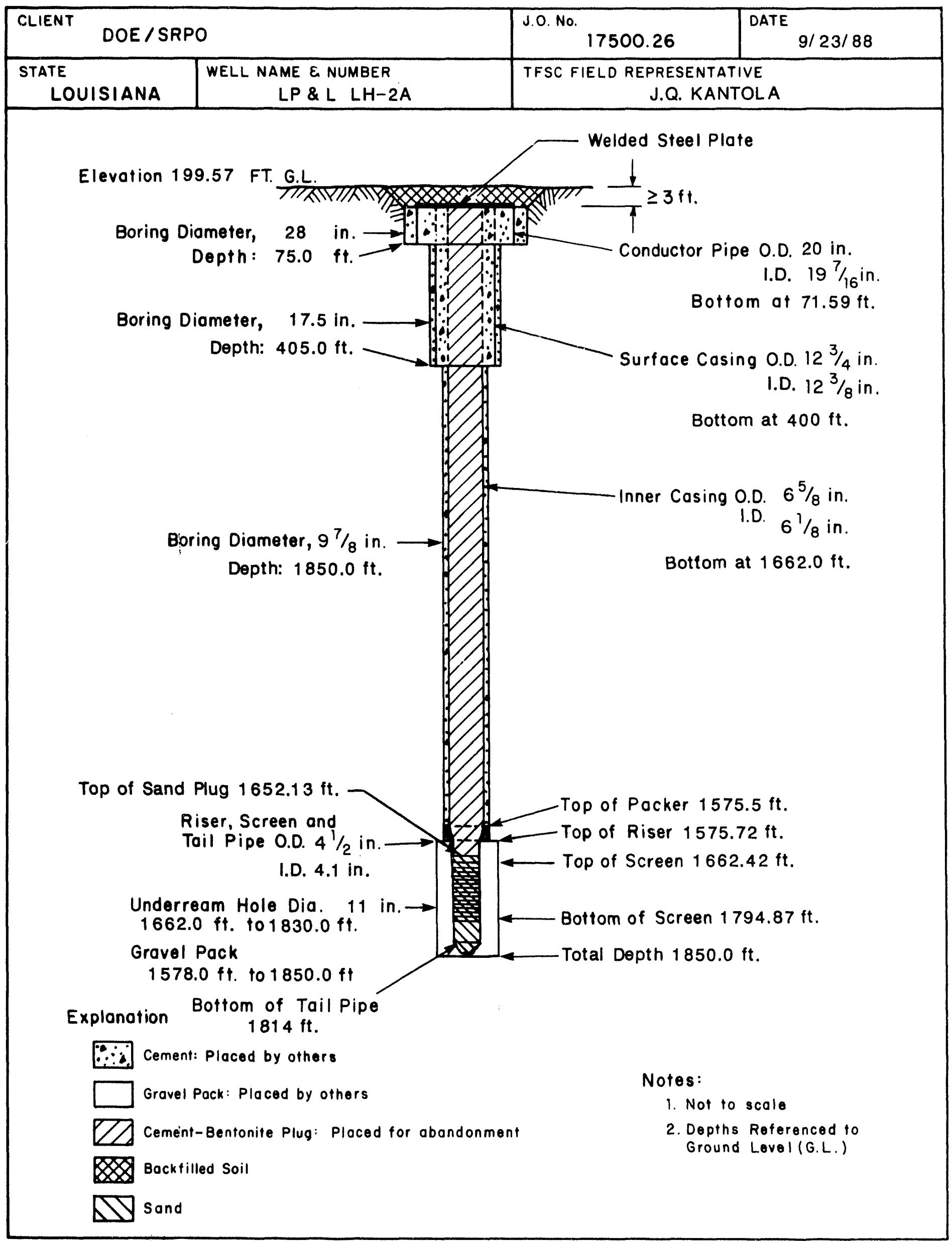




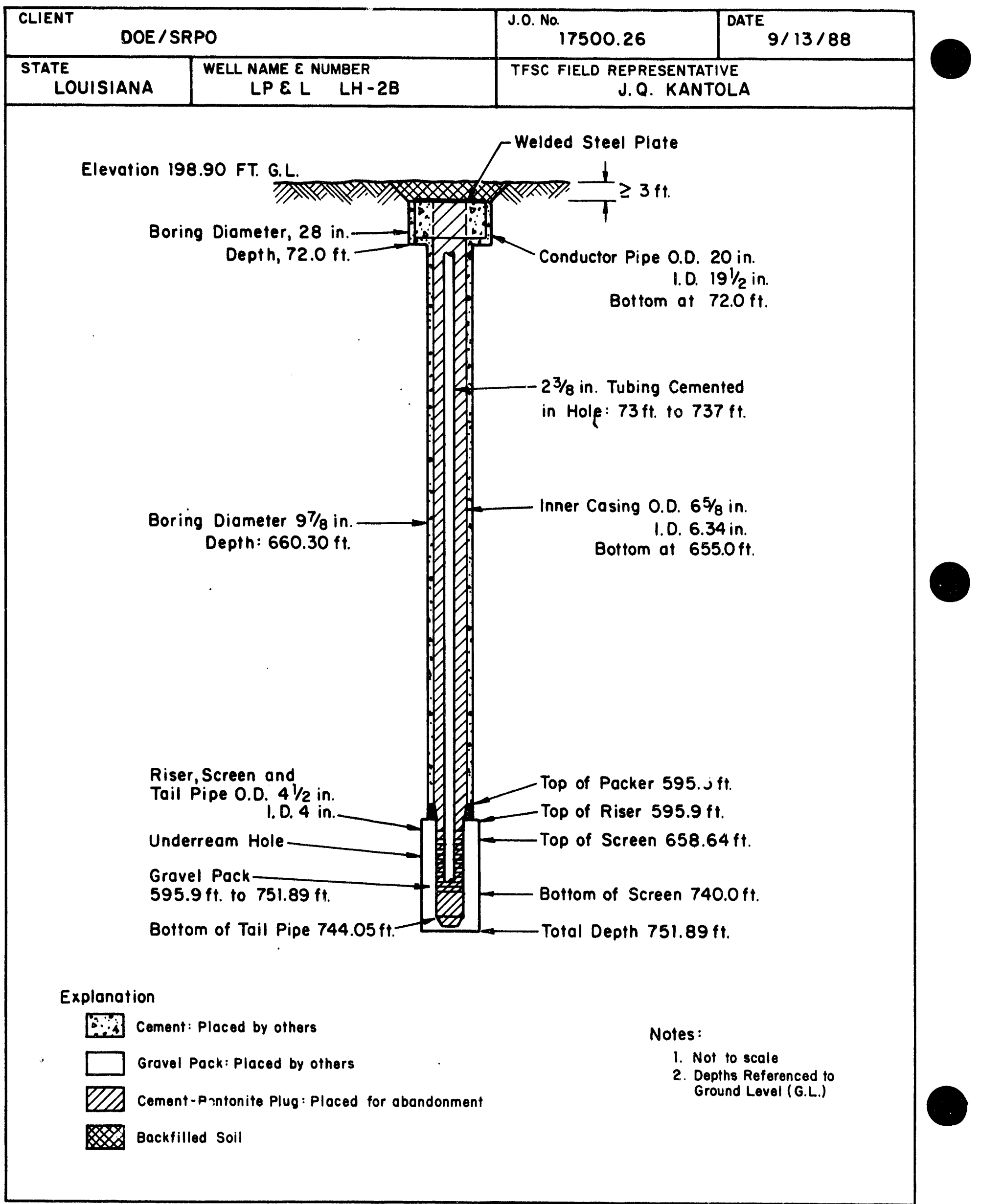




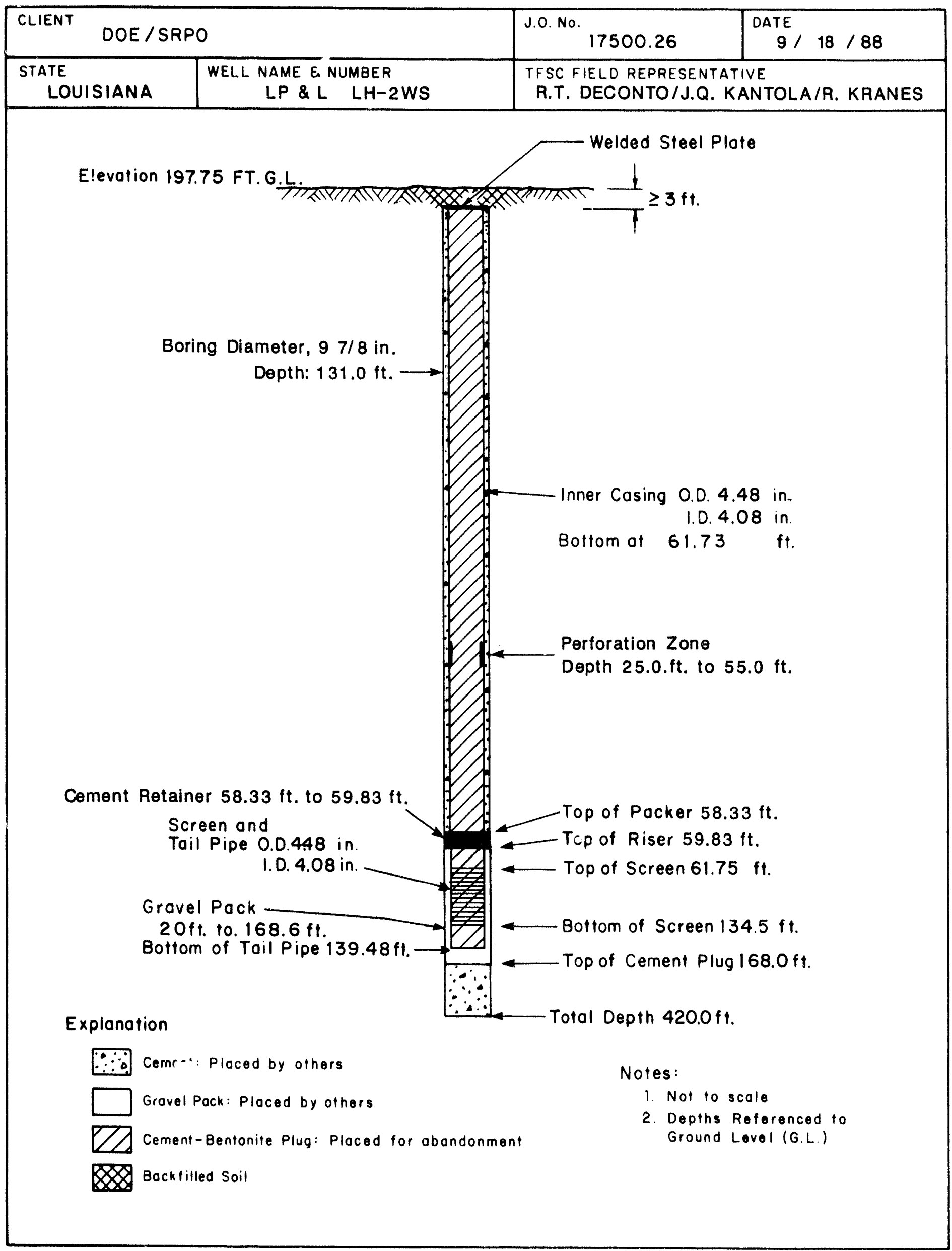




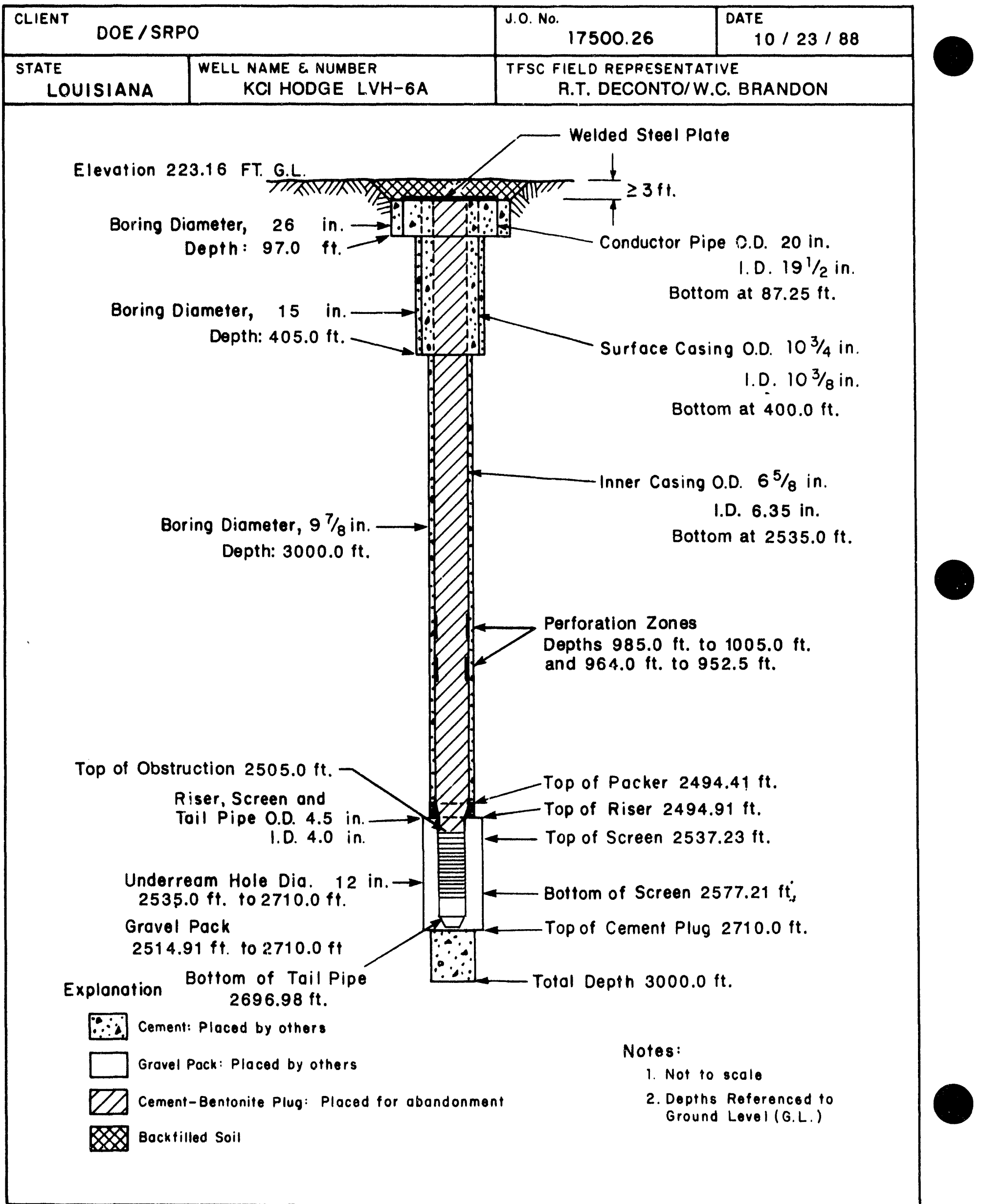




\begin{tabular}{|l|l|l|l|}
\hline CLIENT DOE / SRPO & $\begin{array}{l}\text { J.0. No. } \\
17500.26\end{array}$ & $\begin{array}{c}\text { DATE } \\
10 / 26 / 88\end{array}$ \\
\hline $\begin{array}{c}\text { STATE } \\
\text { LOUISIANA }\end{array}$ & $\begin{array}{c}\text { WELL NAME \& NUMBER } \\
\text { KCI HODGE LVH-6B }\end{array}$ & $\begin{array}{l}\text { TFSC FIELD REPRESENTATIVE } \\
\text { W.C. BRANDON }\end{array}$ \\
\hline
\end{tabular}

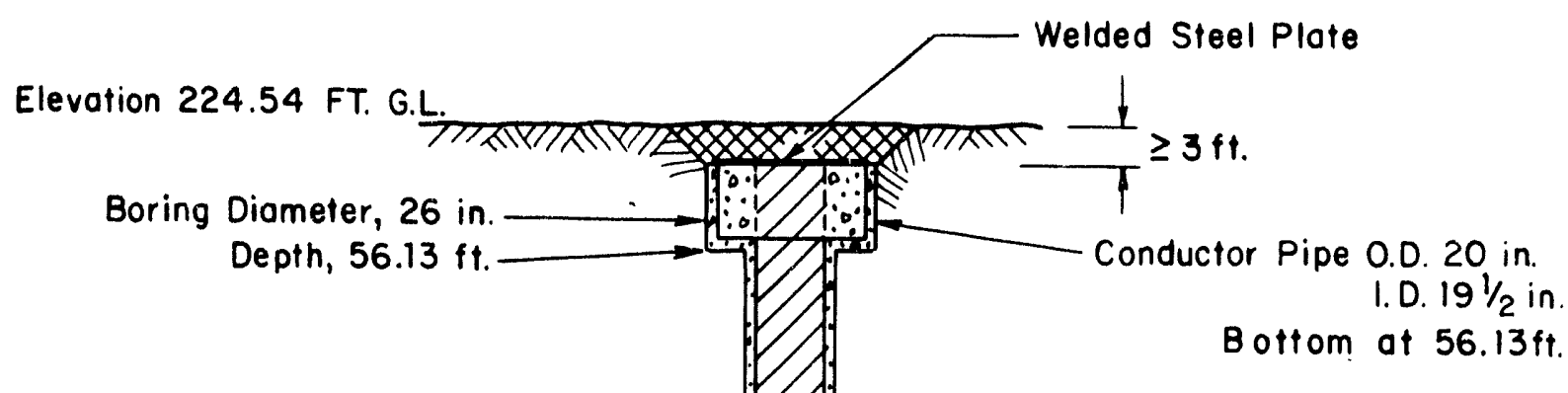

Boring Diameter, $97 / 8$ in. $\rightarrow \quad$ Bottom at $1826.0 \mathrm{ft}$. Depth: $1828.0 \mathrm{ft}$.

Inner Casing 0.D. 65/8 in.

Boring Diameter, 978 in. $\rightarrow \quad$ Bottom at $1826.0 \mathrm{ft}$.

Top of Obstruction $1786.1 \mathrm{ft}$.

Riser, Screen and

Tail Pipe O.D. $4.5 \mathrm{in}$. i. D. $4.059 \mathrm{in}$

Bottom at $1826.0 \mathrm{ft}$.

Perforation Zones

Depths $980.0 \mathrm{ft}$. to $1000.0 \mathrm{ft}$. and $949.0 \mathrm{ft}$. to $960.0 \mathrm{ft}$.

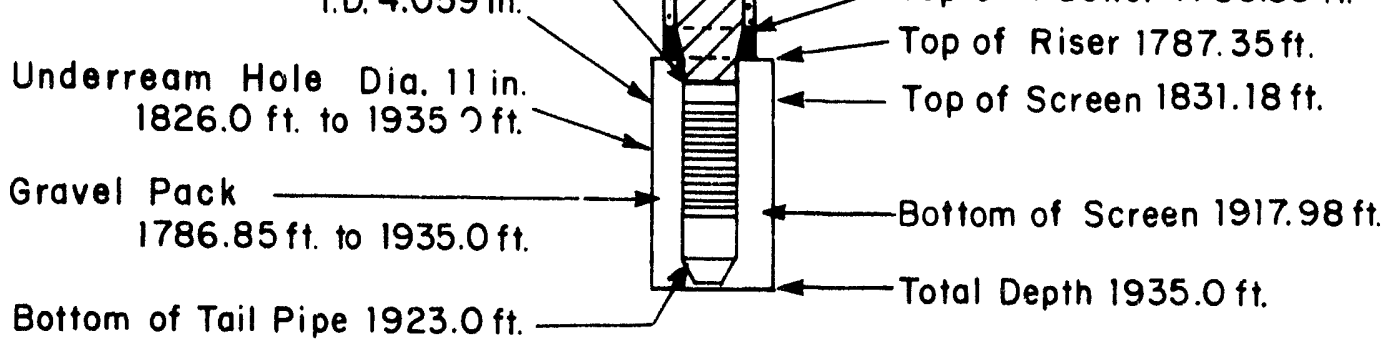

\section{Explanation}

$\therefore \therefore$ Cement: Placed by others

Grovel Pack: Placed by others

Z Cement-Bentonite Plug: Placed for abandonment

Backfilled Soil
Notes:

1. Not to scale
2. Depths Referenced to
Ground Level (G.L.) 


\begin{tabular}{|l|c|c|c|}
\hline \multicolumn{2}{|c|}{ CLIENT DOE / SRPO } & $\begin{array}{l}\text { J.0. No. } \\
17500.26\end{array}$ & \begin{tabular}{c}
$10 / 21 / 88$ \\
\hline $\begin{array}{c}\text { STATE } \\
\text { LOUISIANA }\end{array}$
\end{tabular} \\
\hline
\end{tabular}

Elevation 224.92 FT. G.L.

\section{Welded Steel Plote}

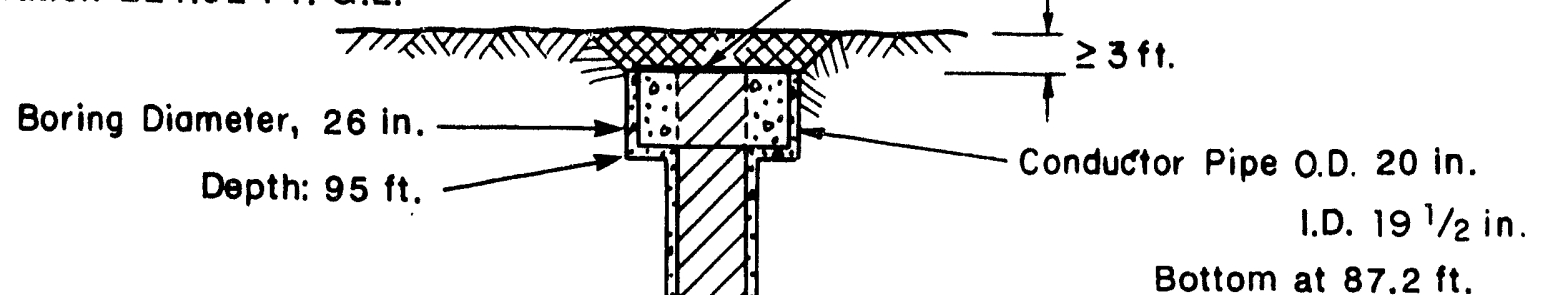

Bottom at $87.2 \mathrm{ft}$.

Inner Car $90.0 .65 / 8 \mathrm{in}$.

I.D. $6 \frac{1 / 16}{\text { in. }}$

Boring Diameter, $97 / 8$ in.

Depth: $910.09 \mathrm{ft}$.

Bottom at $906.45 \mathrm{ft}$.

\section{Perforation Zone}

Depth $813.0 \mathrm{ft}$. to $833.0 \mathrm{ft}$.

Top of Obstruction $868.6 \mathrm{ft}$.

Riser, Screen and

Tail Pipe O.D. $4.5 \mathrm{in}$.

I. D. $4.0 \mathrm{in}$.

Underream Hole Dia. $12 \mathrm{in.}$ $906.45 \mathrm{ft}$. to $974.99 \mathrm{ft}$.

Gravel Pack

$866.64 \mathrm{ft}$. to $985.0 \mathrm{ft}$.

Bottom of Tail Pipe $975.0 \mathrm{ft}$.

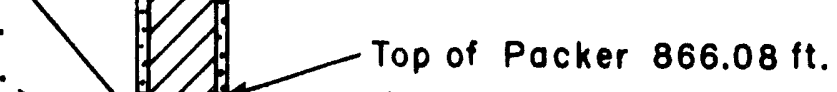

Top of Pocker $866.08 \mathrm{ft}$

Top of Riser $866.64 \mathrm{ft}$.

Top of Screen $908.96 \mathrm{ft}$.

Botfom of Screen $970.0 \mathrm{ft}$.

Total Depth $985.0 \mathrm{ft}$.

\section{Explanation}

$\because \therefore$ Cement: Placed by others

Grovel Pack: Placed by others

ZCement-Bentonite Plug: Placed for abandonment

88 Backfilled Soil
Notes:

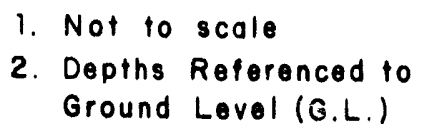

2. Not to scale Ground Level (G.L.) 


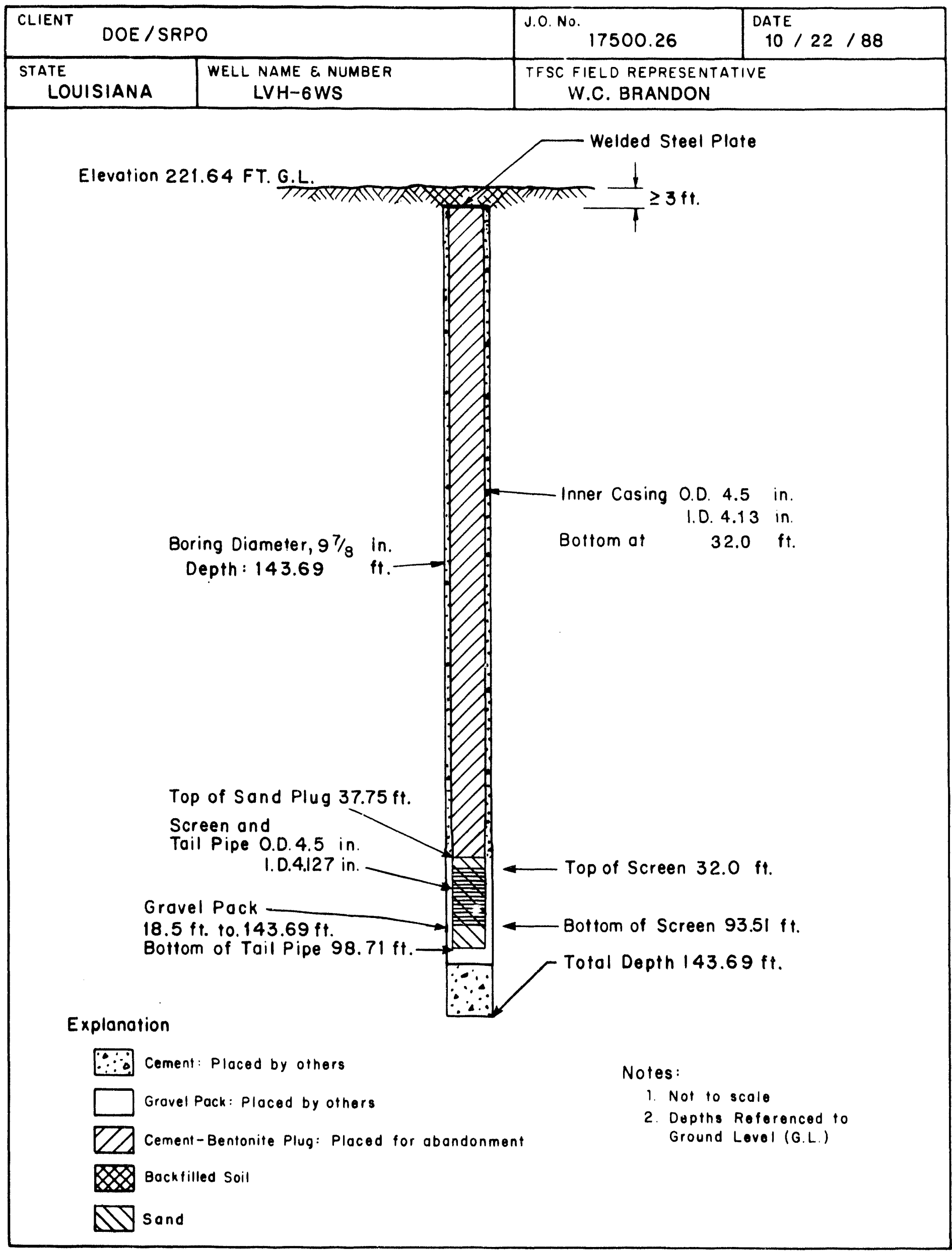




\begin{tabular}{|c|c|c|c|}
\hline CLIENT DOE / SRPO & J.0. No. & 17500.26 & $\begin{array}{c}\text { DATE } \\
9 / 20 / 88\end{array}$ \\
\hline $\begin{array}{c}\text { STATE } \\
\text { LOUISIANA }\end{array}$ & $\begin{array}{c}\text { WELL NAME E NUMBER } \\
\text { KCI HODGE LH-7A }\end{array}$ & $\begin{array}{c}\text { TFSC FIELD REPRESENTATIVE } \\
\text { J.Q. KANTOLA }\end{array}$ \\
\hline
\end{tabular}

Elevation 325.57 FT. G.L. Welded Steel Plate

Depth: $57.0 \mathrm{ft}$ Conductor Pipe O.D. $20 \mathrm{in.}$

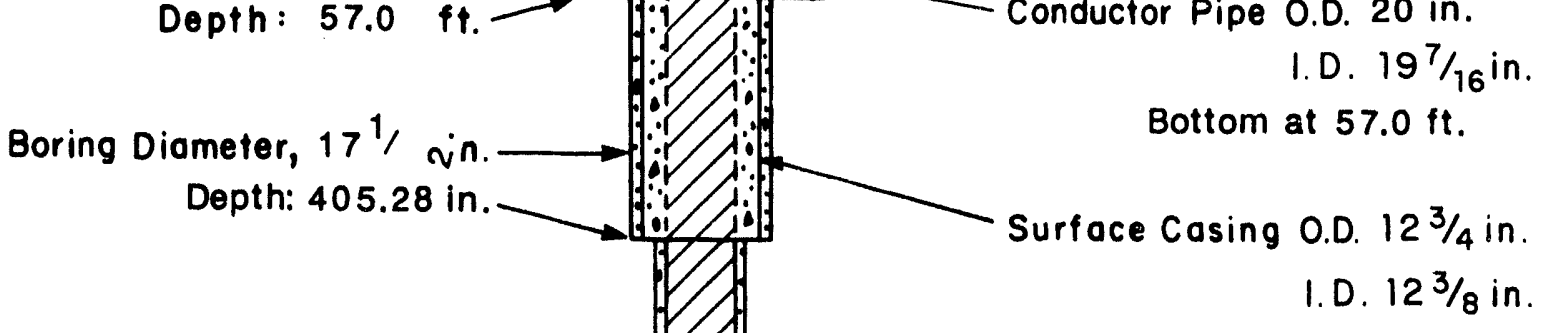

Boring Diometer, $9 \frac{7}{8}$ in.

Depth: $2618.76 \mathrm{ft}$.
Bottom at $400 \mathrm{ft}$.

Bottom at $57.0 \mathrm{ft}$.

$$
\text { I.D. } 12 \frac{3}{8} \text { in. }
$$

Inner Cosing O.D. $6 \frac{5}{8}$ in.

I.D. $6 \frac{1}{16} \mathrm{in}$.

Bottom at $1476.0 \mathrm{ft}$.

Top of Sand Plug $1461.51 \mathrm{ft}$.

Riser, Screen and Toil Pipe 0.D. $4.5 \mathrm{in}$.

I.D. 4.0 in.

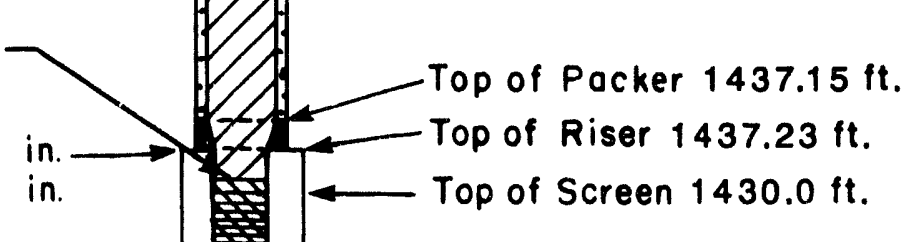

Underream Hole Dia. 12 in. $\rightarrow$ $1476.0 \mathrm{ft}$. to $1570.0 \mathrm{ft}$.

Gravel Pack

$1476.0 \mathrm{ft}$. to $1570.0 \mathrm{ft}$

\section{Explanation}

\section{Bottom of Tail Pipe} $1565.09 \mathrm{ft}$.

$\because \therefore$ Cement: Placed by others

$\square$ Gravel Pack: Placed by othars

23

Cement-Bentonite Plug: Placed for abandonment

88 Backfilled Soil

$\Delta \nabla$ sand
Notes:

1. Not to scale

2. Depths Referenced to Ground Lovel (G.L.) 


\begin{tabular}{|c|c|c|c|}
\hline \multicolumn{2}{|c|}{ DOE / SRPO } & $\begin{array}{l}\text { J.O. No. } \\
\qquad 17500.26\end{array}$ & $\begin{array}{l}\text { DATE } \\
9 / 19 / 88\end{array}$ \\
\hline $\begin{array}{l}\text { STATE } \\
\text { LOUISIANA }\end{array}$ & $\begin{array}{l}\text { WELL NAME \& NUMBER } \\
\text { KCI HODGE LH-7B }\end{array}$ & $\begin{array}{r}\text { TFSC FIELD REPR } \\
\text { RICH }\end{array}$ & $\begin{array}{l}\text { VE } \\
\text { IANES }\end{array}$ \\
\hline
\end{tabular}

Eevation 326.27 FT. G.L. Boring Diomeler, 28 in.

Depth: $58.0 \mathrm{ft}$.
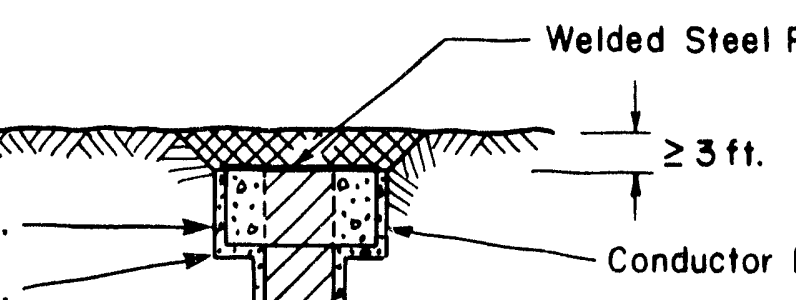

$\therefore: 1 / 10$

(

Bottom at $57.0 \mathrm{ft}$. Inner Casing 0.D. $6 \frac{5}{8}$ in.

Boring Diameter, $97 / 8$ in. I.D. 6.345 in. Depth: $937 \mathrm{ft}$. Bottom at $936.0 \mathrm{ft}$.

Top of Sand Plug $932.0 \mathrm{ft}$. Riser, Screen and

Tail Pipe 0.D. 4.5 in. I. D. $4.0 \mathrm{in}$.

Underream Hole Dia. 12 in. $936.0 \mathrm{ft}$. to $1052.0 \mathrm{ft}$.

in. Top of Packer $889.31 \mathrm{ft}$. Top of Riser $889.81 \mathrm{ft}$.

\section{Gravel Pack}

$889.8 \mathrm{ft}$ to $1052.0 \mathrm{ft}$.

Bottom of Tail Pipe $1051.0 \mathrm{ft}$.

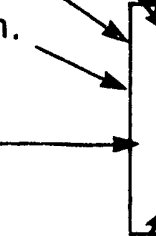
Screen $943.2 \mathrm{ft}$. to $958.56 \mathrm{ft}$. Screen $975.36 \mathrm{ft}$. to $1046.97 \mathrm{ft}$. Total Depth $1052.0 \mathrm{ft}$.

\section{Explanation}

Cement: Placed by others

Gravel Pack: Placed by others

Notes:

Cement-Bentonite Plug: Placed for abandonment
1. Not to scale
2. Depths Referenced to Ground Level (G.L.)

Bockfilled Soil

$\Delta$ sand 


\begin{tabular}{|c|l|l|c|}
\hline CLIENT DOE / SRPO & J.0. No. 17500.26 & $\begin{array}{c}\text { DATE } \\
10 / 31 / 88\end{array}$ \\
\hline $\begin{array}{c}\text { STATE } \\
\text { LOUISIANA }\end{array}$ & $\begin{array}{c}\text { WELL NAME E NUMUER } \\
\text { KCI HODGE LH-7WS }\end{array}$ & $\begin{array}{c}\text { TFSC FIELD REPRESENTATIVE } \\
\text { RICHARD KRANES }\end{array}$ \\
\hline
\end{tabular}

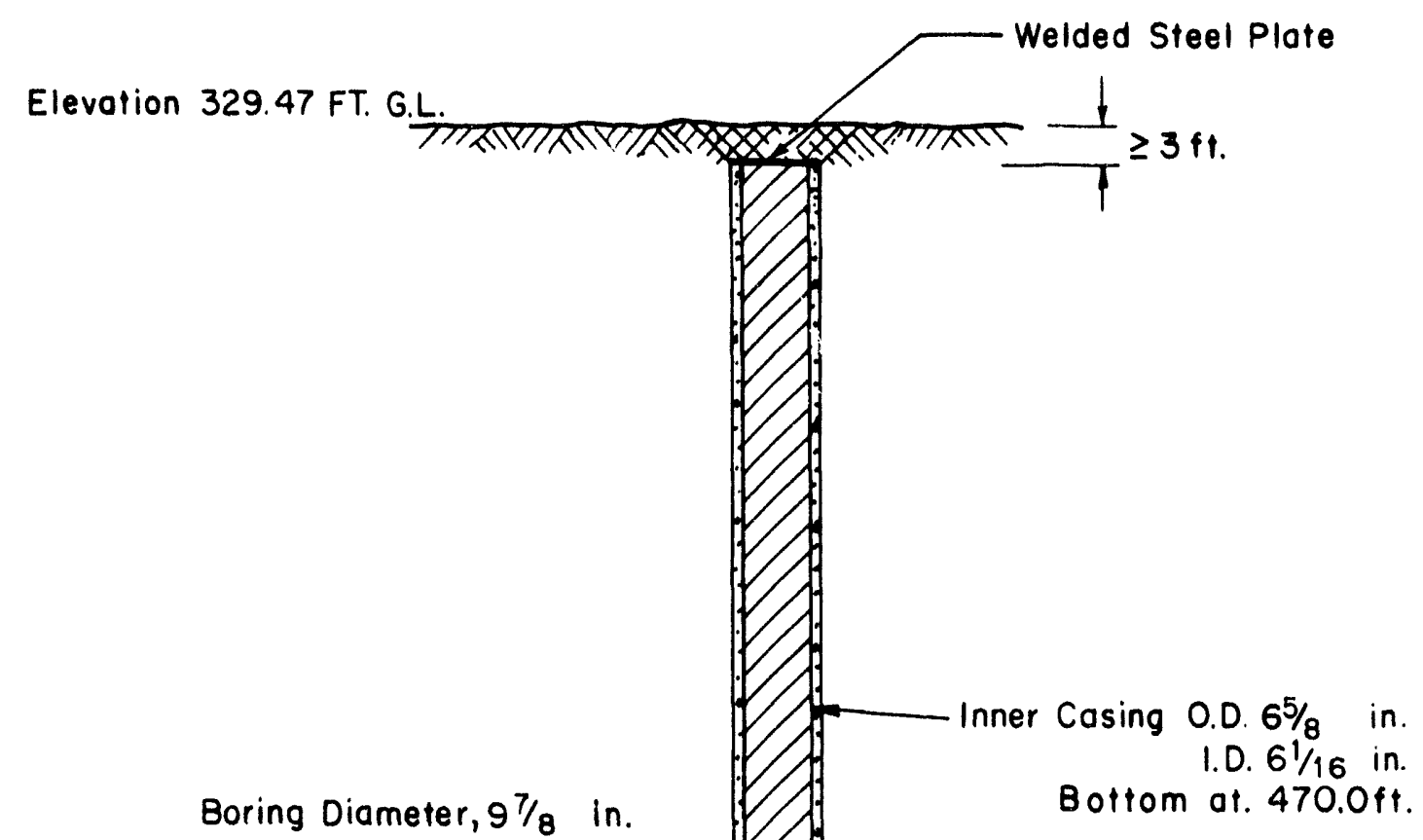

Explanation

Depth: 742.5

$$
\text { Bottom at. } 470.0 \mathrm{ft} \text {. }
$$

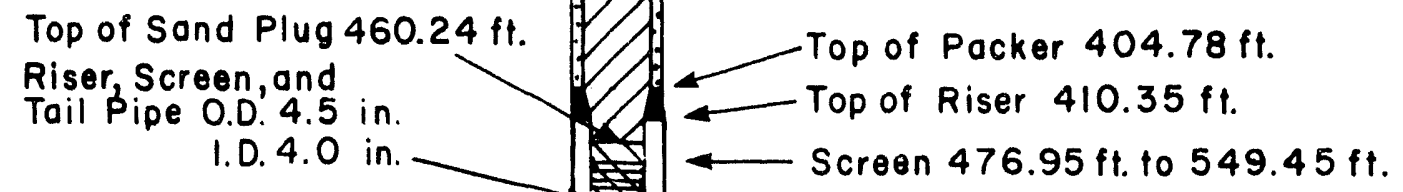

Top of Sand Plug $460.24 \mathrm{ft}$. Riser, Screen, and Tail Pipe O.D. $4.5 \mathrm{in}$. I.D. $4.0 \mathrm{in}$.

-Top of Packer $404.78 \mathrm{ft}$.

- Top of Riser $410.35 \mathrm{ft}$.

$\longleftarrow$ Screen $476.95 \mathrm{ft}$ to $549.45 \mathrm{ft}$.

$\mathrm{ft}$.

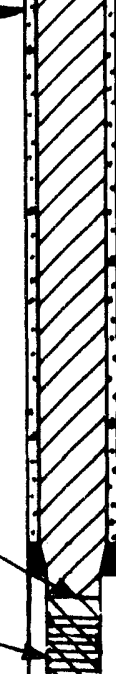

Gravel Pock

$431.07 \mathrm{ft}$ 1 $10.602 .27 \mathrm{ft}$. Bottom of Tail Pipe 595.0ft.

Screen $579.35 \mathrm{ft}$ to $589.8 \mathrm{ft}$.

$\longleftarrow$ Top of Cement Plug $607.27 \mathrm{ft}$.

$\because \because$

$\therefore \therefore$ Cement: Placed by others

W Gravel Pack: Placed by others

ए7

Cement-Bentonite Plug: Placed for abondonment

Total Depth $742.5 \mathrm{ft}$.

Backfilled Soil

$\Delta$ sand

\section{Notes :}

1. Not to scale

2. Depths Referenced to Ground Level (G.L.) 


\begin{tabular}{|c|c|c|c|}
\hline $\begin{array}{l}\text { CLIENT DOE / SRPO } \\
\text { STATE } \\
\text { LOUISIANA }\end{array}$ & $\begin{array}{c}\text { J.0. No. } 17500.26 \\
\text { KCLL NAME E NUMBER } \\
\text { KCI HODGE LH-17A }\end{array}$ & $\begin{array}{c}\text { TFSC FIELD REPRESENTATIVE } \\
\text { L. TYRALA }\end{array}$ \\
\hline
\end{tabular}
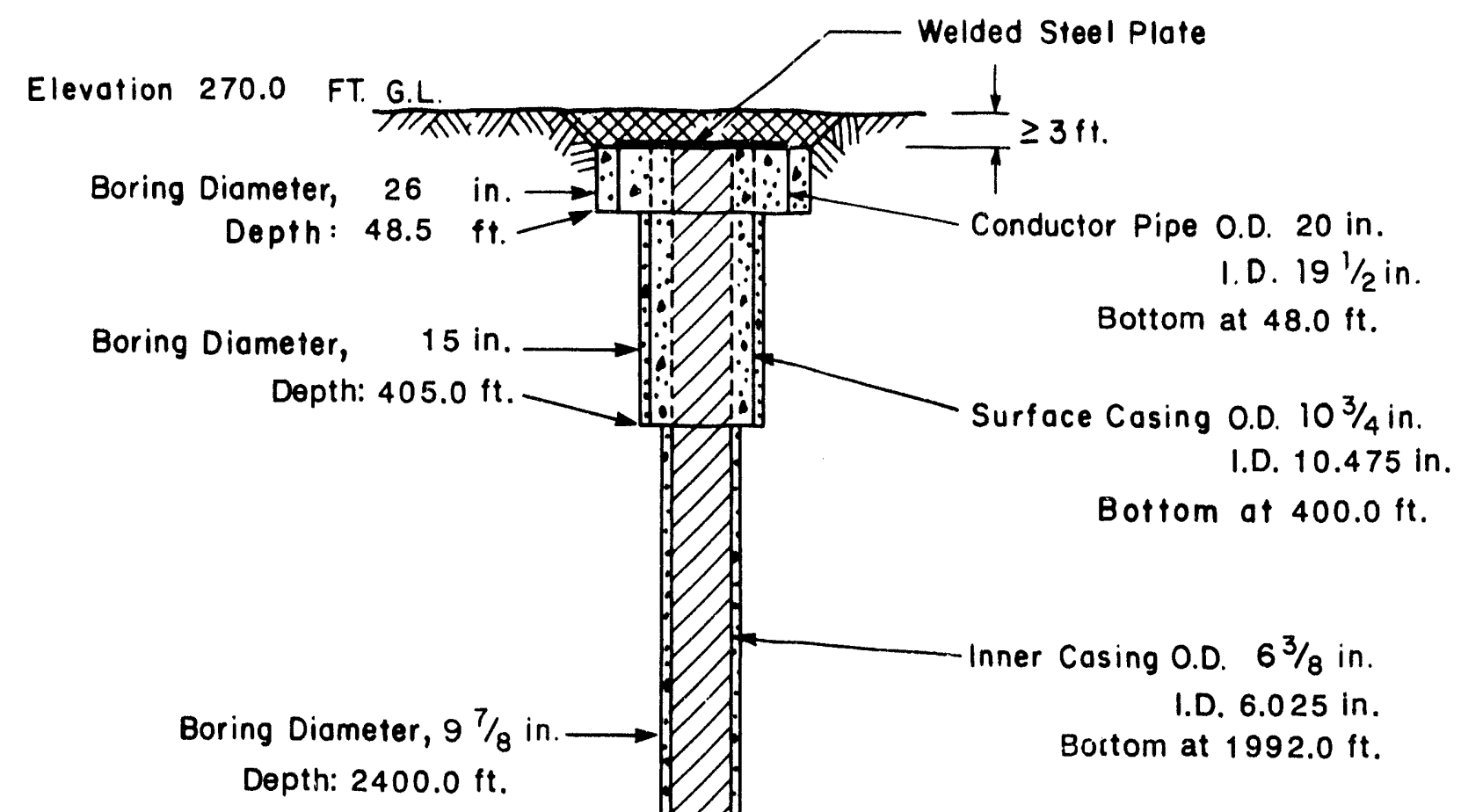

Top of Sand Plug $1959.0 \mathrm{ft}$. Riser, Screen and
Tail Pipe O.D. 4.5 I.D. 4.2 in Bortom at $1992.0 \mathrm{ft}$.

Depth: $2400.0 \mathrm{ft}$.

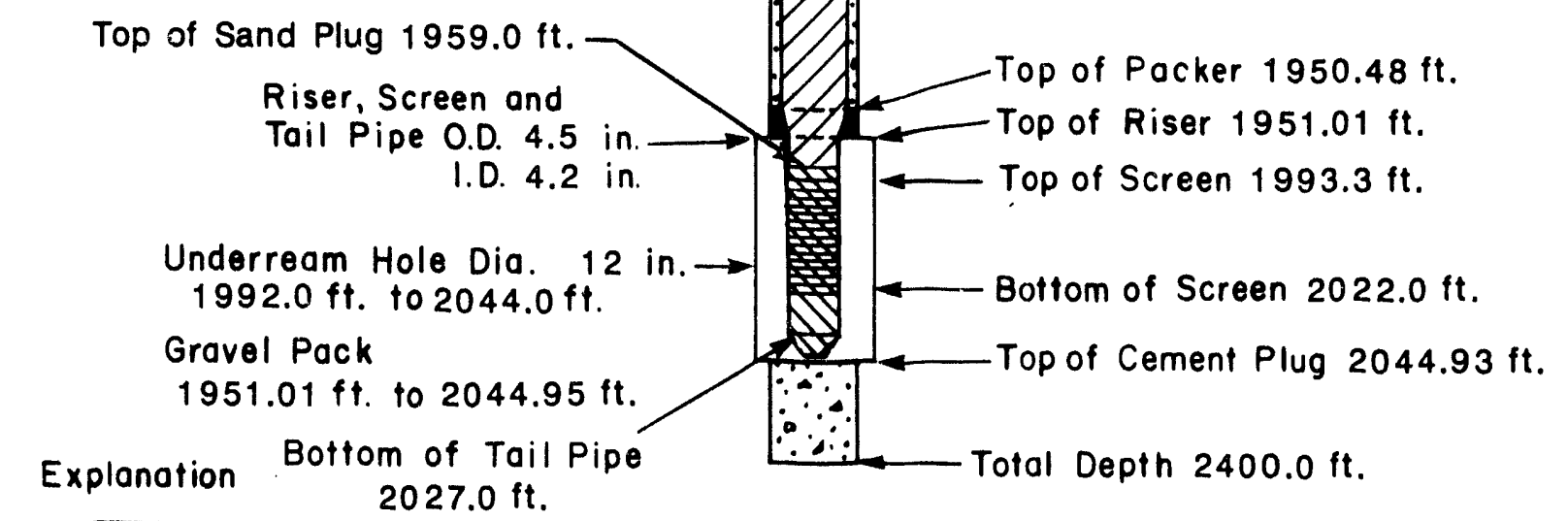

$\because \therefore$ Cement: Placed by others

Gravel Pack: Placed by others

Notes:

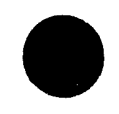

V7

Cement-Bentonite Plug: Placed for abandonment

1. Not to scale

Backfilled Soil

2. Depths Referenced to Ground Level (G.L.)

$\Delta \nabla$ sand 


\begin{tabular}{|l|c|c|c|}
\hline \multicolumn{2}{|c|}{ CLIENT DOE / SRPO } & $\begin{array}{l}\text { J.0. No. } \\
17500.26\end{array}$ & $\begin{array}{c}\text { DATE } \\
11 / 4 / 88\end{array}$ \\
\hline $\begin{array}{c}\text { STATE } \\
\text { LOUISIANA }\end{array}$ & $\begin{array}{c}\text { WELL NAME \& NUMBER } \\
\text { KCI HODGE LH-17B }\end{array}$ & $\begin{array}{c}\text { TFSC FIELD REPRESENTATIVE } \\
\text { W.C. BRANDON }\end{array}$ \\
\hline
\end{tabular}

Elevation 269.72 FT. G.L.
Boring Diometer, 26 in.

Depth: $47.77 \mathrm{ft}$.

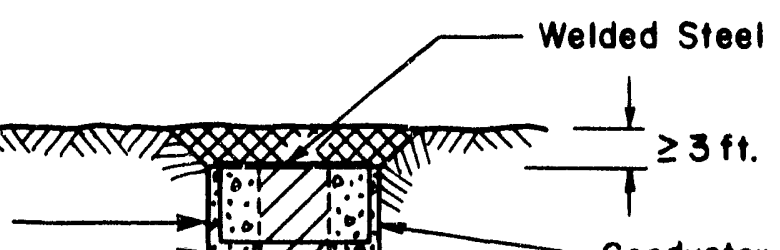

Boring Diameter, $97 / 8$ in Inner Cosing O.D. $6 \frac{5}{8}$ in. I.D. 6.025 in.

Depth: $1312.0 \mathrm{ft}$.

Top of Sand Plug $1298.35 \mathrm{ft}$. Riser, Screen and Tail Pipe O.D. 4.5 in. I.D. 4.048 in. Underream Hole Dia. 12 in. $1312.0 \mathrm{ft}$. to $1385.0 \mathrm{ft}$.

Gravel Pack $1269.32 \mathrm{ft}$. to $1385.0 \mathrm{ft}$. Bottom at $1312.0 \mathrm{ft}$. Bottom at $47.77 \mathrm{ft}$.

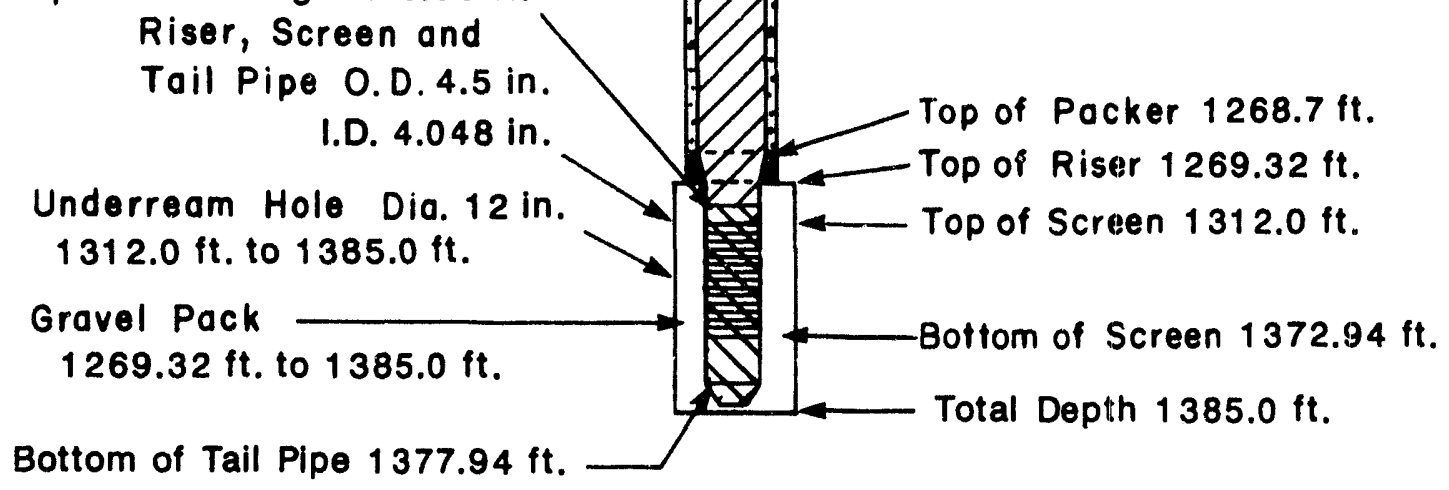

\section{Explanation}

$\because \because 0$ Cement: Ploced by others

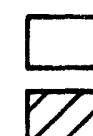

Grovel Pack: Placed by others

Cement-Bentonite Plug: Placed for abandonment

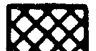

Backfilled Soil

DS sand
Notes:

1. Not to scale

2. Depths Referenced to Ground Level (G.L.) 


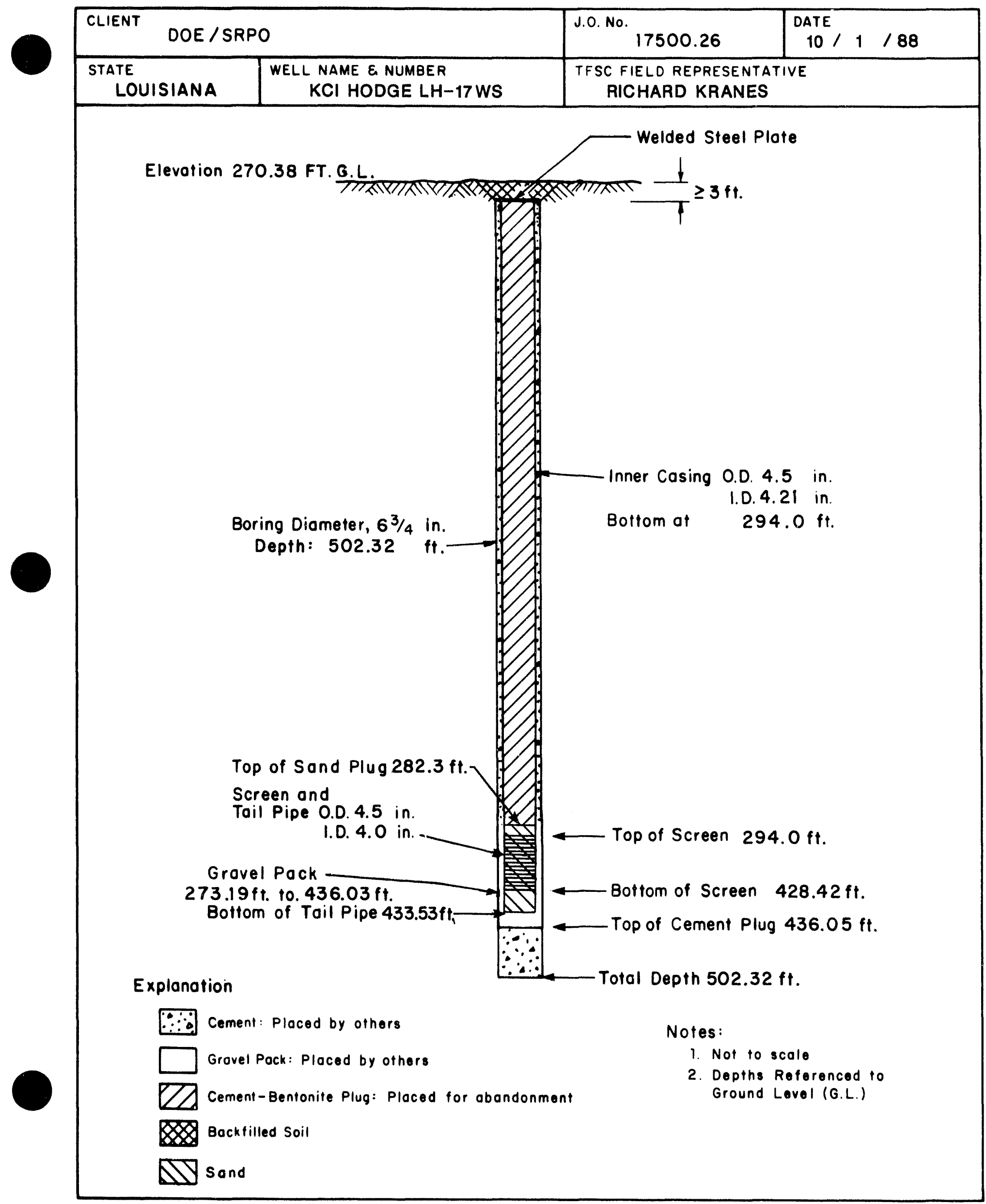




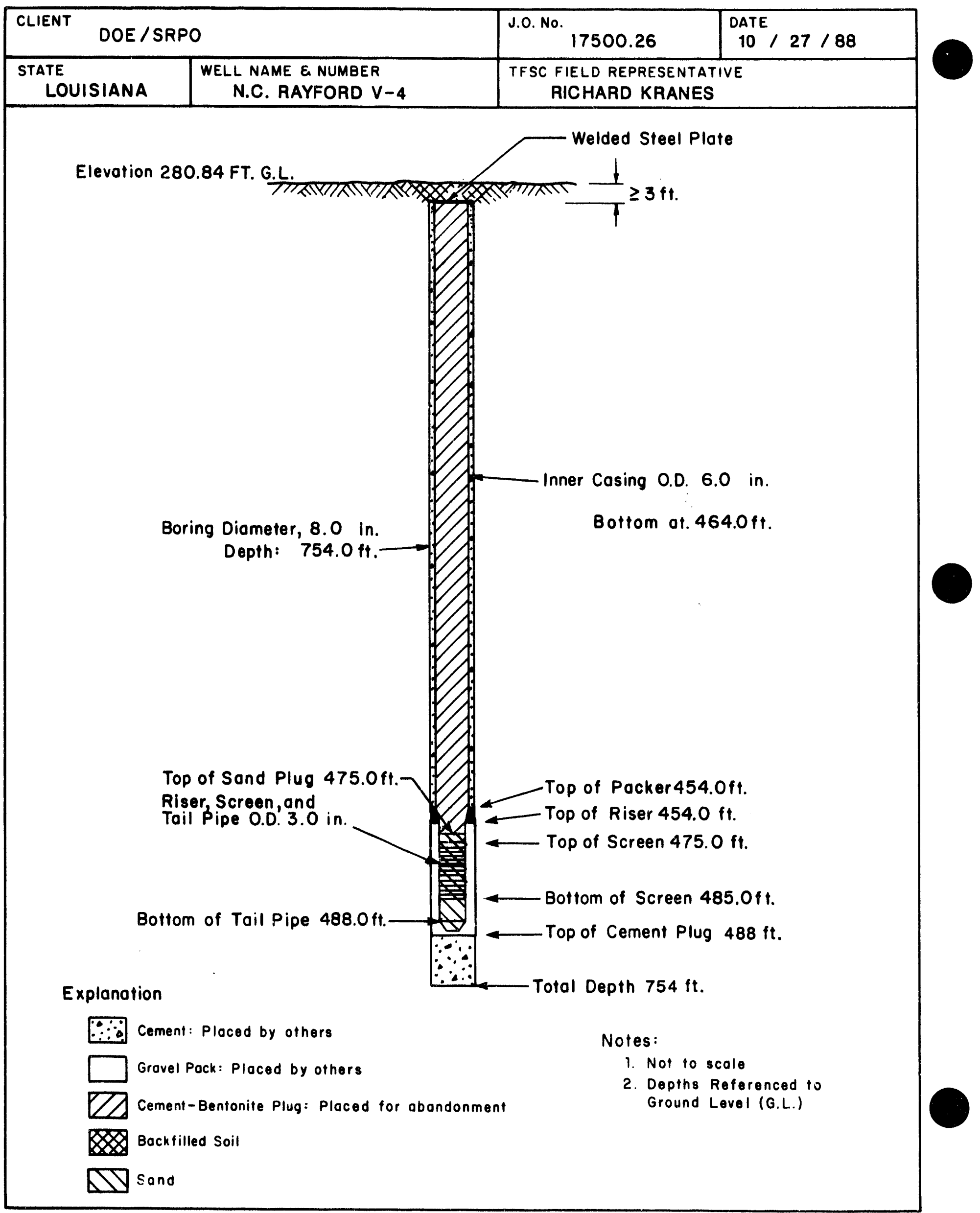




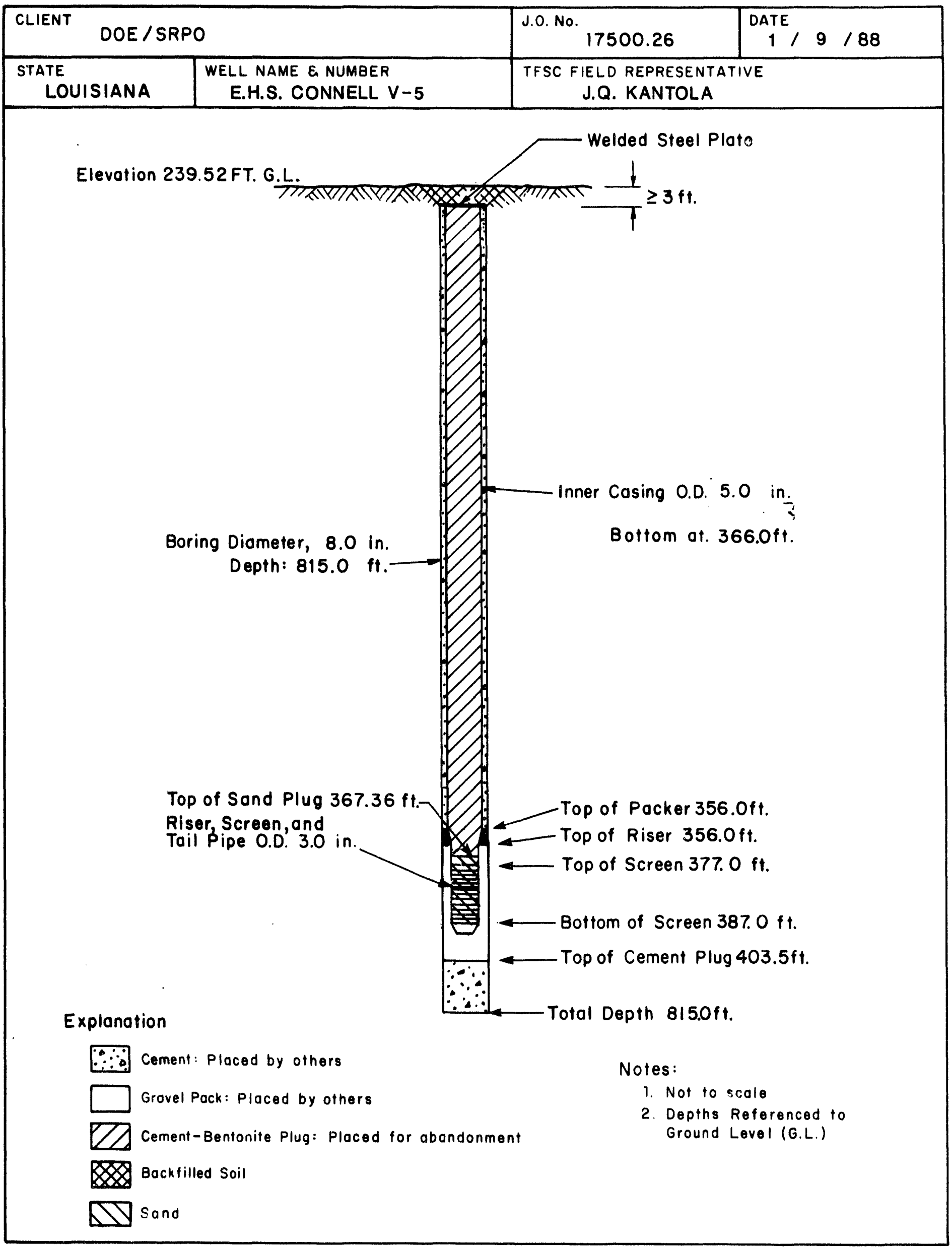




\begin{tabular}{|c|c|c|c|}
\hline CLIENT DOE / SRPO & $\begin{array}{l}\text { J.0. No. } \\
17500.26\end{array}$ & $\begin{array}{c}\text { DATE } \\
10 / 25 / 88\end{array}$ \\
\hline $\begin{array}{c}\text { STATE } \\
\text { LOUISIANA }\end{array}$ & $\begin{array}{c}\text { WELL NAME \& NUMBER } \\
\text { G.P. THEUS V-6 }\end{array}$ & $\begin{array}{c}\text { TFSC FIELD REPRESENTATIVE } \\
\text { C.A. FOSTER }\end{array}$ \\
\hline
\end{tabular}

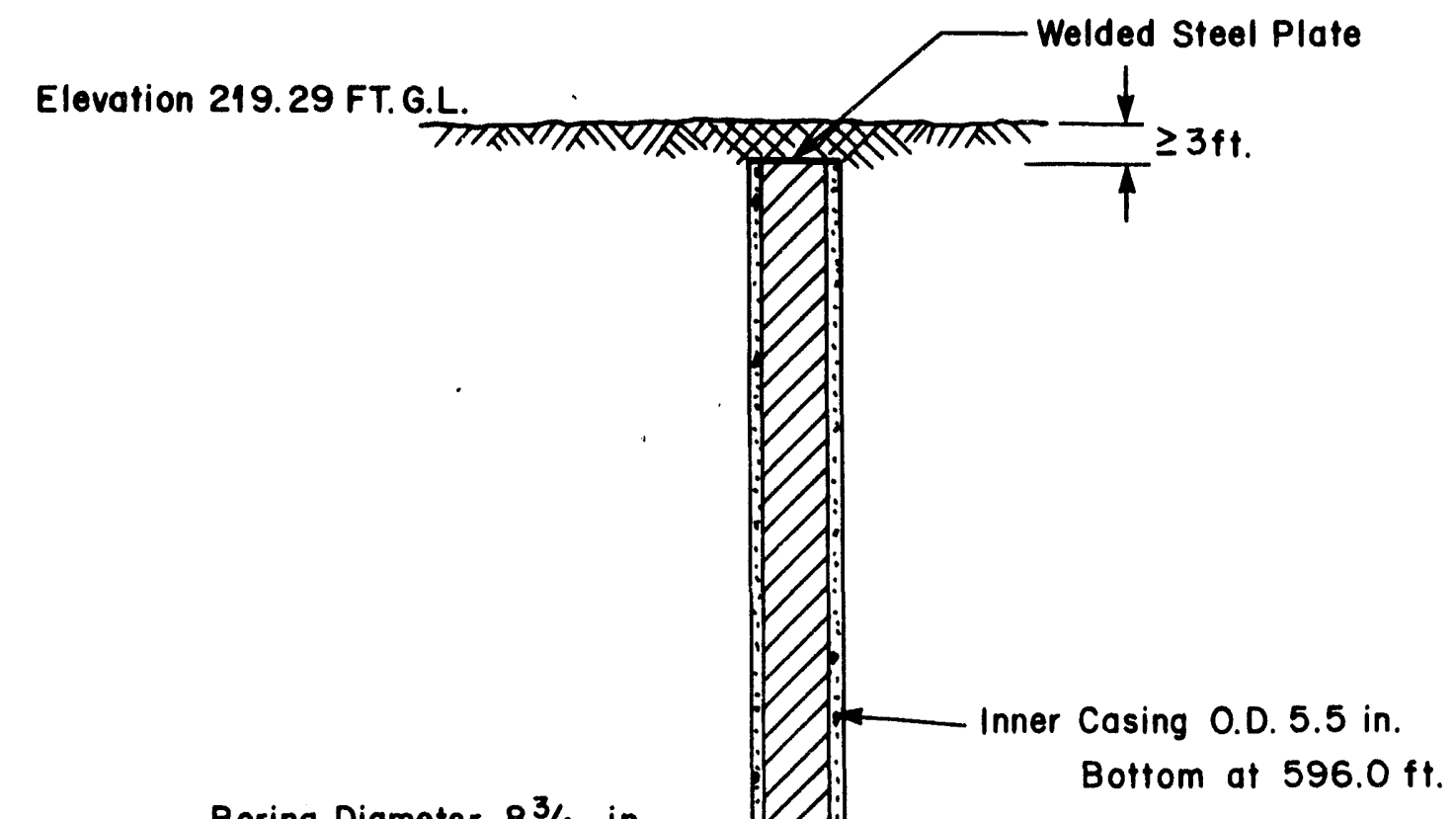

Explanation

Boring Diameter, $8 \frac{3}{4}$ in.

Depth: 643.0

Bottom at $596.0 \mathrm{ft}$.

Cement: Ploced by others

$\square$ Gravel Pack: Placed by others

7 Cement-Bentonite Plug: Placed for abandonment

Q8 Backfilled Soil
Notes:

1. Not to scale

2. Depths Referenced to Ground Level (G.L.) 


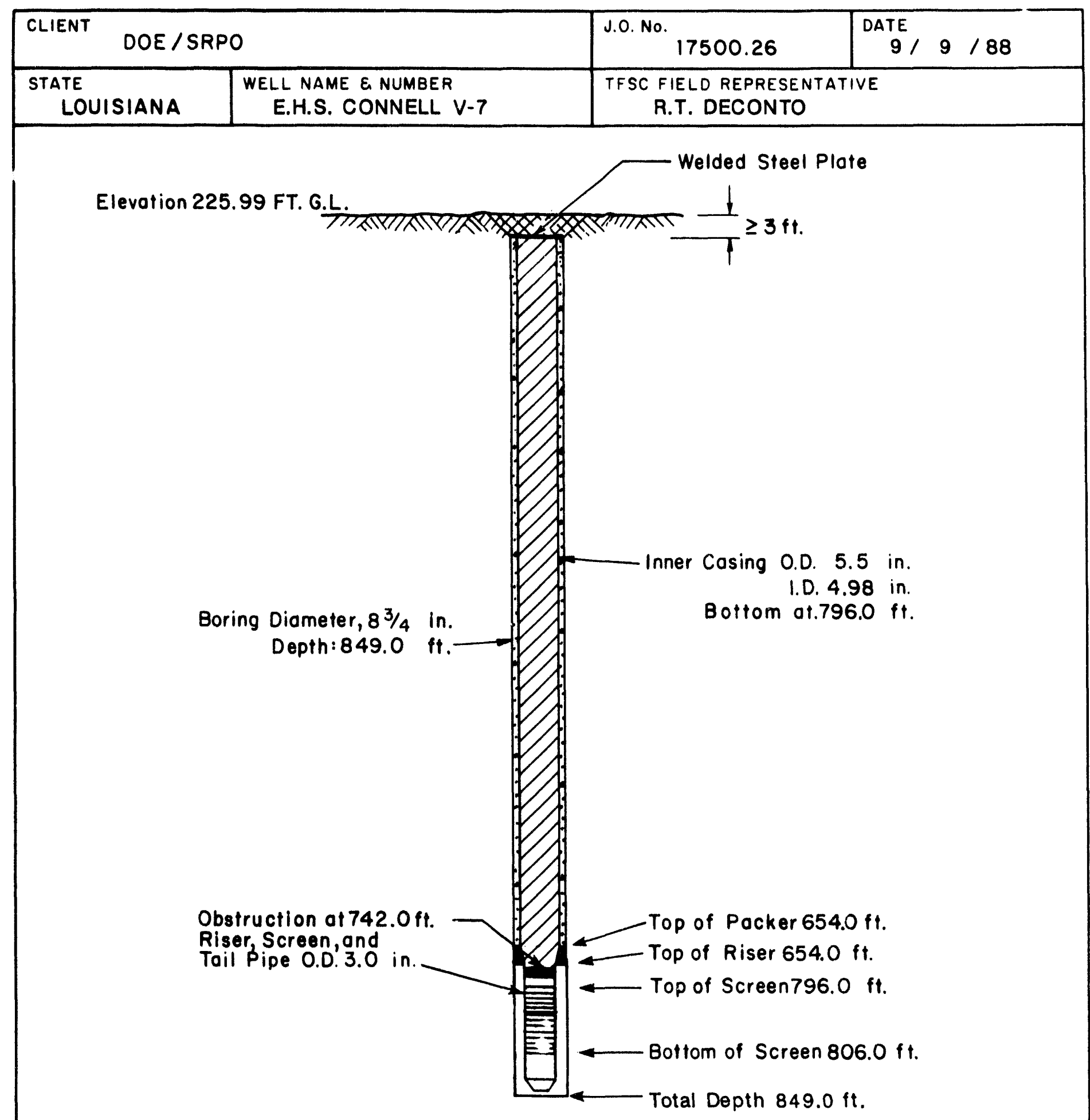

\section{Explanation}

$\because \because$ Cement : Placed by others

Gravel Pack: Placed by others

Cement-Bentonite Plug: Placed for abandonment

Backfilled Soil
Notes:

1. Not to scale

2. Depths Referenced to Ground Level (G.L.) 


\begin{tabular}{|c|l|c|c|}
\hline CLIENT DOE / SRPO & $\begin{array}{l}\text { J.0. No. } 17500.26 \\
\text { DATE } \\
11 / 7 / 88\end{array}$ \\
\hline $\begin{array}{c}\text { STATE } \\
\text { LOUISIANA }\end{array}$ & $\begin{array}{c}\text { WELL NAME \& NUMBER } \\
\text { DOE Smith of al. No. } 1\end{array}$ & $\begin{array}{c}\text { TFSC FIELD REPRESENTATIVE } \\
\text { R. KRANES }\end{array}$ \\
\hline
\end{tabular}

$\begin{array}{lll}\text { Elevation } 227.7 \text { FT. G.L. } & \\ \text { Boring Diameter, } 24 \text { in. } \longrightarrow & \end{array}$

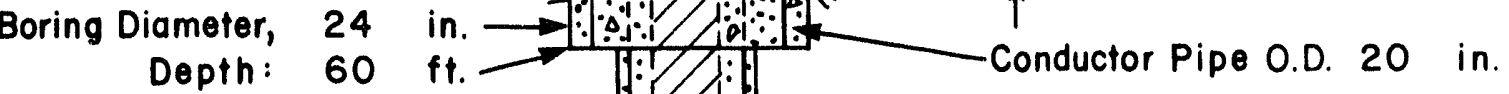

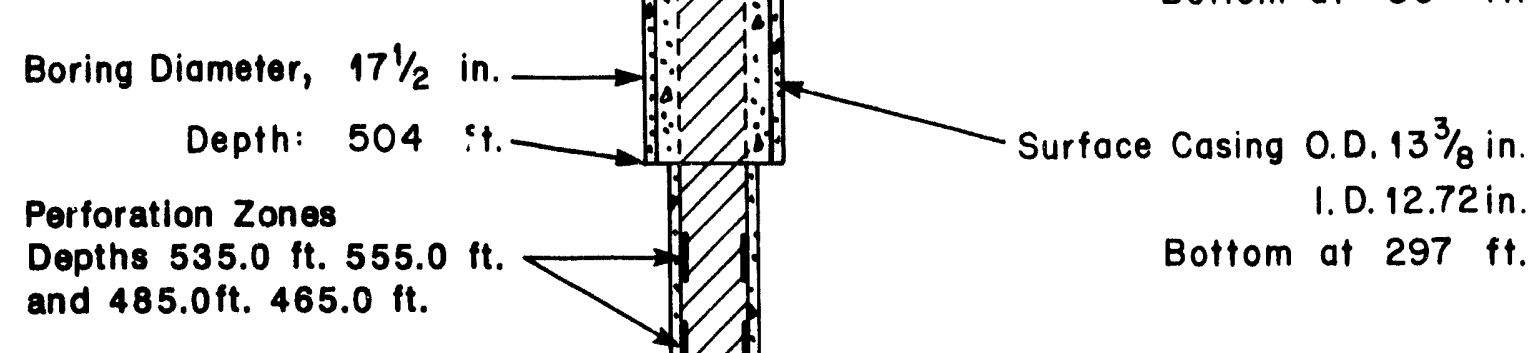

and $485.0 \mathrm{ft} .465 .0 \mathrm{ft}$.

Bottom at $297 \mathrm{ft}$.

Boring Diameter, $8 \frac{1}{2}$ in

Depth: $5,043 \mathrm{ft}$.

Explanation

Total Depth $5,043 \mathrm{ft}$.

Coment: Placed by others

Open Hole w/Saturated Brine

Notes:

4 Botfom of Plug at 1,028.56

I.D.8.84in.

Bottom at $972 \mathrm{ft}$.

Depth: $980 \mathrm{ft}$.

2. Depths Referenced to Ground Level (G.L.) 


\begin{tabular}{|c|c|c|c|}
\hline \multicolumn{2}{|c|}{ CLIENT DOE / SRPO } & J.O. No. 17500.26 & DATE $11 / 3 / 88$ \\
\hline $\begin{array}{l}\text { STATE } \\
\text { LOUISIANA }\end{array}$ & $\begin{array}{l}\text { WELL NAME \& NUMBER } \\
\text { DOE CONTINENTAL F.I. No.I }\end{array}$ & $\begin{array}{r}\text { TFSC FIELD REPR } \\
\text { L. }\end{array}$ & \\
\hline
\end{tabular}

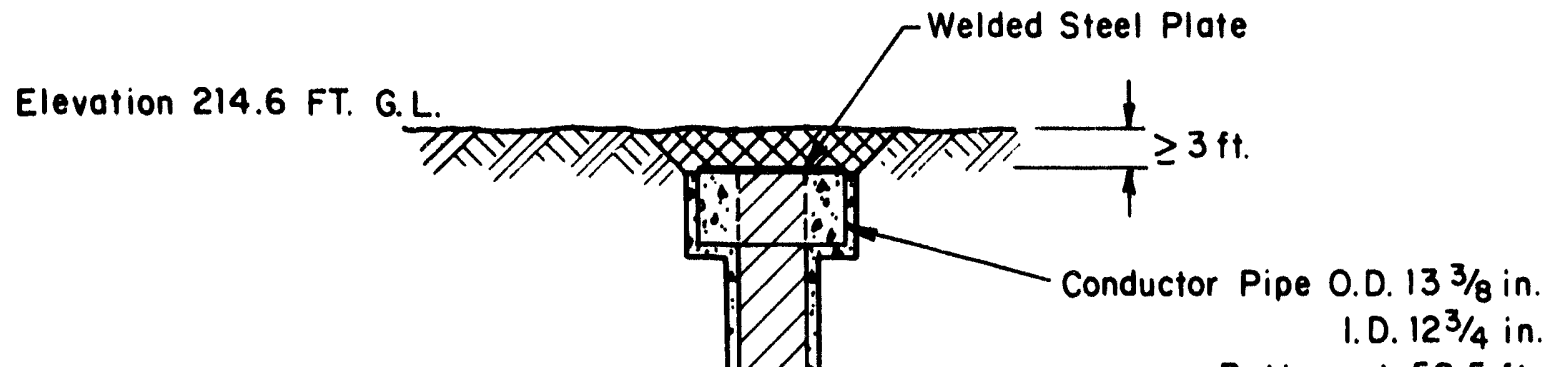

Bottom at $58.5 \mathrm{ft}$.

Inner Cosing 0.0. $95 / 8$ in.

I.D. $8.84 \mathrm{in}$.

Boring Diameter, $12 \frac{1 / 4}{4}$ in Bottom of $412.7 \mathrm{ft}$.

Depth: $418.7 \mathrm{ft}$.

Bottom of Cement Plug at $478.4 \mathrm{ft}$.

Boring Diameter, $81 / 2$ in. $\longrightarrow$

Depth, $5001.7 \mathrm{ft}$.

Total Depth, $5001.7 \mathrm{ft}$.

\section{Explanation}

Cement: Placed by others

Open Hole w/Saturated Brine

Cement-Bentonite Plug: Placed for abandonment

Backfilled Soil
Notes:

1. Not to scale

c. Depths Referenced to

- Ground Level (G.L.) 


\begin{tabular}{|c|c|c|c|}
\hline CLIENT DOE / SRPO & $\begin{array}{c}\text { J. No. } \\
17500.26\end{array}$ & $\begin{array}{c}\text { DATE } \\
10 / 31 / 88\end{array}$ \\
\hline $\begin{array}{c}\text { STATE } \\
\text { LOUISIANA }\end{array}$ & $\begin{array}{c}\text { WELL NAME \& NUMBER } \\
\text { LSU - RIA }\end{array}$ & $\begin{array}{c}\text { TFSC FIELD REPRESENTATIVE } \\
\text { RICHARD KRANES }\end{array}$ \\
\hline
\end{tabular}

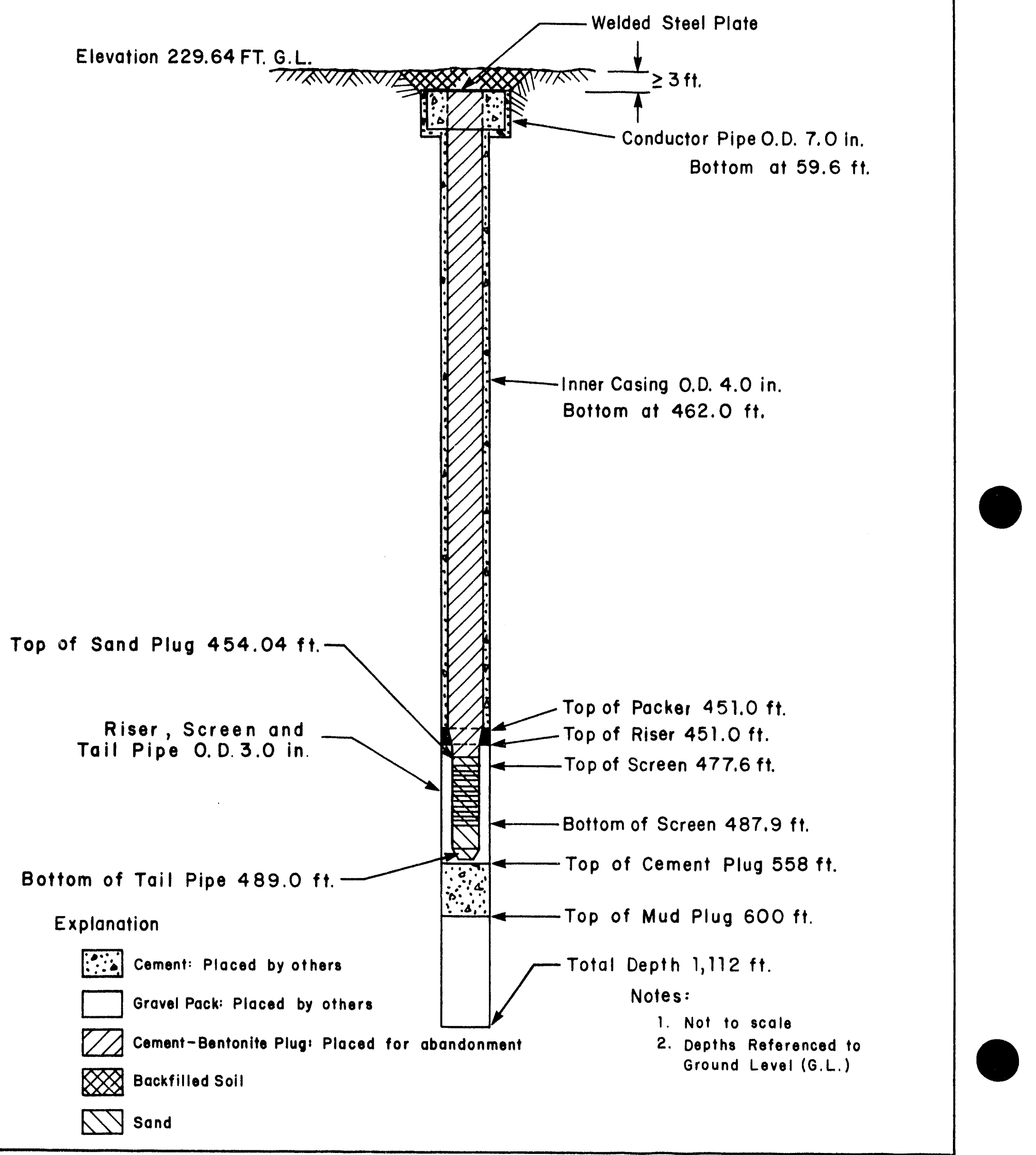


PLUGGING REPORT

(PAGE 1 OF 2)

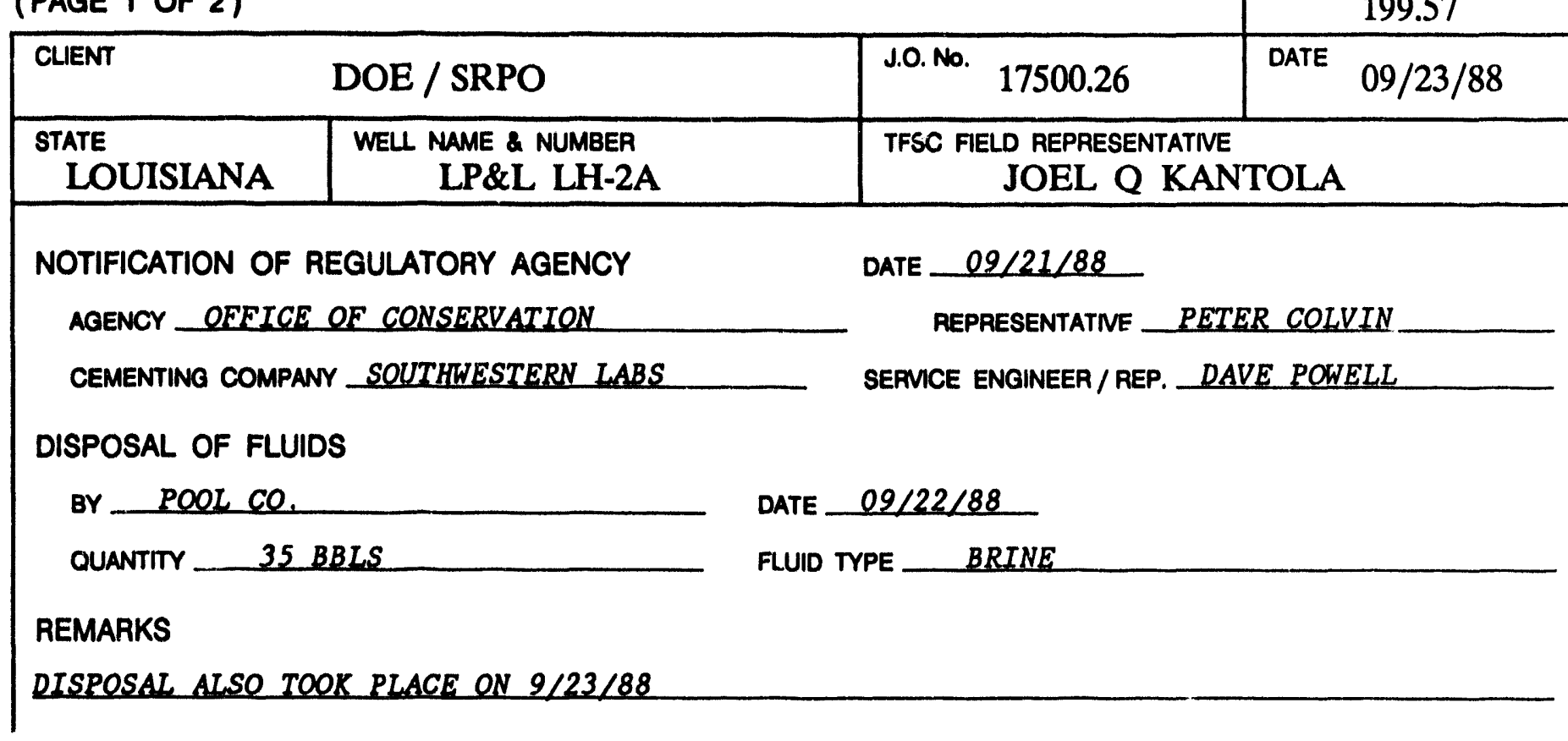

ZONE 1

TYPE PLUG SAND

INTERVAL $1795.88^{\prime}$ TO $1652.13^{\prime}$

DIAMETER OF CASING/HOLE 4.1 IN

BOTTOM OF TUBING OR PIPE 1640.12 FT CEMENT/MUD TYPE NA

NO. OF SACKS 14 YIELD * CU.FT/SK

SLURAY WEIGHT NA LBS/GAL

BRIDGE PLUG TYPE NA

TOP OF PLUG $1652.13 \mathrm{FT}$

REMARKS

* 10.26 LE/SK: ** AMT. PUMPED 143.75 LN FT.

ZONE 2

INTERNAL 1652.13 TO $215.57 \mathrm{FI}$
TYPE PLUG STAGED CEMENT

DIAMETER OF CASING/HOLE 4.1 AND 6.13 IN

BOTTOM OF TUBING OR PIPE 1639.95 FT CEMENT/MUD TYPE TYPE A WITH 88 BENTONITE NO. OF SACKS $180 \quad$ YIELD 1.86 CU.FT/SK. VOL PUMPED 334.8 CU.FT SLURRY WEIGHT 13.1 TO 13.3 LBS/GAL TOP OF PLUG $215.57 \mathrm{FT}$ BRIDGE PLUG TYPE SAND PLUG DEPTH_1795.88 TO 1652.13 REMARKS

O.C. P. COLVIN AGREED STAGE CEMENTING WAS SUFFICIENT IF TUBING BOTTOM WAS KEPT BENEATH CEMENT TOP. THREE STAGES PUMPED. TUBING DEPTH SET AT 1639.52 FT. 861.68 FT., AND $683.08 \mathrm{FT}$. 


\section{PLUGGING REPORT}

(PAGE 2 OF 2 )

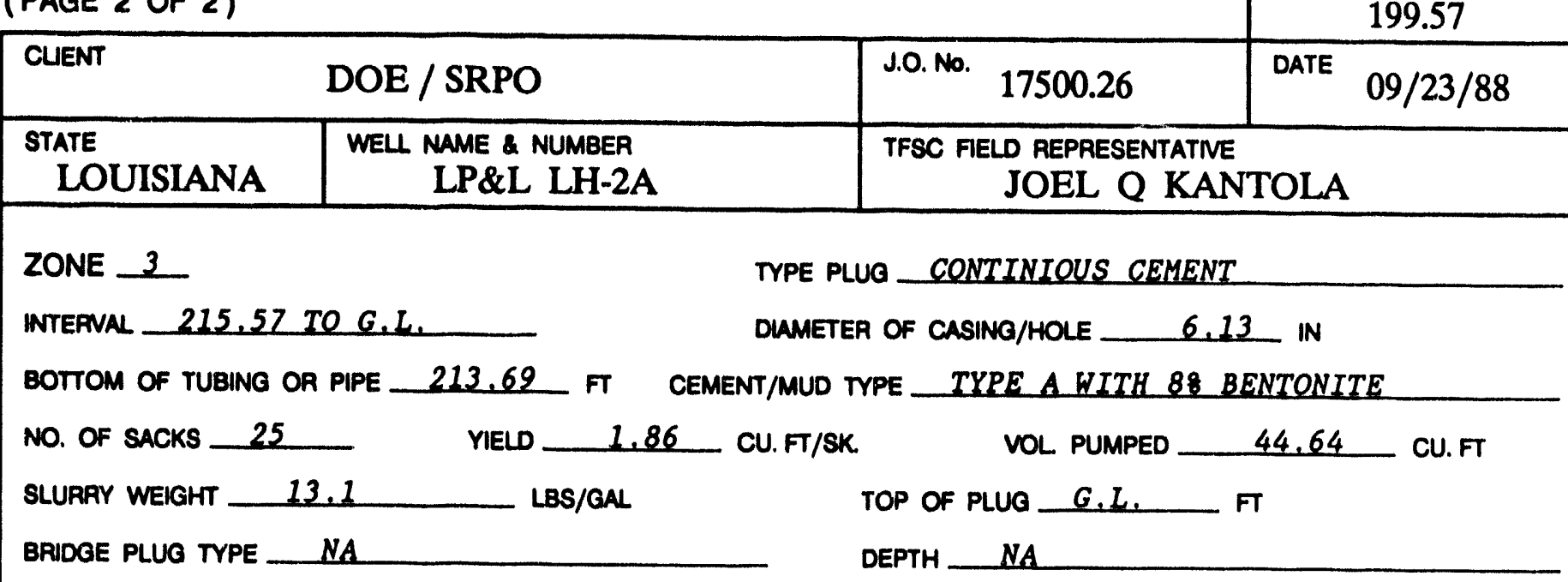

REMARKS

TOTAL NO. OF SACKS NEEDED CALCULATED TO BE 178 SKS BUT 205 SKS WERE REOUIRED.

ZONE

INTERNAL

BOTTOM OF TUBING OR PIPE LBS/GAL

SLURRY WEIGHT

BRIDGE PLUG TYPE

REMARKS
TYPE PLUG

DIAMETER OF CASING/HOLE IN
NO. OF SACKS
CU. FT/SK.
VOL. PUMPED
CU. FT CEMENT/MUD TYPE

TOP OF PLUG FT

DEPTH

\section{REMARS}

ZONE

INTERVAL

BOTTOM OF TUBING OR PIPE

NO. OF SACKS

SLURAY WEIGHT

BRIDGE PLUG TYPE

REMARKS
TYPE PLUG

DIAMETER OF CASING/HOLE IN CEMENT/MUD TYPE CU. FT/SK.

VOL. PUMPED CU. FT FT LBS/GAL

TOP OF PLUG DEPTH 


\section{PLUGGING REPORT}

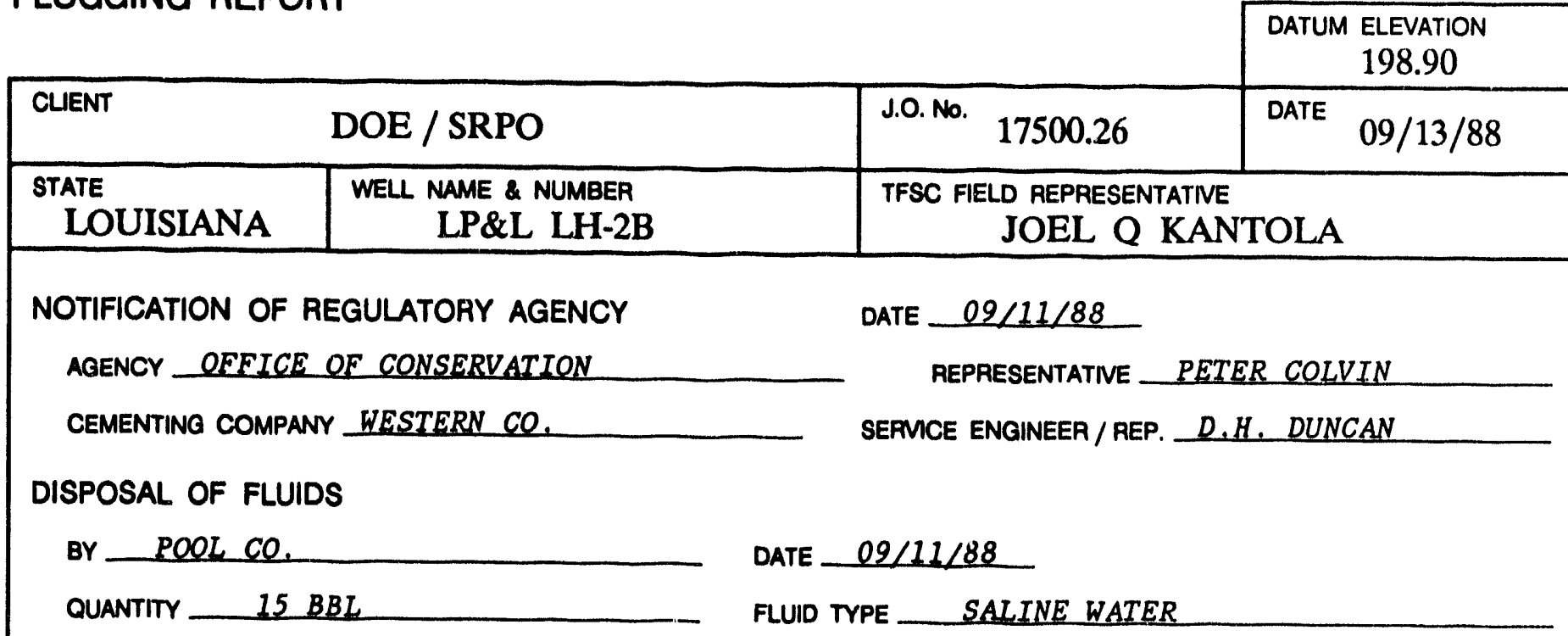

\section{REMARKS}

ZONE 1

TYPE PLUG CONTINUOUS CEMENT

INTERVAL 745.3 TO $72.08 \mathrm{FT}$

DIAMETER OF CASING/HOLE $\quad 6.34$ I.D. IN BOTTOM OF TUBING OR PIPE Z742.18 FT CEMENT/MUD TYPE CLASS A. W/ 88 BENTONITE NO. OF SACKS 78 YIELD 1.86 CU.FT/SK. VOL. PUMPED 145 CU.FT SLURRY WEIGHT 13.3 LBS/GAL TOP OF PLUG 72.08 FT BRIDGE PLUG TYPE NA DEPTH NA REMARKS

224.05' OF TUBING STUCK IN HOLE AFTER 78 SACKS OF CEMENT PUMPED. DEPTH OF CEMENT IN STUCK TUBING 737.0',

ZONE 2

INTERVAL 72.08 TO $3 \mathrm{FT}$

BOTTOM OF TUBING OA PIPE
TYPE PLUG CONTINUOUS CEMENT

DIAMETER OF CASING/HOLE $\quad 6.34$ I.D. IN
VOL. PUMPED 35.34 CU.FT TOP OF PLUG 3.0 DEPTH NA BRIDGE PLUG TYPE NA REMARKS

TUBING CEMENTED FROM 737' TO 73' WITH SLURRY WT. 12.6 \#/GAL. THEN CASING/TUBING ANNULUS CEMENTED FROM 72.08 TO G.L. (SLURRY WT. 13.1 \#/GAL). 
PLUGGING REPORT

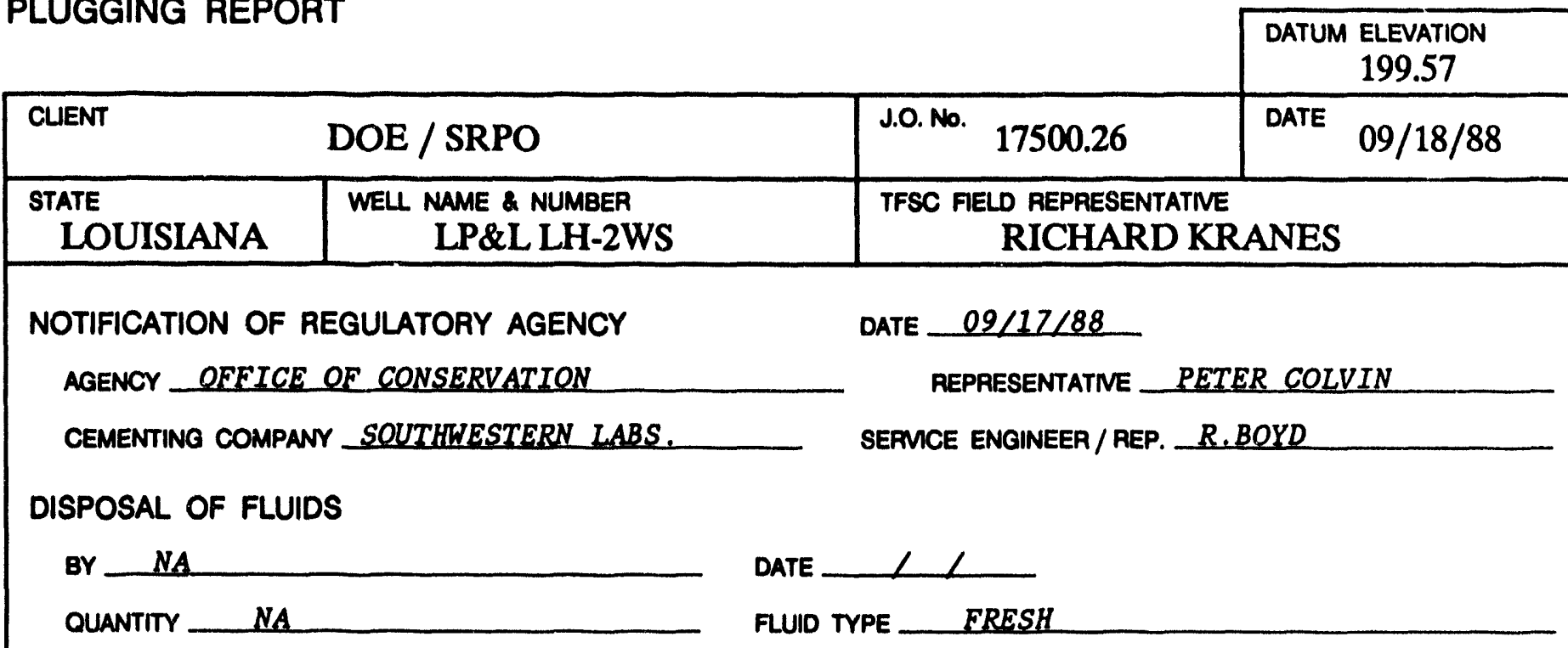

REMARKS

ERESH WATER IN WELL.

ZONE 1

TYPE PLUG CONTINUOUS CEMENT

INTERNAL 134.5 TO $59.33 \mathrm{FT}$

DIAMETER OF CASING/HOLE $\quad 4.08$ IN

BOTTOM OF TUBING OR PIPE NA F CEMENT/MUD TYPE API CLASS A. NEAT

NO. OF SACKS 6 YIELD 1.18 CU. FT/SK. VOL. PUMPED 7.08 CU. FT

SLURRY WEIGHT L 15.2 LBS/GAL TOP OF PLUG **

BRIDGE PLUG TYPE NA DEPTH NA

REMARKS

** CEMENT WAS PUMPED INTO SCREENED AREA THROUGH RETAINER SET AT 58.33 FT (TOP).

ZONE 2

TYPE PLUG CONTINUOUS CEMENT

INTERNAL 59.33 TO SURFACE

DIAMETER OF CASING/HOLE 4.08 I.D. IN

BOTTOM OF TUBING OR PIPE 58.2 FT CEMENT/MUD TYPE CLASS A WITH 88 OF BENTONITE

NO. OF SACKS 3 YIELD 1.86 CU. FT/SK. VOL. PUMPED 5.4 CU. FT

SLURRY WEIGHT 13.2 LBS/GAL TOP OF PLUG G.L.

BRIDGE PLUG TYPE WESTERN WSV RETAINER DEPTH 59.83 TO 58.33 FT

REMARKS 
PLUGGING REPORT

(PAGE 1 OF 2)

\begin{tabular}{|c|c|}
\hline CLIENT & DOE / SRPO \\
\hline $\begin{array}{l}\text { STATE } \\
\text { LOUISIANA }\end{array}$ & $\begin{array}{l}\text { WELL NAME \& NUMBER } \\
\text { KCI HODGE LVH - 6A }\end{array}$ \\
\hline
\end{tabular}

\begin{tabular}{|c|c|}
\hline & $\begin{array}{c}\text { DATUM ELEVATION } \\
223.76\end{array}$ \\
\hline J.O. No. 17500.26 & DATE $10 / 23 / 88$ \\
\hline
\end{tabular}

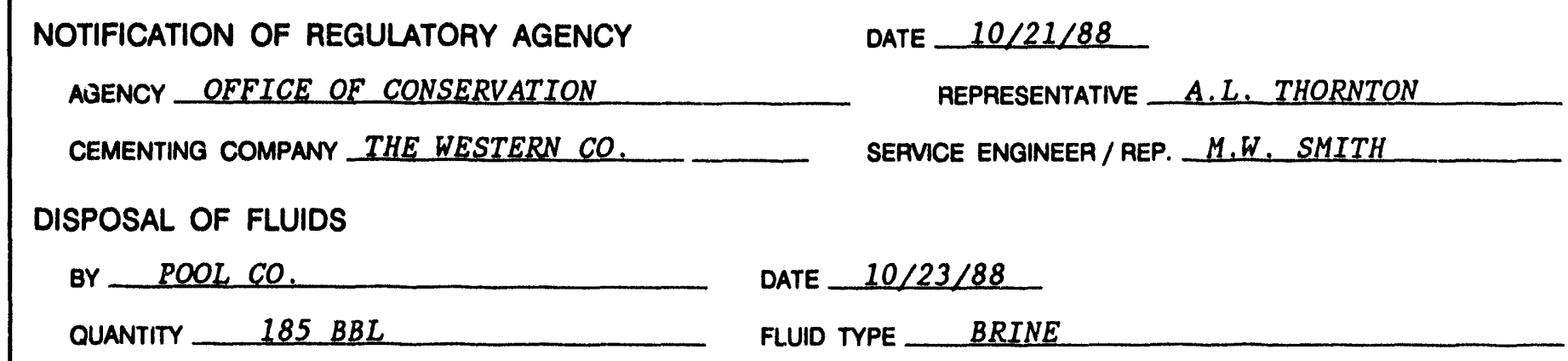

\section{REMARKS}

COLLECTION AND DISPOSAL OF BRINE STARTED ON 10/21 AND WENT UNTIL $10 / 23 / 88$.

ZONE 1

INTERNAL 2505 TO 1348.6

BOTTOM OF TUBING OP PIFE 2496 FT CEMENT/MUD TYPE CLASS A, 88 BENTONITE
TYPE PLUG CONTINUOUS CEMENT

DIAMETER OF CASING/HOLE $\quad 6 \quad 5 / 8$

NO. OF SACKS 162.5 YIELD 1.86 CU.FT/SK. VOL. PUMPED 302 CU.FT

SLURRY WEIGHT 13.2 LBS/GAL TOP OF PLUG 1348.6 FT

BRIDGE PLUG TYPE NA NEPTH NA

REMARKS

OBSTRUCTION AT TOP OF RISER PIPE. 2505 FT (SEE TEXT), DOTD GRANTED VARIENCE TO PLUG ABOVE OBSTRUCTION $(10 / 24 / 88)$. WELL TOOK CEMENT. ALLOWED 12 HOURS TO CURE BEFORE PUMPING SUBSEQUENT PLUG.

ZONE 2

INTERVAL 1348.6 TO $138.3 \mathrm{FT}$
TYPE PLUG CONTINIOUS CEMENT

DIAMETER OF CASING/HOLE $65 / 8$ $\mathbb{N}$

BOTTOM OF TUBING OR PIPE 1348.6 FT CEMENT/MUD TYPE CLASS A. WITH 88 BENTONITE NO. OF SACKS 155 YIELD 1.86 CU. FT/SK. VOL. PUMPED _ 288.3 CU.FT SLURRY WEIGHT LBS/GAL TOP OF PLUG 13.2 L 138.3 FT BRIDGE PLUG TYPE NA NAPTH N NA REMARKS

WELL TOOK CEMENT. ALLOWED 12 HOURS TO CURE BEFORE PUMPING SUBSEQUENT PLUG. 
(PAGE 2 OF 2)

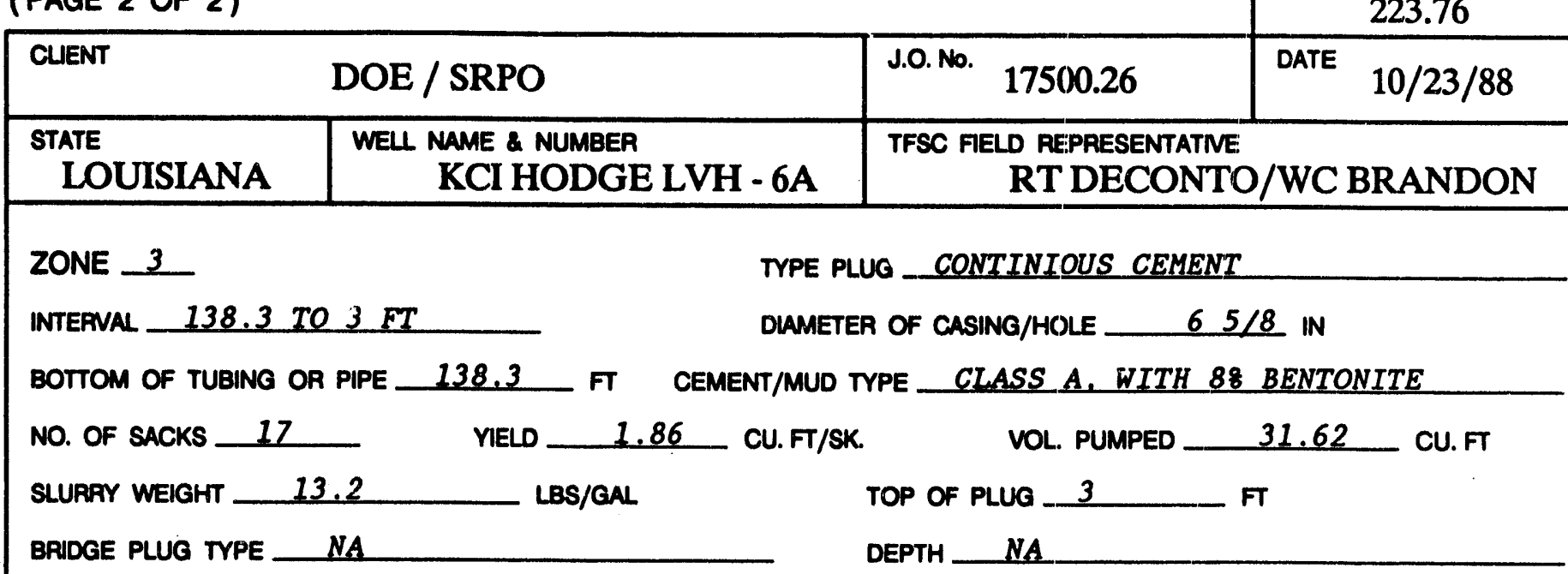

REMARKS

ZONE

TYPE PLUG $6 \quad 5 / 8-10 \quad 3 / 4$ CASING ANNULUS

INTERNAL 42 TO 3 FT

DIAMETER OF CASING/HOLE $N A \quad I N$

BOTTOM OF TUBING OR PIPE 40.25 IT CEMENT/MUD TYPE CLASS A WITH 88 BENTONITE

NO. OF SACKS 7 YIELD 1.86 CU.FT/SK. VOL. PUMPED 13.02 CU.FT

SLURPY WEIGHT LBS/GAL TOP OF PLUG 3.2 FT

BRIDGE PLUG TYPE NA N DEPTH NA

REMARKS

ANNULUS FROM 314 FT TO 42 FT WAS FILLED WITH 87 SACKS OF SAND.

ZONE

TYPE PLUG 10.75-26 FT CASING ANNULUS

INTERNAL 10 TO 3 FT DLAMETER OF CASING/HOLE__ NA IN BOTTOM OF TUBING OR PIPE 9.5 FT CEMENT," "IUD TYPE CLASS A WITH $8 \%$ BENTONITE NO. OF SACKS 8 YIELD 1.86 CU. FT/SK. VOL PUMPED 14.88 CU.FT SLURPY WEIGHT LBS/GAL TOP OF PLUG 3 T T T BAIDGE PLUG TYPE N_ NA DEPTH NA REMARKS 
PLUGGING REPORT

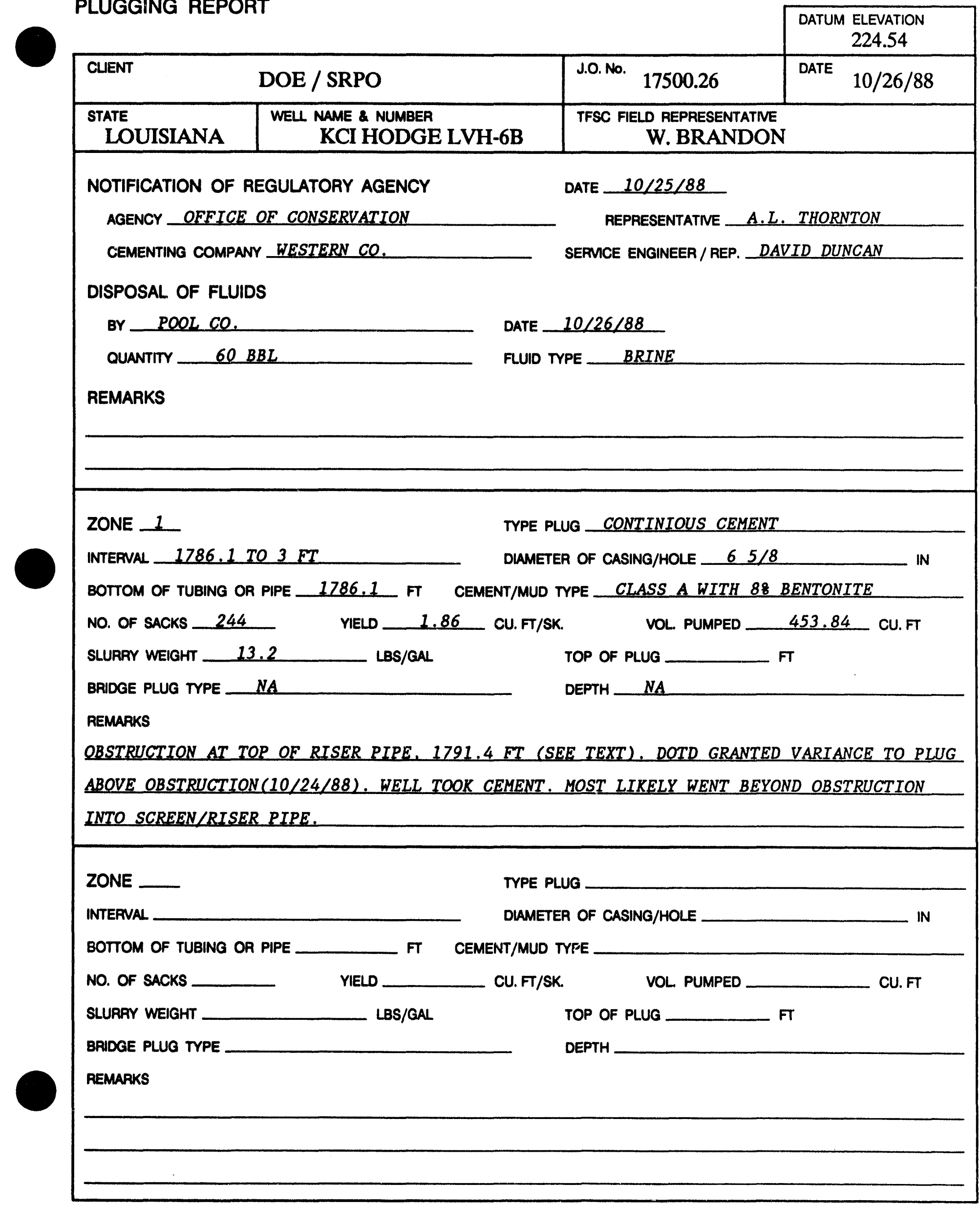




\section{PLUGGING REPORT}

\begin{tabular}{|c|c|c|c|}
\hline & & & 224.92 \\
\hline CLIENT & DOE / SRPO & $\begin{array}{ll}\text { J.O. No. } 17500.26 & \end{array}$ & DATE $10 / 21 / 88$ \\
\hline $\begin{array}{l}\text { STATE } \\
\text { LOUISIANA }\end{array}$ & $\begin{array}{l}\text { WELL NAME \& NUMBER } \\
\text { KCI HODGE LVH - 6C }\end{array}$ & \multicolumn{2}{|c|}{$\begin{array}{l}\text { TFSC FIELD REPRESENTATME } \\
\text { W. BRANDON }\end{array}$} \\
\hline \multicolumn{2}{|c|}{$\begin{array}{l}\text { NOTIFICATIOIN OF REGULATORY AGENCY } \\
\text { AGENCY OFFICE OF CONSERVATION }\end{array}$} & DATE $10 / 20 / 88$ & THORNTON \\
\hline \multicolumn{2}{|c|}{ CEMENTING COMPANY WESTERN CO. } & \multicolumn{2}{|c|}{ SERMCE ENGINEER / REP. M. SMITH } \\
\hline \multicolumn{4}{|c|}{ DISPOSAL OF FLUIDS } \\
\hline \multicolumn{2}{|l|}{ BY POOL CO. } & \multicolumn{2}{|l|}{$10 / 22 / 88$} \\
\hline QUANTITY & FLUID & BRINE & \\
\hline
\end{tabular}

REMARKS

COLLECTION AND DISPOSAL OF BRINE STARTED ON 10/21 AND WENT UNTIL 10/22/88.

ZONE 1

INTERVAL 868.6' TO SURFACE
TYPE PLUG CONTINIOUS CEMENT

DIAMETER OF CASING/HOLE $65 / 8$ in BOTTOM OF TUBING OR PIPE 868.6 FT CEMENT/MUD TYPE CLASS A WITH 88 BENTONITE NO. OF SACKS 95 YIELD 1.86 CU.FT/SK. VOL. PUMPED 176.7 CU.FT SLURAY WEIGHT 13.2 LBS/GAL TOP OF PLUG 113 FT BRIDGE PLUG TPE NA NA DEPTH NA REMARKS OBSTRUCTION AT TOP OF RISER PIPE. 686.6 FT (SEE TEXT). DOTD GRANTED VARIENCE TO PLUG ABOVE OBSTRUCTION. WELL TOOK CEMENT.

\section{ZONE 2}

TYPE PLUG CONTINIOUS CEMENT

INTERNAL 113 TO SURFACE

DLAMETER OF CASING/HOLE $65 / 8$ IN BOTTOM OF TUBING OR PIPE 113 FT CEMENT/MUD TYPE CLASS A WITH 88 BENTONITE NO. OF SACKS 12 YIELD 1.86 CU. TT/SK. VOL. PUMPED 22.32 CU.FT SLURPY WEIGHT 13.2 LBS/GAL TOP OF PLUG G.L. TT BAIDGE PLUG TYPE NA DEPTH NA REMARKS THE ZONE 2 PLUG WAS NECESSARY BECAUSE THE WELL TOOK CEMENT OVERNIGHT. 


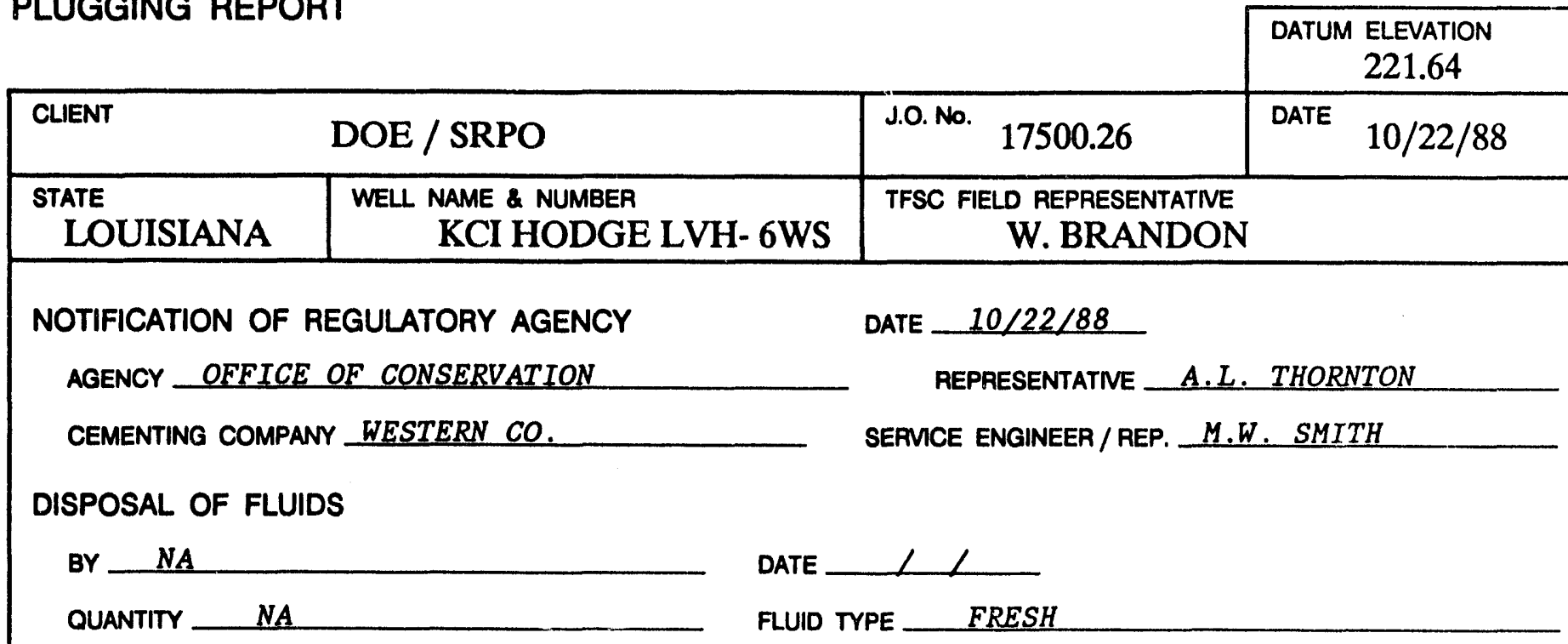

REMARKS

ZONE 1

TYPE PLUG SAND $20-40$ MESH

INTERNAL 93.51 TO $37.75 \mathrm{FT}$

DIAMETER OF CASING/HOLE $\quad 4.127$ IN

BOTTOM OF TUBING OR PIPE NA F CE CEMENT/MUD TYPE_ SAND

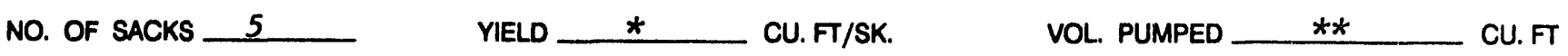
SLURAY WEIGHT NA LBS/GAL TOP OF PLUG 37.75 FT

BRIDGE PLUG TYPE NA NEPTH NA

REMARKS

* 11.15 LF/SKi ** AMT. PLACED 55.76 LN FT.

SAND GRAVITY FED INTO WELL.

ZONE 2

INTERNAL 37.75 TO SURFACE BOTTOM OF TUBING OR PIPE 37 NO. OF SACKS 3 YIELD 1.86 CU. FT/SK. SLURAY WEIGHT 13.2 BRIDGE PLUG TYPE SAND PLUG LBS/GAL REMARKS

TYPE PLUG CONTINUOUS CEMENT

DIAMETER OF CASING/HOLE 4.127 (I.D.) IN

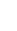


ATTACHMENT 5

PLUGGING REPORT

(PAGE 1 OF 2)

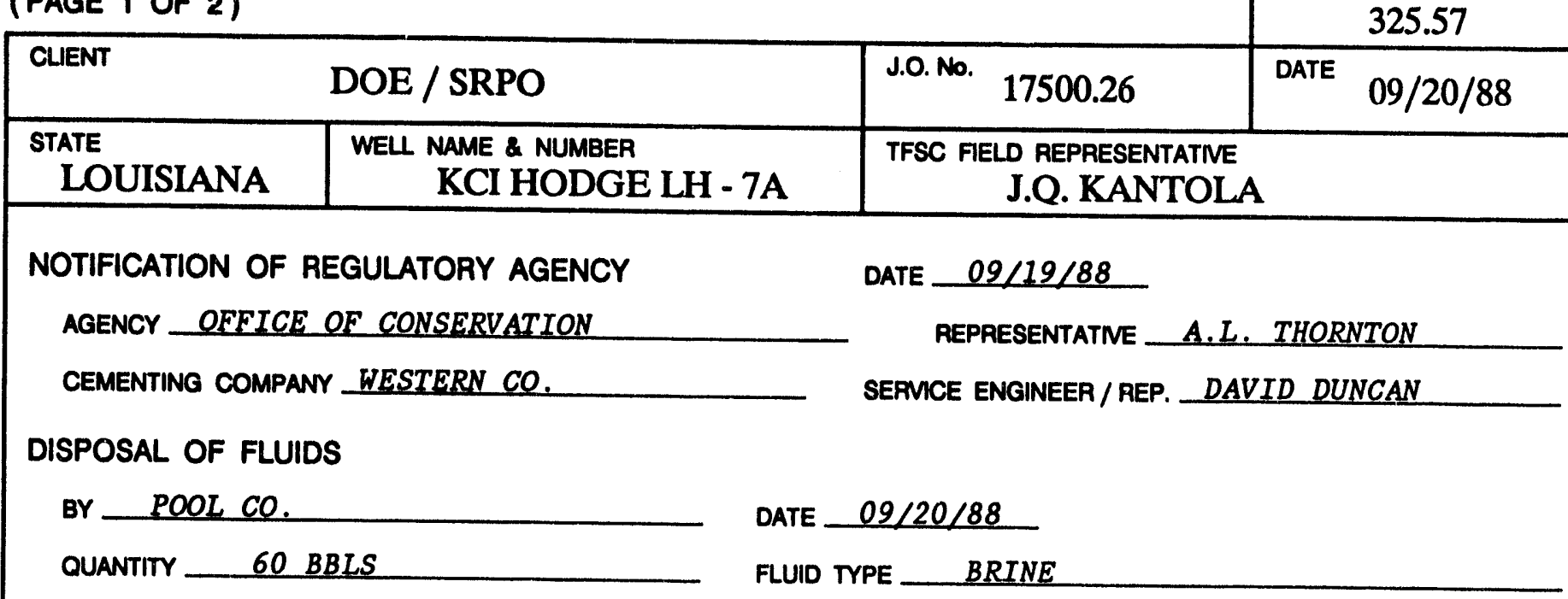

REMARKS

ZONE $*$

TYPE PLUG 6 5/8" TO $123 / 4^{\prime \prime}$ CASING ANNULUS

INTERVAL 58.14 TO G.L.

DIAMETER OF CASING/HOLE _NA

IN

BOTTOM OF TUBING OR PIPE $\quad 58.14$ FT CEMENT/MUD TYPE CLASS A WITH 88 BENTONITE

NO. OF SACKS 22 YIELD 1.86 CU.FT/SK. VOL. PUMPED 40.9 CU.FT

SLURRY WEIGHT 13.3 LBS/GAL TOP OF PLUG G.L. FT

BRIDGE PLUG TYPE _ NA DEPTH N N NA

REMARKS

ANNULUS WAS SOUNDED TO 95', BUT COULD ONLY GET THE 1.0" TUBING TO $58.14^{\prime}$.

ZONE *

TYPE PLUG $123 / 4^{\prime \prime}$ TO 20" CASING ANNULUS

INTERVAL 15.5 TO G.L.

DIAMETER OF CASING/HOLE _ NA IN

BOTTOM OF TUBING OR PIPE 15.37 FT CEMENT/MUD TYPE CLASS A WITH 88 BENTONITE

NO. OF SACKS 10.5 YIELD 1.86 CU.FT/SK. VOL. PUMPED 19.5 CU.FT

SLURPY WEIGHT 13.3 LBS/GAL TOP OF PLUG G.L. FT

BAIDGE PLUG TYPE NA NA DEPTH N NA

REMARKS 
(PAGE 2 OF 2)

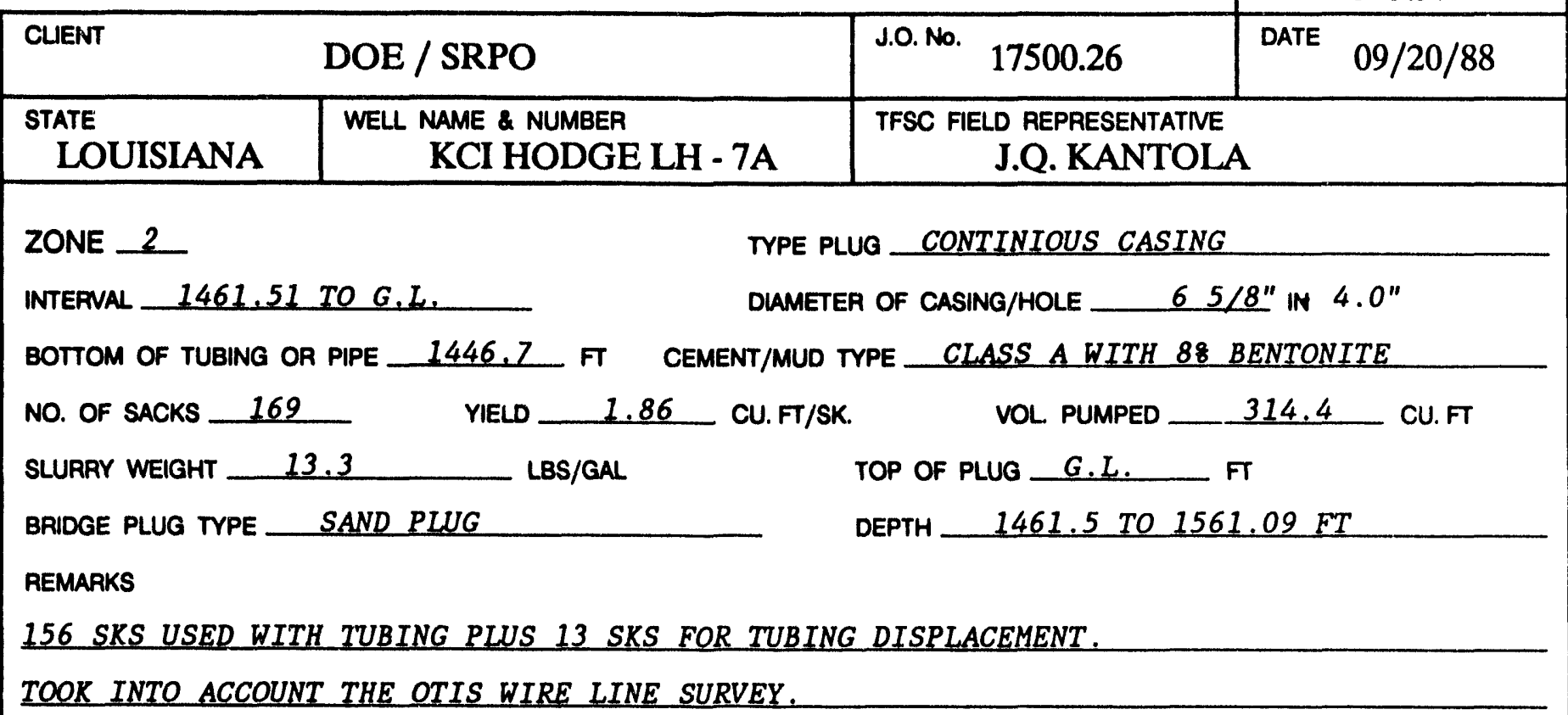

INTERNAL $1561.09-1461.51 \quad$ DIAMETER OF CASING/HOLE $\quad 4.5$ IN

BOTTOM OF TUBING OR PIPE 1470 FT CEMENT/MUD TYPE _ SAND

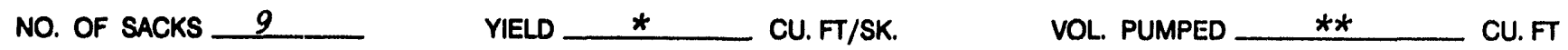

SLURRY WEIGHT NA LBS/GAL TOP OF PLUG 1461.5 FT

BRIDGE PLUG TYPE NA N DEPTH NA

REMARKS

SAND PLUG GRAVITY FED THROUGH 2 3/8" TUBING.*11.06 LN.FT./SK, ** 99.58 LN.FT.

ZONE

INTERVAL

BOTTOM OF TUBING OR PIPE

NO. OF SACKS

SLURRY WEIGHT

BRIDGE PLUG TYPE

REMARKS
TYPE PLUG

DIAMETER OF CASING/HOLE $\mathbb{N}$ FT CEMENT/MUD TYPE YIELD _ CU. FT/SK. VOL. PUMPED CU. FT TOP OF PLUG FT DEPTH 
PLUGGING REPORT

(PAGE 1 OF 2)

\begin{tabular}{|c|c|c|c|}
\hline CLIENT & DOE / SRPO & J.O. No. 17500.26 & DATE $09 / 19 / 88$ \\
\hline $\begin{array}{l}\text { STATE } \\
\text { LOUISIANA }\end{array}$ & $\begin{array}{l}\text { WELL NAME \& NUMBER } \\
\text { KCI HODGE LH - 7B }\end{array}$ & \multicolumn{2}{|c|}{$\begin{array}{c}\text { TFSC FIELD REPRESENTATIVE } \\
\text { R. KRANES }\end{array}$} \\
\hline \multirow{2}{*}{\multicolumn{2}{|c|}{$\begin{array}{l}\text { NOTIFICATION OF REGULATORY AGENCY } \\
\text { AGENCY OFFICE OF CONSERVATION }\end{array}$}} & \multicolumn{2}{|l|}{ DATE $09 / 18 / 88$} \\
\hline & & \multirow{2}{*}{\multicolumn{2}{|c|}{$\begin{array}{l}\text { REPRESENTATIVE A.L. THORNTON } \\
\text { SERMICE ENGINEER / REP. MR. VAN HOORBEKE }\end{array}$}} \\
\hline \multicolumn{2}{|c|}{ CEMENTING COMPANY WESTERN CO. } & & \\
\hline \multicolumn{4}{|c|}{ DISPOSAL OF FLUIDS } \\
\hline \multicolumn{2}{|l|}{ BY POOL CO. } & \multicolumn{2}{|c|}{ DATE $09 / 19 / 88$} \\
\hline \multicolumn{2}{|c|}{ QUANTITY $\quad 60$ BBLS } & BRINE & \\
\hline
\end{tabular}

REMARKS

ZONE _ 1

TYPE PLUG SAND

INTERNAL 1046.97 TO 932 FT.

DIAMETER OF CASING/HOLE _ 4 $\mathbb{N}$

BOTTOM OF TUBING OR PIPE _ 926.59 FT CEMENT/MUD TYPE SAND 20 - 40 MESH

NO. OF SACKS 11 YIELD $\_$CU.FT/SK. VOL. PUMPED $\quad * * \quad$ CU. FT

SLURRY WEIGHT NA LBS/GAL TOP OF PLUG 932

BAIDGE PLUG TYPE N NA DEPTH N NA

REMARKS

SAND GRAVITY FED THROUGH 2 3/8" TUBING.* 10.45 LN.FT./SK ** AMT. PLACED 114.97 LN.FT.

ZONE 2

INTERVAL 932 TO G.L.

BOTTOM OF TUBING OR PIPE 931

NO. OF SACKS 89 YIELD 1.86 CU.FT/SK. LBS/GAL

SLURRY WEIGHT 13.4

BRIDGE PLUG TYPE SAND PLUG

TYPE PLUG CONTINIOUS CEMENT

DIAMETER OF CASING/HOLE $\quad 6 \quad 5 / 8$

IN

REMARKS 


\section{PLUGGING REPORT}

(PAGE 2 OF 2)

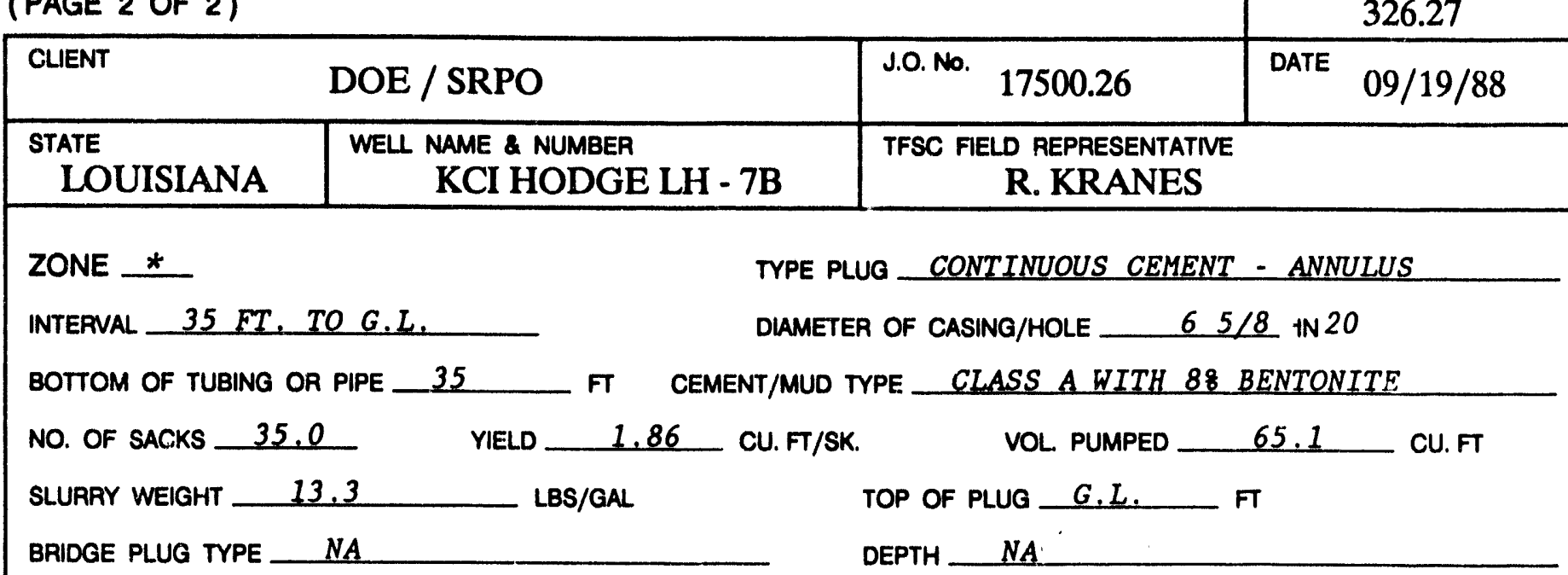

REMARKS

ZONE

INTERVAL

BOTTOM OF TUBING OR PIPE

NO. OF SACKS

SLURPY WEIGHT

BRIDGE PLUG TYPE

REMARKS
TYPE PLUC

DIAMETER OF CASING/HOLE IN FT CEMENT/MUD TYPE

YIELD CU. FT/SK.

VOL. PUMPED CU. FT TOP OF PLUG FT DEPTH

TYPE PLUG

DIAMETER OF CASING/HOLE IN
INTERVAL

BOTTOM OF TUBING OR PIPE

NO. OF SACKS

YIELD LBS/GAL

SLURRY WEIGHT FT CEMENT/MUD TYPE CU. FT/SK.

VOL. PUMPED CU. FT

TOP OF PLUG FT

BRIDGE PLUG TYPE DEPTH 
PLUGGING REPORT

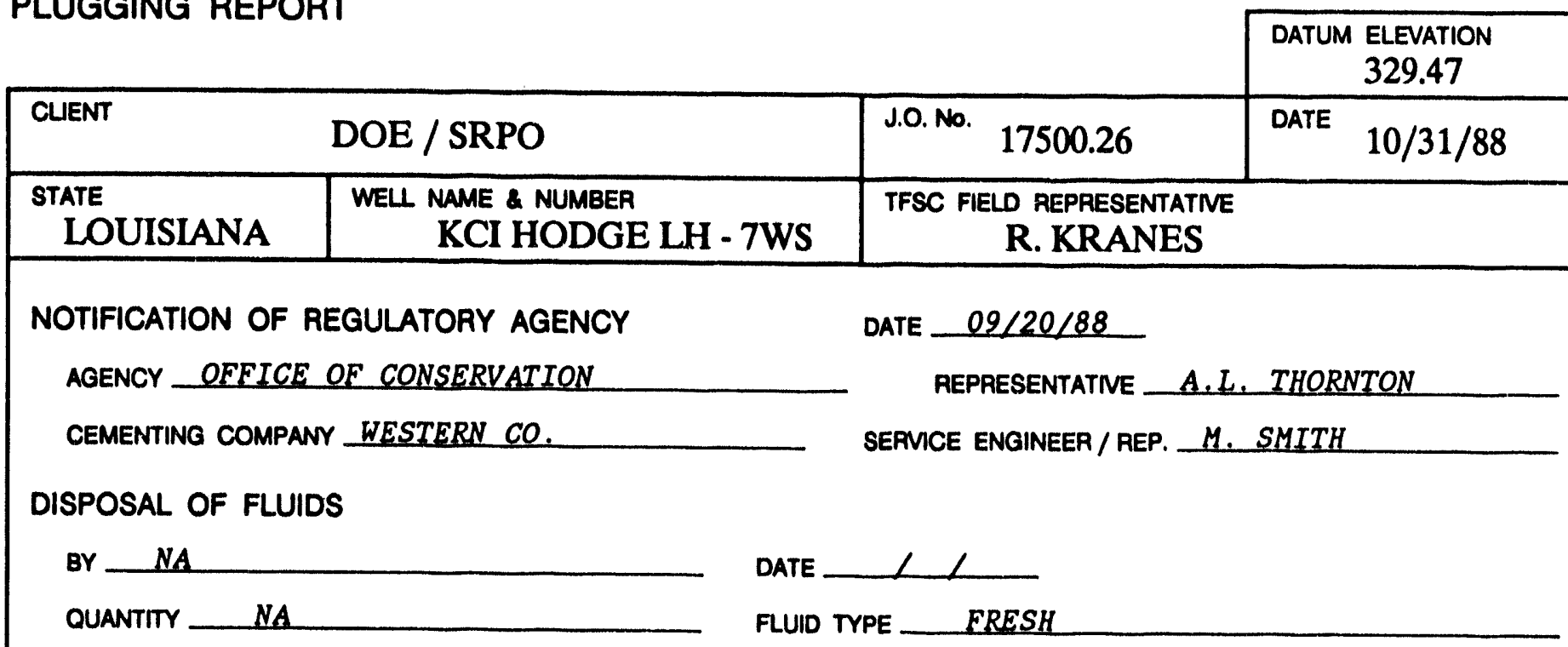

REMARKS

ZONE 1

TYPE PLUG SAND PLUG

INTERNAL $\quad 589.8$ TO 460.24

DIAMETER OF CASING/HOLE $\quad 4.5$ IN

BOTTOM OF TUBING OR PIPE -454 FT CEMENT/MUD TYPE $20-40$ MESH SAND

NO. OF SACKS 12 YIELD _ $\quad$ _ CU. FT/SK. VOL. PUMPED \# \# _ CU.FT

SLURRY WEIGHT NA LBS/GAL TOP OF PLUG 460.24 FT

BRIDGE PLUG TYPE NA N DEPTH NA

REMARKS

* 10.79 LN.FT. $\angle S K . *$ * 129.56 LN.FT. SAND GRAVITY FED THROUGH $23 / 8$ "TUBING.

ZONE 2

TYPE PLUG CONTINIOUS CEMENT

INTERNAL 460.24 TO 3 FT

DIAMETER OF CASING/HOLE $4.5-65 / 8 *$ IN

BOTTOM OF TUBING OR PIPE 459 FT CEMENT/MUD TYPE CLASS A WITH 88 BENTONITE

NO. OF SACKS 47 YIELD 1.86 CU.FT/SK. VOL. PUMPED 87.42 CU.FT SLURAY WEIGHT LBS/GAL TOP OF PLUG 3 T

BRIDGE PLUG TYPE NA NA DEPTH NA

REMARKS

* $41 / 2^{\prime \prime}$ RISER PIPE ( $\left.460-410.35\right) 65 / 8^{\prime \prime}$ CASING $(410-3)$ 
PLUGGING REPORT

(PAGE 1 OF 2)

\begin{tabular}{|l}
\hline CLIENT \\
\hline $\begin{array}{l}\text { STATE } \\
\text { LOUISIANA }\end{array}$
\end{tabular}

DOE / SRPO

WELL NAME \& NUMBER

KCI HODGE LH-17A

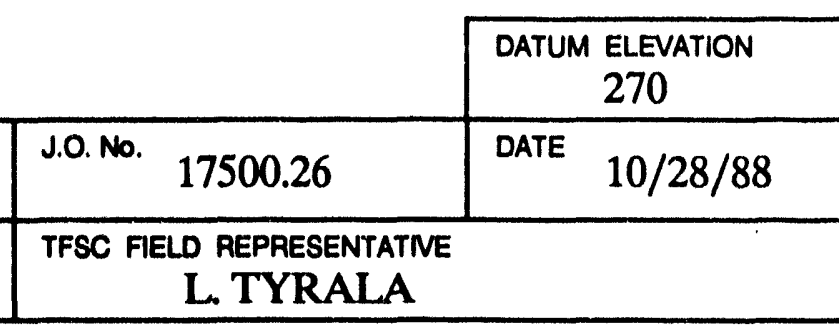

NOTIFICATION OF REGULATORY AGENCY

AGENCY OFEICE OF CONSERVATION

CEMENTING COMPANY WESTERN CO.

DISPOSAL OF FLUIDS

BY POOL CO.

QUANTITY 60 BBLS

\section{REMARKS}

\section{DATE $10 / 27 / 88$}

REPRESENTATIVE A.L. THORNTON

SERMCE ENGINEER / REP. M. SMITH
DATE $10 / 28 / 88$

FLUID TYPE BRINE

ZONE 1

TYPE PLUG SAND PLUG

INTERVAL 2022 TO 1959.65 FT

DIAMETER OF CASING/HOLE $65 / 8$ IN

BOTTOM OF TUBING OR PIPE_POURED FT CEMENT/MUD TYPE SAND 20-40 MESH

NO. OF SACKS 3 YIELD \# $\quad$ _ CU.FT/SK. VOL. PUMPED \# * _ CU.FT

SLURRY WEIGHT NA LBS/GAL TOP OF PLUG $1959.65 \mathrm{FT}$

BRIDGE PLUG TYPE _NA DEPTH _NA

REMARKS

HOLE SANDED TO COVER SCREENED INTERVAL 2022 TO 1993 FT. * 20.78 LN.FT./SK. ** AMOUNT

PLACED 62.35 LN.FT.

ZONE 2

INTERVAL 1959.65 TO 3 FT.

BOTTOM OF TUBING OR PIPE 1958.7 FT CEMENT/MUD TYPE CLASS A WITH 88 BENTONITE

NO. OF SACKS $204 \quad$ YIELD 1.86 CU.FT/SK. VOL. PUMPED 379.44 CU.FT

SLURRY WEIGHT 13.2 LBS/GAL

BAIDGE PLUG TYPE SAND

TOP OF PLUG 3 FT

DEPTH SEE ZONE 1

REMARKS

CEMENT PUMPED AGAINST SAND PLUG IN SCREEN. 


\section{PLUGGING REPORT}

(PAGE 2 OF 2)

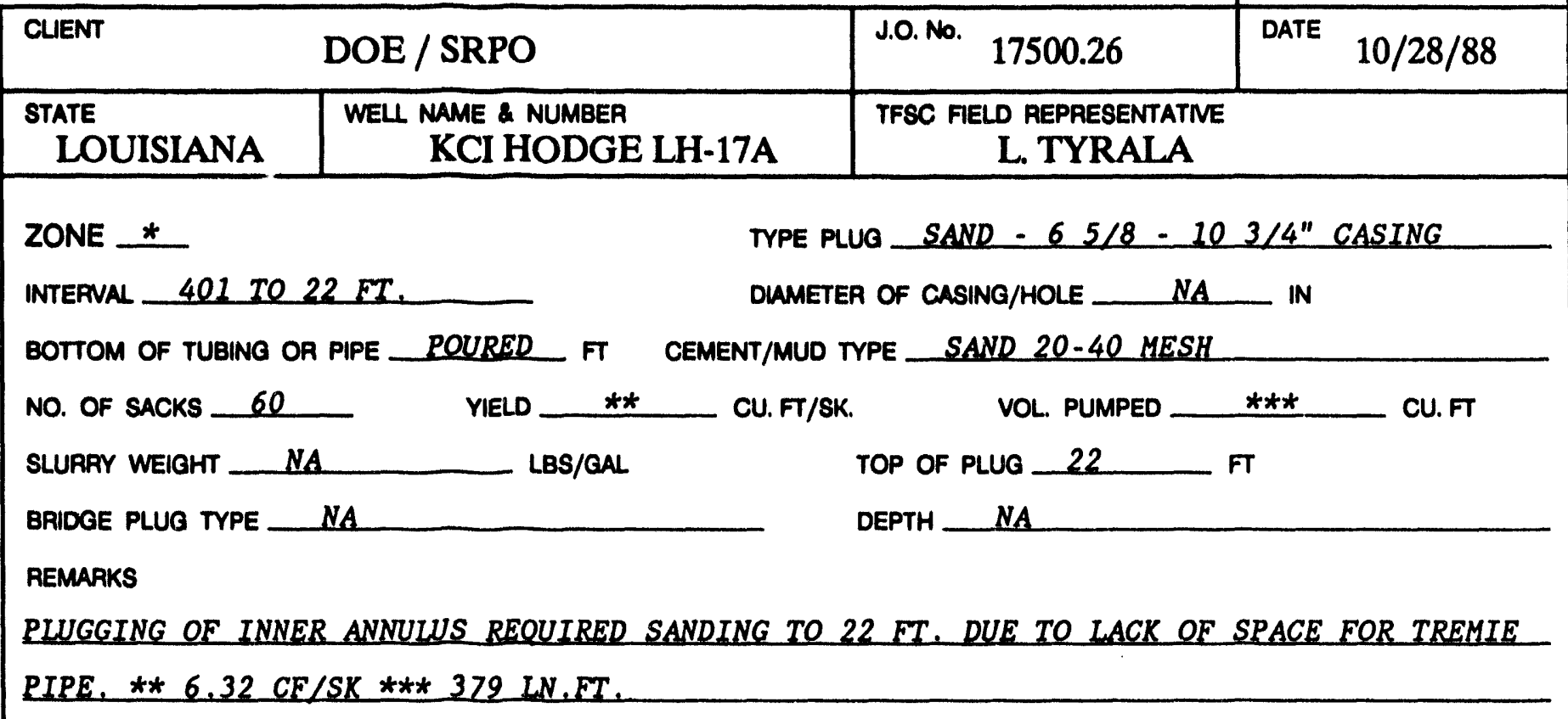

ZONE *

TYPE PLUG CEMENT 6 5/8 - $103 / 4 "$ CASING ANNUL.

INTERVAL 22 TO 3 FT.

DIAMETER OF CASING/HOLE NA IN

BOTTOM OF TUBING OR PIPE 21.7 FT CEMENT/MUD TYPE_CLASS A WITH 88 BENTONITE

NO. OF SACKS 4.5 YIELD 1.86 CU.FT/SK. VOL. PUMPED 8.37 CU.FT SLURAY WEIGHT LBS/GAL TOP OF PLUG 3 T FT

BRIDGE PLUG TYPE NA NA DEPTH NA

REMARKS

CEMENT PUMPED ON TOP OF SAND PLUG.

ZONE *

INTERNAL 24 TO $3 \mathrm{FT}$. NO. OF SACKS 23.1 YIELD $1.86 \mathrm{CU}$. FT/SK. SLURRY WEIGHT L 13.2

BRIDGE PLUG TYPE _ NA REMARKS

ANNULUS BETWEEN CONDUCTOR PIPE AND SURFACE CASING.
TYPE PLUG CEMENT - $103 / 4$ - 20" CASING ANNULUS DIAMETER OF CASING/HOLE NA_ IN 
PLUGGING REPORT

(PAGE 1 OF 2)

\begin{tabular}{|l}
\hline CLIENT \\
\hline STATE \\
LOUISIANA \\
\hline
\end{tabular}

DOE / SRPO

WELL NAME \& NUMBEA

KCI HODGE LH - 17B

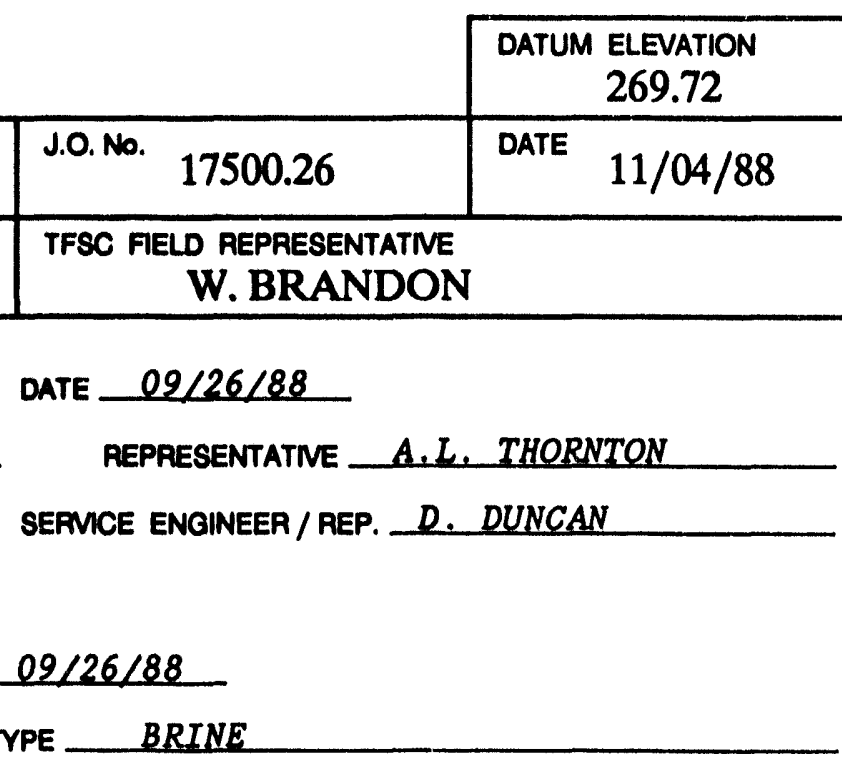

\section{REMARKS}

\section{DATE $09 / 26 / 88$ \\ FLUID TYPE _ BRINE}

ZONE 1

TYPE PLUG SAND

INTERNAL $1372.94^{\circ}$ TO $1298.35^{\circ}$

DLAMETER OF CASING/HOLE 4 IN

BOTTOM OF TUBING OR PIPE FT CEMENT/MUD TYPE_SAND 20 - 40 MESH

NO. OF SACKS 7 YIELD CU. FT/SK.

VOL. PUMPED $\star *$ CU. FT

SLURAY WEIGHT NA LBS/GAL TOP OF PLUG $1298.35 \mathrm{FT}$

BRIDGE PLUG TYPE NA DEPTH NA

FIEMARKS

* $10.66 \mathrm{LN}$. FT $/ S K$ ** TREMIED $74.59 \mathrm{LN} . F T$.

ZONE 2

INTERNAL 1298.35 TO $91.6 \mathrm{FT}$. BOTIOM OF TUBNG OR BOTTOM OF TUBING OR PIPE 1298 NO. OF SACKS 254.7 YIELD 1.86 CU. FT/SK. LBS/GAL

SLURAY WEIGHT 13.2 BRIDGE PLUG TYPE SAND TYPE PLUG CONTINIOUS CEMENT DLAMETER OF CASING/HOLE $65 / 8$ IN

.


PLUGGING REPORT

(PAGE 2 OF 2)

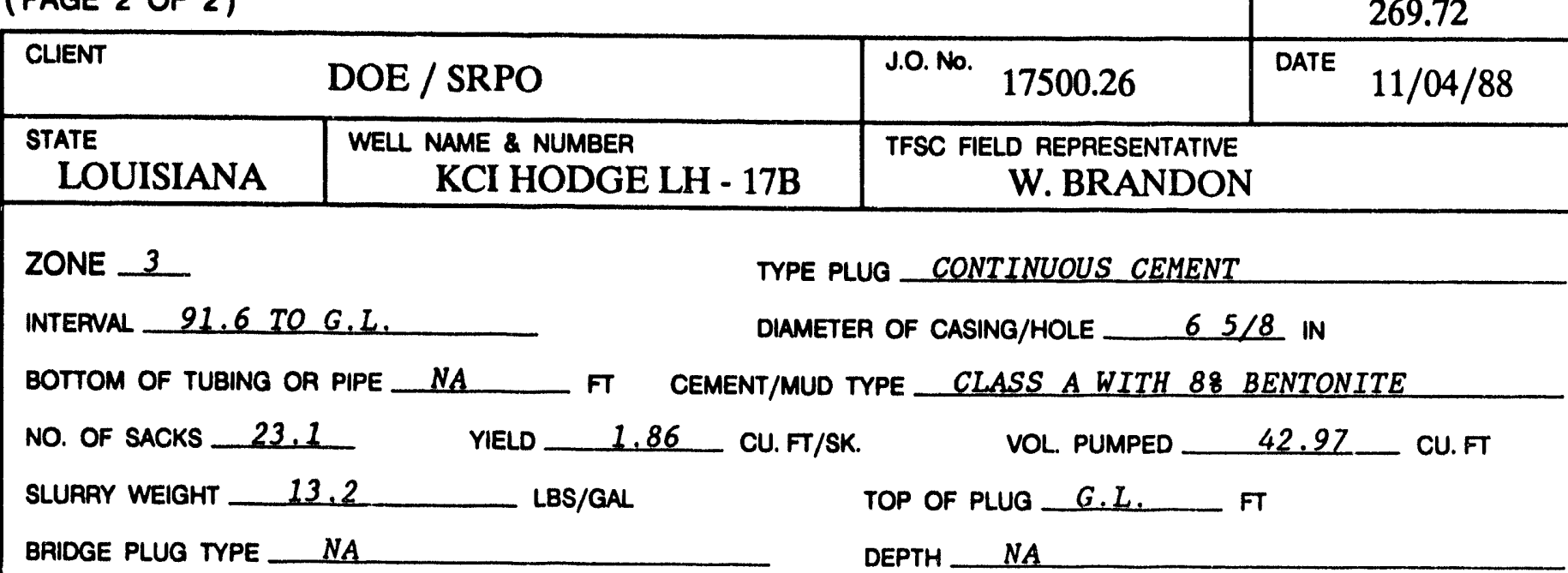

REMARKS

CEMENT POURED IN VOLUME OF CASING LEFT BY TUBING DISPLACEMENT FROM ORIGINAL PLUGGING.

ZONE

INTERVAL

BOTTOM OF TUBING OR PIPE

NO. OF SACKS

SLURRY WEIGHT

BRIDGE PLUG TYPE

REMARKS
TYPE PLUG

DIAMETER OF CASING/HOLE IN FT CEMENT/MUD TYPE

YIELD CU. FT/SK.

VOL. PUMPED CU.FT LBS/GAL

TOP OF PLUG FT

DEPTH

\section{ZONE}

INTERVAL

BOTTOM OF TUBING OR PIPE

NO. OF SACKS

YIELD LBS/GAL

SLURRY WEIGHT
TYPE PLUG

DLAMETER OF CASING/HOLE IN FT CEMENT/MUD TYPE

BRIDGE PLUG TYPE CU. FT/SK.

VOL. PUMPED CU. FT REMARKS

TOP OF PLUG FT 


\begin{tabular}{|c|c|c|c|}
\hline LUGGING REP & & & $\begin{array}{c}\text { DATUM ELEVATION } \\
270.38\end{array}$ \\
\hline CLIENT & DOE / SRPO & J.O. No. 17500.26 & DATE $10 / 01 / 88$ \\
\hline $\begin{array}{l}\text { STATE } \\
\text { LOUISIANA }\end{array}$ & $\begin{array}{l}\text { WELL NAME \& NUMBER } \\
\text { KCI HODGE LH-17WS }\end{array}$ & $\begin{array}{r}\text { TFSC FIELD REPRESE } \\
\text { R. KRAI }\end{array}$ & \\
\hline $\begin{array}{l}\text { NOTIFICATION OF } \\
\text { AGENCY OEFIS }\end{array}$ & $\begin{array}{l}\text { EGULATORY AGENCY } \\
\text { OF CONSERVATION }\end{array}$ & DATE $\frac{09 / 22 / 88}{\text { REPRESENTATIVE }}$ & THORNTON \\
\hline CEMENTING COMF & $Y$ WESTERN CO. & SERMCE ENGINEER / RE & - WORNOCK \\
\hline DISPOSAL OF FLI & & & \\
\hline BY NA & DATE & 11 & \\
\hline QUANTITY N & FLUIC & ERESH & \\
\hline
\end{tabular}

\section{REMARKS}

ZONE 1

TYPE PLUG SAND

INTERNAL 433.53 TO $282.3 \mathrm{FT}$

DIAMETER OF CASING/HOLE $\quad 4.5$ IN BOTTOM OF TUBING OR PIPE 280 FT CEMENT/MUD TYPE SAND, 20-40 MESH NO. OF SACKS 15 YIELD_ * CU.FT/SK. VOL PUMPED 15 CU.FT SLURRY WEIGHT NA LBS/GAL TOP OF PLUG 282.3 FT BRIDGE PLUG TYPE SAND DEPTH NA REMARKS

SCREEN SANDED BEFORE PLUG BACK.

$\star 10.08 \mathrm{LN} \mathrm{FT} / \mathrm{SK}$. ** $151.23 \mathrm{LN} . \mathrm{FT}$.

ZONE 2 TYPE PLUG CONTINIOUS CEMENT

INTERVAL 282.3 TO G.L. DIAMETER OF CASING/HOLE $\quad 4.5$ IN BOTTOM OF TUBING OR PIPE 281 FT CEMENT/MUD TYPE CLASS A WITH 88 BENTONITE NO. OF SACKS 15 YIELD 1.86 CU.FT/SK. VOL. PUMPED 27.9 CU.FT SLURAY WEIGHT LBS/GAL TOP OF PLUG 0 I3.2 FT BRIDGE PLUG TYPE SAND DEPTH SEE ZONE 1 REMARKS 
PLUGGING REPORT

\begin{tabular}{|c|c|c|c|}
\hline 'LUGGING REP( & & & $\begin{array}{c}\text { DATUM ELEVATION } \\
280.84\end{array}$ \\
\hline CLIENT & DOE / SRPO & J.O. No. 17500.26 & DATE $10 / 27 / 88$ \\
\hline $\begin{array}{l}\text { STATE } \\
\text { LOUISIANA }\end{array}$ & $\begin{array}{l}\text { WEL NAME \& NUMBER } \\
\text { A.K.C. RAYFORD V4 }\end{array}$ & $\begin{array}{r}\text { TFSC FIELD REPRESEN } \\
\text { R. KRAN }\end{array}$ & \\
\hline NOTIFICATION OF & EGULATORY AGENCY & DATE $\perp L L$ & \\
\hline AGENCY & & REPRESENTATIVE . & \\
\hline CEMENTING COMP & $Y$ WESTERN CO. & SERMCE ENGINEER / RE & SMITH \\
\hline DISPOSAL OF FLI & & & \\
\hline BY RUN OFF & DAT & $10 / 27 / 88$ & \\
\hline QUANTITY 11 & & YPE & \\
\hline
\end{tabular}

\section{REMARKS}

** NOTIFICATION NOT REQUIRED PER INSTRUCTION OF THE STATE " OFFICE OF CONSERVATION. THE WELL WAS NOT PREVIOUSLY REGISTERED.

ZONE 1

INTERVAL 488 TO UNKNOWN

BOTTOM OF TUBING OR PIPE NA

NO. OF SACKS 2

SLURRY WEIGHT

NA

BRIDGE PLUG TYPE

NA
TYPE PLUG SAND

DIAMETER OF CASING/HOLE _ 3 (screen ) IN - FT CEMENT/MUD TYPE _NA YIELD \# CU.FT/SK. VOL. PUMPED * * CU.FT LBS/GAL TOP OF PLUG $\rightarrow$ DEPTH NA

REMARKS

SANDING OF SCREEN REQUIRED ONLY 93.35\# TO COVER SCREEN. 200 \# OF SAND WERE PLACED IN SCREEN AND RISER PIPE. TOP OF SAND PLUG WAS UNMEASUREABLE BECAUSE TUBING WOULD NOT GO THROUGH TOP OF RISER PIPE.* UNKNOWNN

ZONE 2

INTERNAL * TO 3 FT

BOTTOM OF TUBING OR PIPE
TYPE PLUG CONTINIOUS CEMENT

DIAMETER OF CASING/HOLE _ 4

NO. OF SACKS 45 YIELD 1.86 CU. FT/SK. VOL. PUMPED 83.7 CU.FT SLURAY WEIGHT LBS/GAL TOP OF PLUG 3 T FT

BRIDGE PLUG TYPE NA NEPTH NA

REMARKS

*DEPTH TO TOP OF SAND PLUG COULD NOT BE MEASURED (SEE ABOVE). VOLUME OF CEMENT PUMPED WAS SUFFICIENT TO FILL FULL LENGTH OF RISER PIPE AND CASING COMBINED. 
PLUGGING REPORT

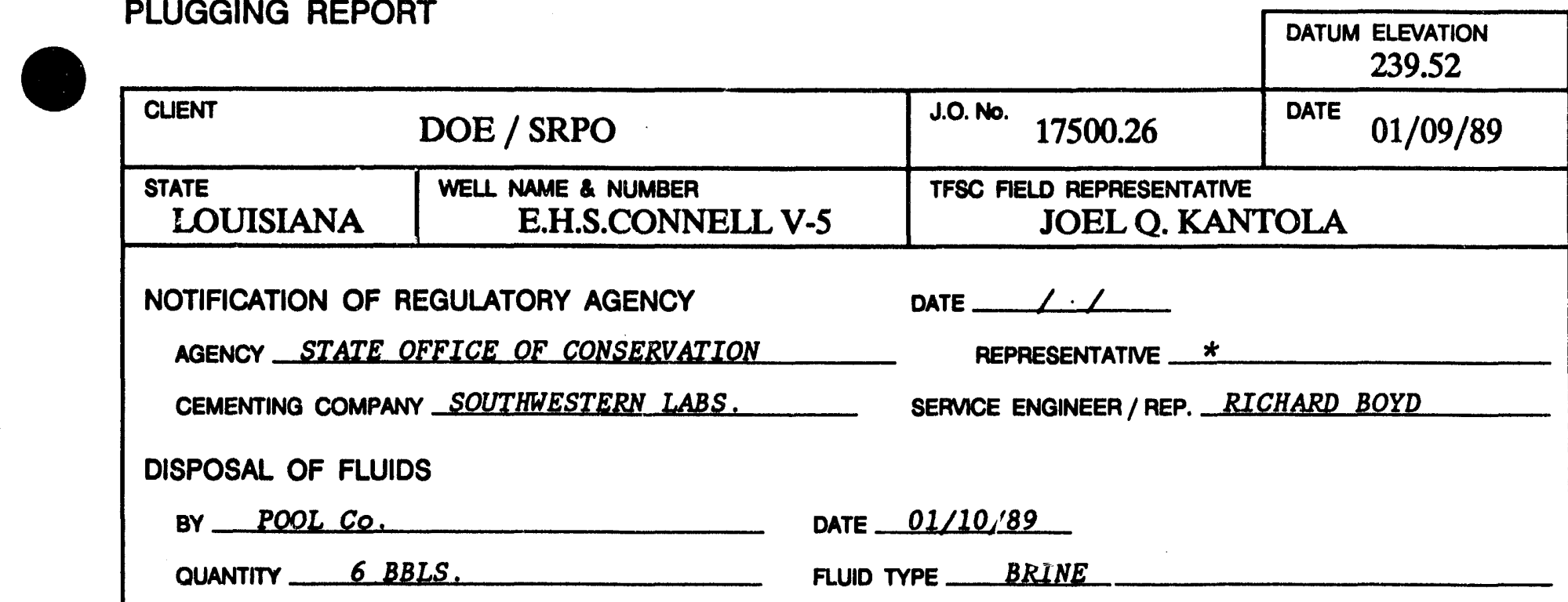

\section{REMARKS}

\#FOR PREVIOUSLY UNREGISTERED WELL SWEC WAS INSTRUCTED BY STATE OFFICE OF CONSERVATION NOT TO NOTIEY LOCAL FIELD INSPECTOR.

ZONE 1

INTEFNAL 403.5 TO 367.36 FT.

BOTTOM OF TUBING OR PIPE $356.66^{\circ}$ FT CEMENT/MUD TYPE _ SAND SAND 20-40 MESH

NO. OF SACKS 11 YIELD $\quad 0.93$ CU.FT/SK. VOL. PUMPED 10.2 CU. FT

SLURPY WEIGHT LBS/GAL TOP OF PLUG 36.3 L 367.36 FT

BRIDGE PLUG TYPE N NA DEPTH N N N

REMARKS

$\star 47 / 8^{\prime \prime}$ OPEN HOLE BELOW SCREEN (403.5'TO 387.0') AND 3.0" 0.D. SCREEN \& RISER PIPE $\left(387.0^{\circ}\right.$ TO $\left.367.36^{\prime}\right)$.

ZONE 2

INTERNAL $367.36^{\prime}$ TO SURFACE

TYPE PLUG CONTINUOUS CEMENT

DIAMETER OF CASING/HOLE _ $\mathbb{N}$

BOTTOM OF TUBING OR PIPE $364.62 *$ FT CEMENT/MUD TYPE CLASS A WITH $8 \%$ BENTONITE

NO. OF SACKS 33 YIELD 1.86 CU.FT/SK. VOL. PUMPED 61.38 CU.FT SLURAY WEIGHT 13.0 - 13.1* LBS/GAL TOP OF PLUG SURF. FT

BRIDGE PLUG TYPE SAND PLUG DEPTH SEE ZONE 1

REMARKS

* PUMPED 23 SK W/ TUBING \& $364.62^{\circ}$ \& WT. -13.0 LB./GAL.: PUMPED 10 SK W/ TUBING a $337.05^{\circ} \&$ WT. $=13.1$ LB. JALL. ** 3.0" O.D. RISER PIPE $\left(367.36^{\circ}\right.$ TO 356.0' $) \& 5.0^{\prime \prime}$ Q.D. CASING ( $356.0^{\circ}$ TO SURFACE). 
PLUGGING REPORT

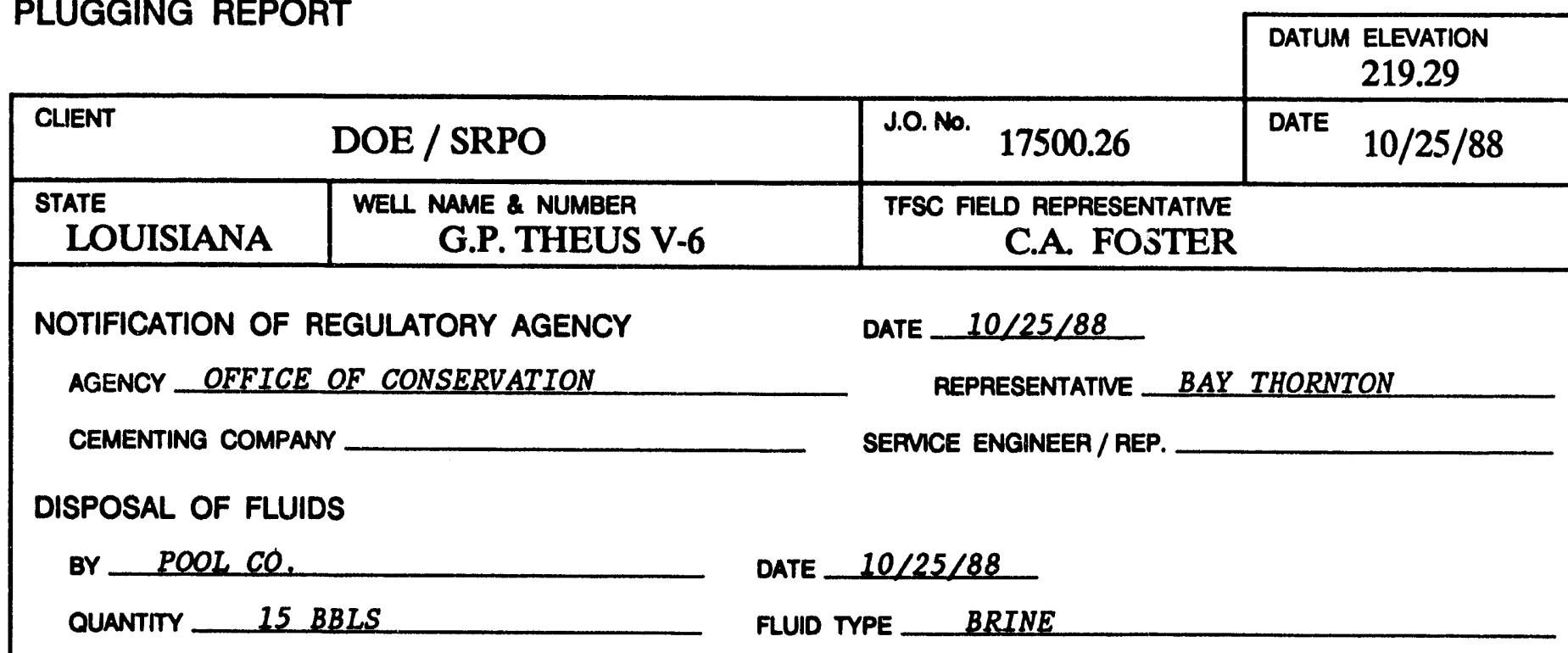

REMARKS

COMMERCIAL FACILITY - FISSETTE \#1

ZONE 1

INTERVAL

BOTTOM OF TUBING OR PIPE

NO. OF SACKS

SLURRY WEIGHT

BRIDGE PLUG TYPE

REMARKS

COULD NOT GET 2 3/8" TUBING BELOW 603' - DECIDED TO GO WITH ALL CEMENT AS DO NOT KNOW IF SCREEN PLUGGED OR OPEN.

ZONE 1

TYPE PLUG CONTINIOUS CEMENT

INTERNAL 603 TO SURFACE

DIAMETER OF CASING/HOLE $51 / 2$
TYPE PLUG SAND

DIAMETER OF CASING/HOLE

VOL. PUMPED CU. FT FT

DEPTH $\mathbb{N}$ FT CEMENT/MUD TYPE LBS/GAL CU. FT/SK.

BOTTOM OF TUBING OR PIPE 596 FT CEMENT/MUD TYPE CLASS A WITH 88 BENTONITE NO. OF SACKS 46 YIEL $\quad 1.89$ CU.FT/SK. VOL. PUMPED 87 CU.FT SLURPY WEIGHT L 13.2 LOS/GAL TOP OF PLUG G.L. F F BRIDGE PLUG TYPE N NA DEPTH NA REMARKS

RETURN TO SURFACE PULLED TUBING \& TOPPED OFF WITH HOSE DIRECT FROM CEMENT TRUCK. 
PLUGGING REPORT

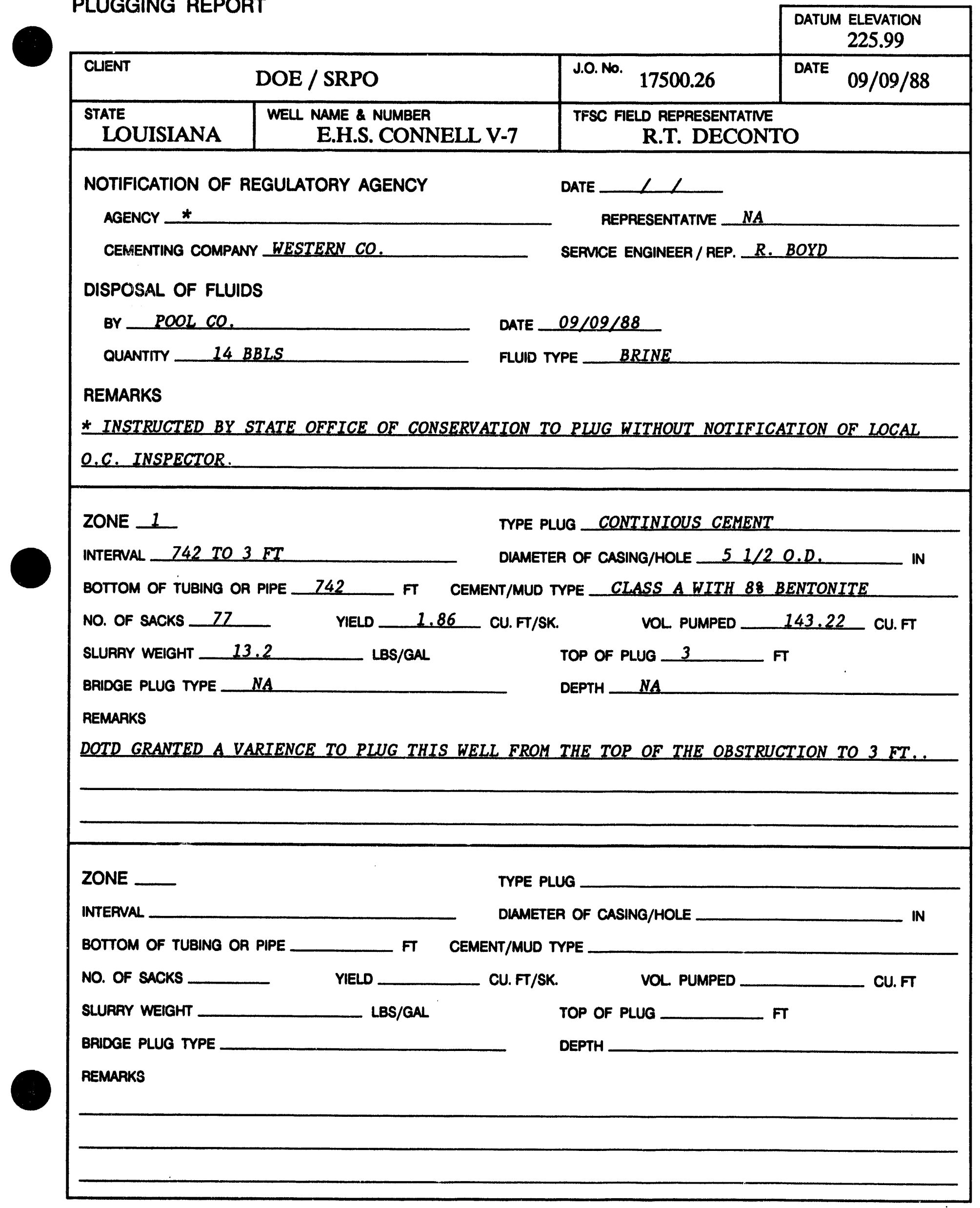


PLUGGING REPORT

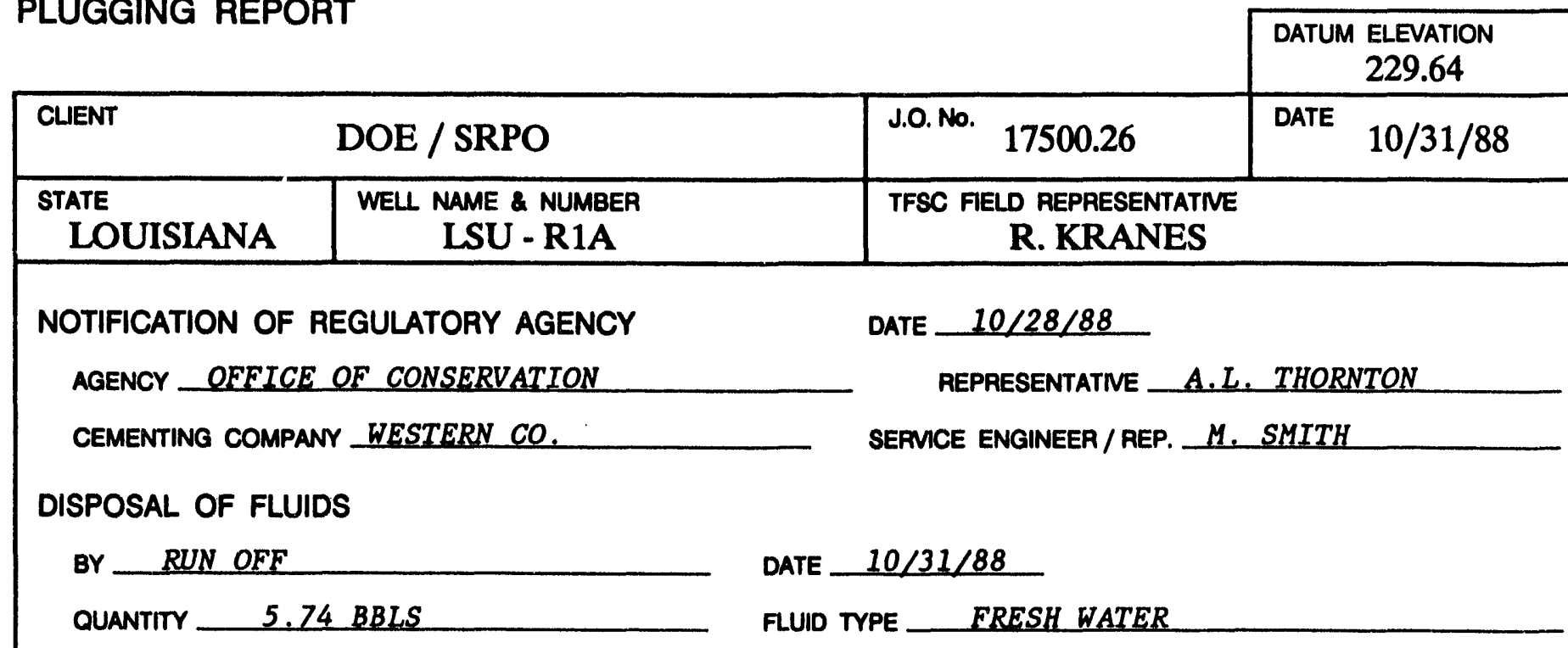

REMARKS

ZONE 1

TYPE PLUG SAND

INTERNAL $\quad 485$ TO 454.04 FT

DIAMETER OF CASING/HOLE $40 . D$. IN

BOTTOM OF TUBING OR PIPE NA N T CEMENT/MUD TYPE SAND, 20-40 MESH

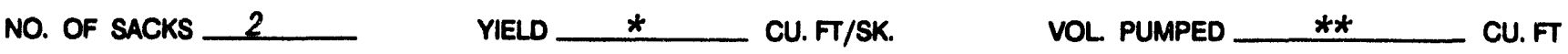
SLURRY WEIGHT NA LBS/GAL TOP OF PLUG $\quad 454.04$ FT BRIDGE PLUG TYPE NA DEPTH NA REMARKS

*15.48 LN.FT./SK: ** AMOUNT PLACED 30.96 LN.FT.

ZONE 2

INTERNAL 454 TO 3 FT BOTTOM OF TUBING OR PIPE $\quad 450$ NO. OF SACKS 24 YIELD 1.86 SLURRY WEIGHT 13.2 BRIDGE PLUG TYPE NA LBS/GAL

\section{REMARKS}

WELL REOUIRED $28 \%$ MORE CEMENT TO PLUG BACK THAN WAS ORIGINALLY CALCULATED. THE INITIAL PLUG USED 22 SACKS. THE REMAINDER USED 2 SACKS FOR COMPLETE PLUG.
TYPE PLUG CONTINIOUS CEMENT

DLAMETER OF CASING/HOLE 4.0 O.D. IN FT CEMENT/MUD TYPE CLASS A WITH $8 \%$ BENTONITE 
PLUGGING REPORT

(PAGE 1 OF 2)

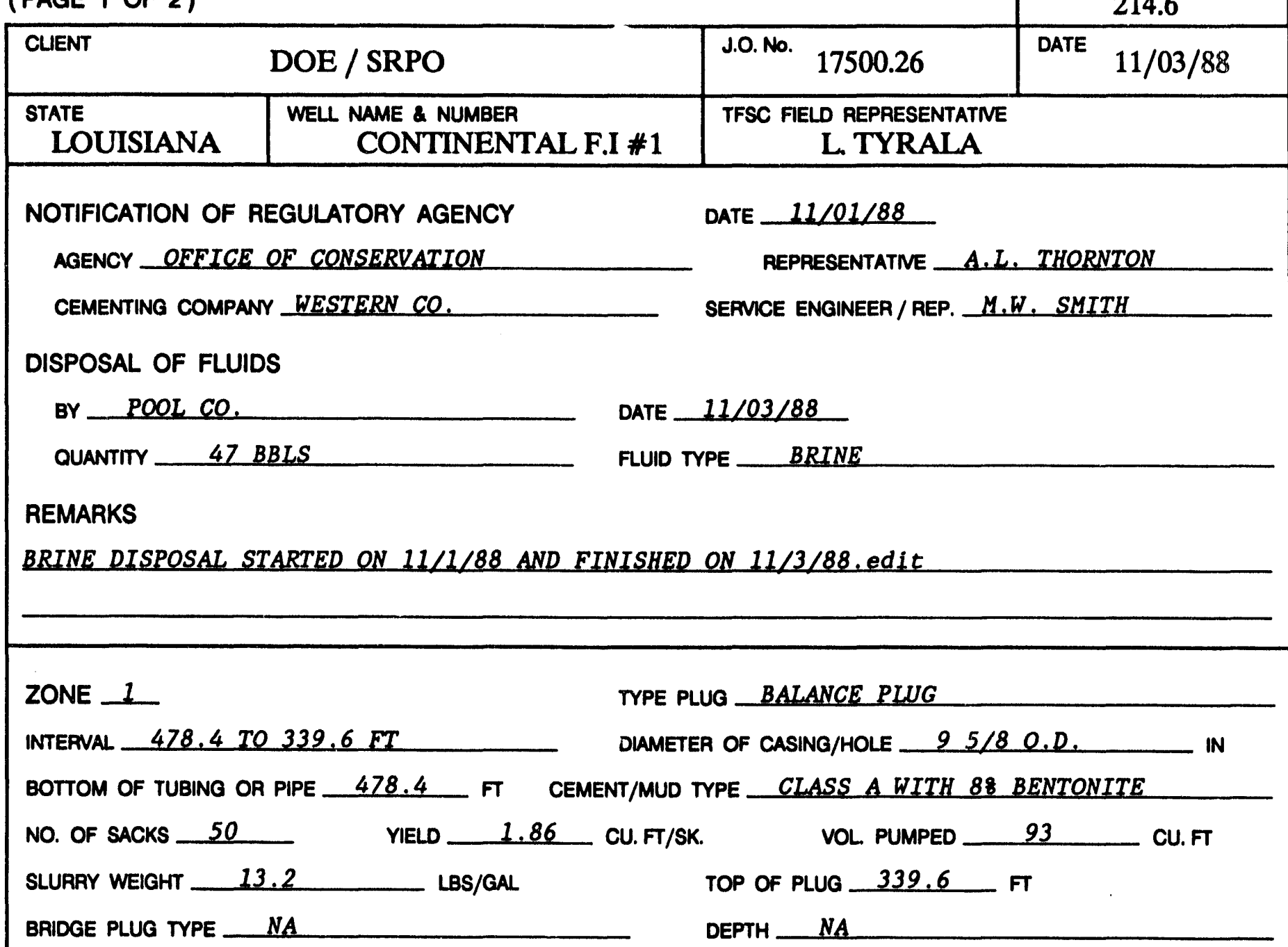

REMARKS

THIS IS A BLANCE PLUG WITH MINIMUM OF 50 FT BELOW CASING AND 50 FT UP INTO CASING CASING BOTTOM AT 424 FT.. PUMP DATE 11/01/88.

ZONE 2

INTERVAL 339.6 TO $50 \mathrm{FT}$
TYPE PLUG CONTINIOUS CEMENT

DLAMETER OF CASING/HOLE $95 / 8$ IN BOTTOM OF TUBING OR PIPE _ 339 FT CEMENT/MUD TYPE CLLASS A WITH 88 BENTONITE NO. OF SACKS 85 YIELD $\quad 1.86$ CU.FT/SK. VOL. PUMPED 158.1 SLURRY WEIGHT L 13.2 LBS/GAL TOP OF PLUG 50 BRIDGE PLUG TYPE _ NA DEPTH _ NA REMARKS TOP OF BALANCE PLUG WAS TAGGED WITH TUBING AT 339.6 FT. PUMP DATE $11 / 02 / 88$. 
PLUGGING REPORT

(PAGE 2 OF 2)

\begin{tabular}{|l}
\hline CLIENT \\
\hline STATE \\
LOUISIANA
\end{tabular}

DOE / SRPO

WELL NAME \& NUMBER

CONTINENTAL F.I \#1
DATUM ELEVATION

214.6

DATE $11 / 03 / 88$
ZONE 3

INTERVAL 50 TO 3 FT

BOTTOM OF TUBING OR PIPE

SLURAY WEIGHT 13.2

LBS/GAL

BRIDGE PLUG TYPE NA

REMARKS

PUMP DATE 11/03/88.
TYPE PLUG CONTINIOUS CEMENT

DIAMETER OF CASING/HOLE _ $95 / 8$ IN

TFSC FIELD REPRESENTATME

L. TYRALA

ZONE

INTERVAL

BOTTOM OF TUBING OR PIPE

NO. OF SACKS

SLURRY WEIGHT

BRIDGE PLUG TYPE

REMARKS
TYPE PLUG

DLAMETER OF CASING/HOLE $\mathbb{N}$ FT CEMENT/MUD TYPE

YIELD CU. FT/SK. VOL. PUMPED CU.FT LBS/GAL

TOP OF PLUG FT DEPTH
ZONE

INTERVAL

BOTTOM OF TUBING OR PIPE

NO. OF SACKS

SLURRY WEIGHT

BRIDGE PLUG TYPE

REMARKS
TYPE PLUG

DLAMETER OF CASING/HOLE $\mathbb{N}$ 
PLUGGING REPORT

(PAGE 1 OF 2)

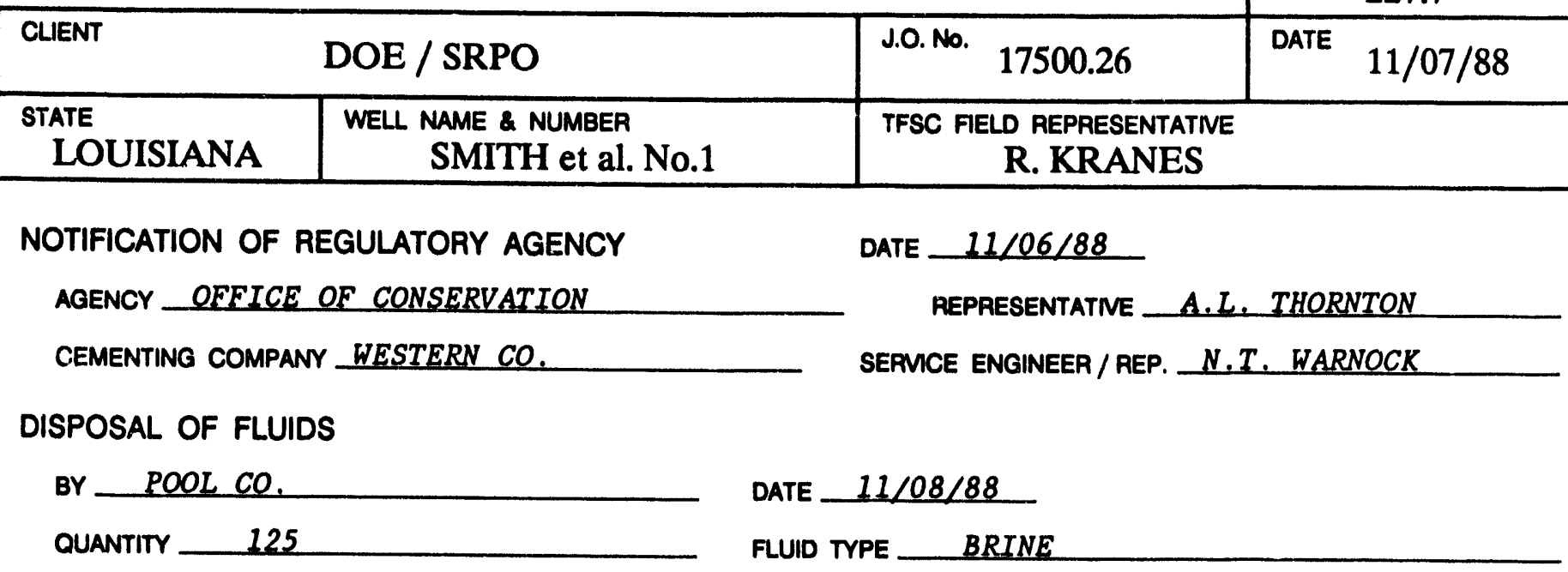

REMARKS

ZONE 1

INTERVAL 1028 TO 843

BOTTOM OF TUBING OR PIPE 1028

NO. OF SACKS $\quad 55 \quad$ YIELD $\quad 1.86$

SLURAY WEIGHT 13.2 LBS/GAL

BRIDGE PLUG TYPE N NA

REMARKS

THIS IS A BLANCE PLUG WITH A MINIMUM OF 50 FT BELOW AND 50 FT UP INTO CASING WITH BASE OF CASING AT 972. PUMP DATE 11/07/88.

ZONE 2

TYPE PLUG CONTINIOUS CEMENT

INTERNAL 843 TO 597.23 FT

BOTTOM OF TUBING OR PIPE $\quad 843$

NO. OF SACKS 62 YIELD 1.86 CU. FT/SK.

SLURRY WEIGHT 13.2

BRIDGE PLUG TYPE NA

REMARKS

PUMP DATE $11 / 08 / 88$.
TYPE PLUG BALANCE PLUG

DIAMETER OF CASING/HOLE $95 / 8$ IN
VOL. PUMPED 102.3 CU.FT TOP OF PLUG 843

DEPTH NA 
PLUGGING REPORT

(PAGE 2 OF 2)

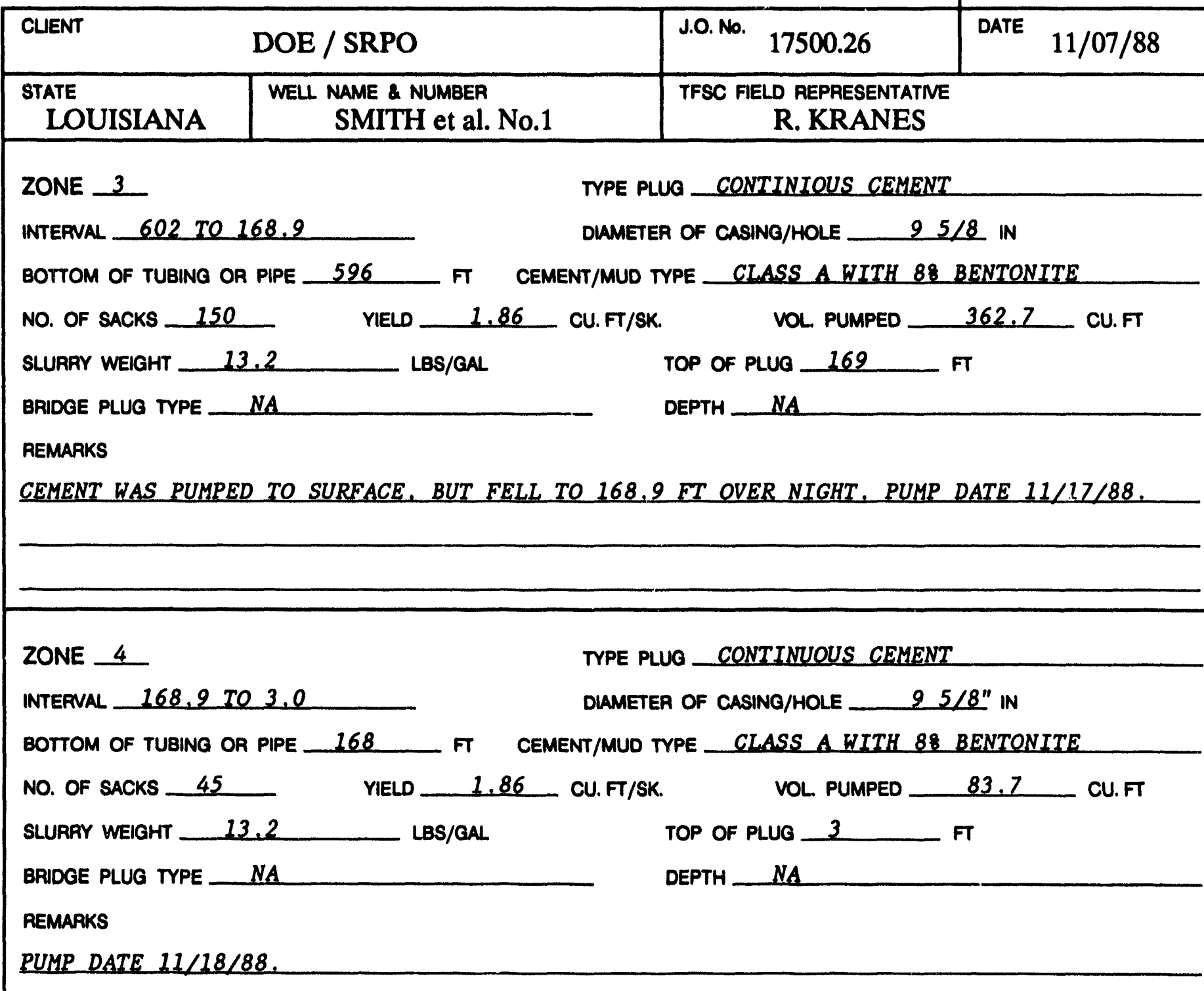

ZONE

TYPE PLUG

INTERNAL

DUAMETER OF CASINQ/HOLE IN

BOTTOM OF TUBING OR PIPE FT CEMENT/MUD TYPE

NO. OF SACKS

YIELD CU. FT/SK.

VOL. PUMPED CU.FT

SLURRY WEIGHT LBS/GAL

TOP OF PLUG FT

BRIDGE PLUG TYPE DEPTH REMARKS 


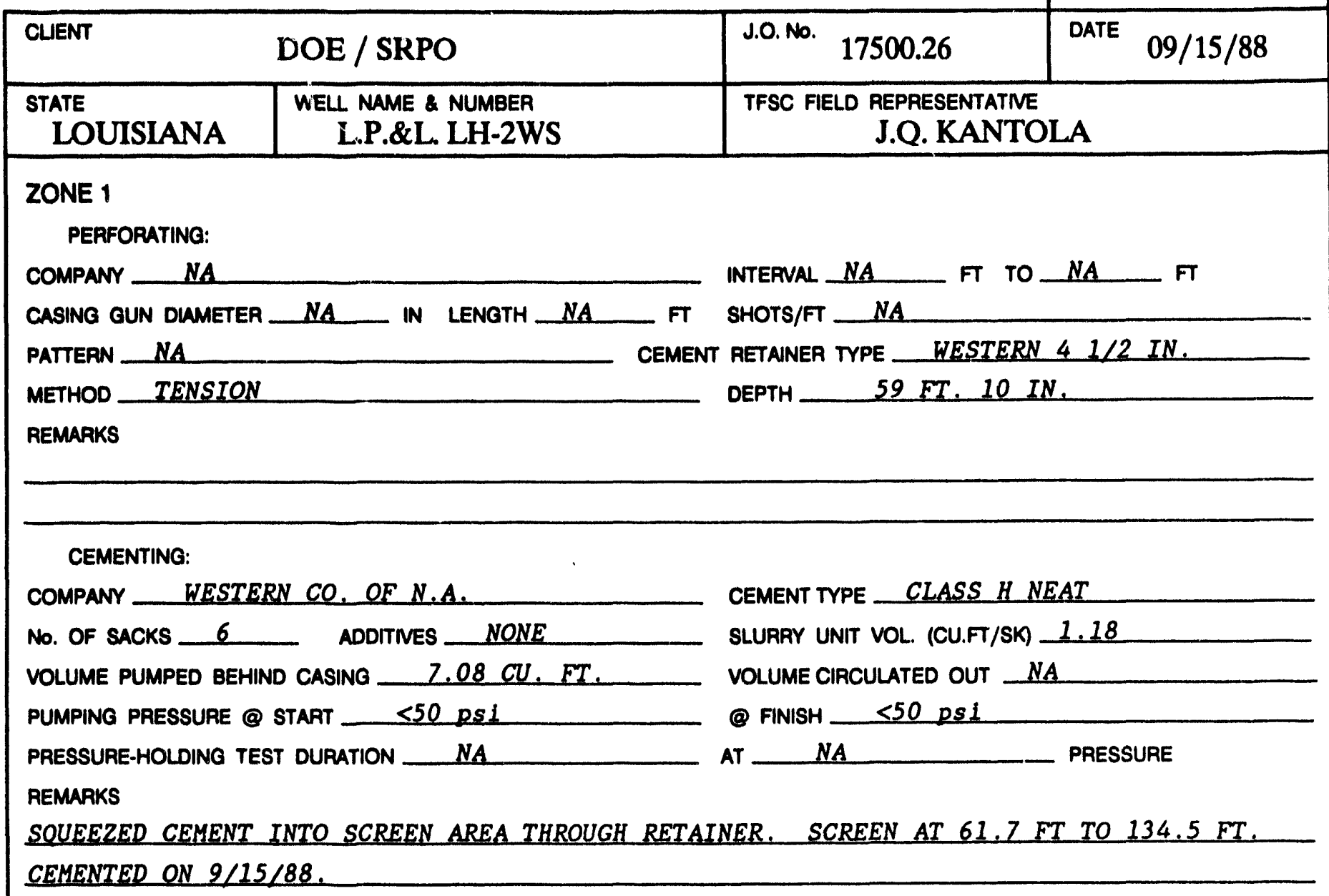

\section{ZONE 2}

PERFORATING:

COMPANY GEARHART INDUSTRIES

CASING GUN DIAMETER 1.0 IN LENGTH 30 FT SHOTS/FT 2

PATTERN 180 DEG.

METHOD TENSION

REMARKS

PEREORATED ON $9 / 15 / 88$.
INTERVAL 25 FT TO 55 CEMENT RETAINER TYPE WESTERN 4 1/2 IN. DEPTH 59 FT 10 IN

\section{CEMENTING:}

COMPANY WESTERN CO. OF N.A.

No. OF SACKS 42 ADDITMES NONE

VOLUME PUMPED BEHIND CASING 49.56 CU.FT.

PUMPING PRESSURE @ START GRAVITY

PRESSURE-HOLDING TEST DURATION NA

REMARKS

ZONE TOOK 27 SACKS MORE THAN ANTICIPATED. SQUEEZE CEMENTED ON $9 / 15 / 88$.
CEMENT TYPE CLASS H NEAT

SLURAY UNIT VOL. (CU.FT/SK) 1.18

VOLUME CIRCULATED OUT NA

@ FINISH _ UNKNOWN

AT NA PRESSURE 
PERFORATING AND SQUEEZE-CEMENTING REPORT

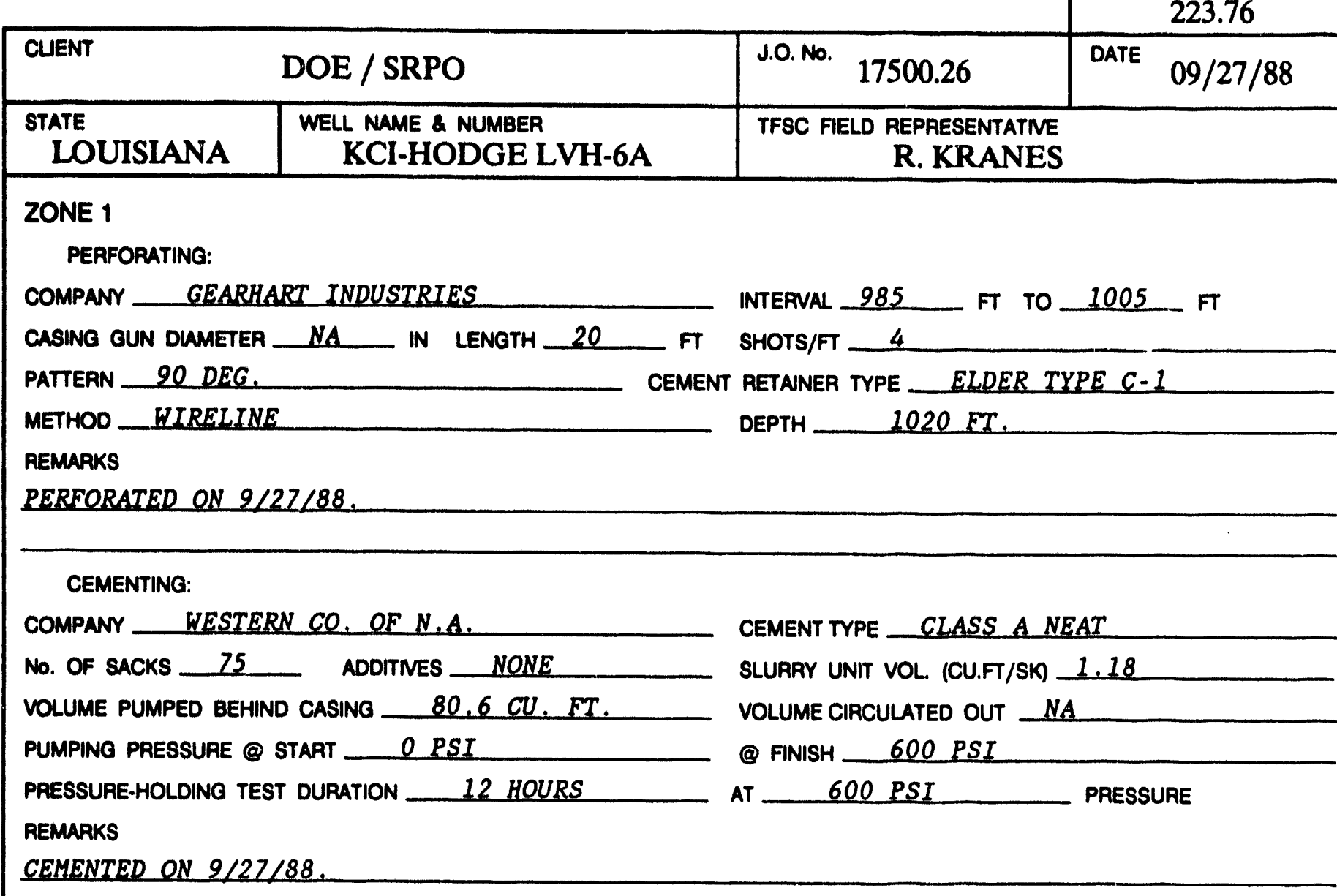

\section{ZONE 2}

PERFORATING:

COMPANY GEARHART INDUSTRIES

CASING GUN DIAMETER NA IN LENGTH 11.5 _ FT SHOTS/FT 2

PATTERN 20 DEG.

METHOD WIRELINE CEMENT RETANER TYPE ELDER TYPE $C$ - 1

REMARKS

PERFORATED ON $9 / 30 / 88$.

\section{CEMENTING:}

COMPANY WESTERN CO, OF N.A.

No. OF SACKS 75 ADDITMES NONE

VOLUME PUMPED BEHIND CASING $65 \mathrm{CU}$. FT.

PUMPING PRESSURE @ START 250 PSI

PRESSURE-HOLDING TEST DURATION 1 HOUR

REMARKS

CEMENTED ON $9 / 30 / 88$.
CEMENT TYPE CLASS A NEAT

SLURRY UNIT VOL. (CU.FT/SK) 1.18

VOLUME CIRCULATED OUT NA

(9) FINISH 600 PSI

AT 600 PSI PRESSURE 
PERFORATING AND SQUEEZE-CEMENTING REPORT

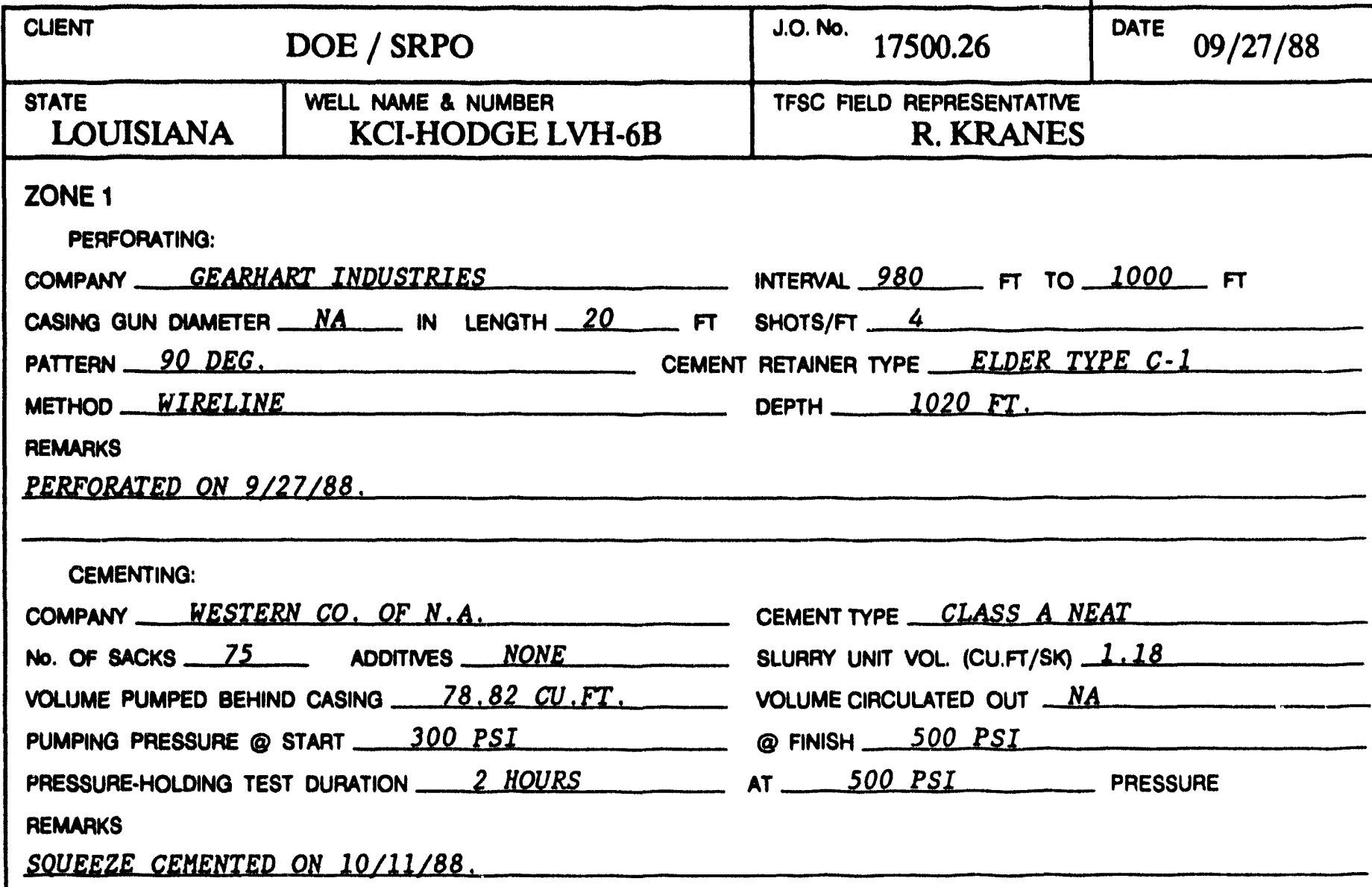

\section{ZONE 2}

PERFORATING:

COMPANY GEARHART INDUSTRIES

CASING GUN DLAMETER NA N IN LENGTH 11

PATTERN 90 DEG.

METHOD WIRELINE

REMURKS

PERFORATED ON 10/13/88.
INTERNAL 949 FT TO 960 FT

SHOTS/FT 2

CEMENT RETANER TYPE ELDER TYPE $C$ - 1

DEPTH 1020 FT.

\section{CEMENTING:}

COMPANY WESTERN CO. OF N.A.

No. OF SACKS 75 ADDITNES NONE

VOLUME PUMPED BEHIND CASING $40.1 \mathrm{CU}$. FT,

PUMPING PRESSURE @ START 500 PSI

PRESSURE-HOLDING TEST DURATION .25 HOURS

REMARKS

SOUEEZE CEMENTED ON $10 / 13 / 88$.
CEMENT TYPE CLASS A NEAT

SLURRY UNIT VOL. (CU.FT/SK) 1.18

VOLUME CIRCULATED OUT NA

(@) FINISH $\quad 700$ PSI

AT 700 PSI PRESSURE 


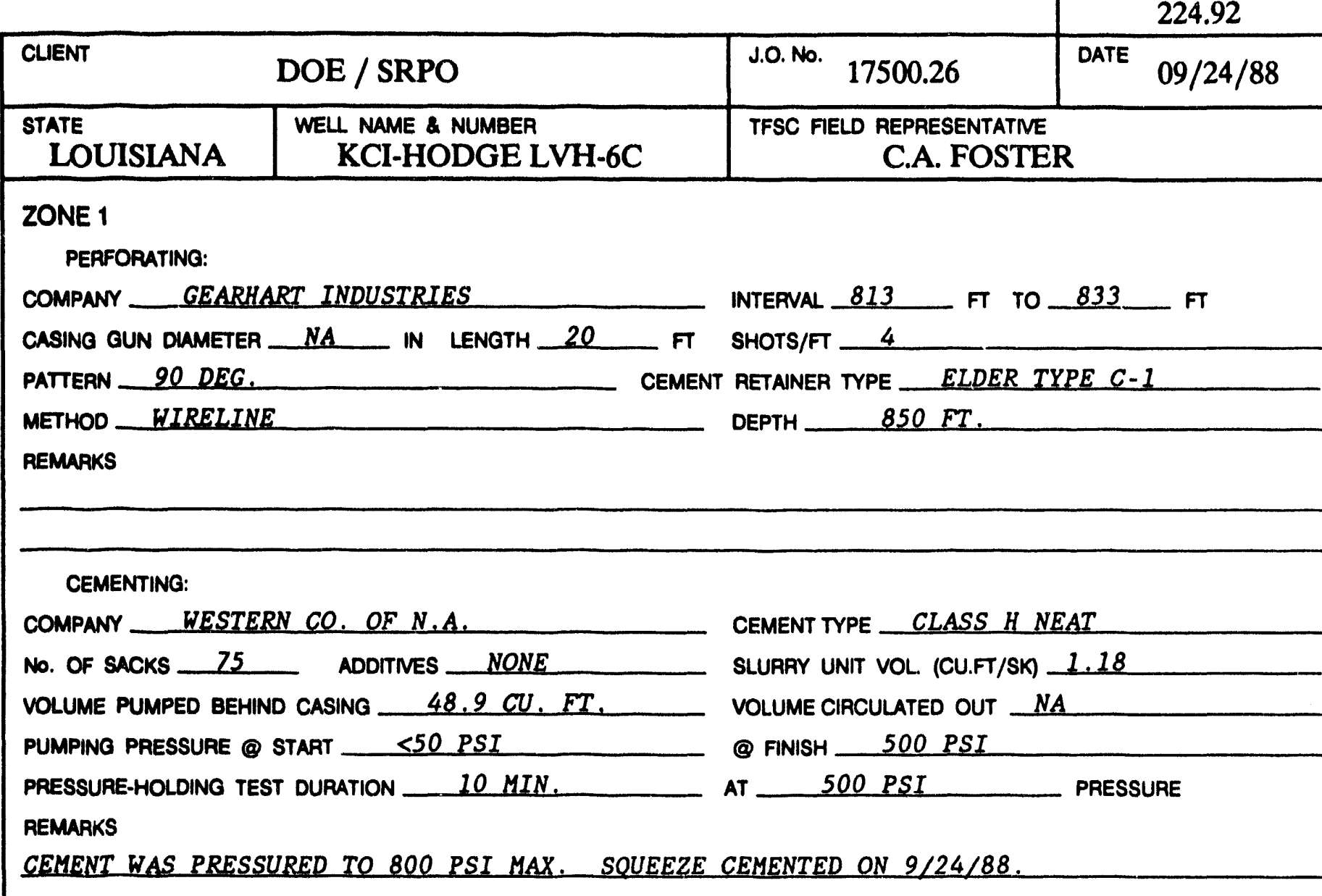

\section{ZONE 2}

PERFORATING:

COMPANY

CASING GUN DIAMETER

PATTERN

METHOD

REMARKS
INTERVAL

FT SHOTS/FT IN LENGTH CEMENT RETAINER TYPE

DEPTH

\section{CEMENTING:}

COMPANY

No. OF SACKS

VOLUME PUMPED BEHIND CASING

PUMPING PRESSURE @ START

PRESSURE-HOLDING TEST DURATION REMARKS
CEMENT TYPE

SLURRY UNIT VOL. (CU.FT/SK)

VOLUME CIRCULATED OUT

@ FINISH

AT

PRESSURE 
PERFORATING AND SQUEEZE-CEMENTING REPORT

\begin{tabular}{|l|l|l|l|}
\hline CLIENT & J.0. No. 17500.26 & DATE $11 / 09 / 88$ \\
\hline $\begin{array}{c}\text { STATE } \\
\text { LOUISLANA }\end{array}$ & $\begin{array}{l}\text { WELL NAME \& NUMBER } \\
\text { SMITH et al. NO. } 1\end{array}$ & $\begin{array}{c}\text { TFSC FELD REPRESENTATNE } \\
\text { R. KRANES }\end{array}$ \\
\hline
\end{tabular}

\section{ZONE 1}

PERFORATING:

COMPANY GEARHART INDUSTRIES

CASING GUN DUMETER NA IN LENGTH 20 FT SHOTS/FT 4

PATTERN 90 DEG. CEMENT RETANER TYPE (SEE REMARK BELOW)

METHOD NA

DEPTH

598 FT.

REMARKS

PERFORATED ON $11 / 09 / 88$.

CEMENTING:

COMPANY WESTERN CO. OF N.A.

No. Of SACKS 75 ADOITMES NONE

VOLUME PUMPED BEHIND CASING $71.5 \mathrm{CU}$. FT.

PUMPING PRESSURE @ START 0 PSI

PRESSURE-HOLDING TEST DURATION 16 HOURS

CEMENT TYPE CLASS H NEAT

SLURRY UNIT VOL. (CU.FT/SK) 1.18

VOLUME CIRCULATED OUT NA

@ FINISH 250 PSI

AT 250 PSI PAESSURE

REMURKS

SQUEEZES AGAINST CEMENT PLUG AT 598 FT. ON 11/10/88. NO PRESSURE REMAINING AT 16 HR.

\section{ZONE 2}

PERFORATING:

COMPANY GEARHART INDUSTRIES

CASING GUN DIAMETER NA IN LENGTH 20 IN SHOTS/FT 4

PATTERN 90 DEG. CEMENT RETANER TYPE

METHOD NA DEPTH 2598 FT.

REMARKS

PERFORATED ON $11 / 14 / 88$. DRILLED OUT CEMENT TO 598 FT. . SQUEEZED AGAINST CEMENT PLUG.

CEMENTING:

COMPANY WESTERN CO. OF N.A.

No. OF SACKS 75 ADDITMES NONE

VOLUME PUMPED BEHIND CASING $82.76 \mathrm{CU} . F T$.

PUMPING PRESSURE @ START 0 PSI

PRESSURE-HOLDING TEST DURATION 15.75 HOURS

REMARKS

SOUEEZE CEMENTED ON 11/14/88. NO PRESSURE REMAINING AT END OF 15.75 HOURS
CEMENT TYPE CLASS H NEAT

SLURRY UNIT VOL. (CU.FT/SK) 1.18

VOLUME CIRCULATED OUT NA

(@) FINISH 800 PSI

AT 700 PSI PRESSURE 


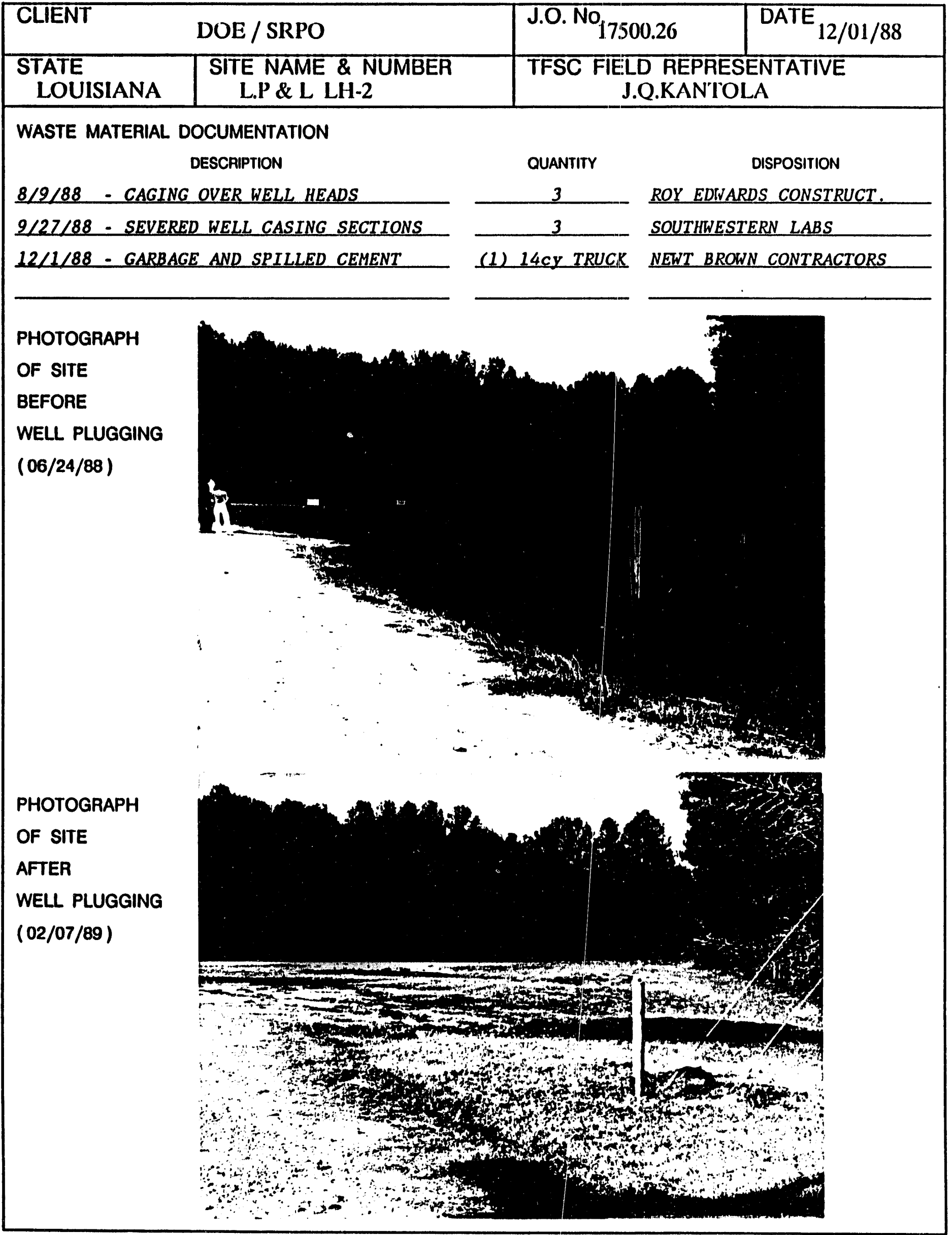




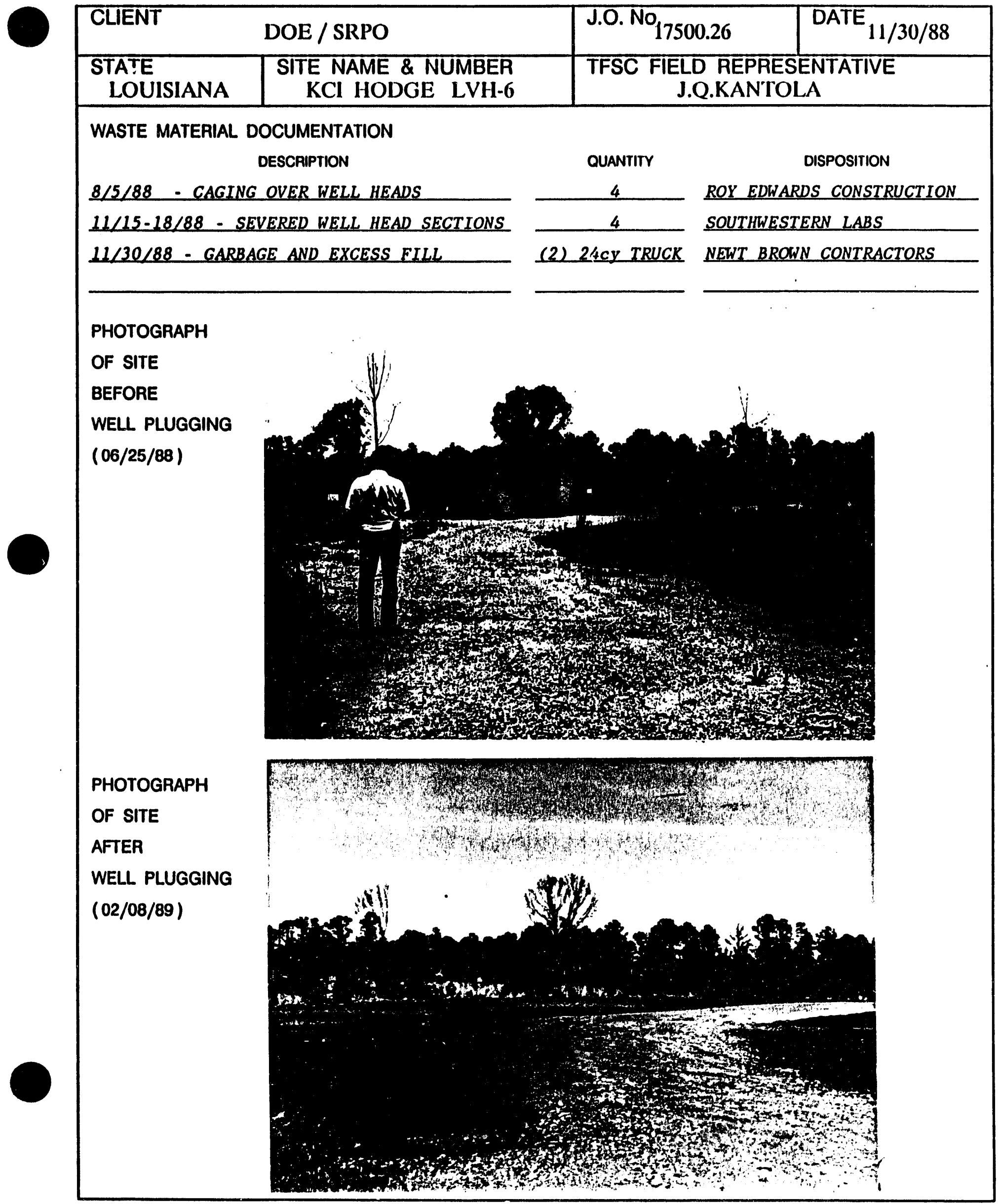




\begin{tabular}{|c|c|c|c|}
\hline \multicolumn{2}{|c|}{$\begin{array}{ll}\text { CLIENT } & \text { DOE / SRPO }\end{array}$} & J.O. No $_{17500.26}$ & DATE $_{12 / 01 / 88}$ \\
\hline $\begin{array}{l}\text { STATE } \\
\text { LOUISIANA }\end{array}$ & $\begin{array}{l}\text { SITE NAME \& NUMBER } \\
\text { KCI HODGE LH-7 }\end{array}$ & \multicolumn{2}{|c|}{$\begin{array}{l}\text { TFSC FIELD REPRESENTATIVE } \\
\text { J.Q.KANTOLA }\end{array}$} \\
\hline \multicolumn{4}{|c|}{ WASTE MATERIAL DOCUMENTATION } \\
\hline & DESCAIPTION & QUANTITY & DISPOSITION \\
\hline \multicolumn{2}{|c|}{$8 / 9 / 88$ - CAGING OVER WELL HEADS } & $\underline{R O Y}$ & DS CONSTRUCTION \\
\hline \multirow{2}{*}{\multicolumn{2}{|c|}{$11 / 30 / 88$ - SEVERED WELL CASING SECTIONS }} & $\underline{\mathrm{SOU}}$ & SOUTHWESTERN LABS \\
\hline $12 / 1 / 88-G A R B$ & & 14CY TRUCK NEW & $N$ CONTRACTORS \\
\hline
\end{tabular}

\section{PHOTOGRAPH}

OF SITE

BEFORE

WELL PLUGGING

(06/24/88)

PHOTOGRAPH

OF SITE

AFTER

WELL PLUGGING (02/08/89)
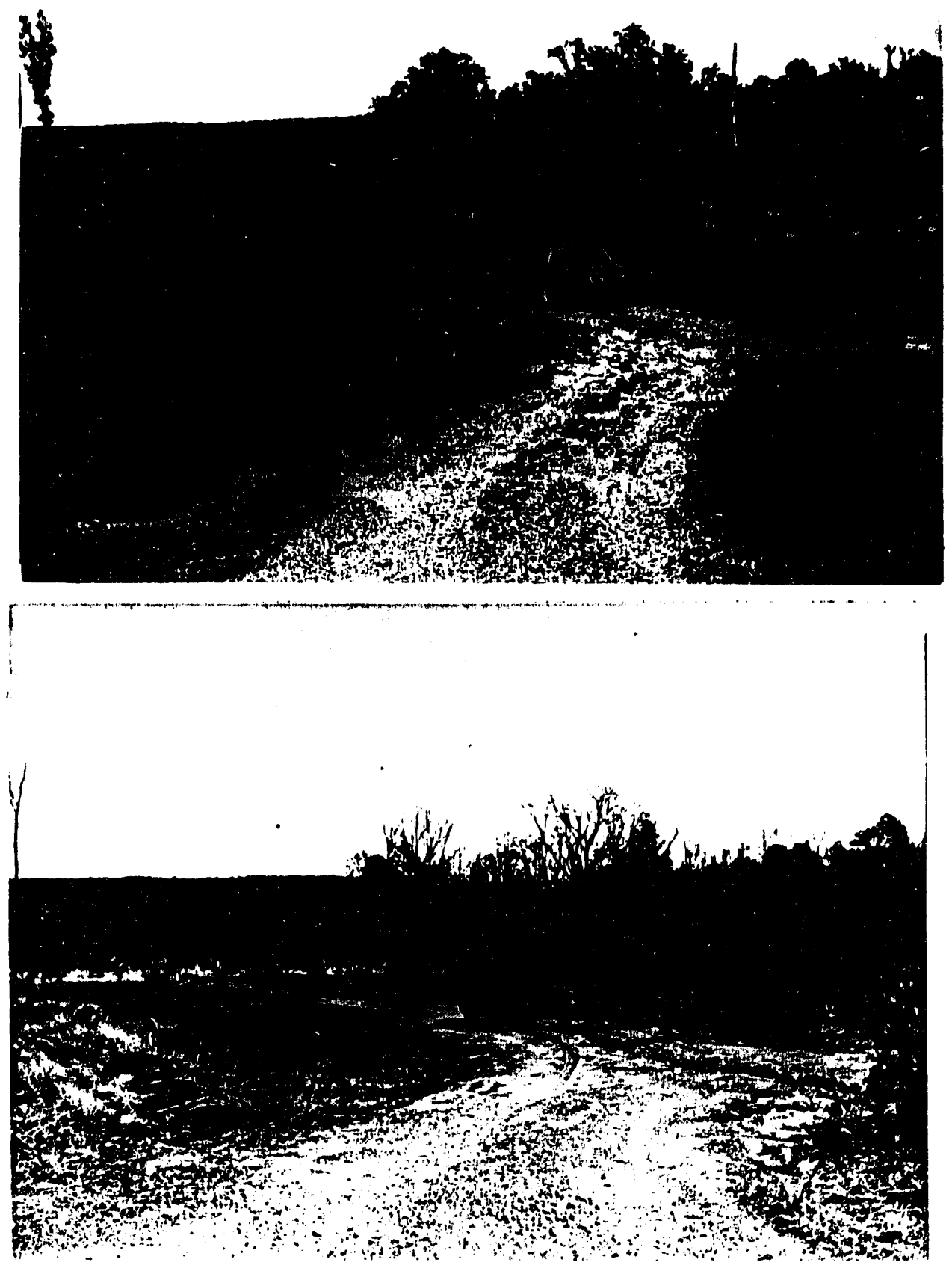


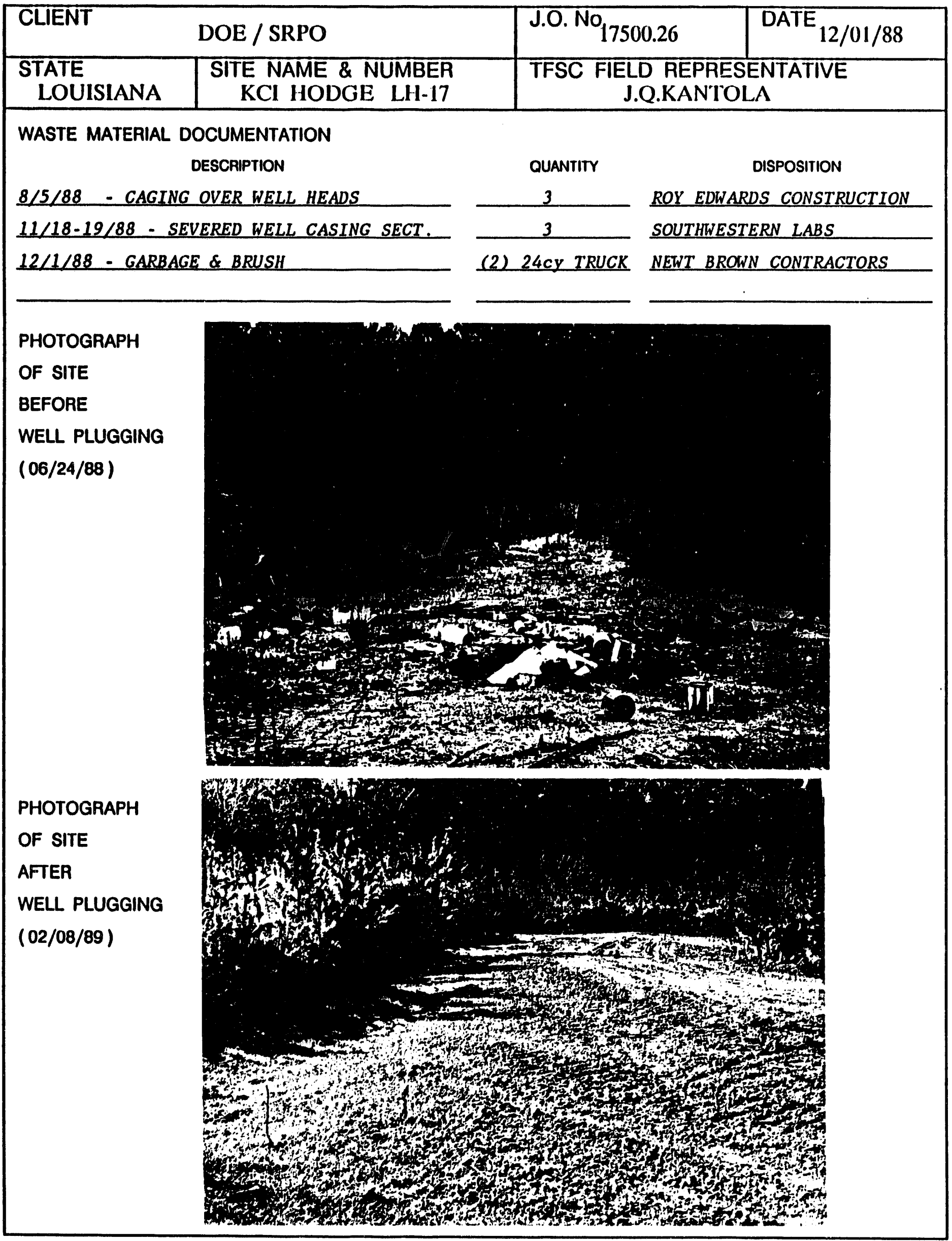




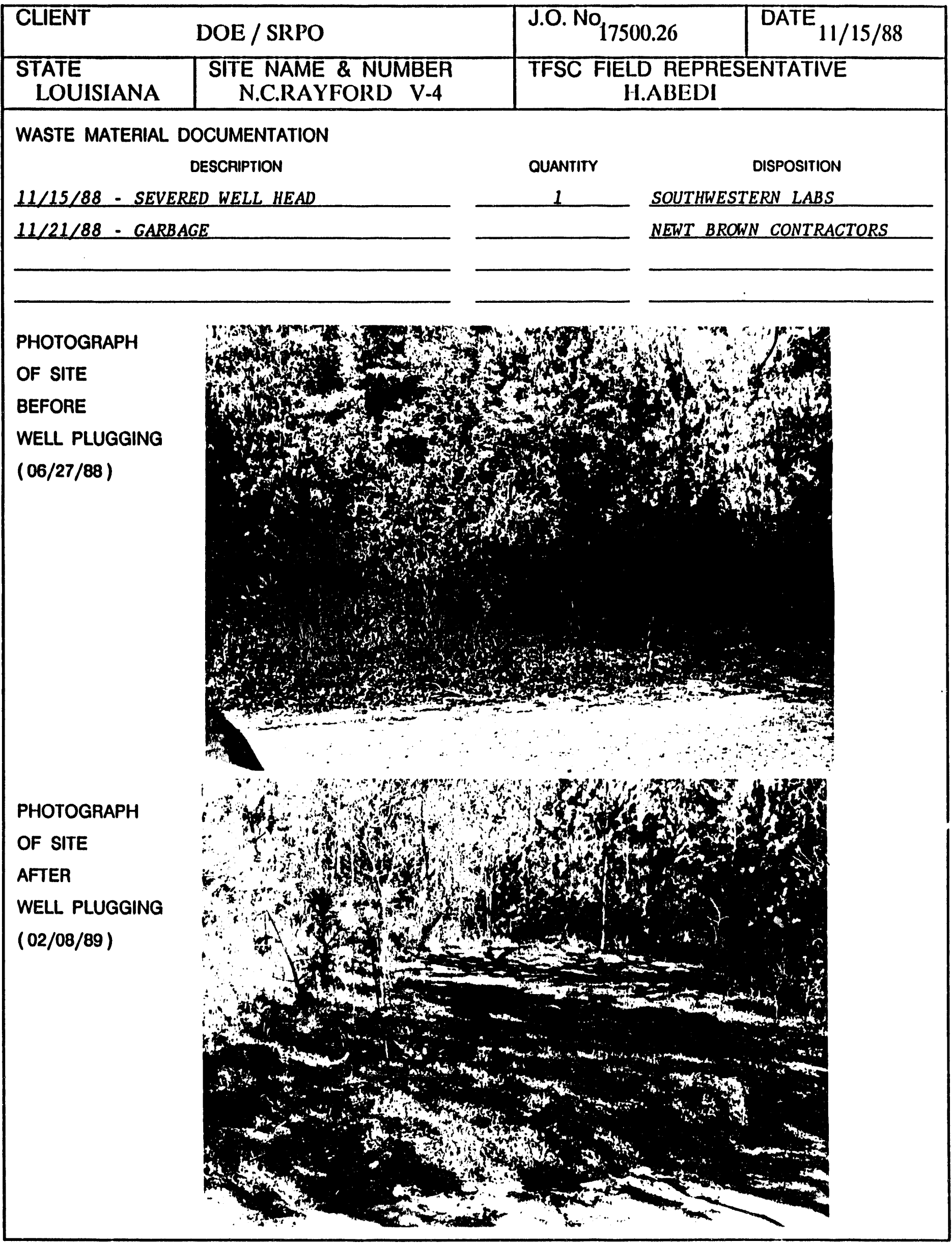




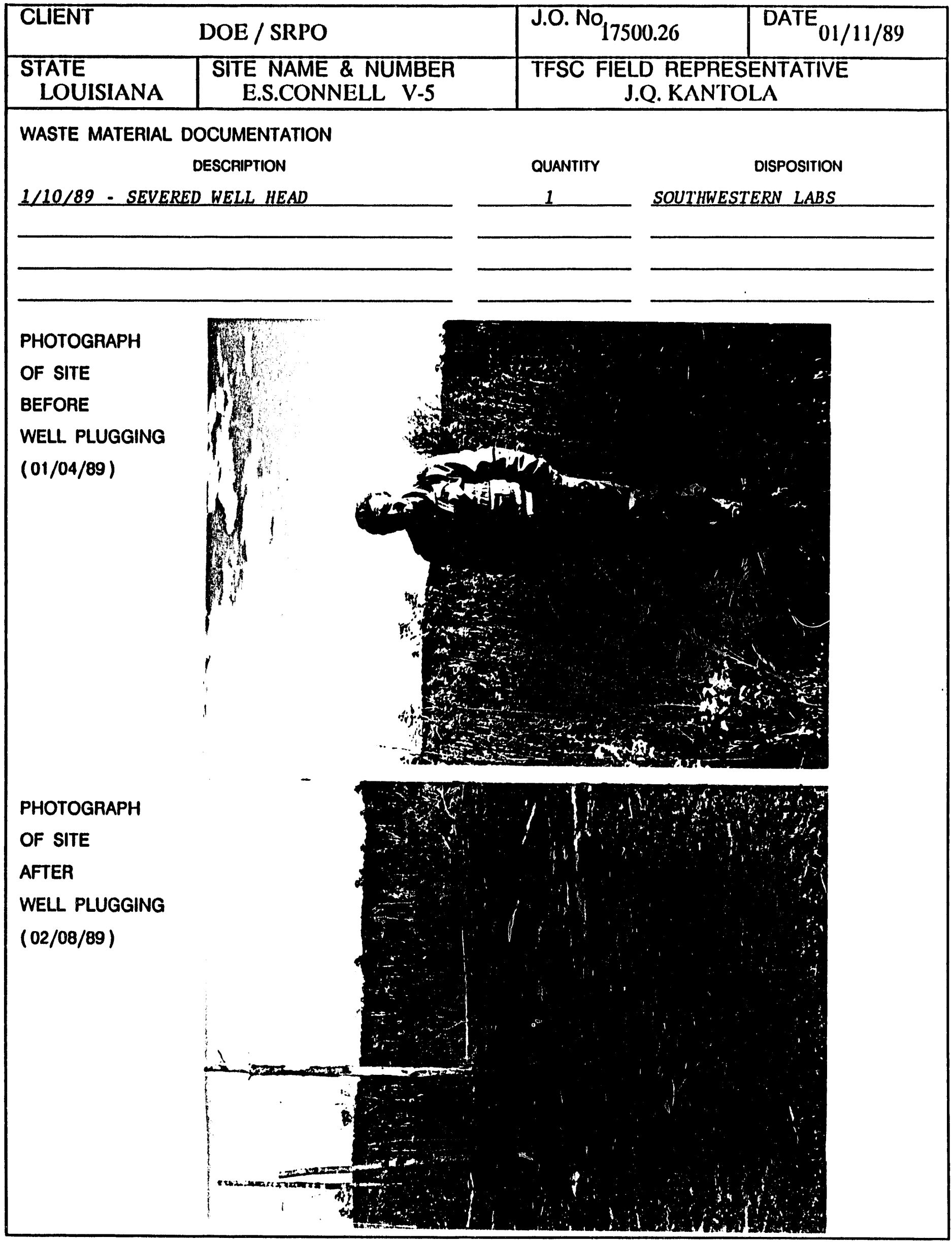




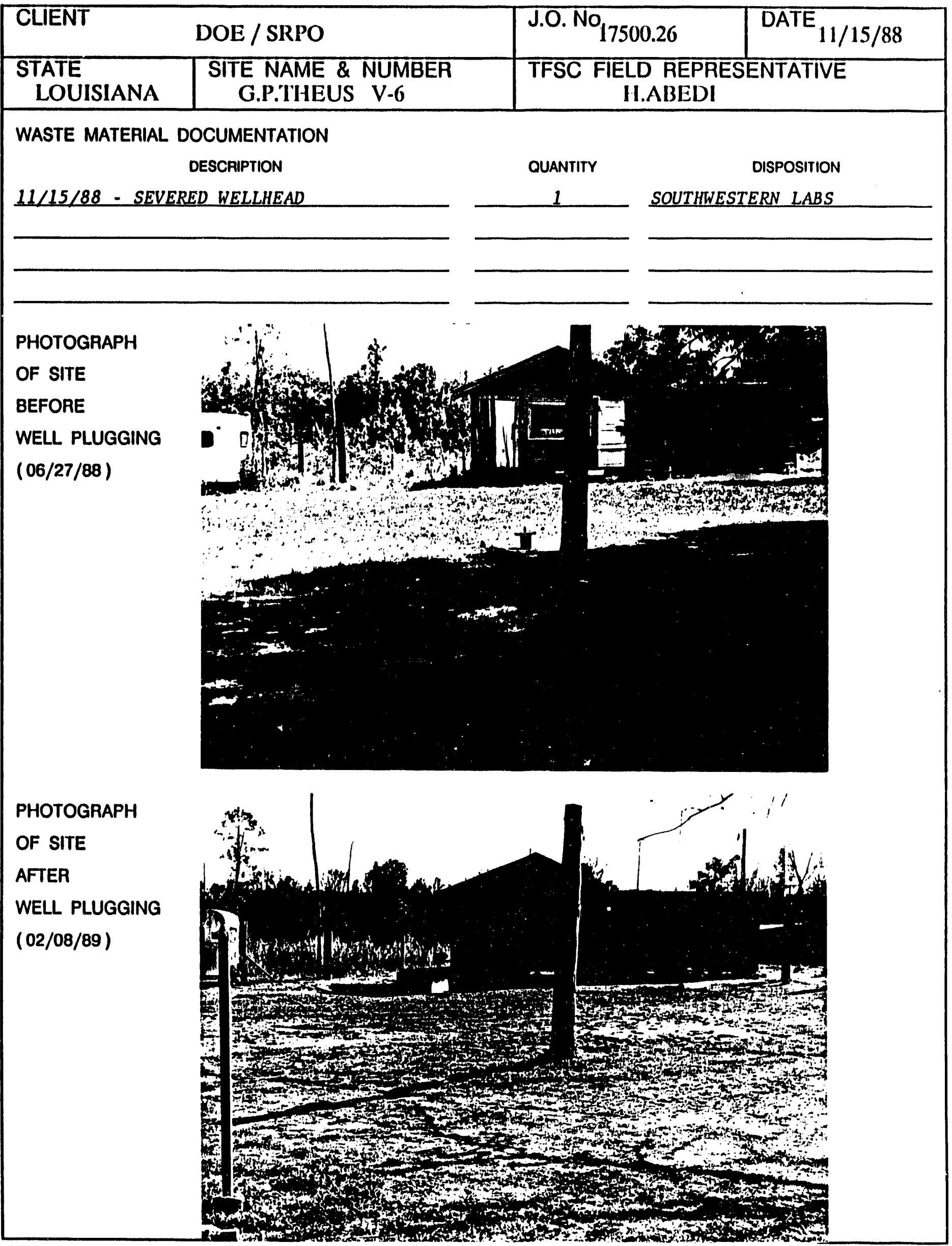




\begin{tabular}{|c|c|c|c|}
\hline CLIENT & DOE / SRPO & J.O. $\mathrm{No}_{17500.26}$ & DATE $_{11 / 30 / 88}$ \\
\hline $\begin{array}{l}\text { STATE } \\
\text { LOUISIANA }\end{array}$ & $\begin{array}{c}\text { SITE NAME \& NUMBER } \\
\text { E.S.CONNELL V-7 }\end{array}$ & $\begin{array}{r}\text { TFSC FIELD RE } \\
\text { J.Q.KA }\end{array}$ & $\begin{array}{l}\text { ENTATIVE } \\
\text { A }\end{array}$ \\
\hline WASTE MATERIAL & CUMENTATION & & \\
\hline & ESCRIPTION & QUANTITY & DISPOSITION \\
\hline $9 / 27 / 88 \cdot S E V I$ & $D$ WELLHEAD & Sov: & ERN LABS \\
\hline $11 / 21 / 88 \& 11 /$ & 88-BRUSH \& EXCESS FILL & TRUCKS & N CONTRACTORS \\
\hline
\end{tabular}

PHOTOGRAPH
OF SITE
BEFORE

WELL PLUGGING $(06 / 27 / 88)$

PHOTOGRAPH OF SITE AFTER WELL PLUGGING (02/08/89)
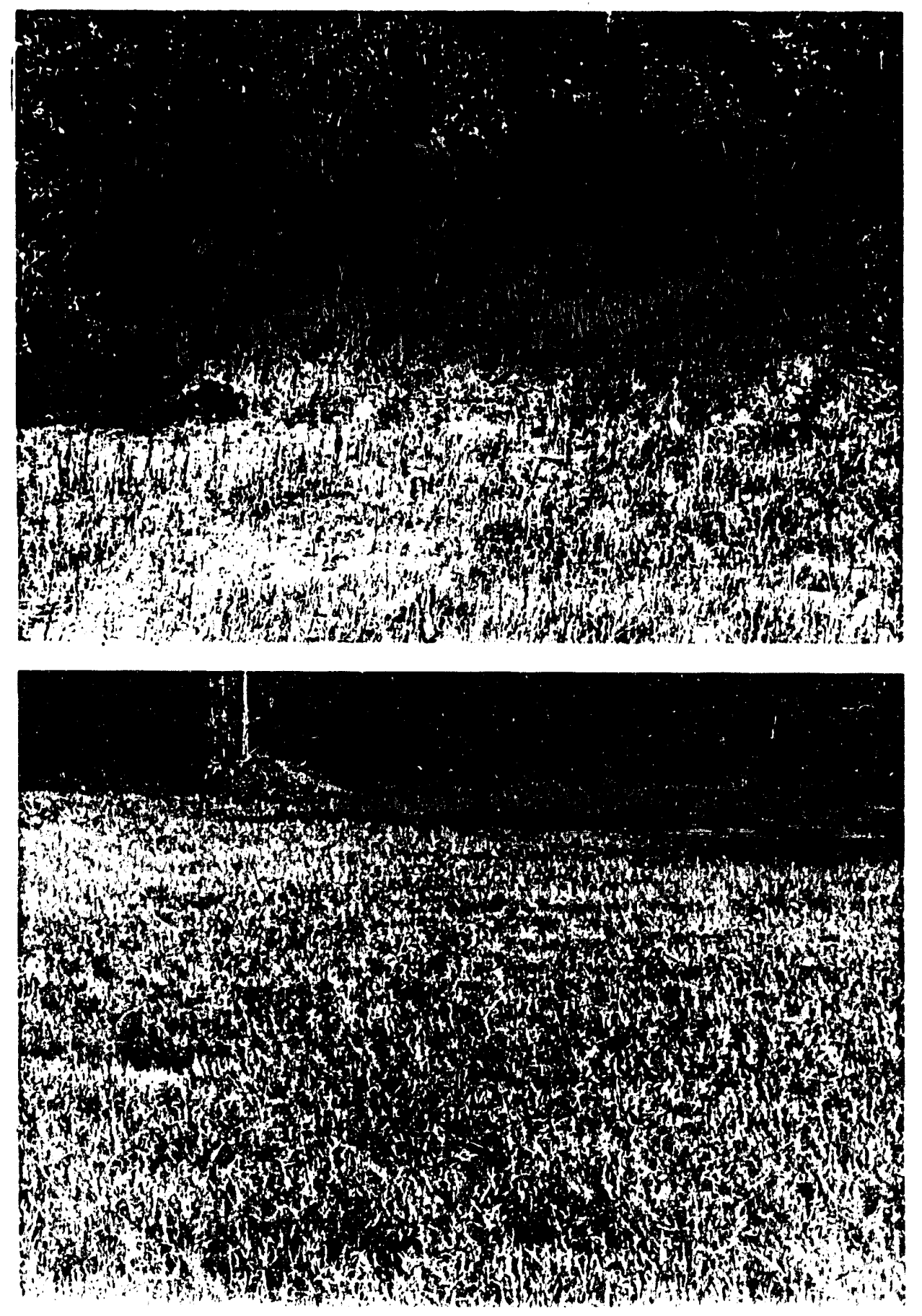


\begin{tabular}{|c|c|c|c|}
\hline \multicolumn{2}{|r|}{ DOE / SRPO } & J.0. $\mathrm{No}_{17500.26}$ & DATE $_{12 / 01 / 88}$ \\
\hline $\begin{array}{l}\text { STATE } \\
\text { LOUISIANA }\end{array}$ & $\begin{array}{l}\text { SITE NAME \& NUMBER } \\
\text { LSU-R1A }\end{array}$ & \multicolumn{2}{|c|}{$\begin{array}{c}\text { TFSC FIELD REPRESENTATIVE } \\
\text { J.Q.KAN'TOLA }\end{array}$} \\
\hline \multicolumn{4}{|c|}{ WASTE MATERIAL DOCUMENTATION } \\
\hline & DESCAIPTION & QUANTITY & DISPOSITION \\
\hline \multicolumn{2}{|c|}{$11 / 20 / 88$ - SEVERED WELLHEAD } & $\underline{S O U}$ & SOUTHWESTERN LABS \\
\hline \multicolumn{2}{|c|}{ 12/01/88 - GARBAGE \& BRUSH } & & NEWT BROWN CONTRACTORS \\
\hline
\end{tabular}

PHOTOGRAPH

OF SITE

BEFORE

WELL PLUGGING

$(08 / 13 / 88)$

PHOTOGRAPH

OF SITE

AFTER

WELL PLUGGING $(02 / 08 / 89)$
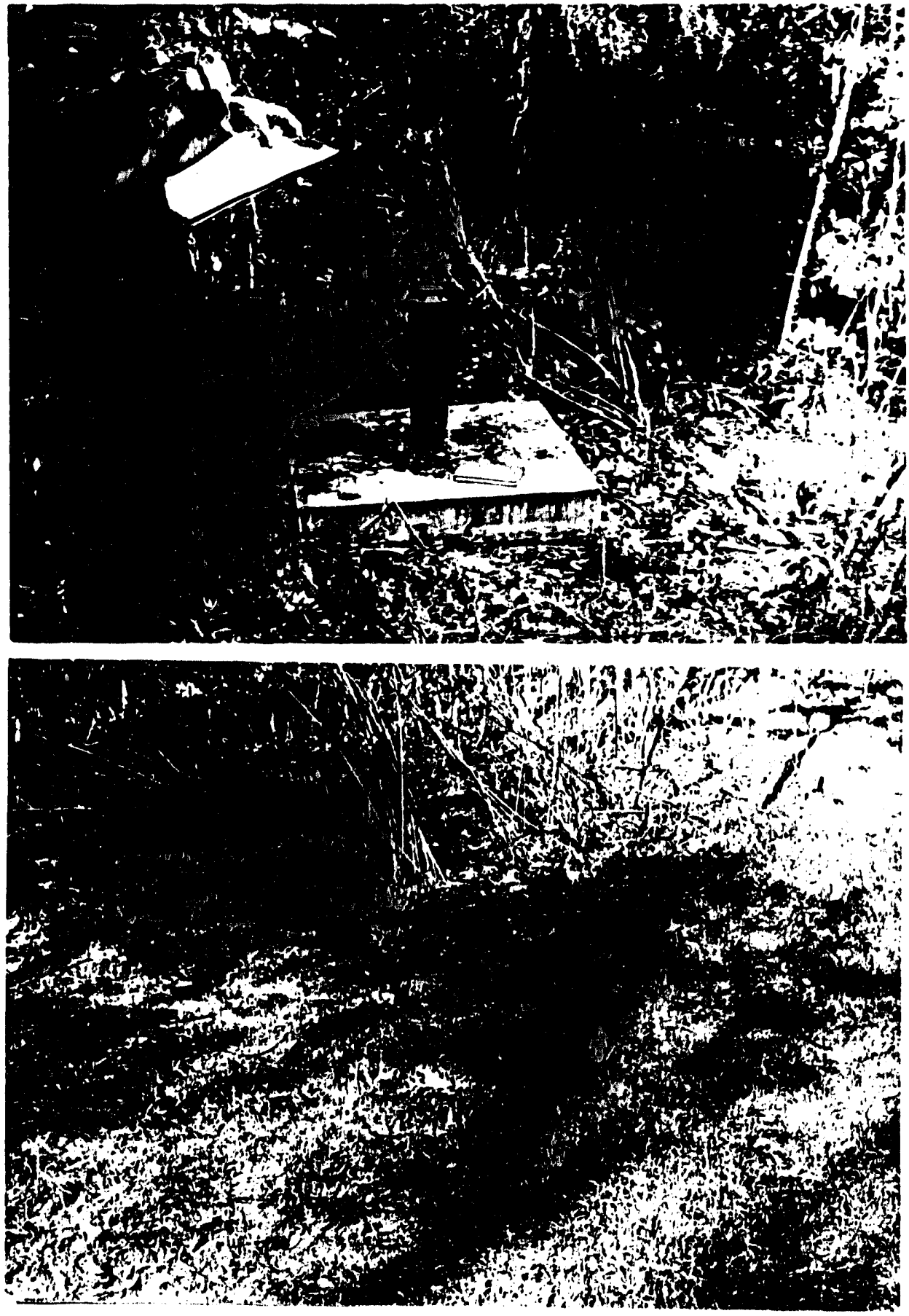


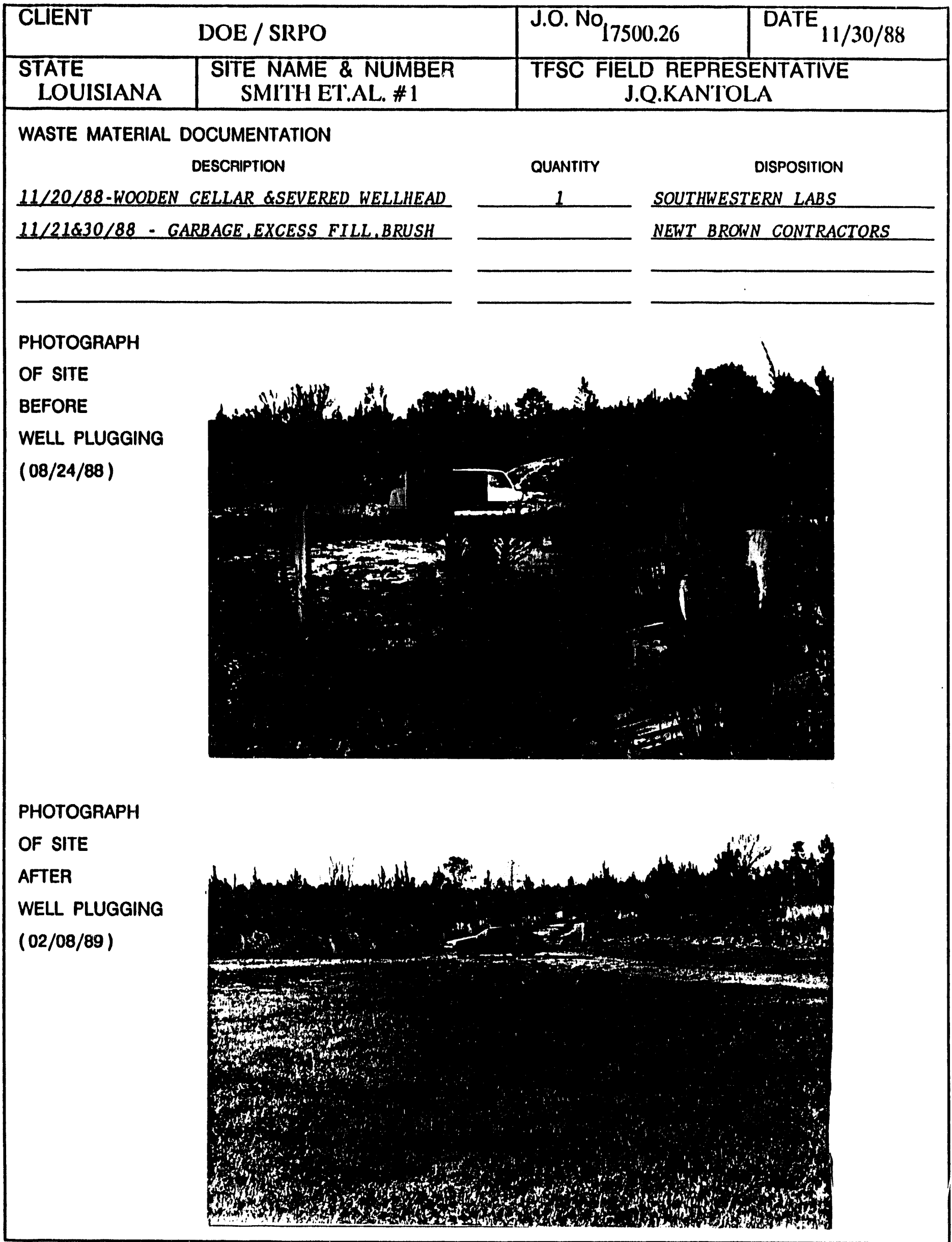




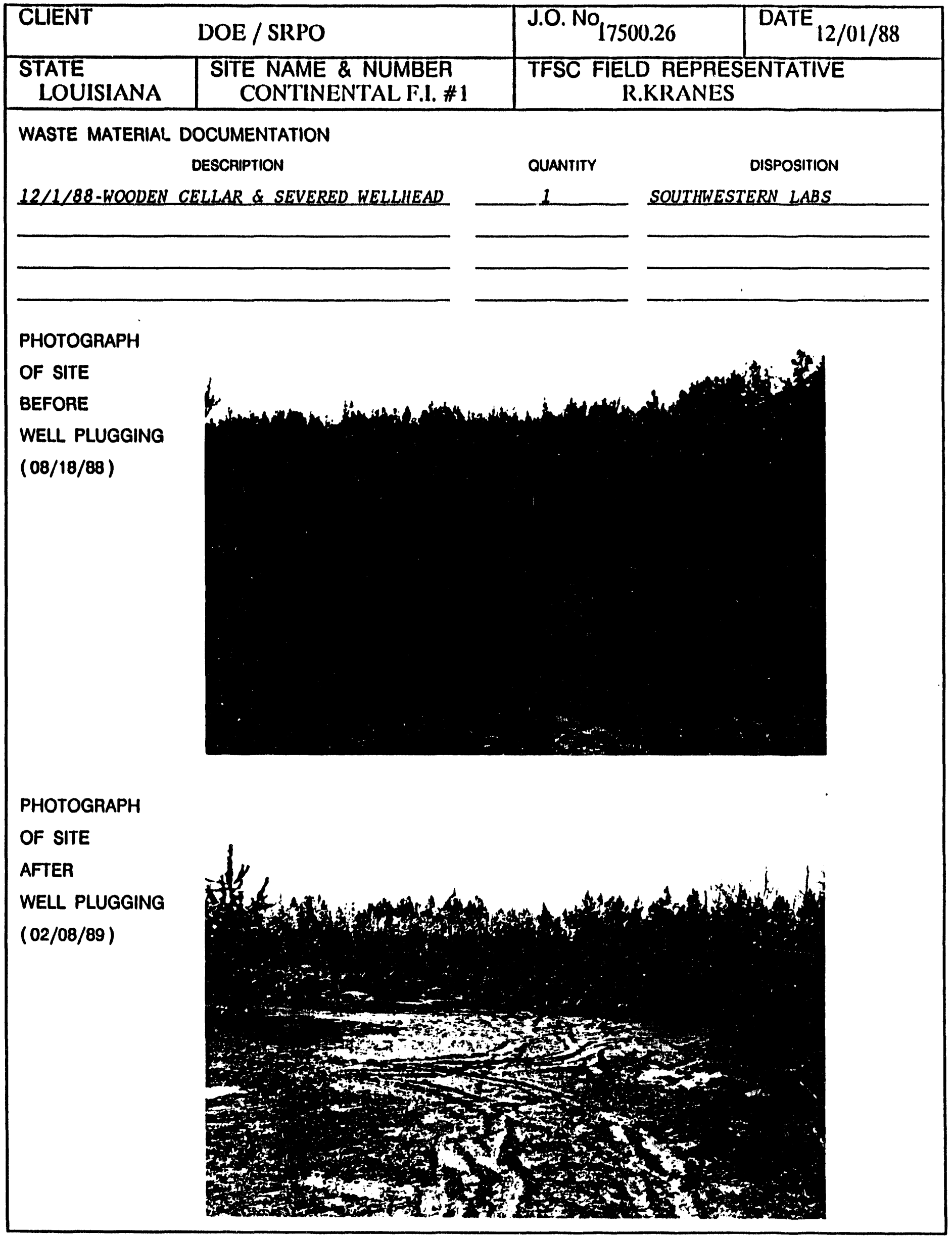




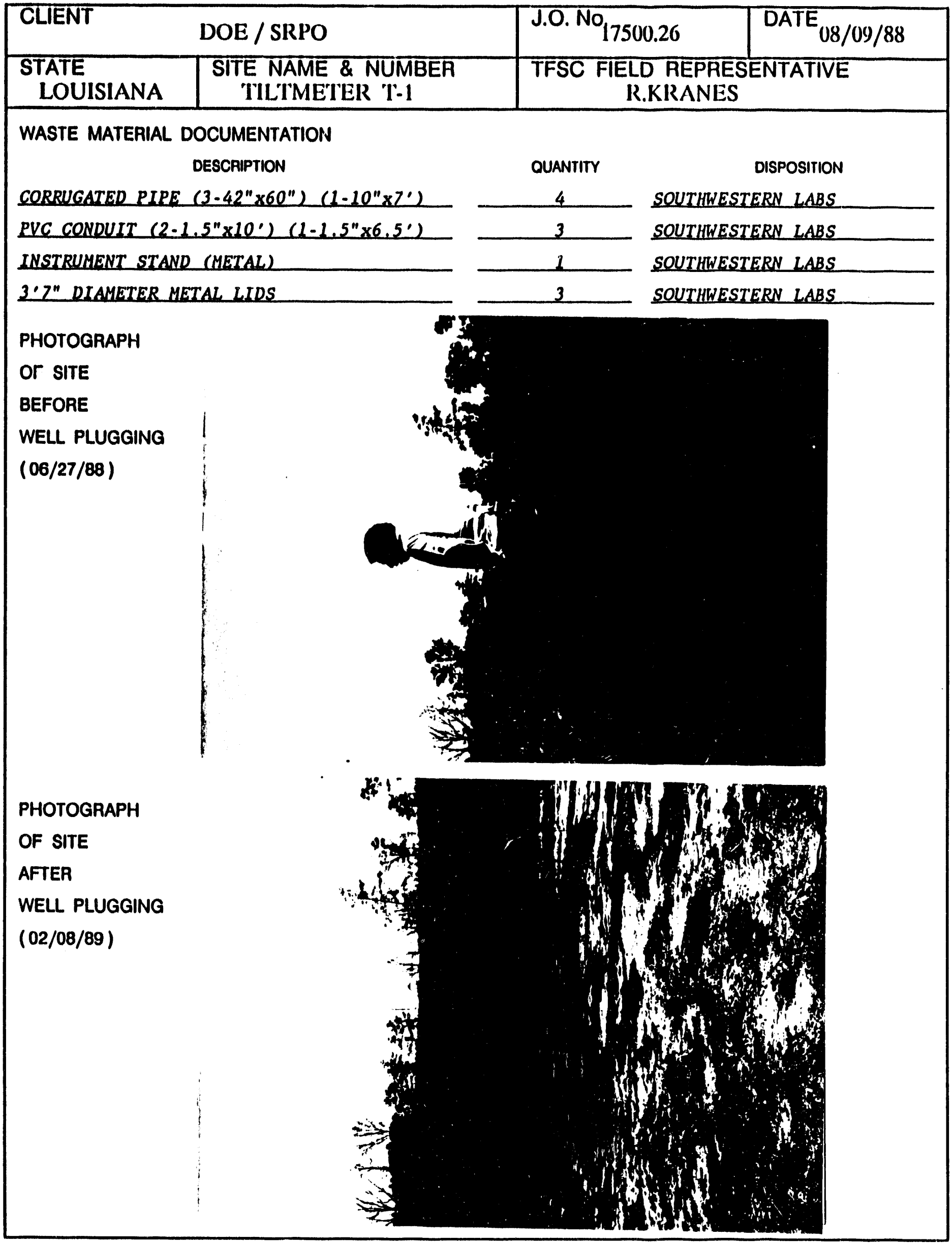




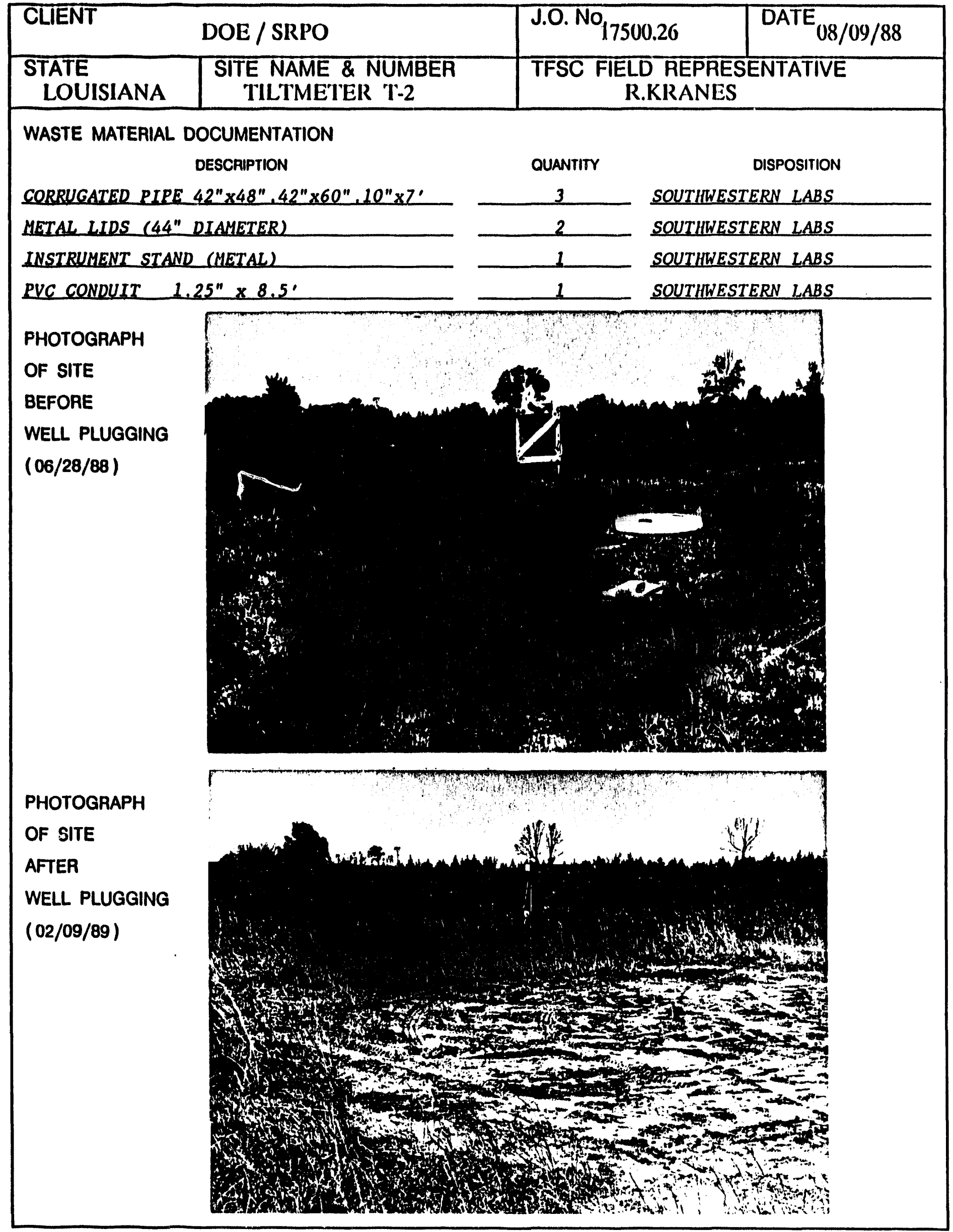




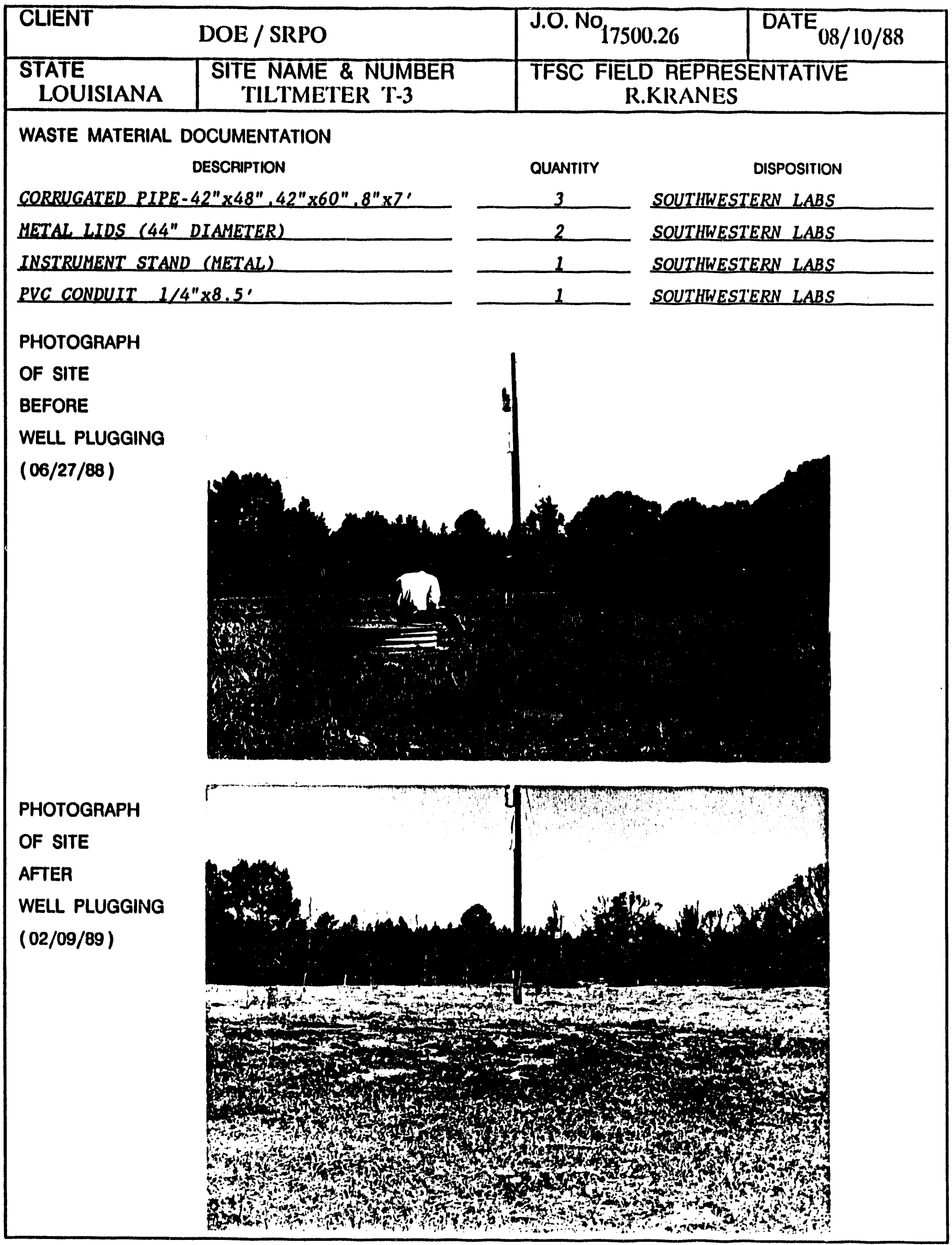




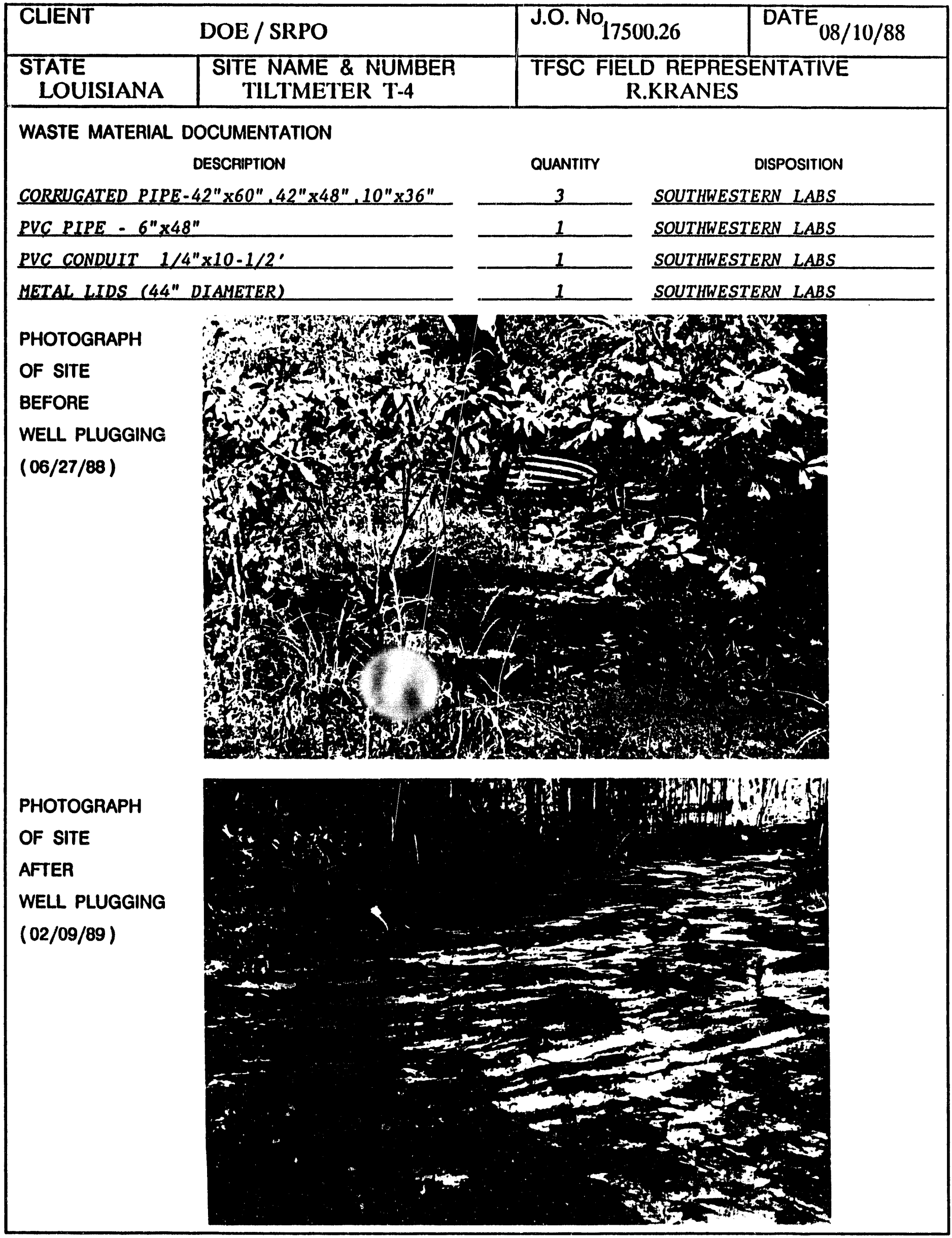




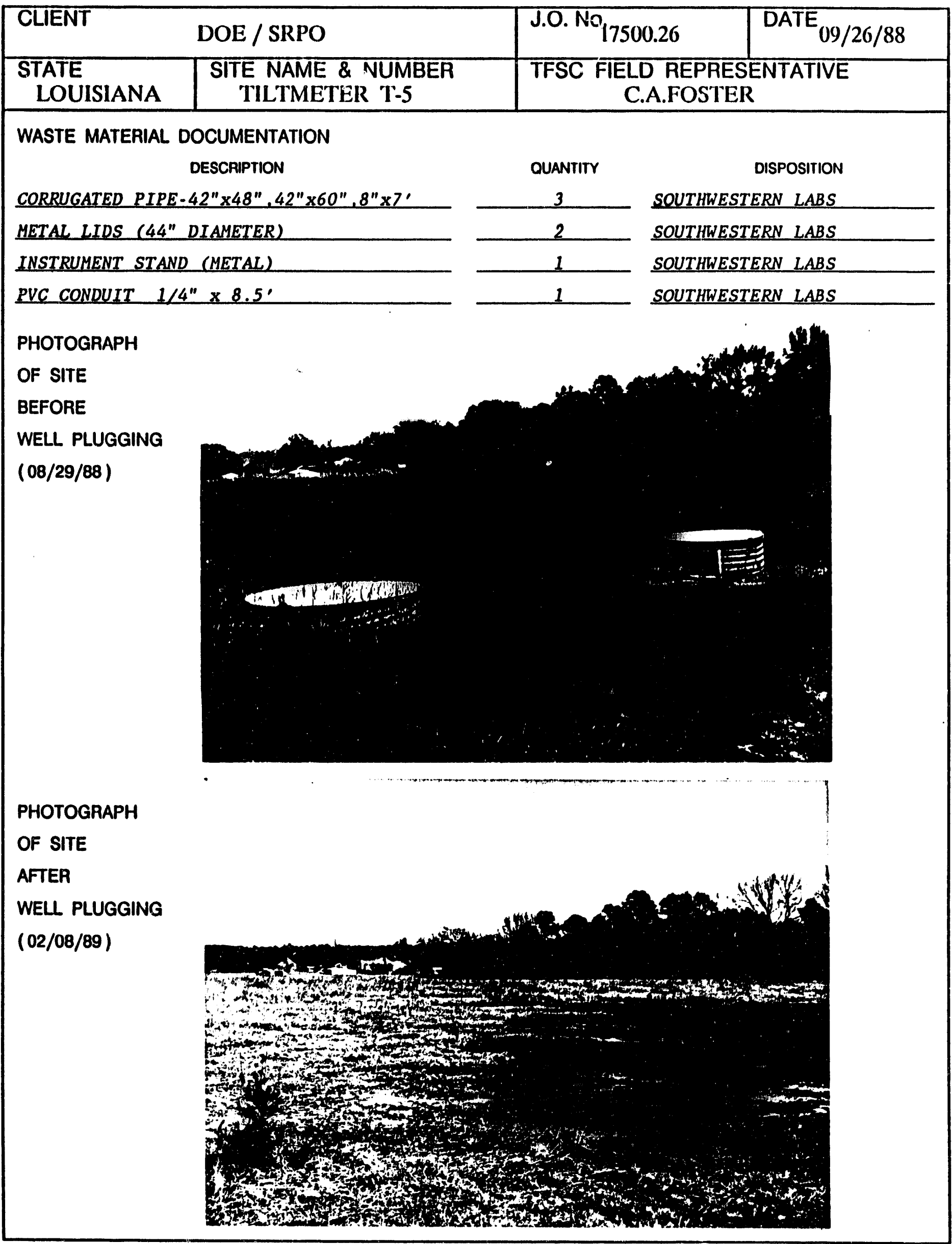




\section{APPENDIX}

STATE DOCUMENTATION 


\section{$20 \times 15-15$}

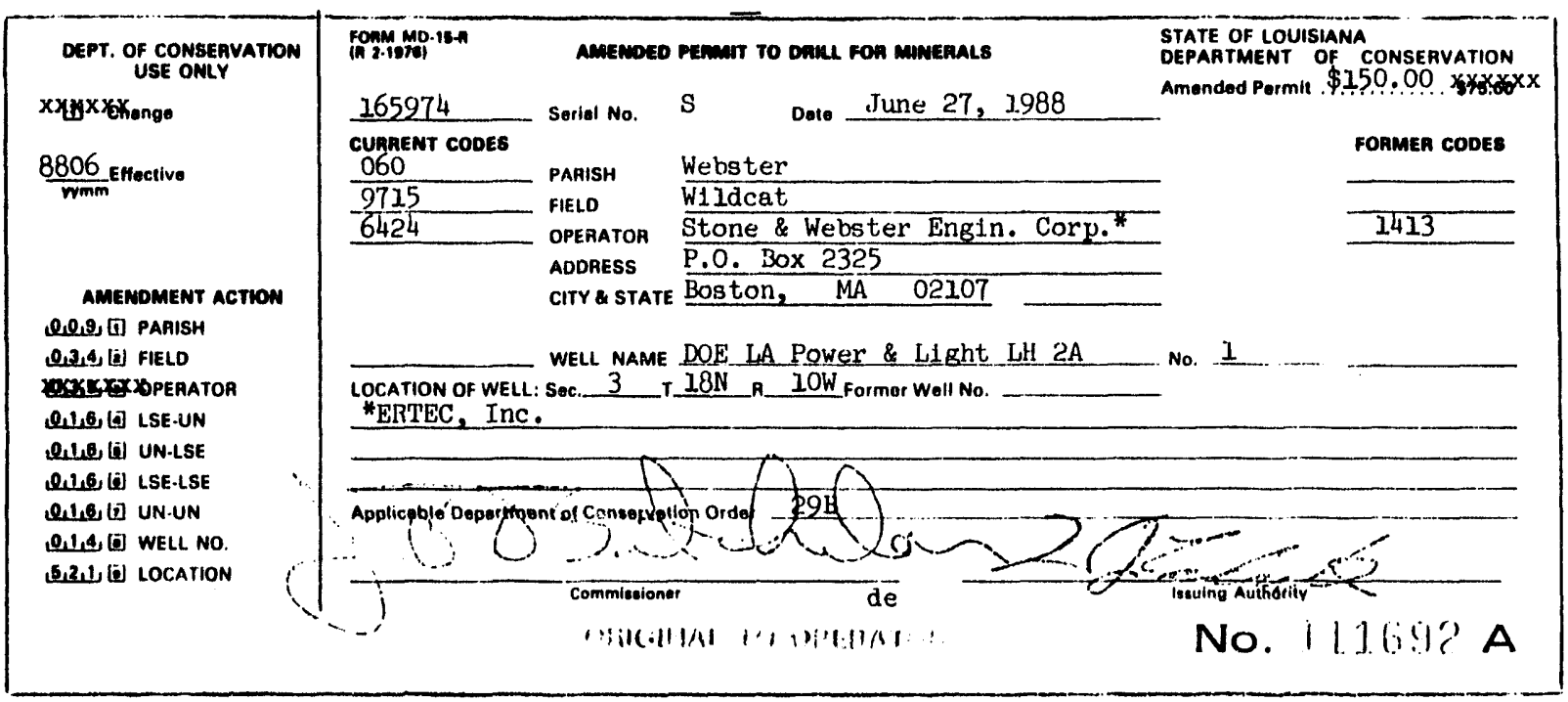

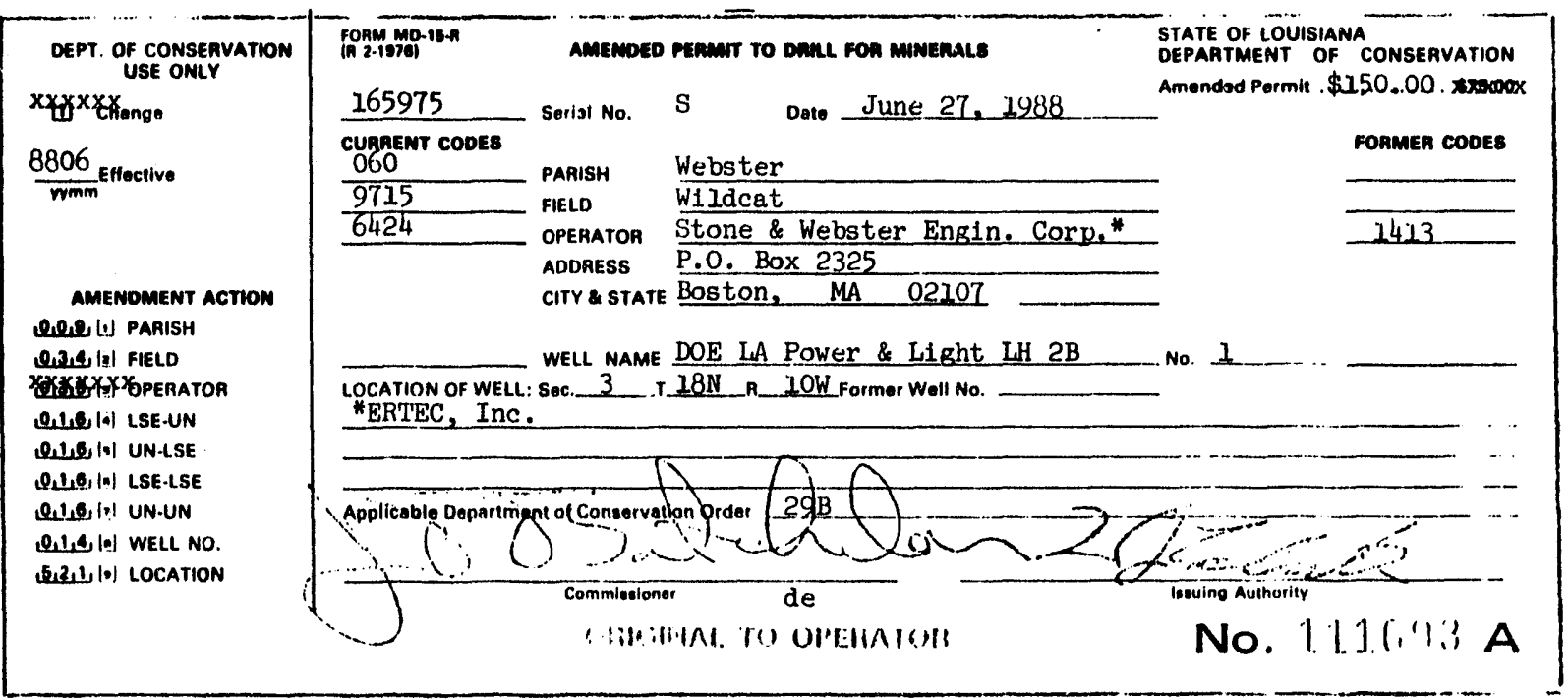

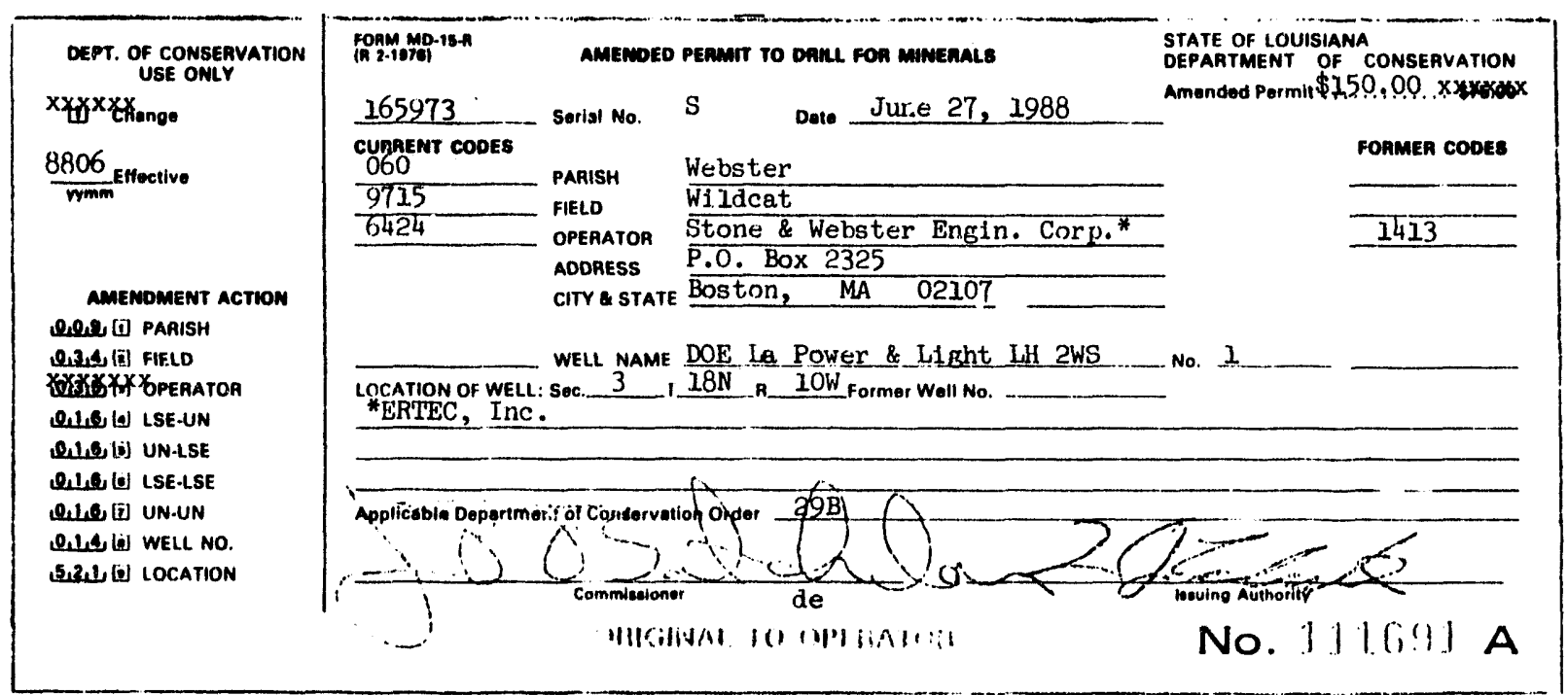




\section{BORY ND-15-R}

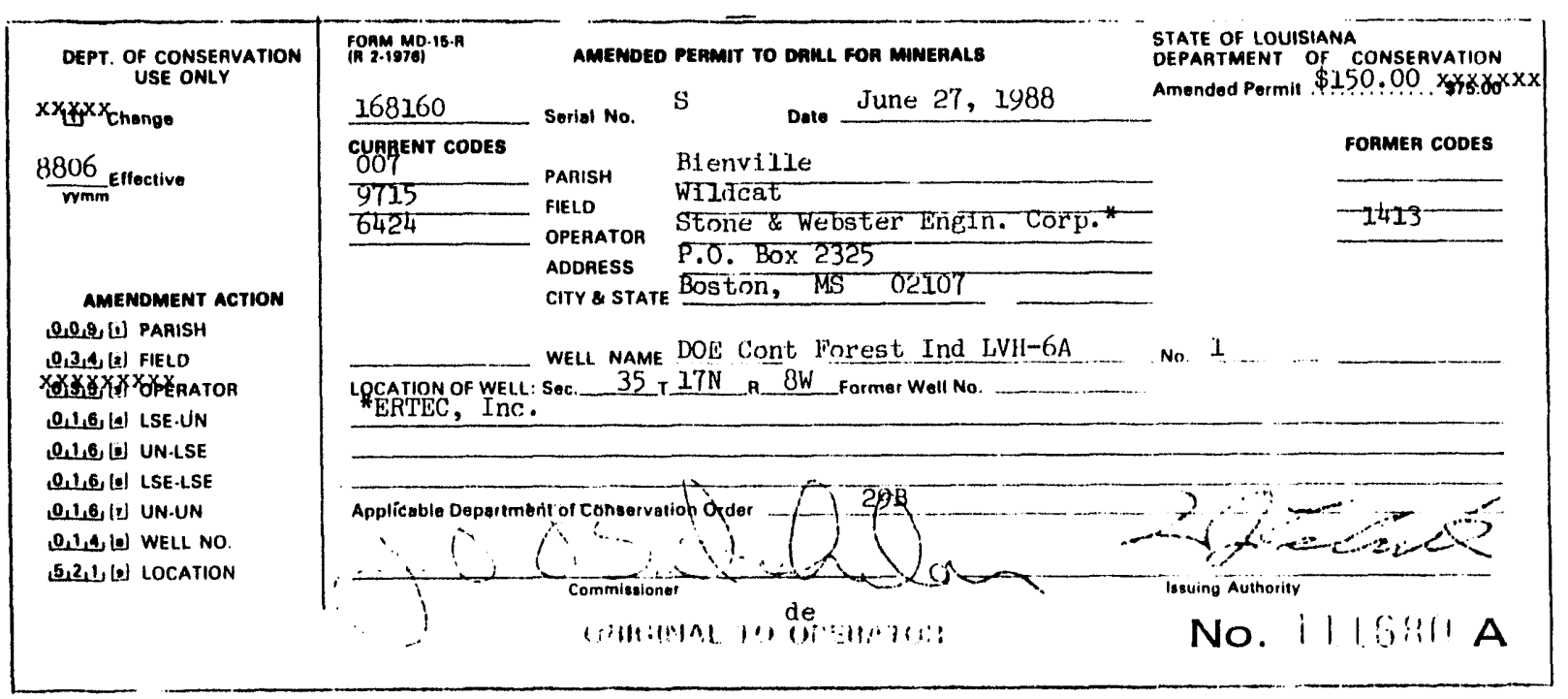

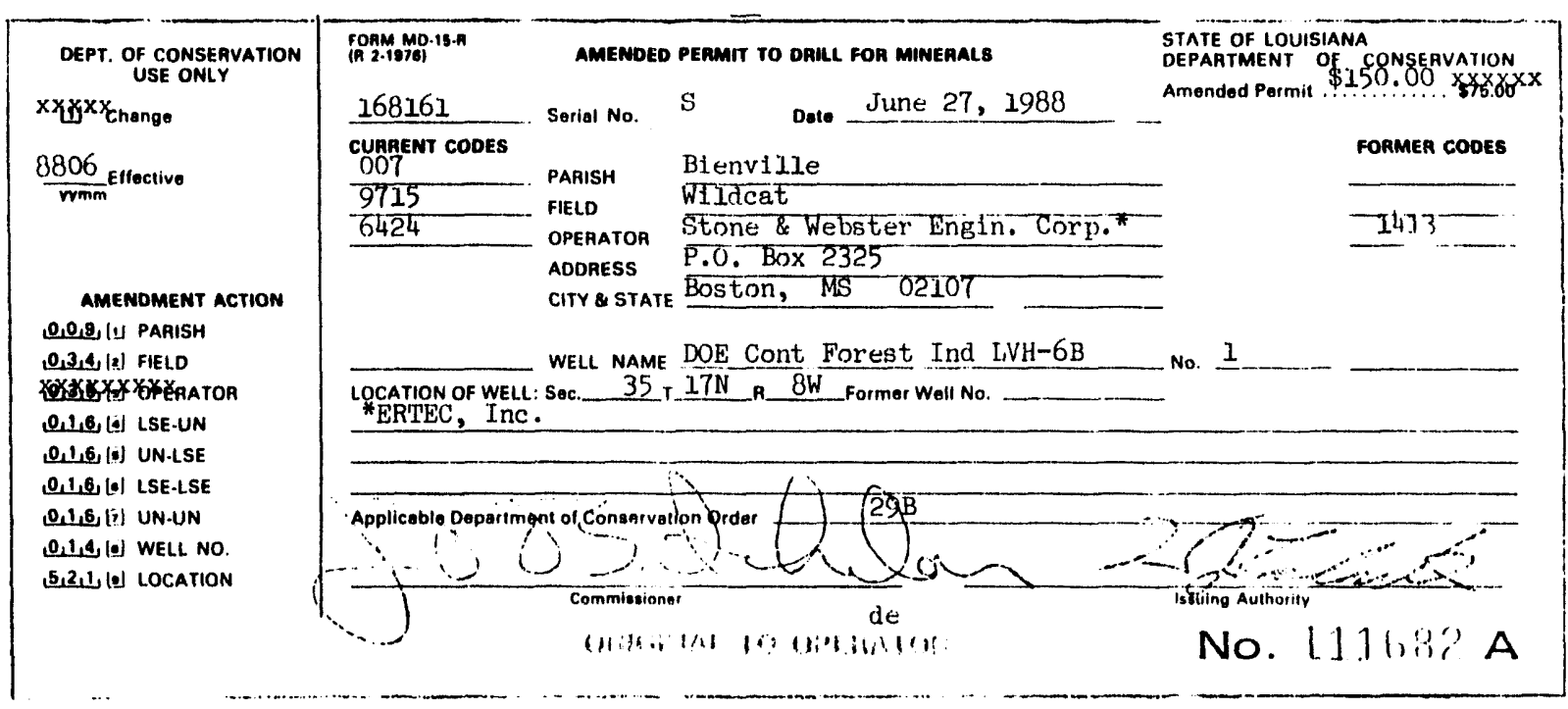

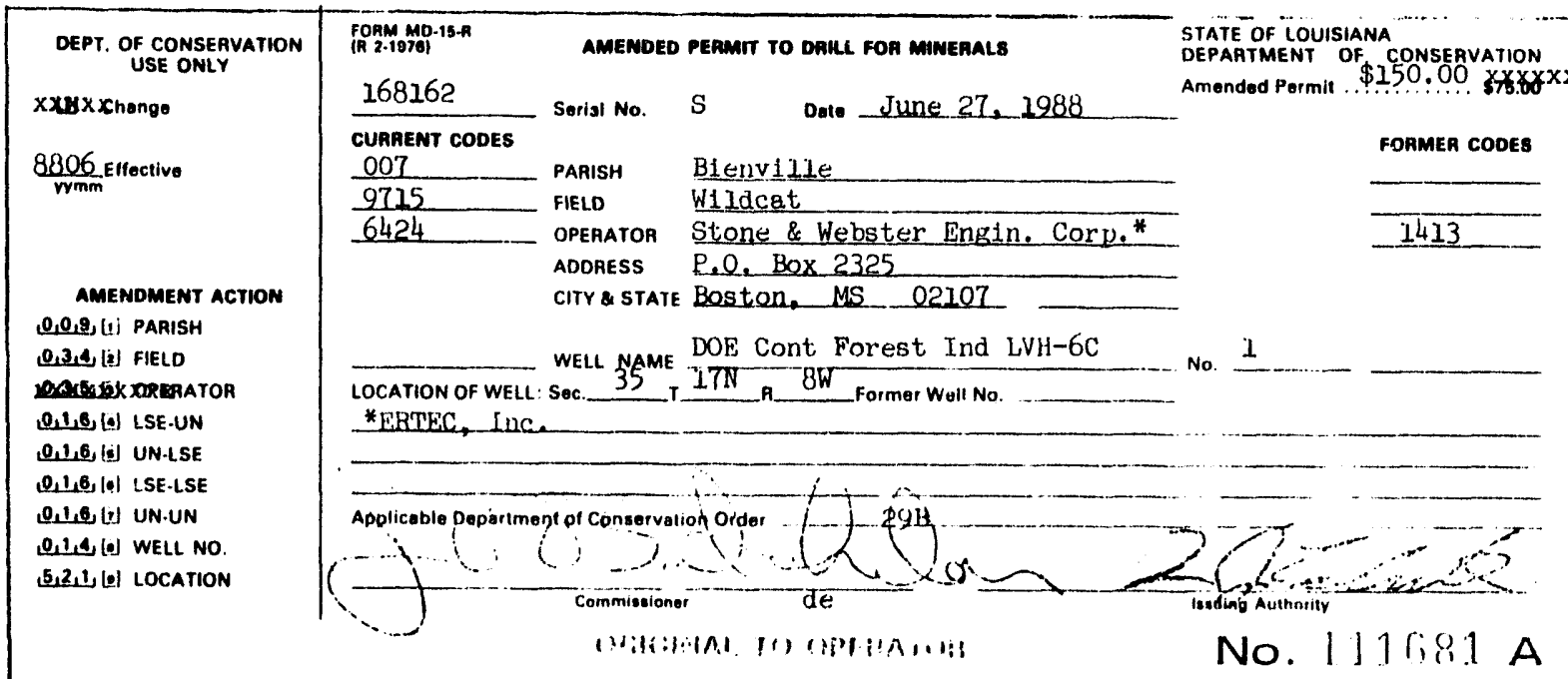




\section{FORY YD-1,5-?}

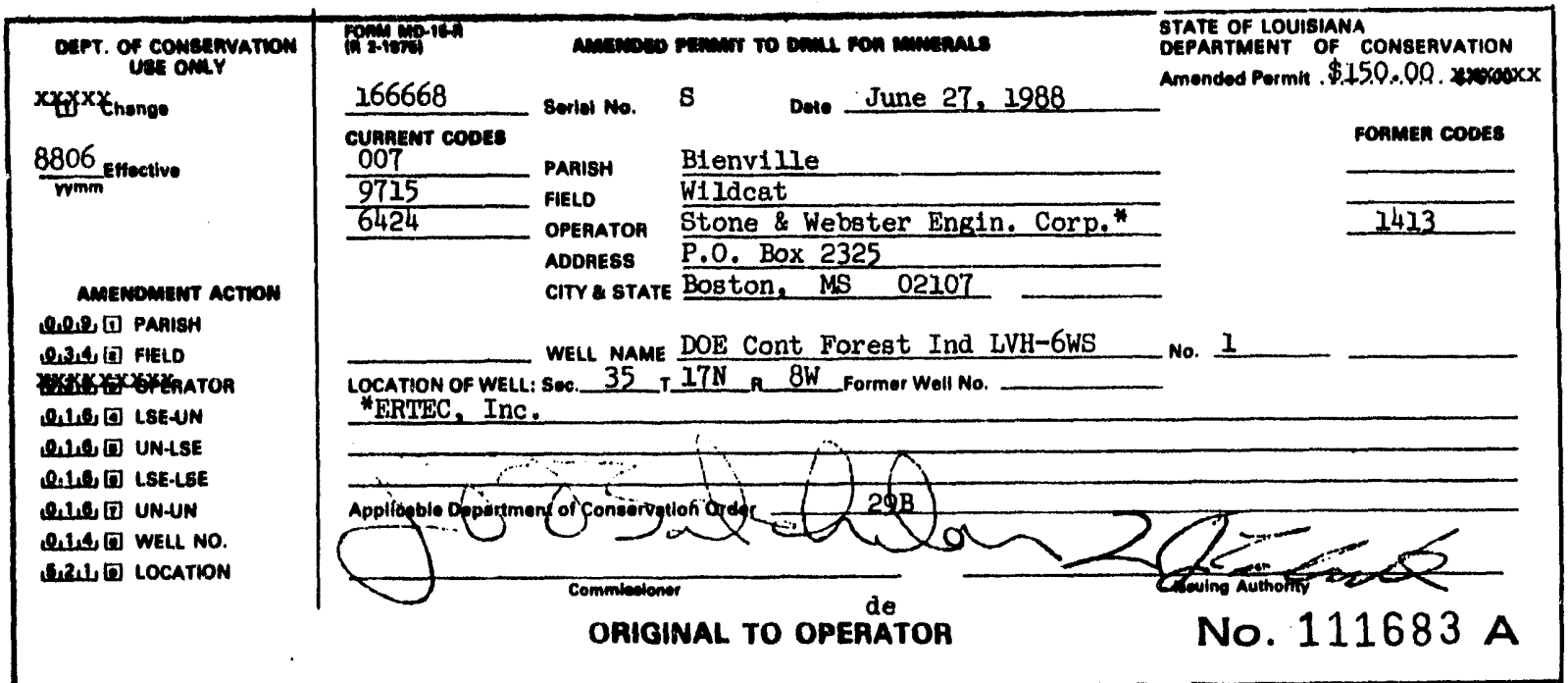

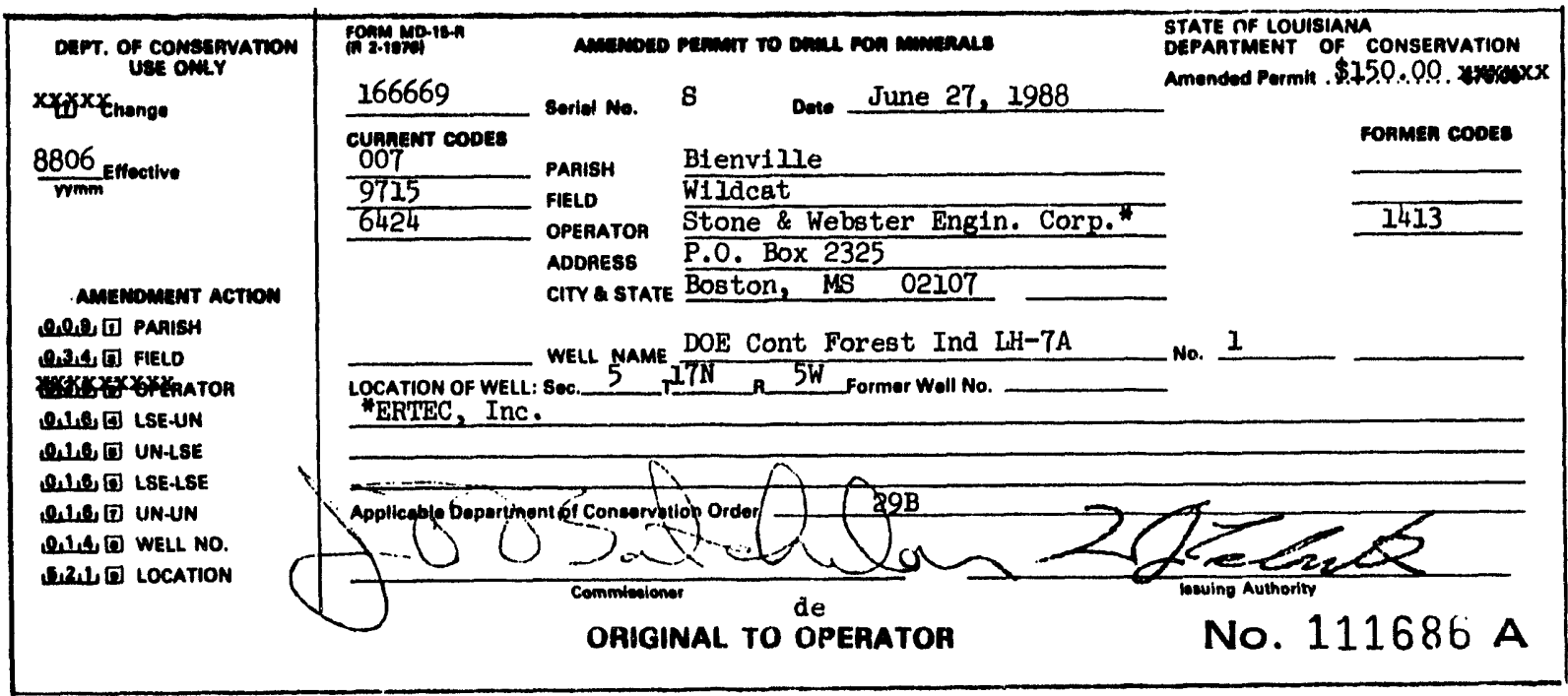

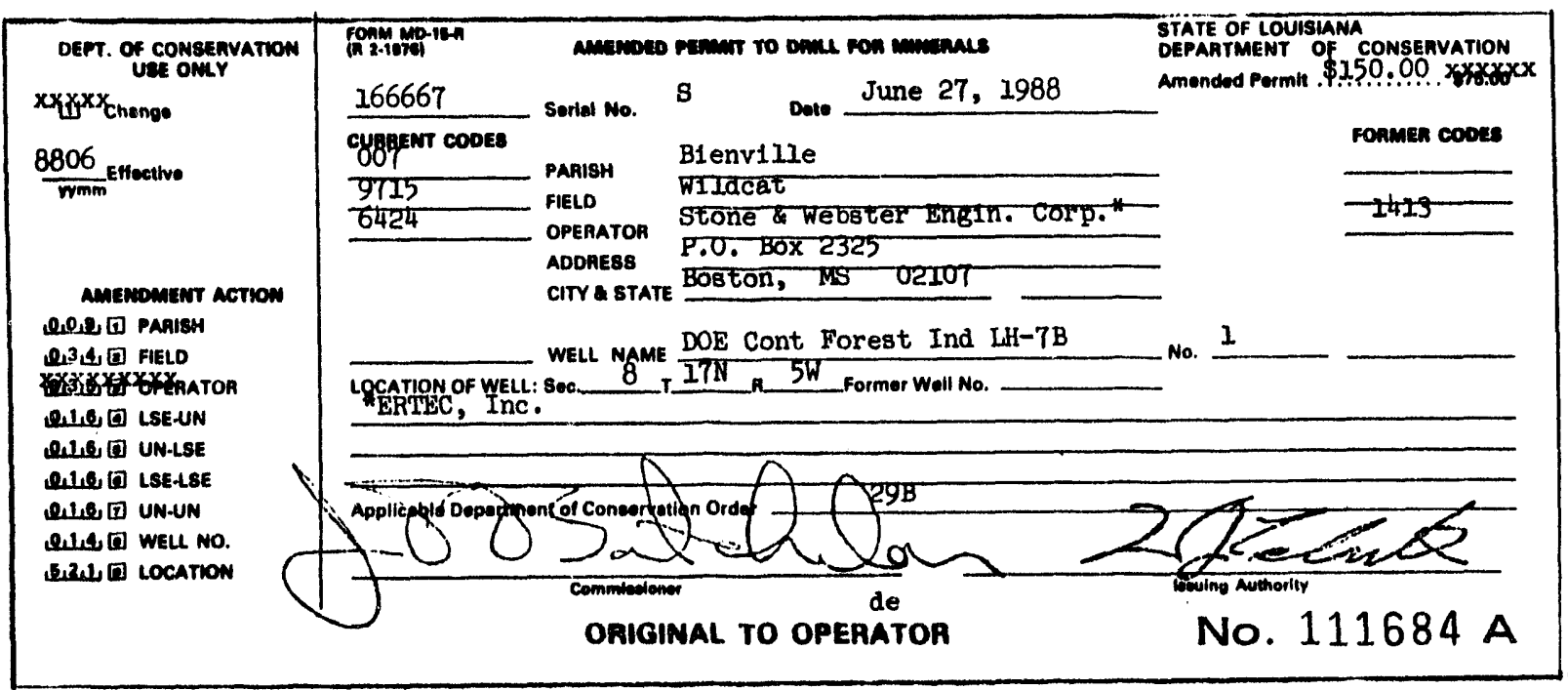


BOPL YD-15-8

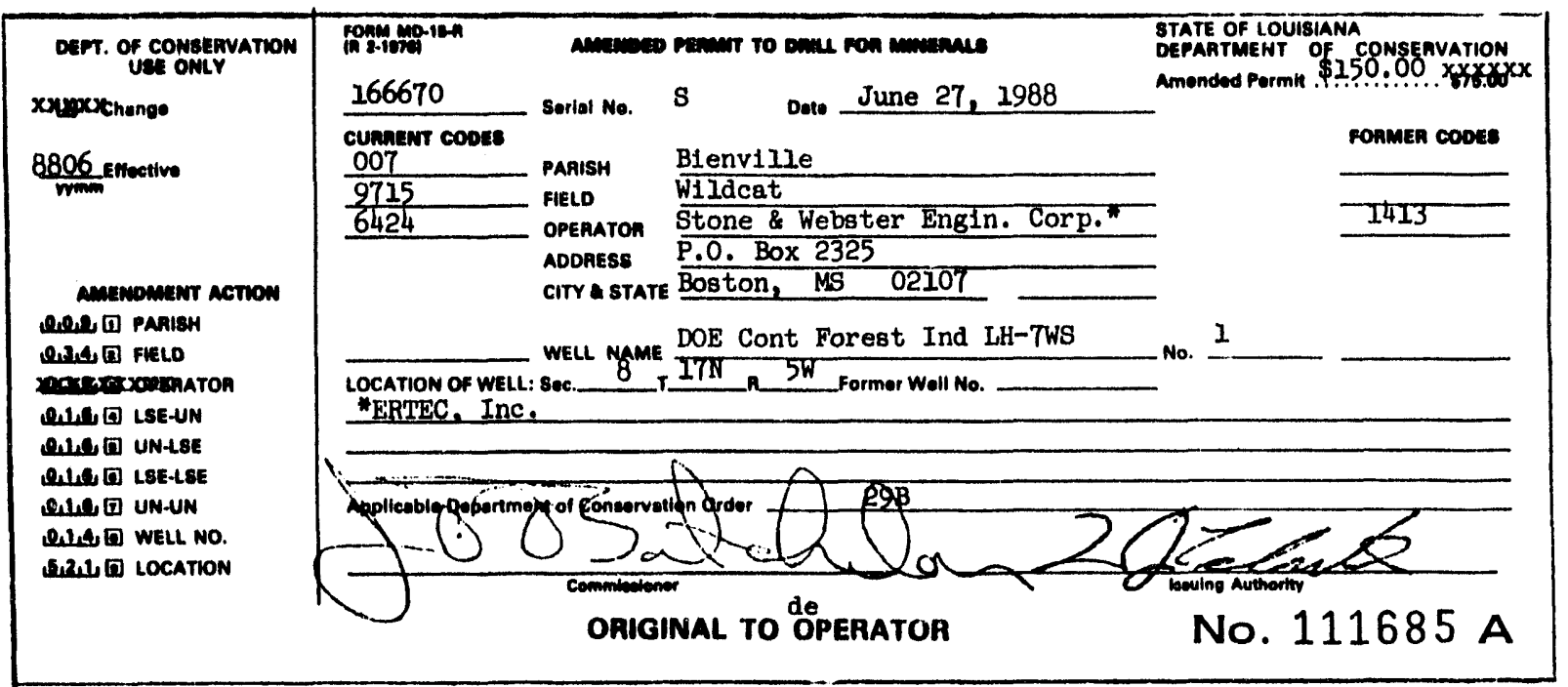

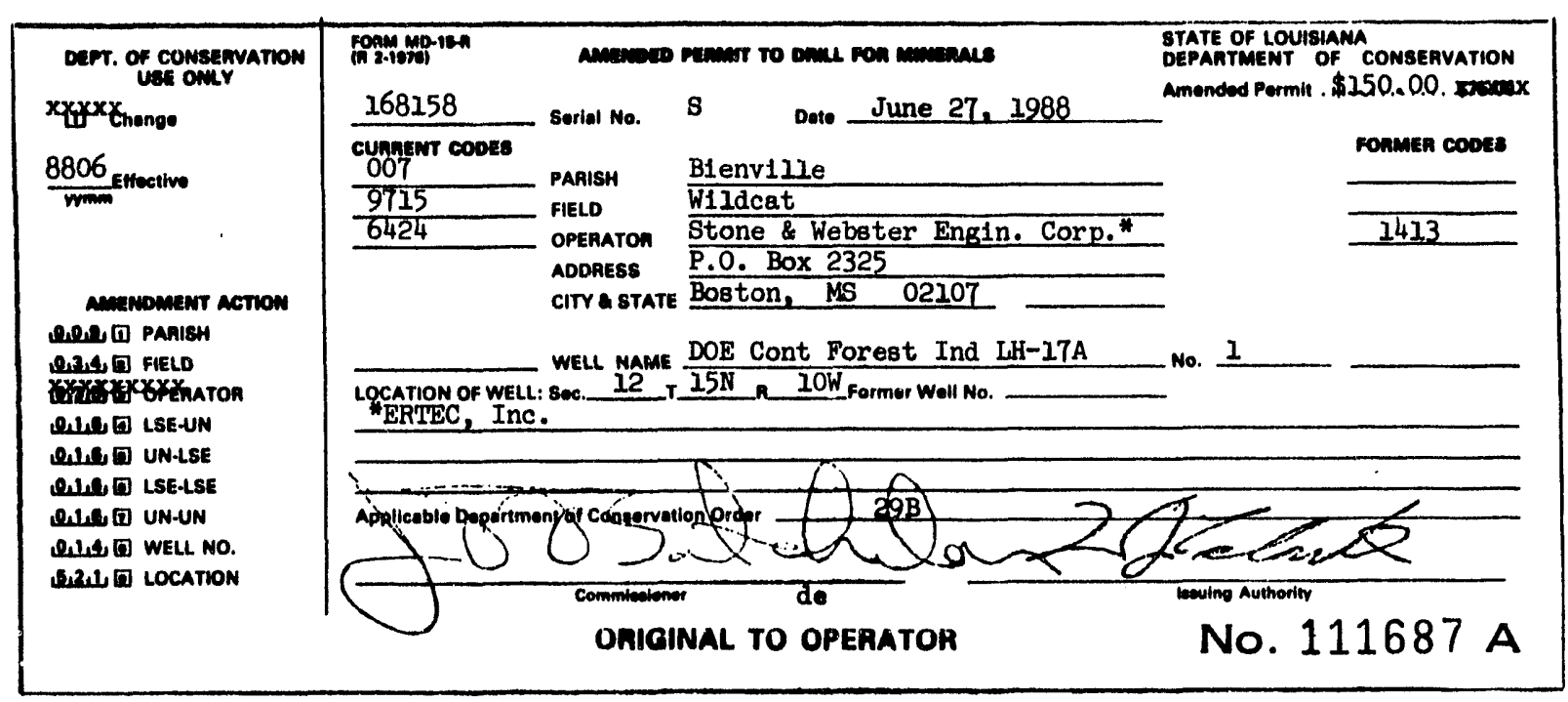

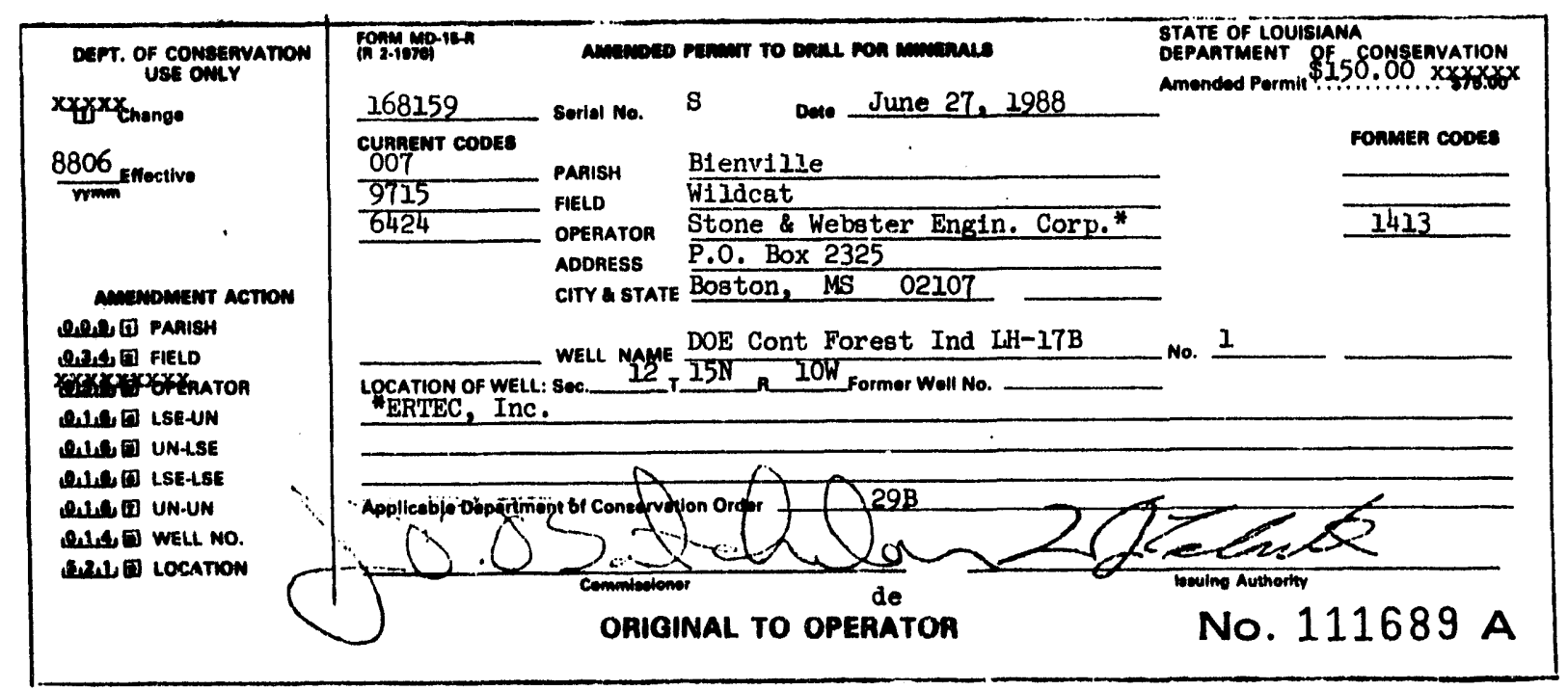




\section{BORY XP-15-R}

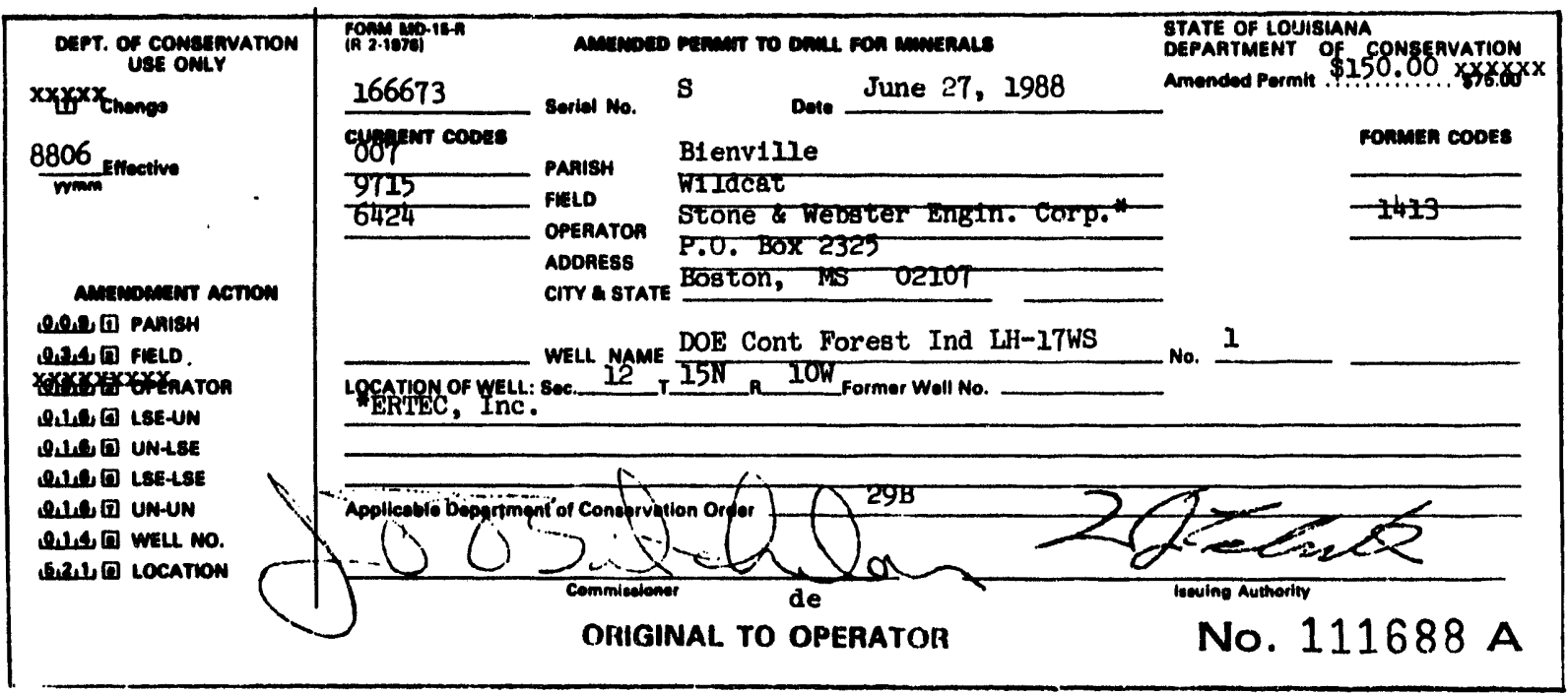

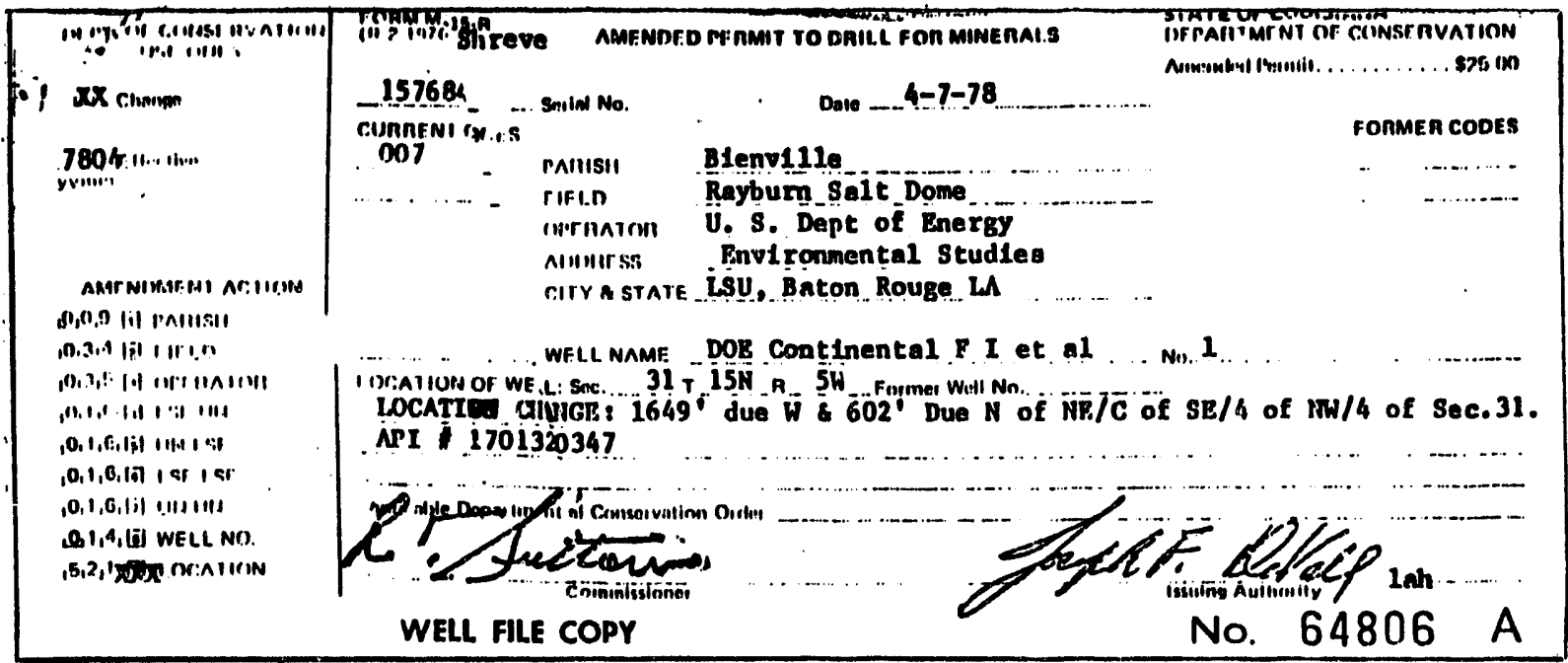

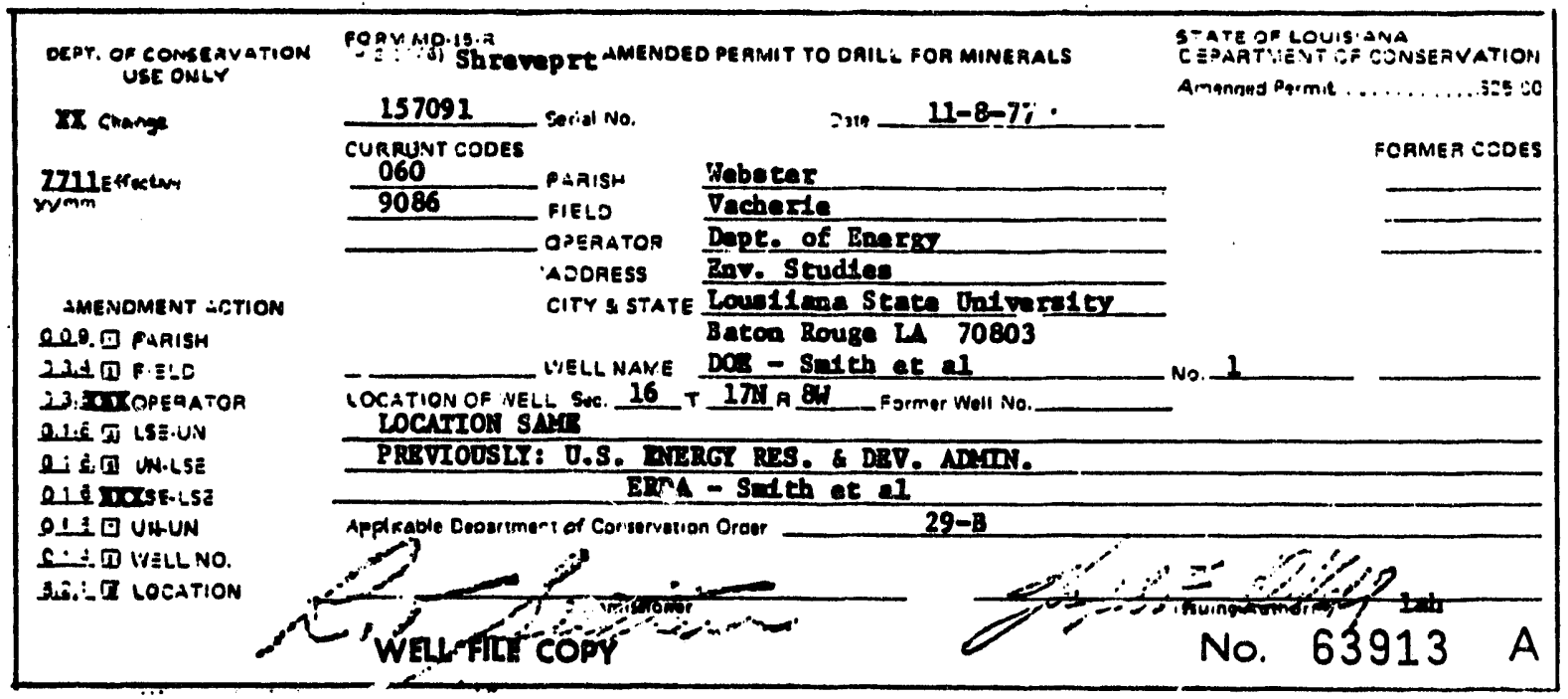


Work Permit

STATE OF LOUISIANA DEPARTMENT OF CONSERVATION

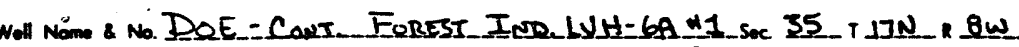
Field WILDCAT cormit Sariol Na 168160 Wort Permit No. $=1054=88=1$

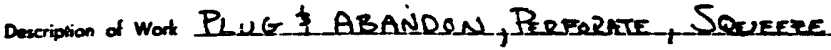

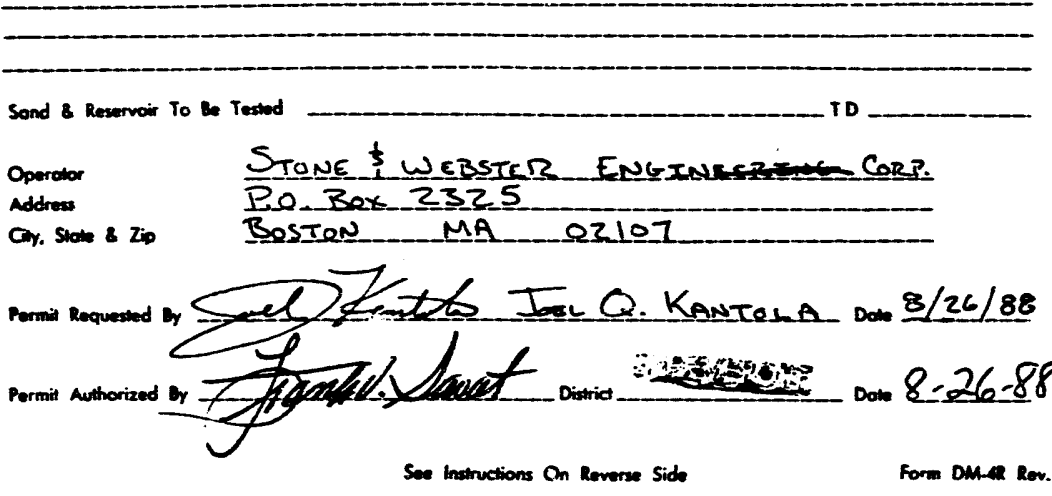

Form DM- Rov.
Work Permit

STATE OF LOUISIANA DEPARTMENT OF CONSERVATION

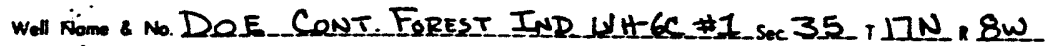
Fied WILD_CAI

Permít Seriol No. 168162 Pariat BIENUILLE

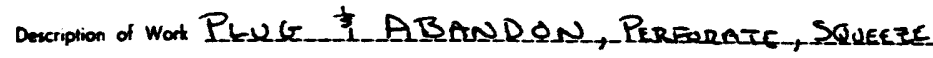

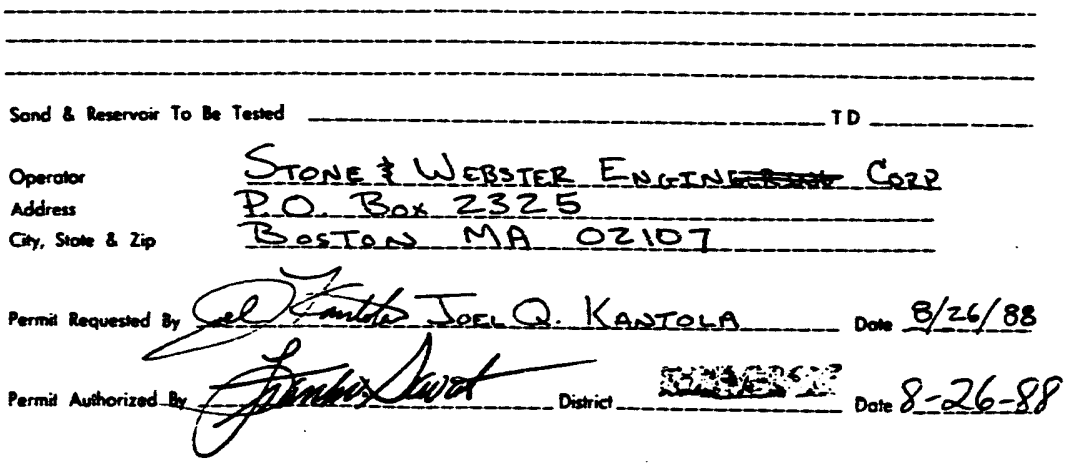

Work Permit

-TATE OF LOUISIANA DEPARTMENT OF CONSERVATION

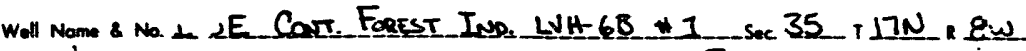
Find WILDCAT

Permil Serial tha 168161 Work Permit Nol $1=41053-8 \dot{1}$ Description of Work Plug \$ ABNinden, PEREarate, SqueEze

Sond \& Reservoir To Be Testod
Operdor
Addrons Stote \& zip

\section{Work Permi}

STATE OF LOUISIANA DEPARTMENT OF CONSERVATION

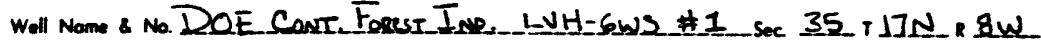
Find WILDCAT Parish BIEN UTLLE Permit Seriol No 166668 Description of Work PLuG_ ABENDON

Sond \& Reservoir To Be Testad
Operator
Addrest


Work Permit

STATE OF LOUISIANA DEPARTMENT OF CONSERVATION Woll Nome \& No. Dro Fermin Sorid No 165973

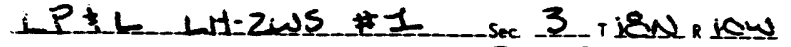
Description of Work PERFORATE, SQueEE $115-130$

Sond \& Reservoir to be Tested _._._. TO $140^{\prime}$

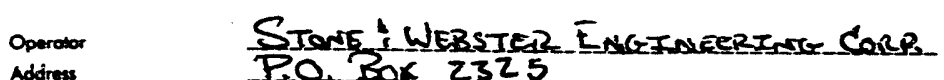

Adaress

Cay, Shote 8 Itp

Boston Ma oz107

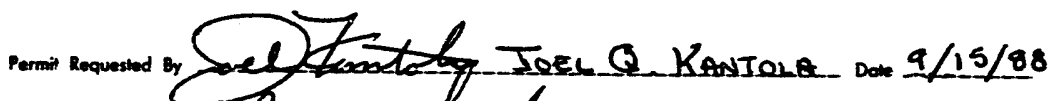

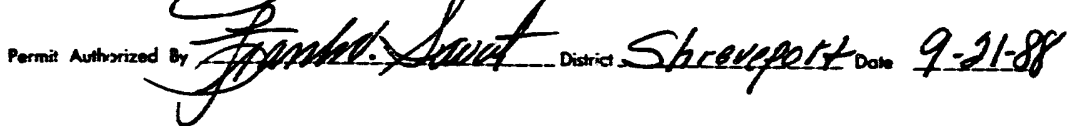

Soe tratructions On Reverse Side

Form Domen nor.

Work Permı

STATE OF LOUISIANA DEPARTMENT OF CONSERVATION

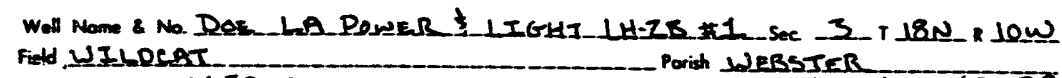

Permit Seriol No 165975 Porish WERSTER

Description of Work PLULE_A_ASANDON Wotk Permit No.

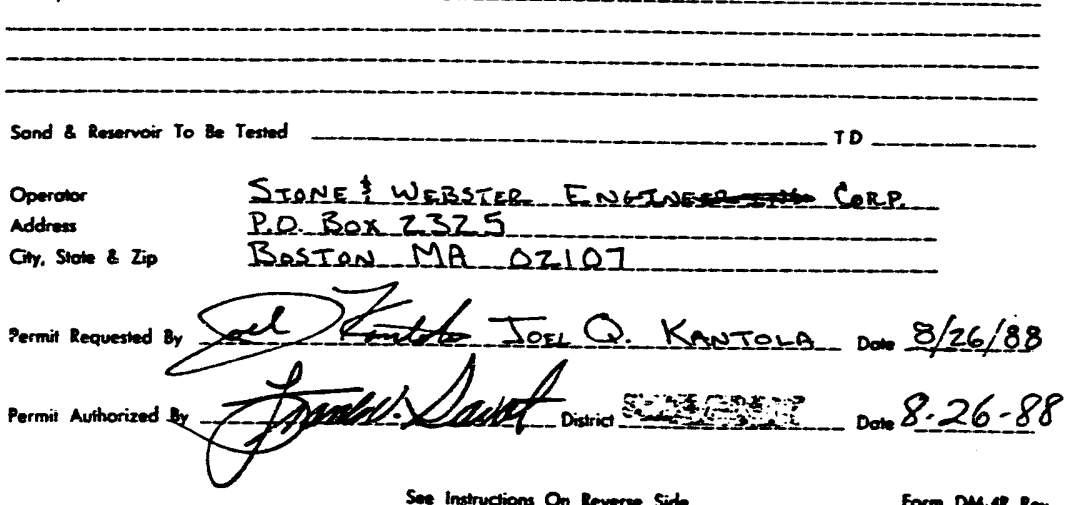

See Instructions On Reverese Side

Form DM.en Rev.
Work Permn

STATE OF LOUISIANA DEPARTMENT OF CONSERVATION

Wall Nome \& No. DOE LA POWER LLTGHT LH-ZWS 1 Soc 3 T IRN R JOW Field. WILQRenT

Permin Serid is 165973

Porih WeBSTER

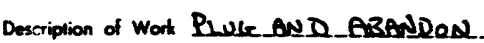

Wort Permit No. Ci=1/C48 $-88-1$

Sond \& Reswovoin To be Testod

To

Operotor STRE I WEBSTER ENGIN CORP.

Nodrew P.0.Box 2325

ciry, stow \& zip BeSTen MA OZleZ

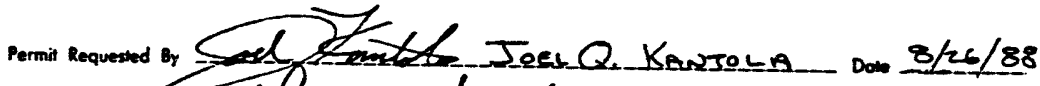

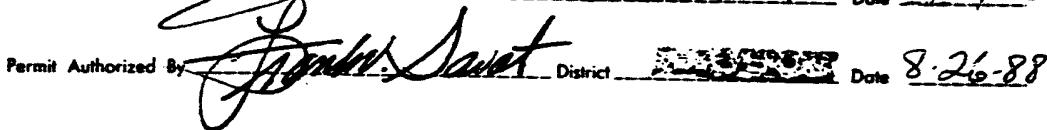

Soe Instructions on Reverse Side

Form DMuR Ren.

Work Permit

STATE OF LOUISIANA DEPARTMENT OF CONSERVATION

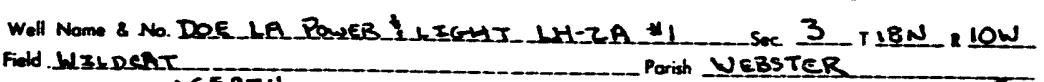
Permit Sorial No. 165974

Description of Work PLUG GND_ABANDON 3

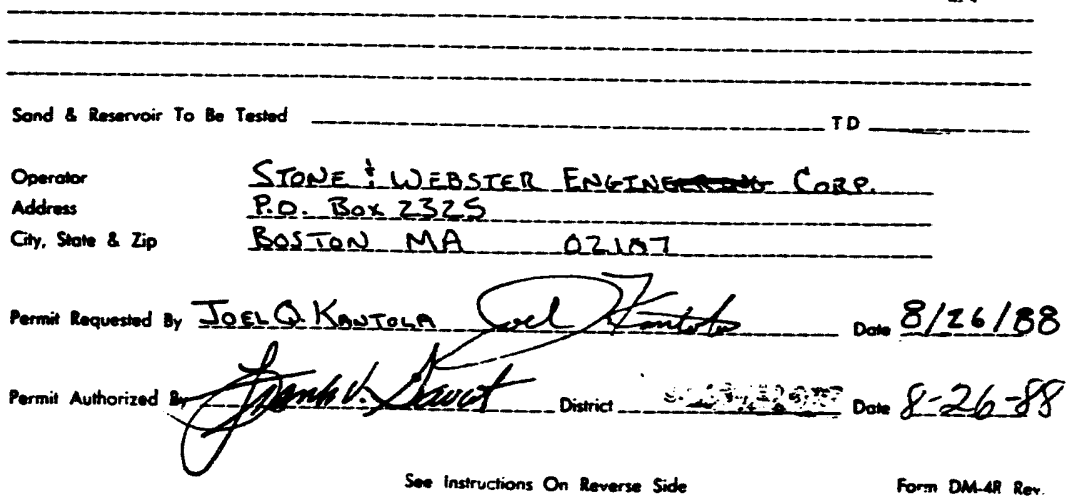


Work Perm!

- STATE OF LOUISIANA DEPARTMENT OF CONSERVATION

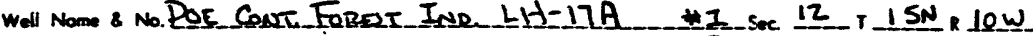
Field JILD.CAT Parish BTinverut Work Permil No $1042-88=1$ Denciption of wort PLuE 3 ABENDON

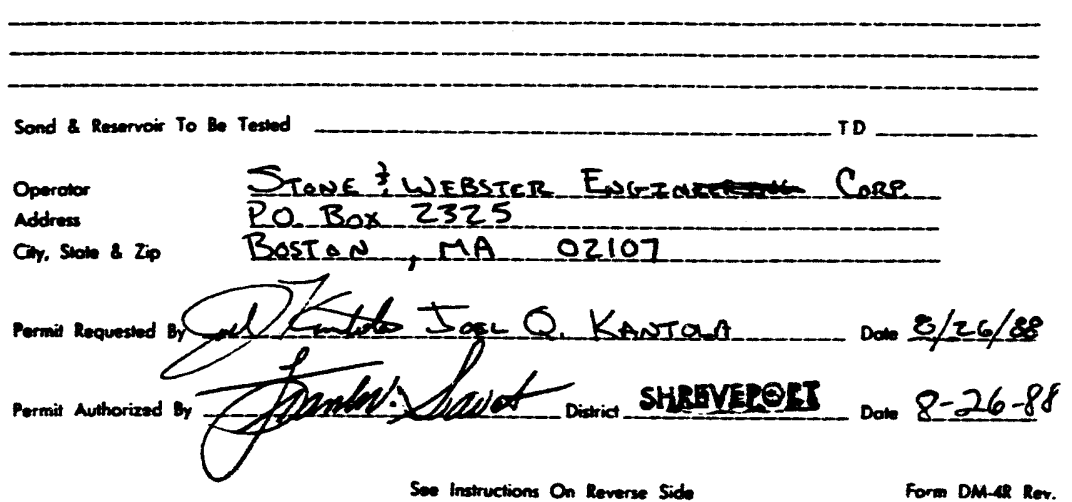

Work Permit
STATE OF LOUISIANA DEPARTMENT OF CONSERVATION

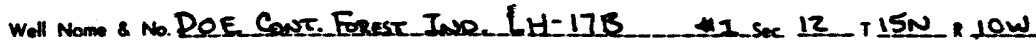
Find $W$ I Permil Serid No _- 68159

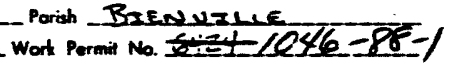
Description of Wort Plug $\$$ Apensoons

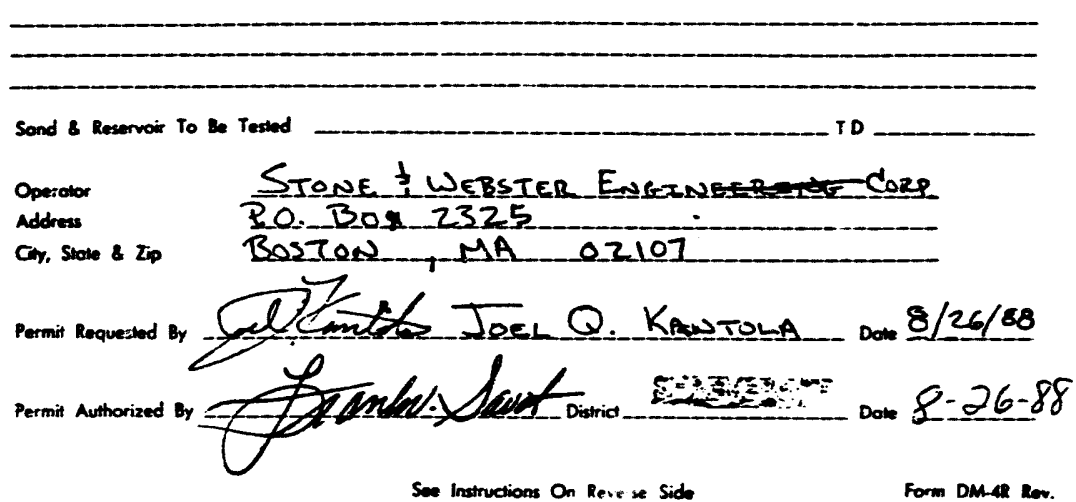

Work Permit

STATE OF LOUISIANA DEPARTMENT OF CONSERVATION

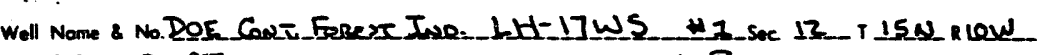
Field $W I$ IDCAT Permit Seriol No 166623 Work Permit No.

Descripion of Wort PLitu 3 ABANDon $\overline{-}$

Sond 8 Resorvoir to be Tessed _- TO

Sond \& Resorvoir to Be Tessed STONE

Operotor P. . BOX_2325

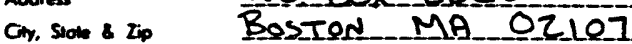

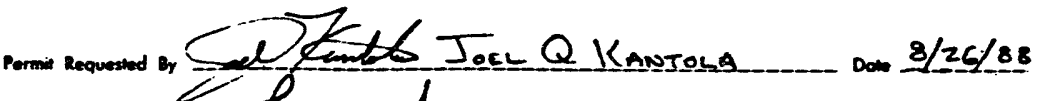

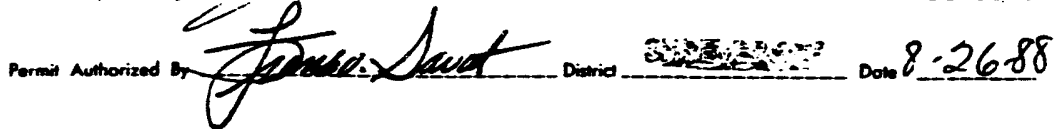


Work Permut

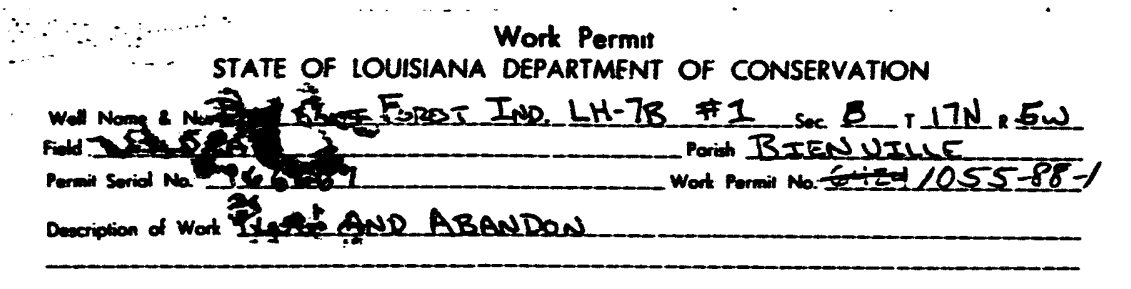

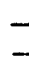

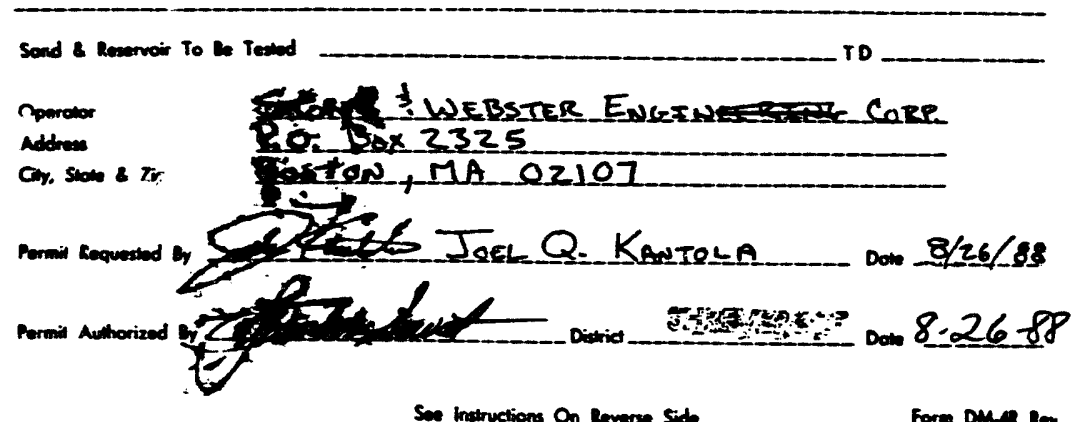

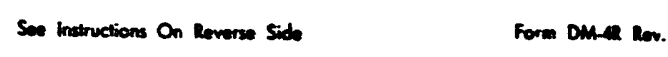

STATE OF LOUISIANA DEPARTMENT OF CONSERVATION

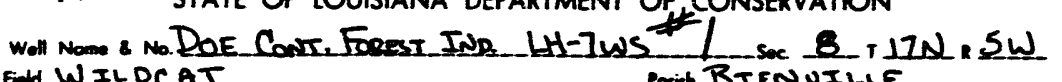
Find WIILRCAT

Permin Sorid No. 166670 Porihh BIEN UILLE

Description of Work PLUG

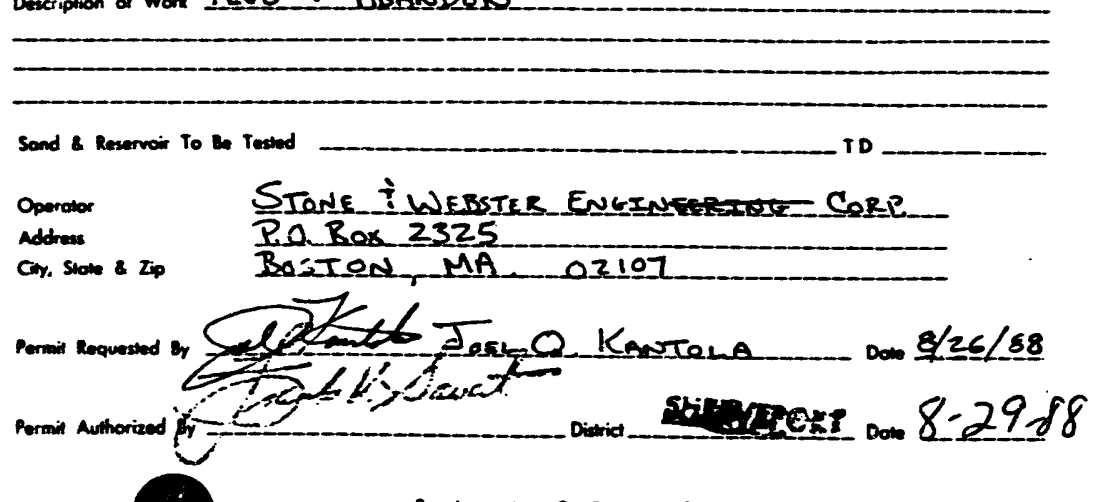

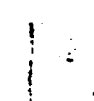

STATE OF LOUISIANA DEPARTMENT OF CONSERVATION

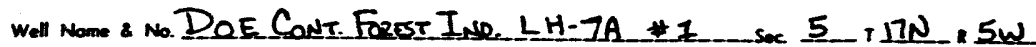
Field W WILDCAT Permit Sorial No 166669 Porish BIENUILLE Description of Wort Pule t ABANDon

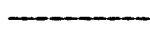

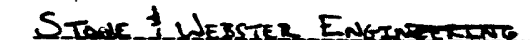

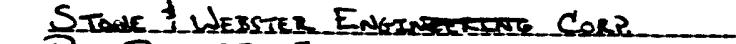

Cary Stow is ip Bostens MA 02107

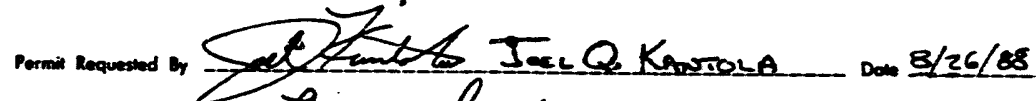

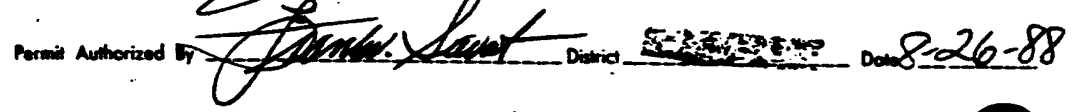

Son matructions on Reveres side 


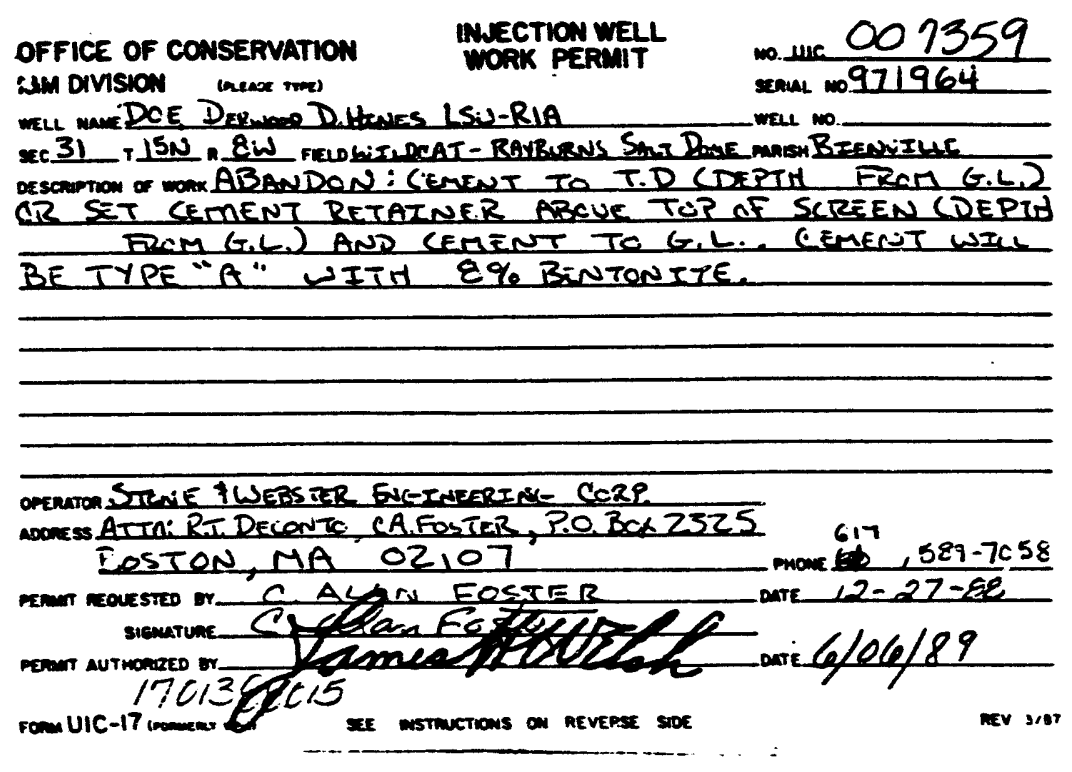

Work Perm!

STATE OF LOUISIANA DEPARTMENT OF CONSERVATION

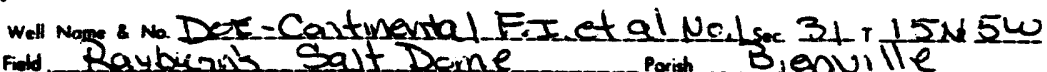

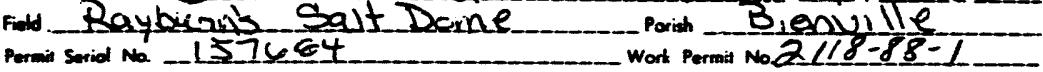
Description of wot __ Pug $\$$ Abandon

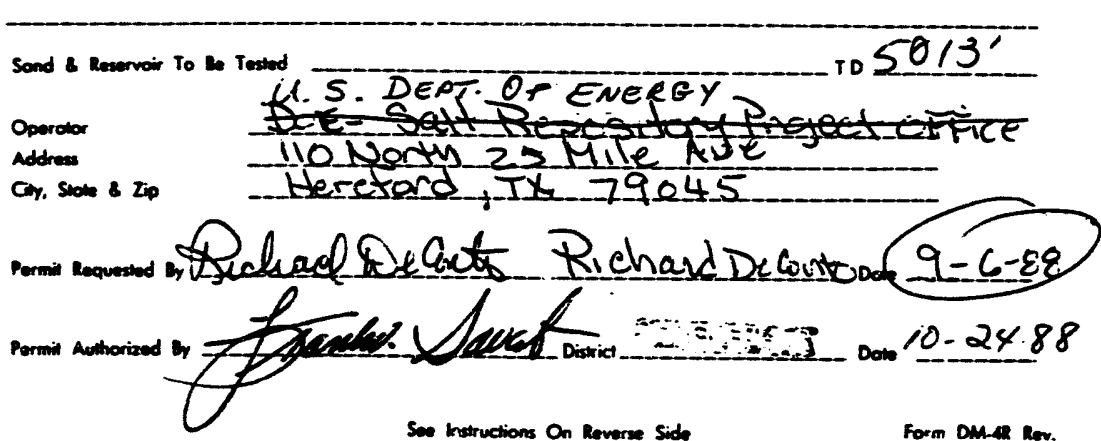

Work Permit

STATE OF LOUISIANA DEPARTMENT OF CONSERVATION

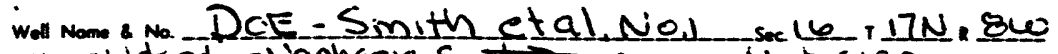

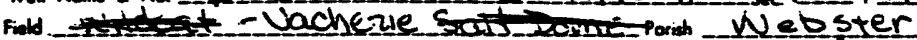

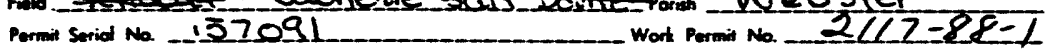
Desciption of Work PJug tAbandon. PSRForASE AnR SQOSEZE INIFYAC $535=550^{\prime}$

Sond \& Reservoir To the Tesod $1050 \times 3^{\prime}$

Oportor Dezartiment. of Erengy

addous Lialt kepositary Predest of Fice

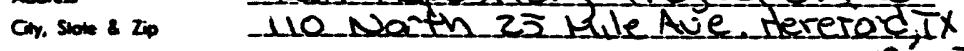

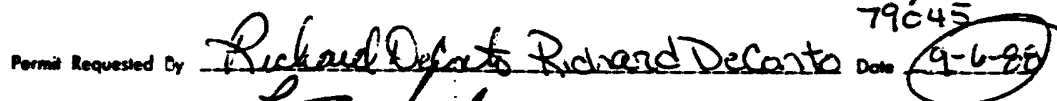

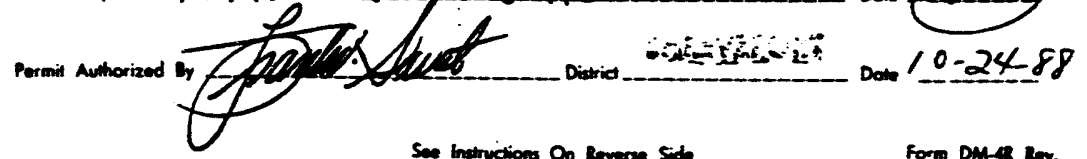




\section{INTECTION WRT, WORT PERMIF}

FOR TIC -17

\section{OFFICE OF CONSERVATION - INJECTKON WELL IBM DIYISION Inease mes WeLL mus DOE N.C. Rayrors V-4 weu wo. (1) Wabster

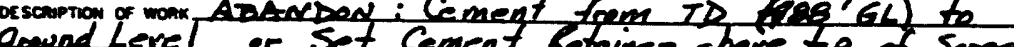

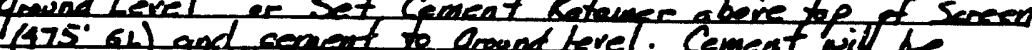 Ifpe 'A' with at ben tanite}

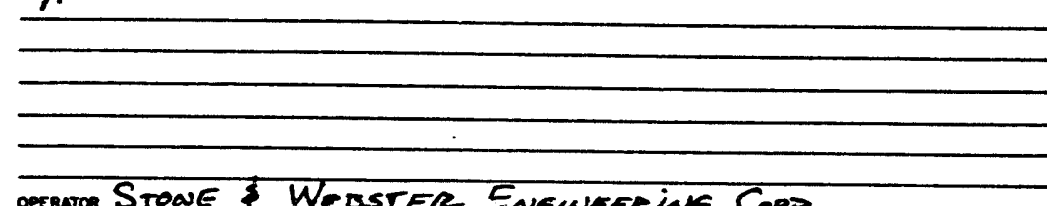

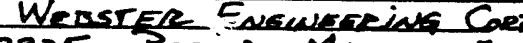

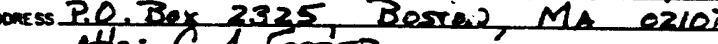

Atn: C.A. Fester

prome $\frac{617,59-208}{12-23-89}$

menur nous ste or Zich drenes dare $12-23-88$

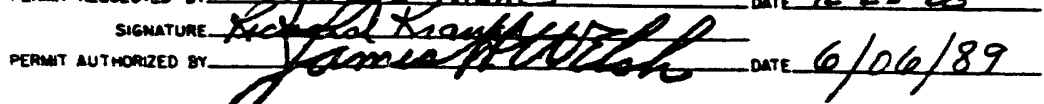

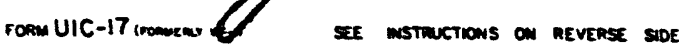

MEv s'er
OFFICE OF CONSERVATION INJECTION WELL

PM DISION

DOE E.S. CONNELL $V-5$

007357 semen 971961 was No. 1 xc22 $17 \mathrm{~N}$ 8W

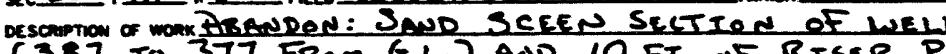
(387 TO 377 FrOn 6.L.) AdD 10 FT OF RISER PIPE (377 TO 367 POON G.L.). CEMENT RISER PIPF (367 T0 356 From G. L.) AND CASTNG ( 356 TO G.L) w/ API CLASS "A" CEMENT $W / 8 \%$ BENTONITE. NOTE: SAND wTL BE TREMIED CEAENT wTL BE PuAPEP Down

omerion STONE t WSESTER ENGTNBERTN6 CORP

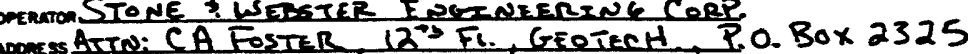
Beston MA. 02107

reman roustio or $C$. ACON EOSTER Cuabue fas $1-19-8$

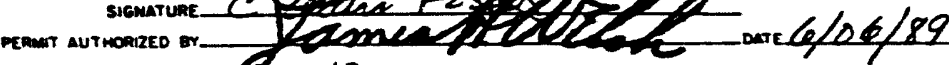
fom VIC-17 inomitio 8013

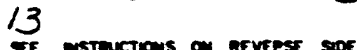

OFFICE OF CONSERVATION INUECTION WELL WORK PERMIT W.ME 971962

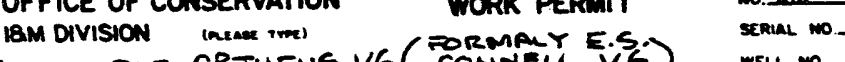

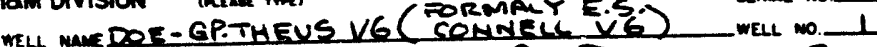
22 i $17 \mathrm{~N}$ RW FILL VACHERIE SAXT DOME MRISH BIENNVICLE

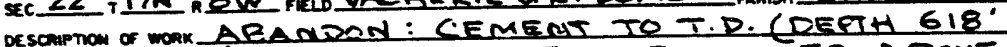

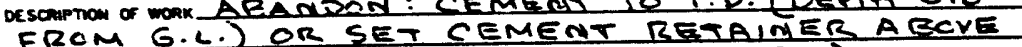
TOP AF SCREEN (DEPTH GO8'FROM G.L.) AND CEMENT TO SURFATE WITH TYPE" $A$ " WINH AEMENT TO SENTONISE

\footnotetext{
2.
}

STONE \& WERSTER ENGINEFRIDG CORP.

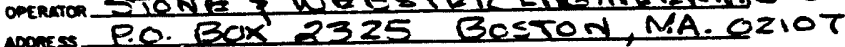

ATNN: C.A. FOSTER

mone $617,589-2058$ pent roustro or $C$. mone $\frac{617,1599-2098}{12-23-88}$

permit aUthofized or $17 \mathrm{Cl}=8$

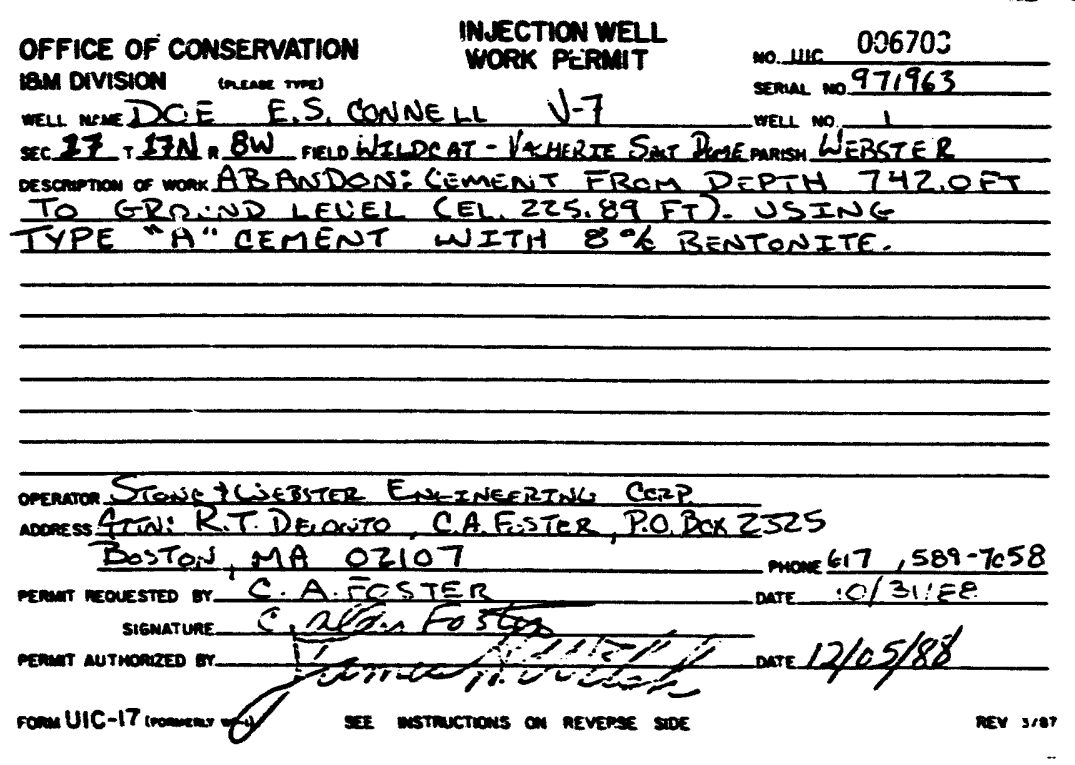




\section{PIDC NID NBNMDON RSPORT}

EORY P 6

\section{OFFICE OF CONSERVATION}

\section{PLUG AND ABANDON REPORT}

ORK PERMIT NO. $1050-88-1$

WELL SERIAL NO. 165924 DATE WORK FINISHED (MM.DD.YY) Z228 Shaevepeat DISTRICT

(Three Copies 10 be Filed with the Disfric: Office)

NOTE: This Report Will Be Refurned if Not Properly Completed And Signed.

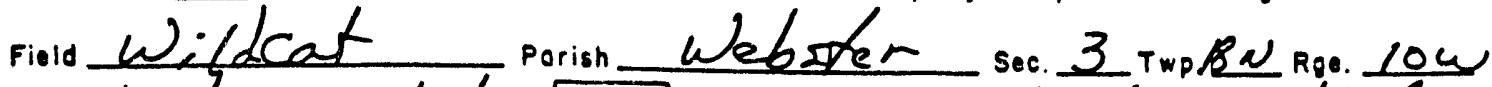

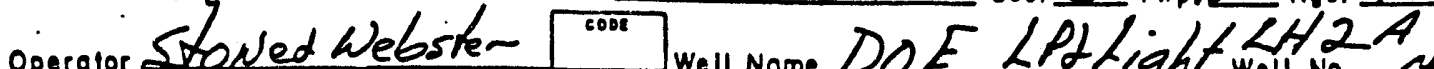

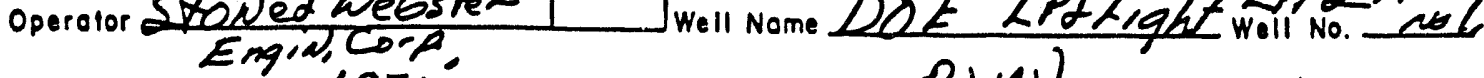
Tolol Depth Condition of Well $p \alpha K^{\prime} d$

ene ex apmagpaute sox.

Q29 DRY HOLE

$\square 30$ FORMERLY PRODUCTIVE WELL

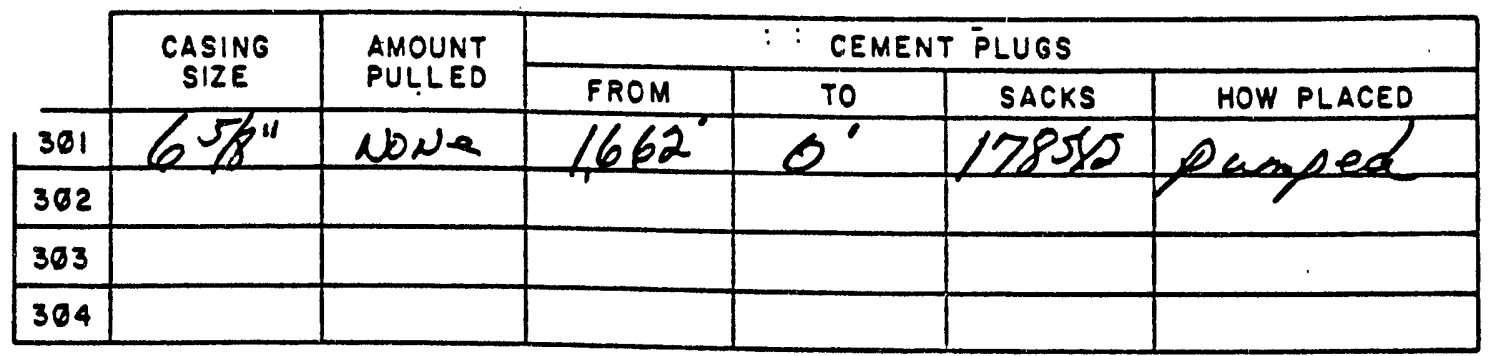

Mud Record: Weighe Freshuater

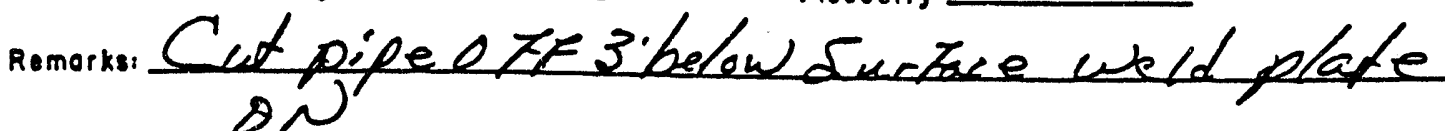

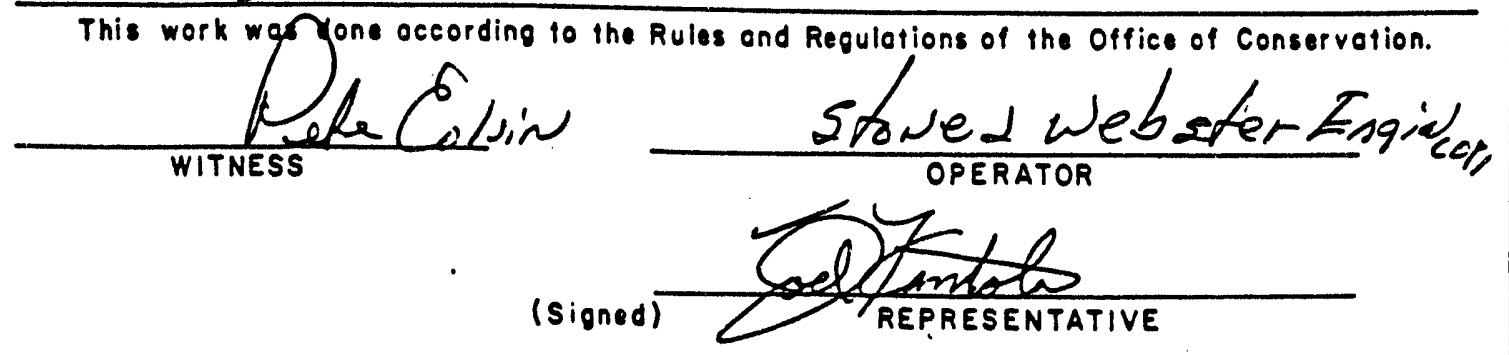




\section{PLUC AND ABANDOY REPORT FORX $P: A$}

\section{OFFICE OF CONSERVATION \\ PLUG AND ABANDON REPORT}

WELL SERIAL NO. 165975

SHREVEPORT DISTRICT

(Three Copies to be Filed with the District Office).

NOTE: This Report Will Be Refurned If Not Properly Completed And Signed.

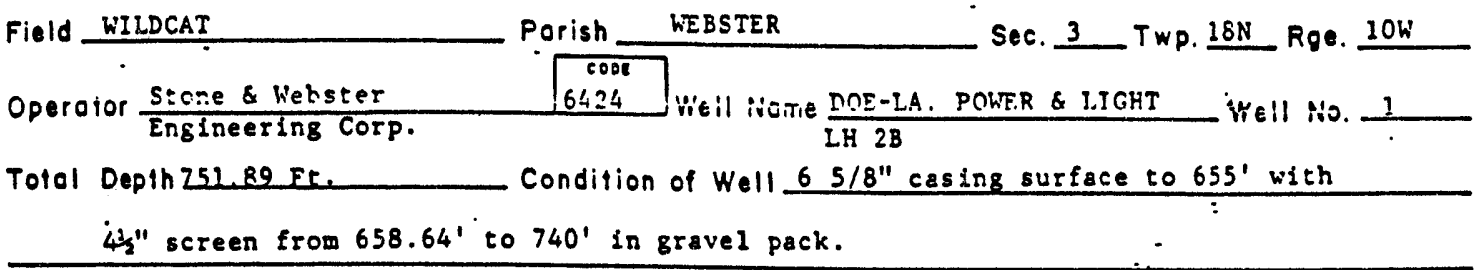

ERECX APPMOPRIATE BOXI

29 DRY HOLE

30 FORMERLY PRODUCTIVE WELL

\begin{tabular}{|c|c|c|c|c|c|c|}
\hline & \multirow{2}{*}{$\begin{array}{c}\text { CASING } \\
\text { SIZE }\end{array}$} & \multirow{2}{*}{$\begin{array}{l}\text { AMOUNT } \\
\text { PULLED }\end{array}$} & \multicolumn{4}{|c|}{ CEMENT PLUGS } \\
\hline & & & FROM & TO & SACKS & HOW PLACED \\
\hline 301 & $65 / 8^{\prime \prime} 0.0$. & 0 & Surface & $655^{\circ}$ & & \\
\hline 362 & $\begin{array}{l}\lambda i s c r \\
4 x " 0.0 .\end{array}$ & $e$ & $595.9^{\prime}$ & $658.64^{\prime}$ & $=97$ & Pump Down \\
\hline 303 & 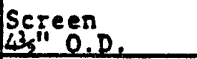 & 0 & $658.64^{\prime}$ & $740^{\circ}$ & & \\
\hline 304 & $\begin{array}{l}T \text { Tafl Pipe } \\
4 y^{\prime \prime}\end{array}$ & 0 & $740^{\prime}$ & $744.05^{\prime}$ & & \\
\hline
\end{tabular}

Mud Record: Weight NA

Viscosity NA

Remorks: $23 / 3^{\prime \prime}$ tublns souck in hole after 78 sacks of cement pumped. Tubing cemented in hole from 73' to $737^{\prime}$.

This work wos done occording to the Rules and Regulations of the Office of Conservotion.

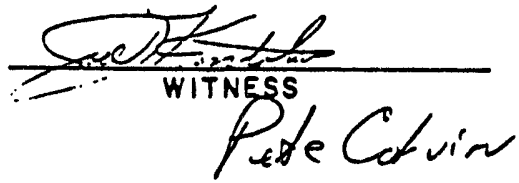

Stone \& Webster Engin:ering Corporation OPERATOR

(signed)

Alnea Foston REPRESENTATIVE

i.

Porm P A 1.70$)$ 


\section{i PLOG AND ABANDON REPORT \\ FORY $P \& A$}

\section{OFFICE OF CONSERVATION \\ PLUG AND ABANDON REPORT}

IORK PERMIT NO. $1048-88-1$

WELL SERIAL NO:

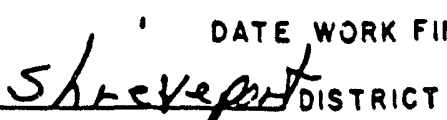

(Three Copies 10 be Filed with the Oistrict Office)

NOTE: This Report Will Bo Relurnod if Not Properly Complefed And Signed.

Field Wild cat

operoionstonted webster

Engive Corf.

Totol Depih

$$
7.2168
$$
porish Webater sec. I twp. L8Rkg. Law

EMECK APPROPRIATE BOX:

$\nexists 29$ DRY HOLE

7. 30 FORMERLY PRODUCTIVE WELL

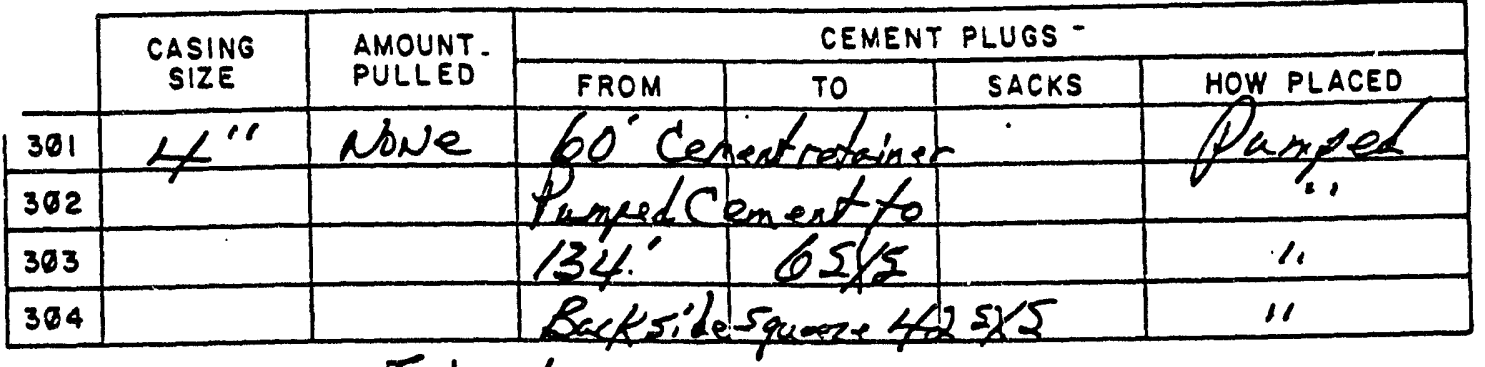

Mud Record: weight Treshwater remork: Cut pipe OTF3 \%.elow surtae weld plate ON

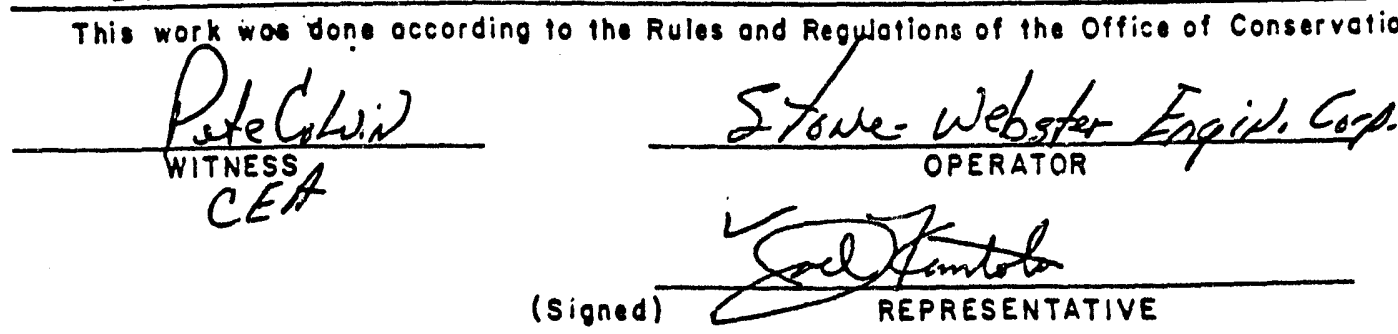




\section{PLUG AND ABANDON REPORT FORY $P \& A$}

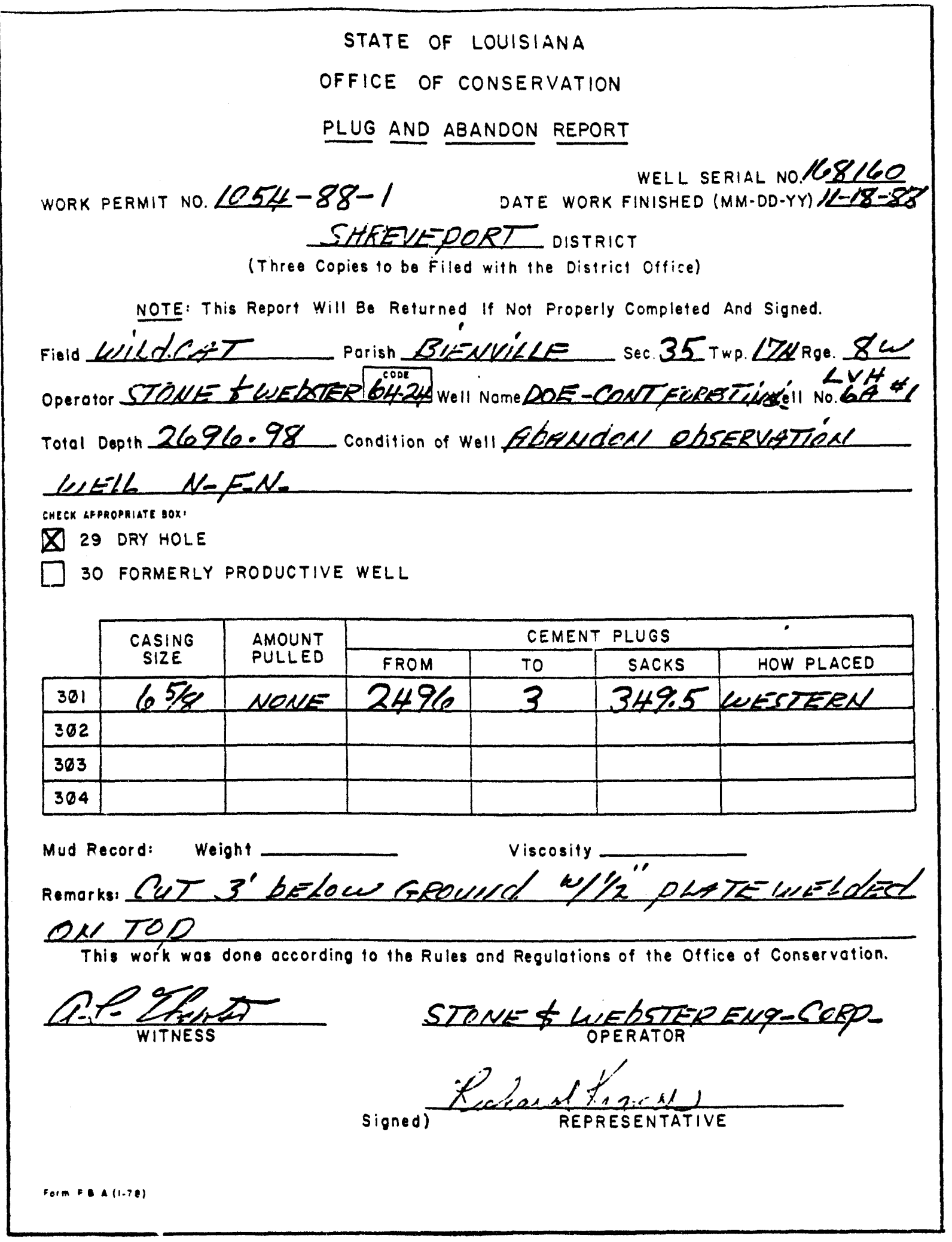




\section{PLUG AND ABANDON REPORT}

FORY P \& A

\section{STATE OF LOUISIANA \\ OFFICE OF CONSERVATION \\ PLUG AND ABANDON REPORT}

WORK PERMIT NO. $1053-88-1$

WELL SERIAL NO. "KOZ/Ól

DATE WORK FINISHED (MM-DD-YY) $11-18-88$

\section{SHPEIIEPCPT DISTRICT}

(Three Copies to be Filed with the District Office)

NOTE: This Report Will Be Refurned if Not Properly Compleied And signed.

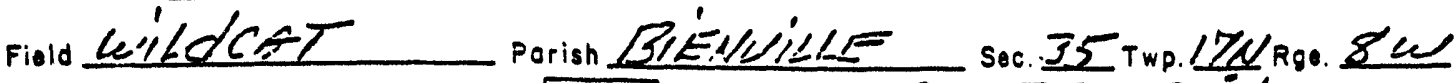

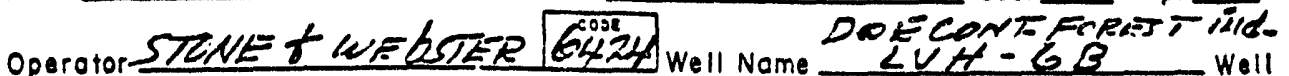

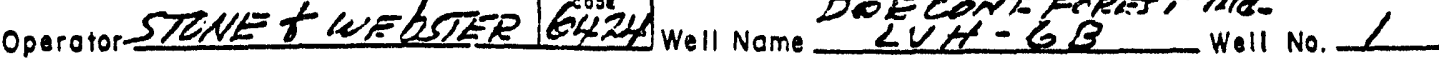

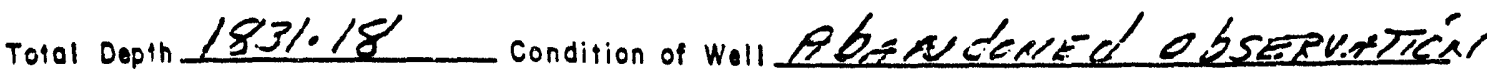
WFLL - NFAK

ehEEX APPROPRIATE HOX:

(X) 29 DRY HOLE

$\square 30$ FORMERLY PRODUCTIVE WELL

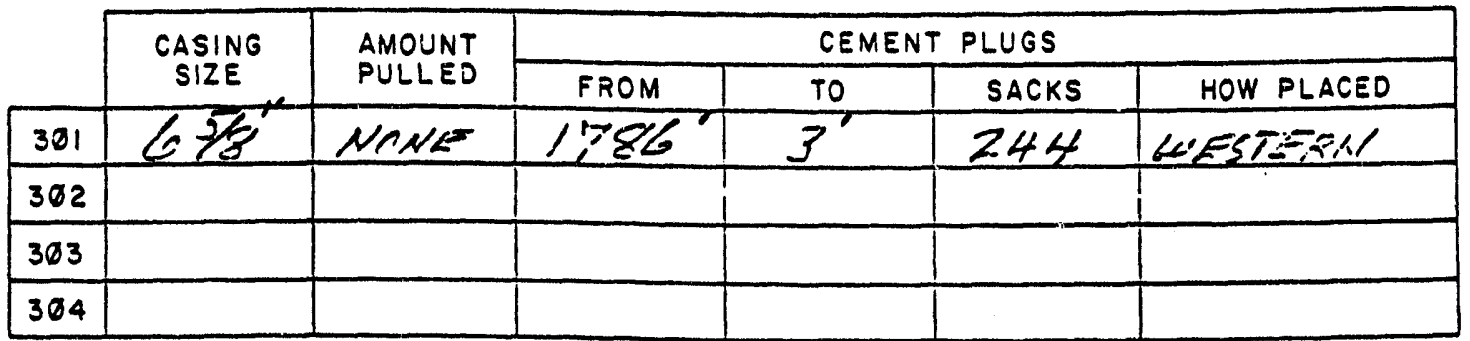

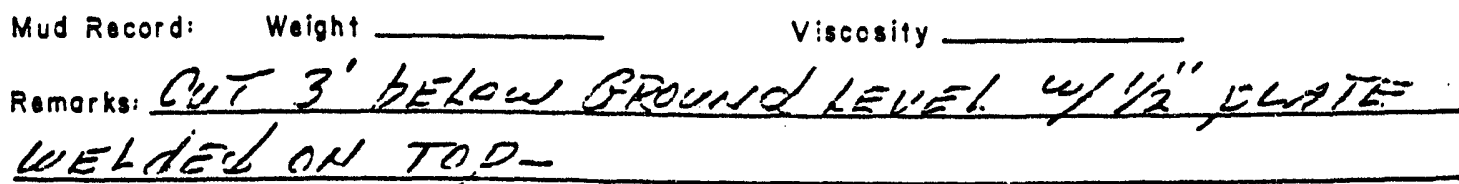
This work wos done occórding to the Rules and Regulations of the Office of Conservation.
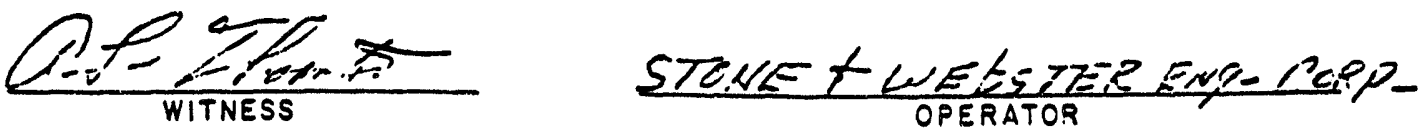

(signed)

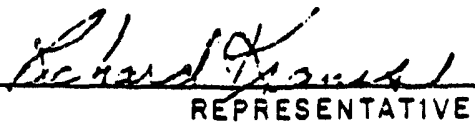

Form $P A(1 .+0)$ 


\section{PLUG AND ABANDON REPORT FORY P \& A}

\section{STATE OF LOUISIANA \\ OFFICE OF CONSERVATION \\ PLUG AND ABANDON REPORT}

WORK PERMIT NO. $105 Z=88^{\prime}-1$

WELL SERIAL NO. KERIG?

DATE WORK FINISHED (NM-DD-YY) $\mathbb{I - I Q - S P}$

\section{SITPEVIEFORT DISTRICT}

(Three Copies to be Filed with the District Office)

NOTE: This Report Will Be Returned if Not Properly Compieted And Signed.

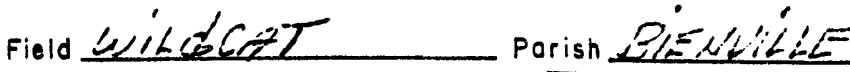

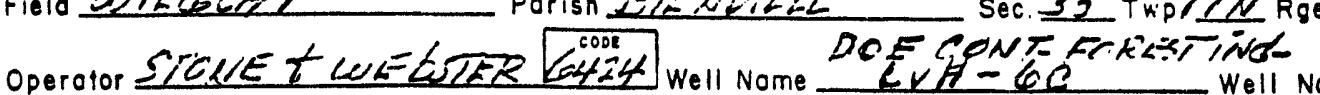

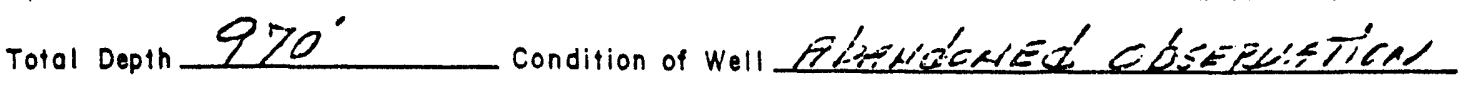

\section{UELL N-EN-}

EHECK AFPROPRILTE BOX:

Х 29 DRY HOLE

$\square 30$ FORMERLY PRODUCTIVE WELL

\begin{tabular}{|c|c|c|c|c|c|c|}
\hline & \multirow{2}{*}{$\begin{array}{l}\text { CASING } \\
\text { SIZE }\end{array}$} & \multirow{2}{*}{$\begin{array}{l}\text { AMOUNT } \\
\text { PULLED }\end{array}$} & \multicolumn{4}{|c|}{ CEMENT PLUGS } \\
\hline & & & FROM & TO & SACKS & HOW PLACED \\
\hline 301 & $65 / 8$ & NGNE & 868.6 & 3 & 107 & WESTERU \\
\hline 302 & & & & & & \\
\hline 303 & & & & & & \\
\hline 304 & & & & & & \\
\hline
\end{tabular}

Mud Record: Weight Viscosity

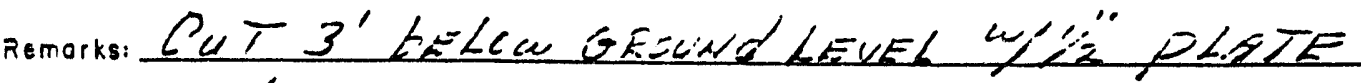
WELCEC ON TOP-

This work wos done occording to the Rules and Regulations of the Office of Conservation.
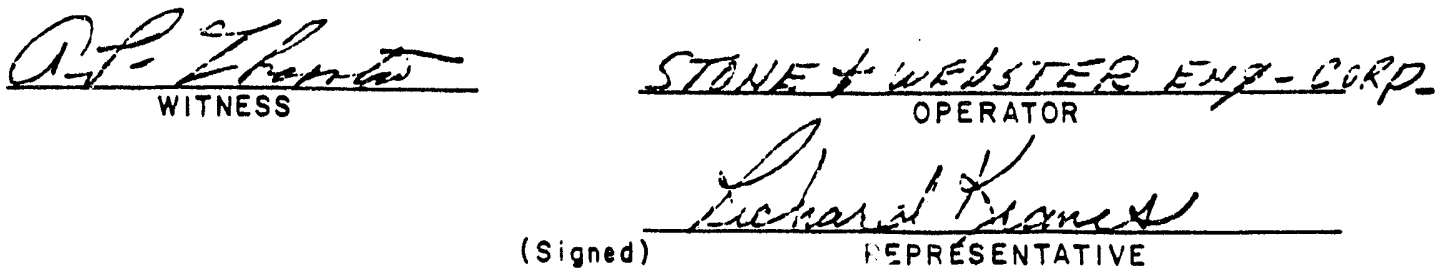
PLUC AND ABNADON REPORT

BORY P \& A

\section{STATE OF LOUISIANA \\ OFFICE OF CONSERVATION \\ PLUG AND ABANDON REPORT}

WORK PERMIT NO. IOSI-SYO-1

HELL SERIAL NO./CS GST DATE WORK FINISHED (MM-DD-YY) $17-78-8 \delta$

\section{S.TREVIEFEET} DISTRICT

(Three Copies 10 be Filed with the District office)

NOTE: This Report Will Bo Returned if Not Properly Completed And Signed. Field LiLdCFT

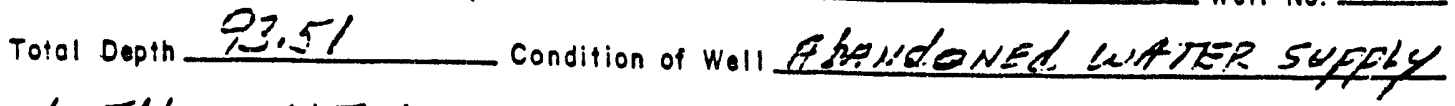
UNELL NENA

EREEK APPROPRILTE BOX:

¿ 29 DRY HOLE

$\square 30$ FORMERLY PRODUCTIVE WELL

\begin{tabular}{|c|c|c|c|c|c|c|}
\hline & \multirow{2}{*}{$\begin{array}{c}\text { CASING } \\
\text { SIZE } \\
\end{array}$} & \multirow{2}{*}{$\begin{array}{l}\text { AMOUNT } \\
\text { PULLED } \\
\end{array}$} & \multicolumn{4}{|c|}{ CEMENT PLUGS } \\
\hline & & & FROM & TO & SACKS & HOW PLACED \\
\hline 301 & $40.52^{\prime \prime}$ & LENE & & $3 \% !$ & $5 \frac{5}{5} 5 x$ & HERTEU DElQ CR \\
\hline 302 & & & 37.7 & $3^{\prime}$ & 3 & WEF, \\
\hline 303 & & & & & & \\
\hline 364 & & & & & . & \\
\hline
\end{tabular}

Mud Record: Weight Viscosity

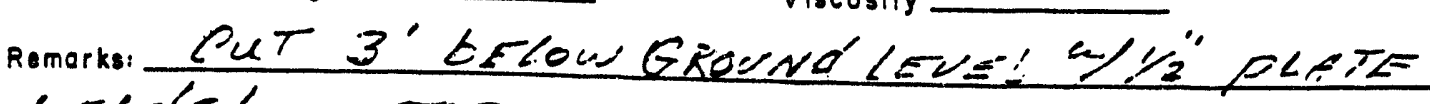
WEL dER ON TEP.

This work wos done occording to the Rules and Regulotions of the Office of Conservation.

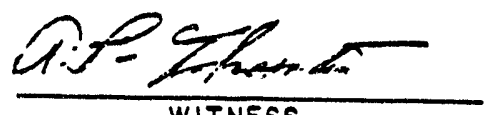

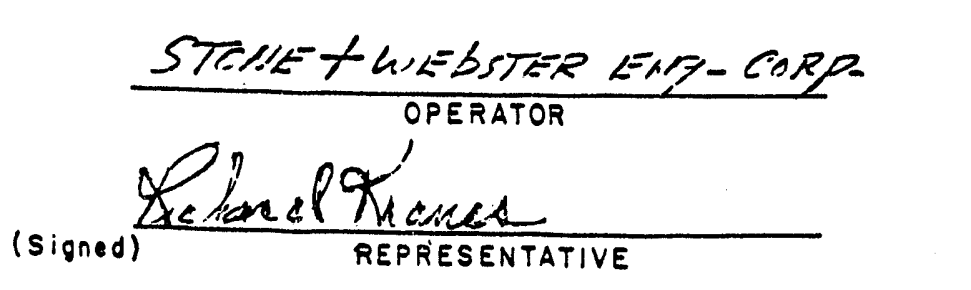




\section{PLOC AID ABNIPON REPORT}

\section{FORY P E A}

\section{STATE OF LOUISIANA \\ OFFICE OF CONSERVATION \\ PLUG AND ABANDON REPORT}

WORK PERMIT NO. $1056-88^{\circ}-1$

W'ELL SERIAL NO. KGleG697

SLREVUEFCRT DISTRICT

(Three Copies to be Filed with the District Office)

NOTE: 'This Report Will Be Returned if Not Properly Completed And signed.

Field euilCAZ Porish BËNVILLE sec. 5 Twp. 17Rkge. $\frac{5 a}{56}$

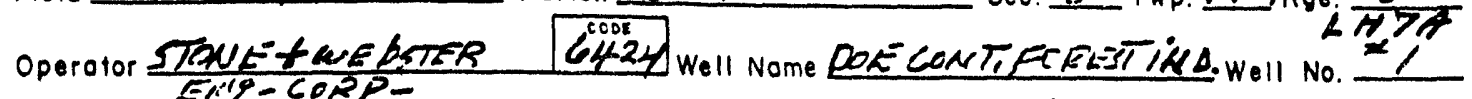
Total Depth $\angle 569$ Condition of Well CLSEREPTIOA CWELL -

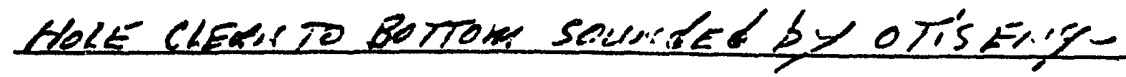
EHECK APPROPRIATE BCX:

29 DRY HOLE

$\square 30$ FORMERLY PRODUCTIVE WELL

\begin{tabular}{|c|c|c|c|c|c|c|c|}
\hline & \multirow{2}{*}{$\begin{array}{c}\text { CASING } \\
\text { SIZE }\end{array}$} & \multirow{2}{*}{\multicolumn{2}{|c|}{$\begin{array}{l}\text { AMOUNT } \\
\text { PULLLED }\end{array}$}} & \multicolumn{4}{|c|}{ CEMENT PLUGS } \\
\hline & & & & FROM & TO & SACKS & HOW PLACED \\
\hline 301 & $20 " .0$ & lostris & $\mathcal{L}$ & 1569 & litbit & 9 spind & HORTOU, EFIVG \\
\hline 302 & $123 / 4 s$ & & 11 & $14 \div 4$ & 3 & 158 & UMESTERAM \\
\hline 323 & $6.5 / 80$ & 59 & $\mu$ & 9.5 & 3 & 30 & WESTERAI \\
\hline 304 & $4 / 2 L$ & $\omega E, Z$ & $\Delta$ & $151 / 2$ & 3 & 9 & WESTERN \\
\hline
\end{tabular}

Mud Record: Weight Viscosity

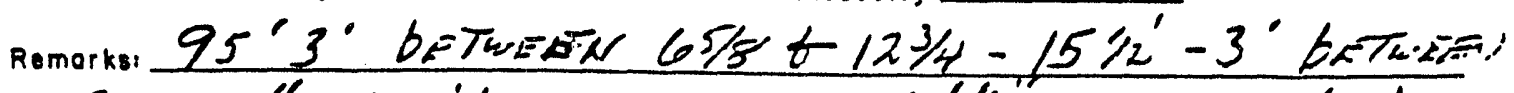

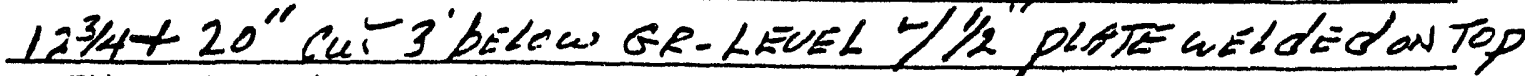

This work was done according to the Rules and Regulations of the Office of Conservation.

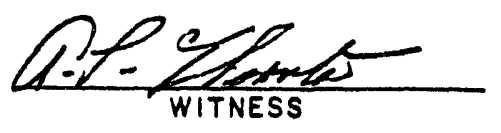

$\frac{\text { STCNE- T WEBSTER ENQ-COEP. }}{\text { OPERATOR }}$

(signed)

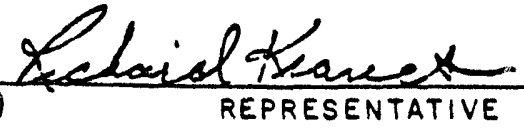




\title{
PLOC NID ABANDOY RBPORT FORY $P \& A$
}

\author{
STATE OF LOUISIANA \\ OFFICE OF CONSERVATION \\ PLUG AND ABANDON REPORT
}

WELL SERIAL NO. $/ 6 G E 67$

$$
\begin{aligned}
& \text { WORK PERMIT NO. } 1055=88-1 \text { SHPEVLEPCFT DISTRICT } \\
& \text { (Three copies to be Filed with the District Office) }
\end{aligned}
$$

NOTE: This Report Will Be Returned if Not Properly Completed And Signed.

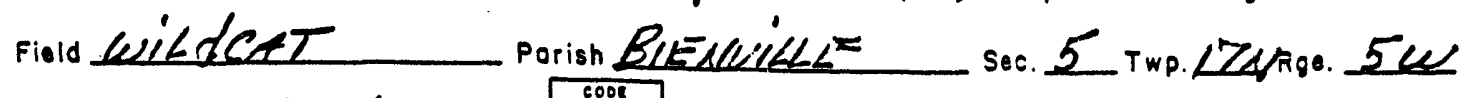
OperatorSTONLFWESSTER Totol Depth LO52' Condition of Woll ObSERUATIOH WELL

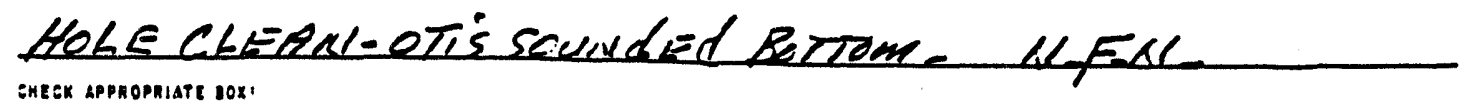

$\square 29$ DRY HOLE

\begin{tabular}{|c|c|c|c|c|c|c|}
\hline & \multirow{2}{*}{$\begin{array}{l}\text { CASING } \\
\text { SIZE }\end{array}$} & \multirow{2}{*}{$\begin{array}{l}\text { AMOUNT } \\
\text { PULLED }\end{array}$} & \multicolumn{4}{|c|}{ CEMENT PLUGS } \\
\hline & & & FROM & TO & SACKS & HOW PLACED \\
\hline 301 & 658 & NONE & 1052 & 932 & 11-sand & $H E R T S A$ \\
\hline 302 & & & $932^{\circ}$ & $3^{\circ}$ & 89 & $m=5 T=R \|$ \\
\hline 363 & $20 " 6$ & TRR & 35 & $3^{\prime}$ & 35 & $\mu$ \\
\hline 304 & & & & & & \\
\hline
\end{tabular}

$\square 30$ FORMERLY PRODUCTIVE WELL

Mud Record: Weight Viscosity

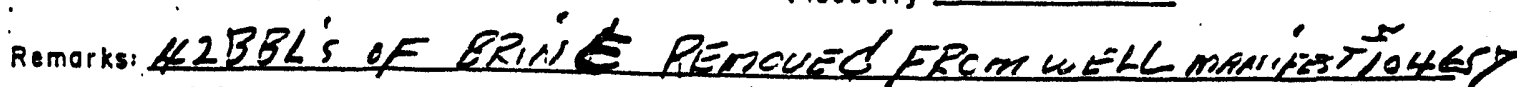

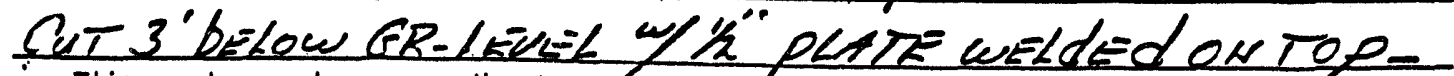

This work wos done occording to the Rules and Regulations of the Office of Conservation.

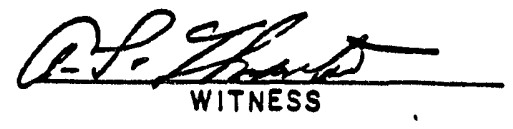

STONE WLESTER ENG CORP

$i$

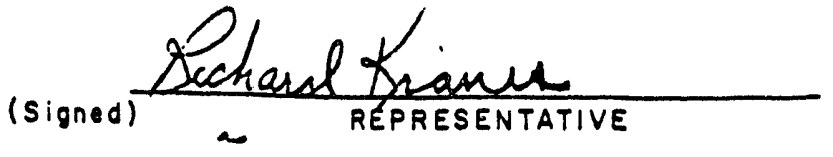




\section{PLUC AND ABANDON REPORT TORY PEA}

\section{STATE OF LOUISIANA \\ OFFICE OF CONSERVATION \\ PLUG AND ABANDON REPORT}

WORK PERMIT NO. $1058-88-1$

WELL SERIAL NO. 166670

DATE WORK FINISHED (MM-DD-YY) II- $\$ C-Q Z$

SHREVEPORT DISTRICT

(Three Copies to bo Filed with the District Office)

NOTE: This Report Will Be Returned if Not Properly Completed And Signed.

$=$ Luildere

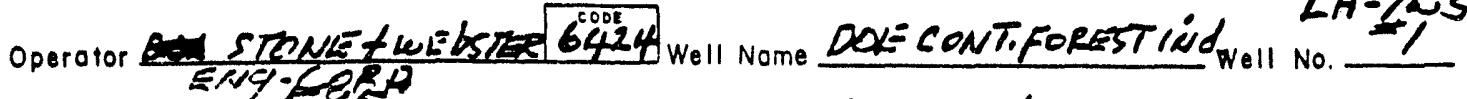

Total Depin ENG

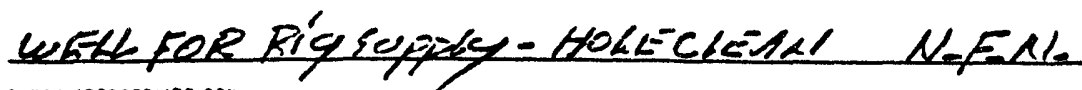

imECK APPROPRIATE BOX:

$\square 29$ DRY HOLE

30 FORMERLY PRODUCTIVE WELL

\begin{tabular}{|c|c|c|c|c|c|c|}
\hline & \multirow{2}{*}{$\begin{array}{l}\text { CASING } \\
\text { SIZE }\end{array}$} & \multirow{2}{*}{$\begin{array}{l}\text { AMOUNT } \\
\text { PULLED }\end{array}$} & \multicolumn{4}{|c|}{ CEMENT PLUGS } \\
\hline & & & FROM & TO & SACKS & HOW PLACED \\
\hline 381 & $65 / 8$ & NONE & $595^{\circ}$ & 464 & $12 \operatorname{sen}$ & HoRTON \\
\hline 302 & $x / 2$ & NONE- & $464^{\prime}$ & $3^{\prime}$ & 50 & WESTERN \\
\hline 303 & & & & & & \\
\hline 304 & & & & & & \\
\hline
\end{tabular}

Mud Record: Weight Viscosity

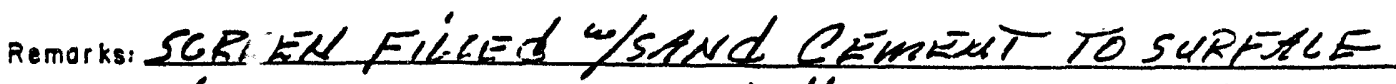
CUT 3'bELOW GR LEVEL W/ $/ 2$ "PUTTE WELdEC ON TOP-

This work wos done according to the Rules and Regulations of the office of Conservation.

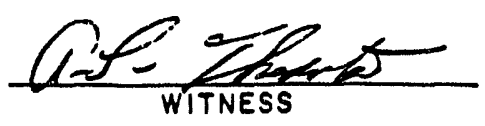

$\frac{\text { STONE T WEGSTER EIRI- }}{\text { OPERATOR }}$

(signed)

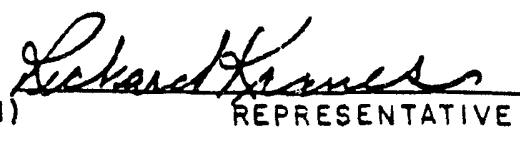

retm $\rightarrow \triangle(1.78)$ 
BLOC NMP ABNIDON REPORT FORX P \&

\section{STATE OF LOUISIANA \\ OFFICE OF CONSERVATION \\ PLUG AND ABANDON REPORT}

WORK PERMIT NO. $\angle C 47=85^{\circ}-1$

WELL SERIAL NO. KLE.EHTYY STIFEVEFEET DISTRICT

(Three Copies to be Filsd with the District Office)

NOTE: This Report Will Be Returned if Not Properly Compleied And Signed.

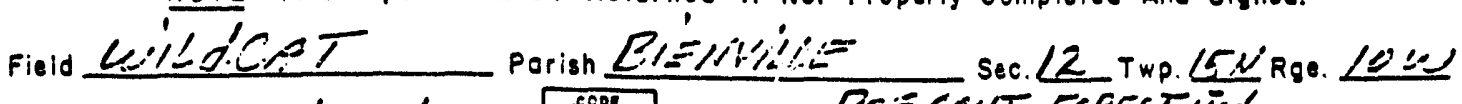

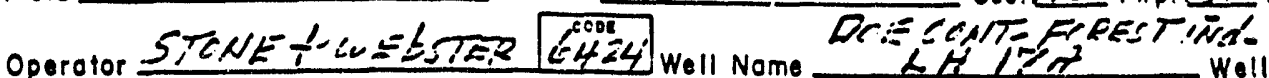

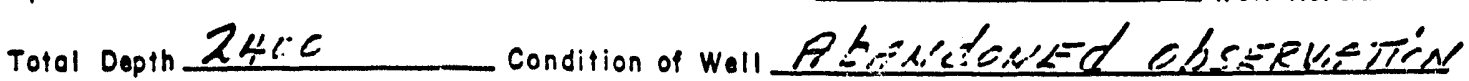
LELL ULENL

Entex APPnOPniate sox.

D) 29 DRY HOLE

$\square$ ( 30 FORMERLY PRODUCTIVE WELL

\begin{tabular}{|c|c|c|c|c|c|c|}
\hline & \multirow{2}{*}{$\begin{array}{l}\text { CASING } \\
\text { SIZE, }\end{array}$} & \multirow{2}{*}{$\begin{array}{l}\text { AMOUNT } \\
\text { PULLLED }\end{array}$} & \multicolumn{4}{|c|}{ CEMENT PLUGS } \\
\hline & & & FROM & TO & SACKS & HOW PLACED \\
\hline 381 & 633 & NOUE & 2406 & -3 & 236 & WESTERN \\
\hline 362 & & & & & & \\
\hline 303 & & & & & & \\
\hline 384 & & & & & & \\
\hline
\end{tabular}

Mud Recerd: Woight Viscosity

Remork:

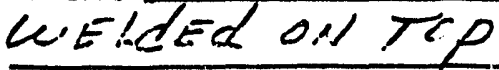

This work wos done according to the Rules and Regulations of the Office of Conservation.

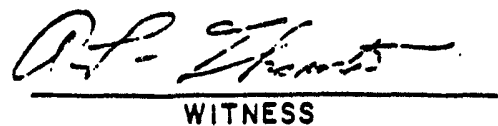
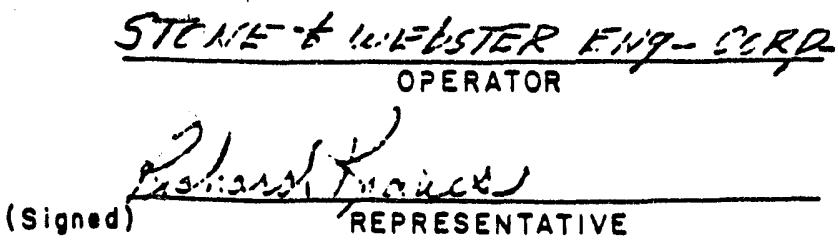


\section{PLOC AND ABANDON REPORT \\ RORY PEA}

\section{STATE OF LOUISIANA \\ OFFICE OF CONSERVATION \\ PLUG AND ABANDON REPORT}

WORK PERMIT NO. LOLLLE-8E-/ DATE WORK FINISHED (MM-DD-YY) II-21-88 SHEELEPECAT DISTRICT

(Three Copies to be Filed with the District Office)

NOTE: This Report Will Be Returned if Not Properly Completed And Signed.

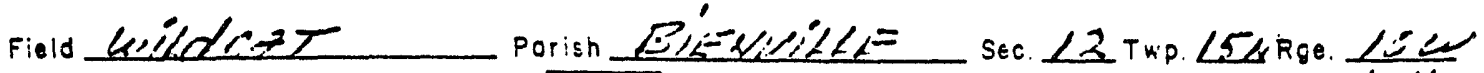

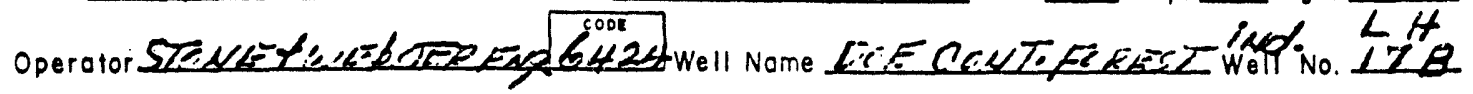

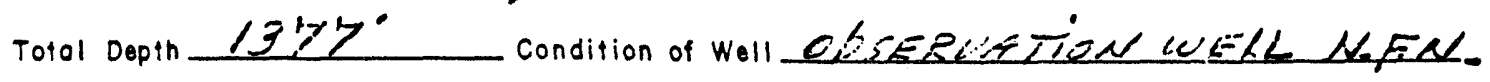

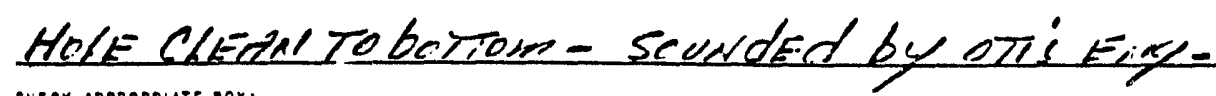
EHE EK RPPROPRIATE BOX:

$\square 29$ DRY HOLE

$\square$ 3O FORMERLY PRODUCTIVE WELL

\begin{tabular}{|c|c|c|c|c|c|c|}
\hline & \multirow{2}{*}{$\begin{array}{l}\text { CASING } \\
\text { SIZE }\end{array}$} & \multirow{2}{*}{$\begin{array}{l}\text { AMOUNT } \\
\text { PULLED }\end{array}$} & \multicolumn{4}{|c|}{ CENEENT PLUGS } \\
\hline & & & FROM & TO & SACKS & HOW PLACED \\
\hline 301 & 65 & MCNA $=$ & 132 & 129 & $75 R$ & He \\
\hline 302 & $41 / 2$ & Melle & 1278 & $3^{\circ}$ & $1 / 165^{-}$ & CUN5TLR' \\
\hline \multicolumn{7}{|l|}{383} \\
\hline 304 & & & & & & \\
\hline
\end{tabular}

Mud Record: Weight Viscosify

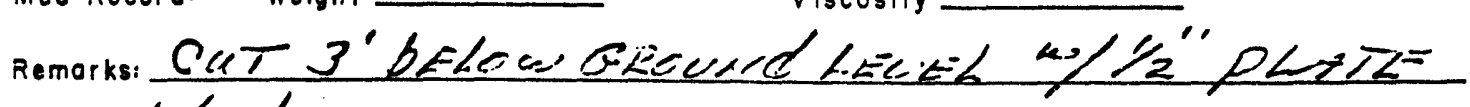
k.Fl. dEd CN TOP

This work wos done occording to the Rules and Regulations of the Office of Conservation.

a-P-

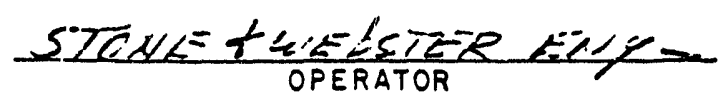

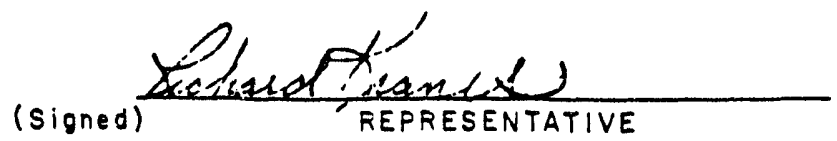




\section{PUDC NTP APNTPOY RTPORT ropr}

\section{STATE OF LOUISIANA \\ OFFICE OF CONSERVATION}

\section{PLUG AND ABANDON REPORT}

WORK PERMIT NO. $2188^{\prime}-3 S-i$

WELL SERIAL NO. $15 / 768 \%$ DATE WORK FINISHED (MM-DD-YY) Z2-1SHPEVE IOERT

(Three Copies to be Filed with the District Office) NOTE: This Report Will Be Returned if Not Properly Completed And Signed. rield Ei:fivise

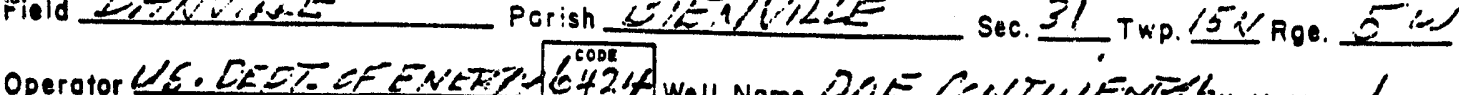

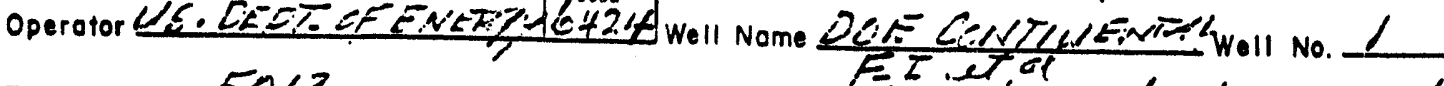
Total Depth $50 / 3$

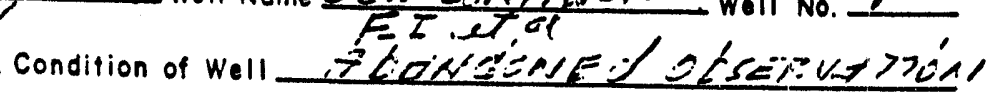

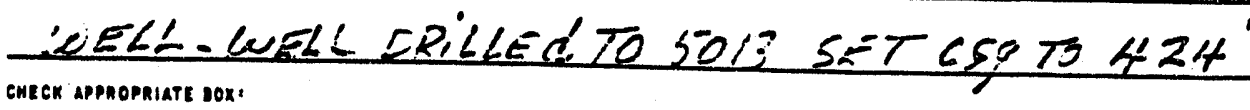

29 DRY HOLE

$\square 30$ FORMERLY PRODUCTIVE WELL

\begin{tabular}{|c|c|c|c|c|c|c|}
\hline & \multirow{2}{*}{$\begin{array}{l}\text { CASING } \\
\text { SIZE }\end{array}$} & \multirow{2}{*}{$\begin{array}{l}\text { AMOUNT } \\
\text { PULLED }\end{array}$} & \multicolumn{4}{|c|}{ CEMENT PLUGS } \\
\hline & & & FROM & TO & SACKS & HOW PLACED \\
\hline 301 & $2 x^{\prime} 8+0^{\circ}$ & A'CNE & 3.40 & +78 & 50 & EOSSTERAV \\
\hline 302 & & & 240 & 3 & .07 & 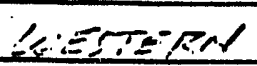 \\
\hline 303 & & & & & & \\
\hline 364 & & & & & & \\
\hline
\end{tabular}

$$
\text { Mud Record: Weight }
$$

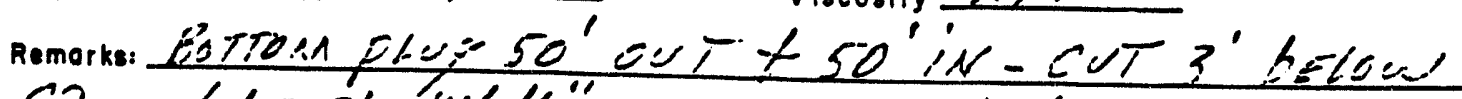

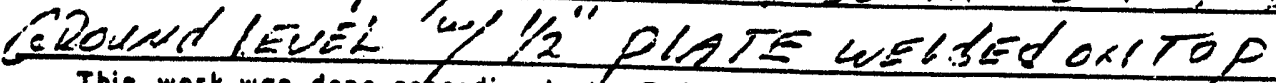

This work was done octording to the Rules and Regulations of the Office of Conservation.
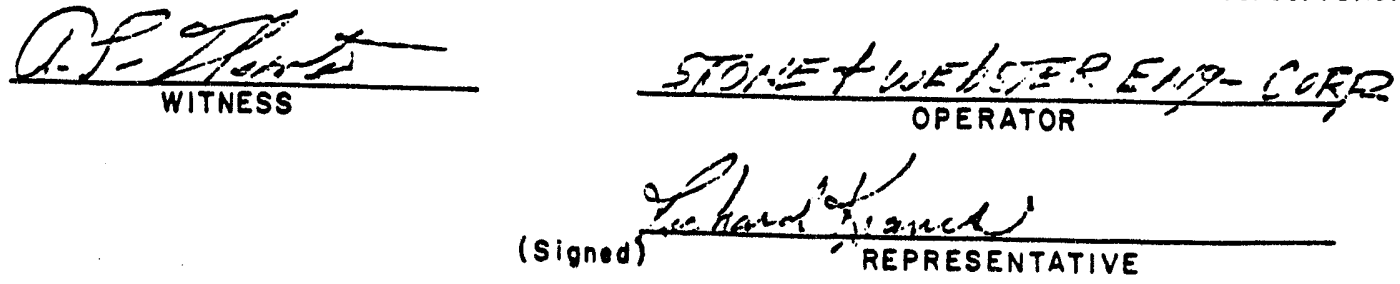


\section{STATE OF LOUISIANA \\ OFFICE OF CONSERVATIDN \\ PLUG AND ABAINDON REPORT}

WORK PERMIT NO. $1257-88-1$

WELL SERIAL NO. 1966623 DATE WORK FINISHED (MM-DD-YY) $11-2 /-88$

SHEEVEFCET DISTRICT

(Three Copies to be Filed with the District Office)

NOTE: This Report Will Be Refurned if Not Properly Completed And Signed.

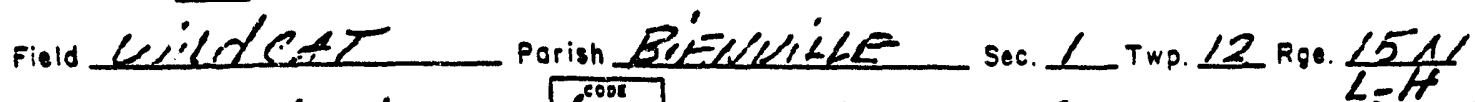

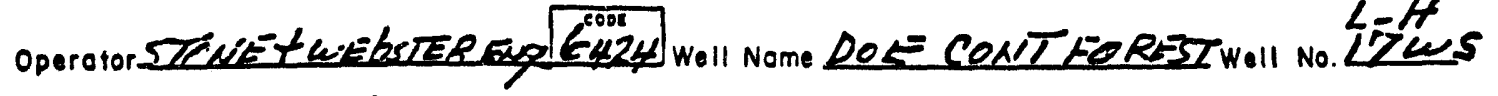

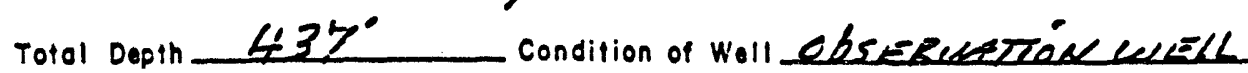

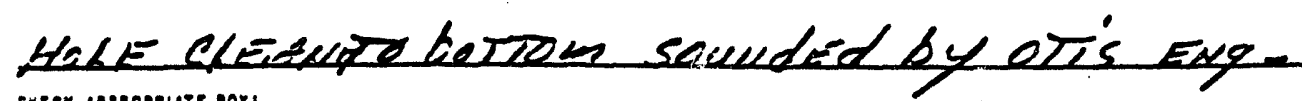

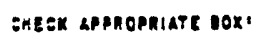

$\square 29$ DRY HOLE

$\square 30$ FORMERLY PRODUCTIVE WELL

\begin{tabular}{|c|c|c|c|c|c|c|}
\hline & \multirow{2}{*}{$\begin{array}{c}\text { CASING } \\
\text { SIZE }\end{array}$} & \multirow{2}{*}{$\begin{array}{l}\text { AMOUNT } \\
\text { PULLED }\end{array}$} & \multicolumn{4}{|c|}{ CEMENT PLUGS } \\
\hline & & & FROM & TO & SACKS & HOW PLACED \\
\hline 301 & $65 \%$ & $M$ & 437 & 287 & 155 rend & HERTEA \\
\hline 302 & $41^{\prime \prime}$ & $M$ & 257 & 3 & 15 & WESTKPN \\
\hline 303 & & & & & & \\
\hline 304 & & & & & & \\
\hline
\end{tabular}

Mud Record: Weight Viscosity

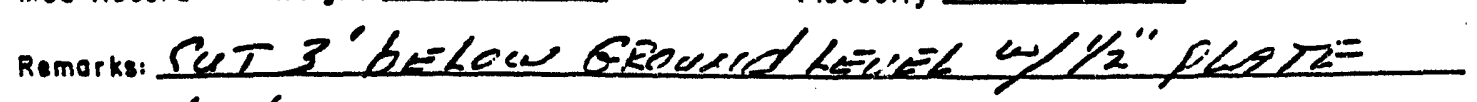
Lehreaten 700

This work wos done occording to the Rules and Regulations of the Office of Conservation.
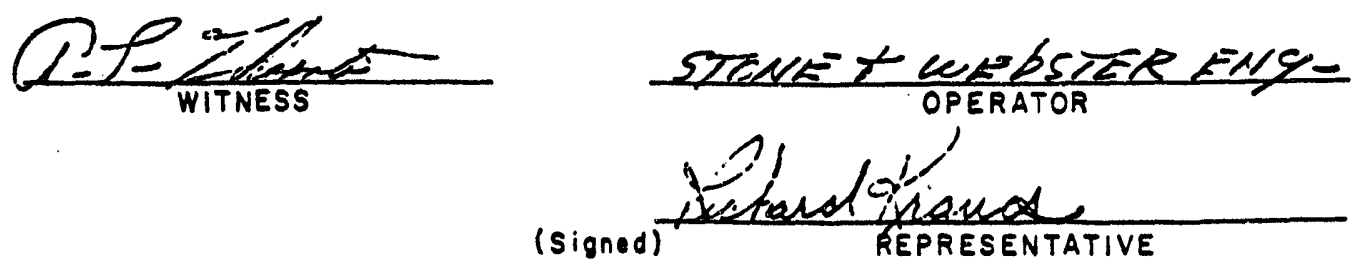


\author{
STATE OF LOUISIANA \\ OFFICE OF CONSERVATION
}

PLUG AND ABANDON REPORT

WORK PERMIT NO. $2.117-8 Z-1$

WELL SERIAL NO. DATE WORK FINISHED (MM-DD-YY) $\angle 1.20-8 S-$ SIUREYSEOLT DISTRICT

(Thiee Copies to be Filed with the District Office)

NOTE: This Feport Will Be Returned if Not Properly Completed And Signed.

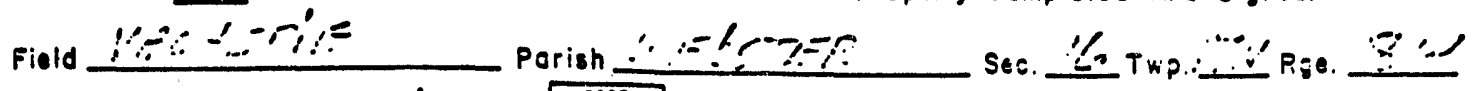

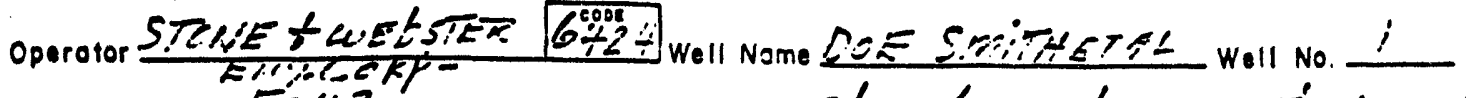

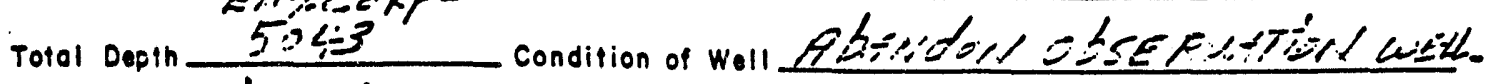

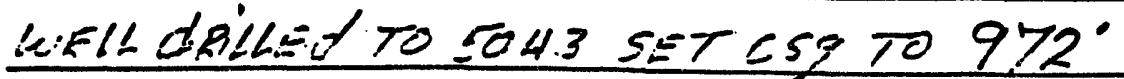

entex appropnuars sex:

$\square 29$ DRY HOLE

D 30 FORMERLY PRODUCTIVE WELL

\begin{tabular}{|c|c|c|c|c|c|c|}
\hline & \multirow{2}{*}{$\begin{array}{l}\text { CASING } \\
\text { SIZE }\end{array}$} & \multirow{2}{*}{$\begin{array}{l}\text { AMOUNT } \\
\text { PULLED }\end{array}$} & \multicolumn{4}{|c|}{ CEMENT PLUGS } \\
\hline & & & FROM & TO & SACKS & HOW PLACED \\
\hline 301 & 9.8 & 18, $14=$ & 843 & 1322 & 55 & $W^{\prime}=S T=E S 1_{1}^{\prime}$ \\
\hline 302 & & & $8 \div 3$ & 3 & .257 & LUESTER.AI \\
\hline 363 & & & & & & \\
\hline 304 & & & & & & \\
\hline
\end{tabular}

Mud Record: weight $N / A$ viscosity $\frac{N / 2}{1 / 2}$

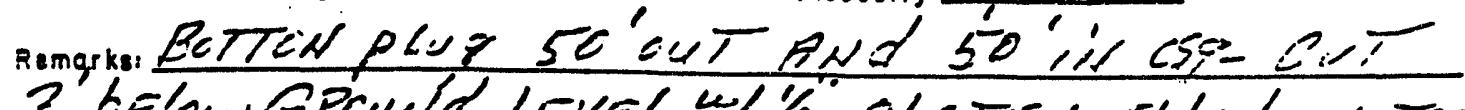

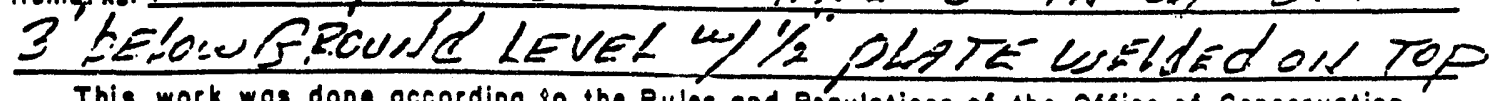

This work wos done oceording io the Rules ond Regulotions of the Office of Conservotion.

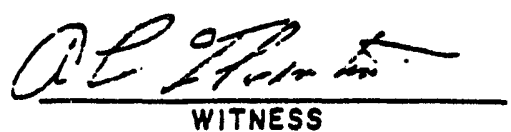

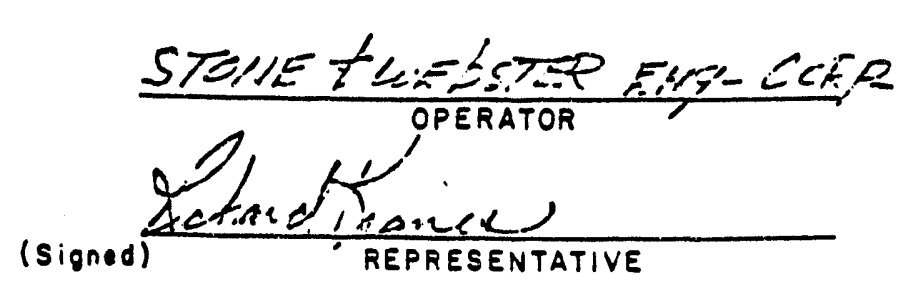

Porm $\bullet(1 .+2)$ 


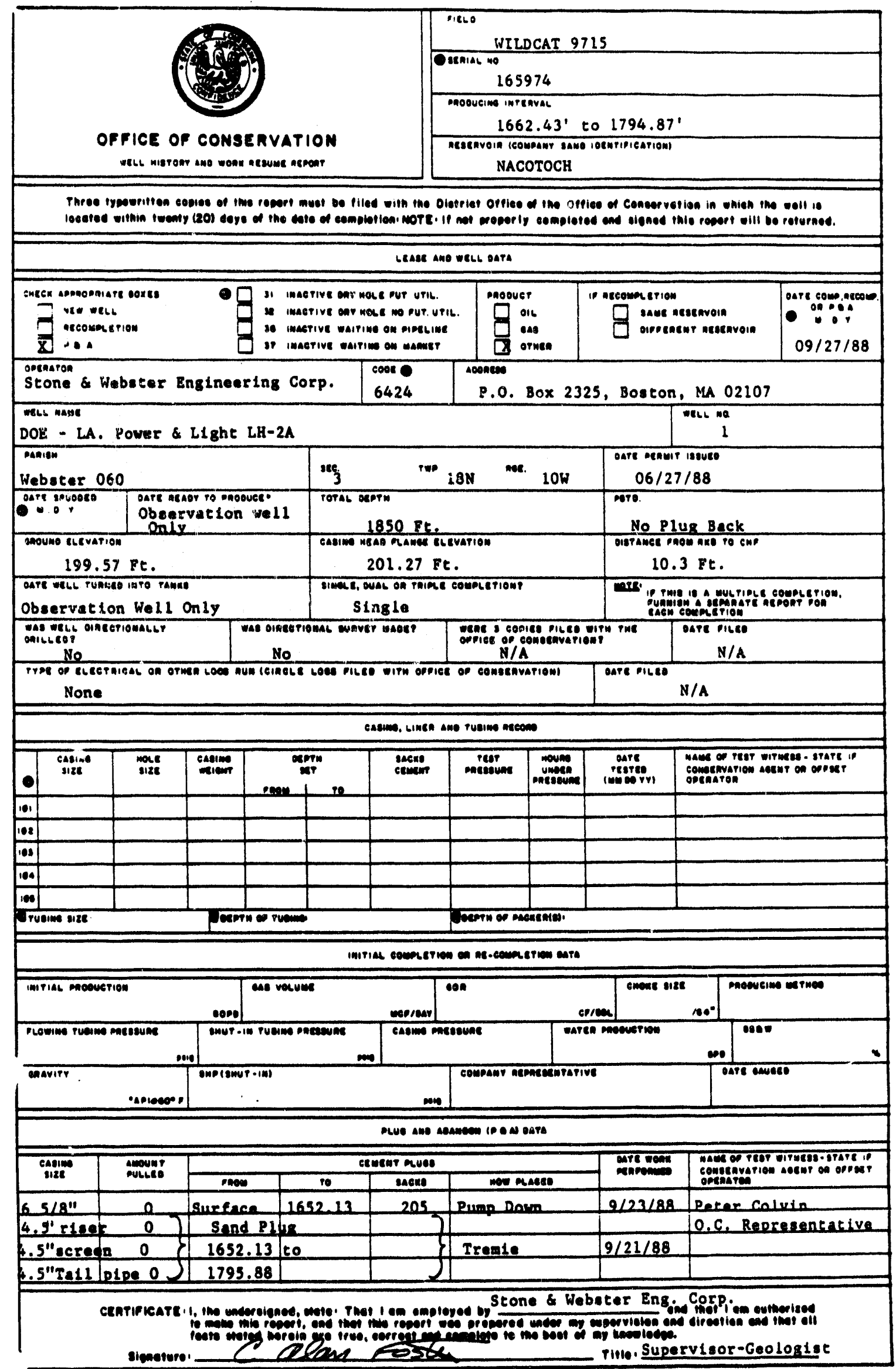

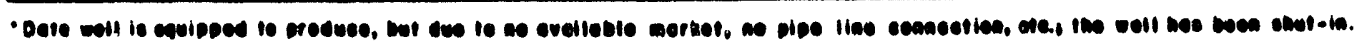


wonk nesune

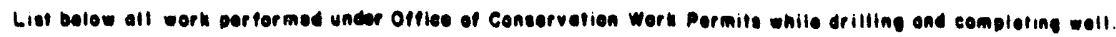

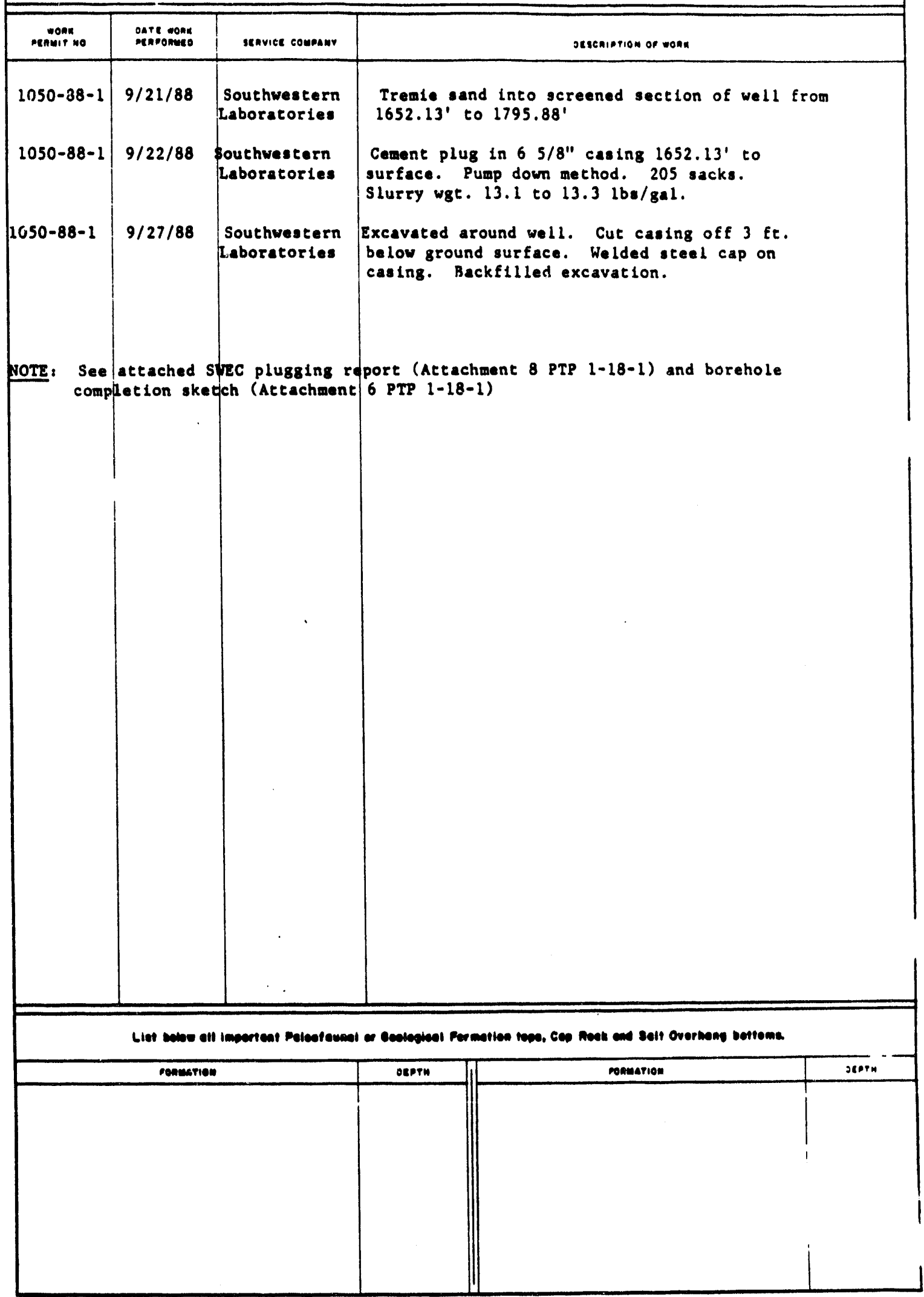




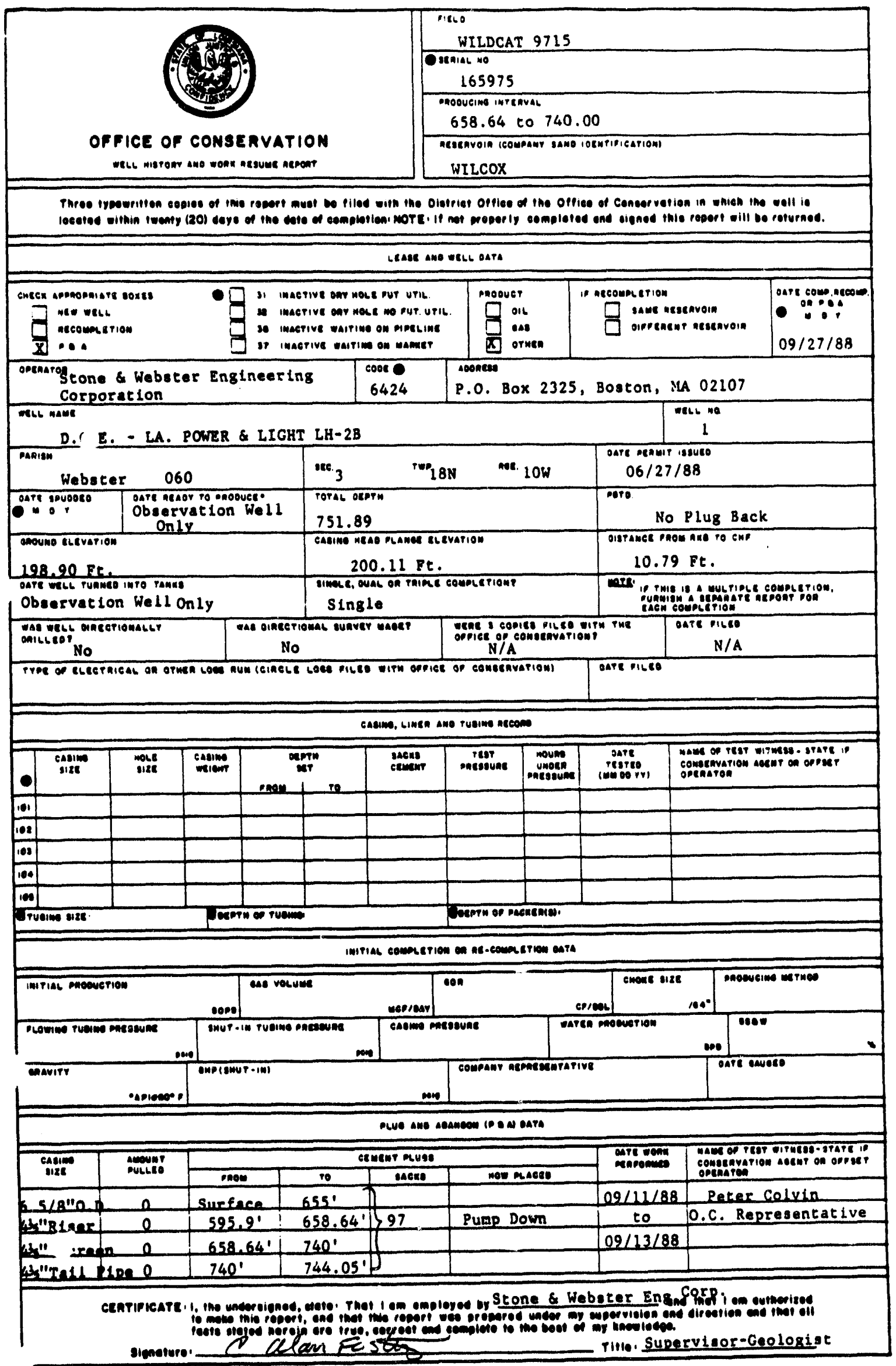

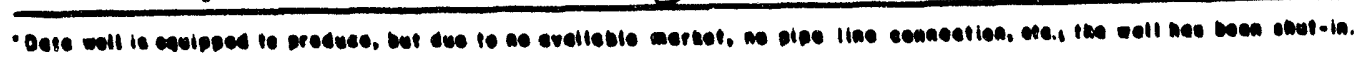


wonn acsube

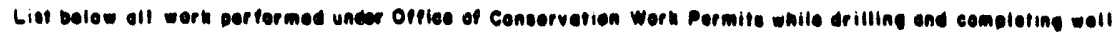

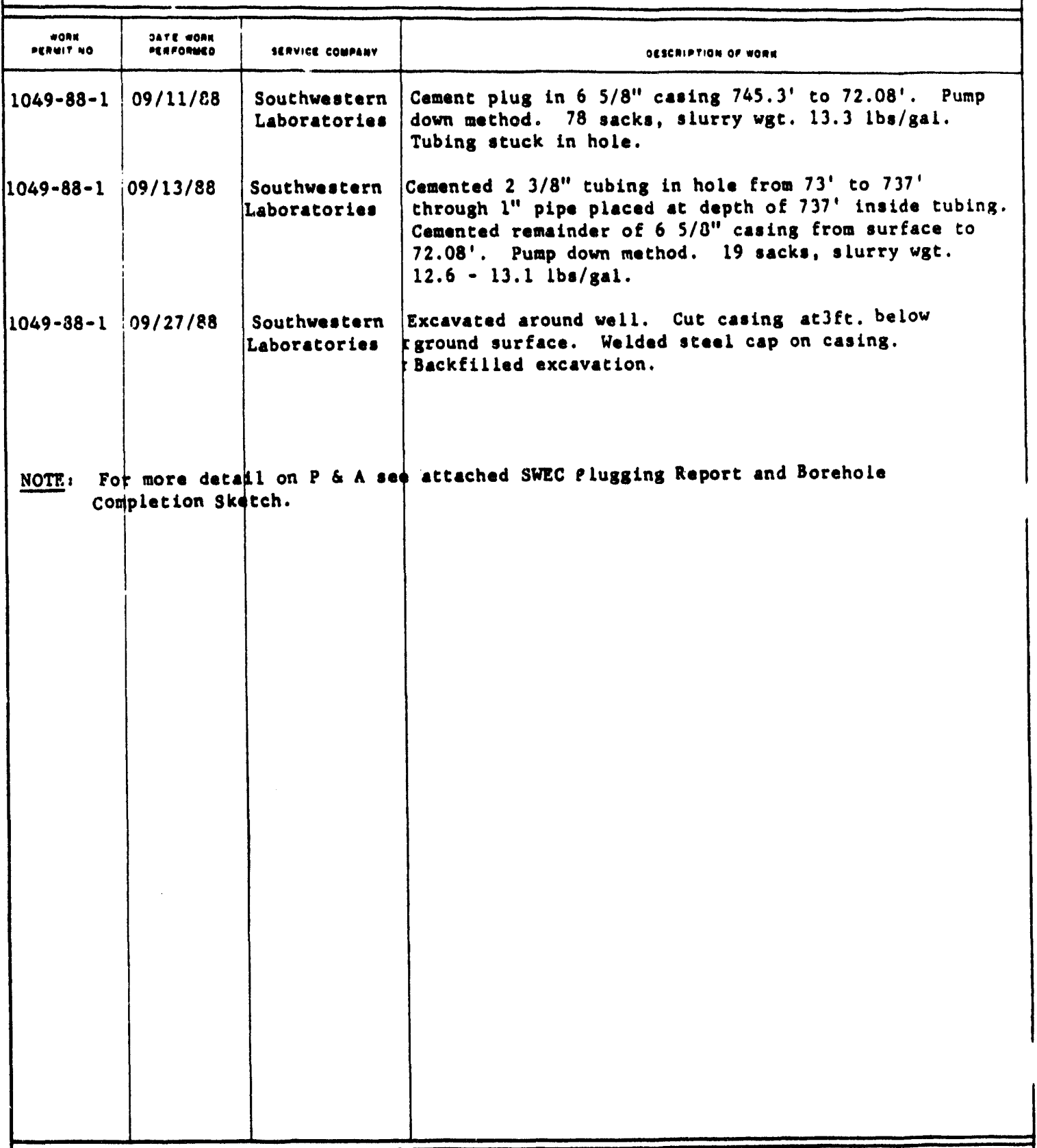

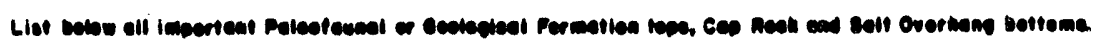

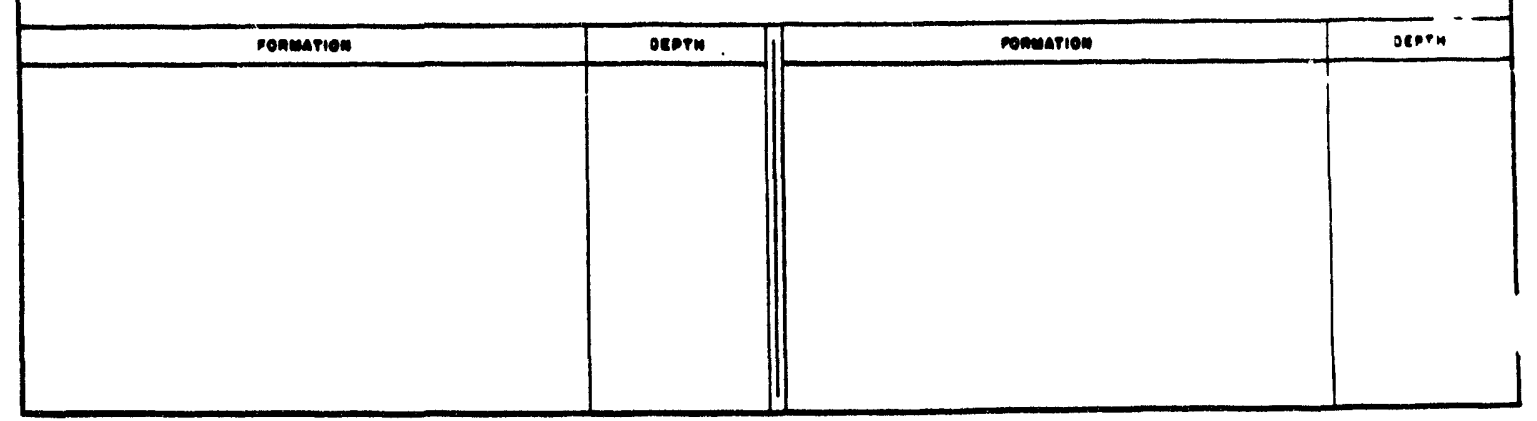




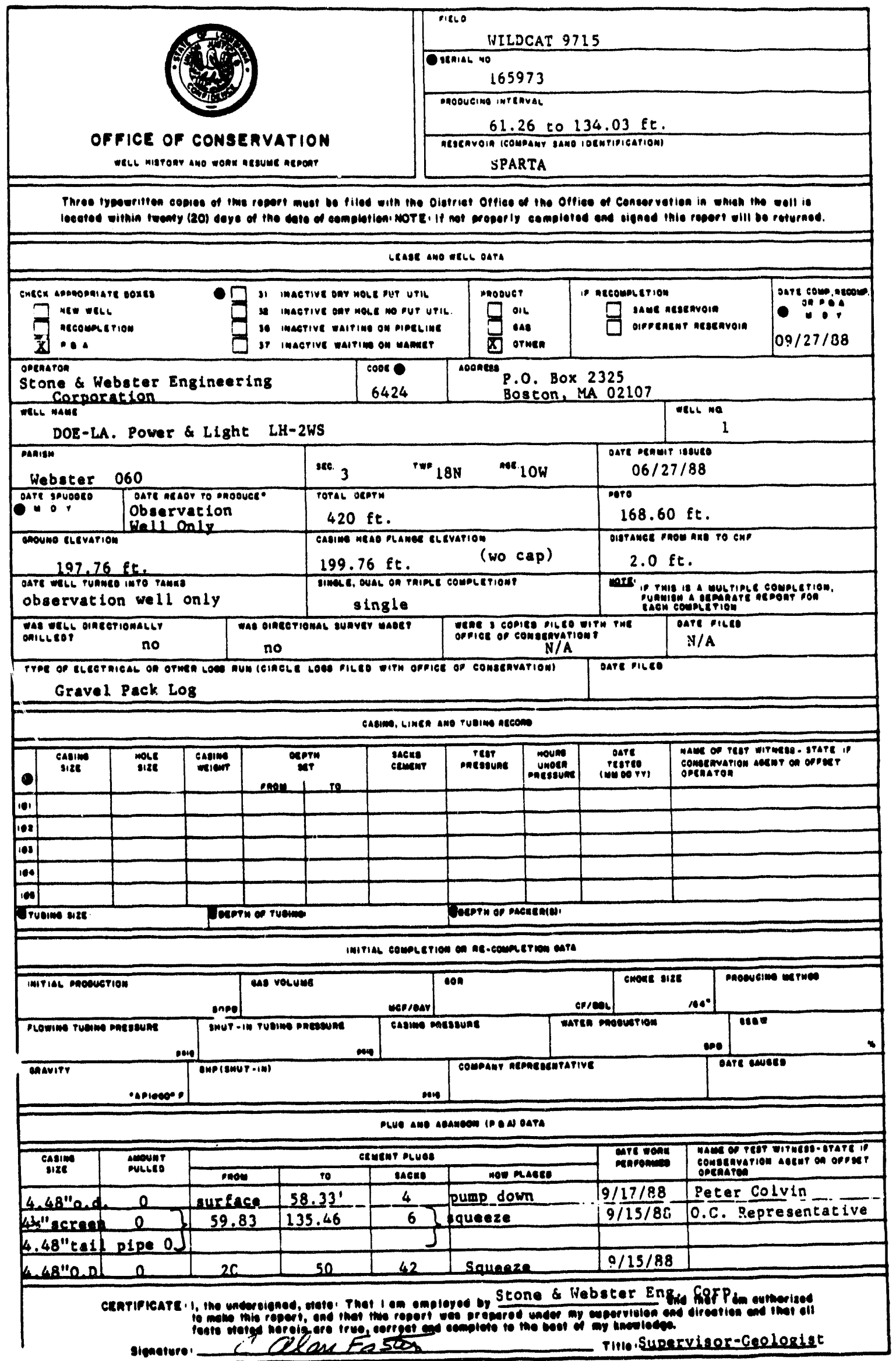

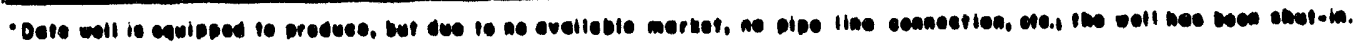


wonk nesuine

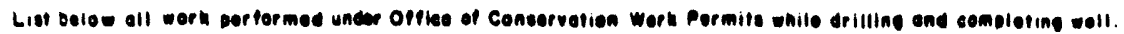

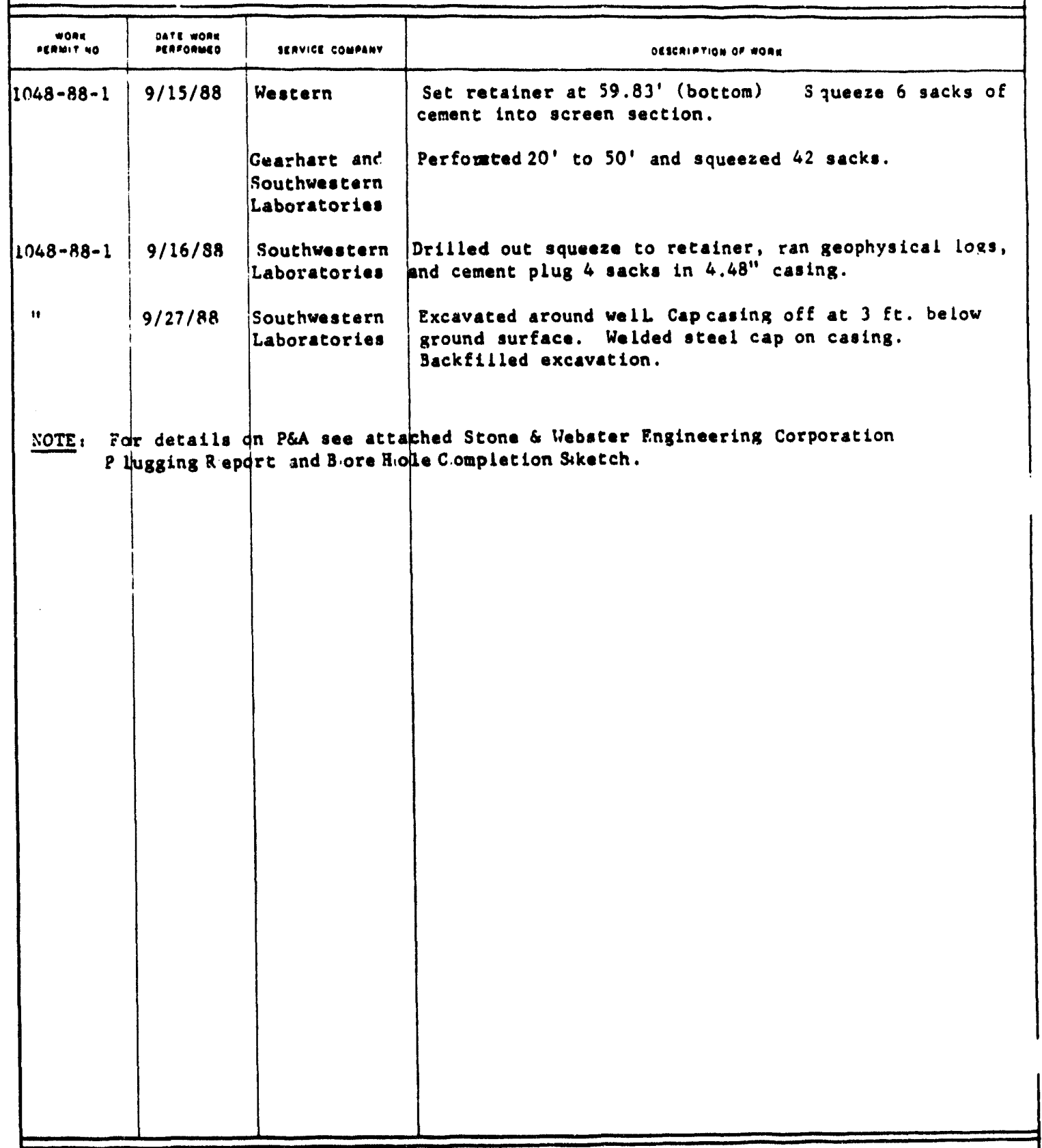

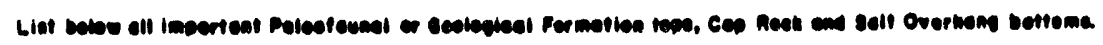

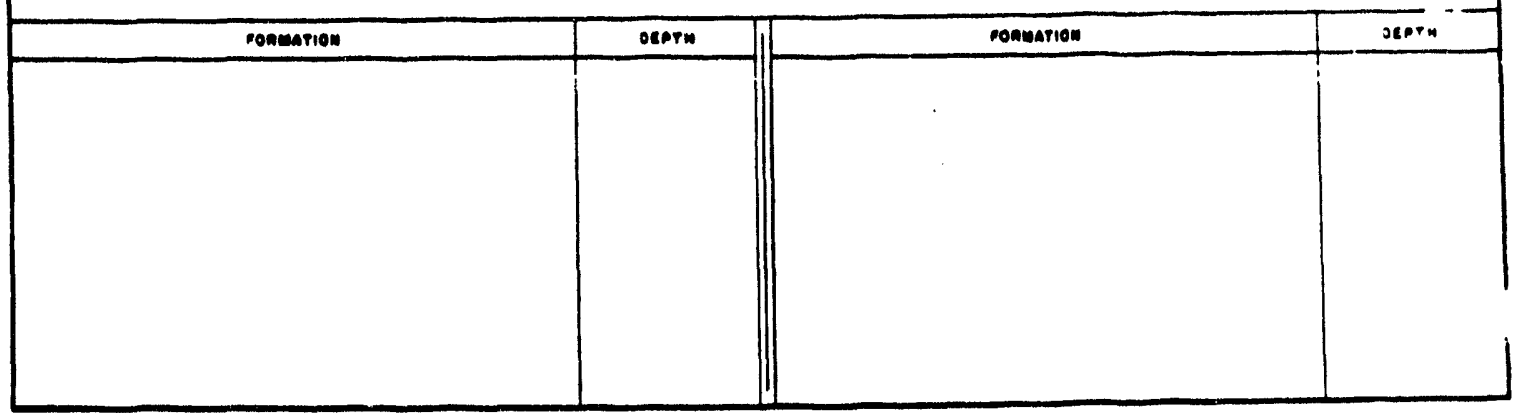




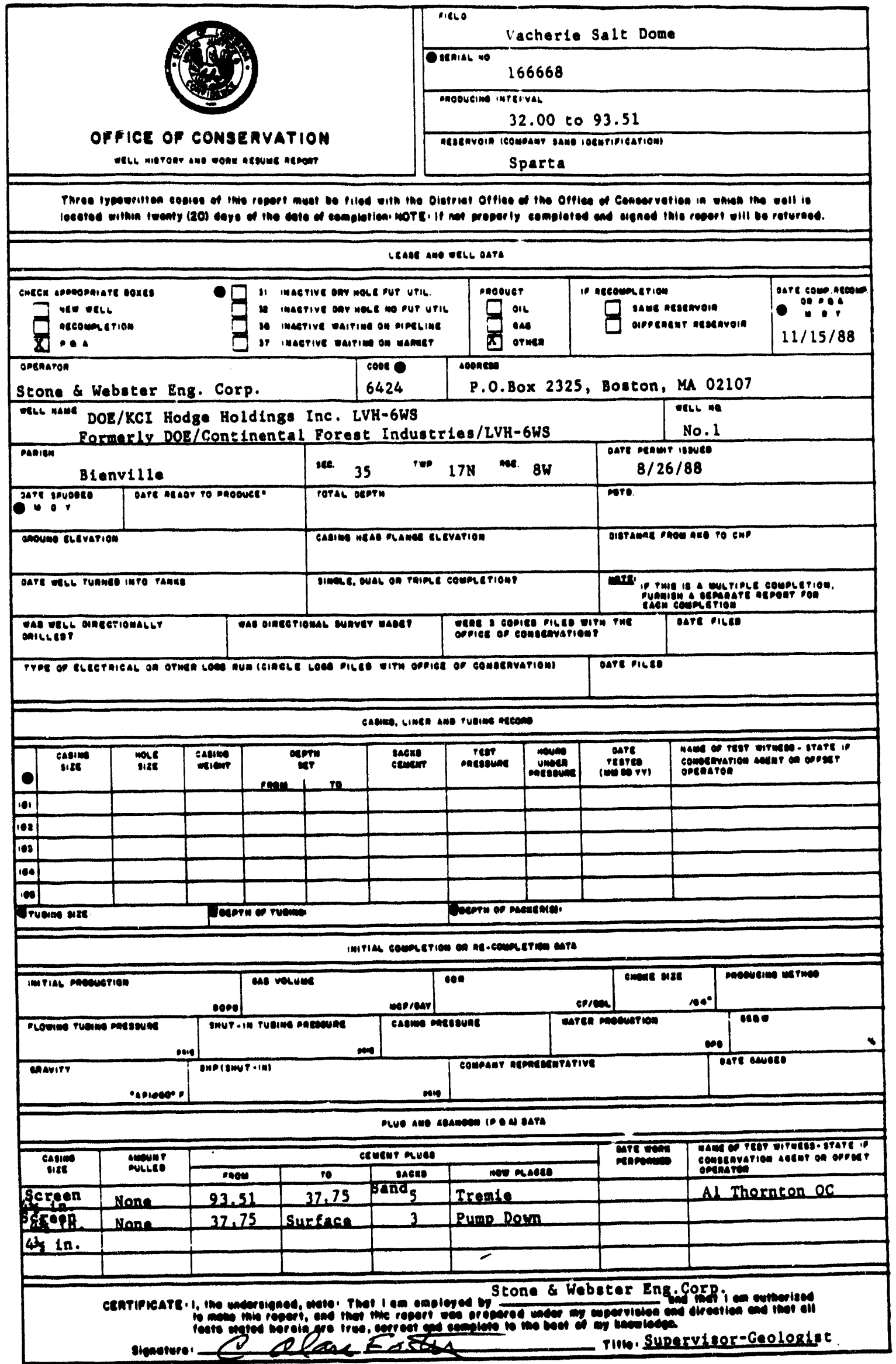

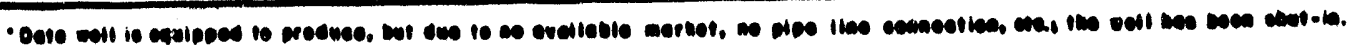




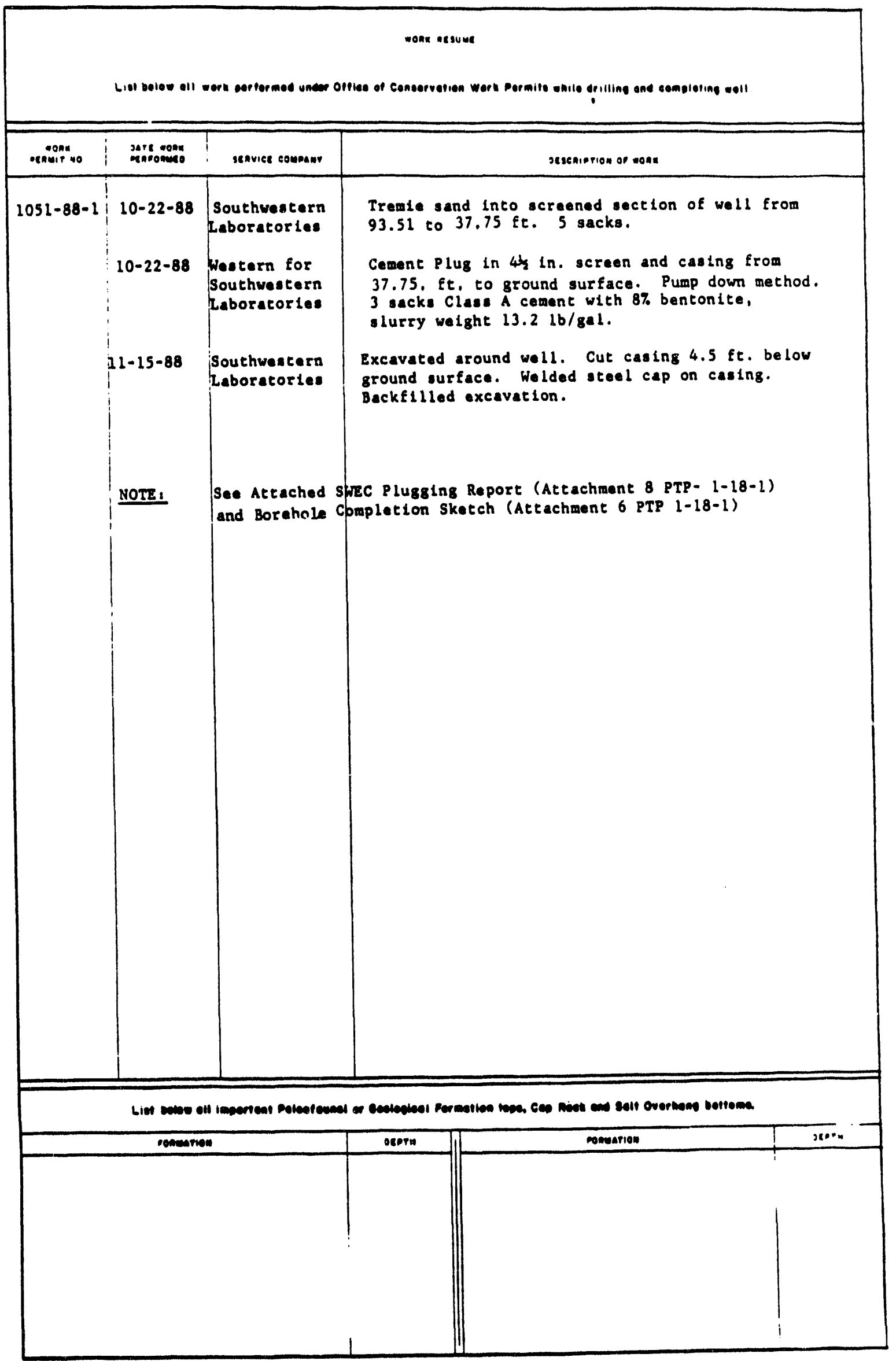




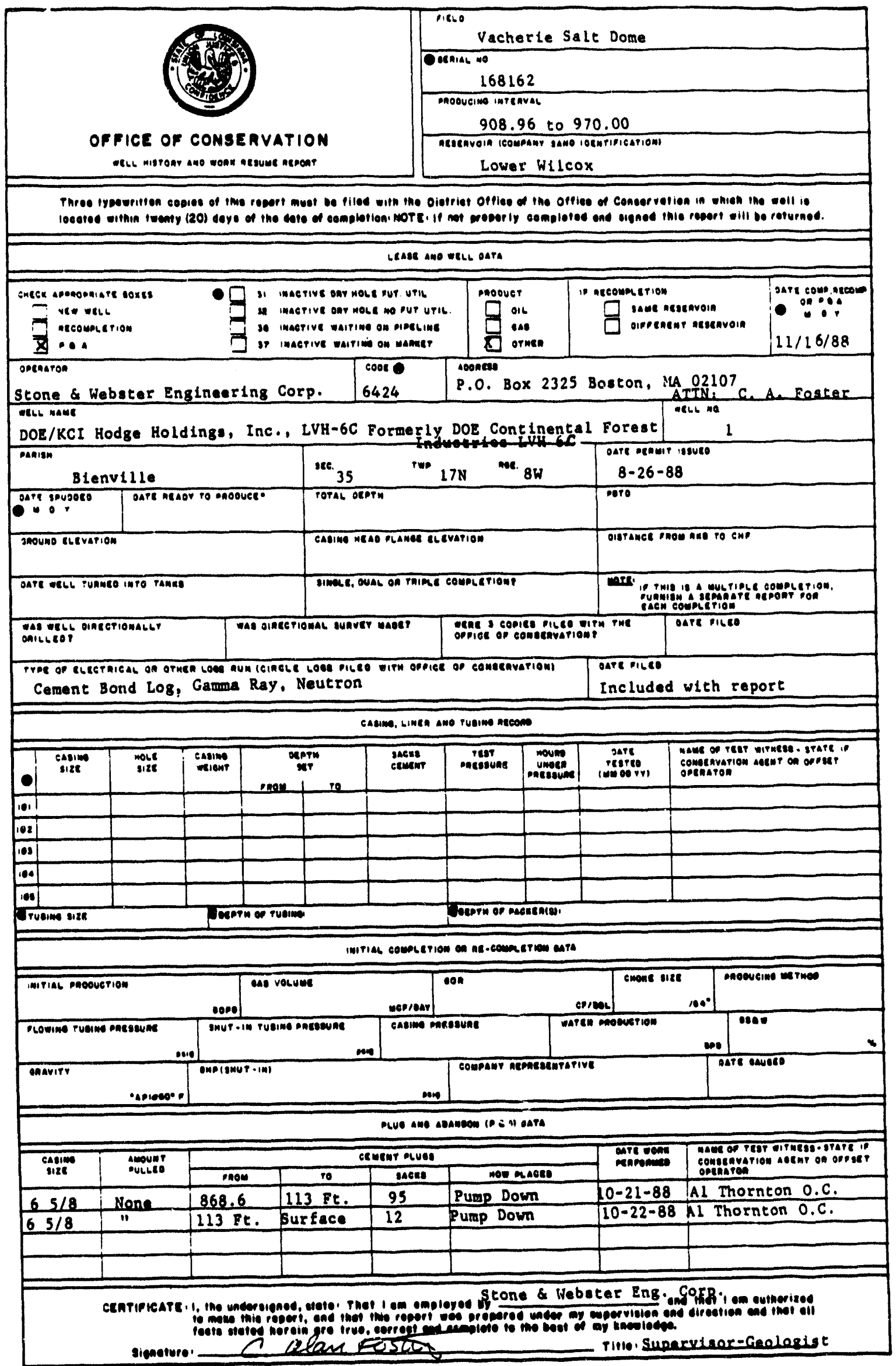

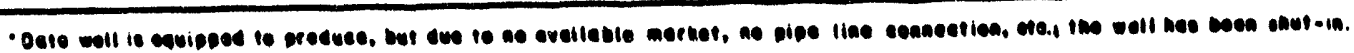


work mesume

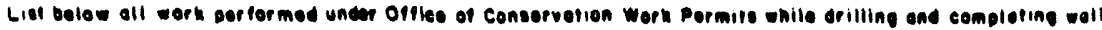

\begin{tabular}{|c|c|c|c|}
\hline 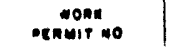 & $\begin{array}{l}\text { jare morke } \\
\text { ateromeves }\end{array}$ & senvice coupany & Deseniperion or conx \\
\hline $1052-88-1$ & $\begin{array}{l}9-23-88 \\
9-23-88 \\
9-29-88 \\
10-21-88 \\
\text { 11/22/88 } \\
\text { See Actect } \\
\text { Borehole } \\
\text { Perforat } 1 \mathrm{~s}\end{array}$ & 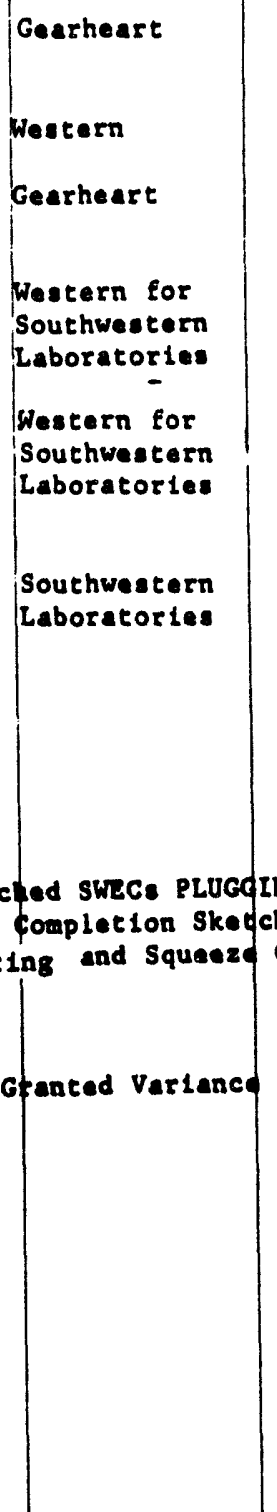 & 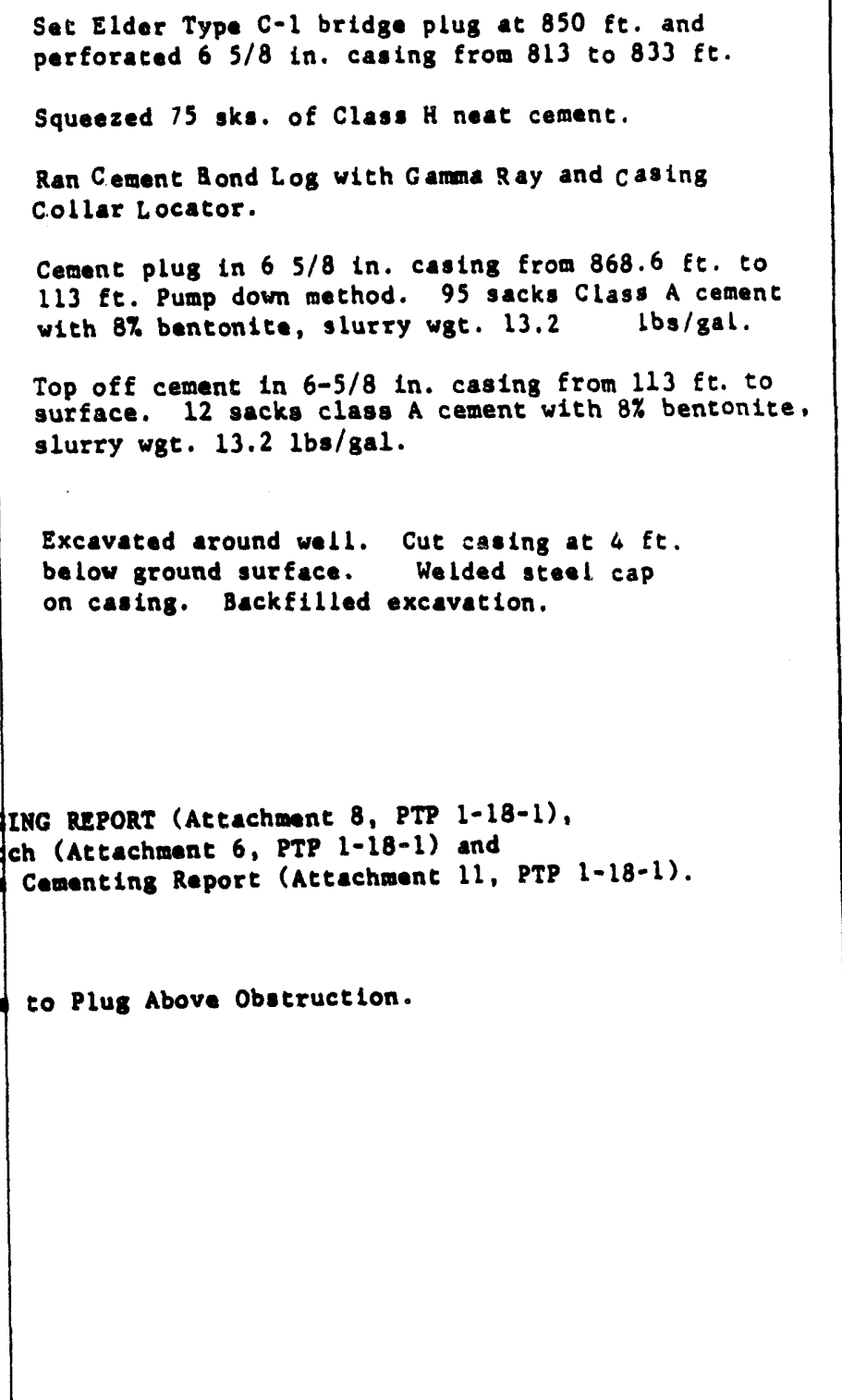 \\
\hline
\end{tabular}

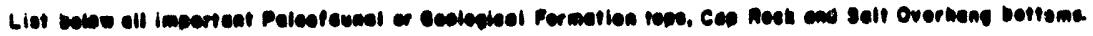

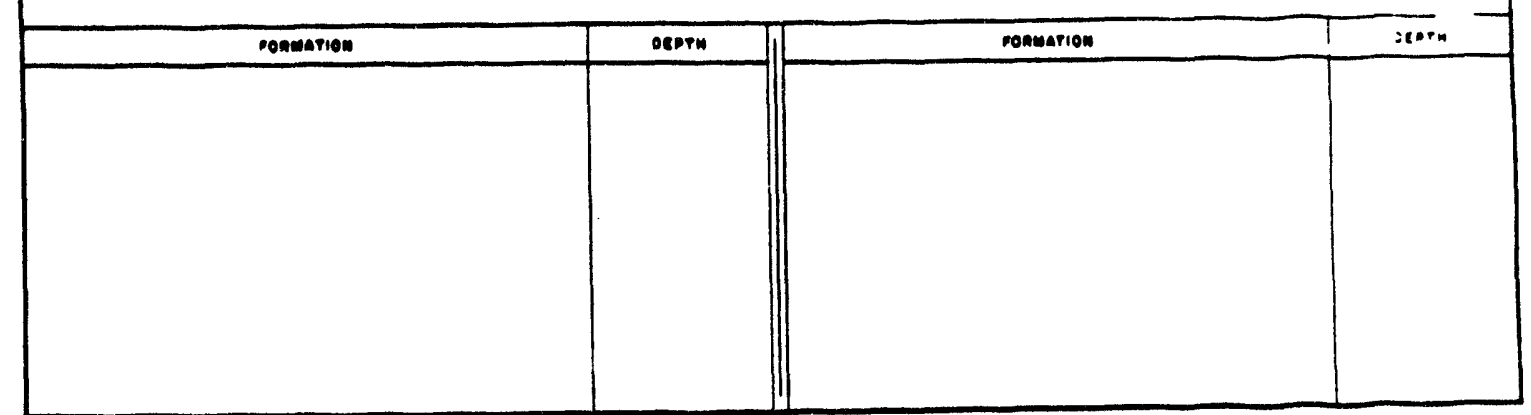




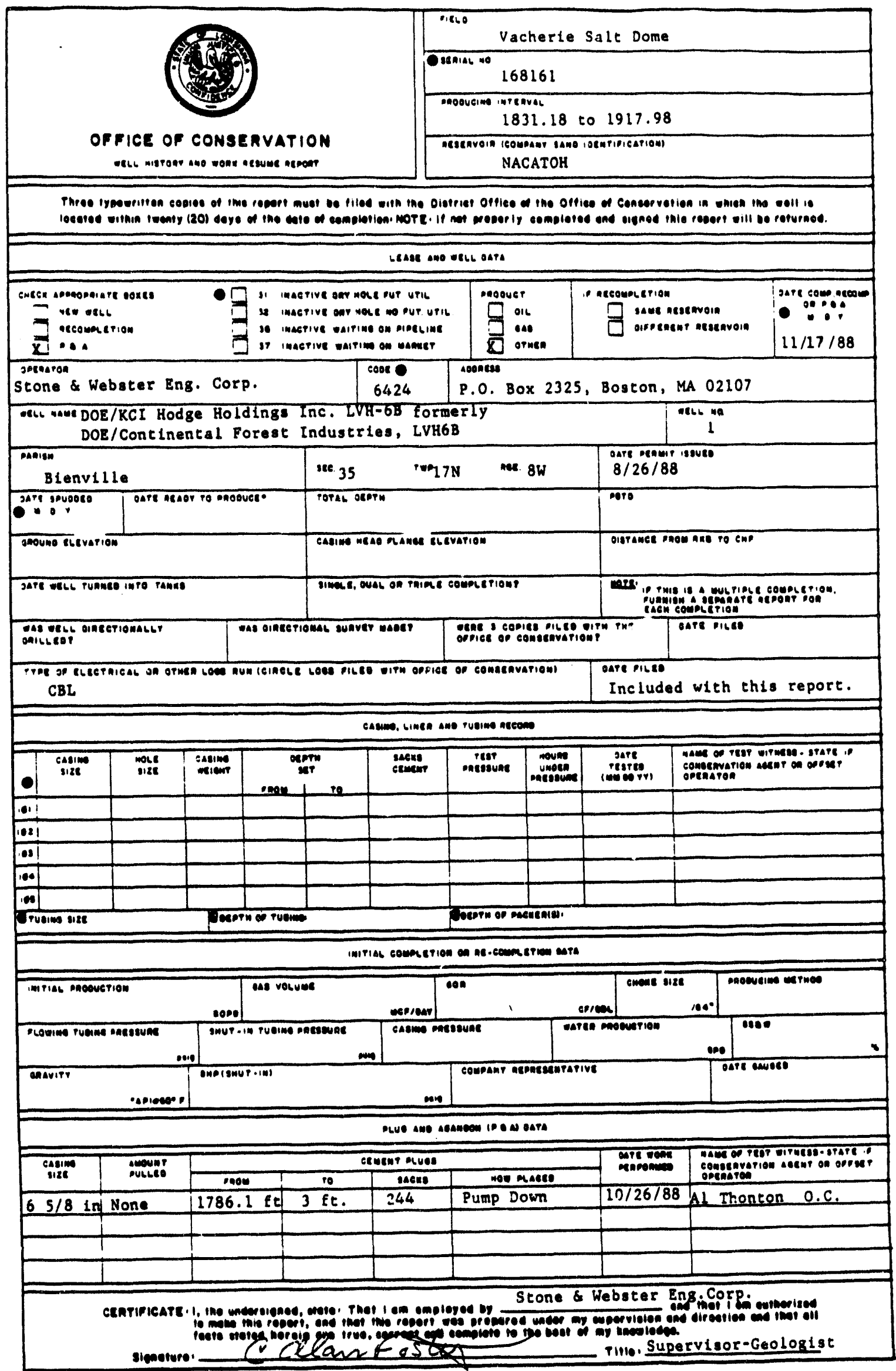

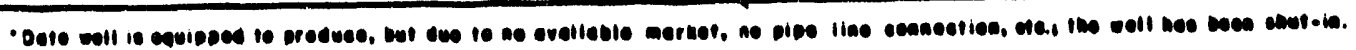


wonk acsume

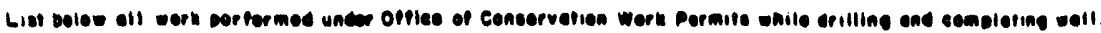

\begin{tabular}{|c|c|c|c|}
\hline Dencoit no & 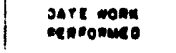 & senviet eoupant & Deseniertion of wonk \\
\hline 1053-88-1:9 & $\begin{array}{l}10-13-88 \\
10-15-88 \\
10-26-88 \\
11-17-88 \\
\text { See Attech } \\
\text { Borehole Co } \\
\star \text { Dotd G }\end{array}$ & \begin{tabular}{|l|} 
Gearhiert \\
Induetries \\
Western \\
Gearhart. \\
Industries \\
Western \\
Se \\
Gearbert \\
Induatries \\
Western for \\
Southwestern \\
Laboratories \\
Gouted Variance \\
Southwestern \\
Laboratories
\end{tabular} & 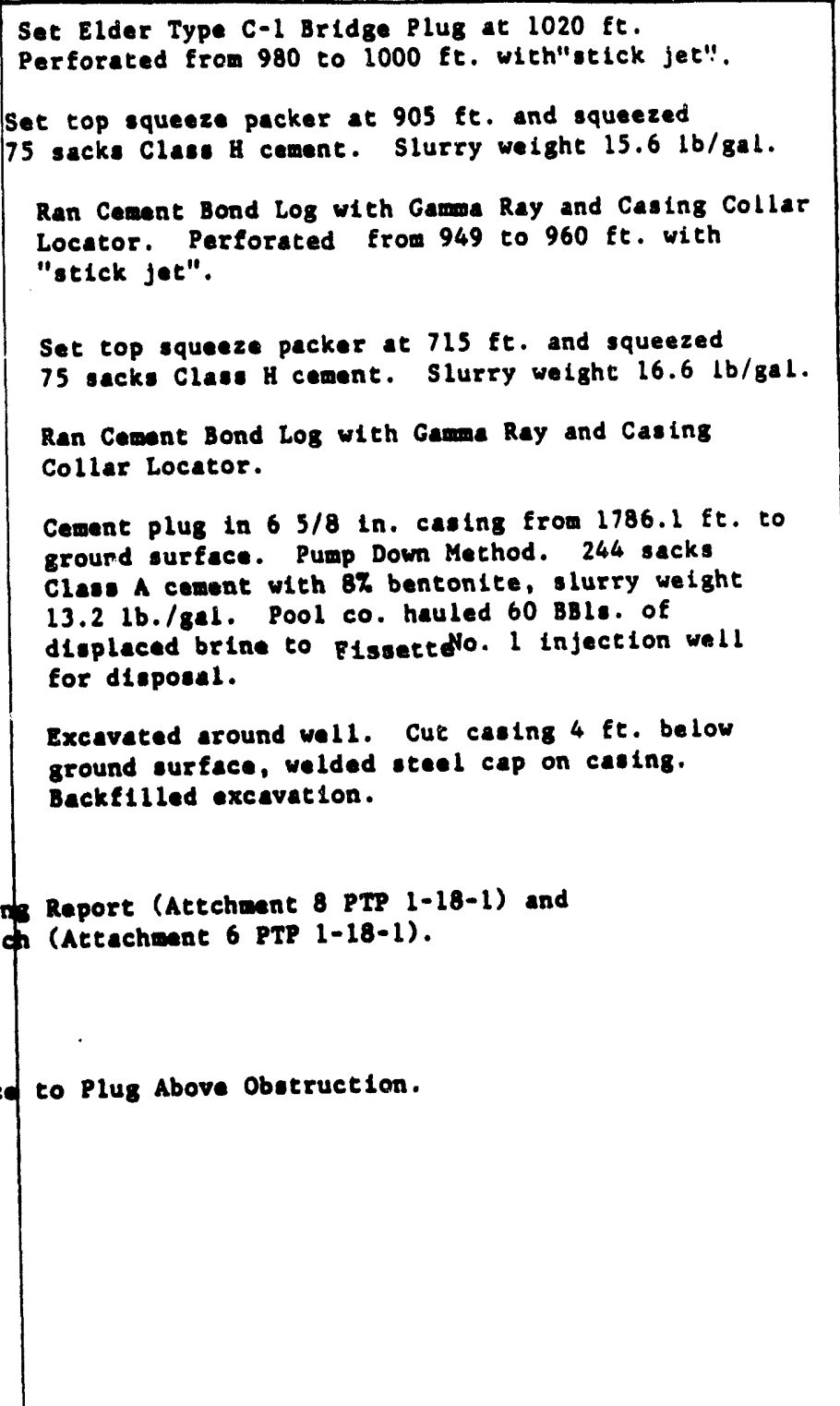 \\
\hline
\end{tabular}

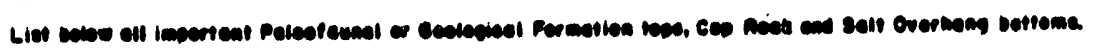

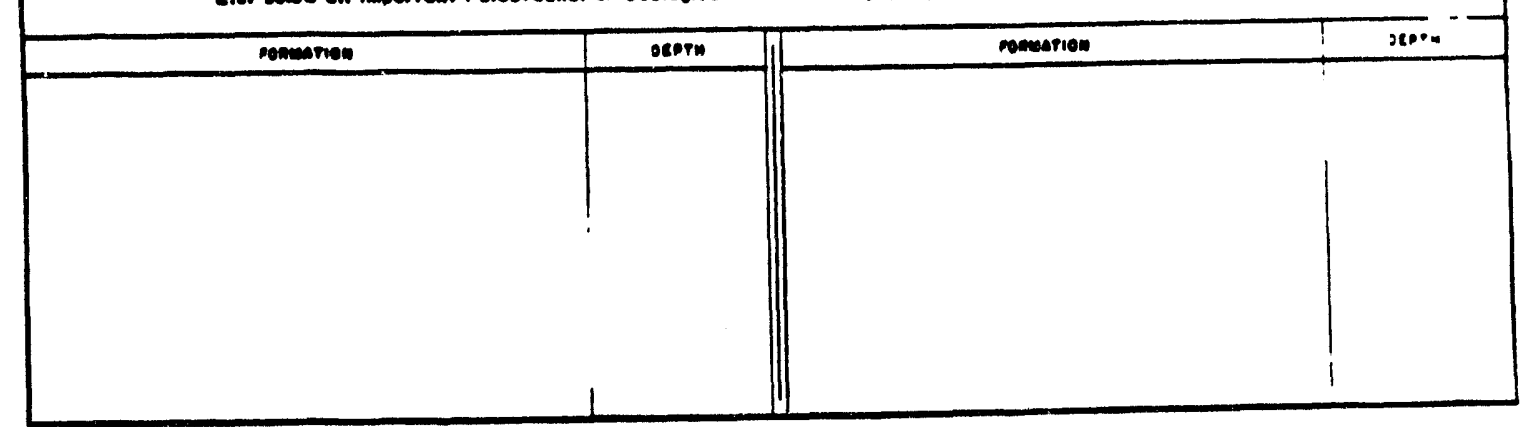




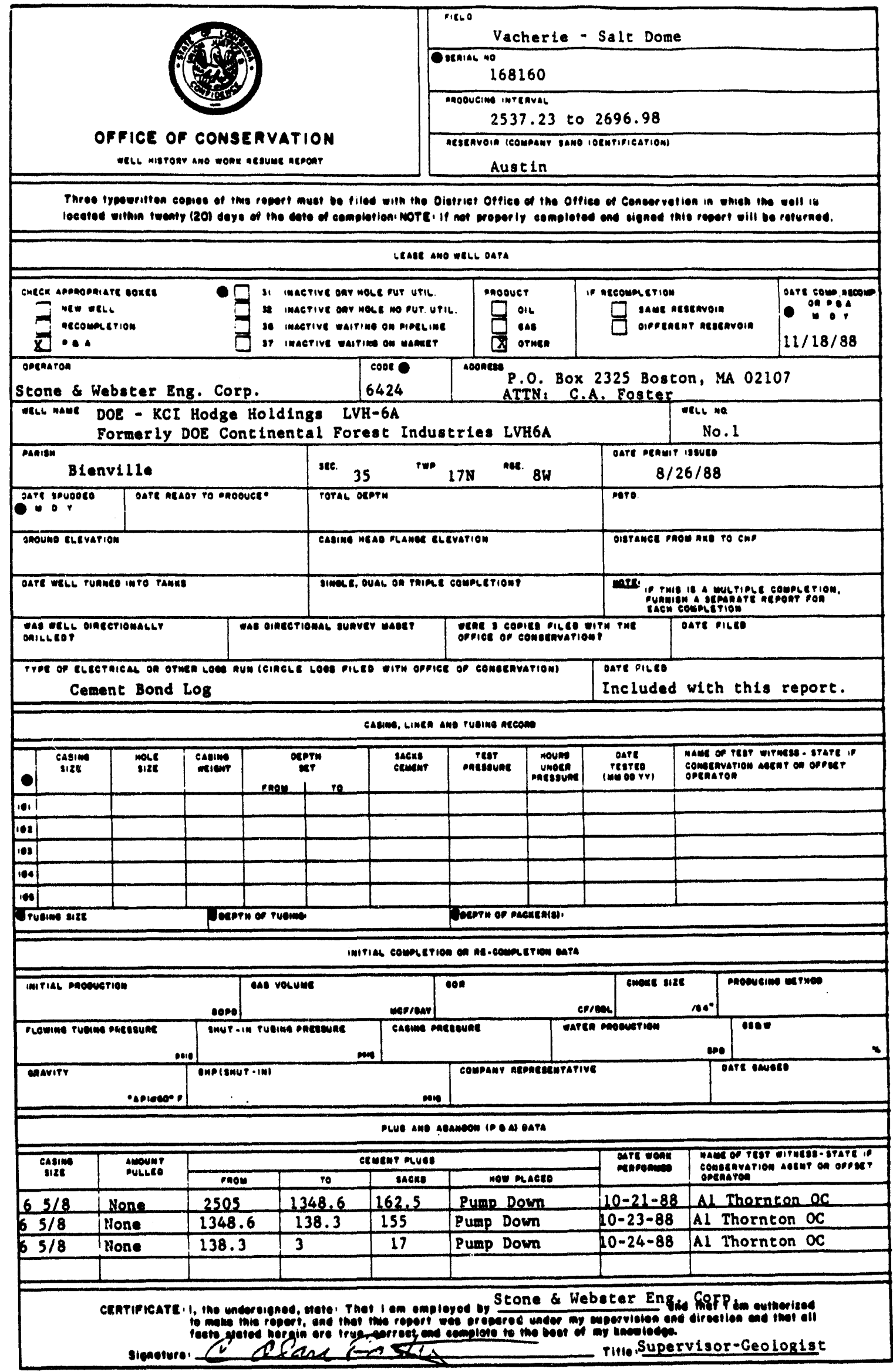

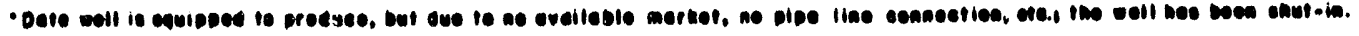


wonk nesume

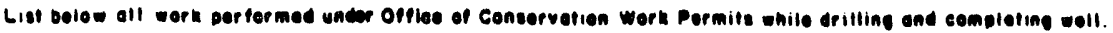

\begin{tabular}{|c|c|c|c|}
\hline monx & 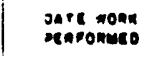 & senviee company & Desenierion of woan \\
\hline $1054-88-1$ & $\begin{array}{l}9-27-88 \\
9-27-88 \\
9-29-88 \\
10-70-88 \\
10-21-88 \\
10-23=88 \\
10-23-88 \\
10-24-88 \\
11-18-88\end{array}$ & \begin{tabular}{|l|} 
Gearhert \\
Industries \\
Gestern \\
Industries \\
Western \\
Gearhart \\
Industries \\
Western for \\
Southwestern \\
Laboratories \\
Western for \\
Southwestern \\
Laboratories \\
Western for \\
Southwestern \\
Laboratories \\
Pool Co.
\end{tabular} & 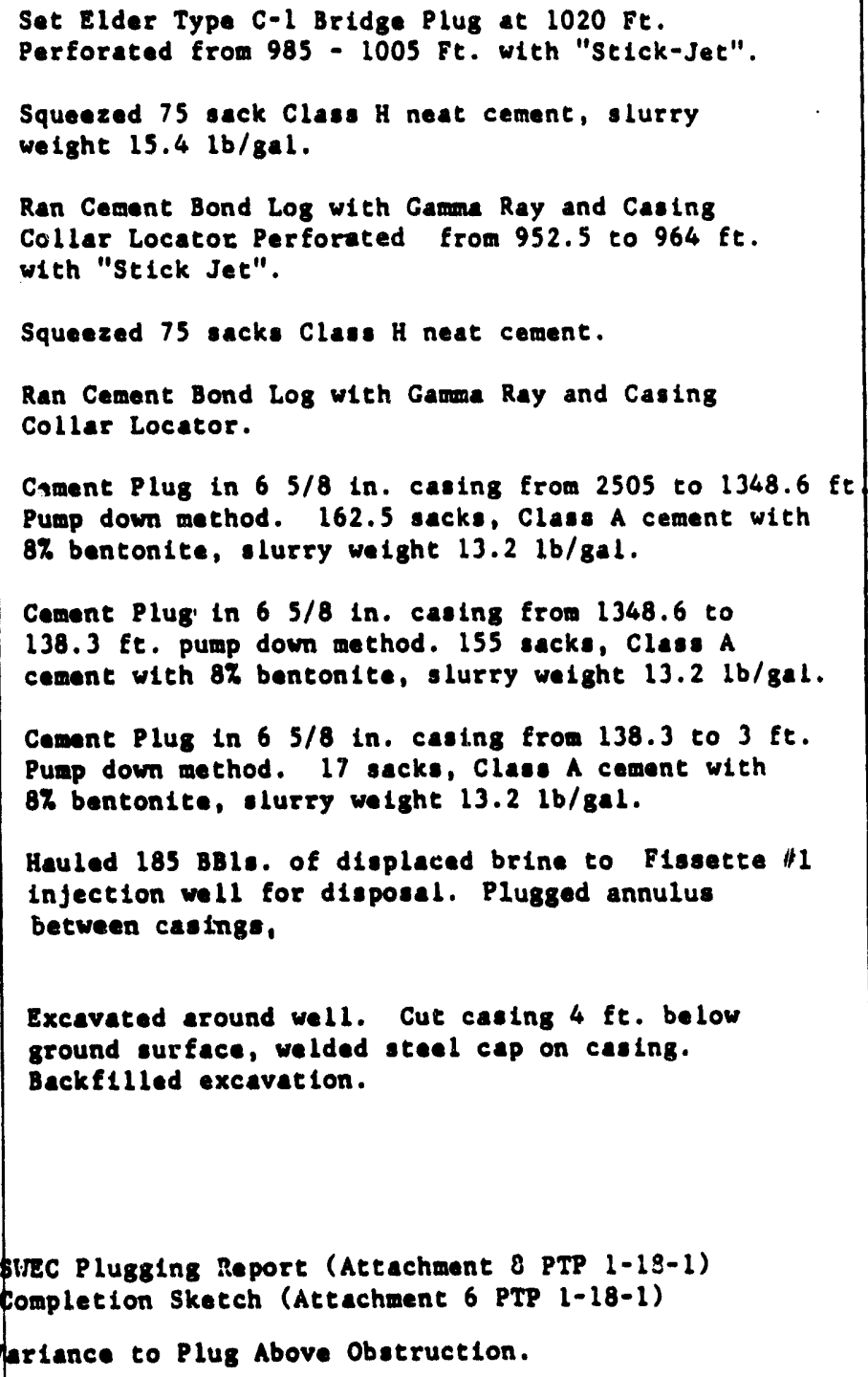 \\
\hline
\end{tabular}

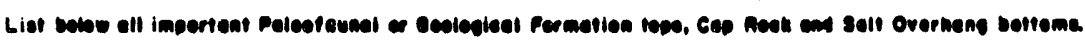

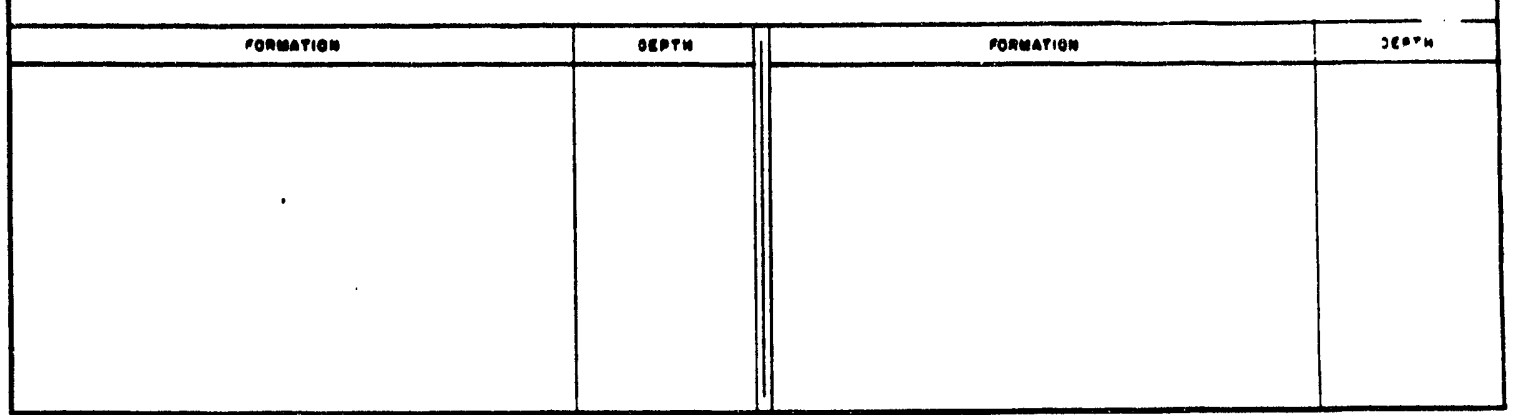




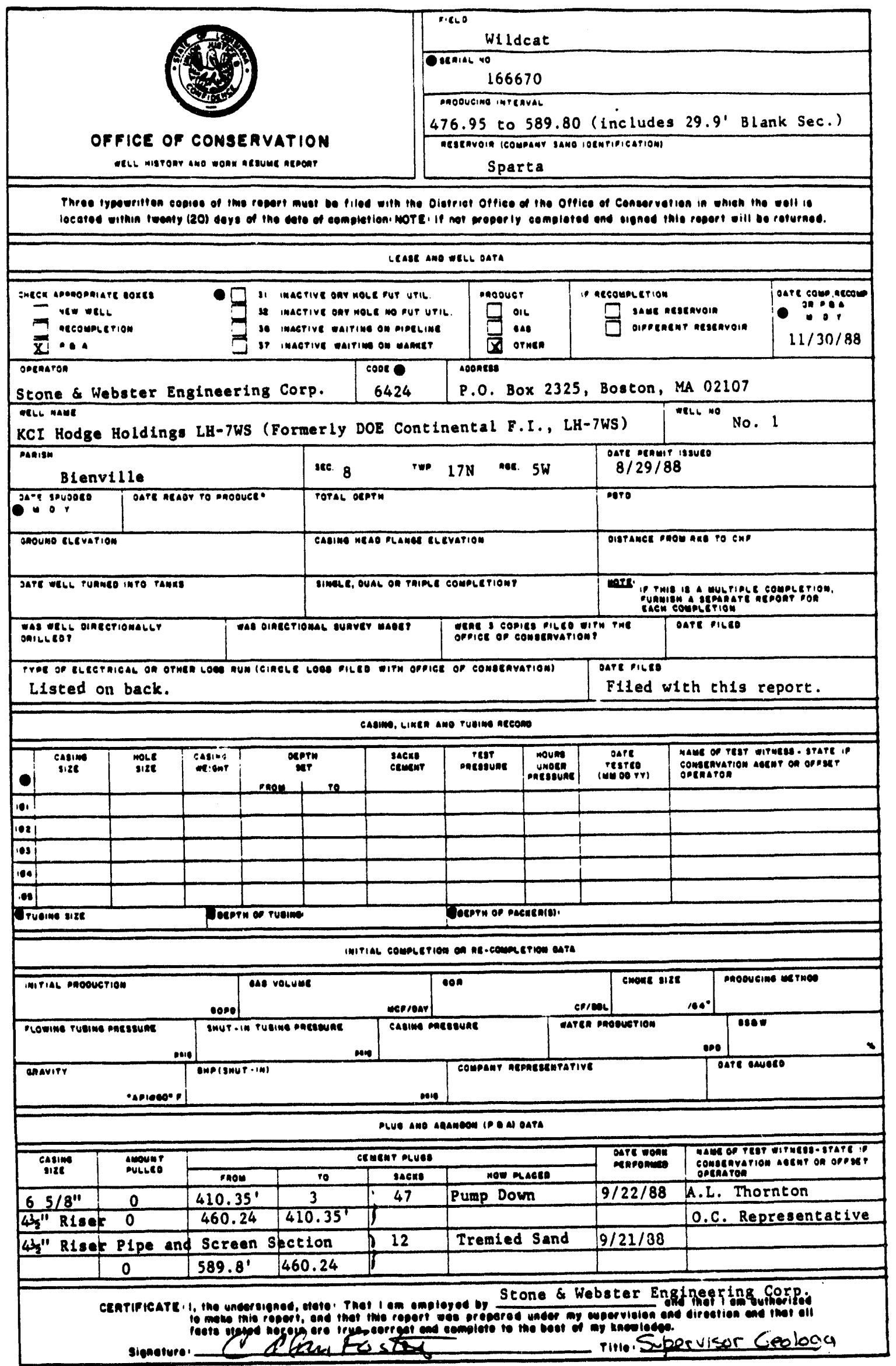

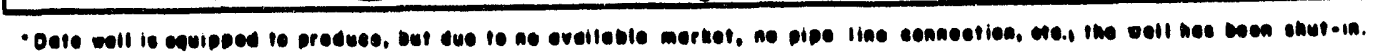




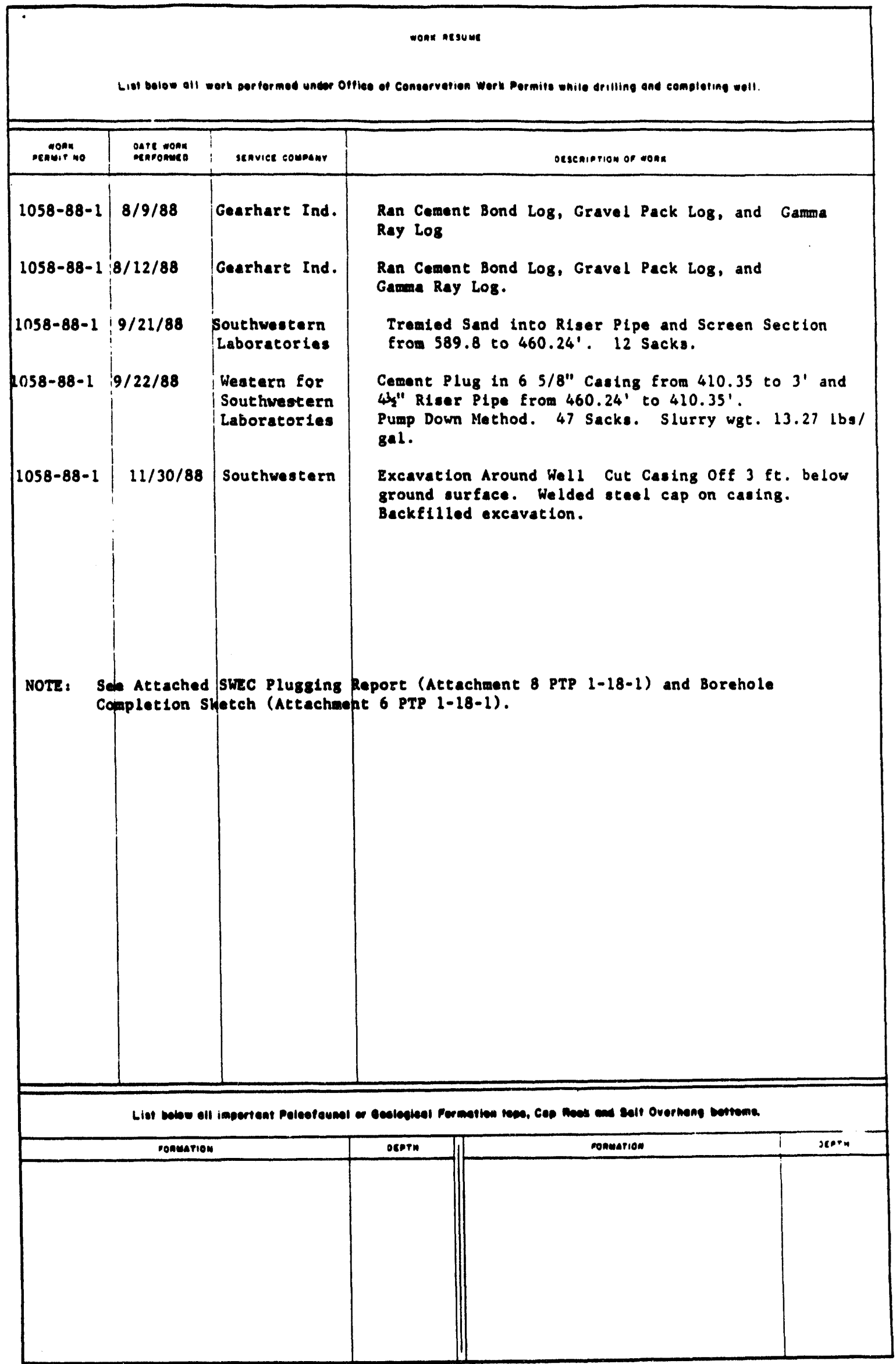




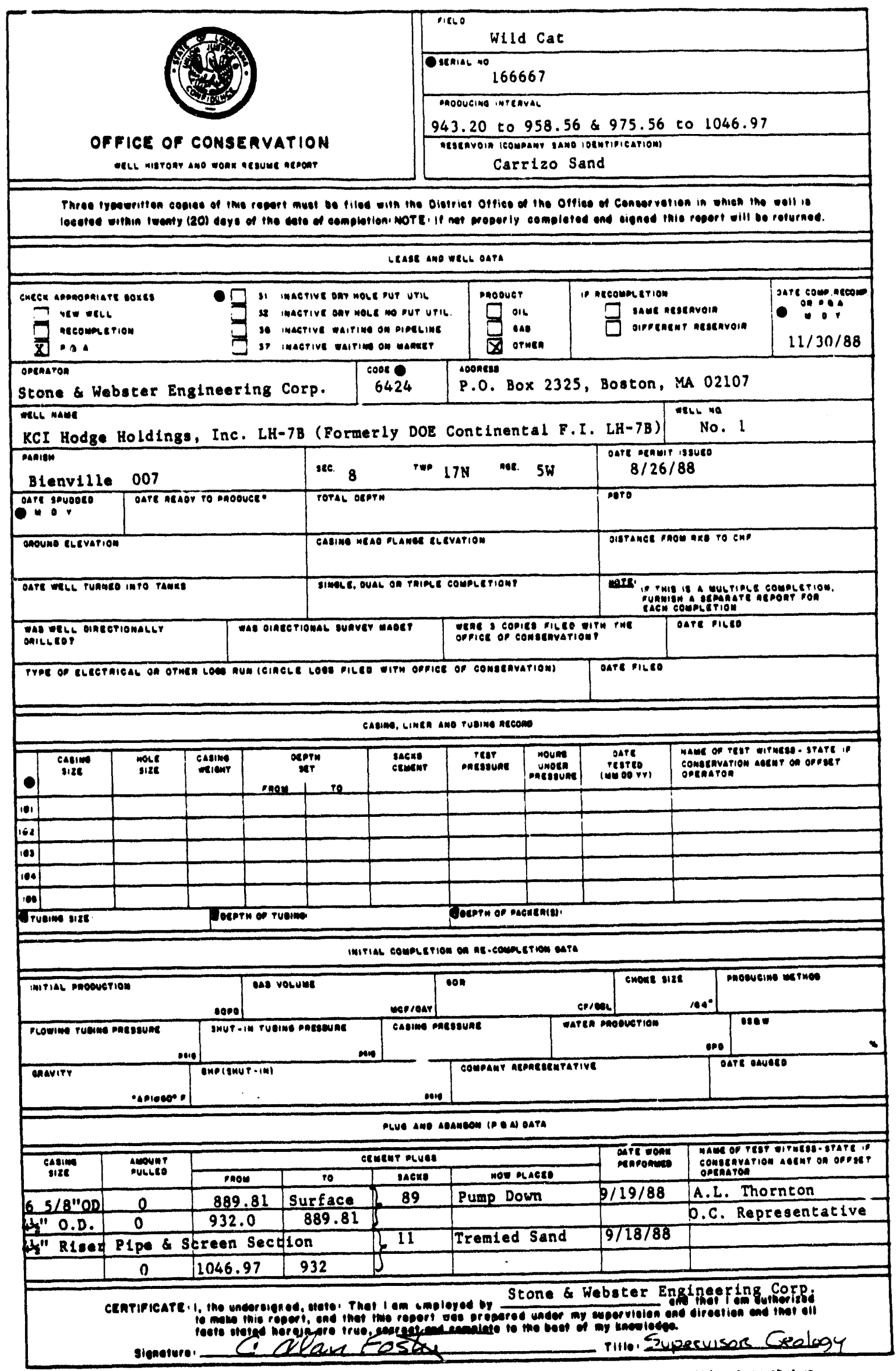

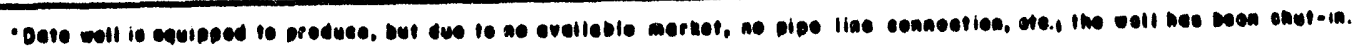




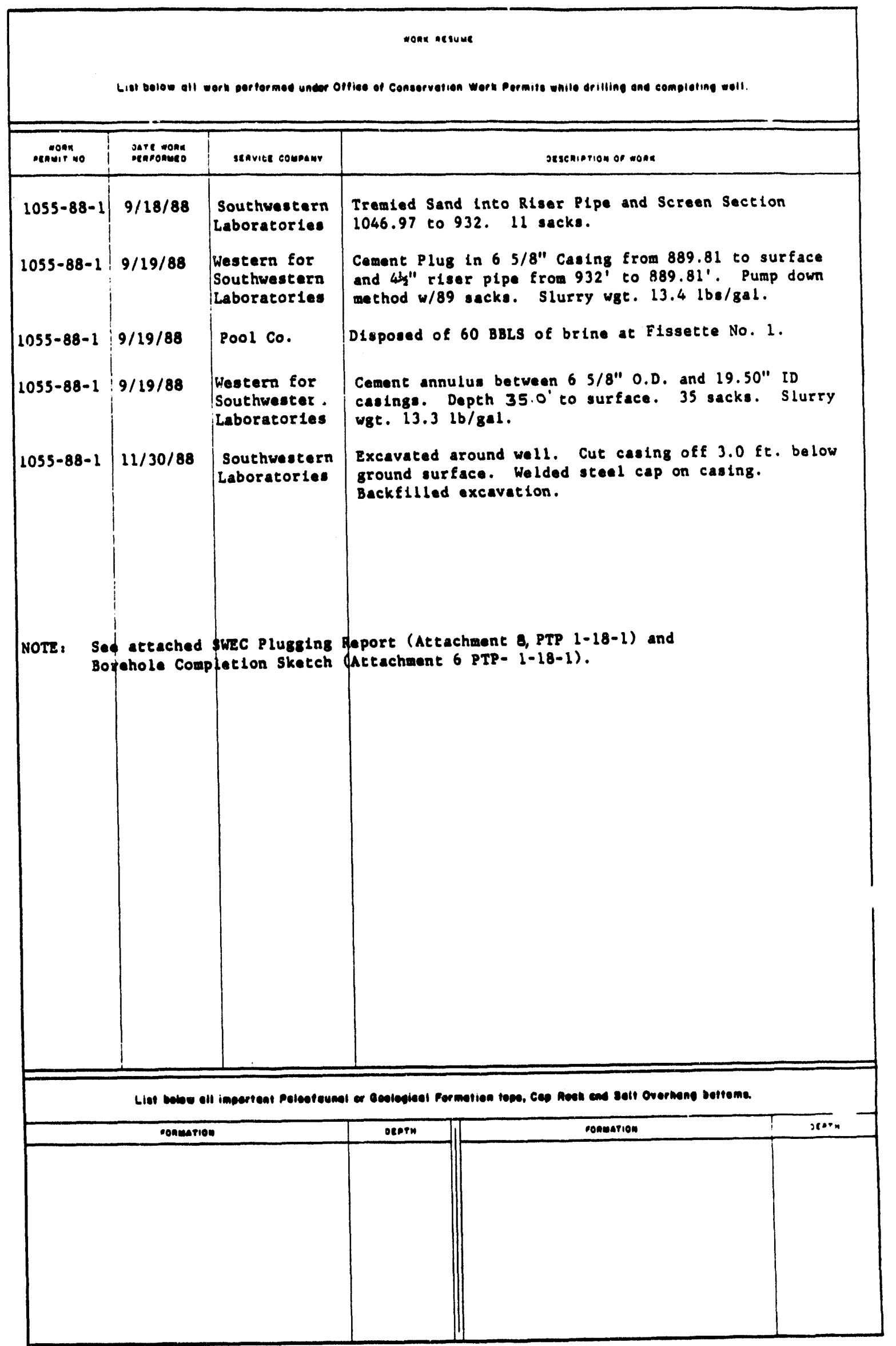




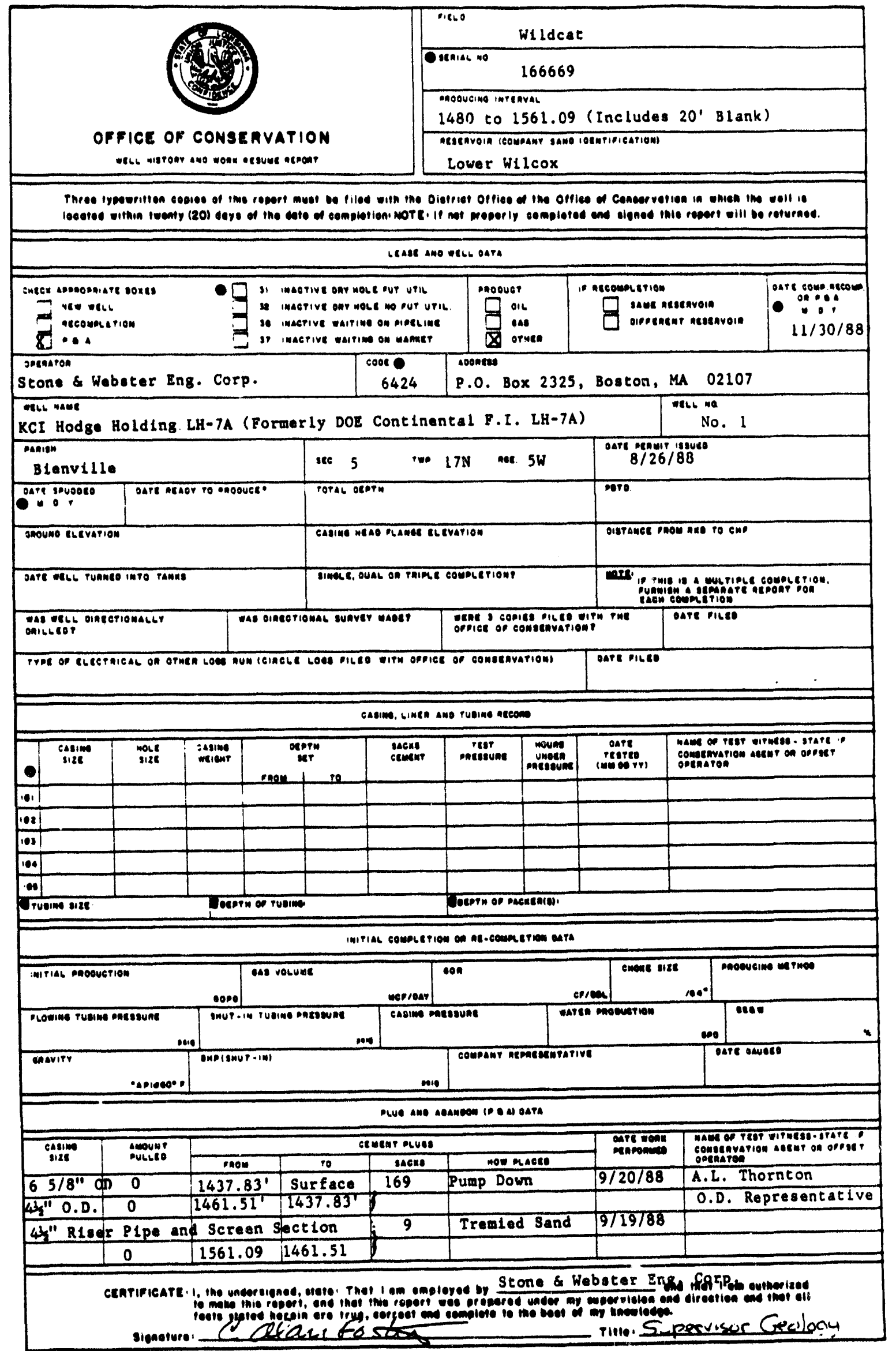

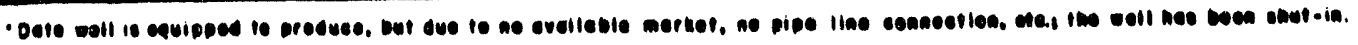


work Mesume

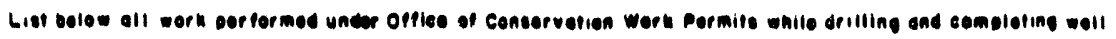

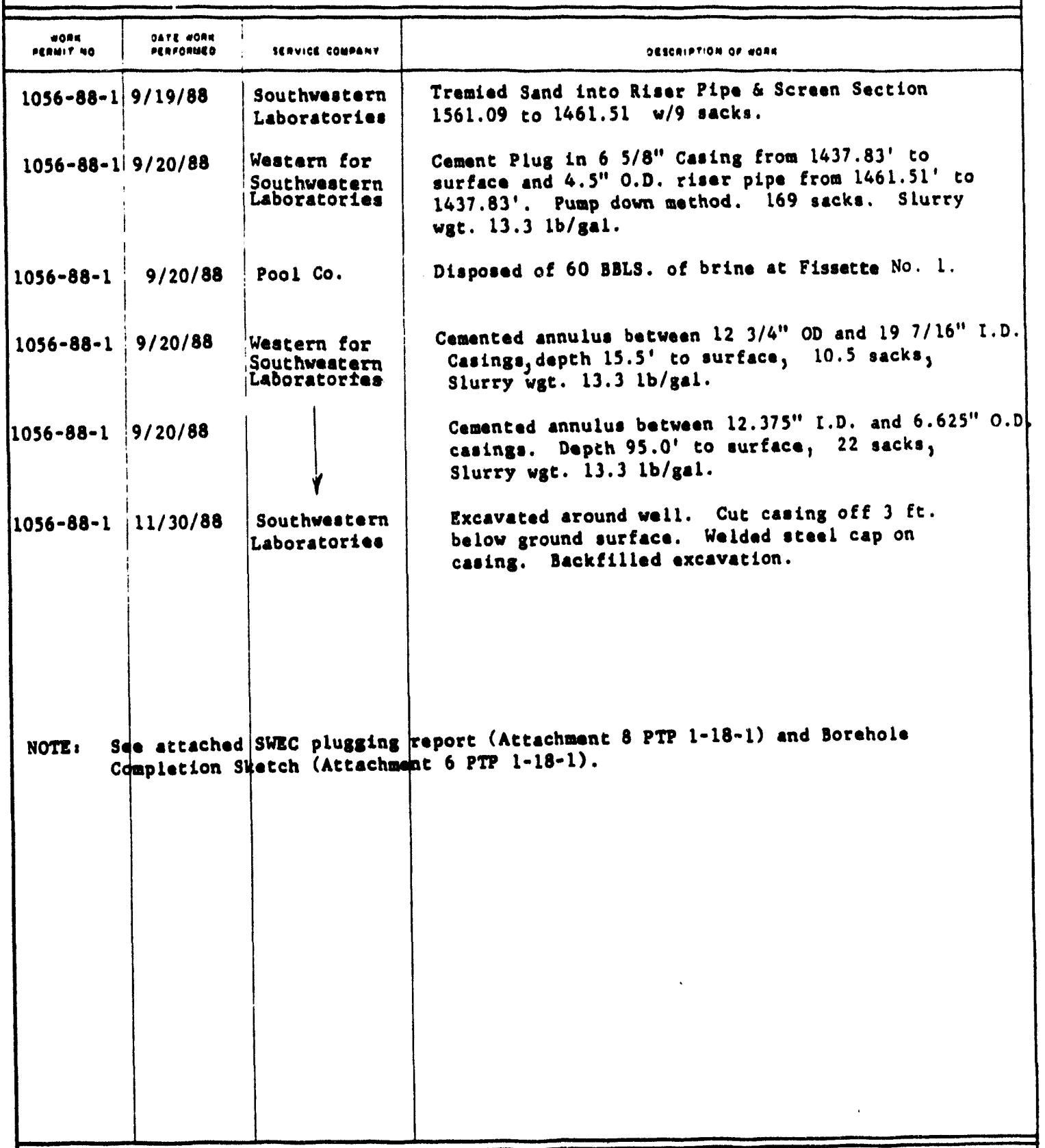

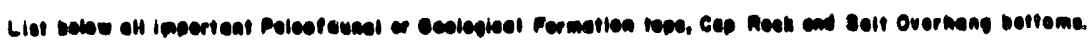

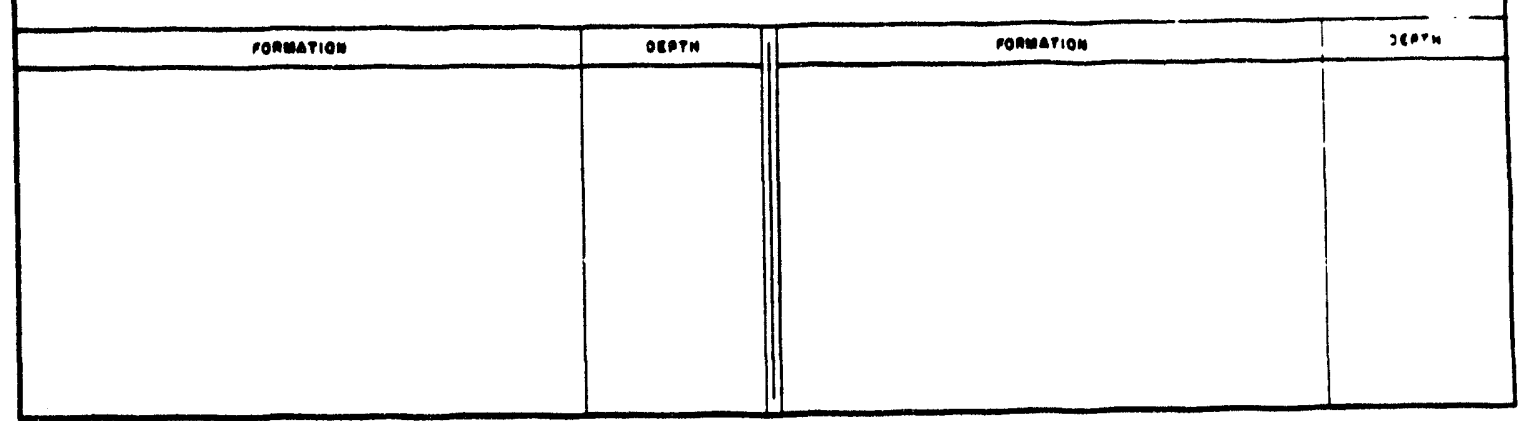




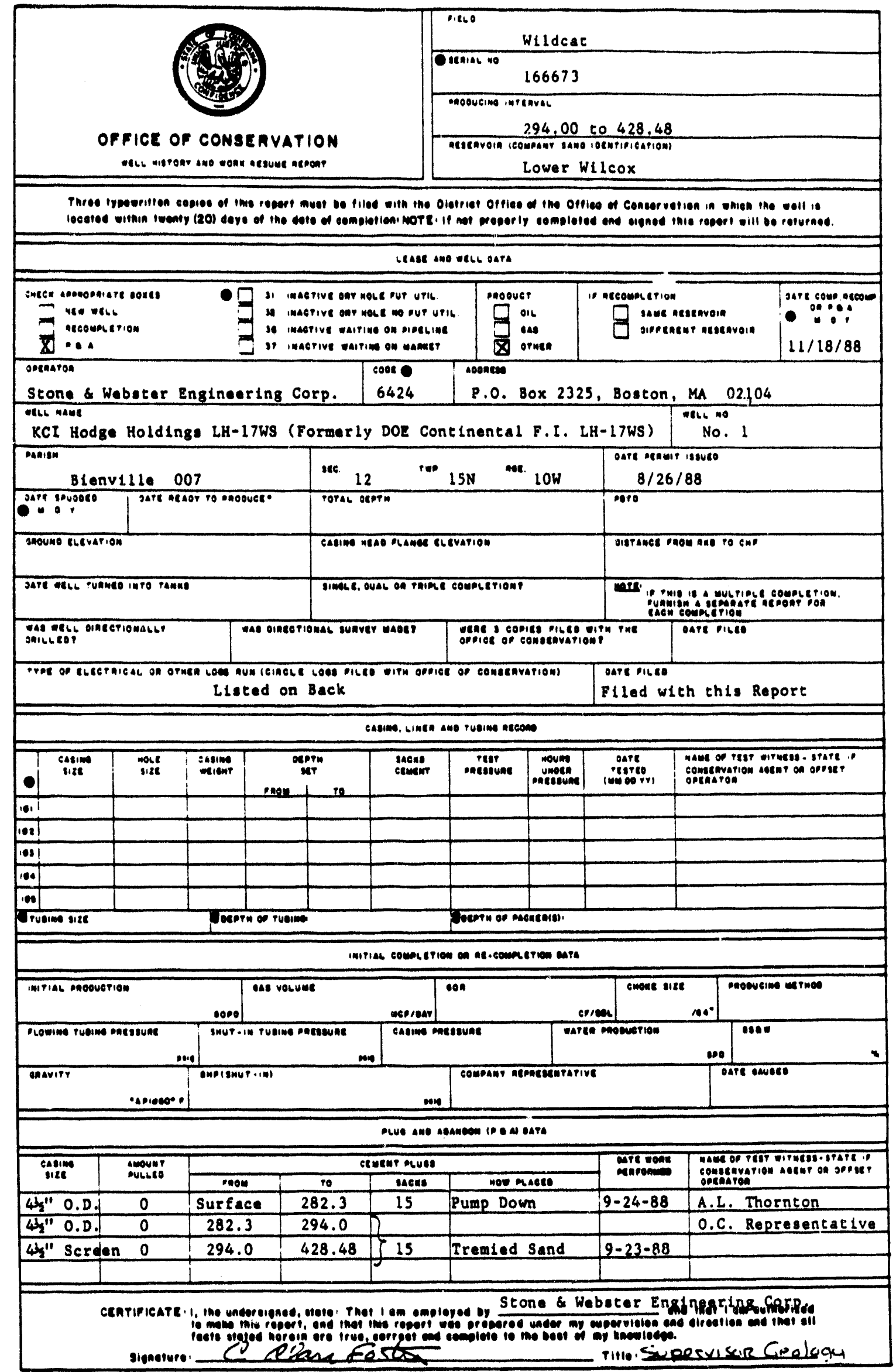

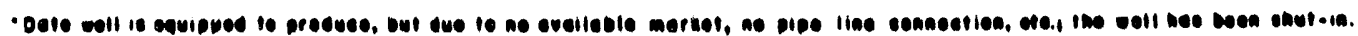


wonk nesume

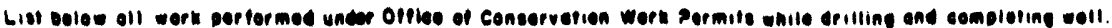

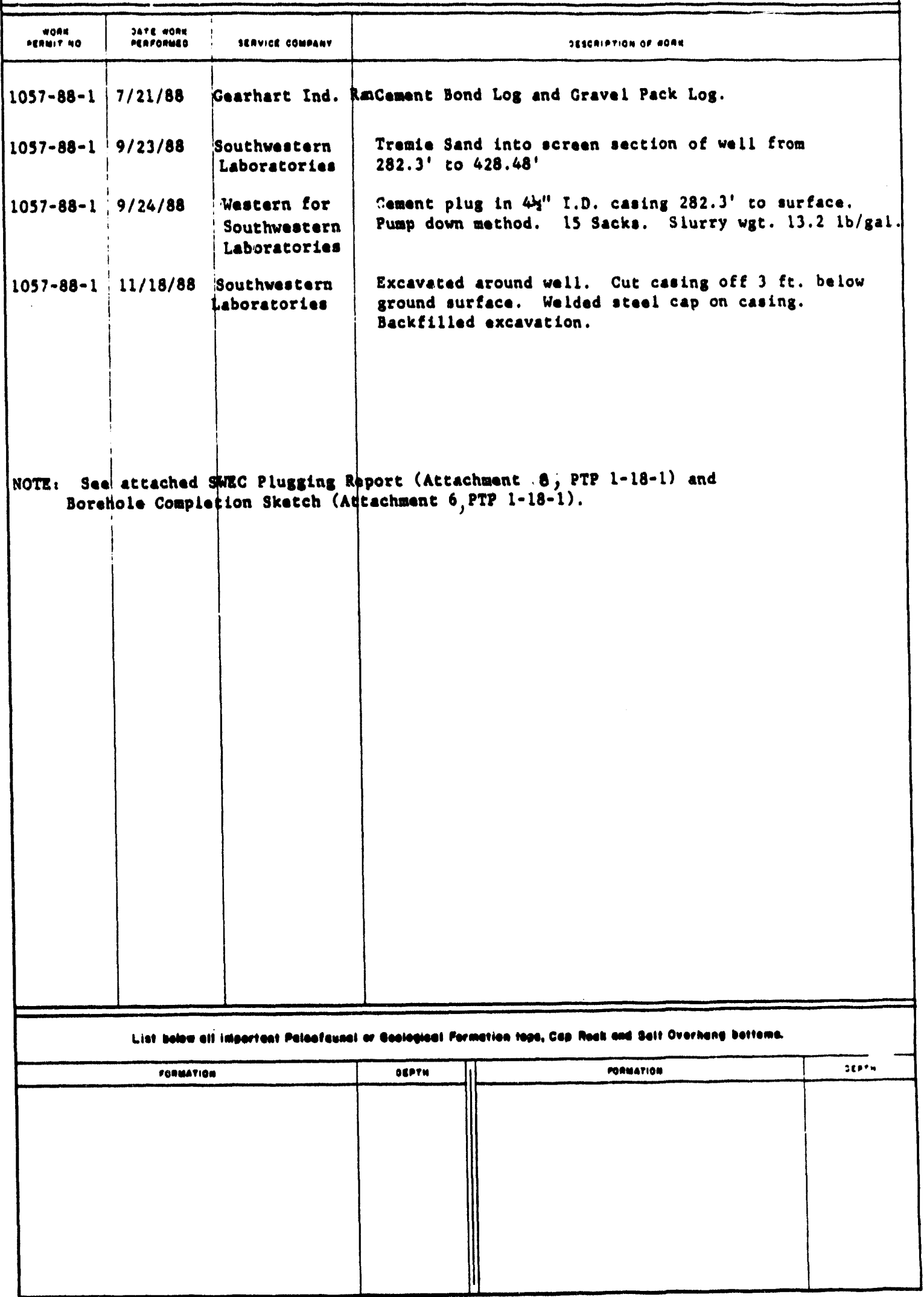




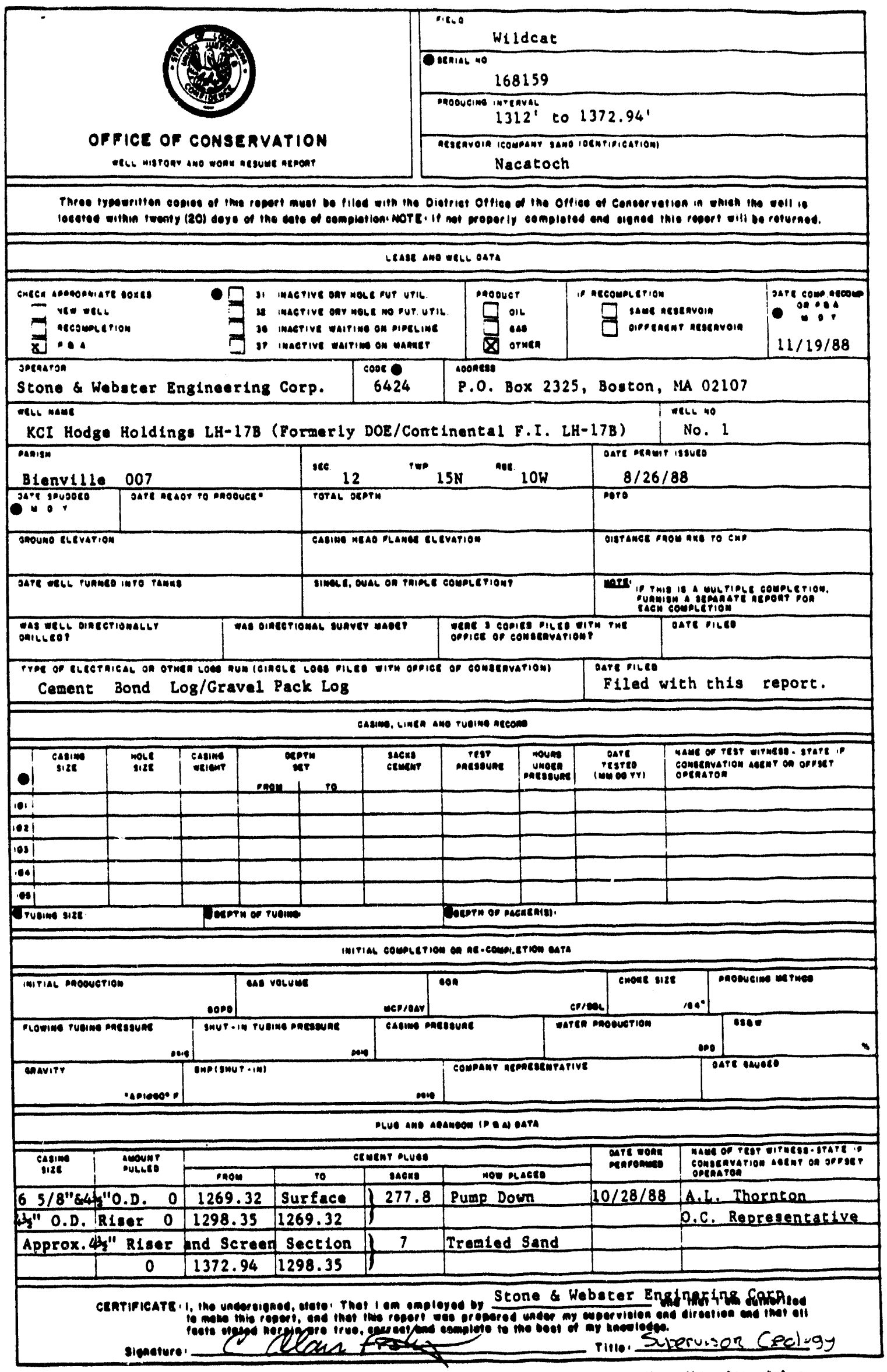

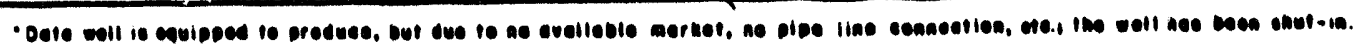


mone nesue

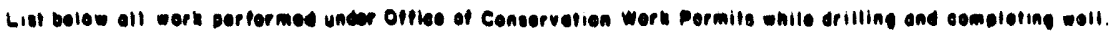

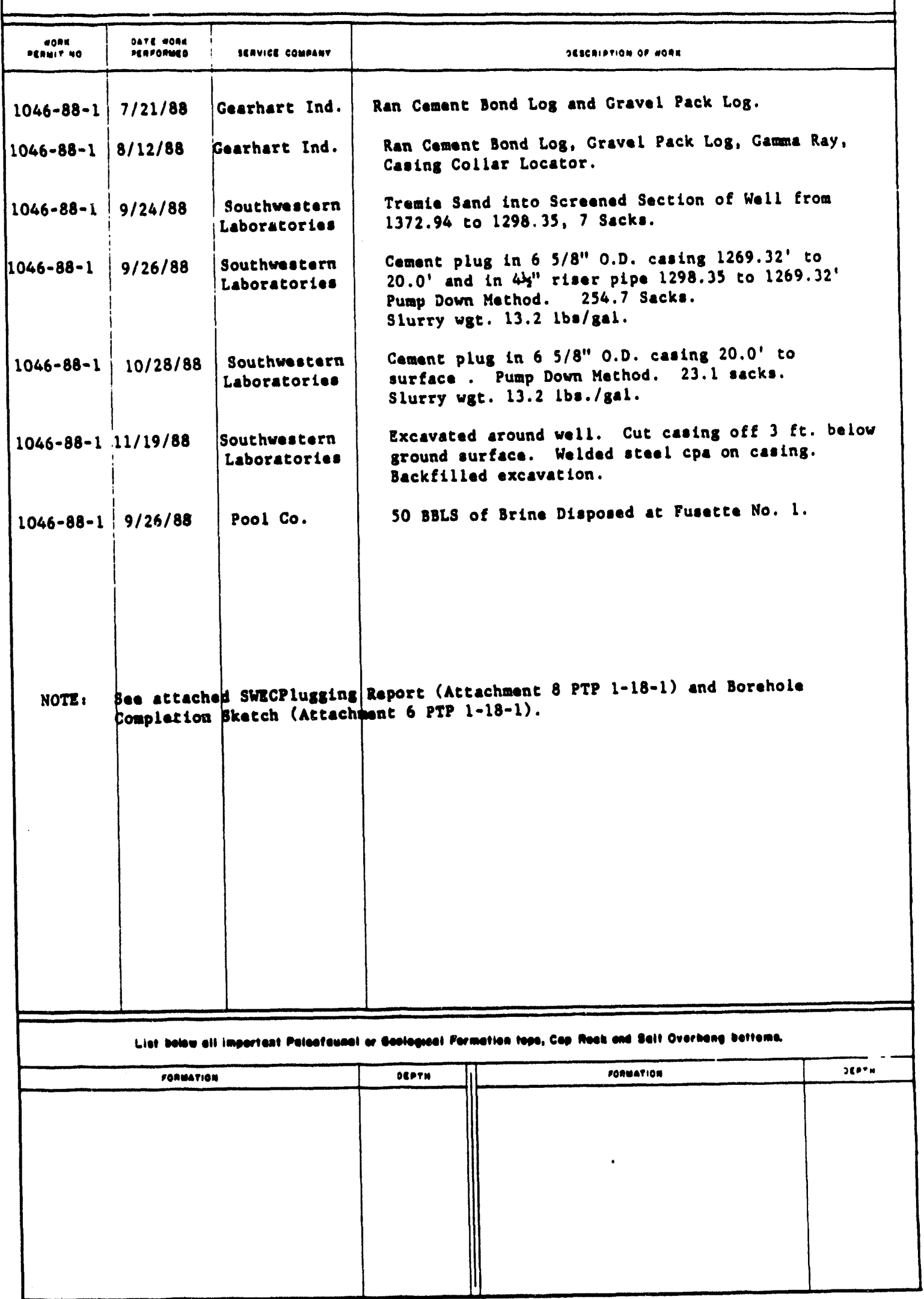




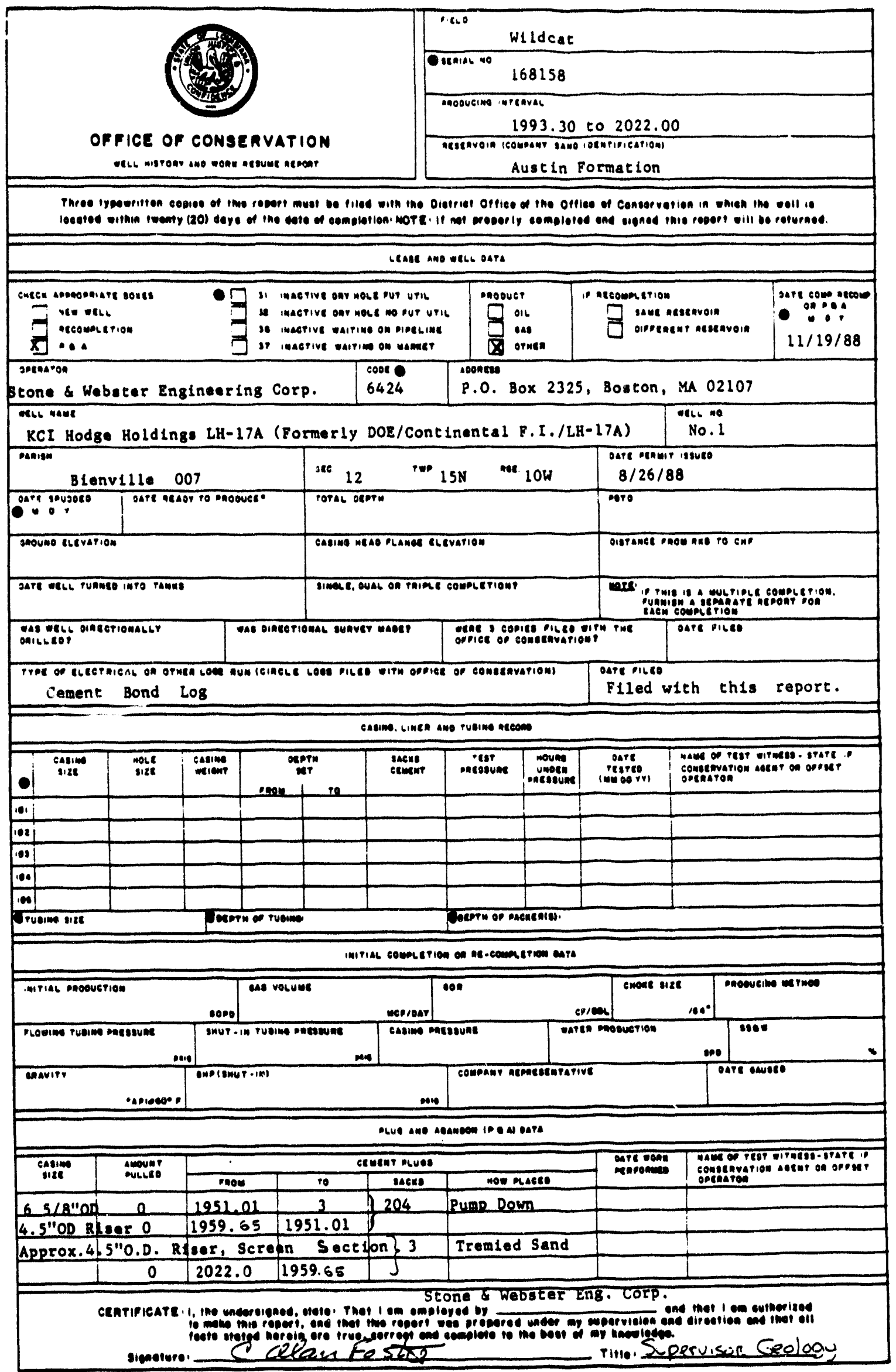

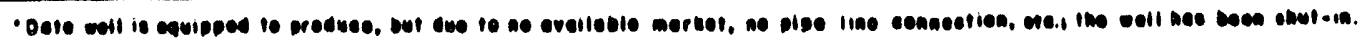


mone nesum

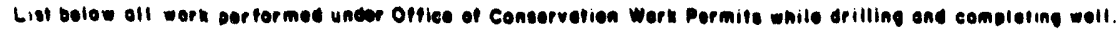

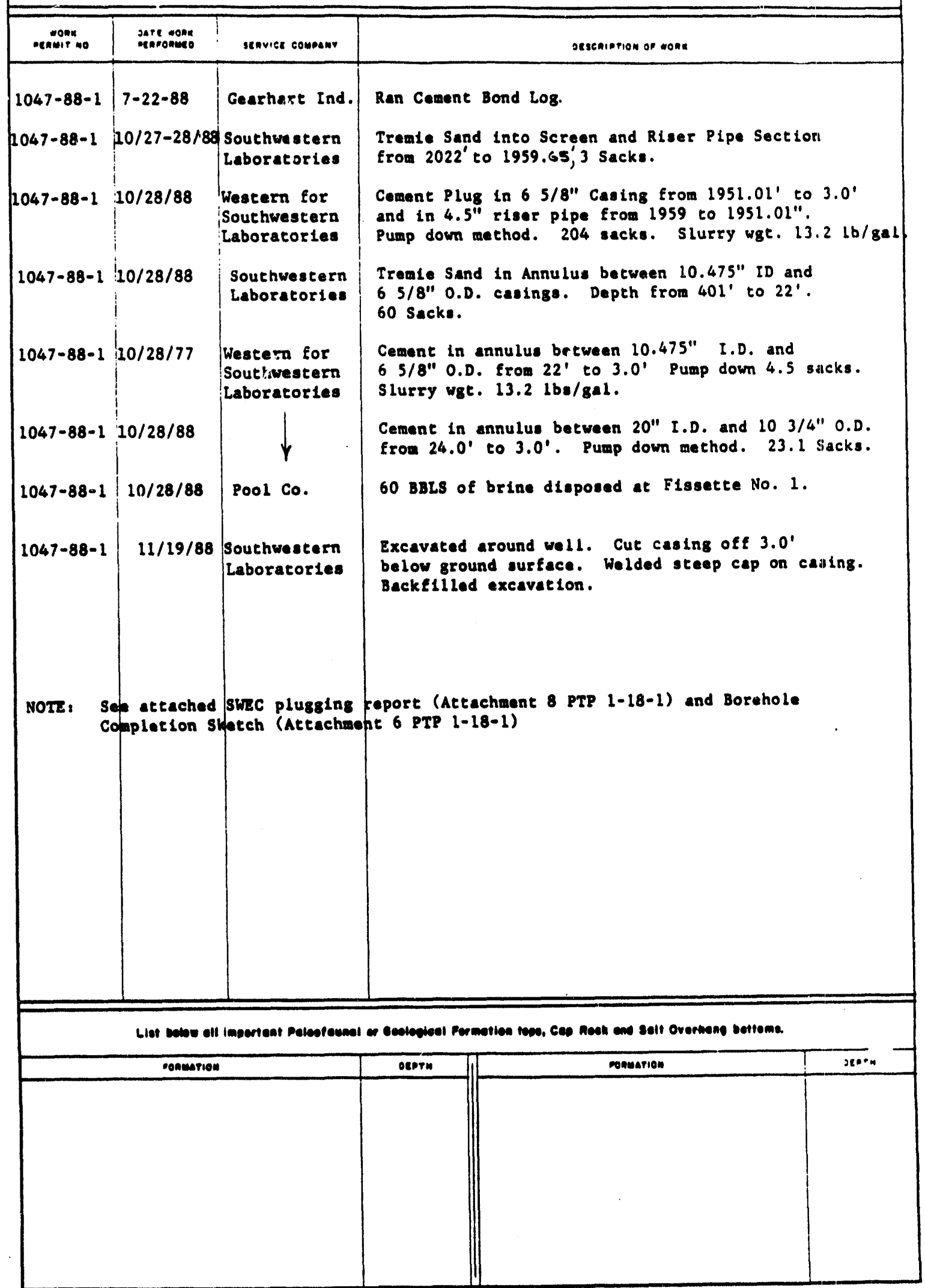




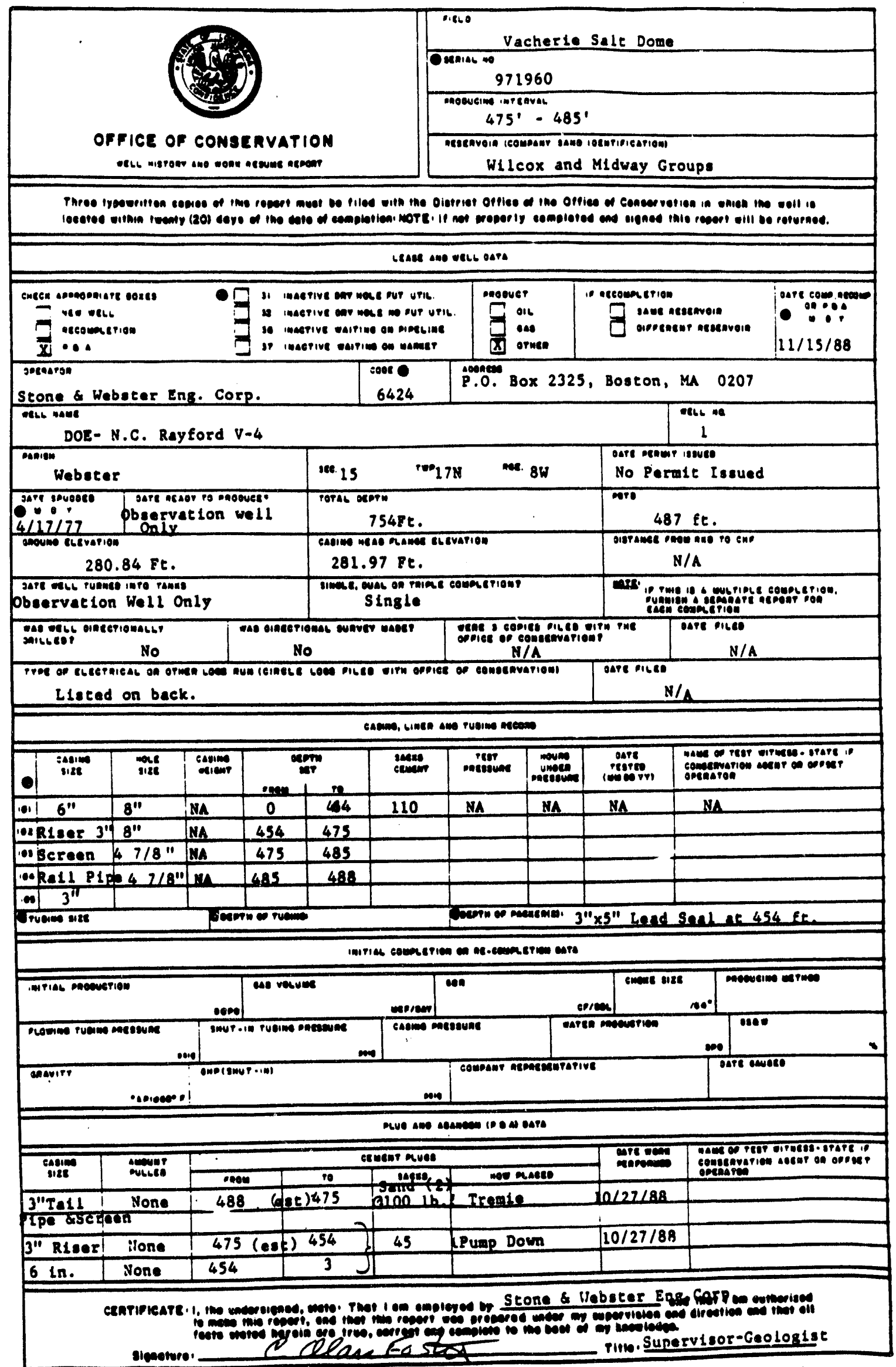

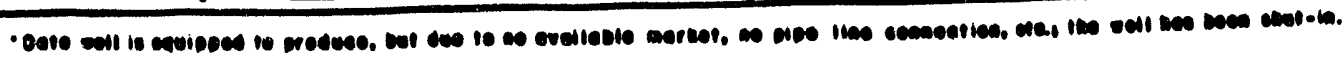


cone nesume

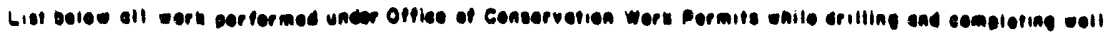

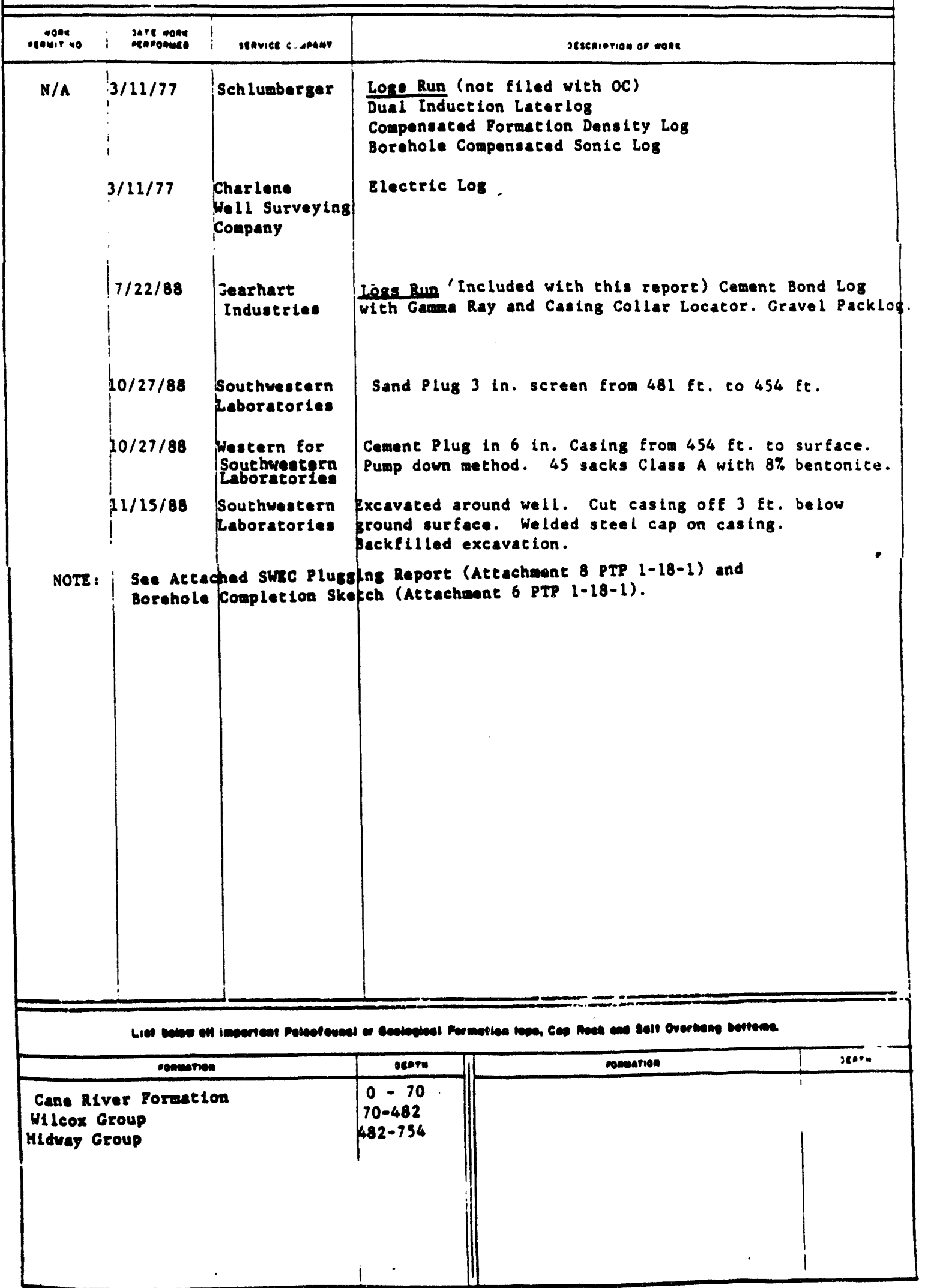




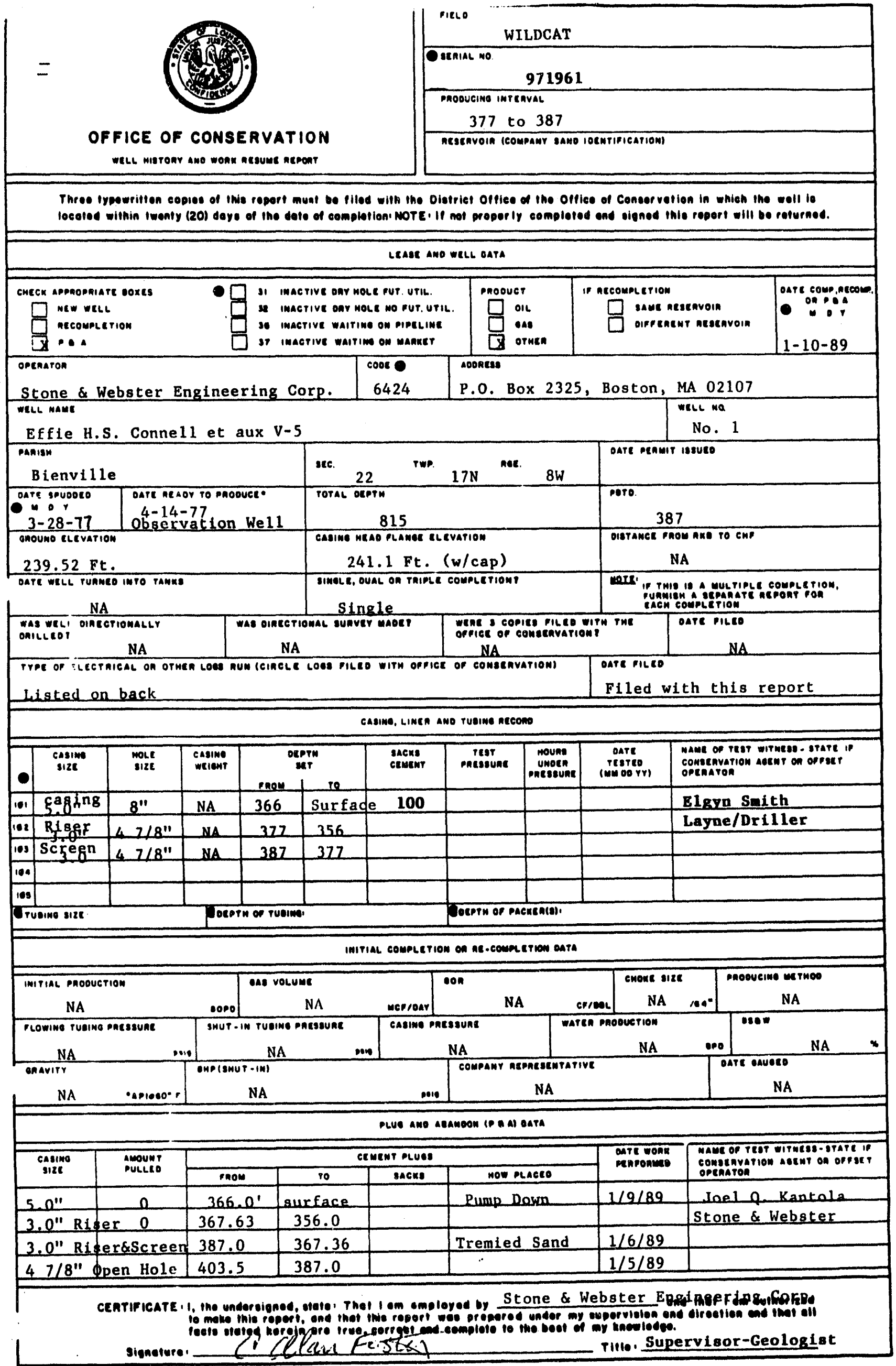

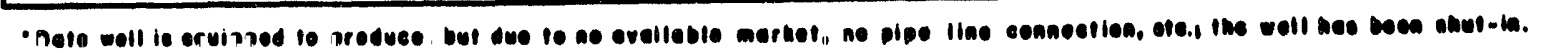


Liel below all work performed under Oflice of Conservation Work Permils while drilling and complefing well.

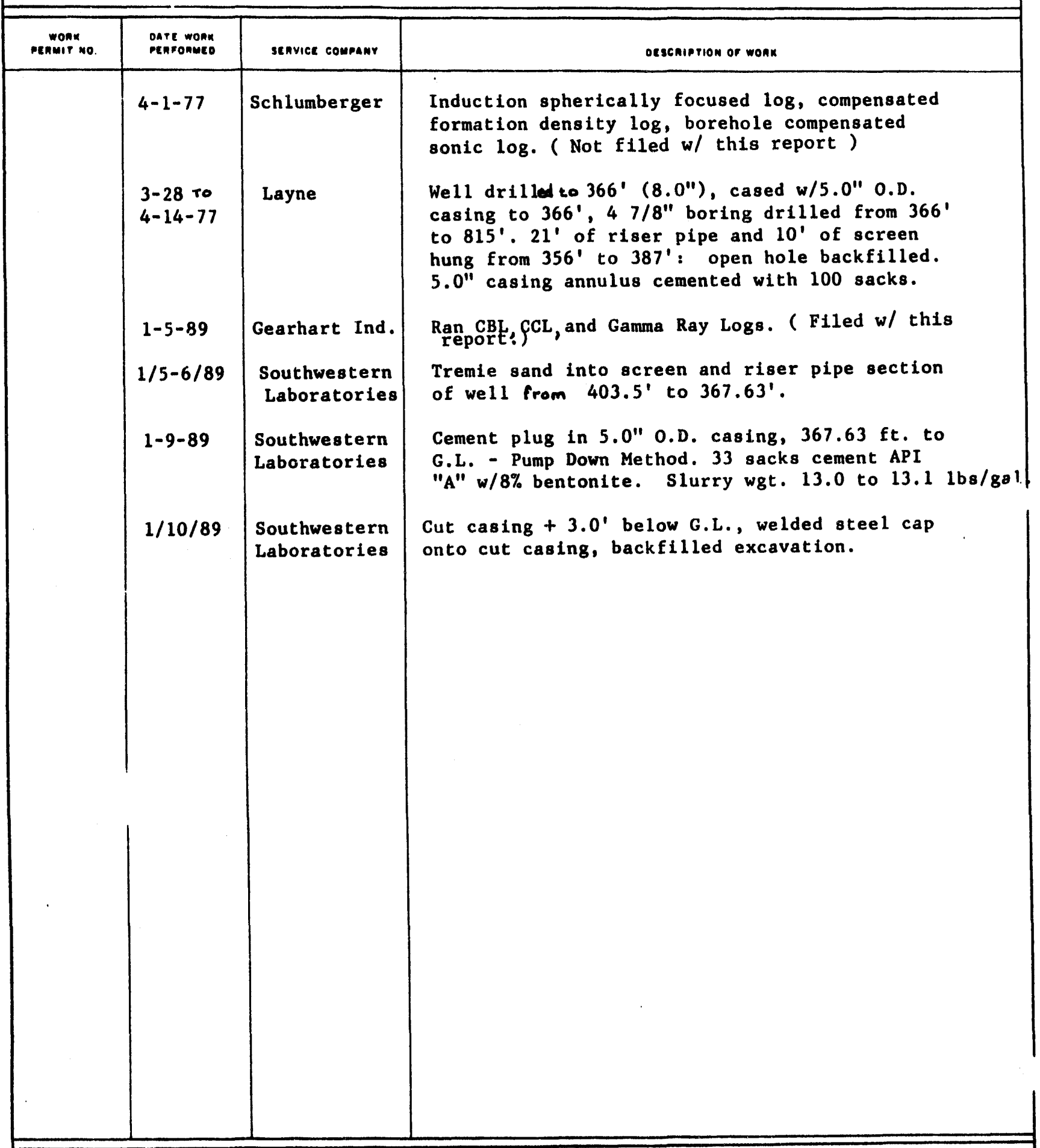

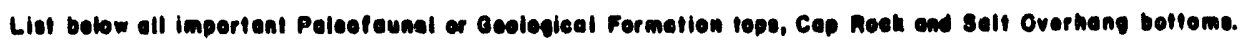

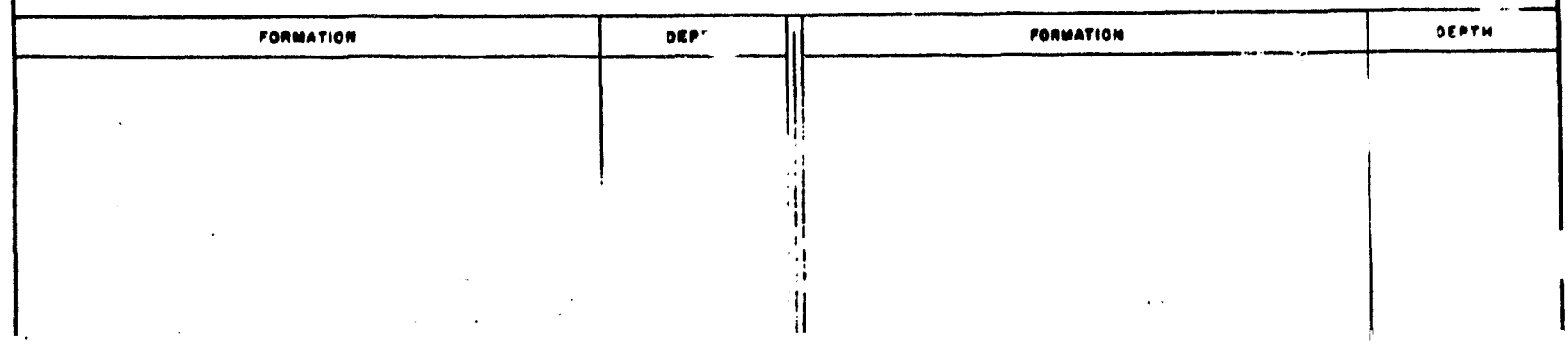




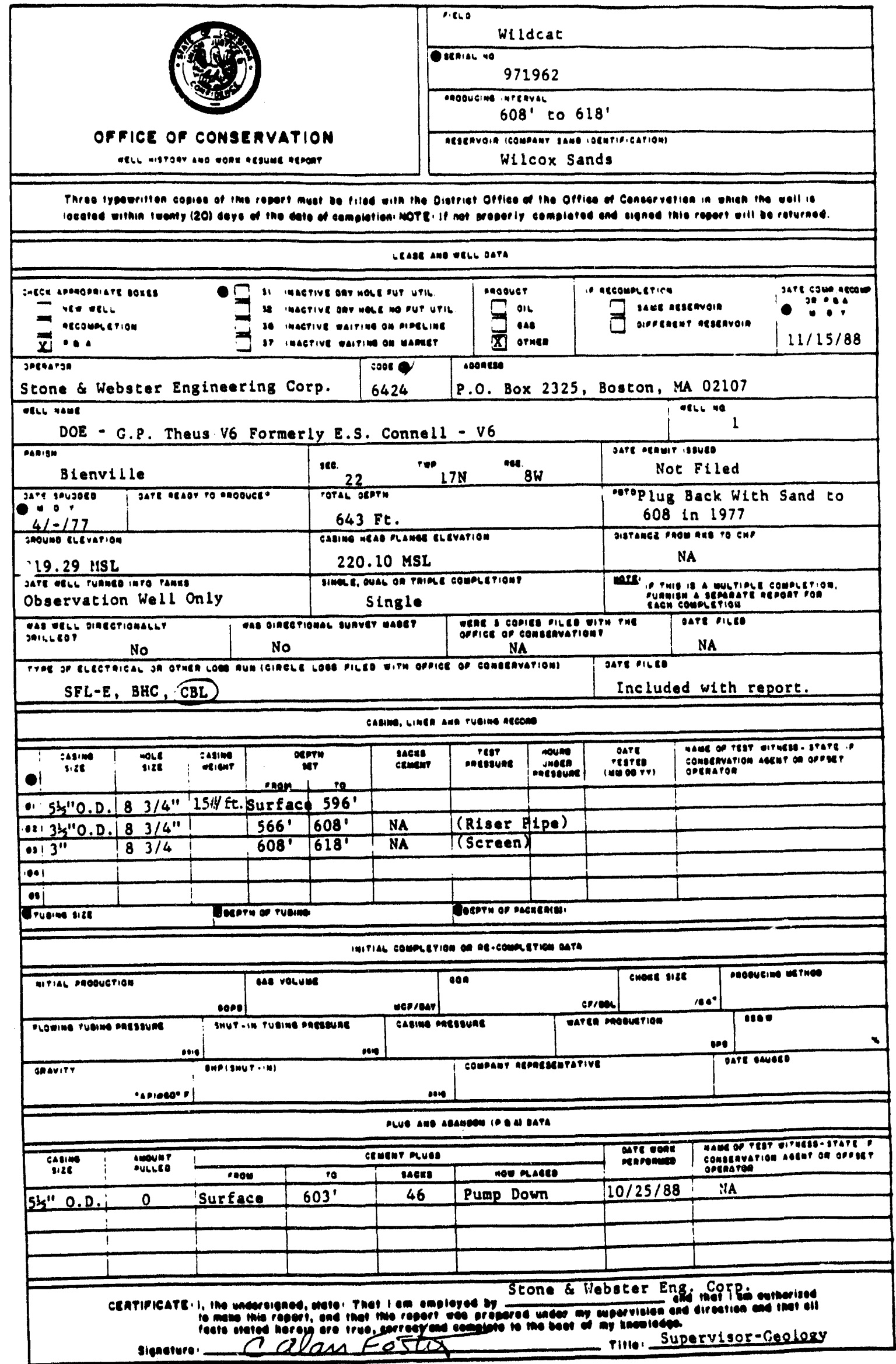

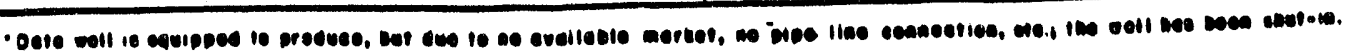


mone nesume

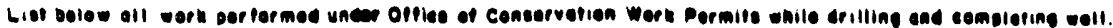

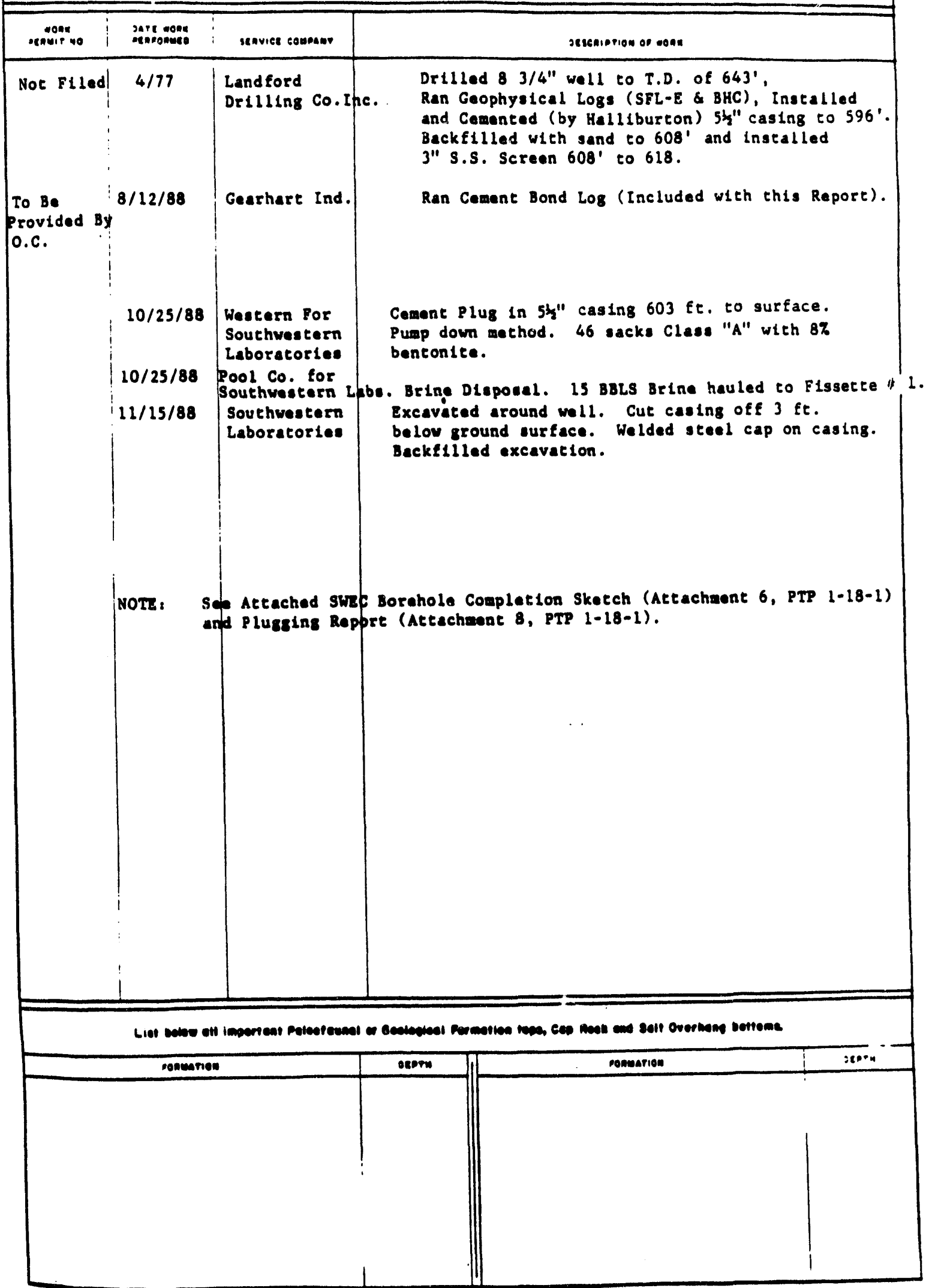




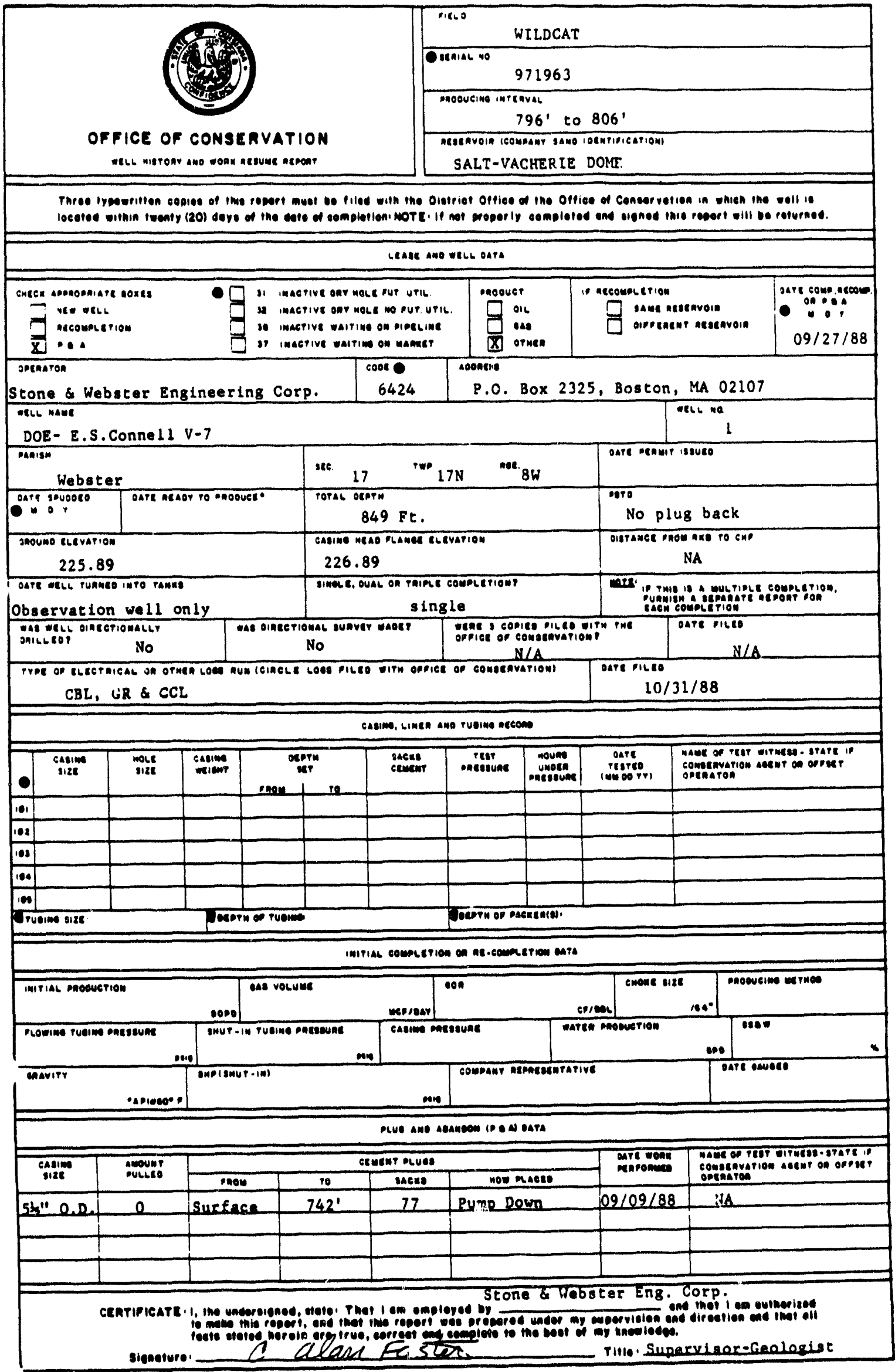

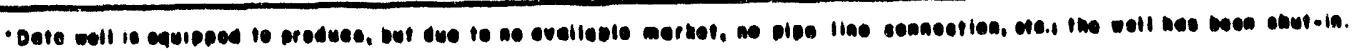




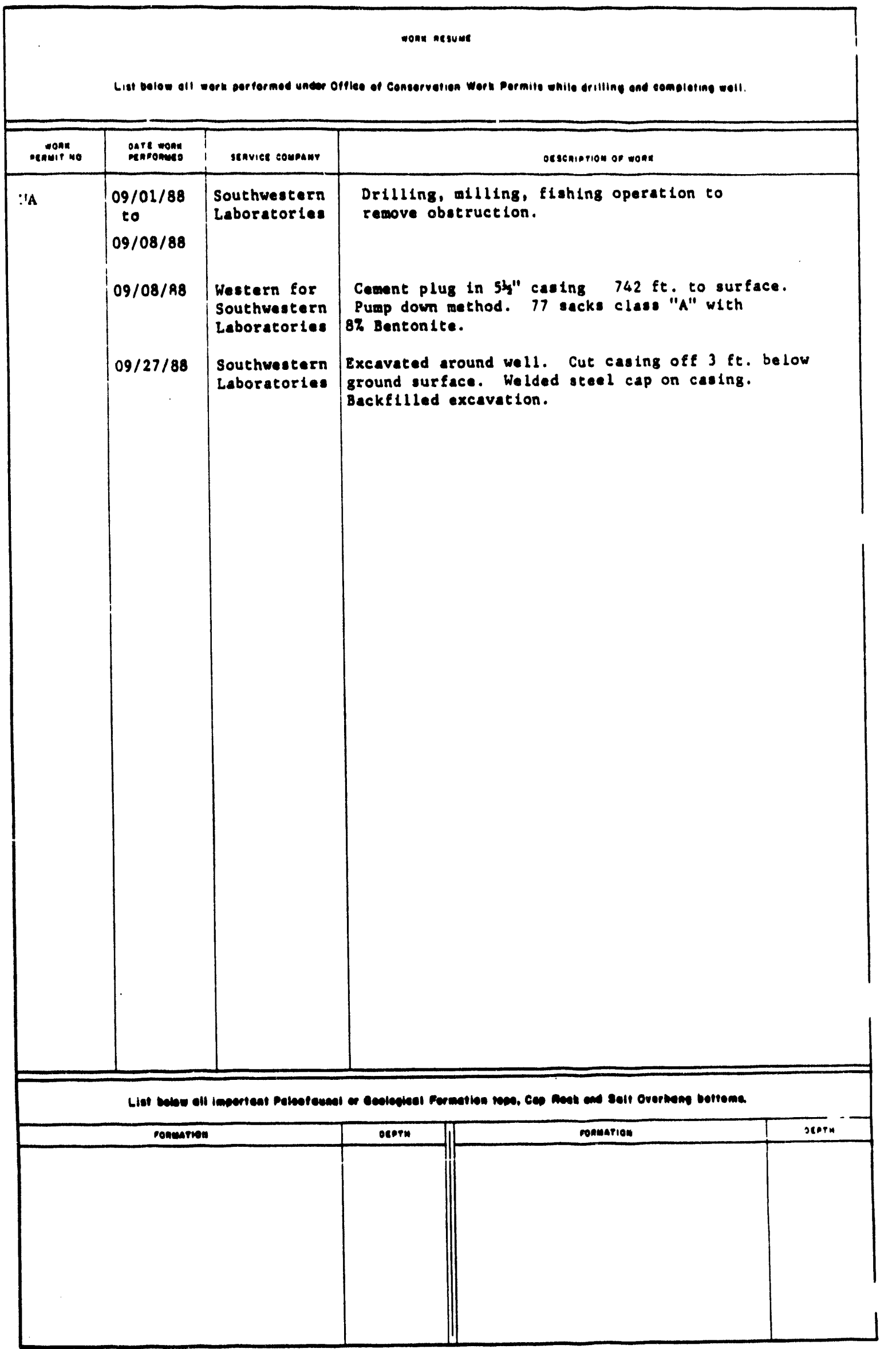




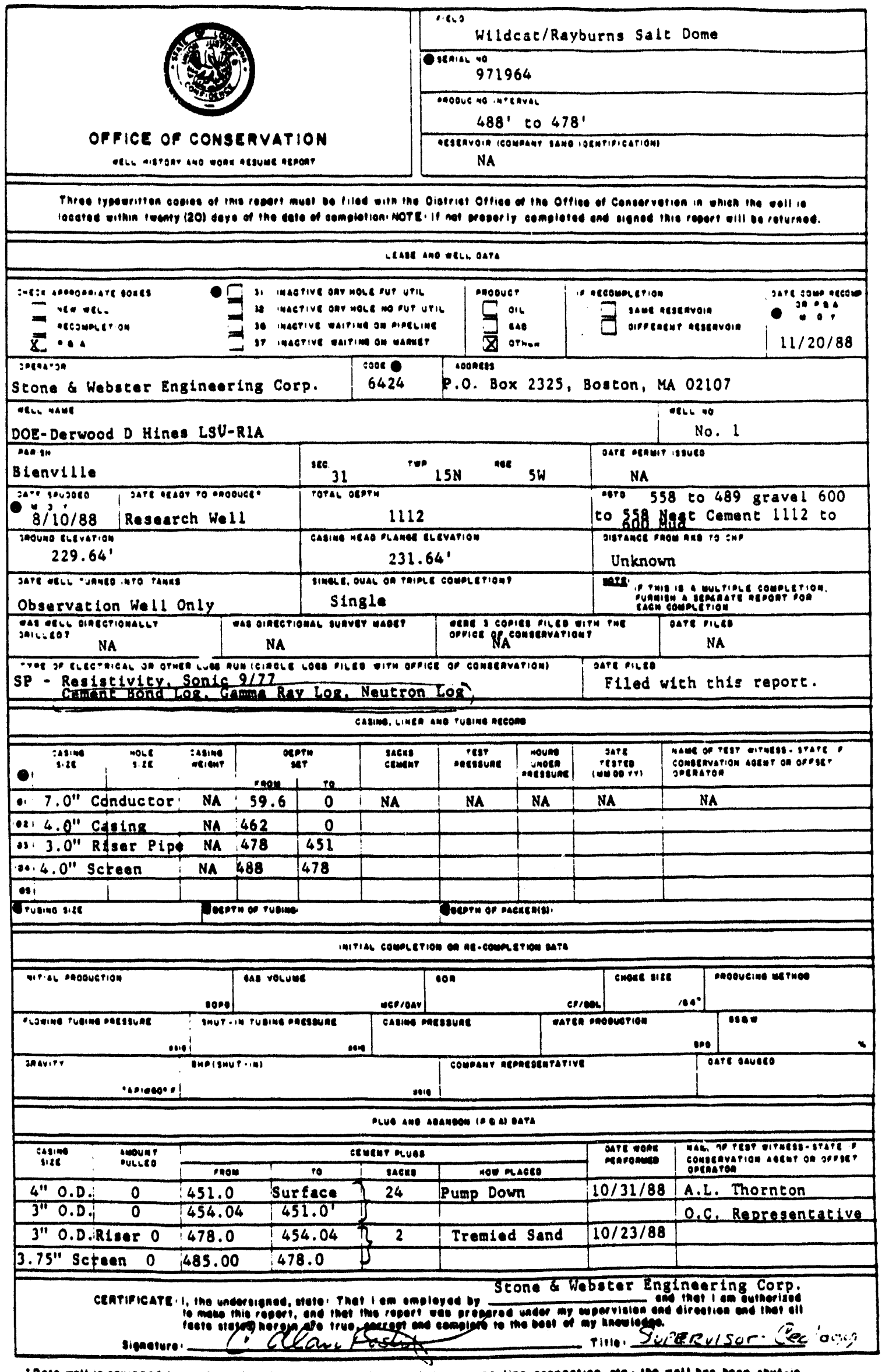

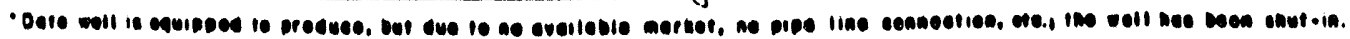


wons nesume

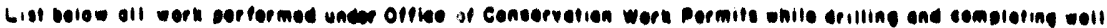

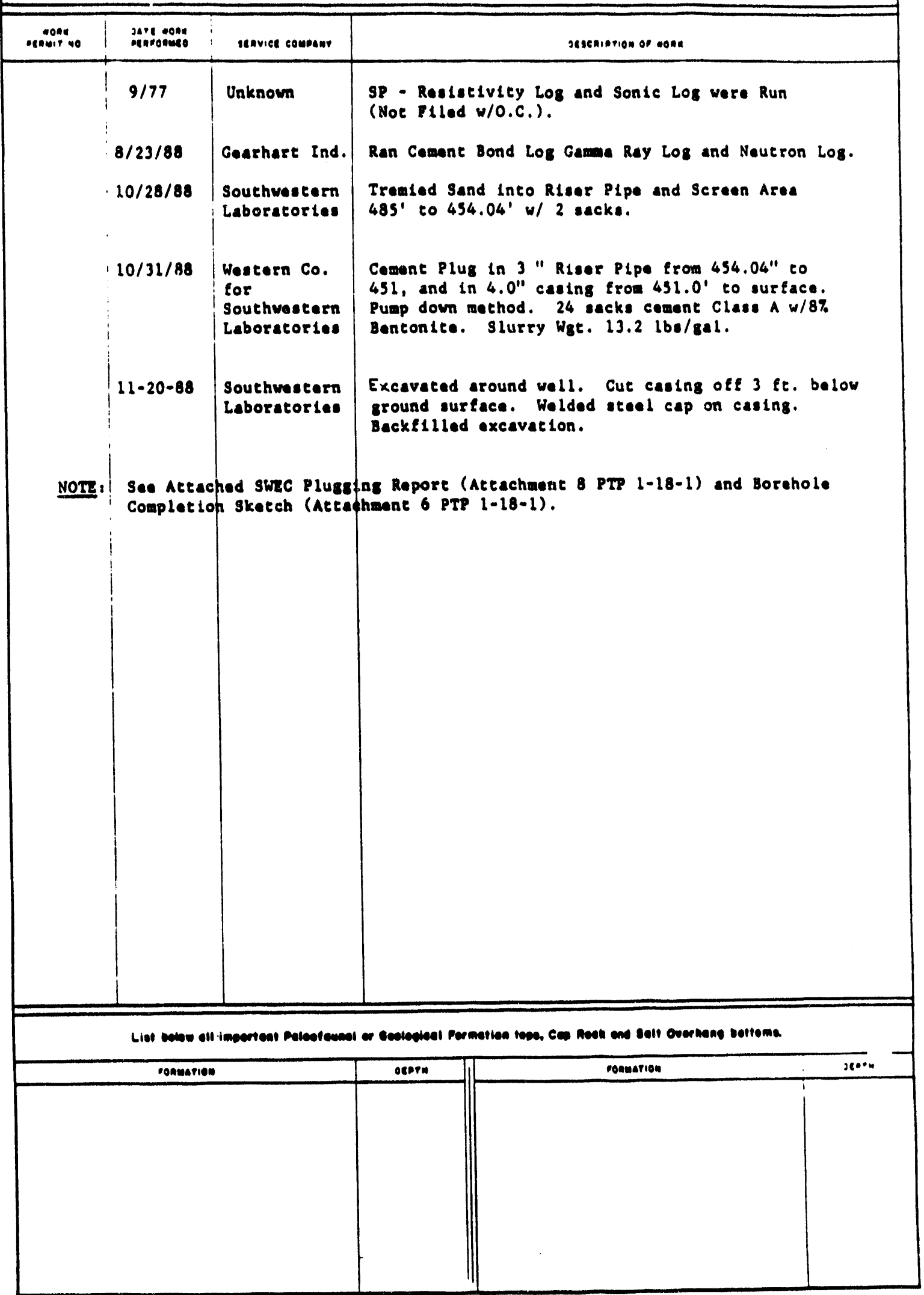




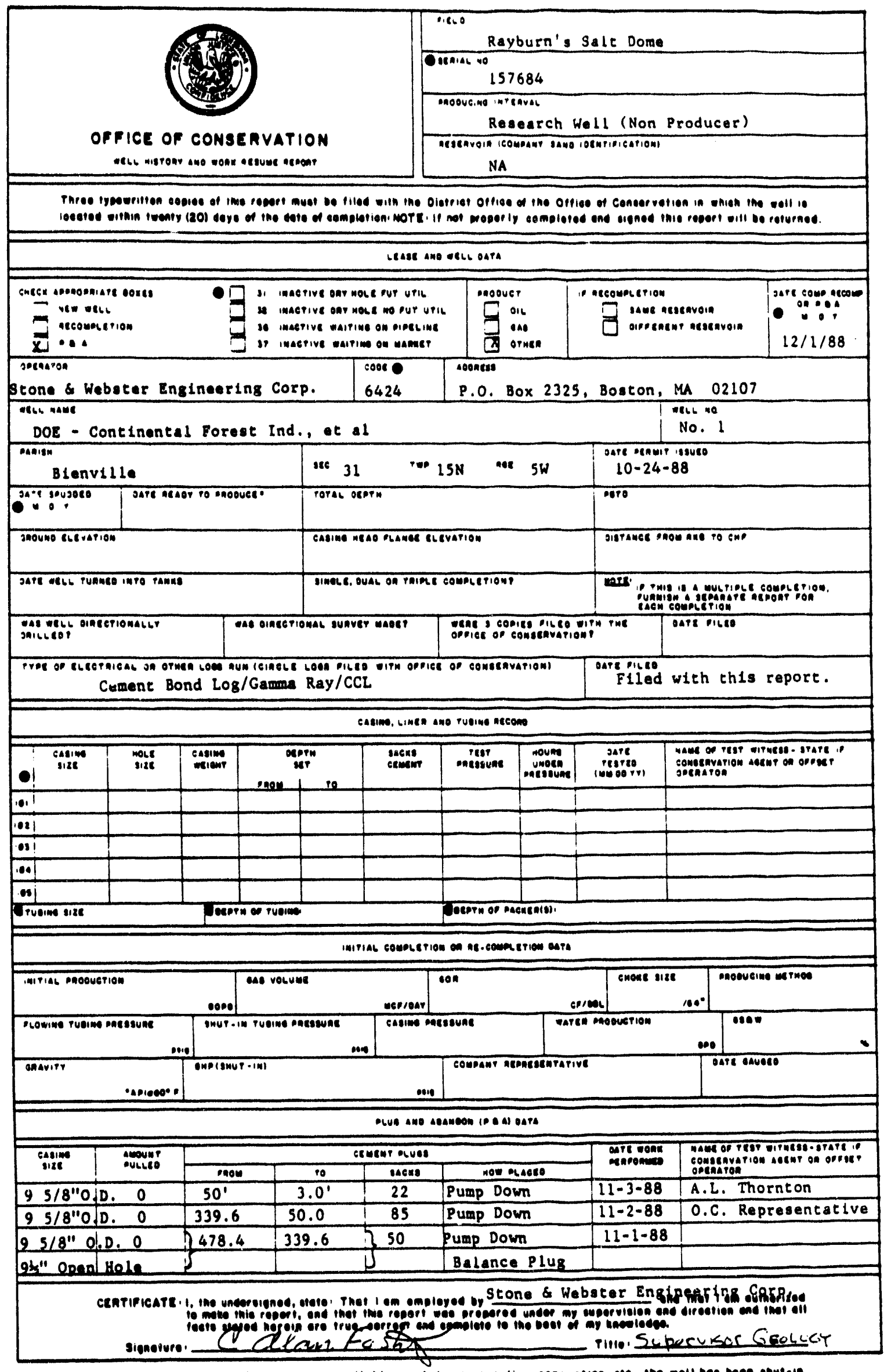

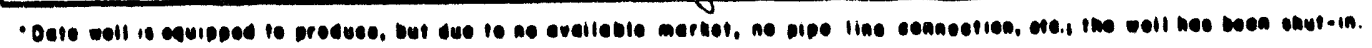


wonn icsume

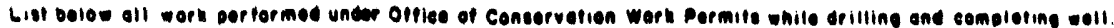

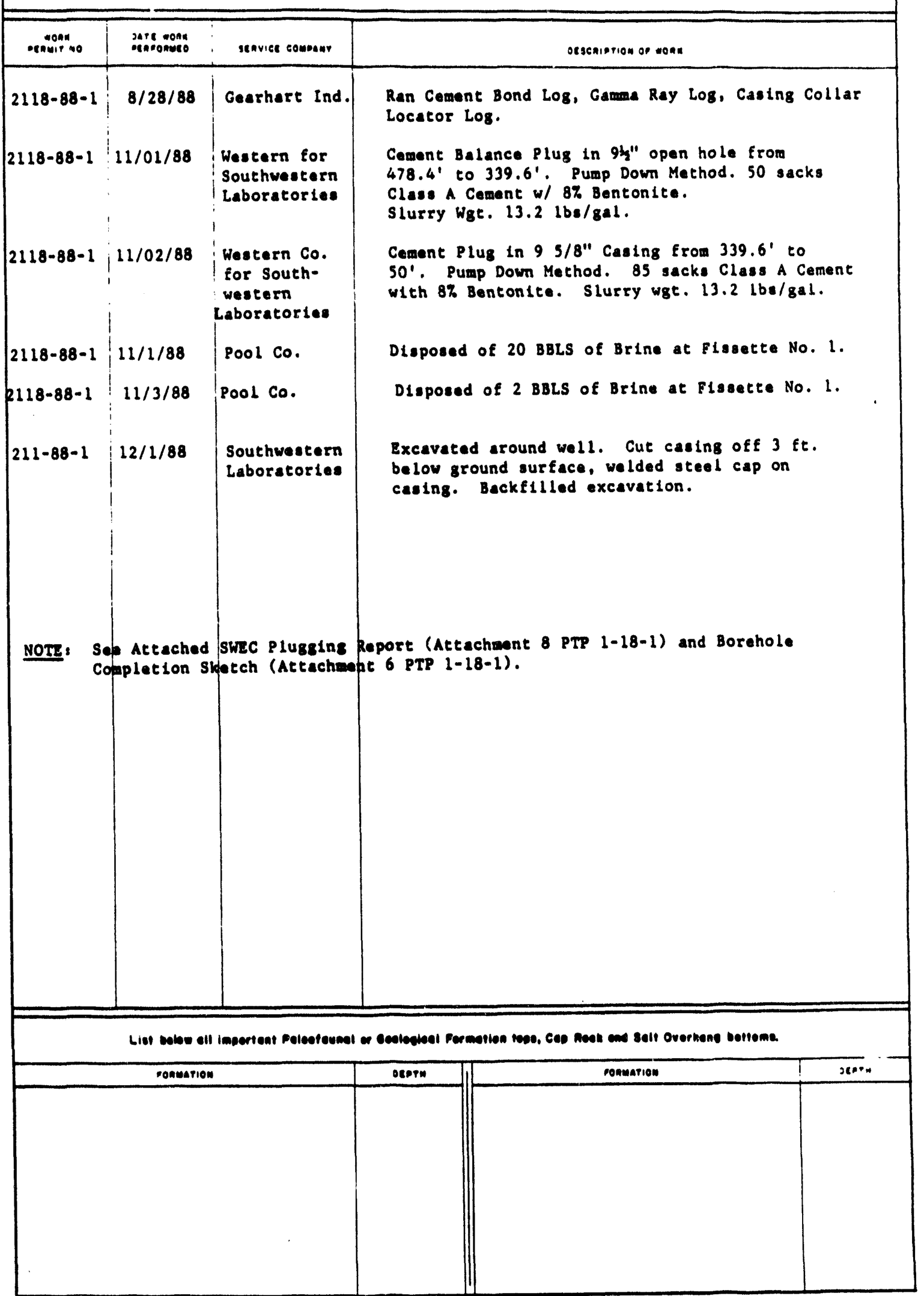




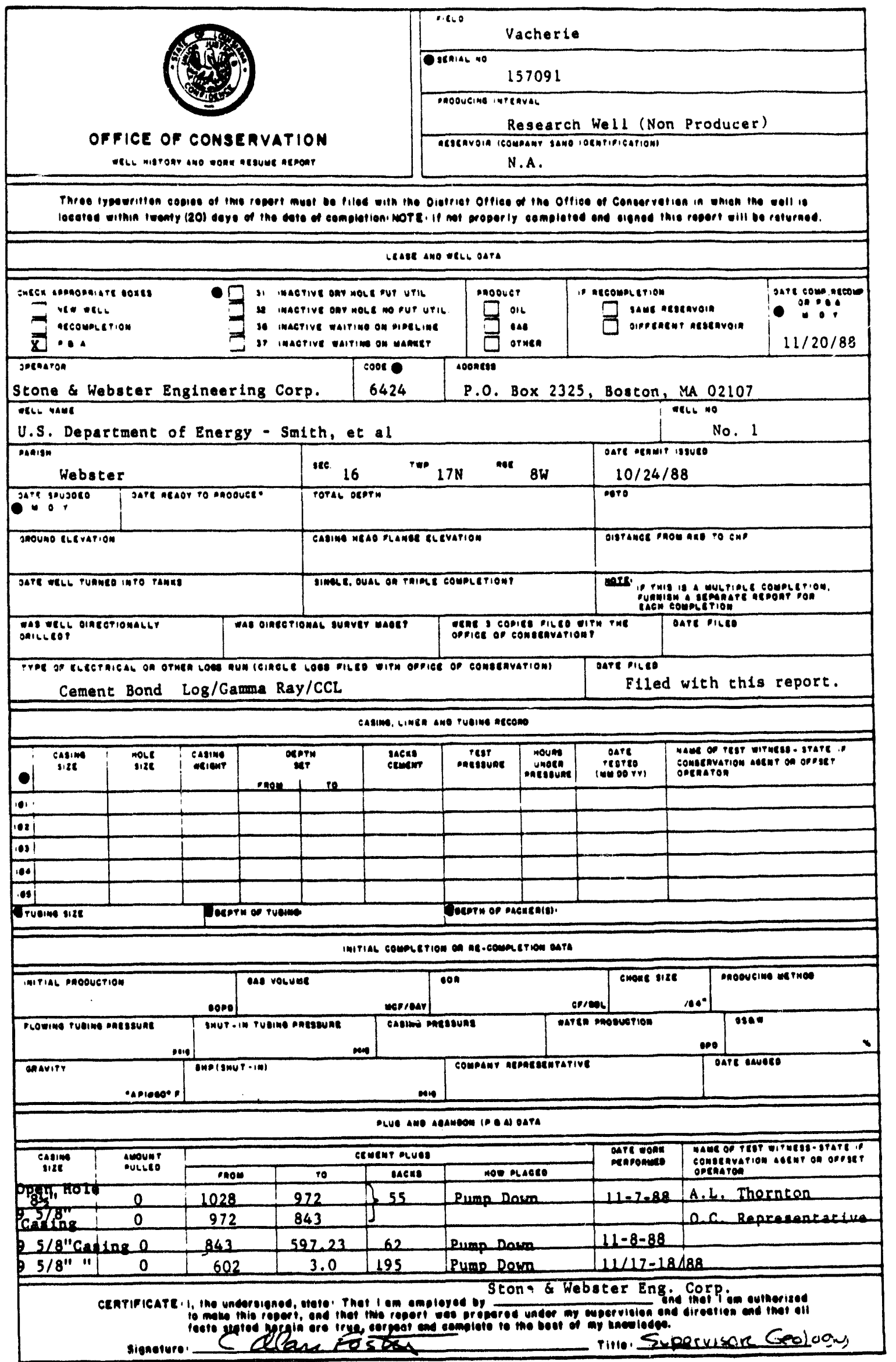

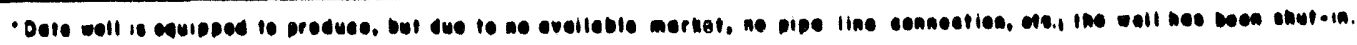


mone nesune

List below oll work performed under Offies of Coneervetion Work Parmits while drilling and completing woll

\begin{tabular}{|c|c|c|c|}
\hline - envir no & $\begin{array}{l}\text { Jare monx } \\
\text { xexponweo }\end{array}$ & service coupany & deseniprion or wona \\
\hline $2117-88-1$ & $9-3-88$ & 'Gearhart Ind. & $\begin{array}{l}\text { Ran Cement Bond LOg, Gamma Ray LOg, and Casing } \\
\text { Coller Locator Log. }\end{array}$ \\
\hline $2117-88-1$ & $11-7-88$ & $\begin{array}{l}\text { Southwestern } \\
\text { Laboratories }\end{array}$ & $\begin{array}{l}\text { Cement Balance Plug In } 8 \frac{1}{2} " \text { Open Hole from 1028.56' } \\
\text { to } 972 \text { and } 9 x_{2}^{\prime \prime} \text { Casing from } 972 \text { to } 843.28^{\prime} \text {. } \\
55 \text { Secks. Pump Down Method. Slurty Wgt. } 13.2 \text { lbs/gal. }\end{array}$ \\
\hline $\begin{array}{l}2117-88-1 \\
2117-88-1\end{array}$ & $\begin{array}{l}11-7-88 \\
11-8-88\end{array}$ & $\begin{array}{l}\text { Pool co. } \\
\text { Pool Co. }\end{array}$ & $\begin{array}{l}\text { Disposed } 25 \text { BBLS of Brine at Fissette } 1 \text {. } \\
\text { Disposed } 100 \text { BBLS of Brine at Fissette } 1 \text {. }\end{array}$ \\
\hline $2117-88-1$ & $11-8-88$ & $\begin{array}{l}\text { Southwestern } \\
\text { Laboratortes }\end{array}$ & $\begin{array}{l}\text { Cement in } 95 / 8^{\prime \prime} \text { casing from } 843.28 \text { ' to } 597.23^{\prime} \text {. } \\
\text { Pump Down Method. w/62 Sacks, Slurry wgt. } \\
13.2 \text { lbs/gal. }\end{array}$ \\
\hline $2117-88-1$ & $11-9-88$ & Gearhart Ind. & 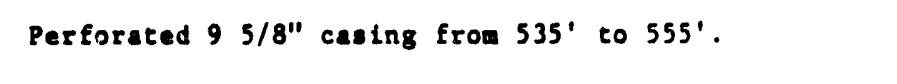 \\
\hline $2117-88-1$ & $11-10-88$ & Western & "Bullhead" squeeze w/75 scks of cement ("H" Neat). \\
\hline $2117-88-1$ & $11-11-88$ & Gearhart Ind. & $\begin{array}{l}\text { Ran Cement Bond Log, Gamma Ray LOg and Casing } \\
\text { Collar Locator Log. }\end{array}$ \\
\hline $2117-88-1$ & $11-14-88$ & & Performated 9 5/8" Casing frow 485' - 465'. \\
\hline $2117-88-1$ & $11-16-88$ & Western Co. & $\begin{array}{l}\text { "Bullhead" squeeze w/75 sacke of Class H Neat } \\
\text { Cement. }\end{array}$ \\
\hline $2117-88-1$ & $11-16-88$ & Gearhart Ind. & $\begin{array}{l}\text { Ran Cemant Bond Log Gamma Ray Log, and Casing } \\
\text { Collar Locator Log. } 595 \text { to surface. }\end{array}$ \\
\hline $2117-88-1$ & $11-17-88$ & $\begin{array}{l}\text { Western Co. } \\
\text { for } \\
\text { Southwestern } \\
\text { Laboratories }\end{array}$ & $\begin{array}{l}\text { Coment Plug in } 95 / 8^{\prime \prime} \text { Casing frow } 672 \text { ' to } 168.9^{\prime} \text {. } \\
\text { Pump Down Method. } 150 \text { sacks Class A Cement } \\
\text { with } 8 \% \text { Bentonite, Slurry wgt. } 13.2 \mathrm{lb} / \mathrm{gal} \text {. }\end{array}$ \\
\hline $2117-88-1$ & $11-18-88$ & $\begin{array}{l}\text { Western Co. } \\
\text { for } \\
\text { Southwetern } \\
\text { Laboratories }\end{array}$ & $\begin{array}{l}\text { Cement Plug in S 5ig" Casing frow } 168.9^{\prime} \text { to } \\
3.0^{\prime} \text {. Pump Down Method. } 45 \text { Secks Clase A } \\
\text { Cement w/87 Benton 1te, Slurry wgt. } 13.2 \text { bo/gal. }\end{array}$ \\
\hline $2117-88-1$ & $11-20-88$ & Southwestern & $\begin{array}{l}\text { Excaveted around well. Cut caning off } 3.0^{\prime} \\
\text { below ground surface. Welaed steel tap on } \\
\text { casing. Backfilled excevation. }\end{array}$ \\
\hline NoT: & $\begin{array}{l}\text { Attached } \\
\text { pletion St }\end{array}$ & $\begin{array}{l}\text { SweC Plugging } \\
\text { Hethe ( Attach }\end{array}$ & $\begin{array}{l}\text { Report (Attachment } 8 \text { PTP } 1-18-1 \text { ) and Borehole } \\
\text { pet } 6 \text { PTP } 1-18-1 \text { ) }\end{array}$ \\
\hline
\end{tabular}

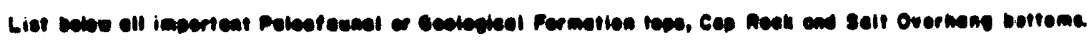

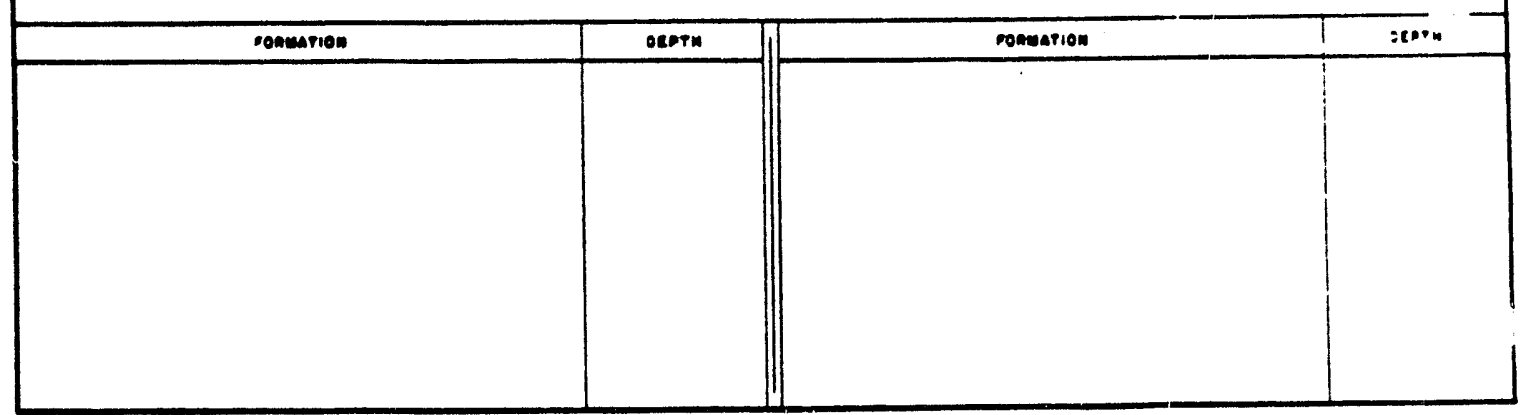


(Please Check One)

SVILZAGE OIL

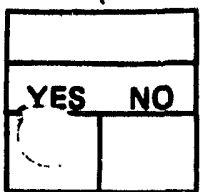

PART IS CODES

6424

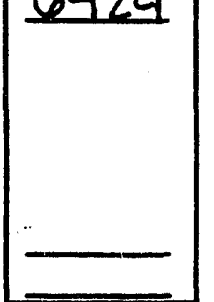

NONHAZARDOUS OILF

\section{STATE OF LOUIBIANA OPFICE OF COMBEAVATION}

P. O. DOX 44278

BATON ROUOE, LA TOEDA42TS
Manifest No.

PS!2. L-2E.

104639

GENERATOR'S COPY

$\leftrightarrow$ If Yes indicate the number of barrels in the "50-Salvage Oil" below. Fit_ PRISECT

T.0. 140,17500

TIFCSRPO

\section{TO BE COMPLETED BY GENERATOB}

POC.A.

$\leftrightarrow$ Generator StonesWezster Enefnefirenc Copr ATt. R.t. Deconto

P.O $* 0036$

Address P.O. Box 2325

$(617)-589-7058$

City/State Boston, MA O2107

Telephone No.

\section{ORIGINATION OF WASTE}

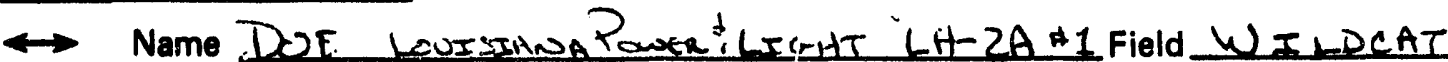

$\leftrightarrow$ Type $11=$ Lese; 2 = Unit; 3= Well; or 5" Other LEASE WASTE IDENTIFICATION AND AMOUNT IIFI 42 GALLON BARRELS)

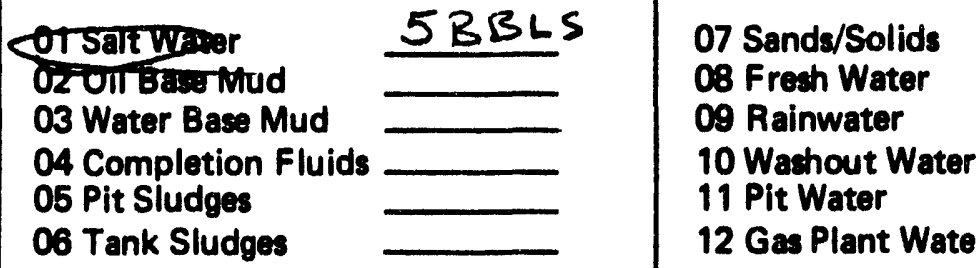

13 Salvage BS \& W

14 Pipeline Test Water

15 Facility Water

16 Cleanup Water

50 Salvage Oil

99 Other

\section{DESTINATION OF WASTE}

$\therefore$

$\leftrightarrow$ Commercial Facility Name

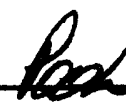

$562 D$

Site Address Pon Gez

City/State Cu/tera

CERTIFICATION: The waste described boove wes condigned to the carrier nemed below. I cartify that the foresoing is true and correct to the best of my knowlodes.

Sign it re of Gonerator's Authorized Anav

PART II: TO BE COMPLETED BY TRANEPORTER IN PRFSENCE OF GENERATOR

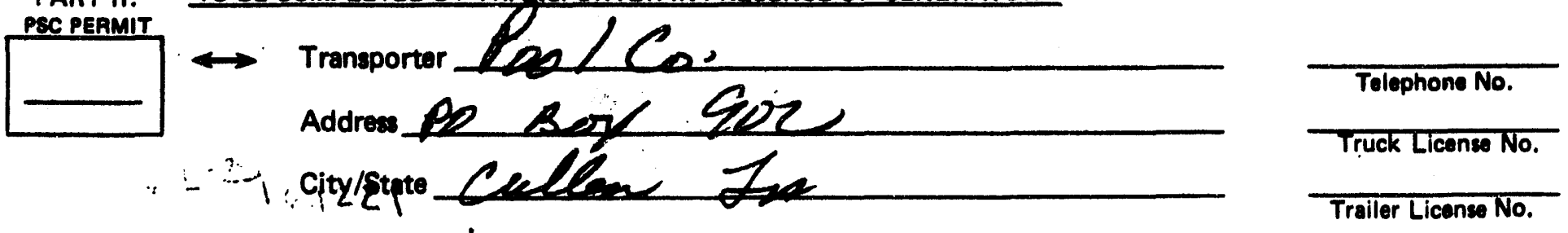

If transported by barge, barge and tug identification

Barge and Tug Id.

CERTIFICATION: I certify that the wasw in quentity above wes received by me for ehipment to the sbove destination.

\section{PART III: TOBE COMPLETED BY COMMERCIAL FACILITY}

$\therefore \leftrightarrow$ Facility Operator

Site Name

CHEMICAL ANALYSES

Chloride (Mg/h)

CERTIFICATION: I certify that the waste described in Pert I was received by ma vis the treneporter deacribed in Part II. 
(Please Chock One)

SALVAGE OIL

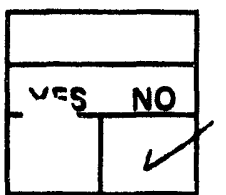

.
NONHAZARDOUS OILFIELD WASTE SHIPPING CONTROL

STATE OF LOUIBIANA

OFFICE OF CONGERVATION

P. O. BOX 49278

BATON ROUOE, LA 70MOARATE
Manifest No. $\quad 104003$

GENERATOR'S COPY

If Yes indicate the number of barrels in the "50-Salvage Oil" below. FILL

PART I: CODES

$6424 \rightarrow$

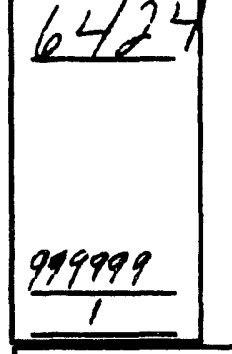

\section{TO BE COMPLETED BY GENERATOR}

Generator STONE WWEhsteR ENG, CORP Address $245 / 12$ skmmer ste City/State ORIGINATION OF WASTE

$\leftrightarrow$ Type 1 1= Lease; 2= Unit; 3= Well; or 5- Other

Field WILU:AT

\section{IF:Pa:ivo \\ P.0. 4036}

ATTN: RT. DECONTO

WASTE IDENTIFICATION AND AMOUNT (IN 42 GALLON BARRELS)

01 Salt Water
02 Oil Base Mud
03 Water Base Mud
04 Completion Fluids
05 Pit Sludges
06 Tank Sludges

$=$

07 Sande/Solids

08 Fresh Water

09 Rainwater

10 Wachout Water

11 Pit Water

12 Gas Plant Water

\subsection{9 .7058 \\ Telephone No.}

$6 n ?$

DESTINATION OF WASTE

$\leftrightarrow$ Commercial Facility Name

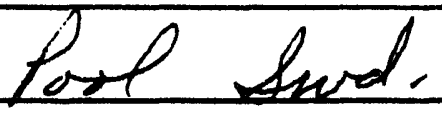

13 Salvage BS \& W

14 Pipeline Test Water

15 Facility Water

16 Cleanup Water

50 Salvage Oil

99 Other

Site Address Bey PO 2

City/state fprenghief, \&A, 7075

CERTIFICATION: The waste described above une canglgned to the carrier nemed below. 1 certify that the forecoing is true and correct to the beat of my knowledpe.

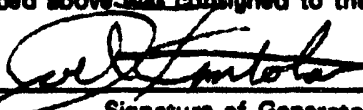

$Z$ Sipnature of Gonorator's Authorized Acant
$9.22-88$ Date end Time of Shipment

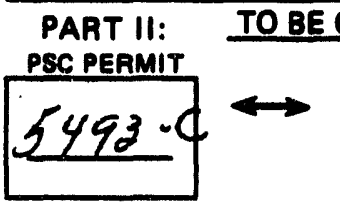

COMPLETED BY TRANSPORTER IN PAESENCE OF GENERATOR

Transporter foel CO.

Addres $B_{2}, 902$

citu/state fercingis:Pf: $\angle A, 7075$
$318.994-2107$

Telephone No.

P46-874 Truck License No.

$0259-134$

If transported by barge, barge and tug identification

Barge and Tug ld.

CERTIFICATION: 1 certify that the weste in quentity above was recaived by me for shipment to the sbove destination.

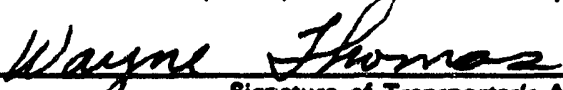

SD BY COMMERCIAL FACILITY

9.22 .88

PART III: TO BE COMPLETED BY COMMERCIAL FACILITY

$\underline{L} \cdot 2 L \leftrightarrow$ Facility Operator Poof CO,

Site Name

CHEMICAL ANALYSES

Chloride $(\mathrm{Mg} / \mathrm{M})$

Conductivity (mmhos/cm)

$\mathrm{pH}$

CERTIFICATION: I certify that the, waste checribed in furt I was received by mo vie the transporter described in Part 11

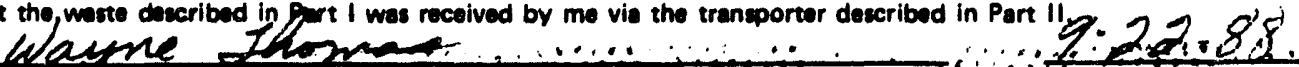

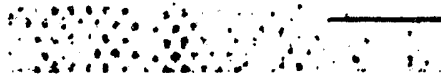

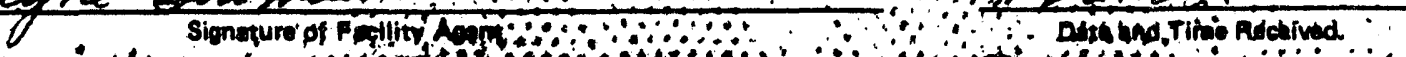


(Please Check One)

SALVAGE OIL

NONHAZARDOUS OLLFIELD WASTE SHIPPING CONTROL TICKET(R)

STATE OF LOUISIANA

OFFICE OF CONBERVATION

P. O. BOX 4475

BATON ROUGE, LA 70004-4275

Manifest No.

$\operatorname{Dg} 3$

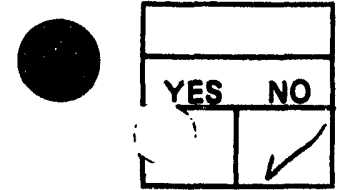

$\leftrightarrow$ If Yes indicate the number of barrels in the "50-Salvage Oil" below.

GENERATOR'S COPY

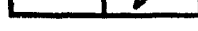

PART 1:

TO BE COMPLETED BY GENERATOR

CODES

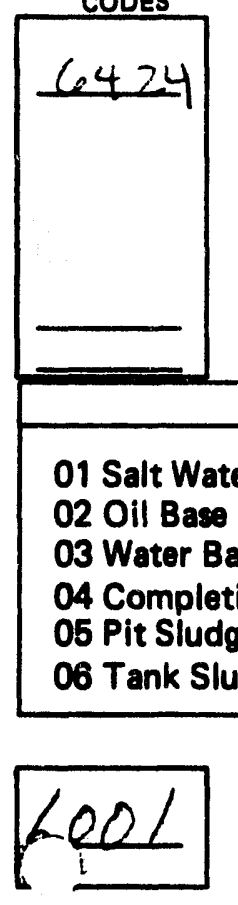

$\leftrightarrow$ Generator

Stanetwebster Eng Conp

Address

$245 / 12$ Suminer st

City/State

Bexston, Base, co2107

ORIGINATION OF WASTE

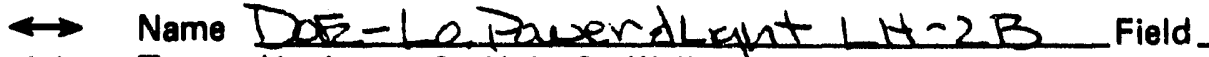

$\leftrightarrow$ Type $\quad 1=$ Lease; $2=$ Unit; $3=$ Well; of $5=$ Other WASTE IDENTIFICATION AND AMOUNT (IN 42 GALLON BARRELS)

01 Salt Water

02 Oil Base Mud LEBBL

03 Water Base Mud

04 Completion Fluids

05 Pit Sludges

06 Tank Sludges

07 Sands/Solids

08 Fresh Water

09 Rainwater

10 Washout Water

11 Pit Water

12 Gas Plant Water
13 Salvage BS \& W

14 Pipeline Test Water

15 Facility Water

16 Cleanup Water

50 Salvage Oil

99 Other

\section{DESTINATION OF WASTE \\ $\leftrightarrow$ Commercial Facility Name}

Sito Addres 2,922

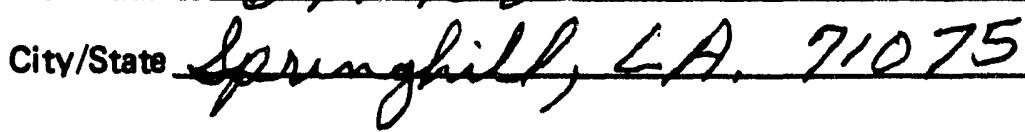

CERTIFICATION: The warte describedabove was gonsigned to the carrier nemed below. I certify that the forepoing is trus and correct to the best of my knowiodos

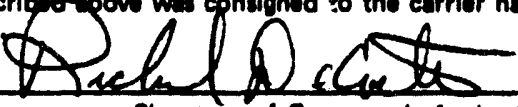

Sinnature of Generator's Authorized Aasent
9. $\angle 1-88$ Bate and Time of Shipment

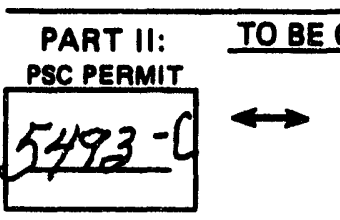

COMPLETED BY TRANE

If thinsported by barge, barge and tug identification

CD

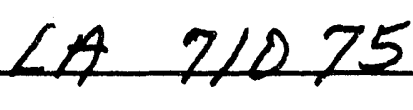

318.994 .2112 Telephone No.

$146-824$ iruck License No. $0259<34$ irailer License No.

CERTIFICATION: 1 certify that the waste in quentity above was recaived by me for shipment to the above destination.

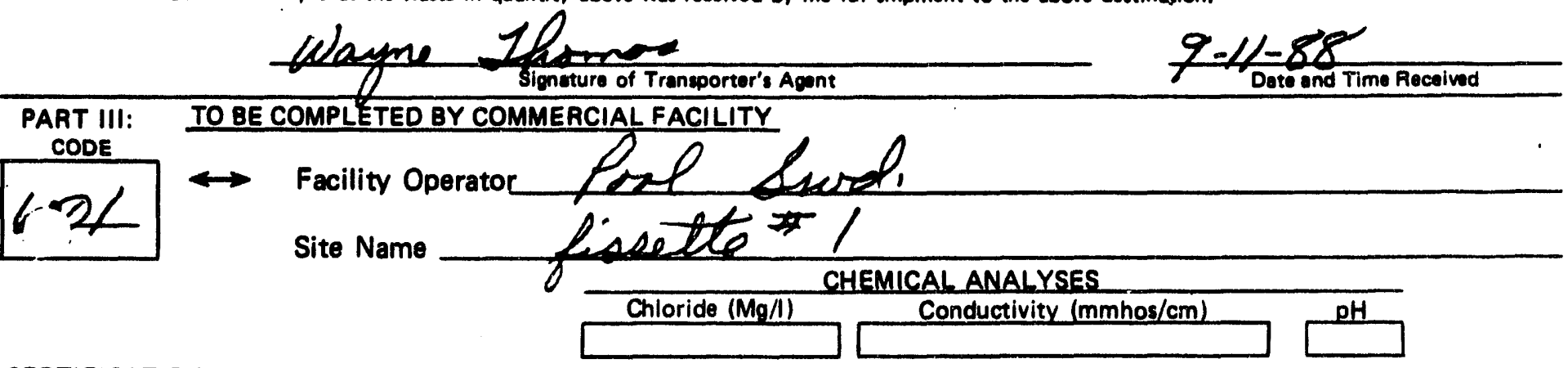

CERTIFICATION: I certify that the waste described infort I was received by me via the tranperter described in Part 110

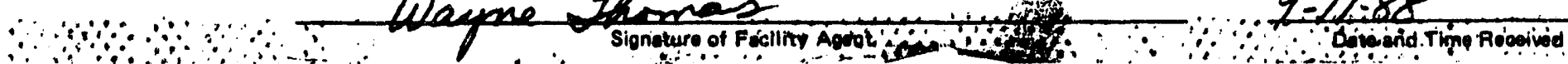


(Please Check One)

SALVAGE OIL

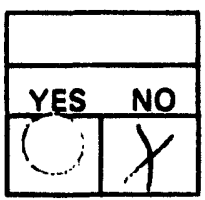

PART I:

\begin{tabular}{|l|}
\hline \multicolumn{1}{|c|}{ CODES } \\
\hline 6424 \\
\hline 01 Salt Wat \\
02 Oil Base \\
03 Water B \\
04 Comple \\
05 Pit Slud \\
06 Tank Slud \\
\hline 6401 \\
\hline \\
\hline
\end{tabular}
NONHAZÁRDOUS OILFIELD WASTE SHIPPING CONTROL TICKET: 12 L -20
STATE OF LOUISIANA

OFFICE OF CONBERVATION

P. O. BOX 44278

BATON ROUGE, LA 70004-42T:
Manifest No.

$\log 4$
GENERATOR'S COPY

If Yes indicate the number of barrels in the "50-Salvage Oil" below.

FILE LUPY J.0. 10.17600

Treasion

TO BE COMPLETED BY GENERATOR STONE \& WESSTER ENG, Co.

$\%$ R. De Tonto

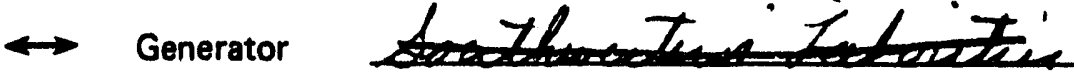

Address 245 Summer ST

P.O 0436

Bostor MA - Mas

$1617-589-2579$

City/State

ORIGINATION OF WASTE

$\leftrightarrow$ Name DOE. LU\& $* 6 \mathrm{~A}$

$\leftrightarrow$ Type $T=$ Lease; $2=$ Unit; $3=$ Well; or $5=$ Other

Field Wildcet WASTE IDENTIFICATION AND AMOUNT (IN 42 GALLON BARRELS)

\begin{tabular}{c|l}
50 & 07 Sands/Solids \\
\hline
\end{tabular}

08 Fresh Water

09 Rainwater

10 Washout Water

11 Pit Water

12 Gas Plant Water
13 Salvage BS \& W

14 Pipeline Test Water

15 Facility Water

16 Cleanup Water

50 Salvage Oil

99 Other

DESTINATION OF WASTE

$\leftrightarrow$ Commercial Facility Name

Site Address

bas 902

City/State

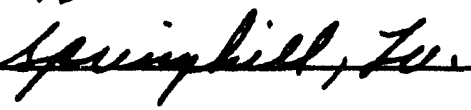

CERTIFICATION: The weste describegebove was consigned ty the carrier nemed below. 1 certify that the foresoing is true and correct to the best of my knowledpe

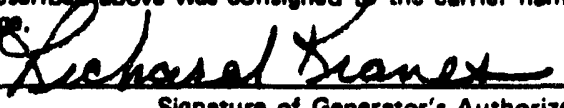

Signeture of Generator's Authorized Apent
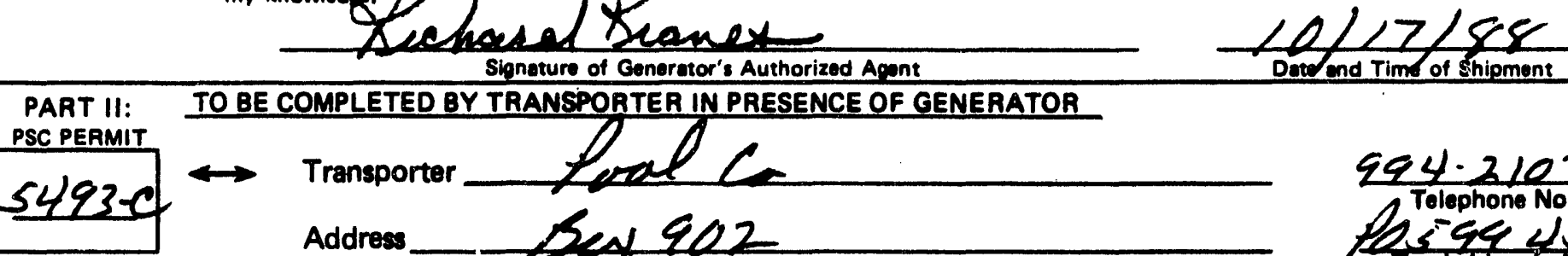

Transporter

BY TRANSPORTER IN PRESENCE OF GENERATOR

Address

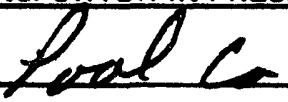

City/State

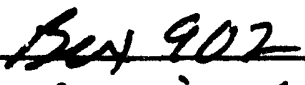

If transported by barge, barge and tug identification

Barge and Tug ld.

CERTIFICATION: I certify that the waste in quantity above was received by me for shipment to the sbove destinetion.

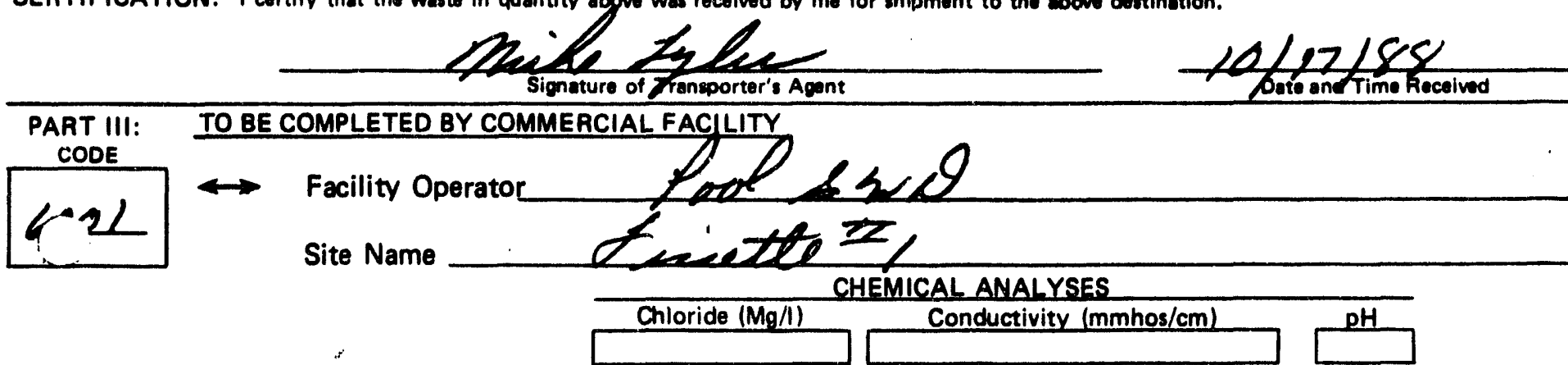

CERTIFICATION: I certify that the waste described in Part I way feeived by me vig the transporter described in Part II. 
(Please Check Gine)

SALVAGE OIL

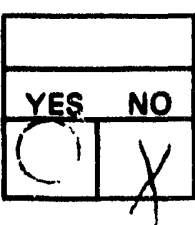

PART I:

CODES

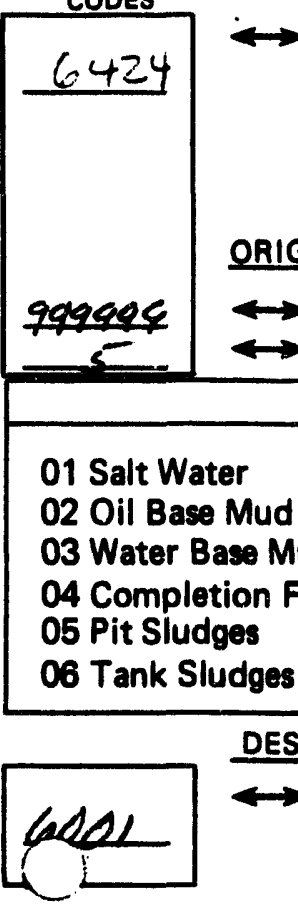

\section{TO BE COMPLETED BY GENERATOR}

$\leftrightarrow$ Generator

Ston

Address

City/State

ORIGINATION OF WASTE

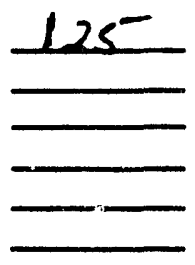

DESTINATION OF WASTE

$\leftrightarrow$ Commercial Facility Name
STATE OF LOUIBIANA

OFFICE OF CONBEAVATION

P. O. BOX 4276

BATON ROUOE, LA 7000M-42T6
Manifest No. $\operatorname{Pg} 55258$

GENERATOR'S COPY

If Yes indicate the number of barrels in the "50-Salvage Oil" below.

FILE COPY d.O. NO. 17601

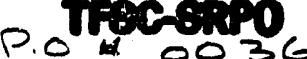

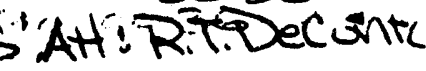
F.0. $*$ oc 36 $\frac{(617)-587-7058}{\text { Telephone No. }}$

$\leftrightarrow$ Name DOE-KCI HODGE LUHGA \&6C

$\leftrightarrow$ Type $\quad 1=$ Lease; $2=$ Unit; $3=$ Well; or $5=0$ Other WASTE IDENTIFICATION AND AMOUNT (IN 42 GALLON BARRELS)

07 Sands/Solids

08 Fresh Water

09 Rainwater

10 Washout Water

11 Pit Water

12 Gas Plant Water
13 Salvage BS \& $W$

14 Pipeline Test Water

15 Facility Water

16 Cleanup Water

50 Salvage Oil

99 Other

foalders

Site Address__ Lex 922

City/State

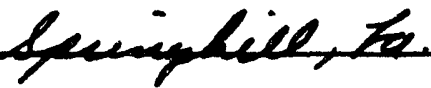

CERTIFICATION: The waste degenth deboye wa consigned to the cerrier named below. I certify that the foregoing is true and correct to the beat of my knowleded Juchatiocis

PART II: TO BE COMPLETED BY TRANSPORTER IN PRESENCE OF GENERATOR

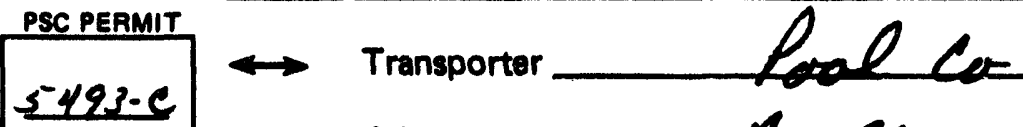

Address__an 922

City/State

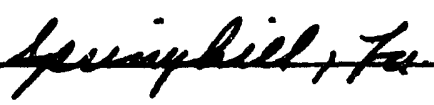

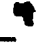

If transported by barge, barge and tug identification

Barge and Tug Id.

CERTIFICATION: I certify that the weste in quantity above was received by me for shipment to the above destination.

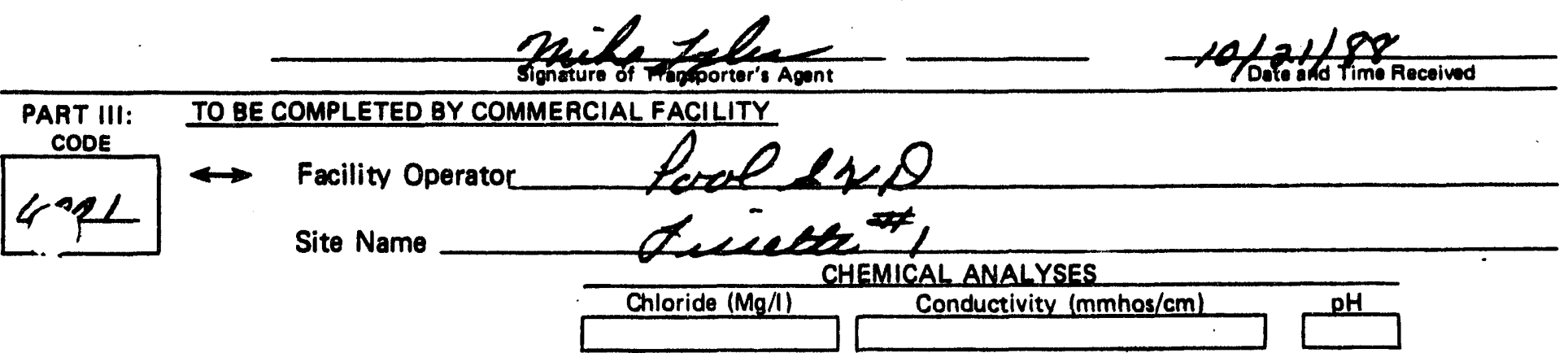

CERTIFICATION: I certify that the waste described in Part I was receiy d by me via the transporter deacribed in Part II. 
(Please Check One) SALVAGE OIL

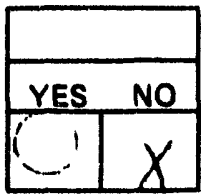

PART 1: CODES

\begin{tabular}{|l|}
\hline 6424 \\
299899 \\
\hline 01 Salt Wat \\
02 Oil Base \\
03 Water B \\
04 Complet \\
05 Pit Slud \\
06 Tank Slud \\
\hline \\
\hline 12 \& L \\
\hline
\end{tabular}

NONHAZARDOUS OILFIELD WASTE SHIPFING CONTROL TICKET STATE OF LOUISIANA OFFICE OF CONBEAVATION

P. O. BOX 44275 BATON ROUOE, LA 70804-1275
$L-2 F$

Manifest No.

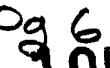

105262

GENERATOR'S COPY

$\leftrightarrow$ If Yes indicate the number of barrels in the "50-Salvage Oil" below.

TO BE COMPLETED BY GENERATOR

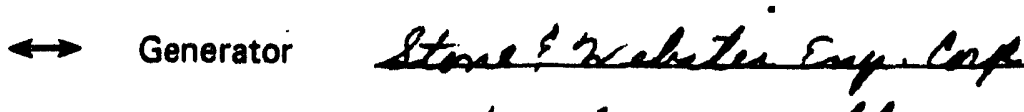

Address

$245 / 12$ Lexmanes

City/State

sacton, Zewn 22102

EH $-6 A$

FILE COP d.0. No.17600

T.OBC-SRPO

(4) $21-589 \div-72158$

Telephone No.

\section{ORIGINATION OF WASTE}

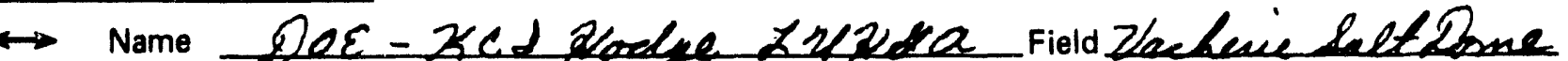
$\leftrightarrow$ Type $\quad(1=$ Lease; $2=$ Unit; $3=$ Well; 6r $5=$ Other WASTE IDENTIFICATION AND AMOUNT (IN 42 GALLON BARRELS)

\begin{tabular}{|c|}
\hline 60 \\
\hline \\
\hline \\
\hline
\end{tabular}

07 Sands/Solids

08 Fresh Water

09 Rainwater

10 Washout Water

11 Pit Water

12 Gas Plant Water

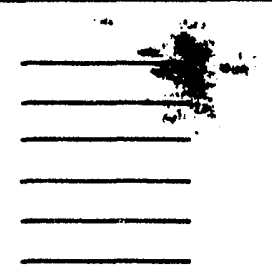

13 Salvage BS \& $W$ 14 Pipeline Test Water 15 Facility Water 16 Cleanup Water 50 Salvage Oil 99 Other

DESTINATION OF WASTE

$\longleftrightarrow$ Commercial Facility Name

Site Address

Sxq21

City/State

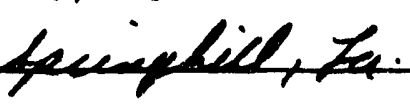

CERTIFICATION: The waste deccribed sbove was consigned to the carrier named below. I certify that the foregoing is true and correct to the best of my knowledg. in ?

11) Duan

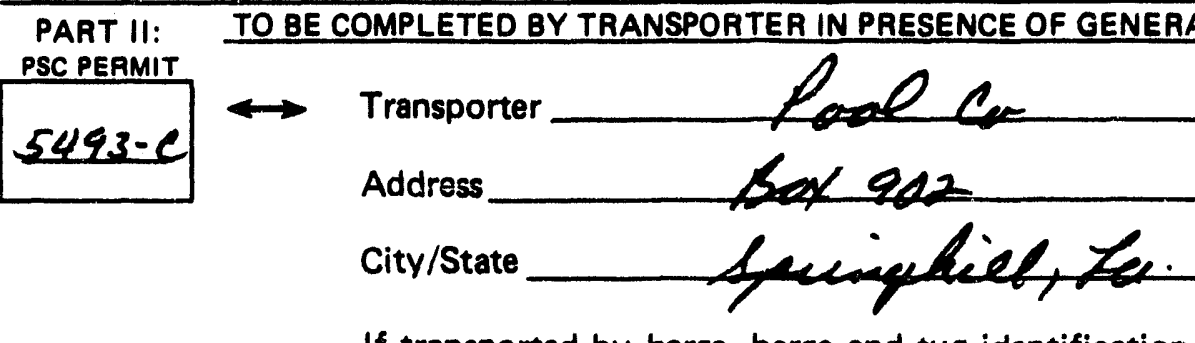

If transported by barge, barge and tug identification

Barge and Tug Id.

CERTIFICATION: I certify that the waste in quantity obove was received by me for shipment to the above destination.

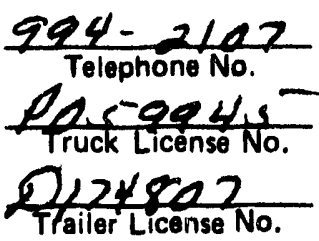

Trailer License No.

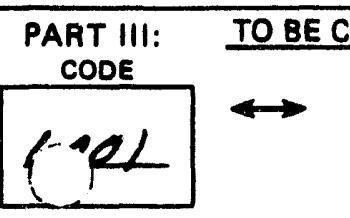

Site Name
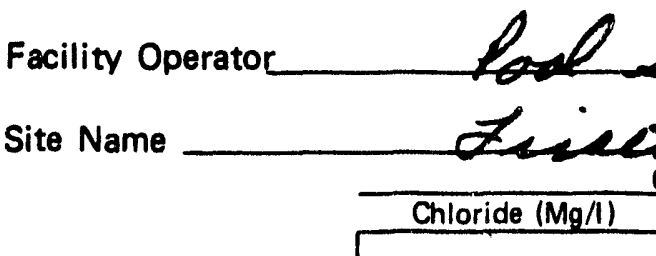

Conductivity (mmhos/cm)

CERTIFICATION: I certify that the waste described in Part I was receive by me yja the ransporter described in Part II. 
(Please Check One)

SALVAGE OIL

NONHAZARDOUS OILFIELD WASTE SHIPPING CONTROL TICKET

STATE OF LOUISIANA

OFFICE OF CONBERVATION

P. O. BOX 44278

BATON ROUCE, LA 70804-4275

Manifest No.

g $7 \quad L-2 G$

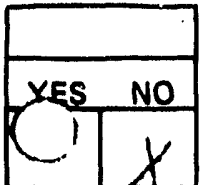

$\leftrightarrow$ If Yes indicate the number of barrels in the "50-Salvage Oil" below.

PART I:

TO BE COMPLETED BY GENERATOR

CODES

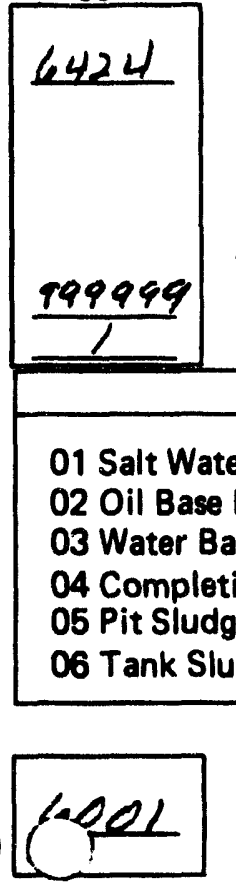

$\leftrightarrow$ Generator

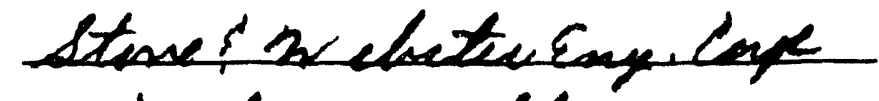

Address

$245 / 2$

City/State

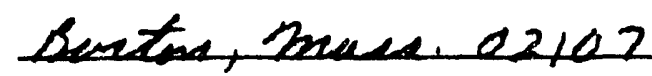

ORIGINATION OF WASTE

$\leftrightarrow$ Name $2 \mathcal{W H}-\angle S$

$\leftrightarrow$ Type $\quad(1=$ Lease; $2=$ Unit; $3=$ Well; or $5=$ Other

Field Vachine Leselome

GENERATOR S COPY

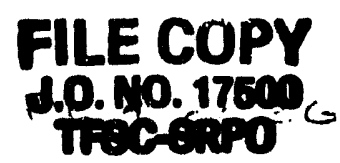

pie $\cos 36$."

(2)17) $=589$ - 205

Telephone No. WASTE IDENTIFICATION AND AMOUNT (IN 42 GALLON BARRELS)

08 Fresh Water

09 Rainwater

10 Washout Water

11 Pit Water

12 Gas Plant Water
13 Salvage BS \& W

14 Pipeline Test Water

15 Facility Water

16 Cleanup Water

50 Salvage Oil

99 Other

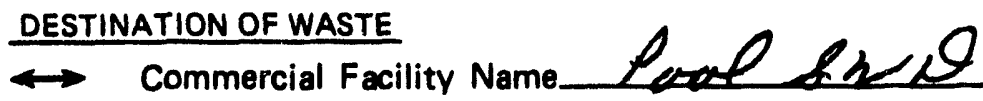

Site Address

sex 822

City/State

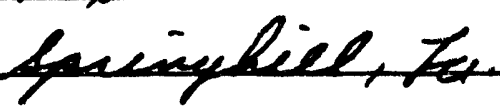

CERTIFICATION: The waste described above was consigned to the carrier nemed beluw. 1 certify that the foregoing is true and correct to the best of my knowiledge

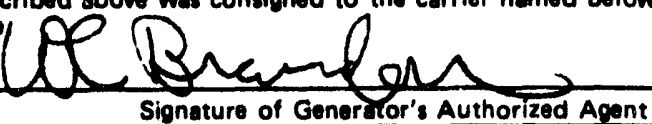

$10 / 26 / 88$ bate and Time of Shipment

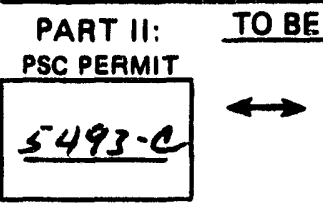

Transporter Dearece

294-2102

Address Dex 922

City/State Cresingliel, Zu. Telephone No. arsers Juck License No. 0174807 Trailer License No.

If transported by barge, barge and tug identification Barge and Tug ld.

CERTIFICATION: I certify that the waste in quantity above was received by me for shipment to the above destination.

Signature of Transporter'y agene
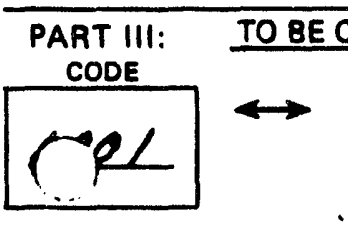

Facility Operator

ALFACILITY

Site Name

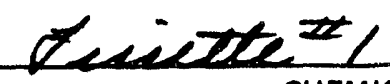

\begin{tabular}{c} 
CHEMICAL ANALYSES \\
Conductivity (mmhos/cm) \\
\hline
\end{tabular}

CERTIFICATION: I certify that the waste described in Pary was recaived me via the transporter described in Part II. 
(Please Check One)

SALVAGE OIL

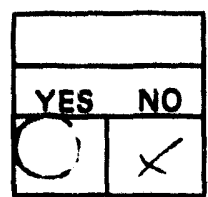

PART I: CODES

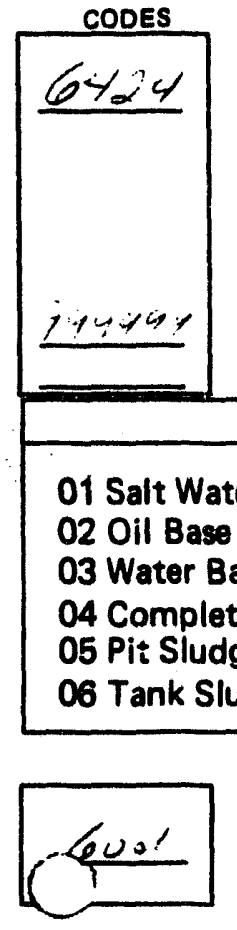

\section{TO BE COMPLETED BY GENERATOR}

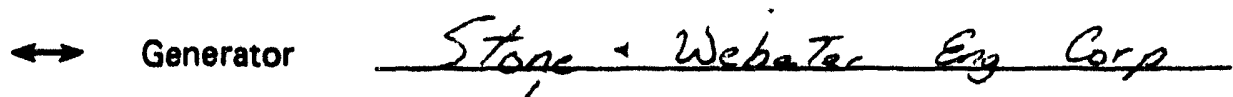

Address

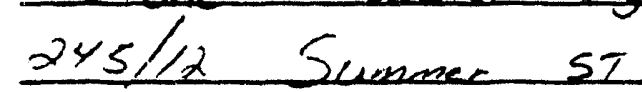

City/State

Bocton Nelars $\quad 32<0 ?$

If Yes indicate the number of barrels in the "50-Salvage Oil" below. ORIGINATION OF WASTE

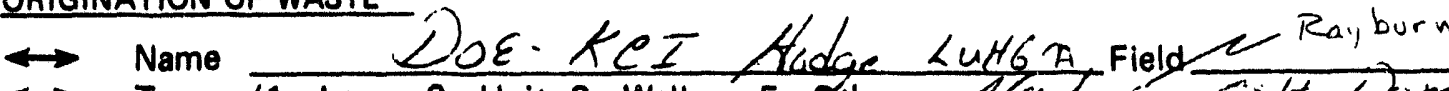

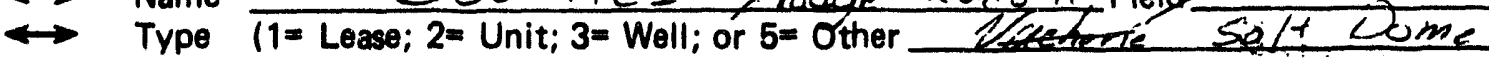
WASTE IDENTIFICATION AND AMOUNT (IN 42 GALLON BARRELS)
01 Salt Water 07 Sands/Solids

02 Oil Base Mud

03 Water Base Mud

04 Completion Fluids

05 Pit Sludges

06 Tank Sludges
08 Fresh Water

09 Rainwater

10 Washout Water

11 Pit Water

12 Gas Plant Water
DESTINATION OF WASTE

Commercial Facility Name__

Manifest No.

$L-2 H$

$\therefore \cdots+$

8TATE OF Louibiana

P. O. BOX 44278

BATON ROUBE, LA 70004-4270
GENERATOR'S COPY
$\mathrm{Pg} 8$

105464
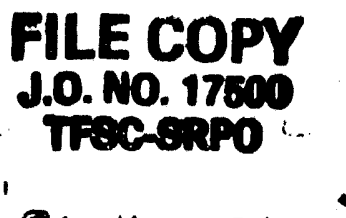

PO. 436

$(6,7)-5842058$

Telephone No.

13 Salvage BS \& W

14 Pipeline Test Water

15 Facility Water

16 Cleanup Water

50 Salvage Oil

99 Other

City/State

CERTIFICATION: The waste described above wes consigned to the carrier nemed below. I certify that the foregoing is true and correct to the best of my knowledpe.

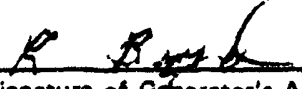

Signature of Gr herator's Authorized Apent
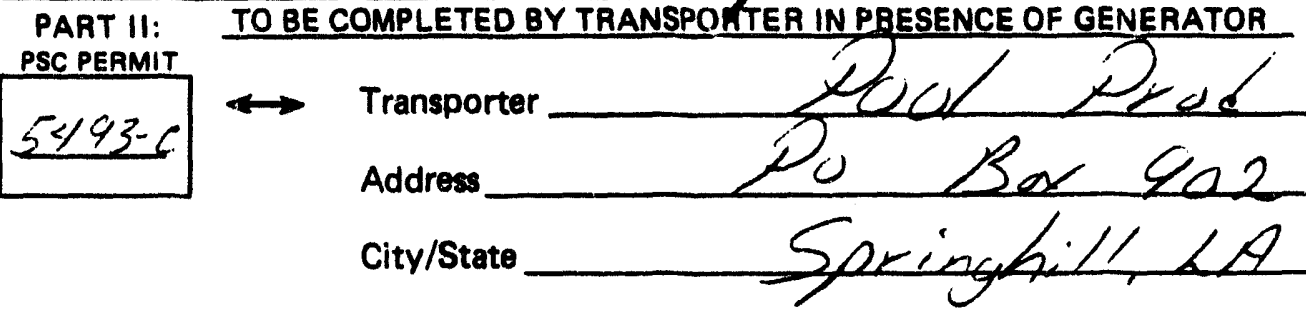
Date and Time of Shipment

If transported by barge, barge and tug identification

$$
\text { Barge and Tug Id. }
$$

CERTIFICATION: I certify that the waste in quantigyabove was received by me for shipment to the above destination.
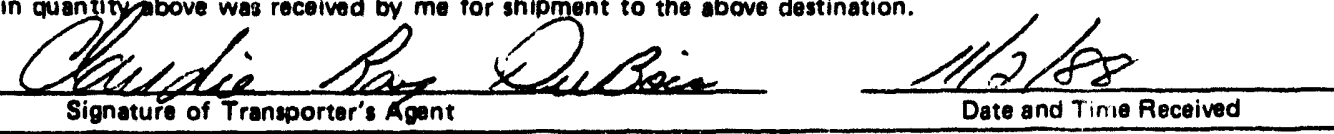

PART III: TO BE COMPLETED BY COMMERCIAL FACILITY

+ Facility Operator $\leftrightarrow$ Site Name

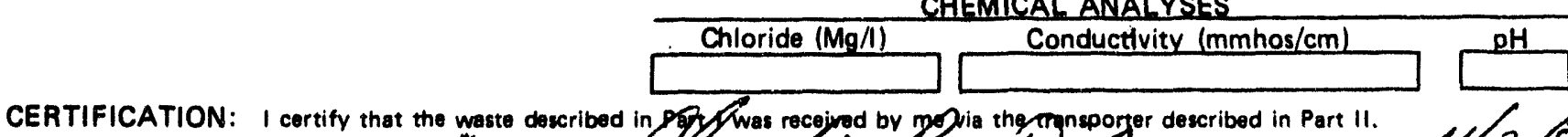

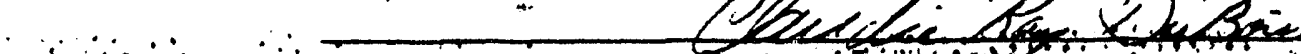

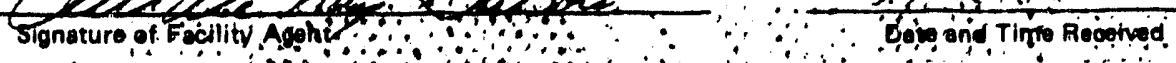


(Ploase Check Ono) SALVAGE OIL

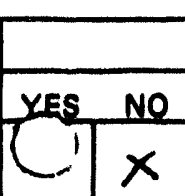

PART 1: CODES

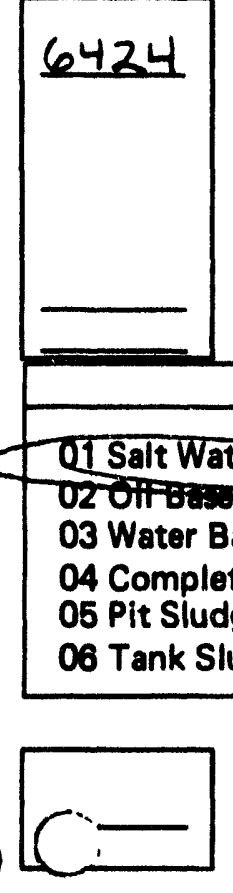

TO BE COMPLETED BY GENERATOR

$\leftrightarrow$ If Yes indicate the number of barrels in the "50-Salvage Oil" below.

$\leftrightarrow$ Generator STONE 3 WEESTER EN

P.O. ROX 2325

Address

BOSTON

City/State

ORIGINATION OF WASTE

$\leftrightarrow$ Name DOE CONTINENTAL F.I. - LH-7A

$\leftrightarrow$ Type (1= Lease; 2= Unit; 3= Well; or 5= Other

\section{Le 07 Sands/Solids}

08 Fresh Water

09 Rainwater

10 Washout Water

11 Pit Water

12 Gas Plant Water

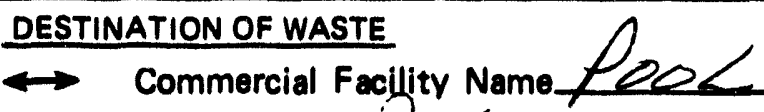

Site Address tofer 1 i $1 \mathrm{Le}$
NONHAZARDOUS OILFIELD WASTE SHIPPING
STATE OF LOUIBIANA
ORFICE OF CONBERVATION
P. O. BOX 44278
BATON ROUOE, LA 70SO4-4270

NONHAZARDOUS OILFIELD WASTE SHIPPING
STATE OF LOUIBIANA
ORFICE OF CONBERVATION
P. O. BOX 44278
BATON ROUOE, LA 70SO4-4270

NONHAZARDOUS OILFIELD WASTE SHIPPING
STATE OF LOUIBIANA
ORFICE OF CONBERVATION
P. O. BOX 44278
BATON ROUOE, LA 70SO4-4270

NONHAZARDOUS OILFIELD WASTE SHIPPING
STATE OF LOUIBIANA
ORFICE OF CONBERVATION
P. O. BOX 44278
BATON ROUOE, LA 70SO4-4270

ENG)

$\rightarrow$ Generator WASTE IDENTIFICATION AND AMOUNT (IN 42 GALLON BARRELS)
Manifost No.

$L-2 I$

GENERATOR'S COPY
FILE COPY d.0. 10.17000 TFeceripo
C.A. FOSTER
ATTN: R.T. DELONTTO

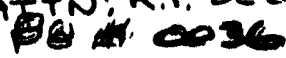

$(617)-589-7058$

Telephone No.

Field WILDLAT

13 Salvage BS \& W

14 Pipeline Test Water

15 Facility Water

16 Cleanup Water

50 Salvage Oil

99 Other

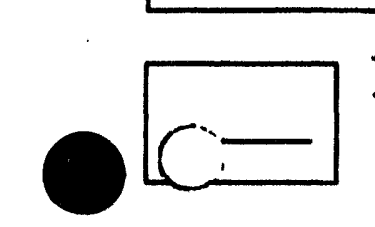

City/State $23 x \times$ Iez

CERTIFICATION: The waste described above wes consigned to the cerrier nemed betame Leexify that the foresoing is true and correct to the bent of my knowledos.

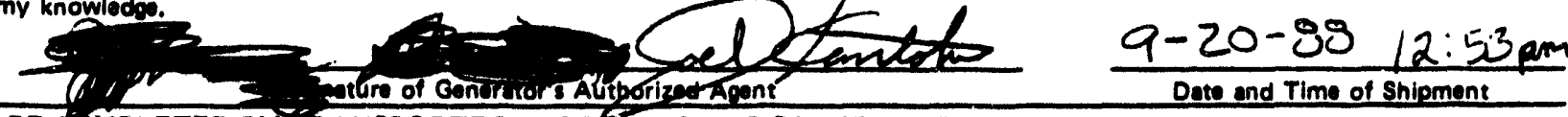

PART II: TO BE COMPLETED BY TRANSPORTER IN PRESENCE OF GENERATOR
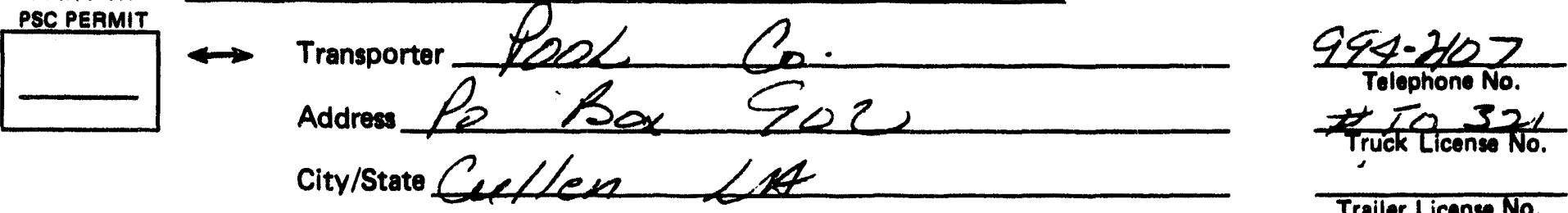

If transported by barge, barge and tug identification

Barge and Tug ld.

CERTIFICATION: I certify that the waste in quentity above was received by me for shipment to the above destination.

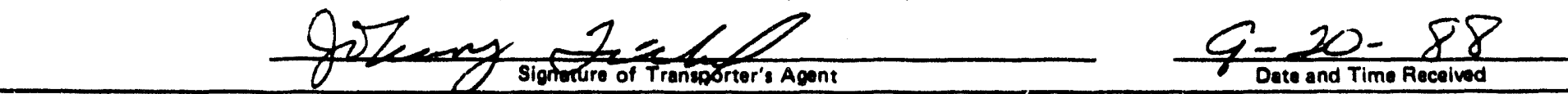

PART III: ' TO BE COMPLETED BY COMMERCIAL FACILITY

CODE

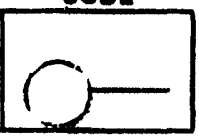

$\leftrightarrow$ Facility Operator

Site Name CHEMICAL ANALYSES

\begin{tabular}{l} 
CHEMICAL ANALYSES \\
Conductivity $(\mathrm{mmhos} / \mathrm{cm})$ \\
\hline $1 \ldots$ \\
\hline
\end{tabular}

CEAfIFICATION: I certify that the waste described in Part I was received by me via the transporter described in Part II.

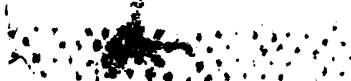

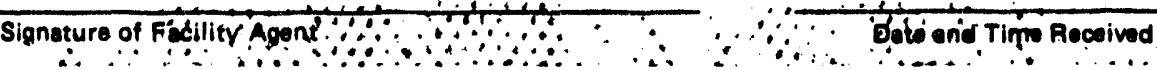


(Please Check Ono)

SALVACE OIL

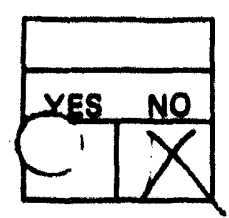

NONHAZARDOUS OILFIELD WASTE SHIPPINO CONTROL TICKET

BTATI OF LOUIBIANA

OPFICE OR CONBEAVATION

P. U. BOX 44278

BATON ROUGE, LA 70004-42T0

Manifost No.

$L-2 J$

104657

GENERATOR'S COPY

If Yes indicate the number of barrels in the "50-Salvage Oil" below. FILE CUPY J.0. No. 17000 Treceripo

PART I: TO BE COMPLETED BY GENERATOR

CODES

6424

$\leftrightarrow$ Generator

STONE i WETSTER EnG.Ca

Address

City/State 245 SHmast SUmmer SI:

$\frac{(617)-589-2579}{\text { Telephone No. }}$ ORIGINATION OF WASTE

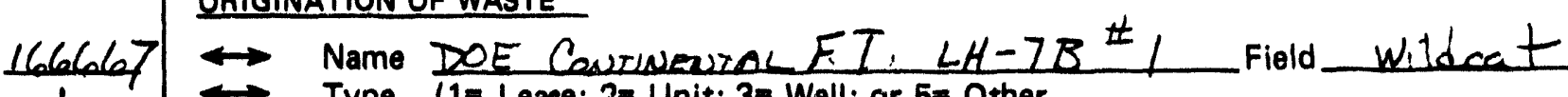
$1+$ Type $11=$ Lease; $2=$ Unit; $3=$ Well; or $5=$ Other

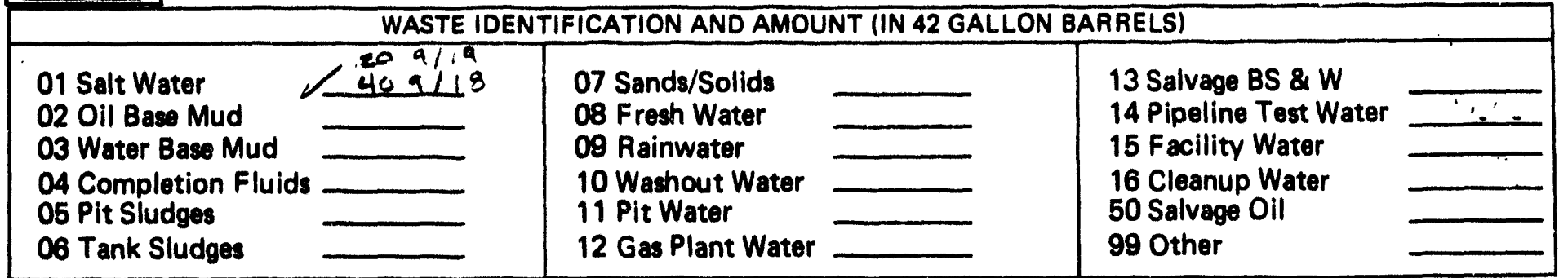
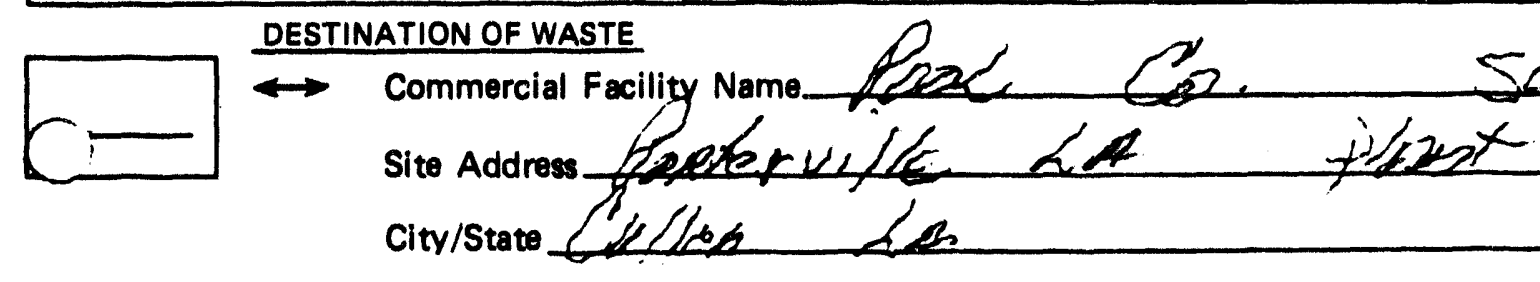

2.

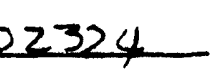

13 Salvage BS \& $W$

14 Pipeline Test Water

15 Facility Water

50 Salvage Oil

99 Other

CERTIFICATION: The weste decribed ghove was consigned to the carrier nemed below. I certify that the foresoing is true and correct to the best of my knowlodis.

Signeture of Generator's Authorized Anent

Dese and Time of shipmen?

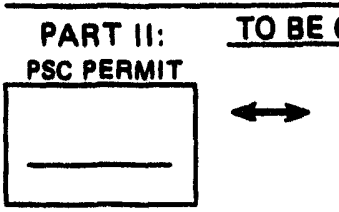

Transporter $\rightarrow$ Address

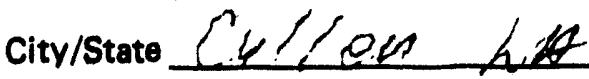

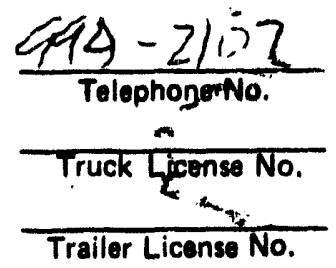

If transported by barge, barge and tug identification

Barge and Tug ld.

CERTIFICATION: I certify that the waste in quentity above was received by me for ahipment to the above destination.

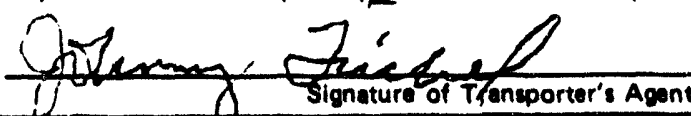

Ste $\frac{19}{\text { Date ond Timo Roceived }}$

PART III: TOBE COMPLETED BY COMMERCIAL FACILITY CODE

$\longrightarrow \leftrightarrow$ Facility Operator

Site Name

CERTIFICATION: I certify that the waste described in Part I wes received by me via the transporter described in Part 11 .

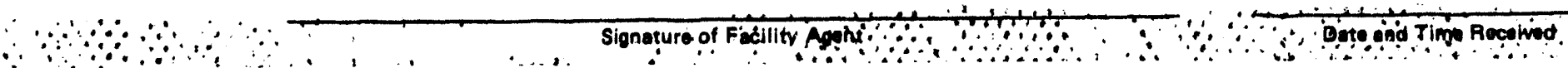


(Plesese Check One)

SALVAGE OIL

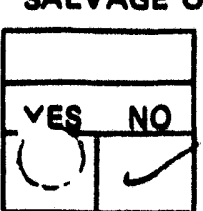

PART 1:

\begin{tabular}{|l|}
\hline CODES \\
\hline 6424 \\
999999 \\
\hline 2 \\
\hline 01 Salt Wat \\
02 Oil Base \\
03 Water B \\
04 Complet \\
05 Pit Slud \\
08 Tank Slud \\
\hline 4 Ool \\
\hline
\end{tabular}

IOBE COMPIETED BY GENERATOR.

$\leftrightarrow$ If Yes indicate the number of barrels in the "50-Salvage Oil" below.

STAT OP LQUIBANA

oprice o

ce of CONELNVATION

P. O. DoX 4478

BATON ROUGR, LA Tomanet.

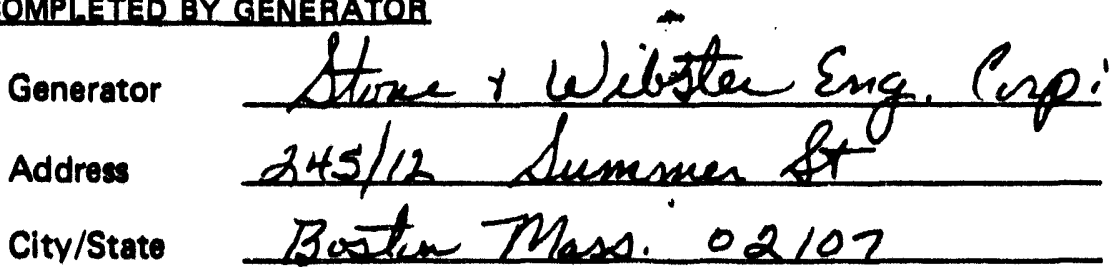

\section{Field

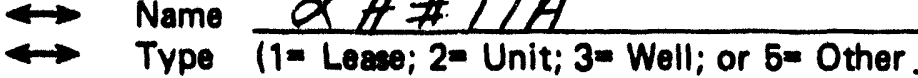 WASTE IOENTIFICATION AND AMOUNT (IN 42 GALLON BARAELS) \\ ORIGINATION OF WASTE}

07 Sands/Solids
08 Frest. Water
09 Rainwater
10 Washout Water
11 Pit Water
12 Gas Plant Water

DESTINATION OF WASTE

$\leftrightarrow$ Commercial Facility Name

Rool \&u

Site Address

POB $\times 902$
Manifest No.

Bg $1 / L-2 k$

105070

genERATOR'S COPY

FILe CUPY

J.0. 10.17000

Trecesino

pot $\$ 36$

$1617-589-8613$

Telephone No.

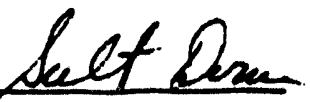

13 Salvage BS \& $W$

14 Pipeline Test Water

15 Facility Water

16 Cleanup Water

50 Salvage Oil

99 Other

City/Stato

Apinglill $2 \mathrm{D}=1075$

CERTIFICATION: The waste dexcribed sbove we consigned to the carribr nemed bolow. I cortify that the forceoling is true and correct to the best of my knowledige.

\section{4 renk}

Signature of Generator's Authorized Acent

PART II: TO BE COMPLETED BY TRANSPORTER IN PAESENCE OF GENERATOR

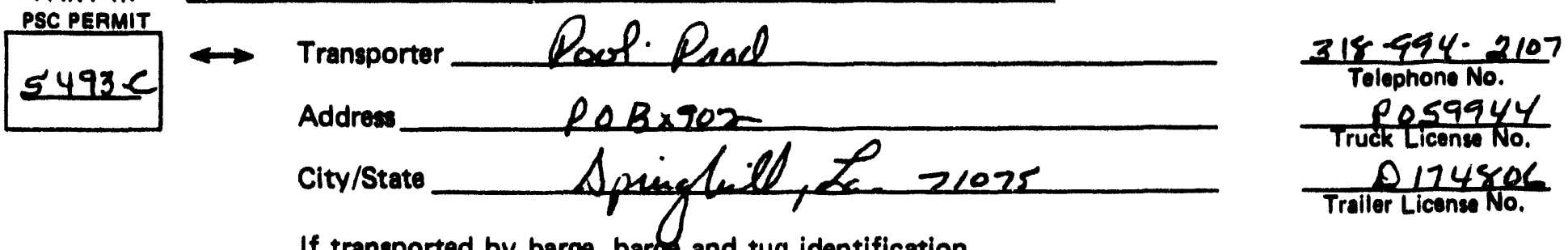

If transported by barge, barga and tug identification
$10-28-58$

Date and Time of Shipment

CERTIFICATION: I certify that the weste in quentity above wes received by me for shipment to the above deatination.

Pancl ASToluenea Signdure of Trantporter's Apent

Barge and Tug ld.

CERTIFICATION: I cortify that the west in quentity above wes recoived by me for shipment to the above deatination.
PART III:
COOE

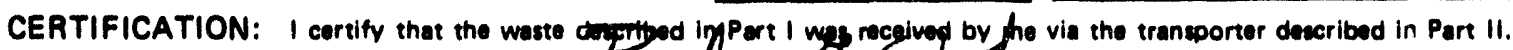


(Please Check One)

SALVAGE OIL

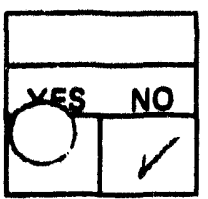

PART 1:

CODES

\begin{tabular}{l}
6424 \\
919999 \\
\hline
\end{tabular}
NONHAZARDOUS OILFIELD WASTE SHIPPINO CONTROL TICKET

STATE OR LOUISIANA

OFFICE OF CONBEAVATION

P. 0. BoX 49278

BATON ROUOE, LA TOEOA-42TS
Fg 1

Manifert No.

$2 /$

$L-2 L$

104015

GENERATOR'S COPY

If Yes indicate the number of barrels in the "50-Salvage OII" below.

TO BE COMPLETED BY GENERATOR

$\leftrightarrow$ Generator SToNet Webster EAG Corp.

Address $245 / 12$ summer 5T.

City/State boston, Mass, 02107

ORIGINATION OF WASTE

$\leftrightarrow$ Name DOE CONT. IND, LHA7B

$\leftrightarrow$ Type 11= Lease; 2= Unit; 3=Well; or 5= Other

FILE CUPY

J.0. N0.17600

TFocespo

P. O4 0036 C/ Refouto

and od

16121589.7058

Telephone No.
01 Salt Water

02 Oil Base Mud

03 Water Base Mud

04. Completion Fluids

05. Pit Sludges

06 Tank Sludges WASTE IDENTIFICATION AND AMOUNT (IN 42 GALLON BARRELS)

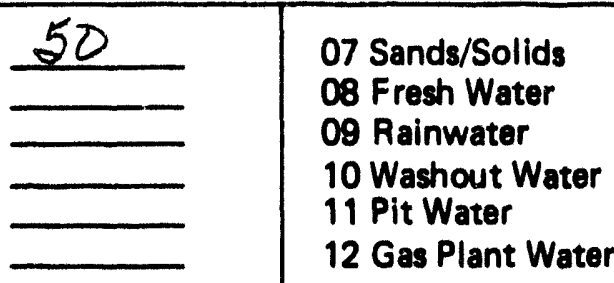

13 Salvage BS \& W 14 Pipeline Test Water

15 Facility Water

16. Cleanup Water

50 Salvage Oil

99 Other

6001

DESTINATION OF WASTE

$\leftrightarrow$ Commercial Facility Name

Pool surd.

Site Address $f x, 902$

City/State Sprenghile, $\angle A$.

CERTIFICATION: The waste described above was consioned to the carrier named below. I certify that the foregoing is true and correct to the best of

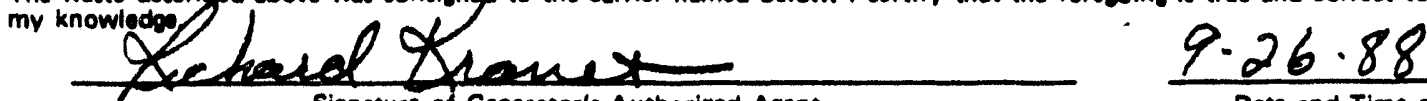

Signature of Generator's Authorized Apont

Date and Time of Shipment

\section{PART II: TO BE COMPLETED BY TRANSPORTER IN PRESENCE OF GENERATOR}
PSC PEAMIT $\leftrightarrow$ Transporter
Pool CD.
Address $8 x, 902$
City/state fermghil, LA. 21075
$\frac{3 / 8 \cdot 994 \cdot 2187}{\text { Telephone No. }}$
$R 46 \cdot 874$
Truck License No.
$0259-134$
Trailer License No.

If transported by barge, barge and tug identification

Barge and Tug ld.

CERTIFICATION: I cartify that the waste in quantity above yas received by me for shipment to the above destination.

$$
\text { Waye the themes }
$$

Q.26.88

Date and Time Received

PART III: TOBE COMPLETED BY COMMERCIAL FACILITY

CODE $\rightarrow$ Facility Operator Pool CD.

Site Name

CHEMICAL ANALYSES

Chloride $(\mathrm{Mg} / 1)$ Conductivity $(\mathrm{mmhos} / \mathrm{cm})$

CERTIFICATION: 1 certify that the yeste described in Pay Dwes received by me via the traneporter described in Part 110.26 .85 


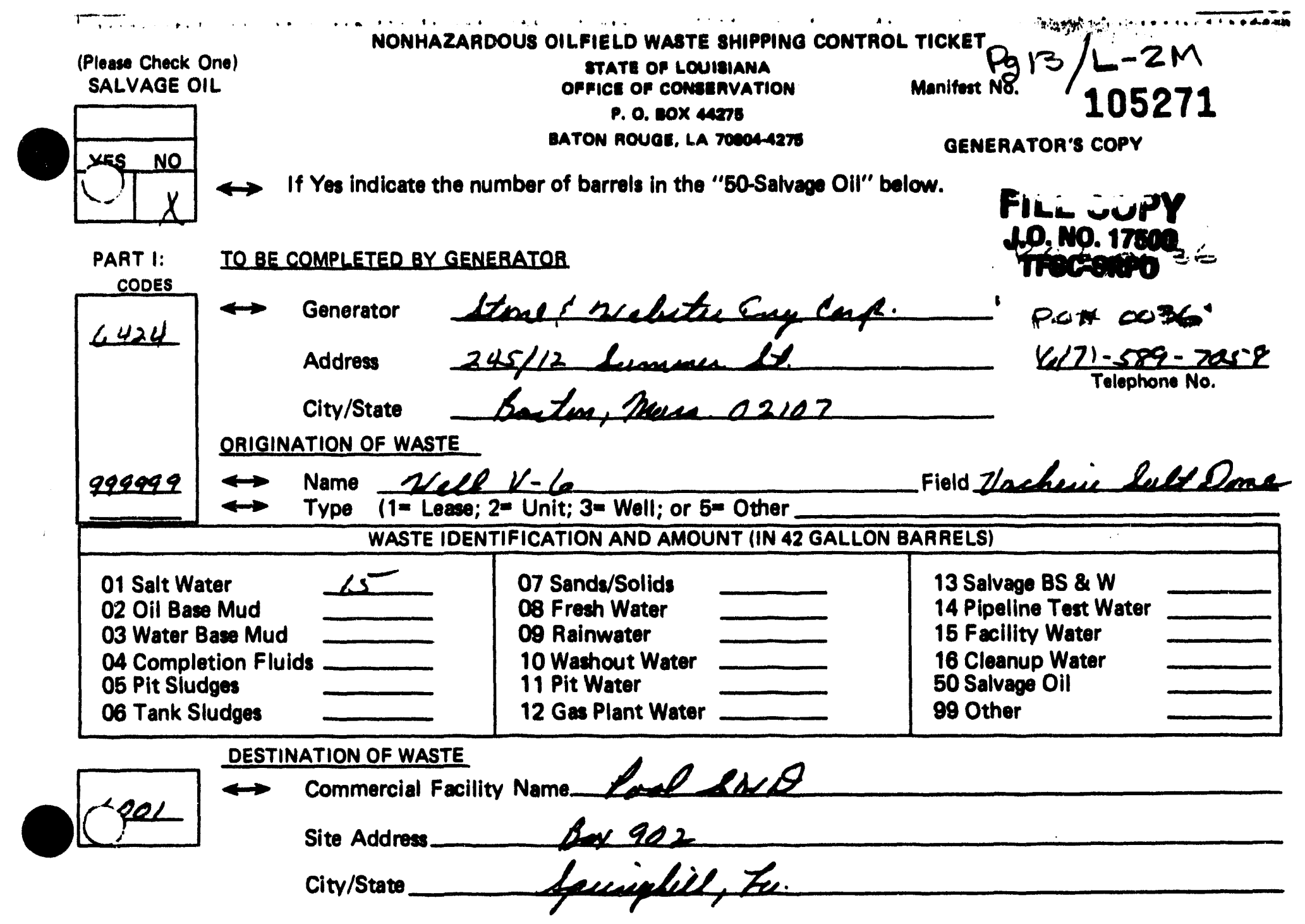

CERTIFICATION: The waste described bove wes condigned to the currior nemed bolow. 1 cartify that the foresoing is true and correct to the beat of my knowledpo.

PART II: TO BE COMPLETED BY TRANSPORTER IN PRESENCE OF GENERATOR
PSC PEAMIT
SLPS-e

If transported by barge, barge and tug identification

CERTIFICATION: I certify that the wast in quentity above wee received by me for shipment to the cbove deatination.

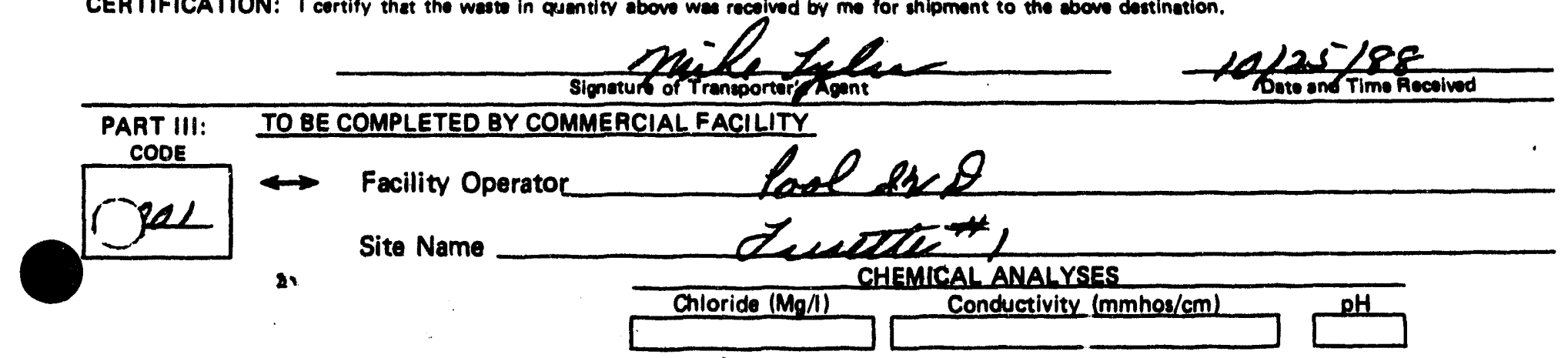

CERTIFICATION: I certify that the waste described in Pert I was recoived by me vig the traneporter described in Part II. 
(Ploase Check One)

SALVAGE OIL

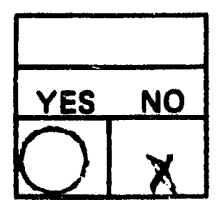

PART 1:

CODES

6424
099959
1
NONHAZARDOUS OILFIELD WASTE SHIPPING

STATE OF LOUISIANA

OFFICE OF CONBEAVATION

P. O. BOX 44275

BATON ROUGE, LA TOSOA-4270

If Yes indicate the number of barrels in the "50-Salvage Oil" below.

$\mathrm{Pg}_{1} 14 / \mathrm{L}-2 \mathrm{~N}$

Manifest Po.

104269

GENERATOR'S COPY CUIOY

J.0. No. 1760

Treceripo

TO BE COMPLETED BY GENERATOR S tone \&leve DSter

$\leftrightarrow$ Generator

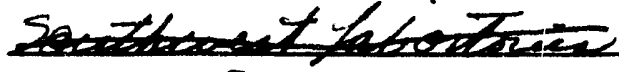

Address

245 Suinwer St

City/State

$$
\text { Bostan, Mass, ozk }
$$

ORIGINATION OF WASTE

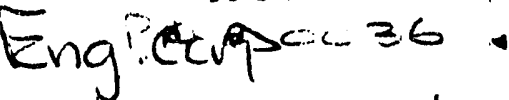

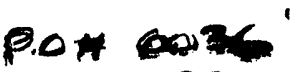

$$
\frac{(617)-589-7058}{\text { Telephone No. }}
$$

$\leftrightarrow$ Name DoF $-V-T$ Manitoring well Field Vachere Salt Daw"

$\leftrightarrow$ Type $\quad 1=$ Lease; $2=$ Unit; $3=$ Well; or $5=$ Other WASTE IDENTIFICATION AND AMOUNT (IN 42 GALLON BARRELS)

01 Salt Water

02 Oil Base Mud

03 Water Base Mud

04 Completion Fluids

05 Pit Sludges

06 Tank Sludges

$\underline{=}$

07 Sands/Solids

08 Fresh Water

09 Rainwater

10 Washout Water

11 Pit Water

12 Gas Plant Water
13 Salvage BS \& W

14 Pipeline Test Water

15 Facility Water

16 Cleanup Water

50 Salvage Oil

99 Other

\section{DESTINATION OF WASTE}

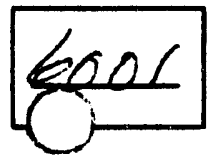

Commercial Facility Name $20 / 2$

Site Address $B \times \Sigma_{0}$

City/State Spusighelle

CERTIFICATION: The waste chacribed aboy $\mathrm{my}$ conaigned tg the carrier nameg below. 1 certify that the foregoing is true and correct to the best of my knowlodpe.

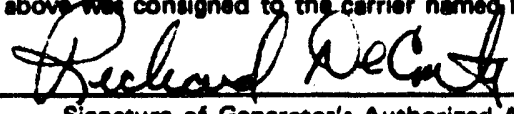

Signature of Generator's Authorized Afjent

$\sum \sum \rho$

Date and Time of Shipment

PART II: TO BE COMPLETED BY TRANSPORTER IN PRESENCE OF GENERATOR

PSC PERMIT $\leftrightarrow$ Transporter POOLC

Address $B \times 22$

City/State Latenintel

If transported by barge, barge and tug identification

$\frac{294-2102}{\text { Telephone No. }}$

Poseples

Truck License No.

Dosize

Trailer License No.

Barge and Tug Id.

CERTIFICATION: I certify that the wast in quentity above was recaived by me for shipment to the above destination.

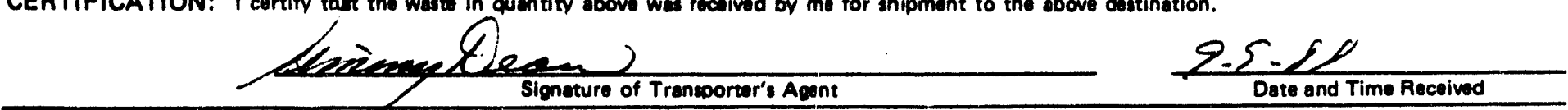

PART III: TO BE COMPLETED BY COMMERCIAL FACILITY

CODE

Facility Operato

Site Name

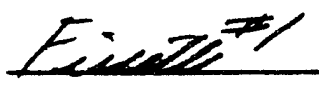

Chloride $(\mathrm{Mg} / \mathrm{l})$ Conductivity $(\mathrm{mmhos} / \mathrm{cm})$

CHEMICAL ANALYSES

CERTIFICATION: I certify that the waste foredribed in Part, I was received by me via the transporter described in Part II.

$\because \because \because \because \therefore \because \therefore$,

$\therefore \because \because \because$

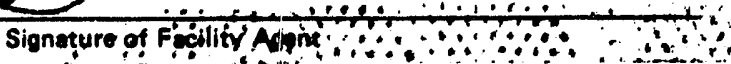

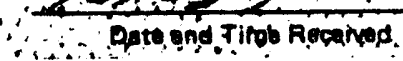


(Ploase Check One)

SALVAGE OIL

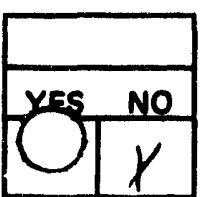

PART 1: CODES

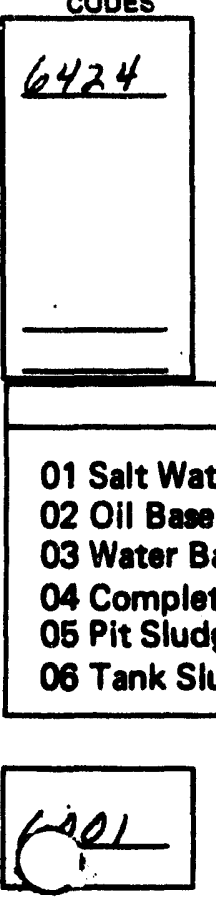

IO BE COMPLETED BY GENERATOR

$\leftrightarrow$ Generator

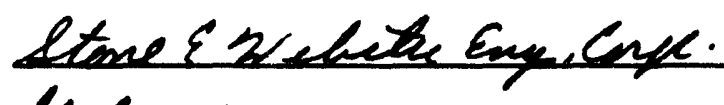

Address

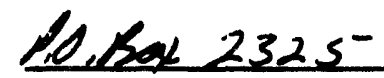

City/State

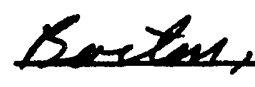

STATE OR LOUIBIANA

OPFICE OF COMBERVATION

P. O. BOX 4 mers

BATON ROUEE, LA TOCOMA2T
If Yes indicate the number of barrels in the "50-Salvage Oil" below.

ORIGINATION OF WASTE WASTE IDENTIFICATION AND AMOUNT (IN 42 GALLON BARRELS)
Oil Base Mud

108

\section{Salt Water}

07 Sands/Solids

08 Freah Water

09 Rainwater

10 Washout Water

11 Pit Water

12 Gas Plant Water
DESTINATION OF WASTE

$\leftrightarrow$ Commercial Facility Name

\section{loolsw $\theta$}

Site Address__ _ _ 1922
Manifest No.

F $15 / L-20$

104103

GENERATOR'S COPY

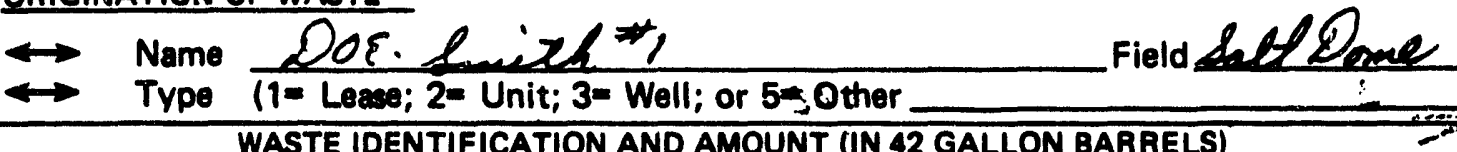

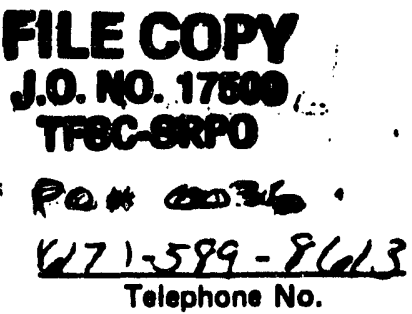

FILE COPY 1.0. 10.1740 Trocesion PQ* बair

Telephone No.
13 Salvage BS \& $W$

14 Pipeline Test Water

15 Facility Water

16 Cleanup Water

50 Salvage Oil

99 Other

City/State feespeleltz.

CERTIFICATION: The weete described above wee consigned to the carrier nemed below. 1 certify that the foresoing is true and correct to the beet of my knowlogtin

Signature of Gonoretor's Authorized Apant

$14 / 8 / 89$

Date and Time of Shioment

PART II: TO BE COMPLETED BY TRANSPORTER IN PRESENCE OF GENERATOR

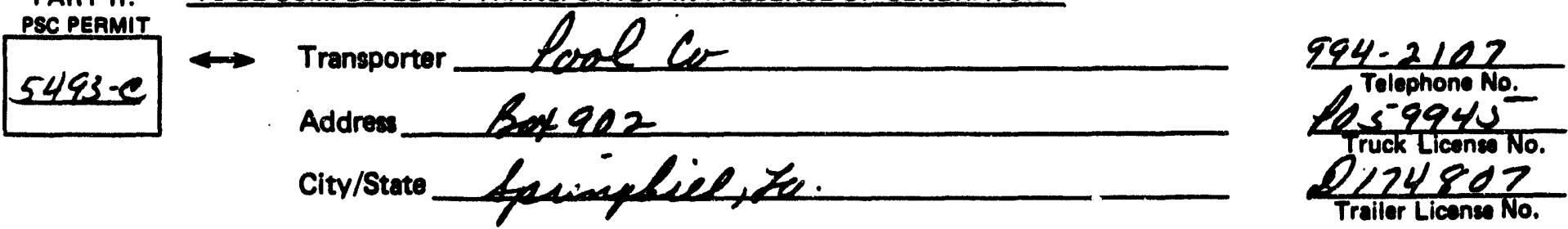

If traneported by barge, barge and tug identification

Barge and Tug ld.

CERTIFICATION: 1 cortify that the was in quantity aboy was recoived by me for shipment to the coove destination.

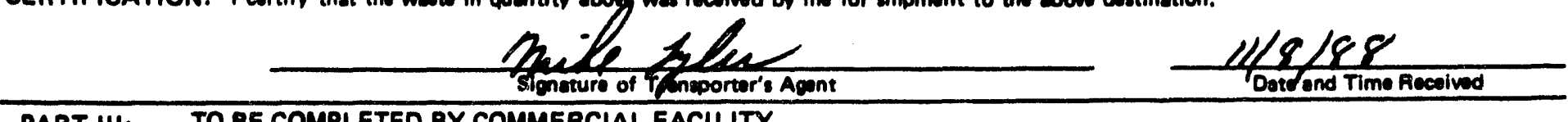

PART III: TO BE COMPLETED BY COMMERCIAL FACILITY

$\leftrightarrow \mathrm{COL} \leftrightarrow$ Facility Operator Site Name

CHEMICAL ANALYSES

Chloride (Mg/I) Conductivity $(\mathrm{mmhos} / \mathrm{cm})-$

CERTIFICATION: I certity that the mase decribed in Prt I we/recelverby ne vis the transporter described in Pant II.

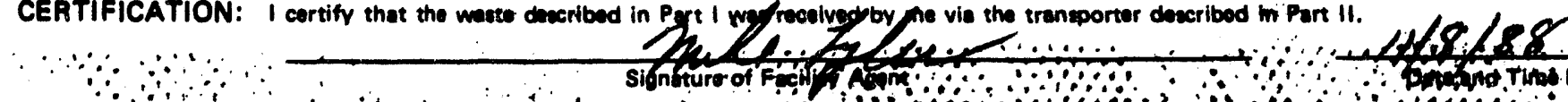

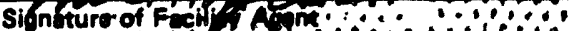

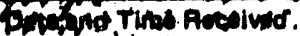


(Please Check One) SALVAGE OIL
NONHAZARDOUS OILFIELD WASTE SHIPPING CONTROL TICKET

STATE OF LOUISIANA

OFFICE OF CONBEAVATION

P. Q. BOX 4 a275

BATON ROUEE, LA 70304-4275
Manifestivo. $L-2 \theta$

GENERATOR'S COPY

YES NO

PART 1: CODES

6424

$\leftrightarrow$

If Yes indicate the number of barrels in the "50-Salvage Oil" bolow.

TO BE COMPLETED BY GENERATOR

$\leftrightarrow$ Generator STONe t Webster Eng.cerp.

Address $245 / 12$ Summen St.

City/State Boston, mass.

ORIGINATION OF WASTE

$15279 \leftrightarrow$ Name DOE smith

2

$\leftrightarrow$ Type

$\{1=$ Lease; $2=$ Unit; $3=$ Well; or $5 ; 0$ ther Wilideat

Field WASTE IDENTIFICATION AND AMOUNT (IN 42 GALLON BARRELS)

01 Salt Water

02 Oil Base Mud

03 Water Base Mud

04 Completion Fluids

05 Pit Sludges

06 Tank Sludges

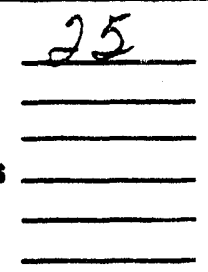

07 Sands/Solids

08 Fresh Water

09 Rainwater

10 Washout Water.

11 Pit Water

12 Gas Plant Water
FILE COPY J.0. N0. 17500 Trecesiso Prosumas. $\frac{6121589-7058}{\text { Telephone No. }}$

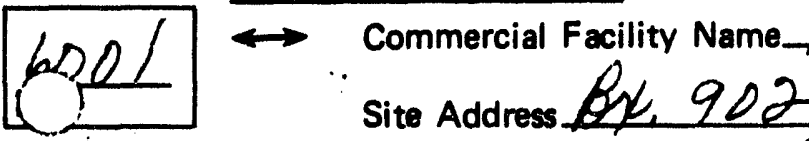

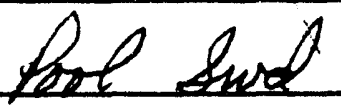

13 Salvage BS \& W

14 Pipeline Test Water

15 Facility Water

16 Cleanup Water

50 Salvage Oil

99 Other

cit/state punghill, $\angle A .21075$

CERTIFICATION: The waste described ebove was consioned to the serrier nemed below. I cartify that the foregoing is true and correct to the best of my knowledo

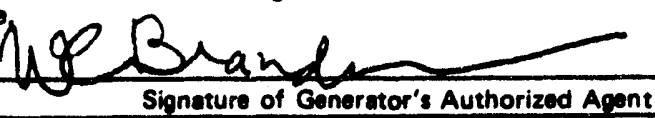

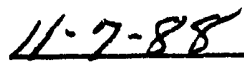
Date and Time of Shipment

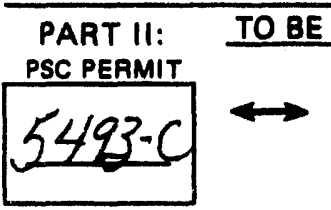

$\frac{3 / 8-994 \cdot 2107}{\text { Telephone No. }}$

Transporter

Address By 902

City/State

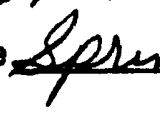<smiles>CCCC1CCCC1C1CCC1</smiles>

CD.

If transported by barge, barge and tug identification

246.874 Truck ticense No. $0259 \cdot 134$ Trailer License No.

CERTIFICATION: I certify that the waste in quentity above wy received by me for shipment to the cbove destination.

Wayne thene the

$12-8-8$

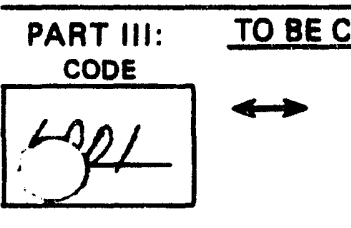

Facility Operator

Site Name

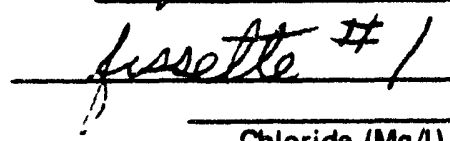

CHEMICAL ANALYSES

Chloride (Mg/I)

Conductivity (rimhos $/ \mathrm{cm}$ )

CERTIFICATION: I certify that the weste deccribed jn Part I was received by mo vis the transporter doecribed in Part II,

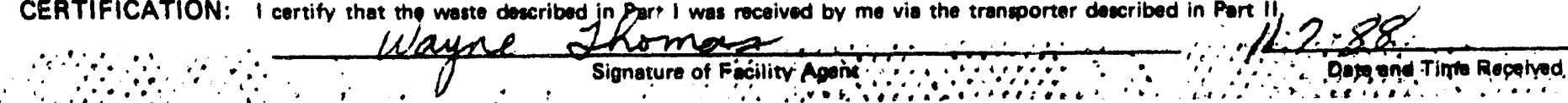




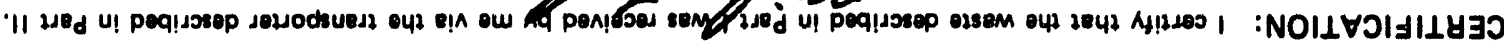
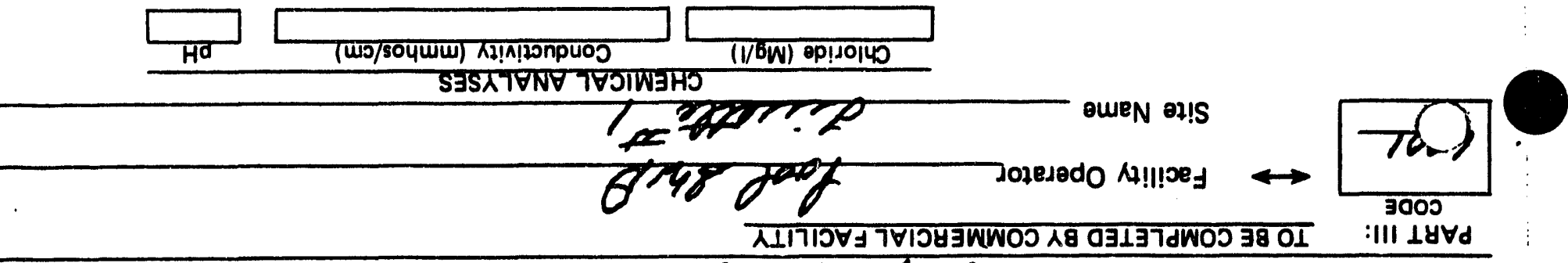

pex!looey ow! pUB o28g 357777

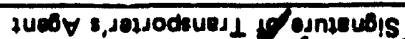

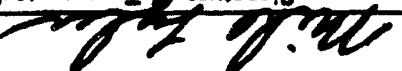

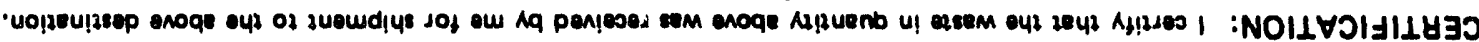

PI $6 n \perp$ pue $86 \mathrm{seg}$

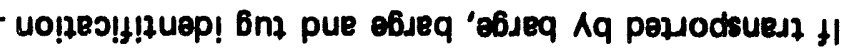
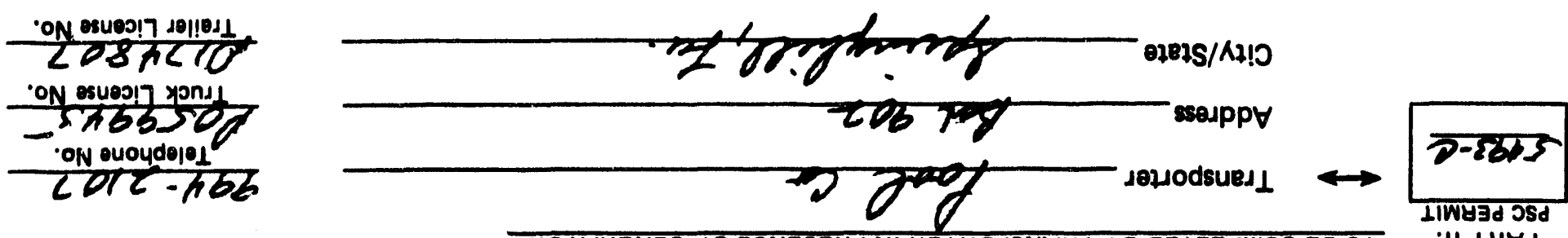

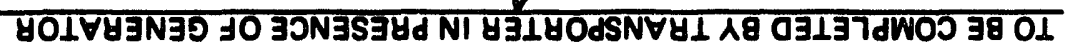

ITWEad JSd

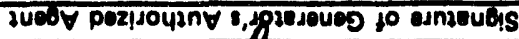

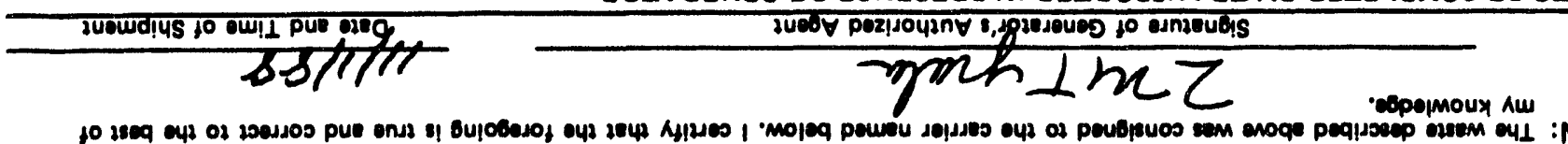

- copomoux AuL
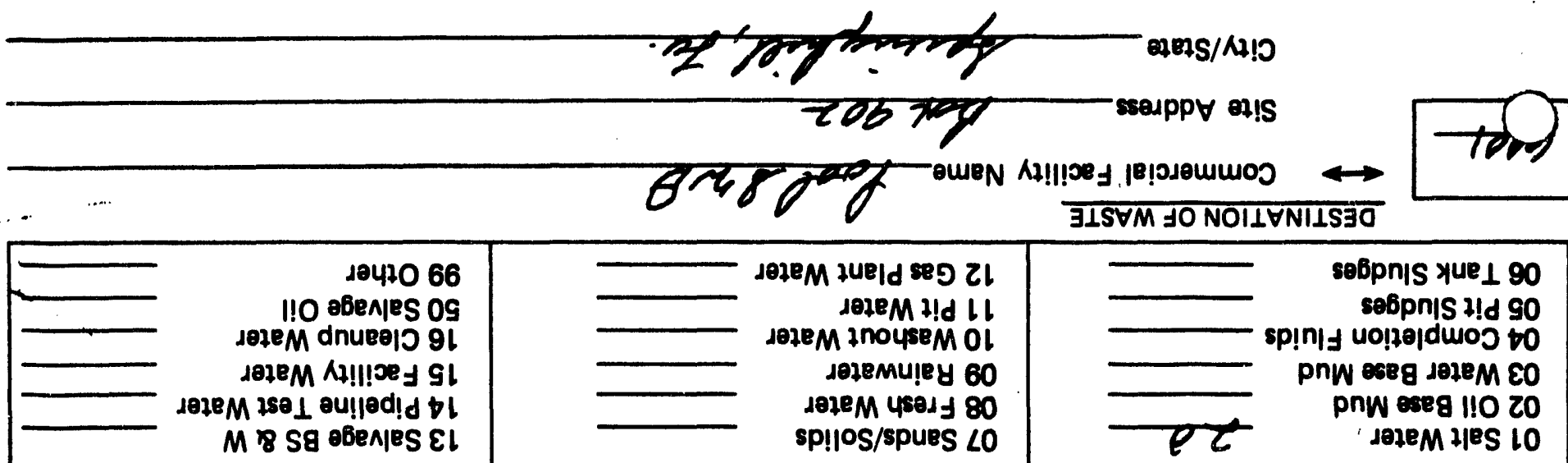
उISVM JO NOIIVNILS 30

II $\perp \forall \forall d$

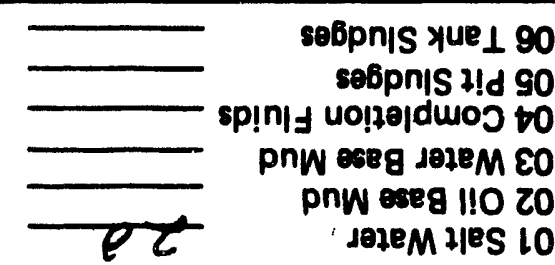

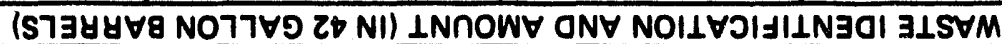

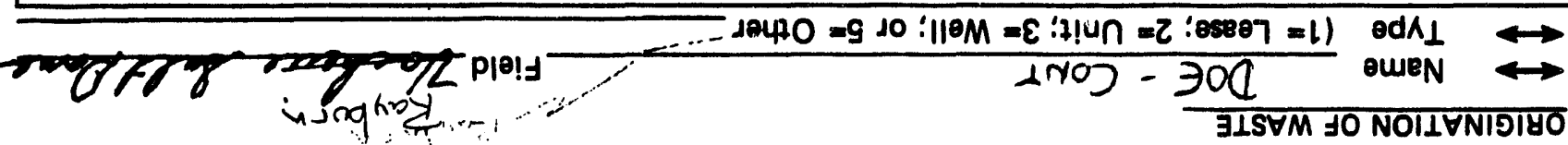

ON ououdopol

JT20 $353-1271$

$\therefore$ give rimised

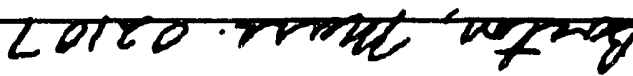

OIS7S/A

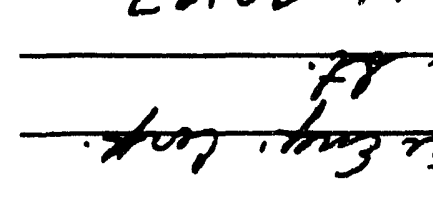

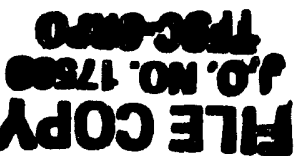
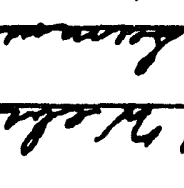

$87 / 572$

$$
\text { ssodpp } \forall
$$

1078deueg $\longrightarrow$

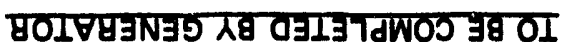

Ћॅकप

s3000

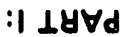

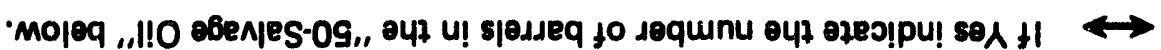

AdOJ S.YOLVY3NG0

06ZSOT

\$2 $-7 / 46$
eLz-600L $\forall 7$ ' 30 OOH NOLVE

scan xog 'o d

NOILVAYBSnOS to goldAO

VNVI8InOT do a1V18

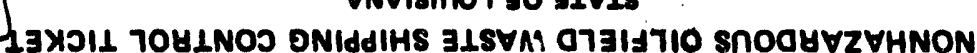

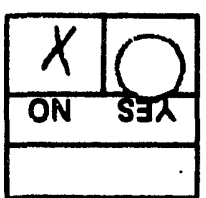

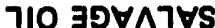

(ouo ॠpous oseold) 
(Please Check One)

SALVAGE OIL
NONHAZARDOUS OILFIELD WASTE SHIPPING CONTROL TICKET $\mathrm{g} / 8 / \mathrm{L}-2 \mathrm{R}$
STATE OF LOUISIANA OFFICE OF CONSERVATION

P. O. BOX 44275

BATON ROUGE, LA 70804-4275
Manifest N8.

104080

If Yes indicate the number of barrels in the "50-Salvage Oil" below.

PART I: CODES

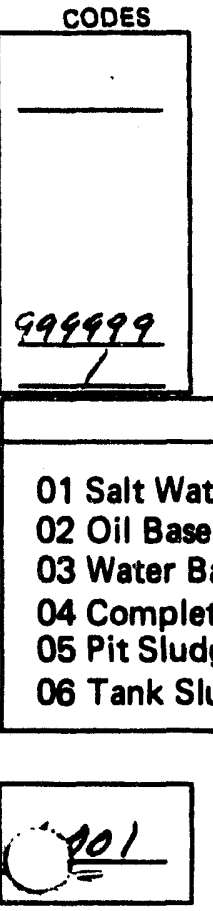

TO BE COMPLETED BY GENERATOR

Generator

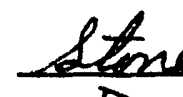$$
P
$$

Address

City/State

\section{ORIGINATION OF WASTE}

$\leftrightarrow$ Name $\frac{20 \varepsilon}{110}$

$$
\text { Boston, MA O2107 }
$$

GENERATOR'S COPY

$\leftrightarrow$ Type (1= Lease; $2=$ Unit; 3= Well; or $5=0$ ther

FILE COPY

J.0. NO. 17500

Trecespo

Por ex:

$167,-589-8613$

Telephone No. Rayburn

Field Zathothe sule Dowe WASTE IDENTIFICATION AND AMOUNT (IN 42 GALLON BARRELS)

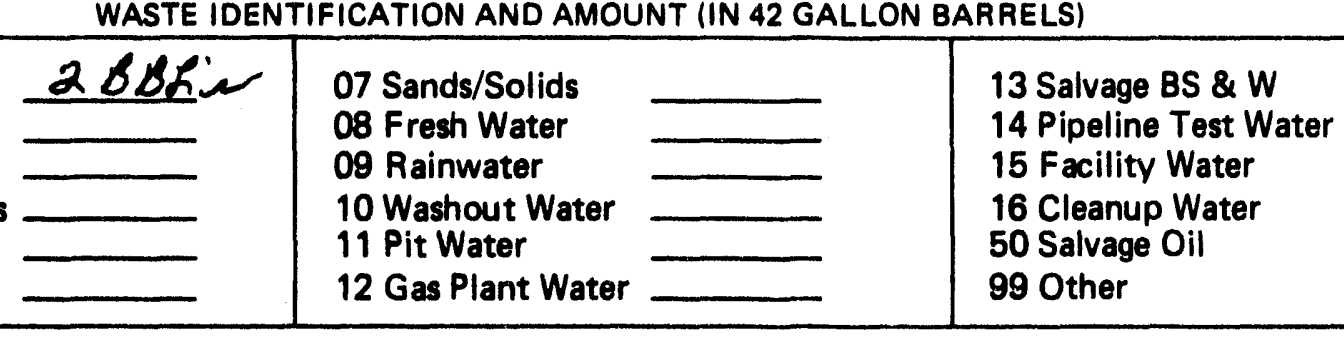

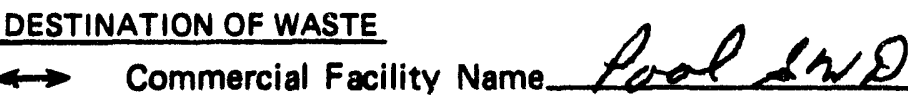

Site Address__ Les 902

City/State

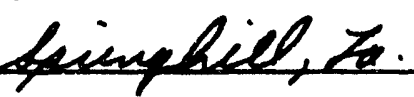

CERTIFICATION: The waste described above was consigned to the carrjor nemed below. I certify that the foregoing is true and correct to the best of my knowiedoe.

$11 / 3 / 28$ bate and Time of Shipment

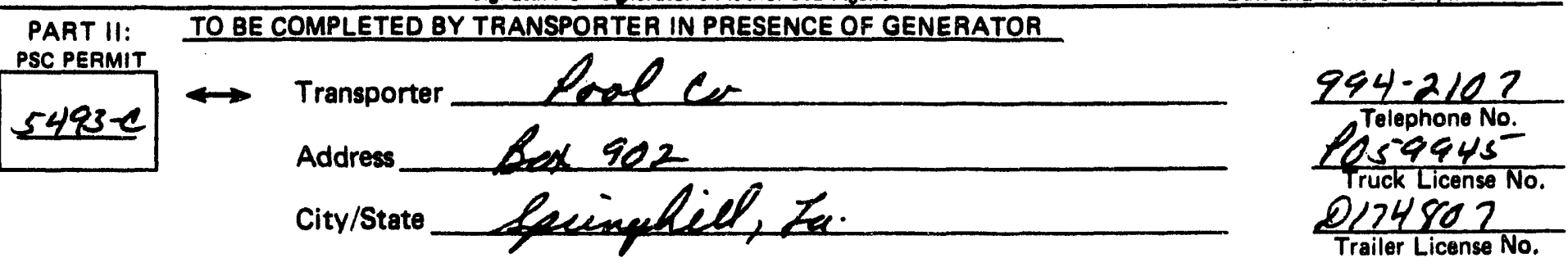

If transported by barge, barge and tug identification Barge and Tug lu.

CERTIFICATION: I certify that the waste in quantity above was received by me for shipment to the above destination.

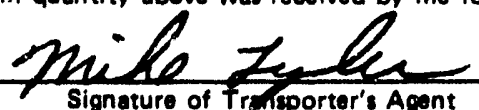

PART III: TO BE COMPLETED BY COMMIERCIAL FACILITY

$+\mathrm{NOL} \leftrightarrow$ Facility Operator $\rightarrow$ Site Name

CHEMICAL ANALYSES

Chloride $(\mathrm{Mg} / \mathrm{l})$ Conductivity $(m \operatorname{mhos} / \mathrm{cm})$

CERTIFICATION: 1 certify that the waste described in Part $($ wacei agby po via the transporter described in Part 11.
$\because \cdots \quad \therefore \quad$

$\because \because \because \because \because$

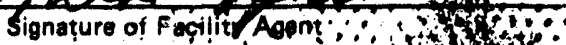


(Please Check One)

SALVAGE OIL

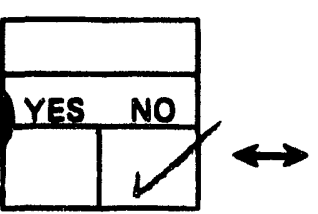

\begin{tabular}{|l|l|}
\hline YES NO \\
\hline
\end{tabular}

PART I: CODES $6424 \rightarrow$

\section{$\frac{991999}{3}$

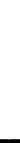

TO BE COMPLETED BY GENERATOR

\author{
STATE OF LOUISIANA \\ OFFICE OF CONBERVATION \\ P. 0. BOX 4 278 \\ BATON ROUGE, LA TOEOMA2TS
}

Manifest No. 161221

\section{GENERATOR'S COPY}

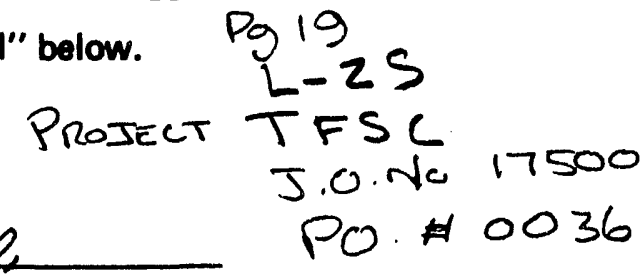

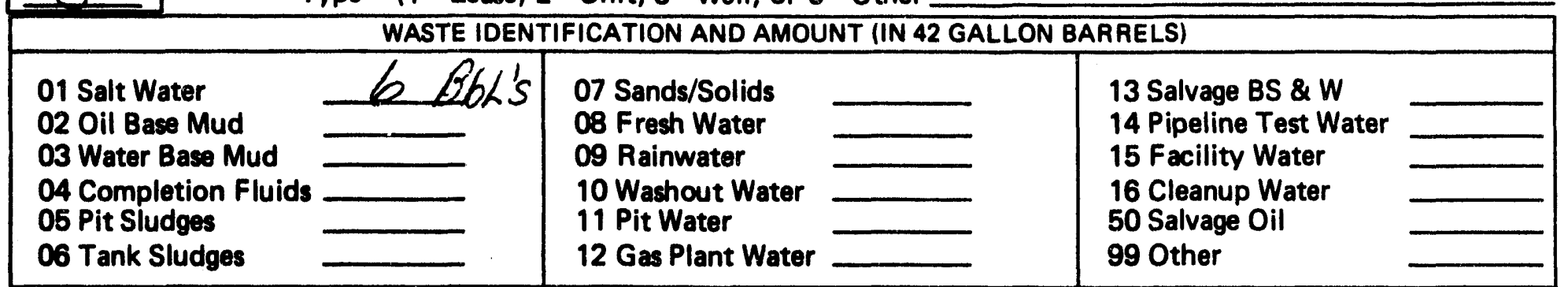

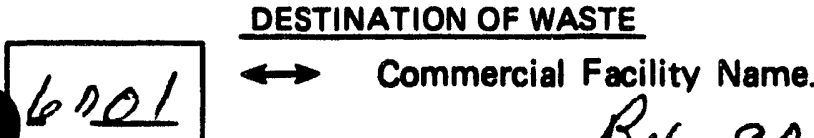

Site Address Bu, 902

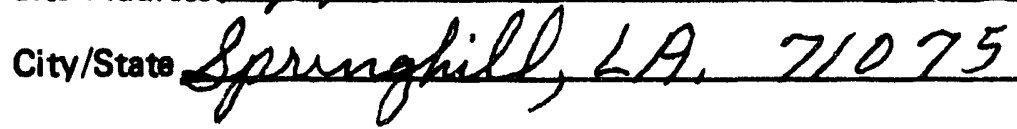

CERTIFICATION: The waste described ebove was consigned to the cerrier nemed below. I certify that the foregoing is true and correct to the best of my knoudadis. Signature of Generator's Authorized Apent $\quad 1-10.89$

Date and Time of Shipment

PART II: TO BECCOMPLETED BY TRANSPORTER IN PRESENCE OF GENERATOR

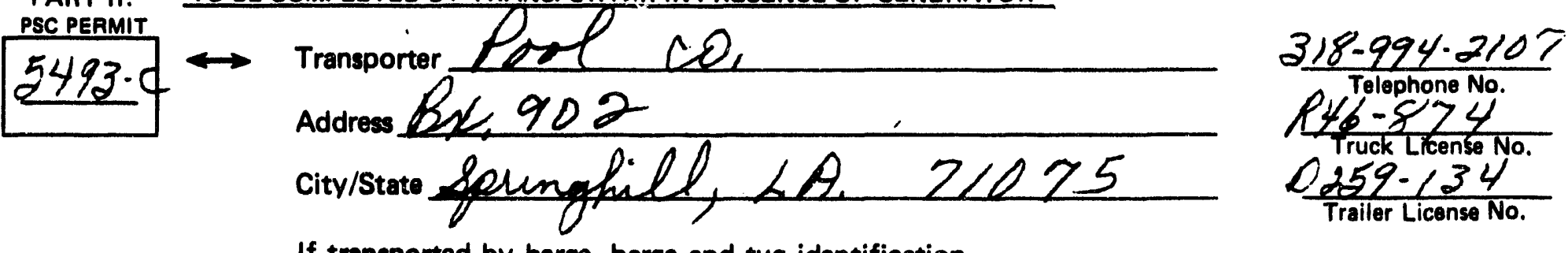

If transported by barge, barge and tug identification

Barge and Tug Id.

CERTIFICATION: I certify that the waste in quantity abovg was recoived by me for shipment to the above destination.

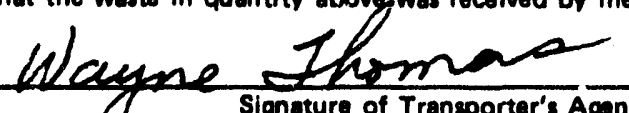

$1.10-89$

Signature of Transporter's Agent

Date and Time Received

PART III: TO BE COMPLETED BY COMMERCIAL FACILITY

CODE $\leftrightarrow$ Facility Operator

Site Name

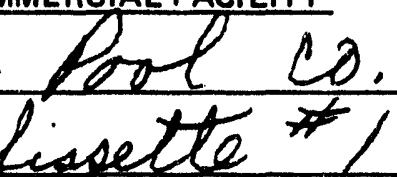

i) CHEMICAL ANALYSES

Chloride $(\mathrm{Mg} / \mathrm{l})$

Conductivity (mmhos $/ \mathrm{cm})$

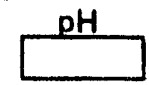

CERTIFICATION: I certify that the waste described in Part I was recaived by me via the transporter described in Part II.

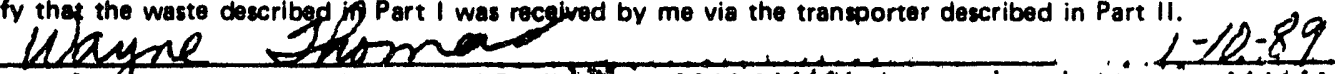




\section{IATER WRLL PLUGCING and ABANDOALENT EORY (DOTD-CI-2)}

PLEASE PRNT DN
NKORTMEE
WHDNCOMPLITNC
THIS FORM

WHaNCOMP

1. WELL OWNER: (fi difterent from owner when dilled, not in item 5)

Loulatana Power s. Iight Co

ADDRESS: 142 Delaronde St. New Orleans, LA 70174 OWNERS WFU NUMBER (it any) DOE LP \& L LH-2A

2. LOCATION Of WELL: Parish: Webster, Well is Near, Minden, LA Approximately 2.6 miles trom Rt. I-20 Exit 44

Hest on Rt. 79

$$
\text { (Please draw sketch on beck of Origina) }
$$

3. WELL INFORMATION: Depth of hole, $1850 \mathrm{~h}$, Diameter ol casing $\frac{6-5 / 8}{\mathrm{in}}$., Depth of completed well, 1652 h. Daw completed $04 / 77$ by (Give name of water well centrector who installed well or hole): Itm=Ce Drilling $\mathrm{CO}$.

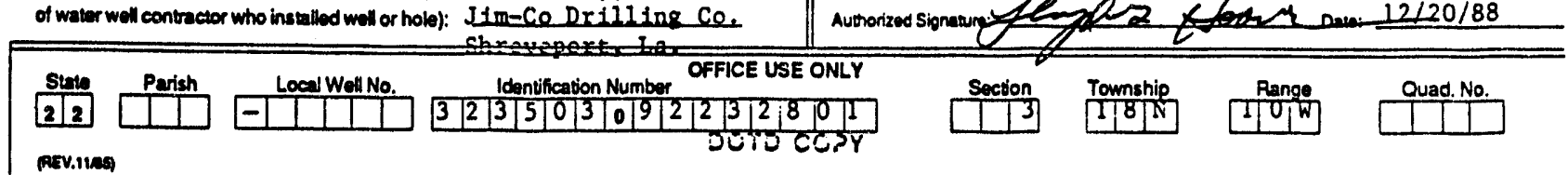

4. Describe in detai how well or hole was plugged: (matorials used, amount of casing and/or screen removed, or lehin hole, otc.) Iremie sand in screenod cection 1652-4796. Cement/bentonite graut in-6-5/8-etng, ot t652, 87-Batonit Pump down 205 sacks. Starm wt. 13.2 16o.tol tut casting at $g^{4}$ tepth. Helded steet cap. BackIIII upper 3 .

5. Remarks: $6-5 / 8^{\prime \prime}$ e.d. Casing surface to $1662^{\prime}$. 4-1/2" Screen Section $1662^{\prime}$ to $1796^{\prime}$.

I corrily that this work wes done and completed in accordance with Rulas and Regulasons of the State on Sept 27 , 1988 by (name and no. of Southweftern Laboratories, Inc. unc 261 contracer Southwe tern Laboratories, Inc. wuc 261

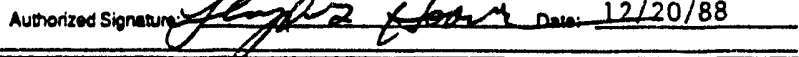
mev.11aต

\footnotetext{
PLEASE PRNTTIN DNORTYPE WHEN COMPLETING THIS FORM
}

1. WELL OWNER: (If diflerent from owner when chilled, nole in item 5 ) Loulstana Power \& Light Company

ADDRESS: 142 Delaronde St. New Orleans. LA 70174 OWNERS WELL NUMBER (H ANY) DOE LPCI IH H-2B

2 LOCATION OF WELL: Parish: Webster Well is Near, Minden IA Approximataly 2.6 miles from Rt I-20 Exit 44 (Crossrosds, Town, City, Raitroad, Any Landmark, elc.) Weat on Rt 70

$$
\text { (Ploase draw sketch on beck ol Original) }
$$

2. WELL INFORMATION: Depth of Kols. 752 th, Diameter of casing $6-5 / 8$ in., Depth of completed well, 752 R. Daw completed 0477 by (Give name of water well contractor who installed well or hole): Iim-Co Drilling Co.

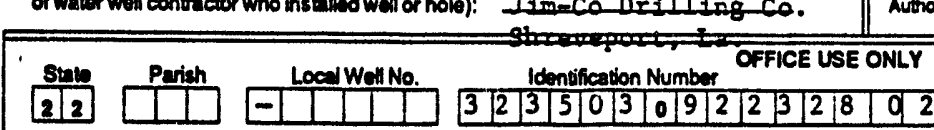
mov.11en ICTS CAPY
ENT OF TRANSPORTATION AND DEVELOPMENT WATER WELL PLUGGING AND ABANDONMENT FORM (DOTD-GW-2)

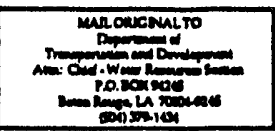

Dascribe in detail how well or hole was plugoed: (malarials used, amount of casing and/or screen removed, or lett in hole, etc.)

Cement/bentonite erout. surface to 744: Pumpdown: 8\% hentonite, slurry wt. $12,6-13,3$ lbs.l gal 97 sacks, Cut casing at 31 dapth; welded steel-eapr-baekf 11 uppex 31.

5. REMARK: $6-5780.0$. Casing surtace to $655,4 \%$ screen section 658 to $744^{\prime} ; 2-3 / 8^{\prime \prime}$ tubing cemented in hole from $73^{\circ}$ to $737^{\circ}$.

l cortity that this work was done and complated in ecoordence with Rules end Regulations of the suivo on Sept. 27 , 19 \&8 by (nume and no. of contrator Southwegern Laboratories, Inc. mpe 261 coninctor Southorized Signawn. \begin{tabular}{|l|l|l|}
\hline Pange \\
\hline 1 & 0 & W \\
\hline
\end{tabular}

Tomahip

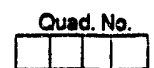

PLEASE PRNT WN
DNKOR TYPE
WHIENCOMPLETING
THIS FORM

1. WELL CWNER: (if difterent from owner when dilled, note in item 5) Loulsiana Power \& Iight Co.

ADUREss: 142 Delaronde St. New Orleans, LA 70174 OWNEAS WELL NUMBER (if anY) DOE - LPEL LH-2WS

2. LOCATION OF WELL: Parish: Webster ,Well is Near, Minden, LA Approximatoly 2.6 miles from Rt. I-20 Exit 44 (Crossroads, Town, City, Railroad, Any Landmark, alc.) West on 79

$$
\text { (Please draw sketch on back of Origina) }
$$

3. WELL INFORMATION: Depth of hol, 420 h. Diameter ol casing $4 \frac{1}{2} \mathrm{~m}$., Depth of completed well, 420 h. Date completed $04 / 7$ I iv (Give name of water woll contractor who installod well or hole): $\mathrm{IIm}-\mathrm{Cl}_{0} \mathrm{Dr}$ il I ing ce.
WATER RESOURCES SECTON WATER WELL PLUGGING AND ABANDONMENT FORM (DOTD-GW-2)

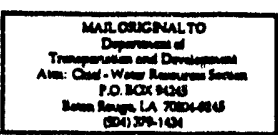

4. Describe in detail how well or hole was plugoed: (materials used smount of gesing $^{\text {a }}$ and/or screen renoved, or lett in hole, etc) Set $r$ et squeeze 6 sacks cement inte screen section. Perforare $20^{\prime}-50^{\prime}$ and squeeze 42 sacks. Dril1 out squeeze to retatner, run geophysical 1080

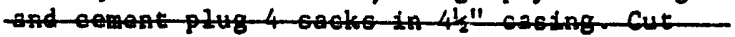
casimg at 9 'deptr. Wetued steel cap.

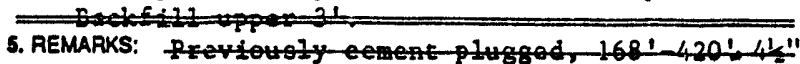

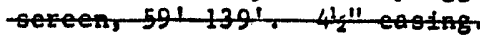

I corrity that this work was tone and completed in acoordance with Aules and Regulation of the Stave on Sept. 27, 1088 by (name and no. of

\begin{tabular}{|c|c|c|c|c|c|c|c|}
\hline Stats & Parish & Looal Well No. & Identficatign Number OFFICE USE ONLY & Section & Tounship & & Quad. iso. \\
\hline \begin{tabular}{|l|l|}
2 & 2 \\
\end{tabular} & & -1 & 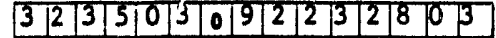 & (3) & \begin{tabular}{|l|l|l|}
1 & 8 & \\
\end{tabular} & I0\% & \\
\hline
\end{tabular}
convecor Southysstern Laboratories, Inc. unc. 261

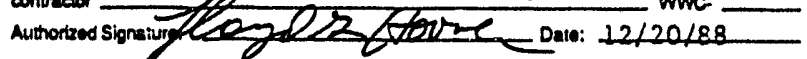




\section{TATER MEL PLOCGIMC And ABANDONMENT BORY (DOTD-GI-2)}

PLEASE PRINT IN DKORTYPE WTENCOMPIDC THIS FORM KCI Hodge Holdings. InC. OWNERS WELL NUMBER (il any) DOE-KCI Hodge Holdings LVH- $-6 \mathrm{~A}$

2. LOCATION Of Well: Parish: Bienville, Well is Near. Fryeburg, LA Approximately 0.6 miles from Intersection Parish Rds. (Crossraads, Town, City, Railroed, Any Landmark, etc.) 499 and 516

$$
\text { (Please draw sketch on back of Original) }
$$

2. WELL INFORMATION: Depth of hole, 3000 h., Diameter of casing $6-5 / 8$ in., Depth of completed well, 2710 n., Date completed 1977 by (Give name of water well contractor who installed well or hole): Jim-Co Drilling $\mathrm{Co}$.

\begin{tabular}{|c|c|c|c|c|c|c|c|}
\hline State & Parish & Local Woll No. & Identification Number OFFICE USE ONLY & Section & Township & Range & Quad. No \\
\hline \begin{tabular}{|l|l|}
2 & 2 \\
\end{tabular} & & \begin{tabular}{|l|l|l|l|l|l|}
-1 & & & & & \\
\end{tabular} & \begin{tabular}{|l|l|l|l|l|l|l|l|l|l|l|l|l|l|l|}
3 & 2 & 2 & 4 & 5 & 7 & 0 & 9 & 3 & 1 & 0 & 0 & 3 & 0 & 1 \\
\end{tabular} & 35 & $1 / 7, M$ & $8 \mathrm{~h}$ & 111 \\
\hline
\end{tabular}

4. Decribe in detail how well or hole was plugaed: (materials used, amount of casing and/or screen removed or lett in hole et: Pump down $8 \%$ Bentorite $92 \%$ Cement

2504 to $1349 \quad 163$ Sacks

1349 to $138 \quad 155$ Sacks

$3+0.138$

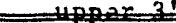

5. REMARKS:

Obstruction at 2504 foot depth.

I cerrily that this wopth wag gofne and compteted in accordance with Aules and Regulations of the Slate on $11 / 18$. 19 . by (name and no. of

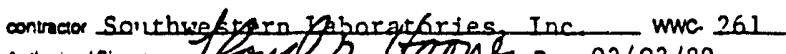

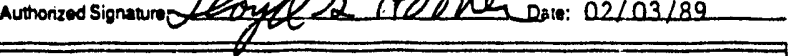
MEV.IIAS
ADDRESS: 1111 Fannin St., Suite 500 Houston, TX 77002
I PLEASE PRNT DN INKORTYPE THISFORM
LOUISIANA DEPARTMENT OF TRANSPORTATION AND DEVELOPMENT WATER RESOURCES SECTION WATER WELL PLUGGING AND ABANDONMENT FORM (DOTD-GW-2)

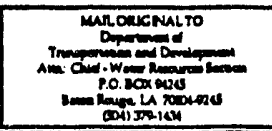

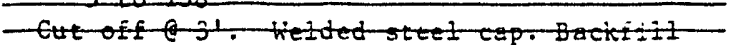

1. WEL OWNER: (il difterent from owner when dilled, note in item 5) KCI Hodge Holdings Inc. ADDRESS: 1111 Fannin St., Suite 500 Houston, TX 77002 OWNERS WELL NUMBER (if any) DOE KCI Hodge Holdings L IVH $-6 \mathrm{~B}$

2. LOCATION Of WELL: Parish: Bienville, Well is Near, Fryeburg, LA Approximately 0.6 mies from Intersection of Parish (Crossreads Town City. Rajilgad, Any Landmark, otc.) (Please draw sketch on back of Original)

WELL INFORMATION: Depth of hole, 193.5 th. Diameter of casing 6-5/8 in., Depth of completed well, 1935 h, Date completed 1977 by (Give name of water well contractor who installed well or hole): Jim-Co D r ill ing Co. Shreveport. OFFICE USE ONLY

4. Describe in detail how well or hole was plugged: (materials used, amount ol casing and/or screen removed, or let in hole, etc.)

Pump dow 8\% Bentont te $22 \%$ coment

$1786-$ to $31-244-$ Stes

Cut off at 3'. Weided steel-cap. Backfil1 upper 3 .

5. REMARKS: Obstruction at 1786'.

I cerrity that this work was done and compleved in ecoordence with Aules and Regulations ot the State on $11 / 17 \quad 10 \quad 88$ by (neme and no. 0 convactor Southwe bern fabogaxories. Inc. wwe 261

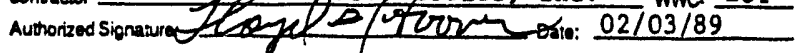

\begin{tabular}{|c|c|c|c|c|c|c|c|}
\hline Siate & Parish & Local Well No. & Idenification Number OFFICE USE ONLY & Section & Township & Range & Quad. No. \\
\hline \begin{tabular}{|l|l|}
2 & 2 \\
\end{tabular} & & -1 & 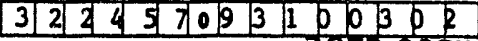 & \begin{tabular}{|l|l|}
13 & 5 \\
\end{tabular} & \begin{tabular}{|l|l|l|}
1 & 7 & $\mathrm{~N}$ \\
\end{tabular} & $8 \mathrm{~W}$ & \\
\hline
\end{tabular}

1 PLEASE PRINT DN DKORTYPE WHEN COMPLETINC THIS FORM

1. WELL OWNER: (II different from owner when drilled, note in item 5) KCI Hodge Holdings, Inc.

ADDRESS: 1111 Fannin St., Sulte 500 Houston, TX 77002 OWNERS WELL NUMBER (if any) DOE/KCI Hodge Holdings LVH-6C

2. LOCATION of WELL: Parish: Bienville Woll is Near, Fryeberg, LA Approximately $\frac{0.6}{\text { (Crossroads, Town, City, Raliroad, Any Landmank, elc.) }}$ Roads 499 and 516

$$
\text { (Please draw sketch on back of Original) }
$$

3. WELL INFORMATION: Depth of hole, $\frac{985}{h}$, Diameter of casing $6-5 / 8$ in., Depth of completed well, 985 h, Date completed 1977 by (Give name of water well contractor who installed well or hole): Jim-Ce Drillifig $\mathrm{Ce}$. OFFICE USE ONLY State Parish Local Well No. Identification Number OFFICE USE ONLY

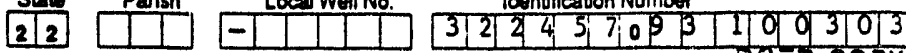
AEV.11A)
TI OF TRANSPOATATION AND DEVELOPMENT ABANDONMENT FOAM (DOTD-GW-2)

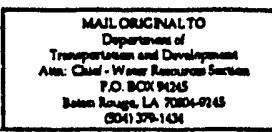

4. Describe in detail how well or hole was plugged: (materials used, amount of casing and/of screen removed or lett in holv, or.

868 to $113 \quad 95$ Sacks

113 to 3 12 Sacks

Cut off at $3 \prime$. Welded steel cap.

Batifit uppex 31 .

5. REMARKS: Obstruction at 868 !

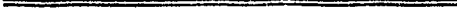
I cerrity that this work was done ane completog in acepectance wion Rules and Regulasions of the State on $11 / 16$.19 by (name and no. of convecor Sowthwestern Iaboratories. Inc. wwe 261.

\begin{tabular}{|c|c|}
\hline Section & Tounship \\
\hline
\end{tabular}

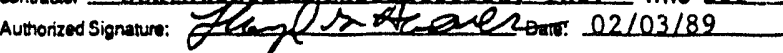

Pange
Quad. No. 
1 PLEASEPRTtin PLEORTMPE WHORTME THISFORM

1. WELL OWNER: (il difierent trom owner when dilled, note in itom 5)

KCI Hodge Holdings. Inc.

ADDRESS: 1111 Fannin St., Sulte 500 Houston, TX 77002 OWNERS WELL NUMBER (I any) DOE/KCI HOdge HOIdIngs LVH-6WS

2 LOCATION OF WELL: Parish: Bienville Well is Near Fryeburg, LA Approximasty 0.6 miles trom Intersection of Parish (Croserands, Town. Cily, Railroad, Any Landmark, atc,) Roads 499 and 516

$$
\text { (Plosece draw sketch on beck ol Origina) }
$$

3. WELL INFORMATION: Depth of hol, 144 th, Diameter of casing 4.5 in Depth of completed well, 92 R. Date completed $04 / 77$ by (Give name

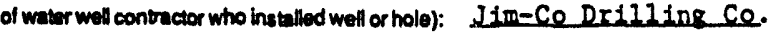

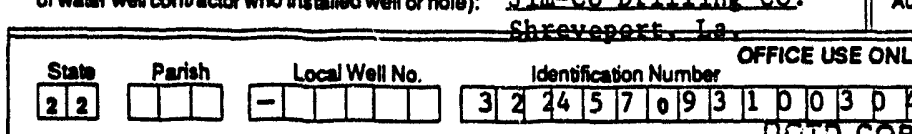
Arv.sies
WATER AESOURCES SECTON WATER WELL PLUGGING AND ABANDONMENT FORM (DOTD-GW-2)

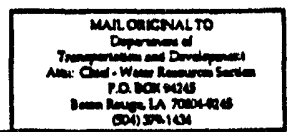

4. Describe in detail how woll or hole was plugged: (materials used, amount of casing andy or screen removed, or lett in hole, etc.) Q3' to 38 ' Tremie Sand 5 Sacks 92\% Cement 3 Sacks Cutiof at 4. 5 ' Welded steel cap-... - - Backf 111 to-surface. -

5. REMARKS: Abandoned Watar Supply We11 Bottom of screan at 93 . Tail pipe 5098 . 14 14

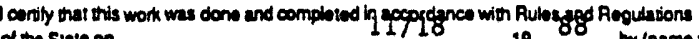
of the Slate on contreor Southwes ferg, Laboratories. Inc. wuc. 261

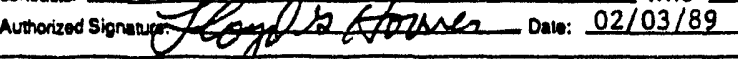

\section{ALY}

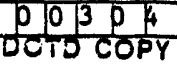

\section{Range}

PLEASE PRINT IN
NKORTPE
WHIENCOMPLETING
THIS FORM

\section{LOUISIANA DEPARTMENT OF TRANSPORTATION AND DEVELOPMENT WATEA RESOURCES SECTION WATER WELL PLUGGING AND ABANDONMENT FORM (DOTD-GW-2)}

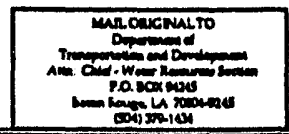

4. Describe in detail how well or hole was plugged: (materials used, amount of casing and'or sereen removed or lett in hole, elc.)

156, to 146, Tremie sand 9 sacks

146 ' to Surface Pump Down Grout

87 Bantonto 227 Comont 20 sacks

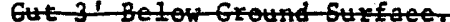
cap. backf 111 upper 3 feet.

12-3/4 Inch surface casing 0-400 $20^{\prime \prime}$ conductor pipe, 0 to 57

I corrity that this work was done and complotod in ecoordence with Ruibg and Rogulabions of the sute on $11 / 30$. 19 88 (neme and no. of convector Southwe stern Igboratories, Inc. unc 261

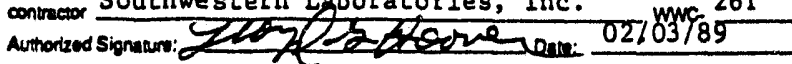

3. WELL INFORMATION: Depth ol hole, $2619 \mathrm{~h}$, Diameter of casing $6-5 / 8_{\text {in. }}$. Depth of completad well. 1570 h. Date completed $04 / 77$ by (Give name of water well contractor who installed well or hole): Jim-Co Drili ing Co. State Parish Local Well No. Shreveport. LA CFFICE USE ONLY

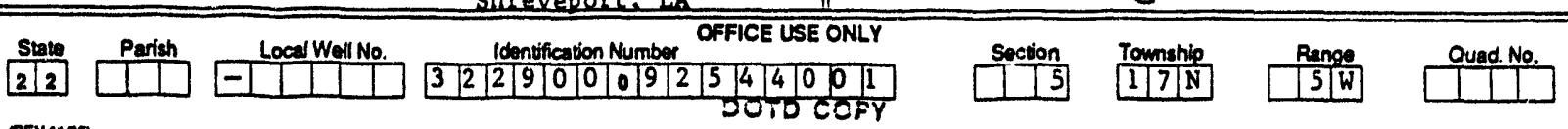
(AEV.11n)

\section{LOUISIANA DEPARTMENT OF TRANSPORTATION AND DEVELOPMENT WATER RESOURCES SECTION WATER WELL PLUGGING AND ABANDONMENT FORM (COTD-GW-2)}

PLEASE PRINT

WHEN COMPLETING THIS FORM

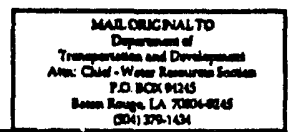

1. WELL OWNER: (if different trom owner when drilled, note in item 5) _KCI_Hadge Holings, Inc. ADDRESS: 1111 Fannin St., Sulte 500 Houston, TX 77002 OWNERS WELL NUMBER (II any) KCI Hodge Holdings LH-7B

2. LOCATION Of WELL: Parish: Bienville, Well is Near, Arcadia, LA Approximately 3.9 miles from $\mathrm{Rt}$. 147, South on (Crossroads, Town, City, Railroad, Any Lancinark, olc.) Partsh road 173 .

$$
\text { (Please draw sketch on back of Original) }
$$

3. WELL INFORMATION: Dephof hole, $\frac{1052}{n}$, Diamefor olcasing $\frac{6-5 / 8}{4}$ in. Depth of completer well, 1047 h. Date completed $04 / 77$ by (Give name of water well contractor who installed woll or hole): Jim-Co Drilling Ce.

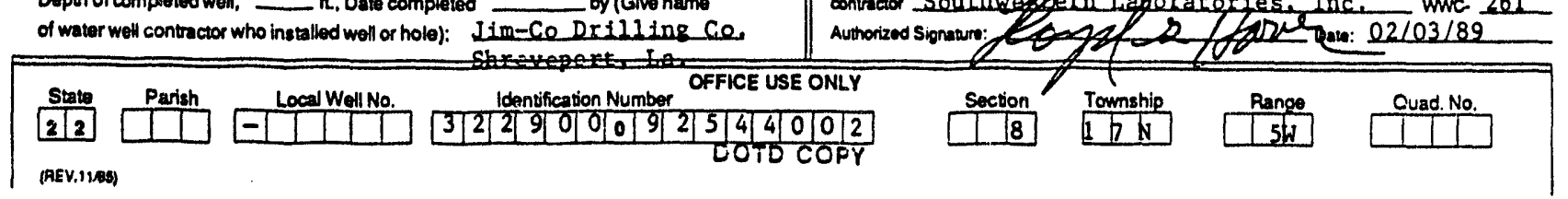

4. Describe in detail how well or hole was plugged: (materials used, amount of casing

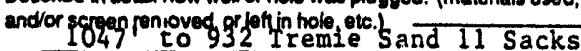
$932^{\prime}$ to surface pump down grout 124 sacks 87 Bentonite 922 Cement Cutoff at $3^{\prime}$ Welded steel cap Dackfill to-surfoer

5. REMARKS: 20 " Conductor pipe, 0 to 571

(a)

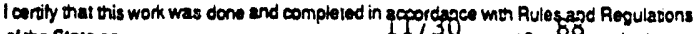
of the State on $11 / 30$. .10 by (name and no. of convation Southwedorer. I.atoratories. Inc unc 261

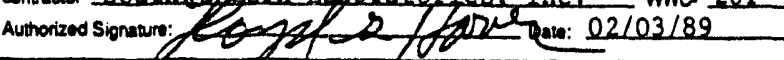
NLY Section Township Township Range KCI Hedre Holdings. Inc.

2 LOCATION OF WELL: Partish: Blenville Well is Near, Arcadia Aproximately 3.9 miles trom Rt. 147. Sow 


\section{MATER MFLT PLOCGINC and ABANDONLENT FORY (DOTD $-G T-2)$}

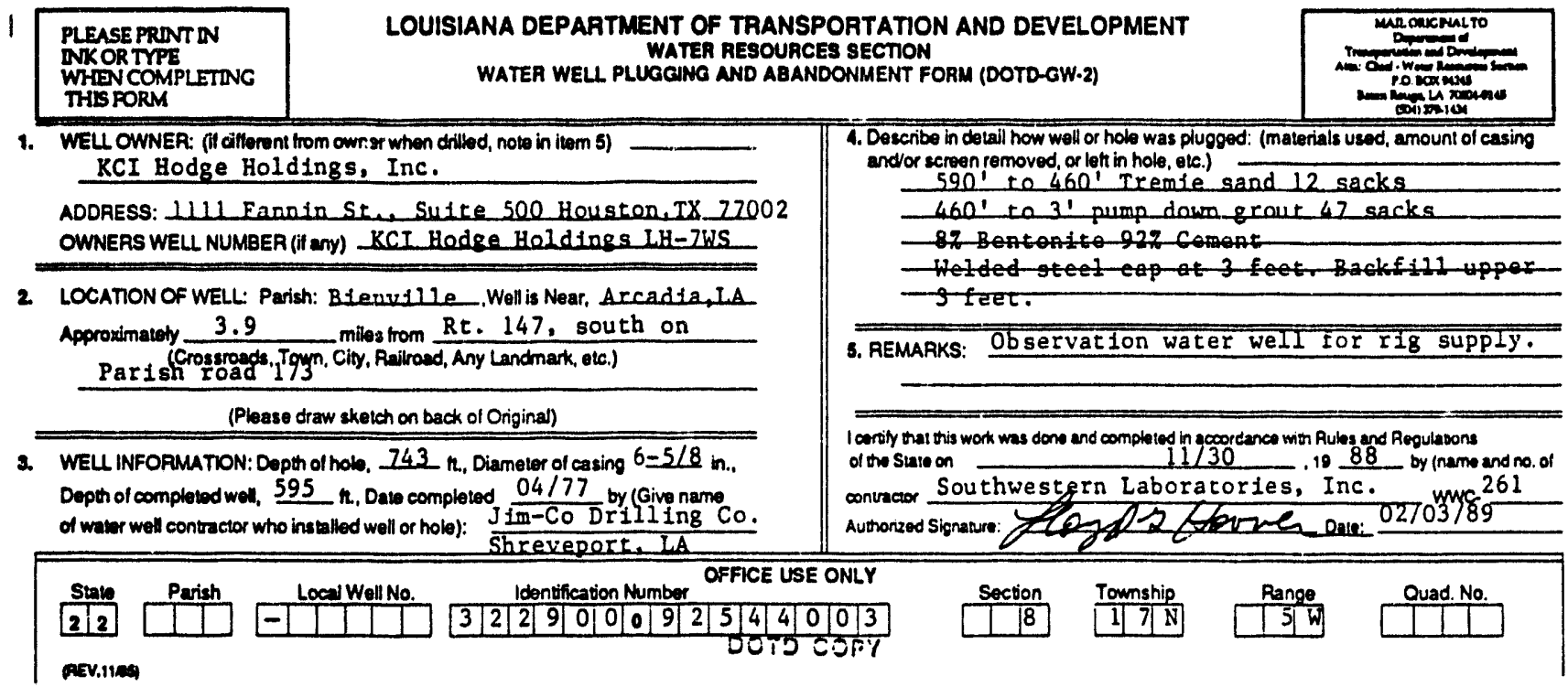

\section{PLEASE PRNT DN DNKOR TYPE THIS FORM} LOUISIANA DEPARTMENT OF TRANSPORTATION AND DEVELOPMENT
WATER RESOURCES SECTION WATER WELL PLUGGING AND ABANDONMENT FORM (DOTD-GW-2)

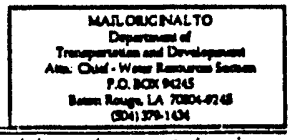

4. Describe in detail how well or hole was plugged: (materials used, amount of casing and/or screen removed, of leth in hole, etc.)

$2022^{\prime}$ to $1960^{\prime}$ Tremie sand 3 sacks

$1960^{\prime}$ te $3 '$ Pumpdown grout 204 sacks 8\% Bericrite $92 \%$ Cement

Cut af 3 foet belded steel olate backfilt to surface.

2. LOCATION OF WELL: Parish: Blenville, Well is Near, RInggold, LA Approximately $\frac{0.4}{\text { (Croserosds, Town, City, Rairoud, Any Lendmat, olc.) }}$

(Please draw sketch on back of Original)

3. WELL INFORMATION: Depth of hole, $2400 \mathrm{th}$, Diameter of casing $6=5 / 8 \mathrm{in}$., Depth of completed well, 2045 h. Date completed $04 / 77$ by (Give name of water well contractor who installed woll or hole): Jim-Co Drili ing Co. ( Shrevepore. IA

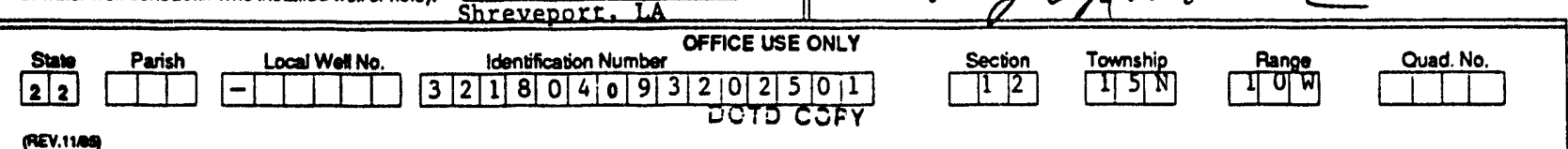

5. REMARKS: $10.15^{\text {Turface casing o to } 400^{\circ}}$ 20.0 " Conductor pipe 0 to $48 \%$

loerity that this work was done and completed in acogrence mot Ruleg grod Regulations of the State on $11 / 21$, 1988 by (name and no. of convactor Southwesgen Laborargries, Inc. 261

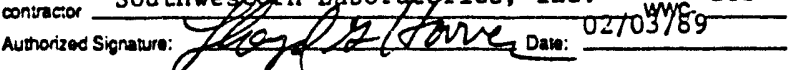

\section{PLEASE PRDNT DN DNKORTYPE WHIN COMPLETINC THISFORM}

1. WELL OWNER: (fi diferent trom owner when drilled, note in itom 5) KCI Hodge Holdings, Inc.

ADDRESS: 1111 Eannin St. Suite 500 Housten. IX 77002 OWNERS WELL NUMBER (fi any) KCI Hodge Holdings IH-17B

2. LOCATION Of WELL: Parish: Btenvilile, Well is Near, Binggold, IA Approximately 0.4 miles from Rt. 154 South on 536 (Crossroads, Towr, City, Railroad, Any Landmark, atc.)

(Please draw sketch on back of Original)

3. WLL INFOFMATION: Depth of hole, 1385 th. Diameter of casing $6-5 / 8 \mathrm{n}$., Depth of completed well, 1385 h. Date completed $04 / 77$ by (Give name of wawe well contractor who installed well or hole): Jim-Co Drilling $\mathrm{Co}$. Sian Parich Local Well No. Identification Number OFFICE USE ONLY

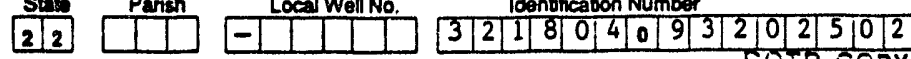
PEV.11日e)

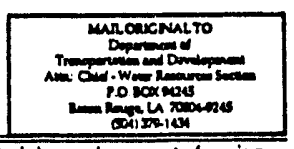

4. Describe in detail how well or hole was plugged: (materials used, amount of casing andlor screen removed, of let in hole, e.:.)

13721 to $1298^{\prime}$ Tremie Sand 7 sacks $1298^{\prime}$ to $3^{\prime}$ pump down grout 278 saclis 82 Bentanite $92 \%$ Cement lut off at $3 '$ Welded steel cap. Backfill uppox 3 foet. _. _ _ _

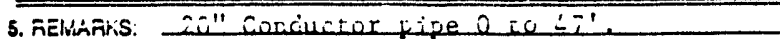

l cerrity tha! this work was done and compleled in acoordance with Rules and Regulations d the State on $11 / 21,19-88$ - by iname and no. of

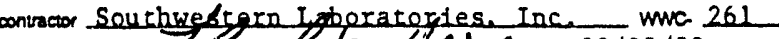

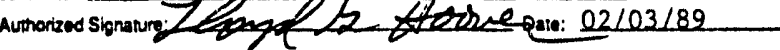




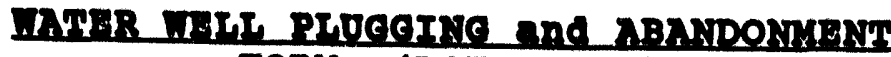 ZORY (DOTD-CI-2)}

PLEASE PRNT IN NKORTMPE 19N COMPLITING THIS FORM

1. WELL OWNER: (ll dilferem from owner when dilled, noto in itom 5) KCT Hodee Holdingen Inc. ADDRESS: 1111 Fannin St., Suite 500 Houston, Tx77002 OWNERS WELL NUMBEA (if any) KCI Hodge HoldIngs LH-17WS

2 LOCATION of WeL: Parich: B fenville, Woll is Noar, RInggold, LA Approximatily 0.4 milas from Rt. 154 south on 536 (Crossroads, Town, City, Reilroad, Any Landmark, etc.)

(Please druw sketch on beck of Original)

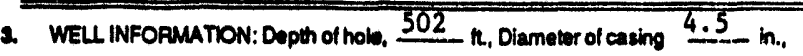
Depth of completed well, 436 R. Daw completed 04/72 by (Give name

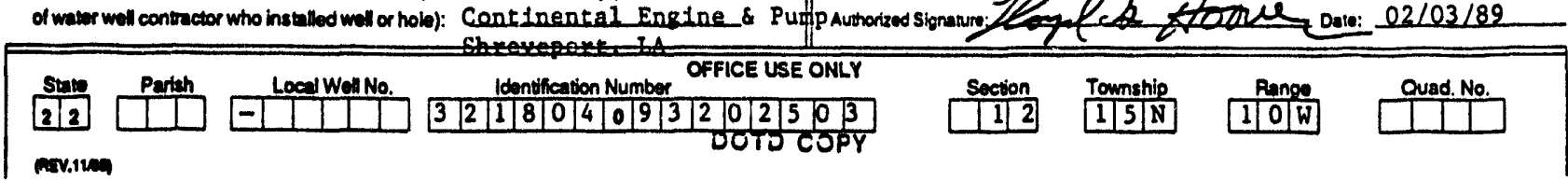

\section{PLEASE PRNT DN DNKORTMPE WHEN COMPLETINC THIS FORM}

1. WELL OWNER: (1 ditterent trom owner when drilled, note in item 5) Norhere C. Rayford ADDREss: 7727 Nottingham St. Baton Rouge, LA 70807 OWNERS WELL NUMBER (if any) DOE N.C. Ray ford V-4

2. LOCATION OF WELL: Parish: Webster, Well is Near, HefI In, LA Approximatoly 1 milos trom Intersection of Parish (Crosegoeds, Town, City, Railrosd, Any Landmark, etc.) Roads 171 and 165

(Plaase draw kkatch on bach of Original)

WELL INFORMATION: Depth of hole. $\frac{754}{\mathrm{~h}}$, Diameler of casing 6 in., Depth of complated well, 488 $\mathrm{n}$. Dale completed 04/77 by (Give name of water well contrecior who installod woll or holo): Layne Central Dif.

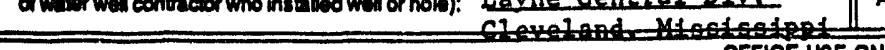

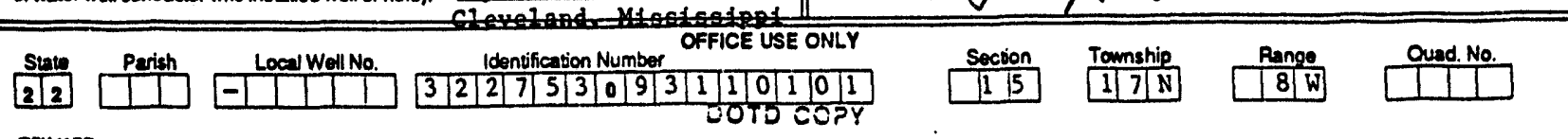

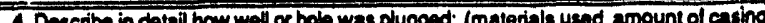
and/grofrean remayg\%, or latin holo oty.

475 to 31 Pump Down Grout 45 Sacks Cut off at 31 Welded Steel Cap. Backfil upper 3 feet.

5. REMhrins:

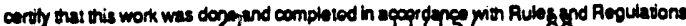
of the Stati on contnetor SouthegRern I aboratories. Inc. whe 261

\section{LOUISIANA DEPAATMENT OF TRANSPORTATION AND DEVEL.OPMENT \\ WATER RESOURCES SECTION WATER WELL PLUGGNG AND ABANDONMENT FOAM (DOTD-GW-2)}

4. Describe in detall how well or hole was phugend: (materials used, amount of casing

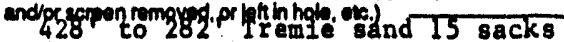
$282^{\prime}$ to $3^{\prime}$ pump down grout 15 sacks Cut off at $3 \prime$. Welded steel cap Backfill upper 3 feer

5. REMARKS:

cartily that this work wes done and completed in ecooctengay fit Rulos and fepulations of the saw on 11721.1908 by (name and no. of contracer Southwofere Iaboracories. Inc. unc 261

REV.11EA

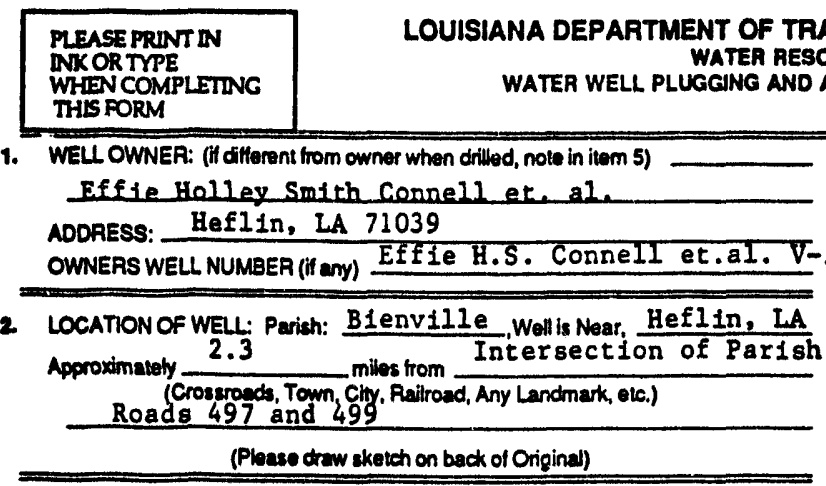

3. WELL INFORMATION: Depth of hole, 815 th, Diameler of casing 5.0 in., Depth of completed well, 387 h. Date completed $03 / 77$ by (Give name of water well contractor who installed well or hole): Layne Central D IV.

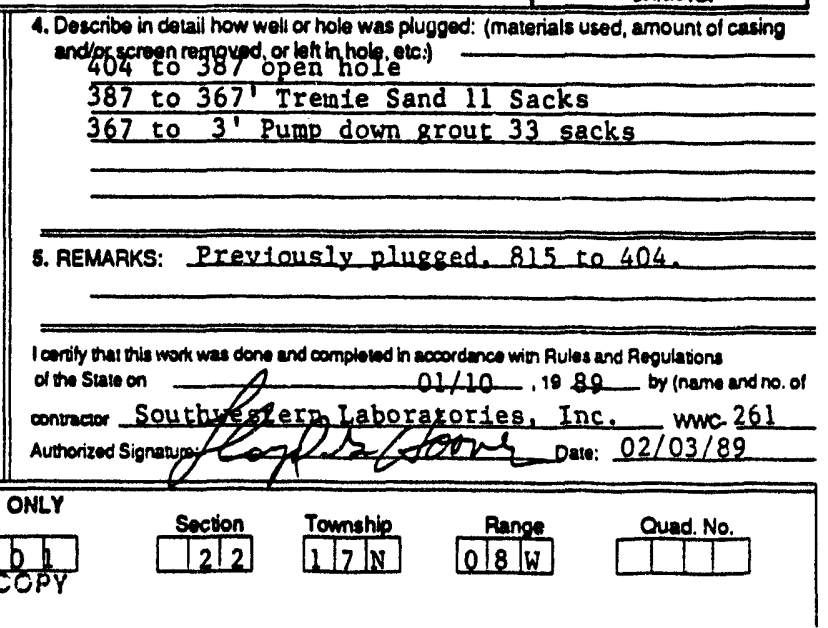




\section{WATER MFI, PLOCGTNC and ABANDONYENT EORY (DOTD-CII-2)}

PLEASE PRNT IN NKKORTYP: MTENCOMPLETING THDS FORM

1. WELL OWNER: (II dillerent from owner when dilled, nole in Item 5) Garland P. Theus

ADDRESS: P. 0. BOX 165 Dubberly, LA 71024 OWNERS WEUL NUMBEA (if any) DOE-G.P. TheY 8 V-6

2. LOCATION OF WELL: Parish: Blenville, Woll is Near, Erybers. IA Approxinauly 2.6 milestrom Intersection of Pardsh

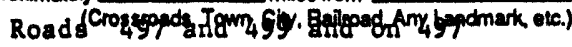

\section{(Please drow skelch on back of Original)}

3. WELLINFORMATION: Depth of hol, $643 \mathrm{~h}$, Dianeter of casing $\frac{5.5}{\mathrm{in}}$., Depth of completed well, 608 th, Daw completed $04 / 72$ by (Give name of water well contractor who installed well or hota): I Ianford Drill ing Co.

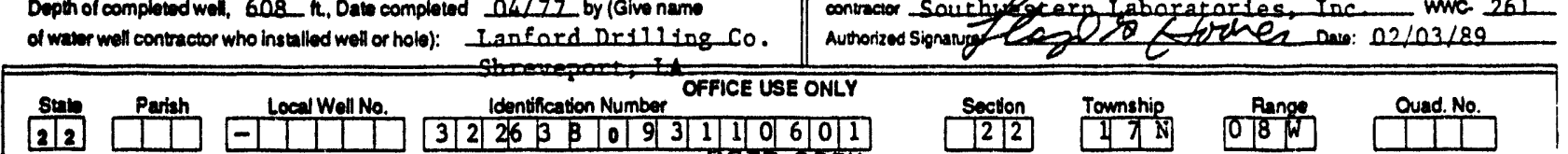

OPANSPORTATION AND DEVELOPMENT

WATEA AESOUACES SECTON

WATEA WELL PLUCGINO AND ABANDONMENT FORM (DOTO-GW-2)

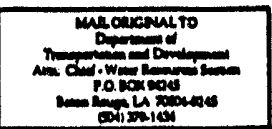

Describe in datail how well o hole was plugoed: (materials used, amount of casing

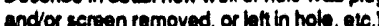
603 to 3 Pump Down Grout 46 Sacks 87 Bentonite 922 Cement

5. REMARKS:

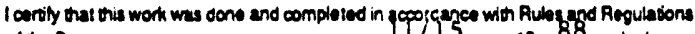
of the Sutio on 19 , 88 by (name and no. of convector Southwherp laboratories, Inc_unc. 261

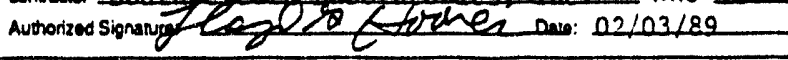
Doto Coके \begin{tabular}{l|l}
2 & Tounship \\
\hline 1 & 1
\end{tabular}

arvinue

I PLEASE PRINT IN

INKOR TYPE

WHEN COMPLETINC

THIS FORM

1. WELL OWNER: (it difterent from owner when dilled, note in ittem 5)

Effle Holley Smith Connell et, al.

ADDRESS: BOX 14 Heflin. IA 71039

OWNEAS WELL NUMBER (if any) DOE - ENS COnnE11 V-7

2 LOCATION Of WELL. Paris: Webster Well is Near, Heflin, IA Approximably 1 miles from South of Intersection of Parlsh Roa'd's Ifly, Railoand Any Landmatk, olc.)

(Please draw sketch on back of Original)

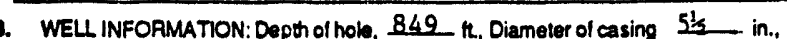
Depth of completed well, 849 R. Date completed $04 / 77$ by (Give name of water well contrector who instaled well or holo): Lanford D I 11 I ing Co. Sun Larish Low Well No. Shreveport. IA

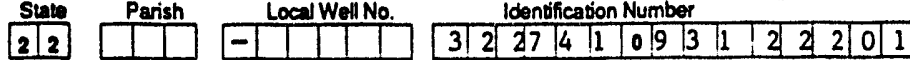
(AEV.11a)
NT OF TRANSPORTATION AND DEVELOPMENT WATER RESOURCES SECTON
WATER WELL PLUGGING AND ABANDONMENT FORM (DOTO-GW-2)

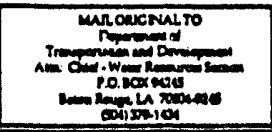

4. Describe in detail how well or hole was plugge of (materiat used anougl of casing

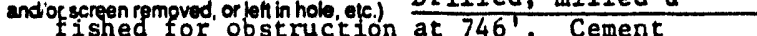
bentonite, 72 sacks cement. Cut casing at 3 'depth. Welded steel cap. Backf 111 upper 31 surface to $742^{\prime} \cdot 8 \%$ bentonite

5. REMARKS: Obtained vactacce to plug above abstruction at 746' sk' casing to $796^{\prime}$ I cerrity that this work was done and gompleled in accordance with Rules apgd Regulabions of the State on SePt. 27, 19 g8 by (name and no. of

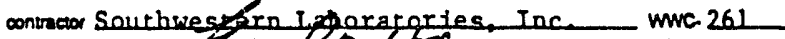

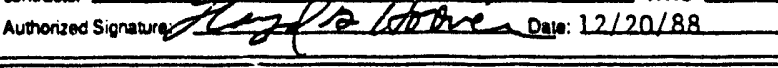
-TTS EOFY

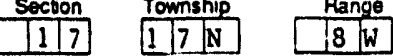

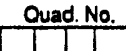

PLEASE PRNT N INKORTTPE WHEN COMPLETWN

\section{LOUISIANA DEPARTMENT OF TRANSPORTATION AND DEVELOPMENT} WATER RESOURCES SECTION WATER WELL PLUGGING AND ABANDONMENT FORM (DOTD-GW-2)

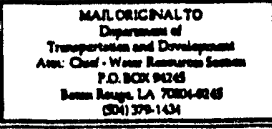

1. WELL OWNER: (if difterent from owner when drilled, note in itom 5)

Derwood D. Hires

ADDRESS: Rt. 1 BOX 79 B Benville, LA 71008 OWNERS WELL NUMBER (if any) DOE Derwood D. HInes LSU-RIA

2 LOCATION OF WELL: Parish: Bienville Woll is Near, Friendship, LA Approximately $\frac{0.25}{\text { (C.os srcads, Town Ciry, Rem troad, Any Landmark, etc.) }}$ of Hory. 4 and 155.

$$
\text { (Please draw sketch on beck of Original) }
$$

3. WELL INFORMATION: Depth of hole, $1112 \mathrm{H}$. Diameter ol casing $4.0 \mathrm{in.}$ Depth ol completed well, 489 h, Date completed $04 / 77$ by (Give name of water well convertor who insallod wall $\alpha$ hole): Stamm-Scheele Inc.

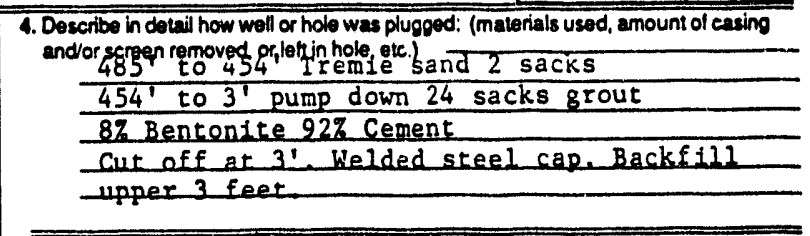

5. AEMARKs: $7^{\prime \prime}$ Surface casing 0 to $60^{\prime}$.

I conily that this work was done and completed in accordence with Rules and Plegulabons of the Siate on $11 / 20,1989$ by Iname and no. of convacior Southwege gon yabpratoyies, Inc. wwe 261

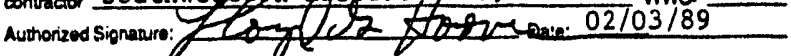

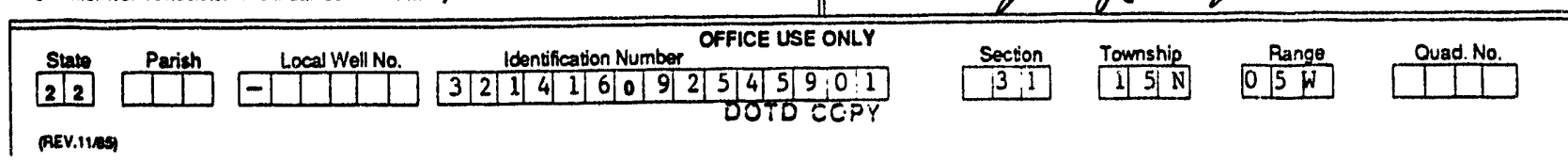




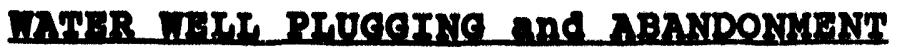 ZORY (DOTD-CI.-2)}

rackginT aN arokTrs ipronse THS PONM

1. WELL OWNER: (I difienent from owner when dillod, noto in Ham g) Cont Inencel Hodes Wondlande. Inc. ADOAEss: P. O. Drawer Hodge, LA 71247 OWNERS WELL NUMBER (Hay) DOE COntInental F.I. et.aI. Nol

2. LOCATION Of WeLL: Parth: Blenville Well Near, Lucky, LA Approximately 4 miles trom Lucky, east on Rt 4 Croseroede, Town, City, Raibroed, Any Landmark, eic.) $680^{\prime}$ down accesp rogd on south side of Rt. 4 (Ploase draw sketch on beck ol Origina)

2. WELL INFORMATION: Dopth of hol, $5013 \mathrm{~h}$, Diameler of casing $9-578 \mathrm{~h}$. Depth ol complesed well. $424 \mathrm{R}$, Daw completed $04 / 72$ by (Give namo of water well contractor who hatalied well or hole): Unknown
ENT OF TRANSPORTATION AND DEVELOPMENT

WATEA RFEOURCEB BECTION WATER WELL FLUOCANO AND ABANDONMENT FORM (DOTO-OW-2)

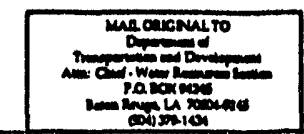
4. Descrbe in dotail how well or hole was plugged: (materials used, anount of casing and/o segen remayed, orlohin hole, elc. ${ }_{\text {to }} 57$ sacks grout 87 Bentonite 927 Cement Gut off at 3 '. Welded steel cap. Back fill uppar 3 feet

6. REMARKS: Open 8. 5" uncased hole. 5013 to $424^{\prime}$ 13.6" Conductor Pipe, $59^{\prime}$ to surface

1 corrity that this work was done and comploted th acoordences witn Rulas and Regulatione

d the Staw on 12/01, 19 88 by (neme and no. of contractor Southwehterg Iaboratories. Inc. unc 261

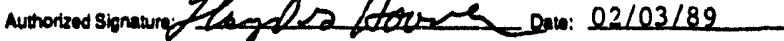

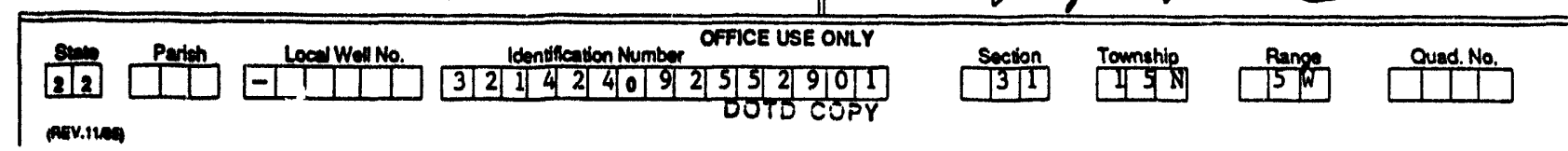

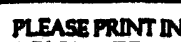

LOUISIANA DEPARTMENT OF TRANSPORTATION AND DEVELOPMENT WATER RESOURCES SECTON WATER WELL PLUGGNG AND ABANDONMENT FORM (DOTD-GW-2)

1. WELL OWNER: (if difterent from owner when dilled, now in item 5 )

Effie Holley Smith Connell at 21 .

ADORESS: Hef1 in, LA 71309

OWNERS WEL NUMBER (it any) DOE/Smith et.al. No. I

2 LOCATION Of WELL: Parich: Webster Woll is Near, Hef I in, LA Approximabely $\frac{0.7}{\text { (Crossroads. Town, City, Rowload, Any Lendmark, etc.) }}$ Road 169 on an access road to the right. (Please draw sketch on back of Origind)

3. WELLINFORMATION: Depth of hol $5043 \mathrm{~h}$. Diameler of casing 2-5/8 in Depth ol completed well, 972 h., Dave completed $04 / 77$ by (Give name of waber well contrector who installed well or hole): Unknown

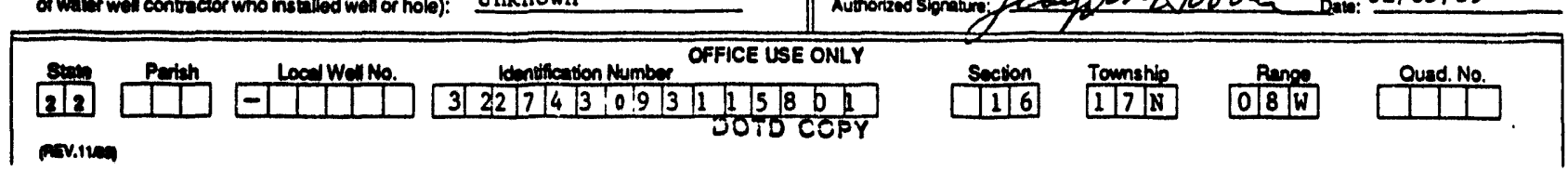


APPENDIX C

ADDITIONAL DOCUMENTATION

Variance Requests and Approvals

Site Location Plats

Landowner Releases 


\section{SOUTHWESTERN LABORATORIES}

Materials, environmental and geotcchnical cnginecring. nondestructive, me'allurgical and analytical scrvices >2e2 Greenwood Rd. • P.O. Box $37577 \cdot$ Shreveport. LA $71133.7577 \cdot 318 / 636 \cdot 3673$

LA DOTD

September 9, 1988 FILE COPY
J.O.NO. 17500
TFSC-SRPO

In accordance with Section 3.2.4.0 of Chapter III state Water $=00=0$ Well Rules, Regulations and Standards we are submitting for your review and approval a variance request for plugging and abandonment of DOE monitoring well $\mathrm{V}-7$. This well is located on Vacherie Salt Dome in Webster Parish, Loulsiana, Township $17 \mathrm{~N}$ Range $8 \mathrm{~W}$ Section 17.

The well was drilled in April of 1977 by Lanford Drilling Company under the direction of Loulsiana State University. A schematic of the completed well design is attached. Since drilling preceded DOTD regulations the well is not registered with the DOTD. Southwestern Laboratories, Incorporated has been contracted to plug and abandon the well by Stone \& Webster Engineering Corporation for the DOE.

Plugging and Abandonment activities commenced on September, 1988. An obstruction was tagged at 124.1 feet in $6-5 / 8$ inch casing. Drill cuttings revealed the obstruction consisted of bottles, cans, wood and rocks. The hole was advanced two (2) feet. On September 2, 1988 drilling activities resumed with a $4-3 / 4$ inch milling tool. The obstruction was cleared to 740 feet the 3-1/2 inch riser pipe, but could be advanced : er. Drilling in the $3-1 / 2$ inch riser pipe resumed tember 9,1988 with a $2-7 / 8$ inch roller bit. The hole was advanced from 740 feet to 744 feet. On September 7, 1988 Otis Wireline fished the obstruction with a magnet, spear, pump bailer, junk basket, and impression block and retrieved evidence of a metal fish. The drilling string was tripped in the hole with a 2-7/8 inch spoon sampler and retrieved 18 inches of 2 inch diameter steel pipe. Another wireline survey indicated that metal remained in the well. On September 8,1988 a 3 inch diamond impregnated milling tool advanced the hole from 744 feet to 746 feet. 
Plugging \& Abandonment

Vacherie Salt Dome

Webster Parish, La.

September 9,1988

Letter, page 2

An examination of the milling tool indicates that the metal obstruction is wedging the tool against and possibly into the $3-1 / 2$ inch riser pipe. We have advanced the hole only 6 feet during four days of drilling, fishing and milling activities. On this basis we request that the hole be plugged using the continuous pumpdown method from the top of the obstruction (at $746 \mathrm{feet}$ ) to ground surface. As shown on the attached sketch the hole has been advanced to within 50 feet of the top of the screen. We believe that bottom cement at the proposed depth will not affect the integrity of the plugging job.

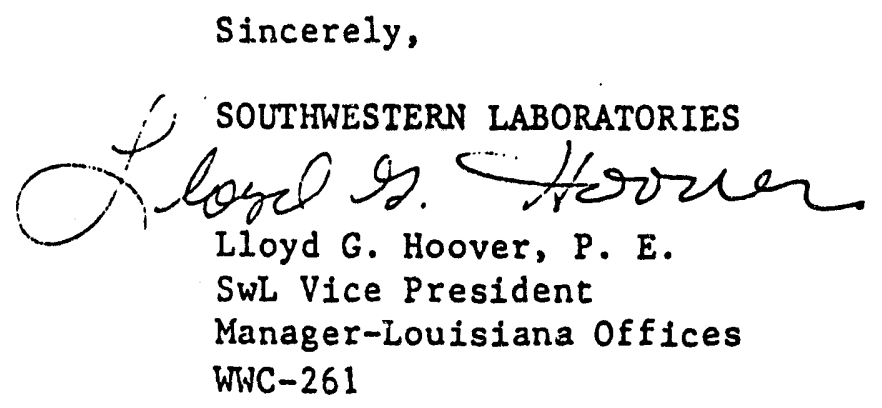

LGH : awd

Stone \& Webster Engineering Company's representatives concurs with this letter.

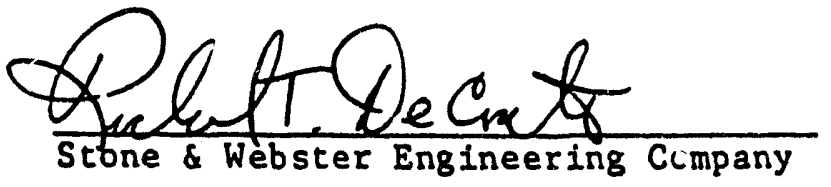


464

$6: 1,-i$

Fl el D N Ni.

Table B-4. Well completion description, Well V-7, Vacherle salt dome.

$h-4 B \quad P_{0} 3 / 4$

hanford Drilling Company, Inc.

-P.O. Box 98 - Shreveport, La.•11161

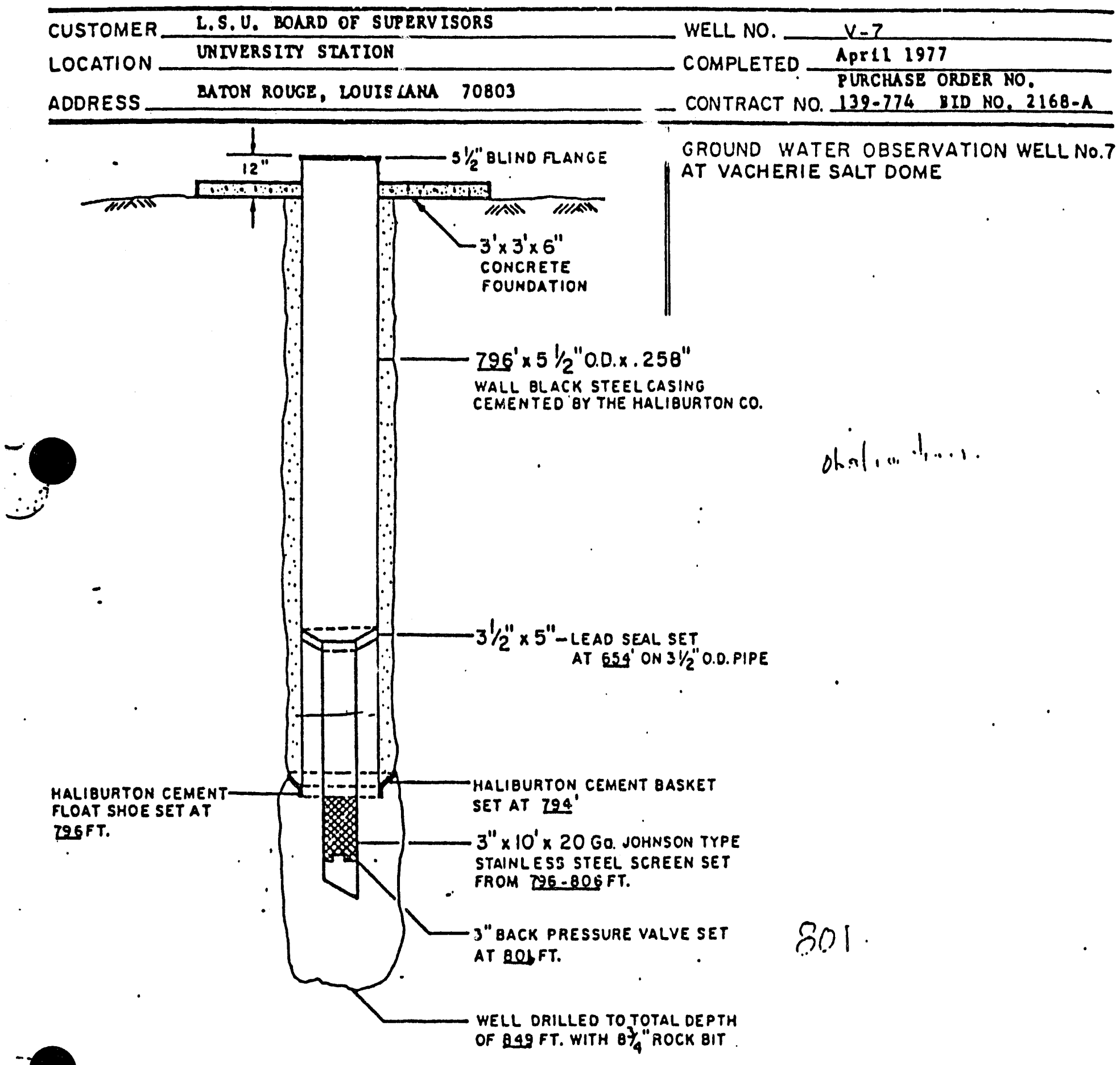




$$
1-4 E \quad F: 4 / 4
$$

\section{LOUISIANA DEPARTMENT OF TRANSPORTATION AND DEVELOPMENT P. Box 94245. Baton Rouge. Louisiana 70804-9245}

\section{TRANSPORTATION}

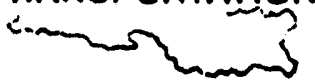

(504) $379-1434$

NEIL L. WNAGCNER, FE.
SECRETARY

BUDOY FOEMER GOVERNOR

September 29, 1988

Mr. Lloyd G. Hoover, P.E.

SOUTHWESTERN LABORATORIES

P.0. BOX 37577

Shreveport, Louisiana 71133-7577

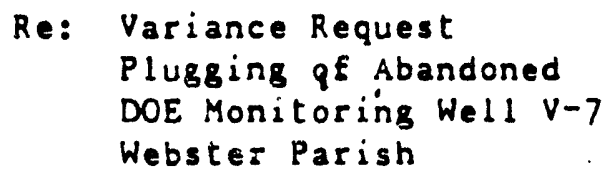

Dear Mr. Hoover:

This is in response to your letter of September 9, 1988, requesting a variance to plug the above referenced monitoring well from the top of the obstruction (746 ieet) to ground surface.

Please be advised that based on the information contained in your let.tel. we have no objection to the $=$ lugging procedure outlined in the subject leller. all other applicable water Well Rules, Regulations, and Standards shall be complied with.

If we may be of any further assistance, please do not hesitate to contact wis office.

Very truly yours,

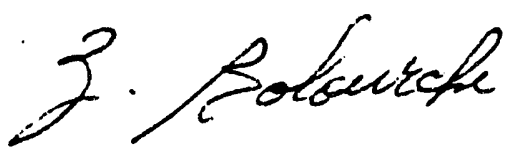

2. "Bo" Bolourchi, P.E.

Chief, Water Resources Section

ZB: ceC

Cc: Mr. Richard T. Deconto 


\section{SOUTHWESTERN LABORATORIES}

Materials, environmental and gcolcchnical cnginccring. nundestructive, melallurgical and analy'ical services >2ee Greenwood Fd. • P. D. Box 37577 • Shreveport. LA >1133.7577・318/636.3673

October 21,1988

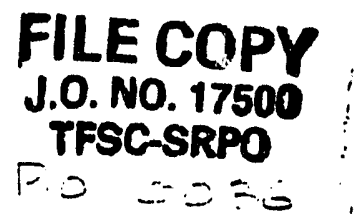

Louisiana Department of Transporation and Development

P. O. Box 94245

Baton Rouge, Louisiana 70804-9245

Reference: Variance Request

Gentlemen:

In accordance with Section 3.2.4.0 of Chapter III State Water Rules Regulations and Standards we are submitting a variance request for plugging and abandonment of Department of Energy (DOE) monitoring wells LVH6-A, $B$ : and $C$. The wells are located on a common drill site in Blenville Parish, Loulsiana, Township 17N, Range 8W Section 35.

The wells were drilled in 1980 by Jim-Co Drilling Company, Incorporated under the direction of Law Engineering and Testing Company. According to DOTD well file records the LVH6C well is the only well registered with the DOTD (No. Bi 226). Schematics of the completed well designs are attached for your information. Southwestern Laboratories, Incorporated has been contracted by Stone \& Webster Englneering Corporation to plug and abandon the wells for the DOE.

As requested by the office of Conservation, the well casings were perforated and squeezed with cement at various Intervals between 800 and 1000 feet beginning on 09-23-88. This activity was performed in order to protect fresh water aquifers (less than 10,000 TDS) from stratigraphically lower saline ground-water. Cement Bond logs verify that all squeeze operations were successful (see attachments).

Problems developed during removal of the drillable plugs used in the squeeze operations. Rubber and metal fragments comprising the plugs bridged over the top of the riser pipes as they disintegrated and fell down-hole during drilling. Various methods have been used in attempts to clear the debris from the riser pipes. Those efforts are summarized for each well as follows: 


\section{BOUTHWEBTEAN LABOPATORIEB}

LA DOTD

Variance Request

October 21, 1988

page 2

LVHGA - Drill on the plug debris with flat face and tapered diamond impregnated milling tools. Fish with taper tap, magnet and grab tools. Advance debris from top of riser pipe at 2494.61 to 2505 feet during six days.

LVH6B - Fish for junk with magnet, spear and grab tools on wireline at top of riser pipe (1786.6 feet). Some metal components were retrieved. No advancement during three days.

LVH6C - Drill out the plug for three days with a roller bit, drag bit and milling tool and follow to top of riser pipe (866.4 feet). Mill on plug debris at top of riser pipe for three days without advancement.

Presently, all the wells are clear to within fifty feet of the top of the screen sections. Since future advancement appears unlikely, we propose to plug the wells with cement from the top of the riser pipe to ground surface. The bottom of the plug will be below the squeeze zones where the annulus has been successfully sealed. If you have any further questions or comments, please feel free to contact this office.

LGH: awd

$$
\text { Sincerely, }
$$

SOUTHWESTERN LABORATORIES

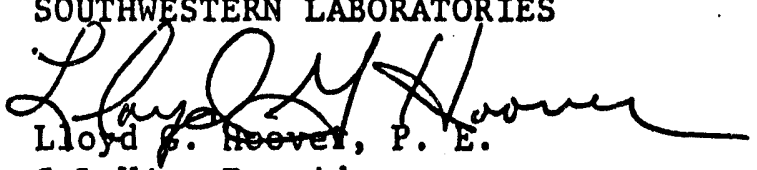

SwL Vice President Manager-Loulsiana Offices WWC-261

\section{Thisawd}

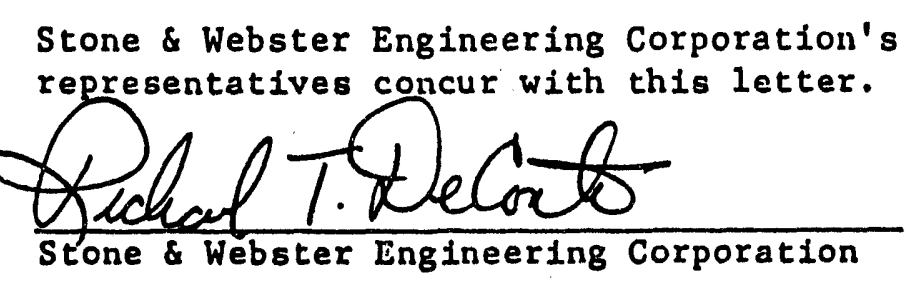




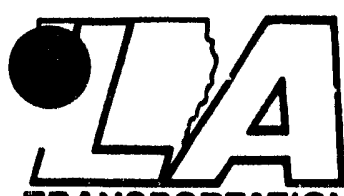

TRANSPORTATION
LOUISIANA DEPARTMENT OF TRANSPORTATION AND DEVELOPMENT

P.O. Box 94245, Baton Rouge, Louisiana 70804-9245

(504) $379-1434$

NEIL L. WAGONER, P.E. SECRETARY
October 24, 1988
BUDDY ROEMER GOVERNOR

Mr. Lloyd G. Hoover, P.E. SOUTHWESTERN LABORATORIES

P.0. BOX 37577

Shreveport, Louisiana 71133-7577

\author{
Re: Variance Request \\ Plugging of Abandoned \\ DOE Monitoring Wells \\ LVH-6A, LVH-6B, \& LVH-6C (Bi-226) \\ Bienville Parish
}

Dear Mr. Hoover:

This is in response to your letter of October 21,1988 , requesting a variance to plug the above referenced monitoring wells from the obstructions at the top of the riser pipes to ground surface. It was noted that the plugging operations will start below the location of the squeeze-packing operations.

Please be advised that based on the information contained in your letter, we have no objection to the plugging procedure outlined in the subject letter. All other applicable Water Well Rules, Regulations, and Standards shall be complied with.

If we may be of any further assistance, please do not hesitate to contact this office.

Very truly yours,

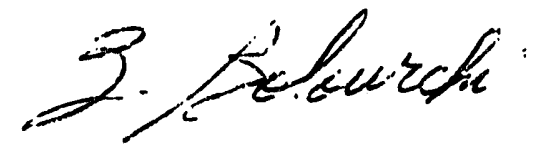

2. "Bo" Bolourchi, P.E.

Chief, Water Resources Section

ZB: cec

cc: Mr. Richard T. Deconto 


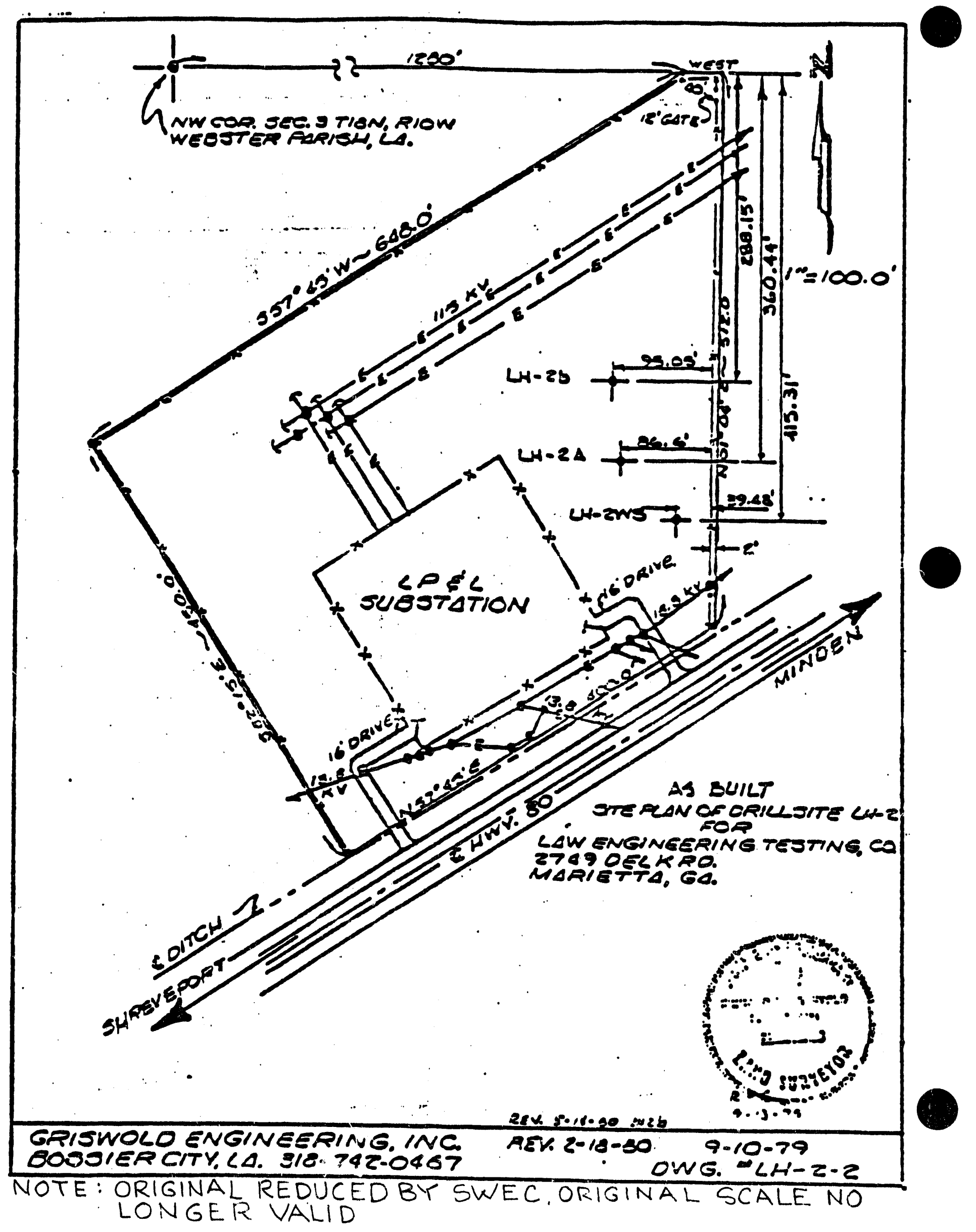




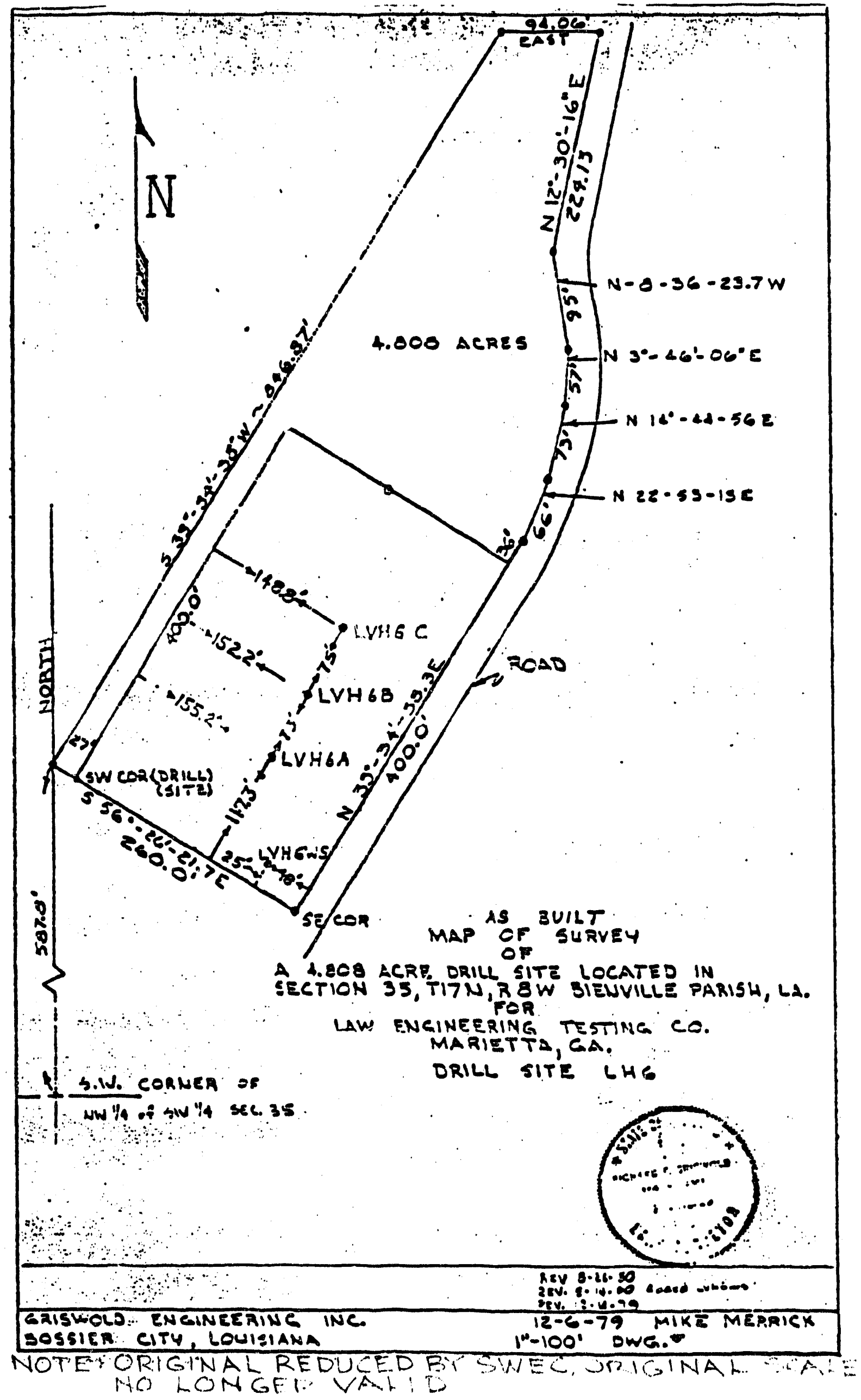




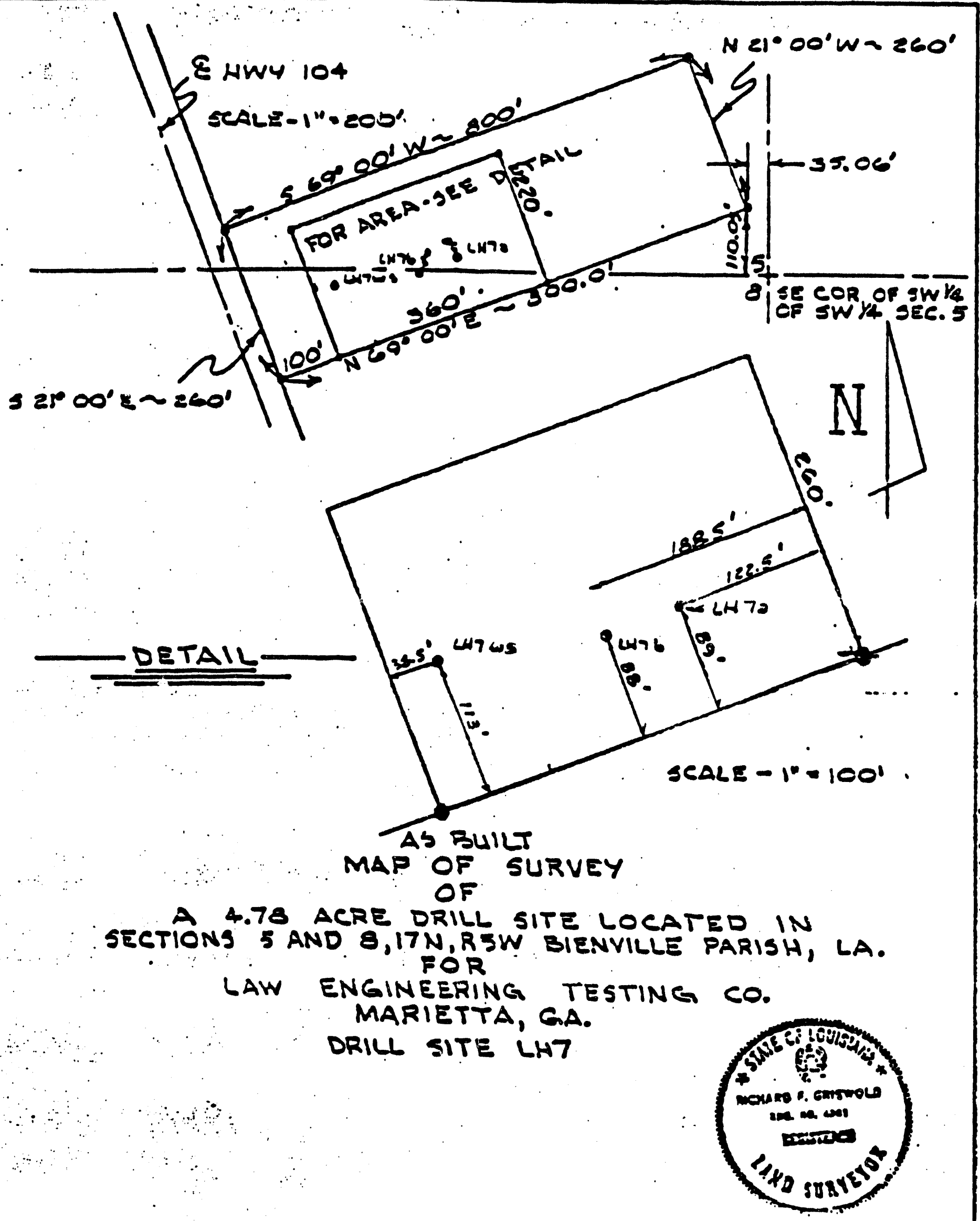

GRISWOLOENANEERING INC. REV. $5.4-90$ \&6 EILT

BOSSIER EITH, LOUISIANA 1 in- $20 \alpha$ U.N. MIKE Mrok. WOTE ORIGINAL REDUCED BY SW LONGER VALID 


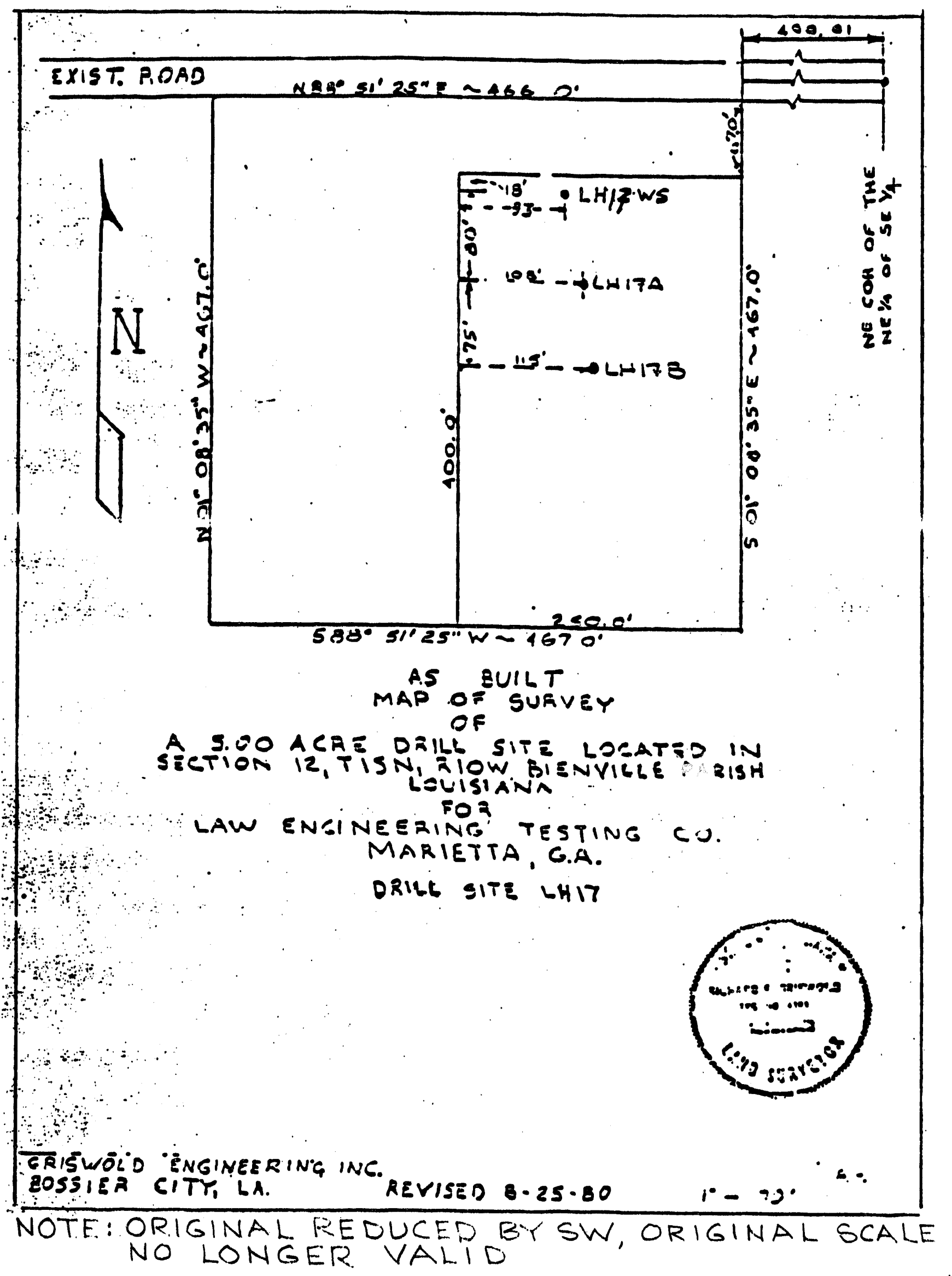




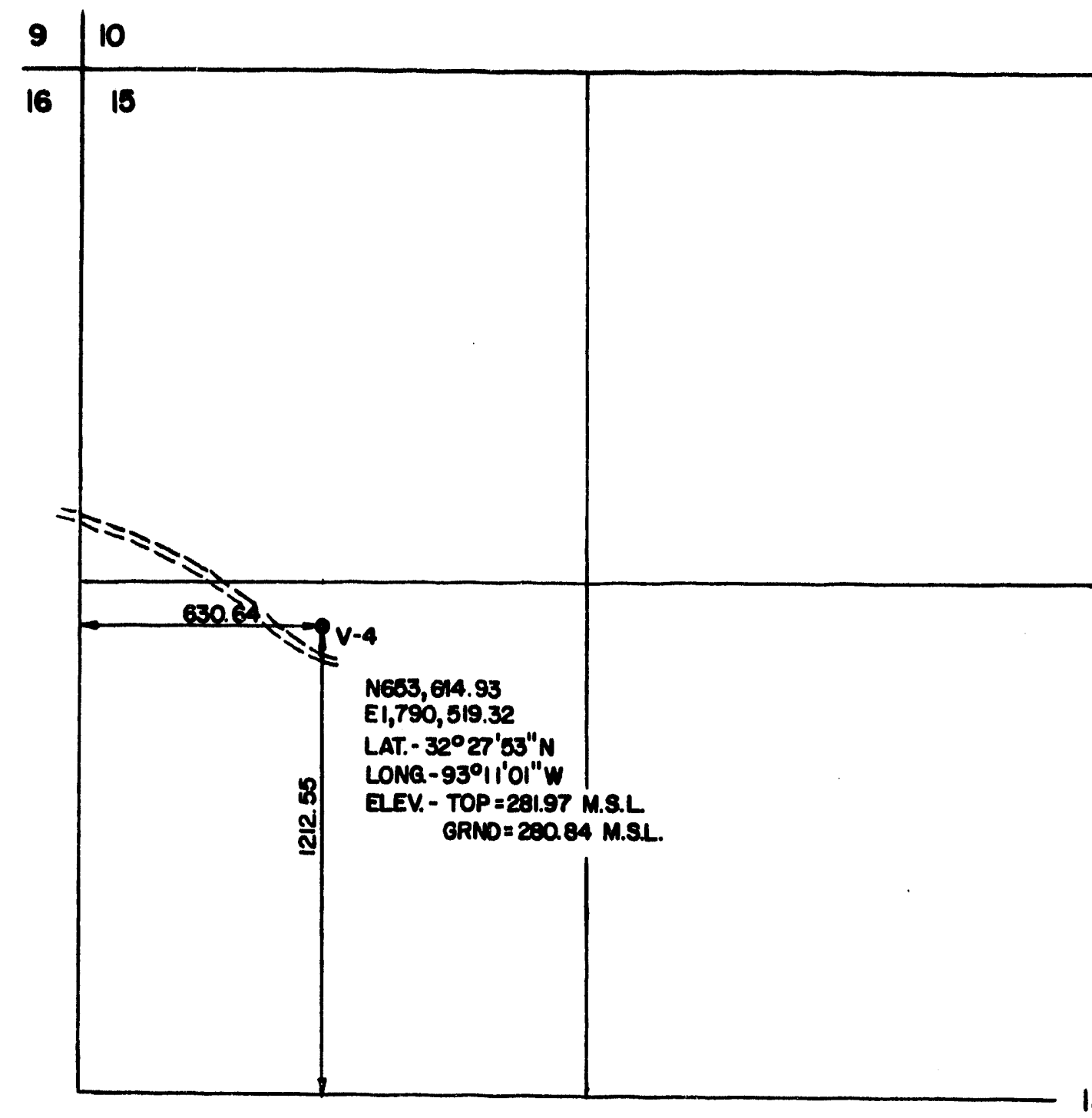

\section{MAP OF LOCATION FOR}

STONE \& WEBSTER ENGINEERING CORPORATION

OF WELL V-4, LOCATED I2I2.55 FT. FROM THE SOUTH LINE AND 630.64 FT. FROM THE WEST LINE OF THE NORTHWEST QUARTER OF SECTION 15, TI7N, R8W, WEBSTER PARISH, LOUISIANA.

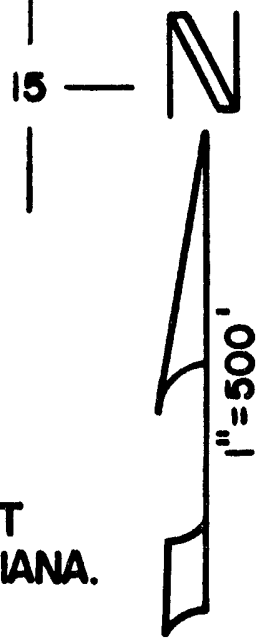

ATCHLEY Q ATCHLEY, INC. CONSULTING ENGINEERS

412 Lasalle St.

Shroveport, Louisiono (318) 222-5821 


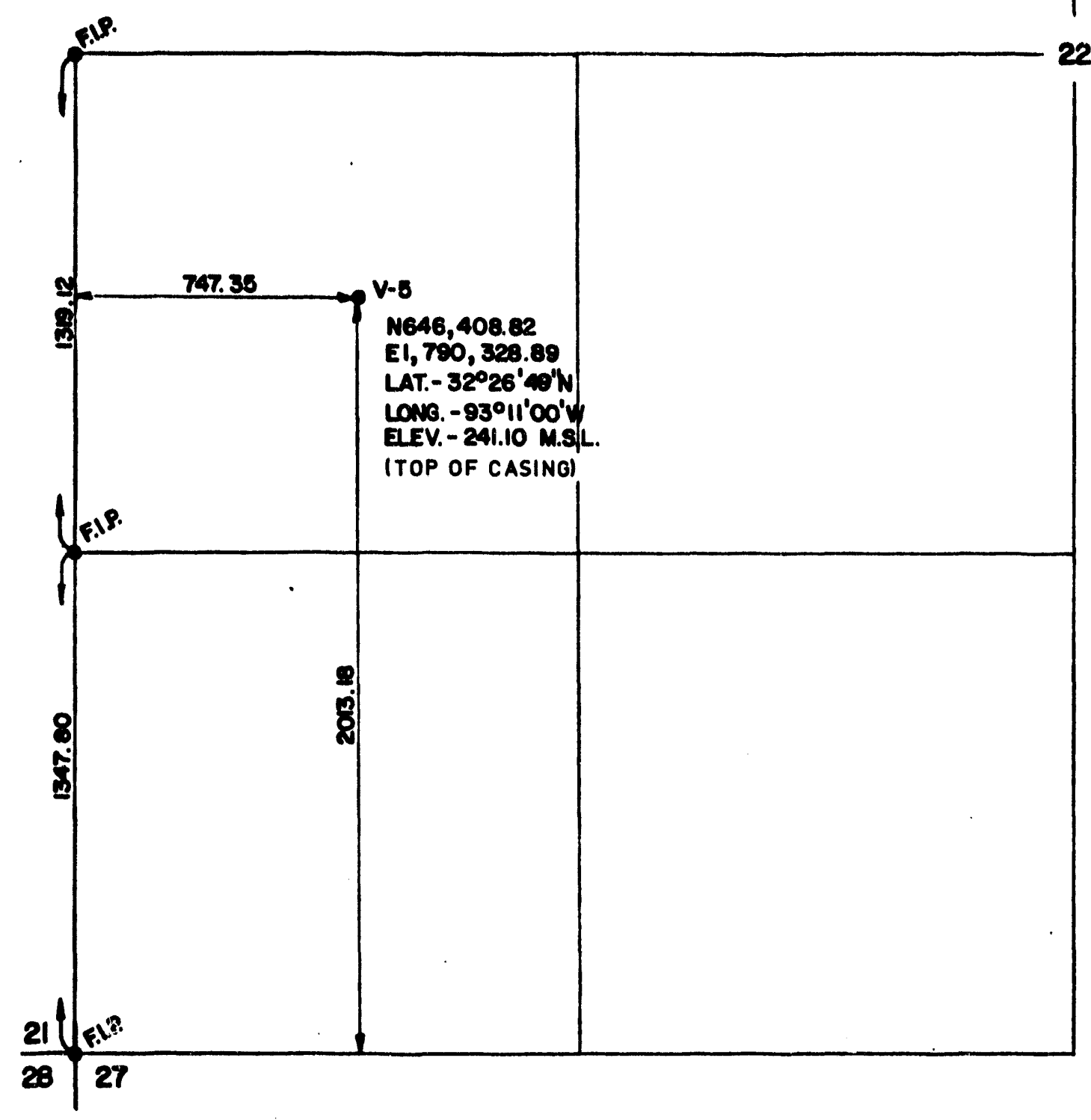

\section{MAP OF LOCATION \\ FOR \\ STONE \& WEBSTER ENGINEERING CORPORATION}

OF WELL V-5 LOCATED 2,013.18 FT. FROM THE SOUTH LINE AND 747. 35 FT. FROM THE WEST LINE OF SECTION 22, TOWNSHP 17 NORTH, RANEE 8 WEST, BIENVILLE PARISH, LOUISIANA.

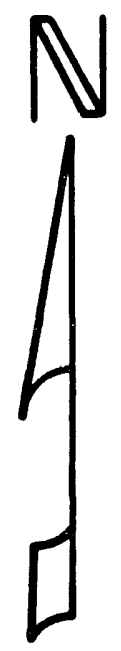

ATCHLEY Q ATCHLEY, INC. CONSULTING ENGINEERS.

412 LaSalle St.

Shroveport, Louisiona (318) 222-5821

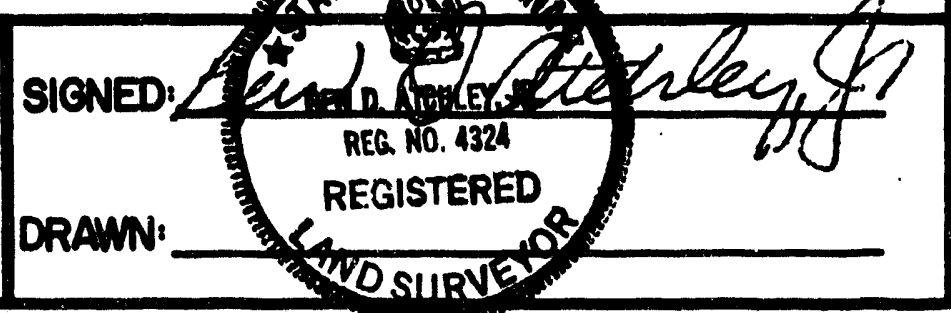




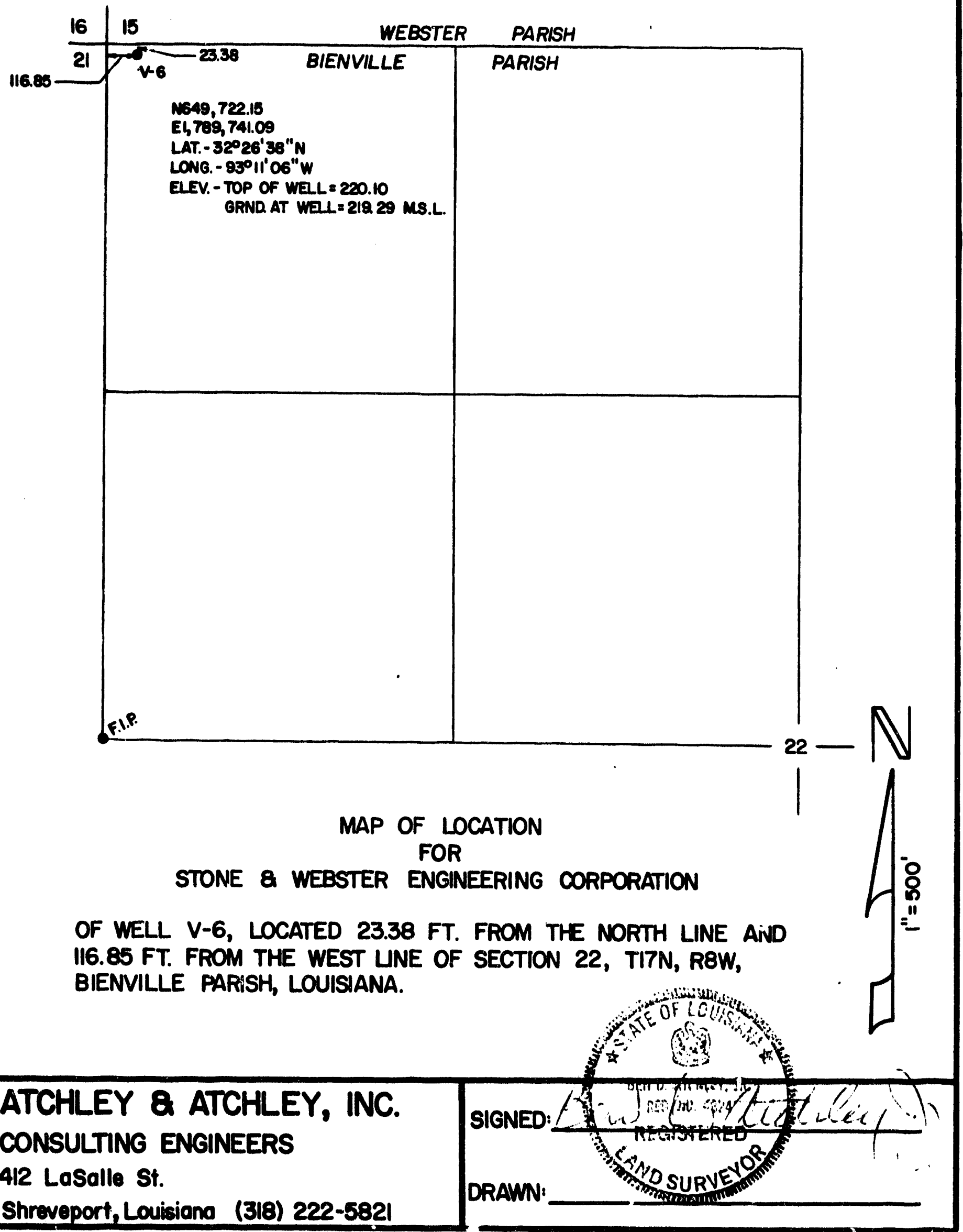



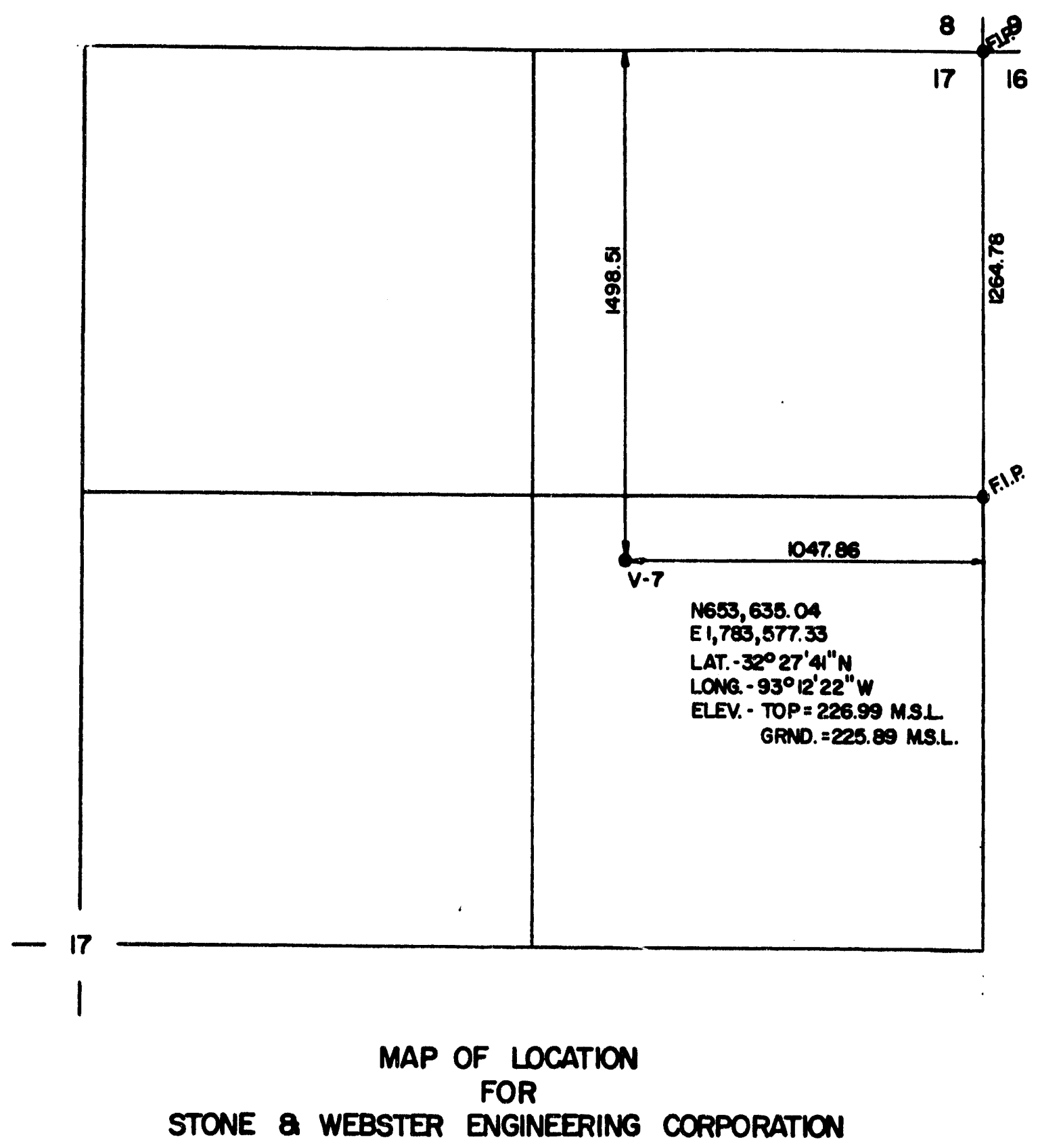

OF WELL V-7, LOCATED 1498.51 FT. FROM THE NORTH LNE AND 1047.86 FT. FROM THE EAST LINE OF SECTION 17, TI7N, R8W, WEBSTER PARISH, LOUISIANA.

ATCHLEY \& ATCHLEY, INC. CONSULTING ENGINEERS 412 LoSolle St. Shreveport, Louisiono (318) 222-5821

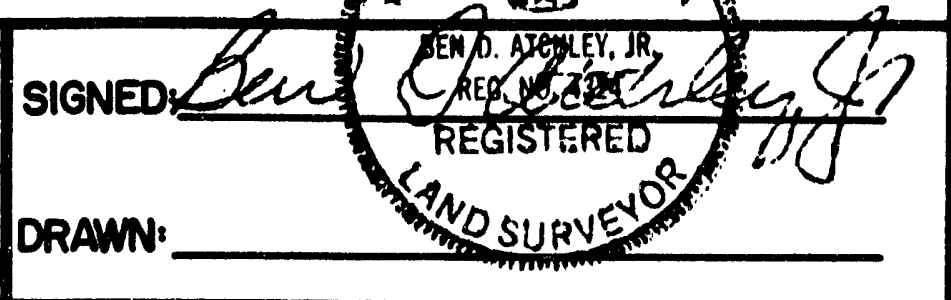




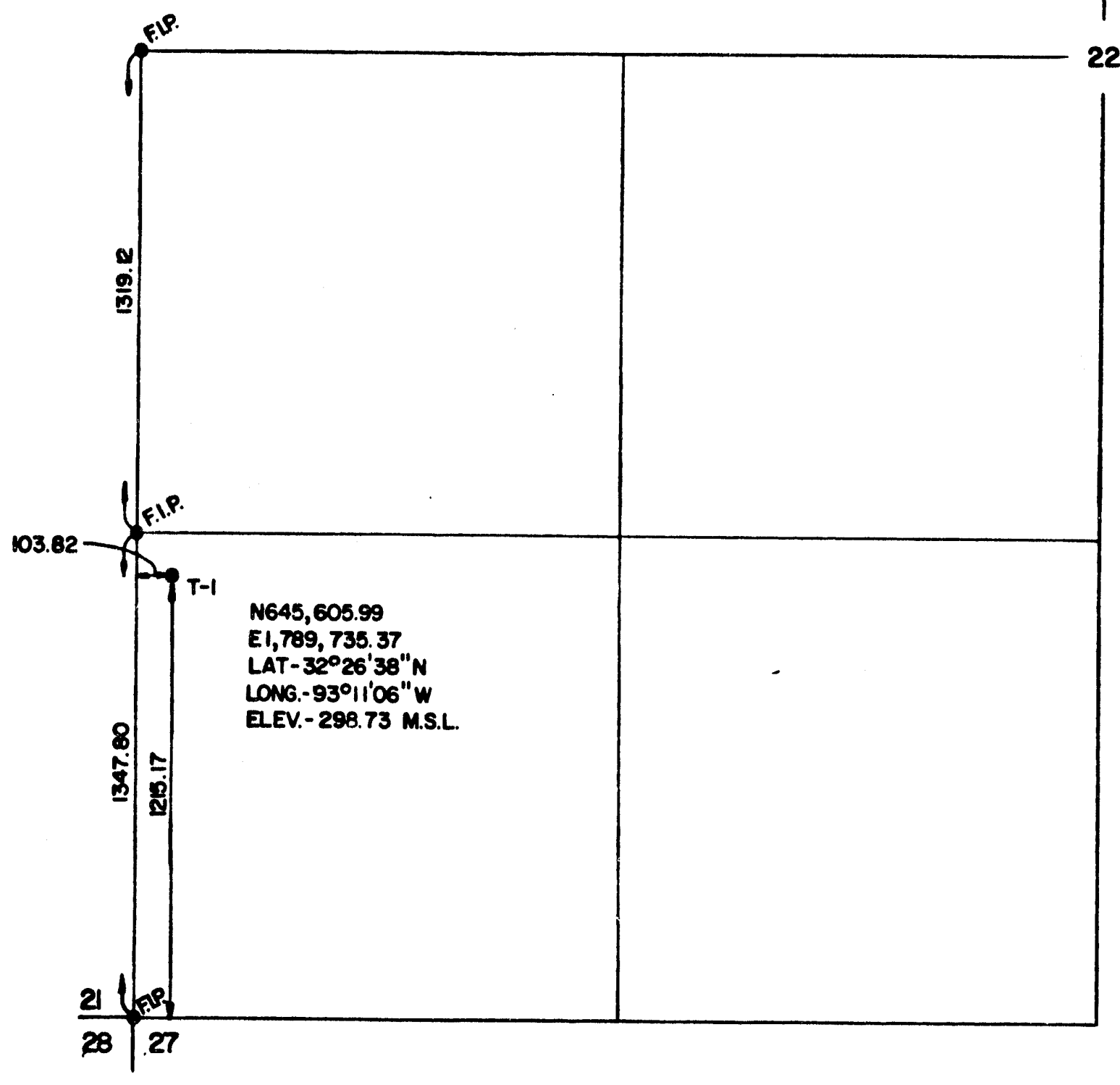

\section{MAP OF LOCATION \\ FOR \\ STONE \& WEBSTER ENGINEERING CORPORATION}

OF TLTMETER T-I, LOCATE I215.17 FT. FROM THE SOUTH LINE AND 103.82 FT. FROM THE WEST LINE OF SECTION 22, TI7N, R8W, BIENVILLE PARISH, LOUISIANA.

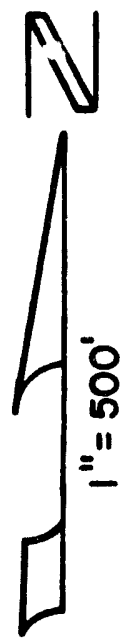

ATCHLEY Q ATCHLEY, INC. CONSULTING ENGINEERS

412 LaSolle St.

Shreveport, Lovisiona (318) 222-5821

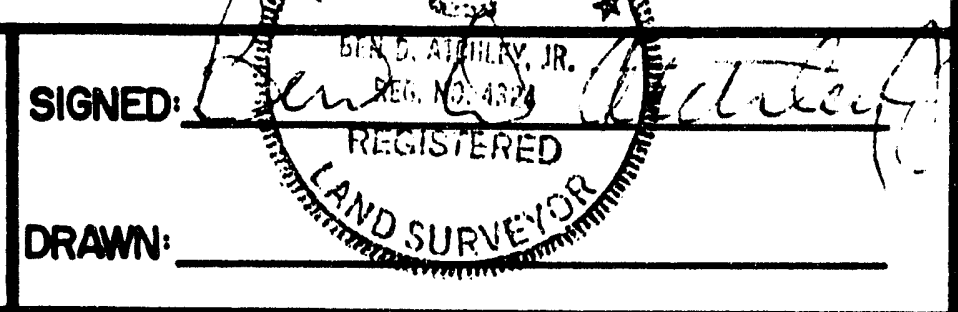




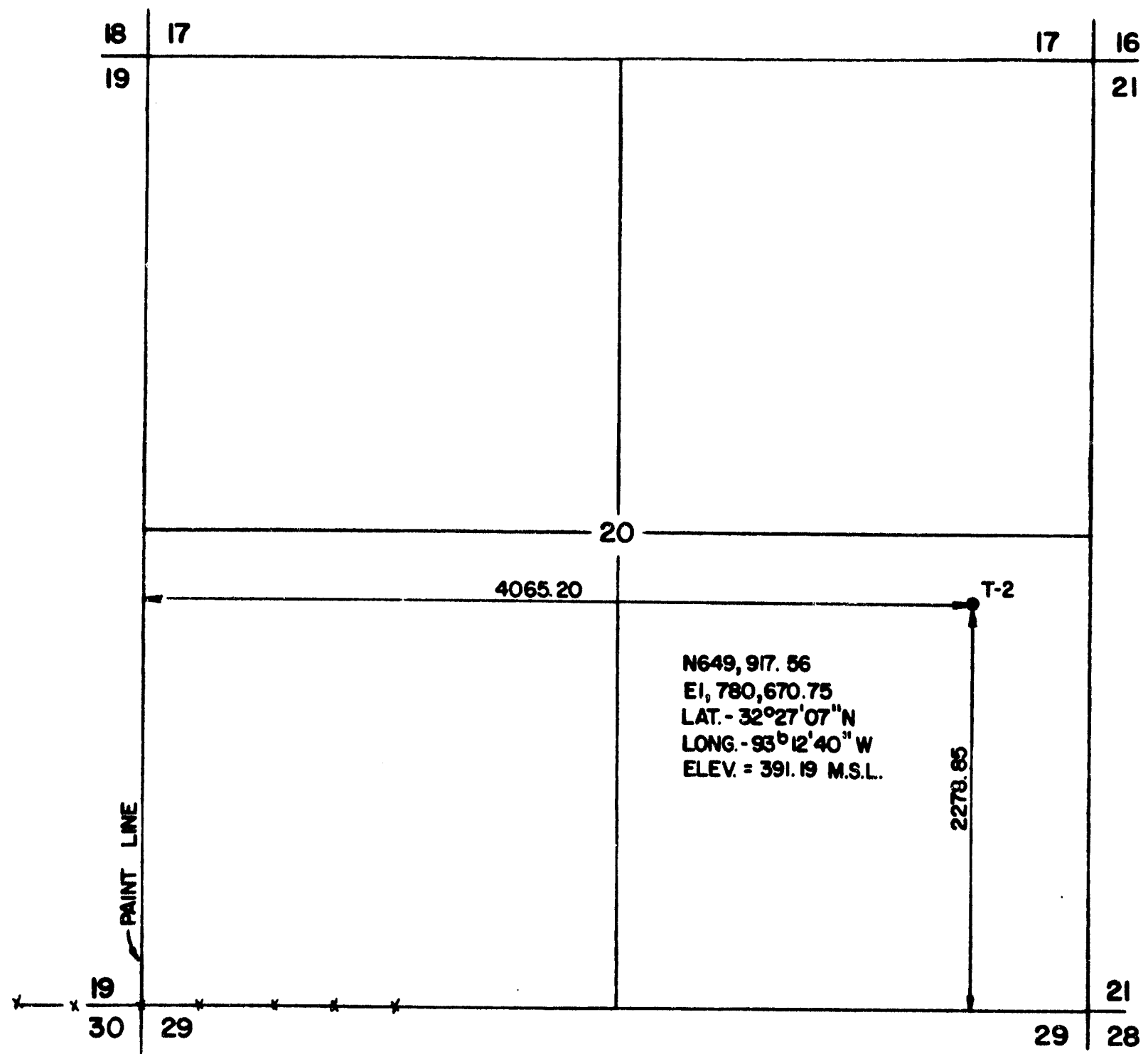

\section{MAP OF LOCATION \\ FOR \\ STONE \& WEBSTER ENGINEERING CORPOFATION}

OF TILTMETER T-2, LOCATED 2278.85 FT. FROM THE SOUTH LINE AND 4065. 20 FT. FROM THE WEST LINE OF SECTION 20, TI7N, R8W, BIENVILLE PARISH, LOUISIANA.

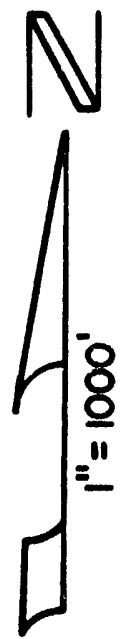

ATCHLEY \& ATCHLEY, INC. CONSULTING ENGINEERS 412 Lasalle St. 


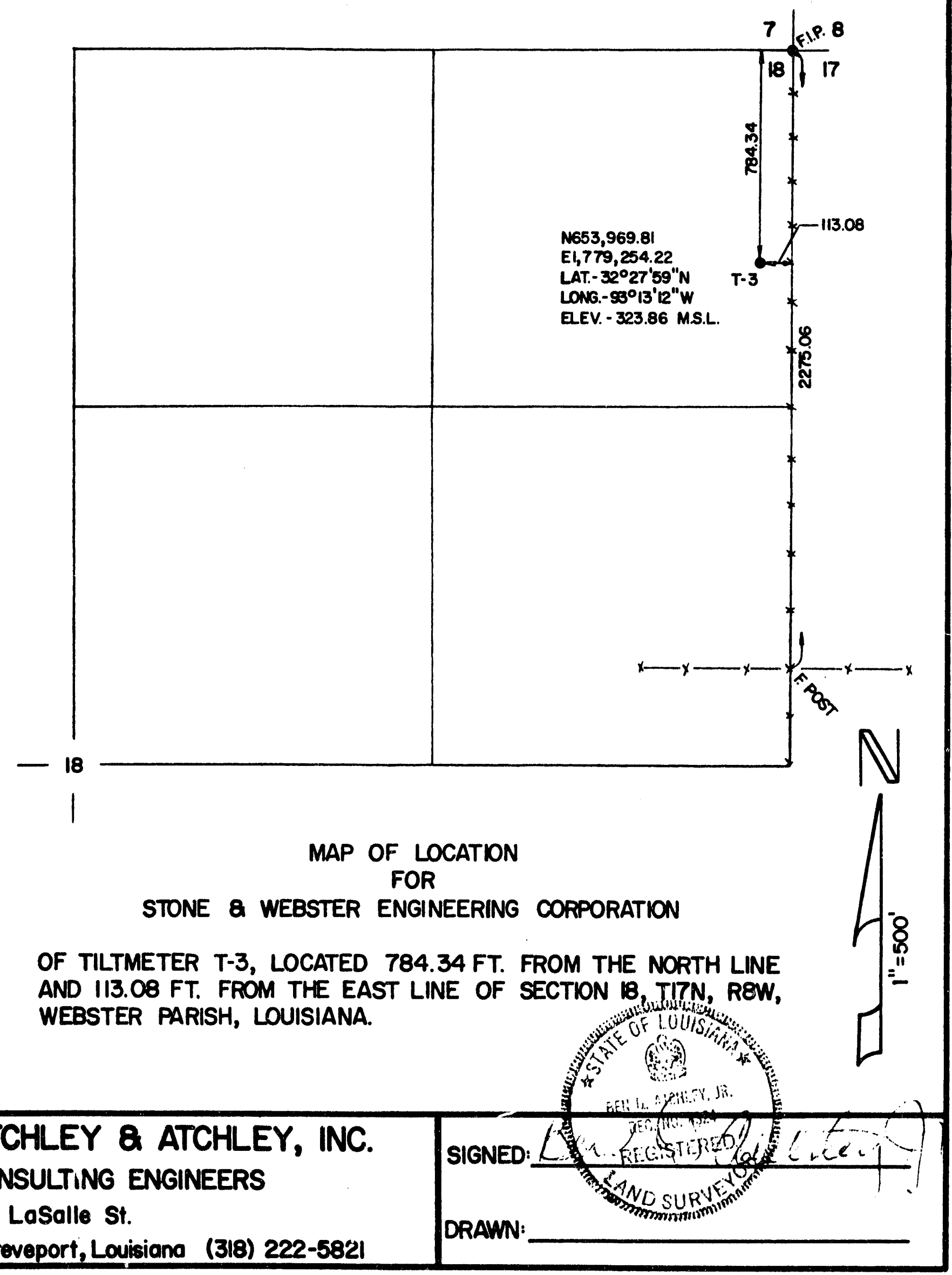




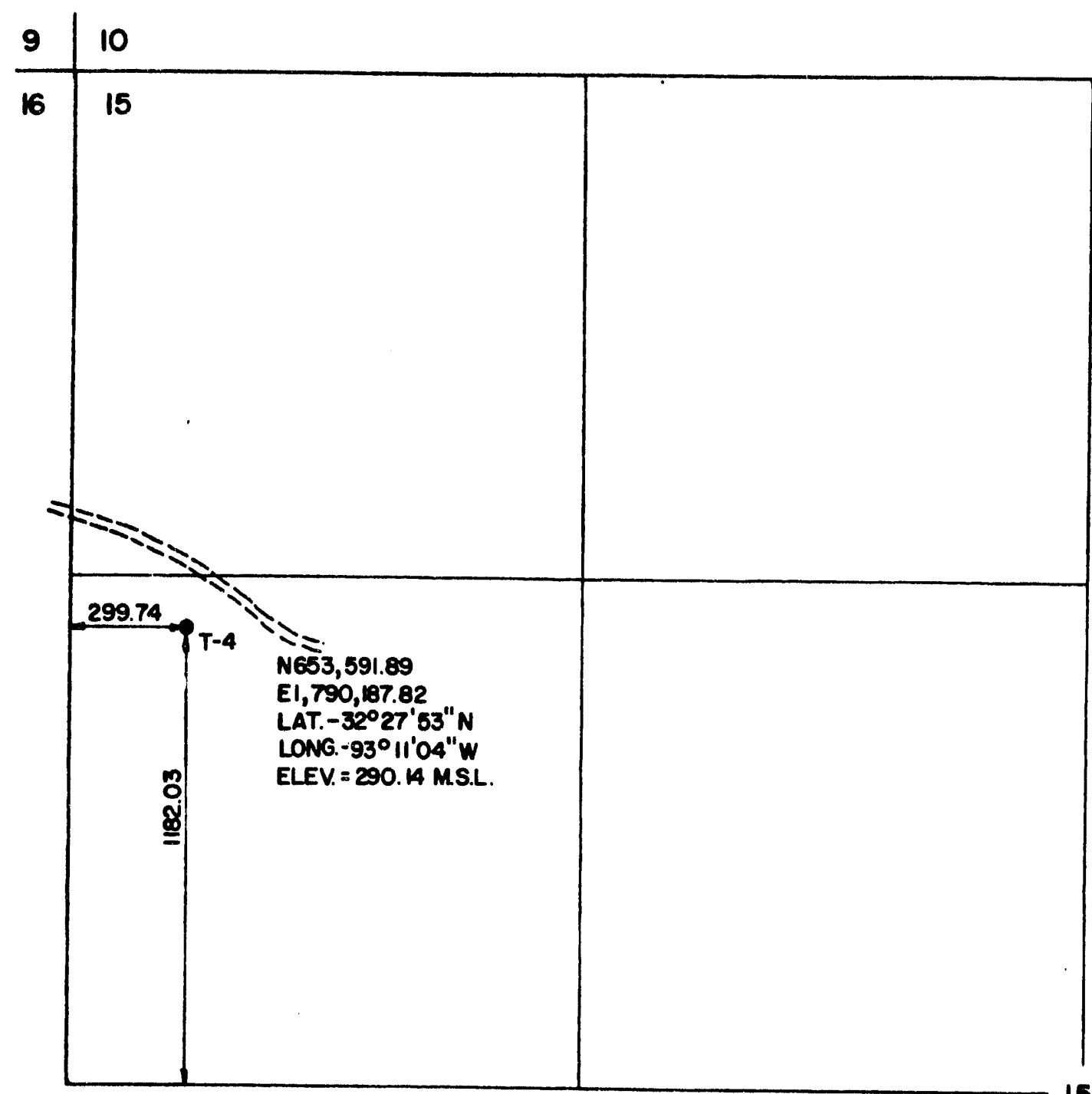

15

\section{MAP OF LOCATION}

FOR

STONE \& WEBSTER ENGINEERING CORPORATION

OF TILTMETER T-4, LOCATED II82.03 FT. FROM THE SOUTH LINE AND 299.74 FT. FROM THE WEST LINE OF THE NORTHWEST QUARTER OF SECTION 15, TI7N, RBW, WEBSTER PARISH, LOUISIANA.

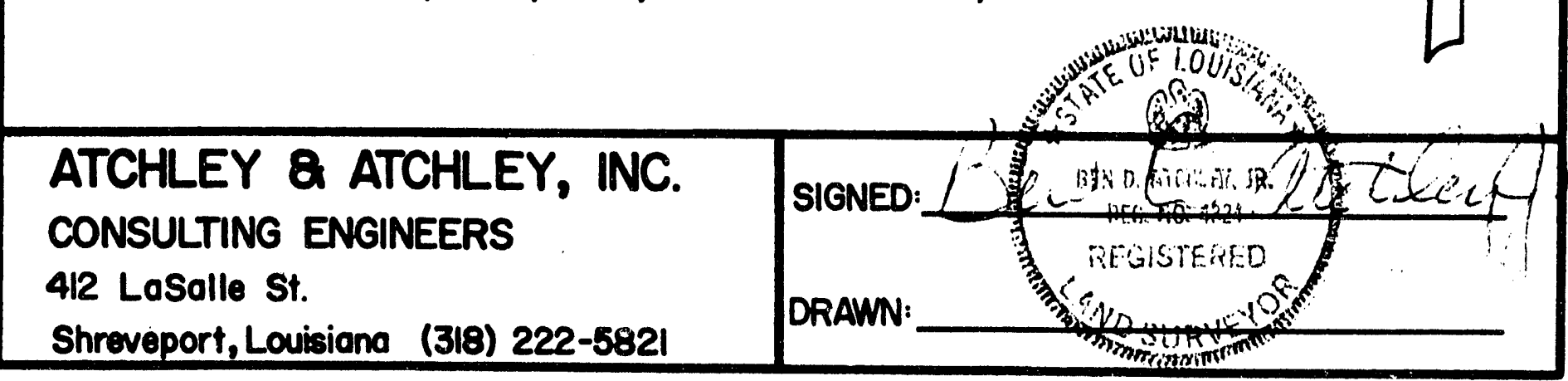




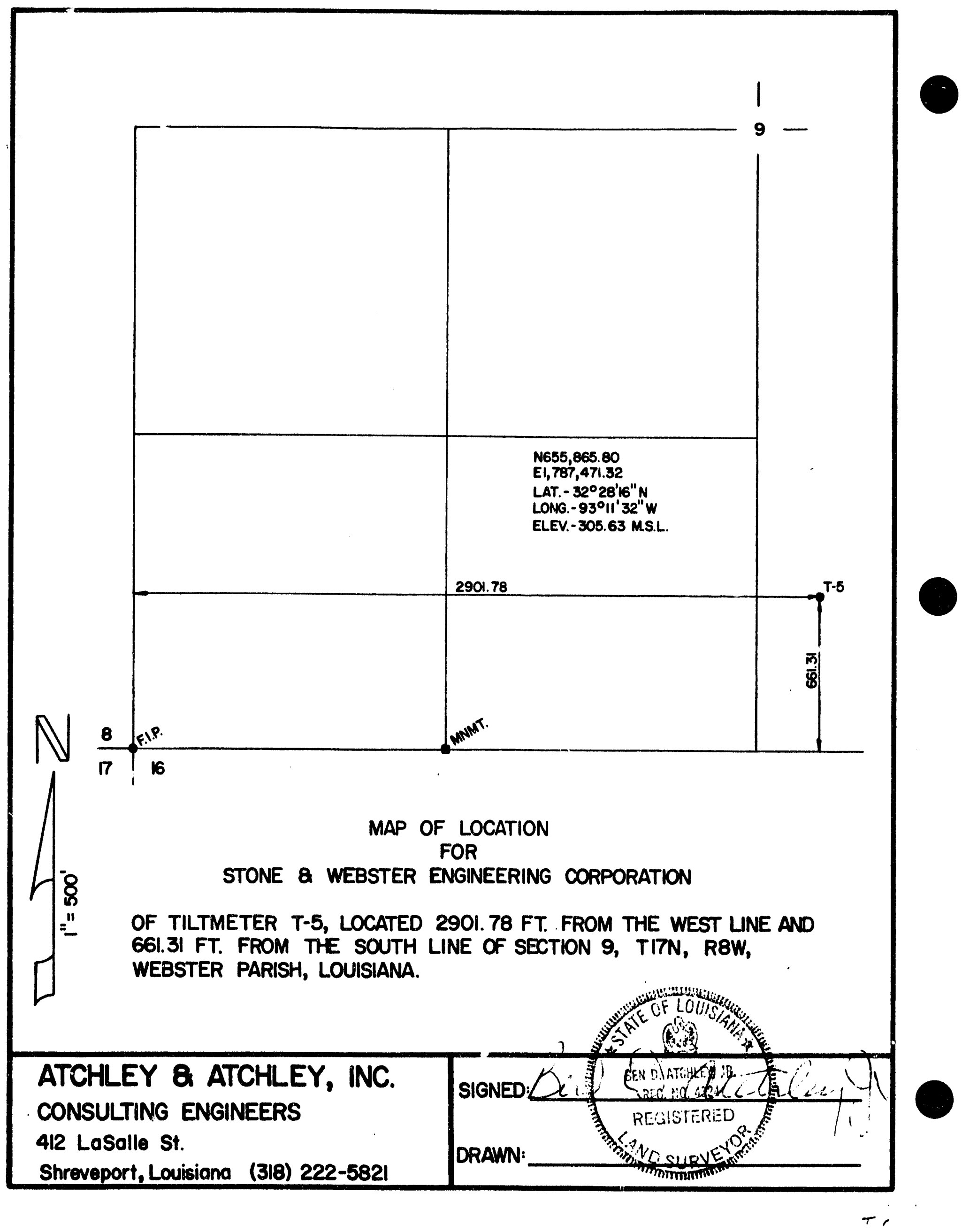




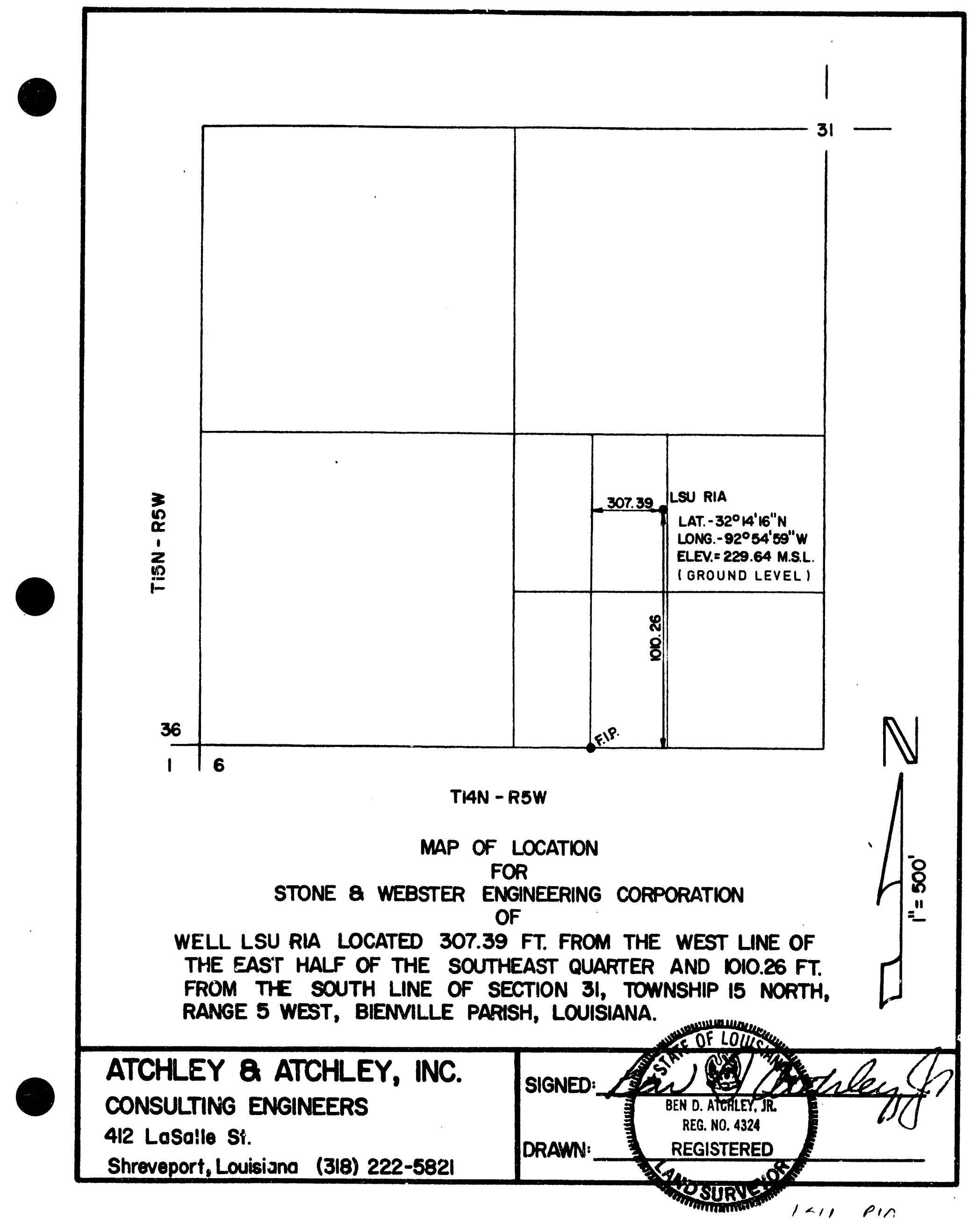


LSU/R1-A

Mr. Derwood D. Hines and

March 6, 1989

Mrs. Bettye Jane Smitherman Hines

Route 1, Box 79

J.0.No. 17500

Bienville, Louisiana 71008

DECOMMISSIONING OF LSU-RIA WELL

AND RESTORATION OF LANDS

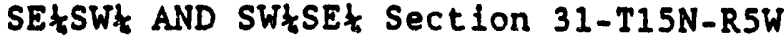

BIENVILLE PARISH, LOUISIANA

Dear Mr. and Mrs. Hines:

On October 31, 1988, Stone \& Webster Engineering Corporation plugged and abandoned the subject well in accordance with the Rules and Regulations of the Louisiana Department of Natural Resources. On November 20, 1988, we cut surface casing to the required depth of 3 feet beneath ground surface. capped the well, and backfilled the well excavation; and on December 1 , 1988, we completed initial site restoration.

I contacted you in January of this year regarding site restoration. You requested that Stone \& Webster add fill to the old pit, smooth over tire ruts, and plant pine seedlings. Subsequently, on January 11, 1989, a stone \& Webster fleld representative backfilled the remainder of the old pit and planted seedlings. Wet ground conditions prevented significant work on the ruts. After this additional restoration work you told stone \& Webster representatives Joel Kantola and Brayant G. Miller that the restoration was acceptable.

In accordance with your request, Stune \& Webster had the Louicisi: Department of Natural Resources send you a letter, dated January 26, 1989, stating that we had complied with requirements of its Rules and Regulations for plugging and abandoning the LSU-R1A well located on your provert:. Further, by letter of February 3, 1989, Stone \& webster sent you copies if all documentation we forwarded to the Louisiana Department of Natural Resources.

Stone \& Webster has plugged and abandoned the subject well and restored the surface of lands therearound in accordance with the terms and conditions of Limited Right of Entry and Use Agreement for Well Abandonment and Decommissioning Activities by and between yourselves and stone \& Webster Engineering corporation dated August 5, 1988, recorded in the official Records of Bienville Parish, Loulsiana as registry No. AE-722 in conveyance Book 535. The agreement will expire by its own terms. 


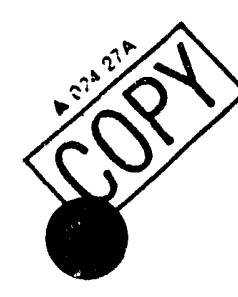

STONE \& WEBSTER ENGINEERING CORPORATION

DDH-BJSH

Unless Stone \& Webster hears to the contrary from you within ten (10) days from the date hereof, Stone \& Webster will consider all obligations fulfilled and the matter closed.

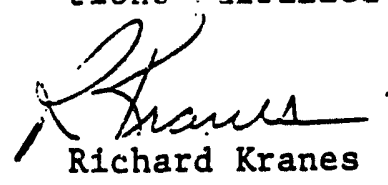

$R K: j x$ 


\section{G. P. THEUS V-6 RFAISTRY RR DAMAGE RELEASE PFFISTTRY AR NUMBER}

The underolgned, for and on belialf of the underolgned and the representatives, helrs and asolpnn of the underalgned, hereby acknowledpea recelpt from Stone Weboter Englneerlng Corporation (SWEC) of the num of one liundred and no/100 dollars,

and other valuable conelderation, the recelpt and ouffelency of which 1s liereby acknowledged, In full and complete oettlement and sat lofact of any and all claims, demands, damages, lossen, octlonn, and cousen of action of every kind and character, whlcli the undernigned or their representatives, heirs and aseigns have or miglit have by reason of owneraliln of the property or real property righte in the property, described below oll which the U.S. Government, and Its agents, servants, employees, successors, asigns and contractors have conducted drllling, hydrologlc monitoring otudies, well plugglng, itte reatoration, and other operat lons. The herelnafter described property is aloo descrlbed in certain apreemento executed by the undersigned which granted right-of-entry and the riglit to perform hydrologle monitoring otudles and other operations on the real property of the underolgned.

The Owner has declded to accept the above payment in lleu of SWEC completing the following it te restoration activitles

\section{Repalr of water line, site clean up and restoration}

II consideration of the above payment, the underalgned hereby forever dincharges and releases the U.S. Government, and Its agenta. nervants, employees, succesoors, asolgils, and contractore from any and all clalma, domandin, damngen, Ionnen, ectloun aul caunen of nct lon whlch the undernlpined or their representativen. lielrs, or nnolgnn, have or might liave orlaing out of, accrulng to or regulting from the performance of hydrologle monitoring otudies and related activitles on or in the vicinity of the property deecrlbed below.

The undersigned reprenentn that he/she/or they are the lawful ownera of the property described below and is the proper party to recelve payment liereunder.

Deacription of Property sltuated In the (Parioh or County) of Blenville State of Loutatana :

5 acres in Nortliwest Corner Section 22, Township 17 North, Range 8 West

IN HITNESS WIIEREOF, we have liereunto net our hands and aeals this the 28th day of Nurawher . 1988.

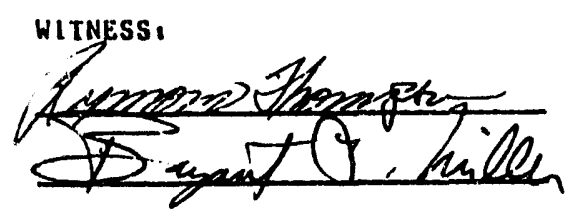

STATE OF
OWNERS .

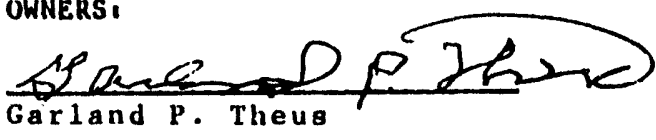

(Parloll or County) of

On thise day of 1 1988, before me personally appeared to me known to be the person(o) described In and who executed the foregolng linetrument, and acknowledged that act and deed.

(SEAL) executed the came of iree Notary Public in and lor (P ipledror County).

\section{(State)}

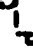




\section{DAMAGE REIEASE}

The undersigned, for and an behalf of the undersigned and the representatives, heirs and assig̣s of the undersigned, hereby acknowledges receipt from Applied Ceonectarics. Ine., of the 5 m of one Dollar and other valuable consiceration, the receipe and sufficiency of which is hereby acknowledged, in full and copplete settlenent and satisfaction of any and all clairs, denands, damaces, losses, actions, and causes of action of every kind and character, wich the unciersigned or their representatives, heirs and assigns have or mighe have by reason of ownership of the property or real property rights in the propersy, described below on which ipplied cecrectanics, Ine. , and its erployees have concueted research studies and otter operatiors. The hereinafter described property is also desczibed in cerain agresenes (the "igreements") executed by the undersigred wich granied rigite-iferty and the right to perforo research stucies and cther operatiors on the real property of the uncersigned.

hell plucging and/cr site gestcration work have been con ileced to the geguizemenes ct the intestens. In consiceration of the above payment, the uncersig̣ied tereby fcrever disciarges and releases ifplied cecontanics, Inc.. and its enployes Em any and all clairs, derands, danaçes, LCsses, acuicrs and causes of acion wtich the lincersiçed cr their representarives, teirs, or assigrs, have

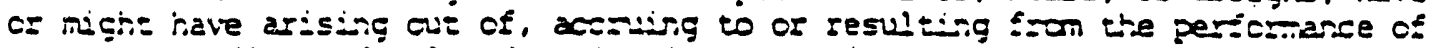
researci sidides and relaced acivzies on or it the vacizify of the fropery des$c=$ ibed beicw.

Tie licersiç.ed refresencs that he/she/or they are the lawfil owners of the

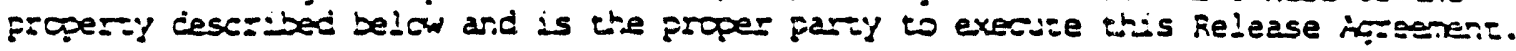

DE Contirental Forest Indistries 11 hiell.

Descifizion of Propery siguated in the Farish of Bierville, State cf Laisiara.

IV wIZESS hizexF, we have hereunco set cur hands and seais this the 17th day of - 1980.

\section{WIAESS :}

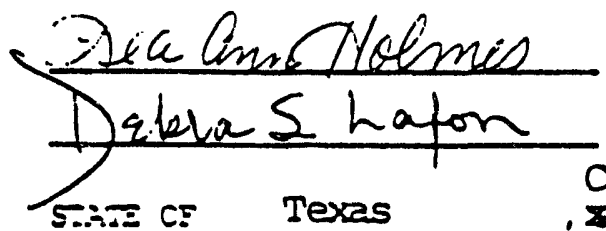

OANES:

IOUISIANA MIRERAIS, ITD.
County 20000003 Marris

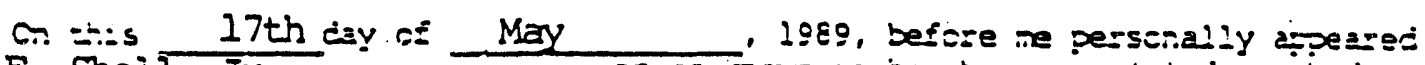
B. F. Sheil, Jr.

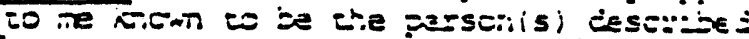

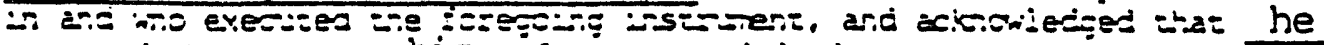
exezises ite sare es his tzes acs and cest.

IS:-:

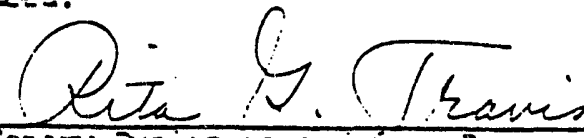

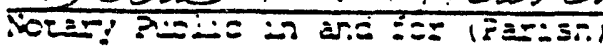
(Staze)

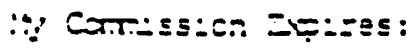

RITA G. TRAVIS

stan of tous

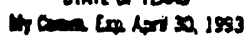


For the Following Wells

KCI HODGE LVH 6A, B, C \& WS

June 1, 1989

KCI HODGE LH 7A, B \& WS

KCI HODGE LH $17 \mathrm{~A}, \mathrm{~B} \&$ WS

\section{MUTUAL RELEASE}

WHEREAS, the Unlted States of Amerlca, herelnafter referred to as the "Government," and Loulslana MInerals, Ltd., herelnafter referred to as the "Lessor," did enter Into Lease No. DACW43-E$87-6$ on 1 October 1986 ; and

WHEREAS, paragraph 5 of sald Lease provldeg for an inspection of the leased premises and a mutual release by the parties as of the explration of the Lease term with regard to any claims;

NOW, THEREFORE, In accordance with the above, and with full and complete knowledge of the condition of the leasehold premises, the Government and the Lessor do hereby release each other from any and all clalms with regard to the Lesse; the condition of the leasehold premlses as of the explration of the Lease; or any other clalms for damages arlsing out of thla Lease.

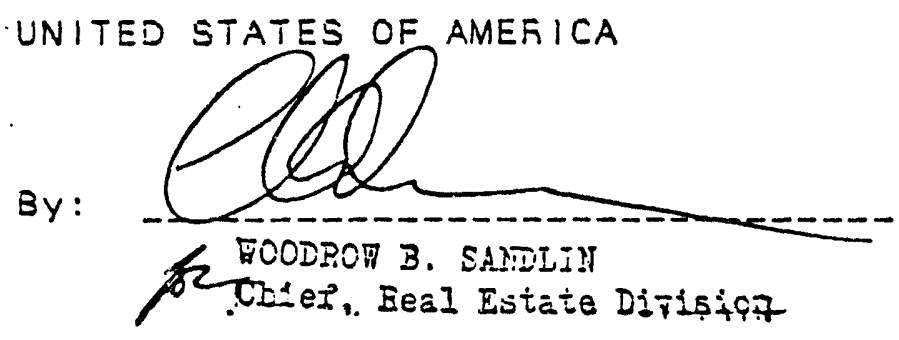

LOUISIANA. MINERAI.S, LTD.

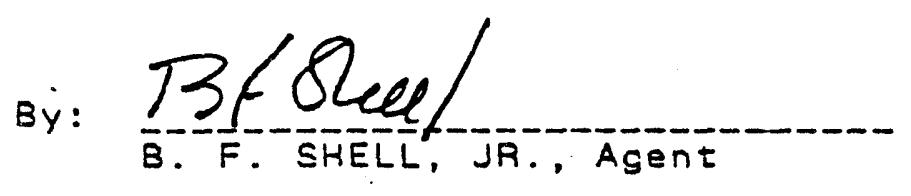

B. F. SHELL, JR., Asent 


\section{MUTUAL RELEASE}

WHEREAS, the Unlted States of Amer lca, hereinafter referred to as the "Government," and Carolyn M. Holley, herelnatter referred to as the "Lessor," dld enter Into Lease No. DACWA3-1$88-145$ on 22 September 1988; and

WHEREAS, paragraph 5 of said Lease provldes for an Inspection of the leased premises and a mutual release by the parties as of the explration of the Lease term with regard to any clalms:

NOW. THEREFORE, In accordance with the above, and with full
and complete knowledge of the condltion of the lessehold
premises, the Government and the Lessor do hereby relesse each
other from any and all claims wlth regerd to the Lease; the
conditlon of the leasehold premises as of the explration of the
Lease; or any other clalms for damages arlsing out of this Lease.

UNITED STATES OF AMERICA

By:

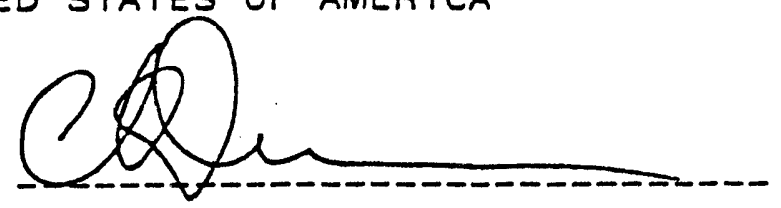

\section{LESSOR}

By: Carolyw m, Jtolley
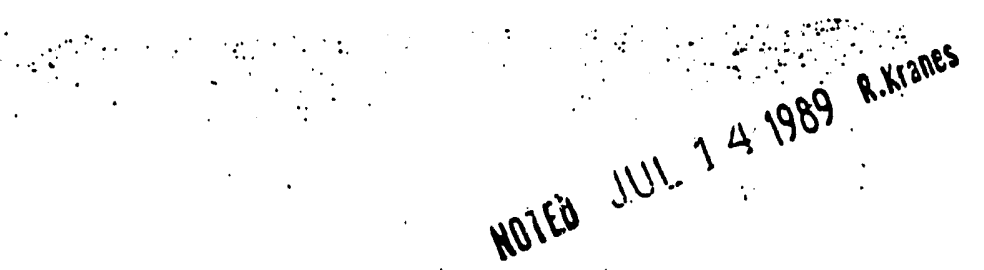
For Wells: E.H.S. CONNELL V-5\&V-7 June 10, 1989

For Tiltmeters: $\mathrm{T}-1 \& \mathrm{~T}-2$

\section{MUTUAL RELEASE}

WHEREAS, the Unlted States of Amerlca, herelnatter referred to as the "Government," and Effle Holley Smlth Connell, et al., herelnafter referred to es the "Lessor," dld enter Into Lesse No. DACW $43-1-88-\frac{147}{147}$ on 22 September 1988 ; and

WHEREAS, paragraph 5 of sald Leage provldes for an Inspection of the leased premlses and a mutual relesse by the partles as of the explration of the lease term with regard to eny cla ims ;

NOW, THEREFORE, In accordance $w$ Ith the above, and $w$ ith full and complete knowledge of the condition of the leasehold premises, the Government and the Lessor do hereby release each other from any and all clalms wlth regard to the Lease; the condition of the leasehold premises as of the expiration of the Lease; or any other claims for damages arlsing out of this Lease.

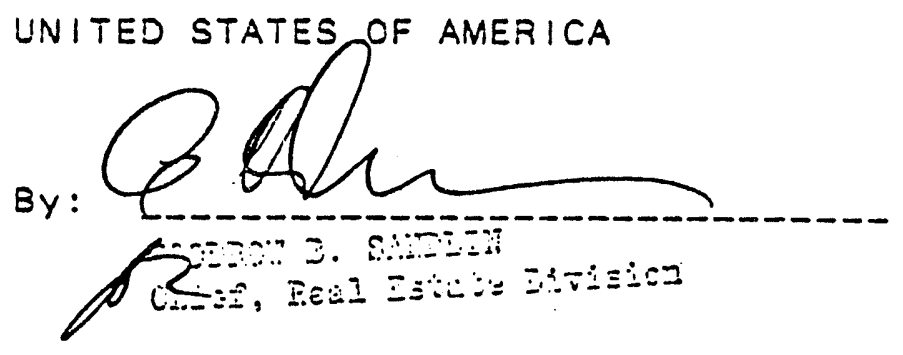

By: Gffei Zfolly Amith Conseld

By: Billy fex

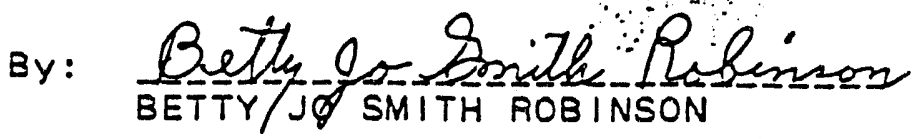


For Well A.K.C. RAYFORD V-4

June 19,1989

For Tiltmeter T-4

\section{MUTUAL RELEASE}

WHEREAS, the Unlted States of Amerlca, herelnafter referred to as the "Government," and Allene $K$. Clark Rayford and Norbert $C$. Rayford, husband and wlfe, herelnafter referred to as the "Lessor," did enter Into Lease Nos. DACW29-5-87-2 and DACW29-5-87-4 on 25 March 1887; and

WHEREAS, paragraph 5 of sald Leases provides for an . Inspection of the leased premlses and a mutual release by the partles as of the explration of the Lease term with regard to any clalms:

NOW, THEREFORE, In accordance with the above, end with full and complete knowledge of the condition of the leasehold premises, the Government and the Lessor do hereby release each other from any and all clalms wlth regard to the Leases; the condition of the leasehold premlses as of the explration of the Leases; or any other clalms for damages ar Ising out of these Leases.

UNITED STATES OF AMERICA

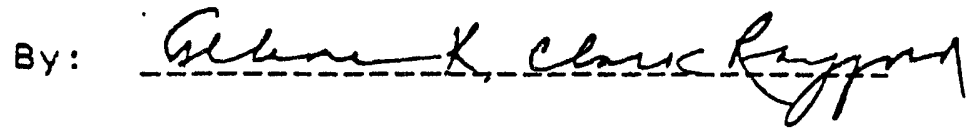

LESSOR

By:

A'LEENE $\bar{K}$. $\bar{C} \overline{L A} \bar{R} \bar{K}-\overline{R A} \bar{Y} \bar{F} \bar{O} \bar{R} \bar{O}$

By:
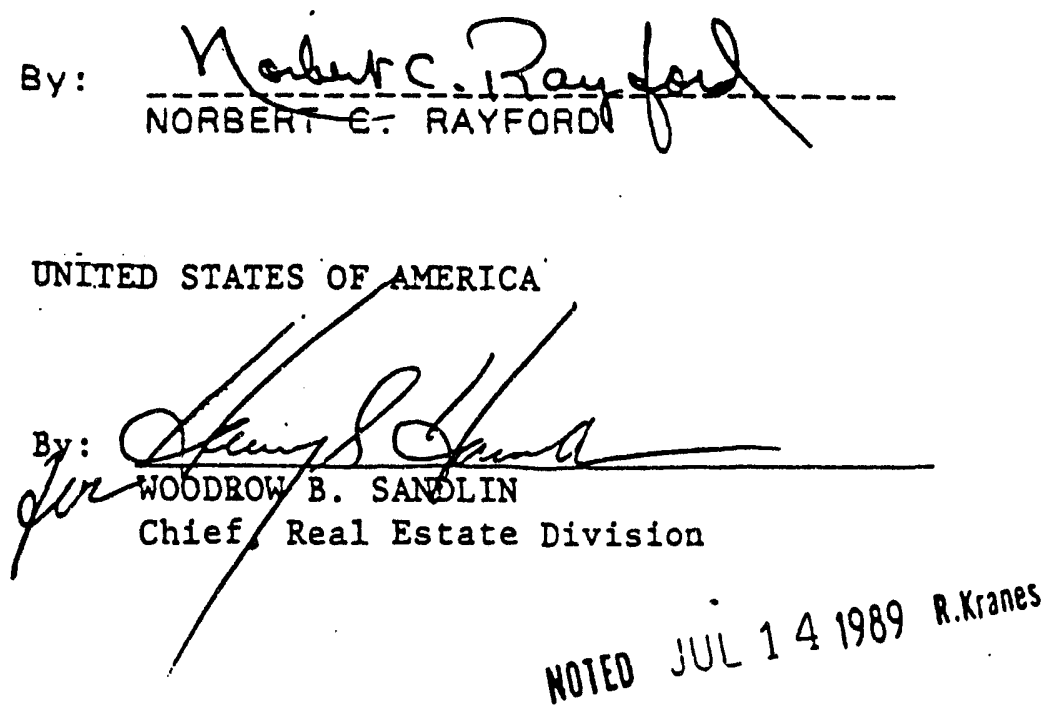
J.O. NO. 17500.

JOB BOOK NO. T2.

SUBJECT FILES

TELEPHONE MEMORANDUM

$S \& W$

TECHNICAL AND FIELD SERVICES CONTRACT

CALL DATE:

Ner 10,88

TIME: $\quad 8: 45$

FROM :

R. KRNNES

OF: ¿WEC

TO:

W. R Rorezis

OF : LA, Pavez $L_{\text {S }}$.

SUBJECT :

Restoration of $\mathrm{LH}-\mathrm{Z}$ well site

on

$L P E L$ property

SUMMARY :

Mr. Roryzis iodicated that site was acceptable in its current condition without cony extensive restoration in the wny of reptantining gracses. If we did "throw dewn" some winter ye $\varepsilon$ bermuda seed that would be fine also. He thought LP\&L would have no problem signing release

ACTION REQUIRED: Contact D. willer concernirig sigming of release.

DISTRIBUTION :

STANDARD

OPTIONAL

OTHERS

E.M. WASHER

C.B. MCSHAIN

C.A. FOSTER

R.G. BURNS

J.H. PECK

C.E. HOUK

F.J. DEHLER 


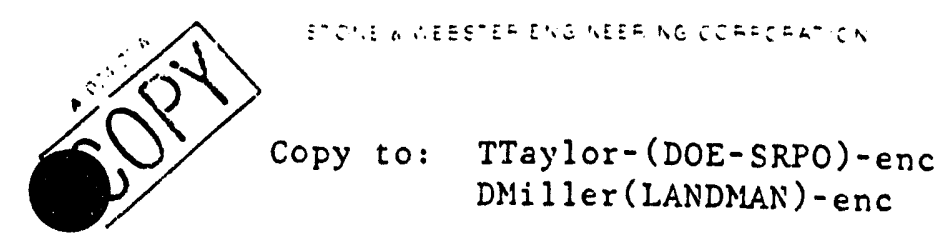

Har. W. R. Roberts, Jr.

Louisiana Power and Light Co.

P.0. Box 707

W. Nonroe, IA 71291-0707
SRS890118011

EMTasher

CAFoster

JHPeck

JKantola

Project Files (M9)

RKranes

DOE TEST-WELL DECOMAISSIONING ACTIVITIES

LANDOKNER DAMAGE RELEASE FORM

January 18,1989

J.0. No. 17500

Dear Mr. Roberts:

As jou requested during our phone conversation with David Miller, January 10, 1989, I am sending you:

1. Information regarding the use of the DOE test wells on the Minden substation site, and

2. rational for requesting a signed relesse.

The DAHAGE RELEASE forwarded to you through David Miller is a standard project form, for use in Loulsiana and Missisolppi, where stone \& Webster Engineering Corporation (SWEC) is in direct agreement with a landowner on whose property a well site is located.

The primary purpose of the landowner release is to establish that surface site restoration (1.e. final grading, seeding, tree planting, access road upgrading or removal) is completed according to the requirements contained in the lease (access) agreement and that this work has been performed to the satisfaction of the landowner.

In regerd to the plugging of wells, the well operator (ShEC) and/or contractors (Southwestern Laboratories) actually performing the plugging are the perties responsible for the proper plugging of wells according to applicable federal, state, and local regulations. The landowner is not responsible, unless he 18 also the operator. Although there are minor differences from state to state, (Texas, Utah, Louisiana, and Mississippi), where SWEC has been plugging DOE test wells, the regulations are explicit in assigning this responsibility.

In the late 1970's, under a program run by the Department of Energy (DOE) to investigate potential sites for a geologic waste repository, Law Engineering Testing Co. (LETCO) was contracted to supervise the drilling of deep - t wells at flve well sites in Loulsiana. The purpose of these wells was to acquire information on the geologic and geohydrologic conditions in the eress of Vacharle and Rayburns Salt Domes. 
On November 19, 1979, LETCo entered into a lease agreement with Loulsiana Power and Ifght Co.(LPAL) allowing LETCo to locate one of the deep test well sites proximate to their Ninden substation. LETCo subcontracted Jim-Co Drilling Company to drill test wells $L \mathrm{~L}-2 \mathrm{~A}(1850 \mathrm{ft})$ and LH-2B $(752 \mathrm{ft})$. They contracted with Continental Engine and Pump Co. to drill a weter supply well LH-2WS $(420 \mathrm{ft})$. Enclosed is LETCo's well completion report detalling the drilling and testing done at that site at that time.

After the drilling phase was completed, leTCo continued to operate the above wells for the purpose of collecting geohydrologic data end water samples for detailed analysis.

On Key 1, 1982. The Earth Technology Corporetion (TETC) assumed operatorship and entered into a limited Right of Use Agreement with LP\&L on January 15, 1985 for the same purpose that LETCo used the wells (collection of hydrologic data and water samples).

On June 27, 1988, SWEC took over as operators of the three wells at the LE-2 site for the purpose of plugging and abandoning (P\&A) these wells. Well screens were completely plugged with sand and casings completely plugged with a cement-bentonite slurry as defined by state regulations. The following chronology details the activitles involved with the P\&A operation. All operations were supervised by a SWEC site representative and are documented on well histories required by the State of Louisiana office of Conservation (see attachment).

\section{CERONOLOGY}

7-19-88 OTIS ENGINEERING Bounded wells to check whetber the wells were open to the constructed depth. All wells were clear. heter semples vere collected to check chlorinity and total dissolved solids content to determine the method of disposing of fluids displaced while plugging. Wells $2 \mathrm{~A}$ and $2 \mathrm{~B}$ required disposal of fluids at brine disposal wells.

9-11-88 to SOUTHESTERN LABORATORIES Plugged LH-2B well (see attached well history and brine disposal manifest).

9-15-88 to SOUTHWESTERN LABORATORIES squeezed and plugged LH-2WS well 9-16-88 (attachments).

9-21-88 to SOUTHWESTERN LABORATORIES plugged LH-2A well (attachments). 9-22-88

9-27-88 SOUTHWESTERN LABORATORIES excavated around the three well heads, cut off caslags $3 \mathrm{ft}$ below ground level, welded a steel plate to the outermost casing, and backfllled the excavation.

12-1-88 NEWT BROHN CONTRACTORS cleaned, graded and seeded the LH-2 site. 
If you have questions or need additional information, please contact me (617) 589-2579 or Mr. David Miller (601) 969-1160.

Very truly yours,

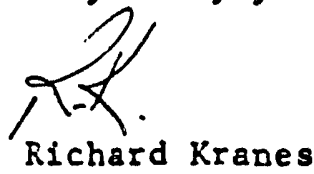

Enclosures

RK: nd 
EWasher

RKranes

HBjorkman

Project Files (M-9)

WPC 245/12 (6433-1750026-B4T

CAFoster
Mr. W. R. Roberts, Jr.

Louisiana Power \& Light Co.

P.0. Box 707

W. Monroe, Louisiana 71291-0707
April 21, 1989

J.0. No. 17500

DECOMMISSIONING OF MINDEN SUBSTATION SITE MINDEN, LOUISIANA

Dear Mr. Roberts:

Regarding the use of land owned by Louisiana Power \& Light Company (LP\&L) for surface geologic studies and test well sites provided under the terms of agreement between IP\&L and the Earth Technology Corporation (ERTEC) dated January 16, 1985, recorded as registry No. 321553, extended by agreement dated December 10, 1986, recorded as registry No. 36033 in the records of Webster Parish, Louisiana, be advised as follows:

Stone \& Webster Engineering Corporation (SWEC) assumed said agreement and on September 10 to 22,1989 , plugged and abandoned wells LH2A, 2B and 2 WS according to appropriate state regulations. On September 22, 1988 , the three well heads were cut off $3 \mathrm{ft}$ below ground surface, steel plates were welded on top of the casing, and excavations were backfilled. On December 1, 1988, the site was cleaned, graded and seeded by SWEC. Subsequently, in discussion with Richard Kranes and SWEC's landman, David Miller, you indicated that you had visited the site and were satisfied with the restoration work.

On January 18, 1987, SWEC forwarded to you a package of information that included state forms, SWEC technical data, and a brief chronology regarding the history of decommissioning activities performed at the site.

SWEC's standard project Damage Release Form was forwarded to you November 29, 1988, by David Miller. On March 15, 1989, LP\&L provided Mr. Miller three executed copies of a modified damage release which SWEC cannot accept to the extent it extends the indemnification beyond that agreed to in the Limited Right of Use Agreement between LP\&L and ERTEC. The three executed copies of this agreement are returned herewith.

SWEC has plugged and abandoned the wells located on the site and restored the site in accordance with the terms and conditions of the above described agreement. 
Unless SWEC hears to the contrary from you within ten (10) days from the date hereof, all obligations under the terms of said agreement will be considered fulfilled and the matter closed.

We appreciate the cooperation and assistance you have provided during decommissioning activities at the Minden Substation Site.

Yours very truly,

C. A. Foster

CAF : cd 
May 1, 1989

West Monroe, Louisiana

Mr. C. A. Foster

Stone \& Webster Engineering Corporation

P. 0. Box 2325

Boston, MA 02107

RE: Decommission of Minden Substation

Site J.0. No. 17500

Dear Mr. Foster:

This will acknowledge receipt of your letter of April 21, 1989 and this is to advise that we must insist that the damage release is subject to the idemnification provisions as contained therein: otherwise, the release of SWEC is of no effect and, of course, the matter is not closed, in the event any claims are asserted now or in the future with respect to the performance of any work or the exercise of any rights under the agreements by the parties, including SWEC.

Yours very truly,

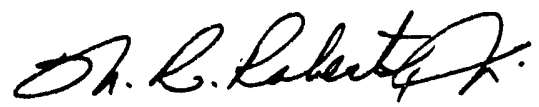

W. R. Roberts, JR.

Senior Right of Way Agent

$c c$ : Mr. George L. Monteverde, of fice

Mr. Doyle P. Wheat, Office

Mr. Billy M. Fuller, office

$M r$. Luke S. Lucas, New Orleans 
FILE COPY . BOSTON

Copy to:

AHandwerker (DOE/CH)

DMiller (Landman)
EWasher

RKranes

HBjorkman

Project Files

WPC $245 / 12(6590-1750000-B 4 T)$

CAFoster
Mr. Ted Taylor

Salt Depository Project Office

Amarillo Petroleum Building

203 W. 8th, Suite 205

Amarillo, TX 79101
May 16, 1989

J.0. No. 17500

DAMAGE REIEASE - LOUISIANA POWER \& LIGHT (LP\&L)

MINDEN SUBSTATION SITE

The purpose of this letter is to provide an update on the status of obtaining a damage release from LP\&L for the Minden Substation Site in Louisiana. The recent history of activities related to obtaining this release is as follows:

April 17, 1989 - Conference call DOE \& SWEC. Concurrence that LP\&L's release is unacceptable. DOE agrees with SWEC recommendation to attempt to obtain documentation of acceptance of site restoration via certified letter to LP\&L.

April 21, 1989 - SWEC's reply to LP\&L notes conditions in modified LP\&L Damage Release that are unacceptable. Further, that the site has been restored in accordance with the terms and conditions of the Limited Right of Use Agreement, and unless contacted in ten days the matter is closed.

May 1, 1989 - LP\&L's reply (attached) acknowledges SWEC letter of April 21, 1989, insists on indemnification provisions in their release, and that the matter is not closed.

The Limited Right of Use Agreement with LP\&L expired on October 1, 1988 . The conditions of the agreement do not specifically require that a release be executed. SWEC still considers the indemnification provisions contained in LP\&L's release unacceptable, and unless DOE agrees to similarly indemnify SWEC, we do not intend to take any further action regarding the LP\&I Agreement.

Please contact us if you do not concur. If additional information is needed, please do not hesitate to contact me (617) 589-2098.

C. A. Foster

WOTED MAY 161989 C.A.FOster

Assistant Project Manager

$\mathrm{CAF}: \mathrm{cd}$ 
APPENDIX D

LIST OF PERSONAL COMMUNICATION REFERENCES 
199

NotEs of CONFERENCE

Location 8. DNR Baton Rouge A/2188:2:00

Attendees: R. De Conto SWEC

T.Regah SW re

J.Maglory DoE

R. Nicks Battelle

R. Deville Harris Assoc

Bill walter DNR OC

Clyde carlson DOTO

General Discussion:

- The DOC is outdated use OC.

- Technically the regulators suction of these wells is ambiguous. Since not all/ gas oc doesnt want them. Since they precede DoT reguation they don't want them. Both agencies surprised to leann that many of the deep wells were permitted by both. Regulation will be performed on the following verbal agreement. DoT regulates any wells cased screened \& oC regulates wells that penetrate freshwater. Some, there fore will be Jointly ne giulated. 
2069

$$
R=2 \text { to } 30 \mathrm{hms}
$$
- Oc protects all aquifers $<10,000 \mathrm{mg} / \mathrm{t}$
ToSs. This will be determined for individual aquifers using Deep Resistivity legs. 0 - $1000 \mathrm{ft}$

3 ohms orhigher $1000-2000 \mathrm{ft} \quad 2$ to $2 \% \mathrm{ohms}$

If logs were not run in well oc will extrapolate from other nearby wells oc will assist swed if we request

- All annulus should be sealed. If no logs run drillers records are acceptable if documentation in dictates circulated to surface.

- Run CBL if ne record.

- The following is list of specific questions/clarifications responses 
3 of 9

DOTD CHAPTER II!

A. DOCUMENTATION/CLARIFICATION

1. Page 51, Section 3.2.10

Obtain the Appendix I to Chapter III referenced in section.

2. Page 52, Section 3.2.3.0.

ole Supplied

Chapter $\mathrm{V}$ necessary for SWEC to obtain?

OK Supplied

3. Page 53, 54, Section 3.2.5.0.

Is the operator responsible for obtaining and submitting any forms?

NO. But stained DOTD-GW-2 for information.

Is (DOT-GW-2) the only required form and is the contractor solely responsible? Yes. Contractor responsi i le for suimiting tins form.

Is Appendix IV available since it contains DOTD-GW-2? The last paragraph implies that Geotechaical Holes may be documented, if so, are the records of Letco boreholes available?.

No. Contractor lust lists how wary Geotecin tolls drilled in yean No other info

4. Page 56, Section 3.2.90. Is notification of work required prior to inspection?

It's not required. However they may inspect at any time.

$5273-1750020-B 4 T$

1 
5. Page 56, Section 3.3.30.

Does the DOTD have construction records for nonpermitted (DOC) boreholes such as Geotechnical Boreholes, shallow borings and V series? Obtain these records if available. Obtain salinity

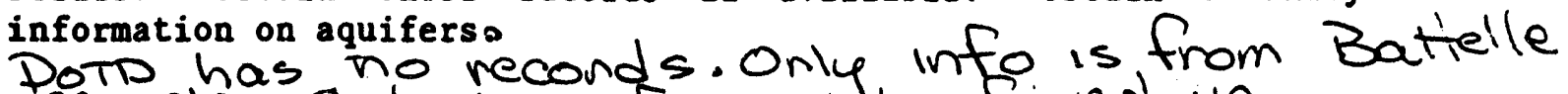
reports. Saluity info can be found in Base of fresinisater resort.

6. Page 57-60, Section 3.4.0.0.

Have the status of the wells been filed with the DOTD? Is it necessary to do now, and what would it be? No doubt the (90) or (30) day plugging dates have been violated..

we have to scan Lat, longt owner from DotD files to determine this. Swec will pravie hat.long. study anea

7. Page 59, Section 3.4.4.1.

The operator/ownership of R-1A may be transferred to the landowner for use as a water supply well. Is there a pOTD document required? There is no. Dotd Form:

Any legal vistrumsil: can be used

8. Page 50; Section 3.0.5.0.

The deep boreholes can be classified as monitoring wells. Was the status changed to active, inactive or standby when monitoring ceased? DOTD doesvit Know

9. Page 61, Section 3.4.7.0.

Are there drilling records for Geotechnical Boreholes demonstrating they were plugged? $N O$ 
5089

B. TECHNICAL CLARIFICATIONS

1. Page 62, Section 3.5.1.0.

If cementonite/bentonite is premixed before water is added is this permitted? No problem. DoC prefers

less bentonite. However max $8 \%$ is ok with both agencies.

2. Page 63, Section 3.5.3.0.

Are calculations to be submitted or on file. Is this the operator's or contractor's responsibility?

lust on File with Contractors

3. Page 65, Section 3.6.1.3.

Can a sand filler be placed from T.D. to the top of the screen? Is there a preferable method for sand placement?

Prefer not to dump it. But it can ce placed from TD TO Top of screen

4. Page 65, Section 3.6.15.

Is a cement bond 108 required to check the annulus seal?

It is suggested. by DOC for liability but not required. we sinould do.

5. Page 66, Section 3.6.1.7.

How does one determine an area of confirmed contamination?

DEQ determines this. Should check. with DEQ. Renee will handle.

6. Page 66, Section 3.6.1.9.

Many of the shallow boreholes 25-200 ft may have caved in and are not recoverable. To what extent are they to be redrilled?

DOTD recommends, drill out top $25 \mathrm{Ft}$ if we can find holes cement to G.S.

$5273-1750026-B 4 T$

3 
6 of 9

DOC - STATEWIDE ORDER 29-B

A. DOCUMENTATION/APPLICATION CLARIFICATION

Are the following applications necessary. What are the fees involved?

1. Page 3, Section 3, August 26, 1974.

Need to obtain MD-11R application to plug and abandon. Is this in addition to DM-4 Rev.? Need copies of previously filed MD-11R's, Where are they located? DoC is not sure what MD -ll ${ }^{2}$ is He suggest See District office in Shrevepat for this (MD-llR). SWEC call district office

2. Page 3, Section 3, August 26, 1974 Need to obtain Well History and Work Resume Report (Form W0). Is this the official record? Yes it is official second See Permit section using permit Nos, copy well file report

3. Are service companies to report their own work to the state?.

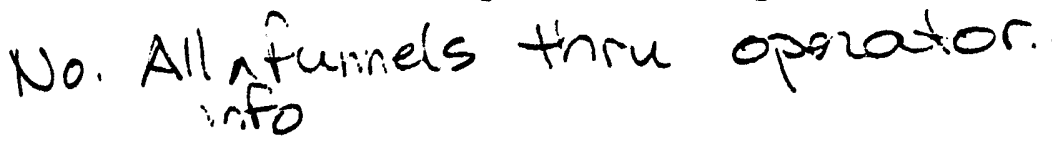

4. Page 17, Section XIX A.2, August 26, 1974

Have the wells been reported on inactive status forms DM-1-R. DT-1 or semi annual INACT WR-1? Should they be reported when we assume operatorship? Doc classified permitted wells as, Monitwor ing wells. The above forms are For olla gas wells unify co not apple to us.

5. Page 18, Section XIX F, August 26, 1974

Obtain transfer of Operatorship Forms MD-10-RA. Are there only prerequisite activities such as access? Will well serial number change? How long approval?

Need (2) original signed copies of MD-10-RA well no. remains same.

$5273-1750026-B 4 T$

4 
7 of 9

6. Page 18, Section XIX F.

Obtain notification of intent to plug forms (Form DM-4 Rev.). Can we file one form for a suite of wells? How long to obtain approval? What is the name and telephone no. of appropriate District Manager for elptification.? No. Must Sworn: T: Pit -4 Two or three weeks for appeal

Jackie Reval or Frank Savant,

Shreveport office $318-226-7585$.

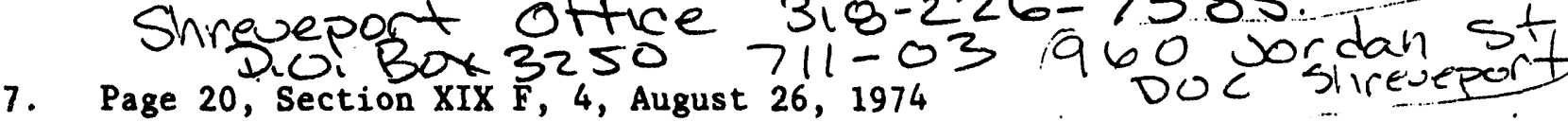
Obtain Form P\&A. Is the cementing report a DOC document -filed by the contractor? Obtain previous P\&A's..

Yes. Get tominordu

8. Page 20, Section XIX G, August 26, 1974

Is there a DOC form for transfer of well to landowner for water well?

lies MD.10-RA if registered

9. Page 26, Section XV, 13.6, January 20, 1986

Is it necessary for the operator to obtain the oil field waste shipping control ticket?

Need abetter in ahwrry to $O C$ for permission to use commutate Facility. $\frac{1}{x}$ 10. Why don't ISO-R1A \& DOE Smith have permit nos? Where can they be
found?

Dol will scan files

ii: Page 15, Section XV, 13.2B.

Is there a list of DOC approved transporters and commercial facilities?

No. licensed by Public Service Commission Renee Decile will contact PSC.

$5273-1750026-B 4 T$

5 
$8 q 9$

B. TECHNICAL CLARIFICATIONS

1. Page 19, Section XIX, 3.d.

What if any freshwater horizons may exist below surface casing?

It is possible- that a freshwater

aquifer could be sandwiched between

saline sands. Therefore Doc prefers that read resistivity logs to determine. They

2. Page 19.", section XIX, 3.d.

Can brine be left in the well rather than displacing it with mud?

Yes. leave brine below bottom plug

3. Page 9, Section XV, 2.6, January 20, 1986.

This section does not address procedures for instrument pit closure. Proposed. AP procedure is Ot as is

4. Page 12, Section XV, 2.7 G1, January 20, 1986

Does produced salt and freshwater require offsite commercial 1 disposal? Produced salt water from a non oll/gas well cannot be disposed of in a cominencial facility unites aforcies it ar This requires a valance. May have to haul out of state. Fresh water can be disposed of on ground surface.

5. Page 15, Section XV 13.1, January 20, 1986

What is the TDS limit for borehole fluids requiring disposal? Is a conductance meter acceptable or is titration necessary for TDS determination? I or 2 mill mhos. Sample from T. D

Titration not necessary, Conductance for 2 minis Sample from TD

6. Page 15, Section XV 13.2, A.4, January 20, 1986

Is there a form for now generated?

Yes. Form Uic-16. Supplied by DOC

$5273-1750026-B 4 T$

6 
7. Page 67, Section 3.6.2.0.

What is the jurisdiction of DEQ over monitoring wells?

Renee Deville says wone.

8. Page 68, Section 3.6.4.0.

It is impractical to plug the entire depth of the DOE, Smith et al, No. 1 well with cement. Do the DOC regs. supersede below the surface casing (saline aquifer)?

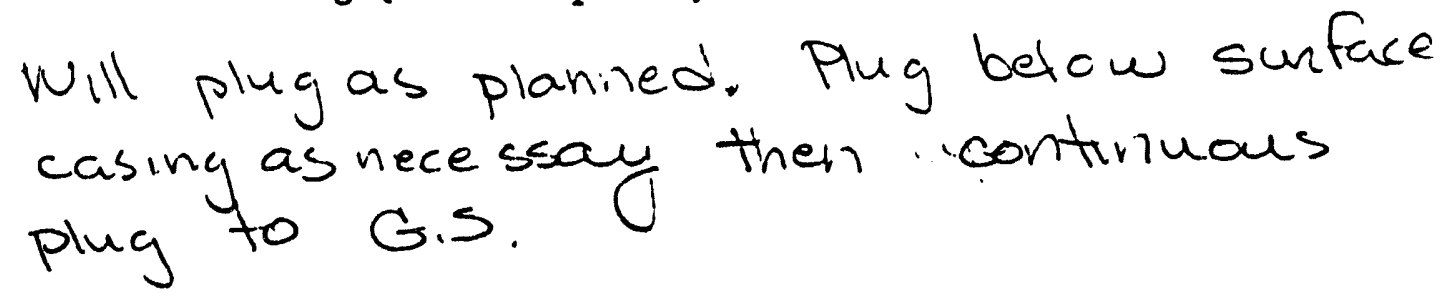




\section{Polecheno Mrecorade}

sey

Technical \& Fleid Services Contract

call oare

17 ZUNE 1488

TrOa TUEL Q. KANTOLA

JCSHN HOLMES (USO/IE)
Tsme

of Sinec

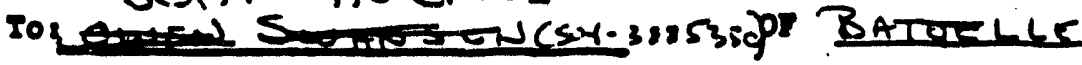

enset SH. BOREHOLES

momar AnNuAl REPORT (BUNe AND Red) SURUEYS NOT REPART IN ANNUAL REPORT - ALL SENT TO COL OHIO

PLUGGING - BACKFIU w/ MATER QUT of HOLE BARORITE NUD $R+T$ FuCONCZTE ANP MUD Q $E^{\prime} \omega$ HICHWAY EROSSE BCACIL LAKE BAYOU - BIUE REPORT SHOWS BLFNE lOCATE GRAD CIOE Q LSU. IJ HOME 6 S LINE LSU GRAD STUPENT HE'll CALL ME BAClL IF HE EZND MICRO. INFO action mevitiso

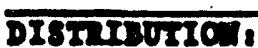

seripun

DTrese

Drisober

Iroject rilee
Orians.

Dra11211ea

Caicshala -

roburse

DSpuncan (Bechtel)

Jipect

Mscray (Bechtel)
DLPente (Colder)

nrszee (Colder Siecleary (wor) Culleno(-vereat) parker (seiv) orvers 
Tolephene merorender

384

Technlcal \& Pleld Services Cootract

cull oure $7 / 8 / \varepsilon 8$

TIME

rrom: R. Decoirto

or Sun

$504-342-8950$

To: Gearae krainer

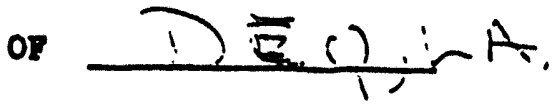

susject Dre Juinsciction

sumar Da - Deauesis that ireu be

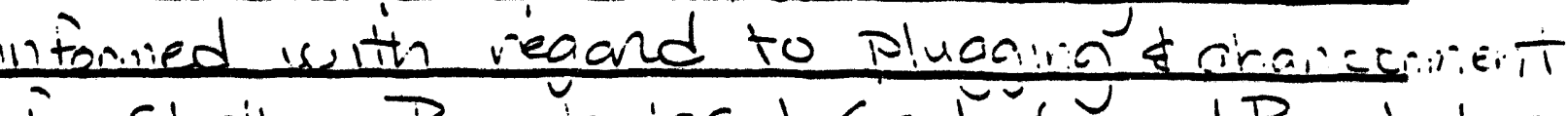

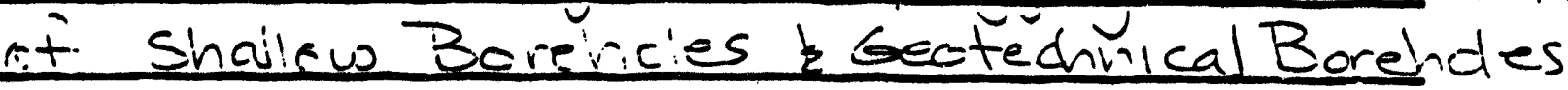
Porticulau tirose Hial aie 200 ftor

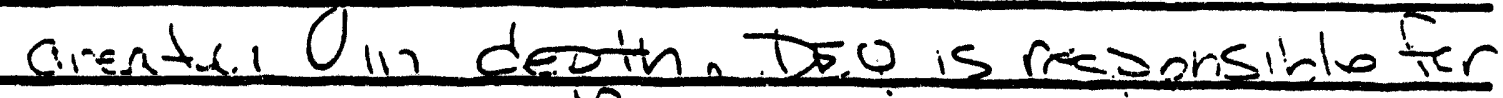
Inetectira aanifers ret cousied bu cither aciencies.

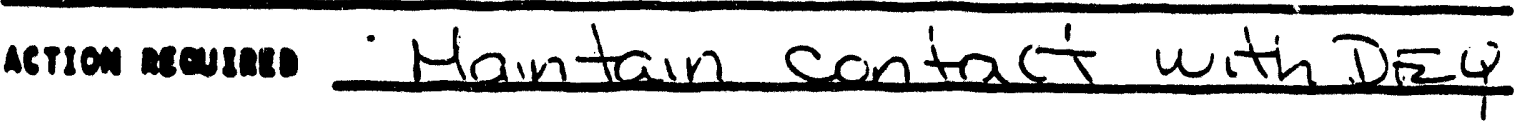

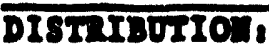

STNinn

$\alpha=$

Ariteober

Project Plle ograns

Dan11111ea

Cavesbalo -

Besura

DSDuncan (Bechted)

Jipeck

Wsaray (Becbed)
Dipents (Golder)

Wrspe (Golder

Jucleary (wcc)

CHLlgas (Bvereet)

DParker (sein) orrase

CAFosten R.T. Decanter 
1 of 3

NOTES Of LONFRRINYE

LOCATION: DEPARTMENT OF NATURAL BESOUESE' OFFICE OE CONSERVATION, BATON RUVGẼ ILA.

DATE 8 8/15/88 10: A.M

ATENDEESO Bill waiter: oC

Clyde Carlson: Doth

R.kranes i SWEC

R. Dedonto 8 SEC

The panay purpose of the meeting was to determine the wells that may require perforating and squeezing, based on Cement Bond Logs and Resisitiuy logs. SWEC had compiledexisting logs from LETCO repents and In formation Service onganizaticir. Cement Bond Logs were recently run ... during. Surd site Reconnaissance activities in those wells; where they had not been previously acquire:

The $O C$ is particularly interested in ensuring that on adequate cement bond protects fresh water (\&10,00TDS') from salt, water. Prior to the meeting, $B_{i}<$ rares selected the fresh/salt interface using OC'S criteria from resistiuty logs the integrity of the annulus cement was then examined at that depth 
2 क्ष.

Logs from the following wells were reviewed? All H-H-2 site wells

All 4 Ht -7 site wells All. LH -17 site wells also R.K All Lvit-6 site wells

$V-4$ well

$v-6$ well

The integrity of the cement bond (between casing and formation) was acceptable to the DoT \& oC except for the LVII $6 A, 6 B, \& 6 C$ wells. Bill walter recommended :

- perforating squeezing too sacks in the sands. above $1000 \mathrm{ft}$.

- Chook the results with a COLi square agon ifnecessanyx oft. cumulative squeeze

other items addressed at the meeting were

- Use of Bridge Plugs. R De conto inquired if Budge Plugs could be placed in the casing above the screens followed by cement to surface. This would bevin lieu of pumping cen lent or sound into the sorer section. Use of the Bridge Plugs would 1.) eliminate excessive cement loss to the formation: through the sores z) expedite cenderiting by avoiding 
300

use of a sand plug in the screen 3) provide an accurate means of calculating volumes for cement to surface in a one step operation. Use of the Bridge Plug was acceptable to ocghavever DotS need to check.

- Restoration of Pit at LSU RIA well - R. Deconto inquired if the $12 \mathrm{ft}$ circular pit, 3 ft dep adjacent. to RIA well would require sampling polemical analyses to satisfy_ OC regulations. Bul walter? said this would not be necessary, and that backfillingthe pit was acceptable.

- Pipe scale in tall pipes. Depth sounding indicated - 0-18 ft thick scale has accumulated in some wells in the tail pipes. Does it have to beremoued? OC Dots said it is not necessary.

- Entrained bases in formation fluid. Sure inquired If it would be necessary to take precautions during ... transport of displaced brine due to possible gas hydrocarbons entrapped in fluid. Bill walter said there would be no problem. for those shallow depths 
d.0. 17500. des cool m. 12. ensese Pllos

\section{Tolesimene Brecorender \\ $8 \mathrm{sin}$ \\ Tochnichl o Field services Coatract}

call are

$9 / 20188$

rem

$$
\begin{aligned}
& \text { rrom: RDPCONTO or SWEC } \\
& \text { ro: Bo.Toluricini or DOTD Ha. }
\end{aligned}
$$

enaset

vomar In Ionived Br that the CBh in

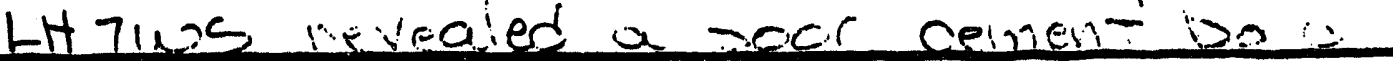
and tint we planned to souefze the arinulus behivid ie suiface casiria. He preferred not to periagite for the following reasons:

1) Believes cement recoids which ricino:bond from $0-470 \mathrm{ft}$ are mac reliaje Tiar. CBLS.

2) May damage exictina baid civina iestasfuree

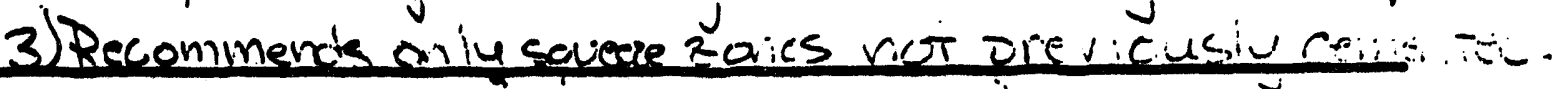
nerrem murars Plua above sand plua to GLL. Da not squeeze

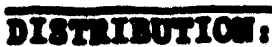

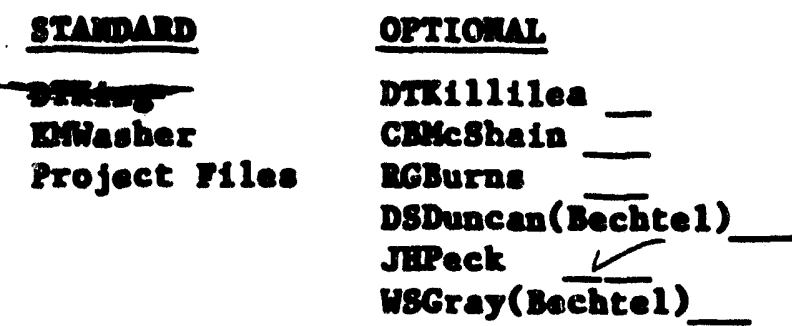

DLPents (Golder) RJyrne (Colder Jiccleary (WCC) Gillgus (Bverest) Harker (sein)
Oxiras RAFoster $\mathcal{L}$ 


\section{Tol edvene meoronder 384 \\ Techalcal rield servicen Contract}

call oare $\quad 8 / 31 / 88$

rom: R. DeConto

Io: Bill walter
IIME

of SWEC

o: DNR OC suser Serial Nos. for hon perinted wells

mmar Walter declined to provide genial nos. for wells in previous discuessions since not ail las urells. However, in orden to a ccept Guec's pluaginalabandonmont documentation senial nos will be assianed as follows:

$14-971960$ \& $/ 5-971961: 1 / 6-9719 \div 2$

1.7-971963 a LSIJRIF- 971964 walter said to file war penmits at Baton Roucie office. Notification of $12 \mathrm{hr}$ prior to pluacing is not required. Also pesforation of risen pipe to fill aulas sipace between riser \& casina is not nerrow newine necessarya

R. Deconto file OC work Perrit DM $4 R$ at Braton Rouge OC, OCwill then assign workpeimitnc.

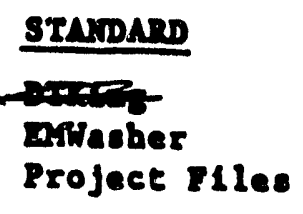

DLPeatz (Golder) RSyrae (Golder McCleary (NCC) CHLlgua (Everest) BParker (S\&W) 
J.0. No. $17500.2 \mathrm{C}$

Job book tho. 12.

subjoet Plles

\section{Tolephone Mecorondw}

sety

Technical \& Field Services Cootract

CAL DATE $10-11-88$

TINE $2: 30$

Prom: IS OEL Q. KANITISA OP SUIEC

MCCLLAND ENLINTERS

To:MR. GaPNiER

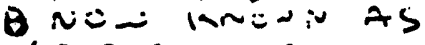
OP LRUS GRINER. AND HUFKYN suaject RegivedT DAfLy Reparts AN IACHERIE Sitallin BerIni-

sumar Recivested INfFo ONj shalicin

BoRINL G NACHERIE. SPECIFILALY ATIEED FQR BS M LINIES.

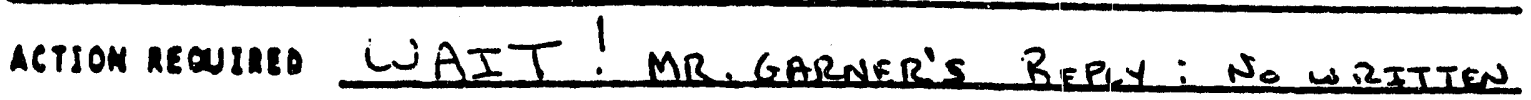
REconos, BUT HE ASSURED ME THEY RACKEILED THE $B, S$, AW M LINES $w /$ CUTIINGS ANO/OR HUD.

\section{DISTRIBUTION:}

\begin{tabular}{|c|c|}
\hline STANDARD & OPTIONAI \\
\hline $\begin{array}{l}\text { Drstug } \\
\text { Earkasber } \\
\text { Project Piles }\end{array}$ & $\begin{array}{l}\text { DTRillilea } \\
\text { CBMcStraln } \\
\text { RGBurds }\end{array}$ \\
\hline & $\begin{array}{l}\text { DSDuncan (Bechtel) } \\
\text { JHPeck } \\
\text { USGray (Bechtel) }\end{array}$ \\
\hline
\end{tabular}

DLPentz (Golder)

RJbyrae (Golder MCCleary (WCC)

CWilgus(Everest)

BParker (Ssbi)

\section{OTERRS}

D. DLscitic:

A. FU:ST:2 


\section{TELEPHONE MEMORANDUM \\ $S \& W$ \\ TECHNICAL AND FIELD SERVICES CONTRACT}

CALL DATE:

FROM :

TO:
$10-29-88$

R. Kranes

FOwlER DewLixg
TIME : $\quad 8: 00$

OF: SWEC

OF:

SUBJECT : Recoras Relatiog to THE RAckFllwivia OR

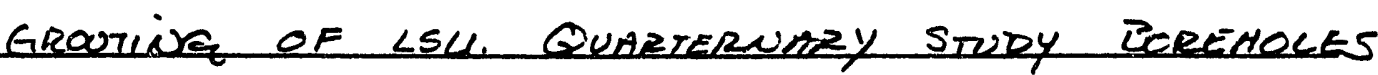

SUMMARY : Me FOMiLER SAID HE HAD WO FORNIRL RECCRPS INDEATINS THAT THE IEEEHCLES WERE GROUTED OR BKKKFILLED, BUT IT WAS COMMON PRACZICE UTIH HIM AND MOST OTHER DRHLERS TO POT ALE MUP + CUTTNG FEK in THE NOES TEPORE leAviNS AUY GIUEO STEE

ACTION REQUIRED:

None

\section{DISTRIBUTION :}

\section{STANDARD}

E.M. WASHER

C.A. FOSTER

J.H. PECK

1
OPTIONAI

OTHERS

C.B. MCSHAIN

R.G. BURNS

C.E. HOUK

F.J. DEHLER 
J.O. NO. 17500 .

JOB BOOK NO. T2.

SUBJECT FILES

\section{TELEPHONE MEMORANDUM \\ $S \& W$ \\ TECHNICAL AND FIELD SERVICES CONTRACT}

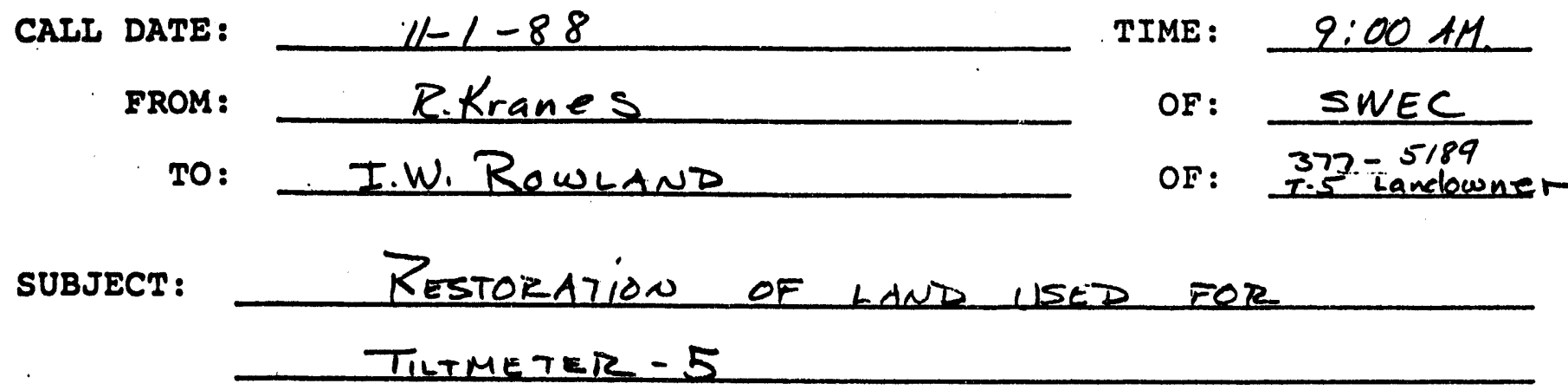

SUMMARY: MR BOWLAND INDICATET THAT HE WAS SATISFIED

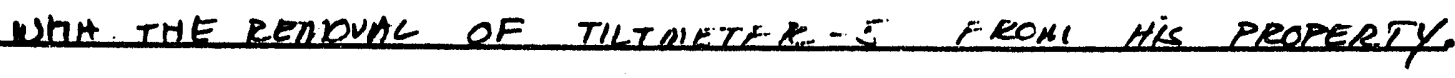

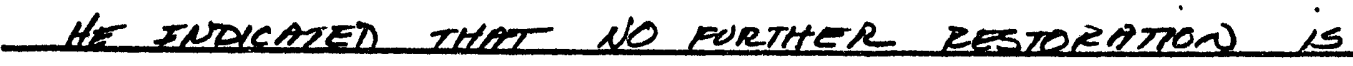

Necessmey

Bowatad stis He woved SIEN t RETURN HIl NECESSMRY

RELEASE FORMS SEXT TO Him TSY CO.E.

ACTION REQUIRED:

Norify C.O.E.

\section{DISTRIBUTION :}

STANDARD

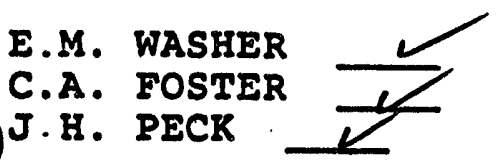

OPTIONAI

OTHERS

C.B. MCSHAIN

R.G. BURNS

C.E. HOUK

F.J. DEHLER 
J.O. NO. 17500 .

JOB BOOK NO. T2.

SUBJECT FILES

\section{TELEPHONE MEMORANDUM}

$S \& W$

TECHNICAL AND FIELD SERVICES CONTRACT

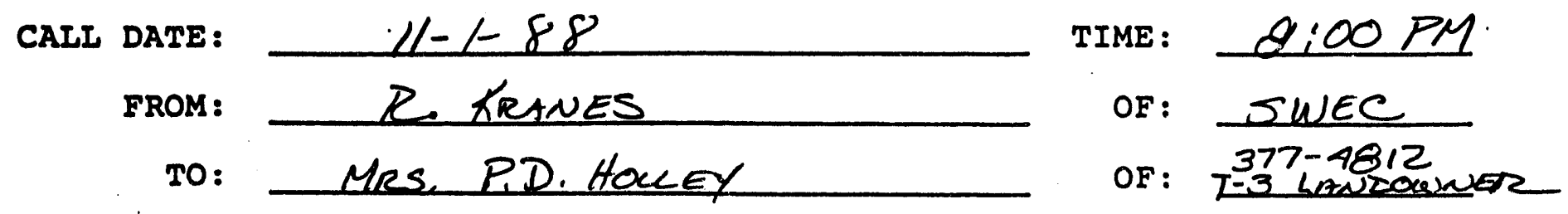

SUBJECT: RESTORATIONO OF LAND USED FOR

TLTMETER - 3

SUMMARY: MES, HELEY INDICATED THOT HE WAS SATISFIED

WITH THE REMOVAL OF TILTMETER-3. FROM HIS

PROPERTY SHE WACATED THIT U FURTHER.

REsTortriea is vecEssMrY.

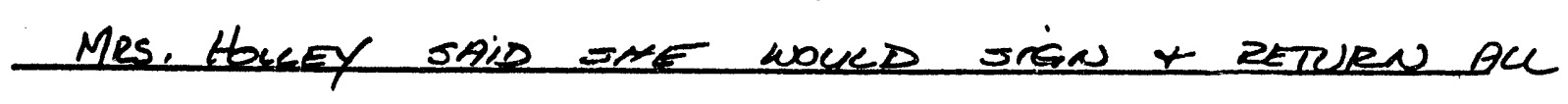

NecessmRY Release forms seUT to her BY C.O.E.

ACTION REQUIRED:

Norify C.O.E.

\section{DISTRIBUTION :}

STANDARD

E.M. WASHER

C.A. FOSTER

J भ. PECK
OPTIONAL

C.B. MCSHAIN

R.G. BURNS

C.E. HOUK

F.J. DEHLER
OTHERS

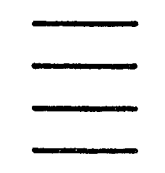


Notes of Meeting witt

Garland Thous

In response to a phone call from Bryant Miller, I $11 / 14 / 88$ contacted GARcia TItus $[(318)-37 t-9121]$ on whose property the LSU V-6 well is located. We arranged to meet at 12:15 to insped and discuss some problems he felt were caused when Western Consent C. was on his property plugging back the KC well. The problems were:

1. Small plastic ap covering the light acturatide onloff switch at the top of the mercury vapor softy light in hs yard ares knocked off

2. The ploy connecting a freezer in his nearby trailer was dislodged by,

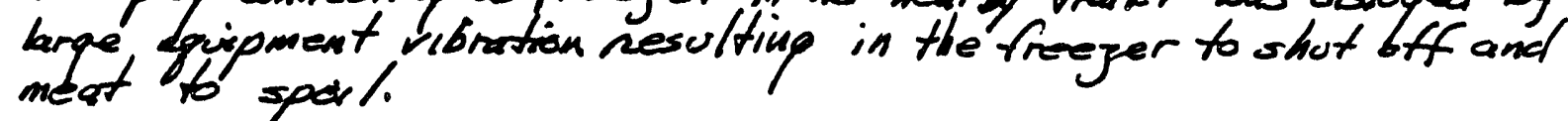
3. Large ogipment entering + leaving his property caused a breakage above in $\$ 2$.

Mr. Their indicated at that time that he would like reasonable comsensation for the disruption and for site reckmatrion rather than have stove \& Webster directly replace lost or broken items or directly do the repair or redamation work. At that time he indicated the worth of the last (spoiled) free ger items (meat) to be at 75. He also indicated of that time that even when we had goipment on site to excavate, cut and app casing he did not wast spilled, cement reasoned from the ground surface.

T. Frames

Dec. 19,1988 settlement finalized 


\section{TELEPHONE MEMORANDUM \\ $S \& W$ \\ TECHNICAL AND FIELD SERVICES CONTRACT}

CALL DATE:

$$
12-8-88
$$

FROM :

TO:
Clyde knox - district mananger R. Krives
TIME :

OF: Willameft=

OF : SWEC

SUBJECT : Acesulability of site resteration - DOE Contineintal F. I. \#

summary: Mre Knax inspected ine site and found the restorativin effort sufficient and acceptable

- R. Kraves interned Mr. Knox that the COF wauld be contacting him regarding the release of the site. Mr. Know acknowhelyed the precess reguired.

ACTION REQUIRED: Notify COE of arok completed and landowner acceptance of site restoration.

\section{DISTRIBUTION :}

STANDARD ,

E.M. WASHER

C.A. FOSTER

H. PECK
OPTIONAL

OTHERS

C.B. MCSHAIN

R.G. BURNS

C.E. HOUK

F.J. DEHLER 


\section{Telephone Mecorandwa}

sey

Technical \& Field Services Contract

CALL DATE $12-12-80$

From: J.R. DIEHL

TO:J.Q. KANTOLA
Tine if:30

or MARATIEN OIL Co. $713-242-5: 93$

or Swec

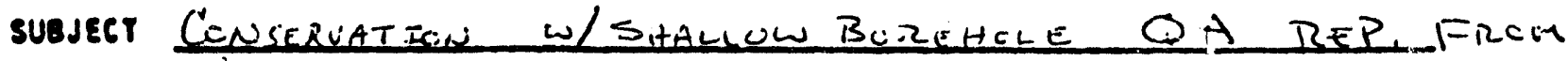
LETCO.

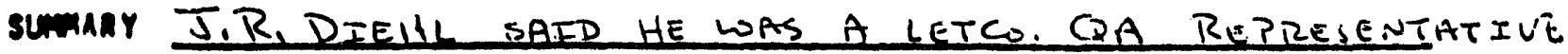

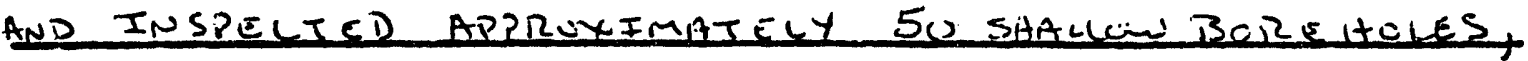
MOST LIKELY THE "B" SERIES. All 50 itoles luere PrOPERLY Plugeed w/ BENTONTTE PELLTS, HUP. AND/OR SUTTINGS. NONE THAT HE wAS IN WUVEP W/ WCRE LEFT OPEN.

ACTION RECUIAES

\section{DISTRIBUTION:}

ST' MDARD

DTRing Exwasher Project Piles
OPTIONAI

DTR11111ea CBMcShain

RGBurns DSDuncan (Bechte1) JiPeck WSGray (Bechtel)
DLPentz (Golder) RJByrne (Golder Juccleary (WCC) CWilgus (Everest) BParker (S\&W) 

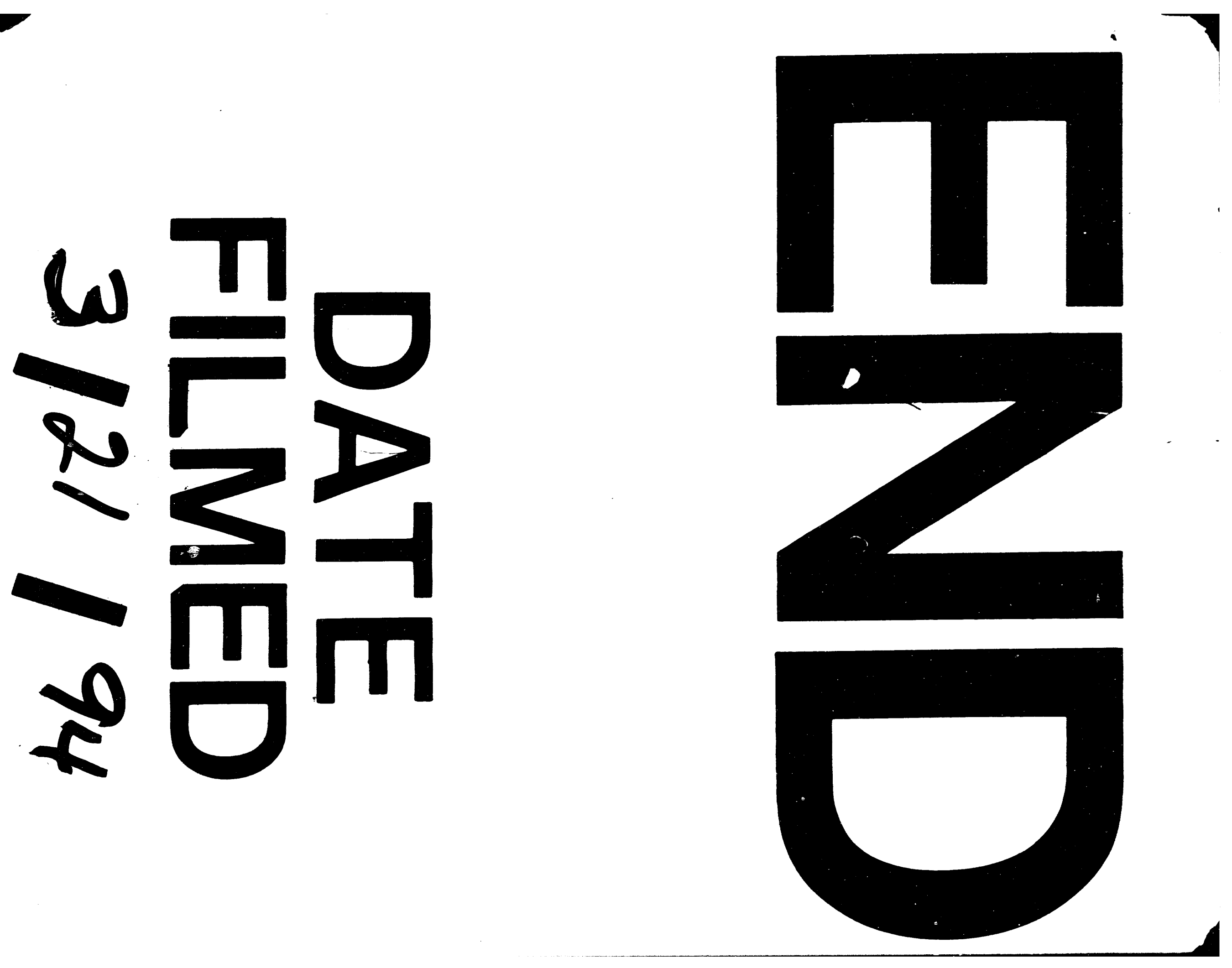
